\title{
Serine-Selective Bioconjugation
}

Julien C. Vantourout ${ }^{1}$, Srinivasa Rao Adusumalli ${ }^{2}$, Kyle W. Knouse ${ }^{1}$, Dillon T. Flood $^{1}$, Antonio Ramirez ${ }^{4}$, Natalia M. Padial ${ }^{1}$, Alena Istrate ${ }^{2}$, Katarzyna Maziarz $^{1}$, Justine N. deGruyter ${ }^{1}$, Rohan R. Merchant ${ }^{1}$, Jennifer Qiao4, Michael A. Schmidt4, Michael J. Deery 5 , Martin D. Eastgate ${ }^{*}$, Philip E. Dawson ${ }^{*}$, Gonçalo J. L. Bernardes ${ }^{*_{2,3}}$ and Phil S. Baran ${ }^{*_{1}}$

${ }^{1}$ Department of Chemistry, Scripps Research, 10550 North Torrey Pines Road, La Jolla, CA 92037, United States.

2Department of Chemistry, University of Cambridge, Lensfield Road, CB2 1EW Cambridge, United Kingdom.

3Instituto de Medicina Molecular, Faculdade de Medicina, Universidade de Lisboa, Avenida Professor Egas Moniz, 1649-028 Lisboa, Portugal.

${ }_{4}^{4}$ Chemical Process Development, Bristol-Myers Squibb, One Squibb Drive, New Brunswick, NJ 08903, United States.

5Cambridge Centre for Proteomics, Milner Therapeutics Institute, Jeffrey Cheah Biomedical Centre, University of Cambridge, Puddicombe Way, CB2 oAW Cambridge, United Kingdom.

\section{Supporting Information}


Table of contents

TABLE OF CONTENTS

$\begin{array}{ll}\text { A. LC/MSD TOF } & 7\end{array}$

$\begin{array}{ll}\text { B. HPLC/MS } & 7\end{array}$

$\begin{array}{ll}\text { C. ESI-MS } & 7\end{array}$

\begin{tabular}{l|l} 
D. LC-MS/MS & 8
\end{tabular}

D. ${ }^{31}$ P NMR

GENERAL PROCEDURE A FOR THE SYNTHESIS OF $\Psi$-MODULES (P(V)-X) 10

GENERAL PROCEDURE B FOR SOLID PHASE PEPTIDE SYNTHESIS (SPPS) 11

METHODS FOR PEPTIDE SYNTHESIS

MATERIALS 12

SOLID PHASE PEPTIDE SYNTHESIS

SYNTHESIS OF $\Psi$-MODULES (P(V)-X)

SYNTHESIS OF P(V)-1

SYNTHESIS OF P(V)-2A

SYNTHESIS OF P(V)-2B 17

SYNTHESIS OF P(V)-3

SYNTHESIS OF P(V)-4 
$\begin{array}{ll}\text { STARTING MATERIALS } & 123\end{array}$

$\begin{array}{lr}\text { Cyclic Peptides Functionalization } & 126\end{array}$

\begin{tabular}{lr} 
PROTEIN FUNCTIONALIZATION & 135 \\
\hline
\end{tabular}

$\begin{array}{ll}\text { STARTING MATERIALS } & 135\end{array}$

$\begin{array}{ll}\text { FUNCTIONALIZATION OF UBIQUITIN } & 137\end{array}$

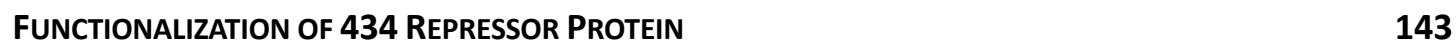

\begin{tabular}{lr} 
DFT COMPUTATIONAL STUDIES & 144 \\
\hline
\end{tabular}

$\begin{array}{ll}\text { A. GENERAL COMPUTATIONAL INFORMATION } & 144\end{array}$

$\begin{array}{ll}\text { B. COMPUTATIONAL RESULTS } & 145\end{array}$

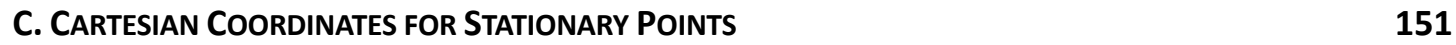

\begin{tabular}{lr} 
TROUBLESHOOTING: FREQUENTLY ASKED QUESTIONS & 198 \\
\hline
\end{tabular}

\begin{tabular}{lr} 
REFERENCES & 200 \\
\hline
\end{tabular}

\begin{tabular}{lr} 
SPECTRA & 205 \\
\hline
\end{tabular}

$\begin{array}{ll}\text { COMPOUND P(V)-1 }{ }^{1} \text { H NMR } & 205\end{array}$

\begin{tabular}{ll} 
COMPOUND P(V)-1 & 13 C NMR \\
\hline
\end{tabular}

\begin{tabular}{lr} 
COMPOUND P(V)-1 & 31P NMR \\
\hline
\end{tabular}

$\begin{array}{lr}\text { COMPOUND P(V)-2A }{ }^{1} \text { H NMR } & 208\end{array}$

$\begin{array}{ll}\text { COMPOUND P(V)-2A } & 13 \text { C NMR } \\ \end{array}$

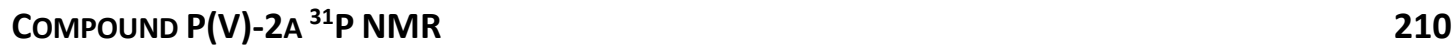

$\begin{array}{ll}\text { COMPOUND P(V)-2B }{ }^{1} \text { H NMR } & 211\end{array}$

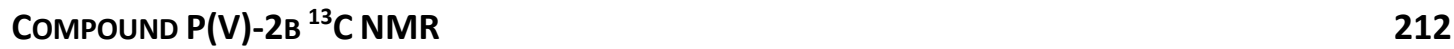

$\begin{array}{ll}\text { COMPOUND P(V)-3 }{ }^{1} \text { H NMR } & 214\end{array}$

\begin{tabular}{ll} 
COMPOUND P(V)-3 & ${ }^{13}$ C NMR \\
\hline
\end{tabular} 
COMPOUND P(V)-3 ${ }^{31}$ P NMR

COMPOUND P(V)-4 ${ }^{1} \mathrm{H}$ NMR

COMPOUND P(V)-4 ${ }^{13}$ C NMR

COMPOUND P(V)-4 ${ }^{31}$ P NMR

COMPOUND $2{ }^{31}$ P NMR

COMPOUND $2{ }^{31} \mathrm{P}$ NM

COMPOUND $34{ }^{1} \mathrm{H}$ NMR

COMPOUND $35^{31}$ P NMR

COMPOUND $35^{31} \mathrm{P}$ NMR COUPLED 225

COMPOUND $36^{31}$ P NMR 226

COMPOUND $36^{31} \mathrm{P}$ NMR COUPLED 227

COMPOUND $37^{31}$ P NMR 228

COMPOUND $37^{31} \mathrm{P}$ NMR COUPLED 229 


\section{General Experimental}

Tetrahydrofuran (THF), N,N-dimethylformamide (DMF), Acetonitrile (MeCN) and dichloromethane (DCM) were obtained by passing the previously degassed solvents through an activated alumina column. 1,8-Diazabicyclo[5.4.0]undec-7-ene (DBU) was purchased from Sigma Aldrich (33482-50ML-F). All reagents were purchased at the highest commercial quality and used without further purification unless otherwise stated. Yields refer to chromatographically and spectroscopically $\left({ }^{1} \mathrm{H}\right.$ NMR and/or ${ }^{31} \mathrm{P}$ NMR) homogeneous material, unless otherwise stated. Reactions were monitored by thin layer chromatography (TLC), LC/MS, and HP/LC. TLC was performed using $0.25 \mathrm{~mm}$ E. Merck silica plates (60F-254), using short-wave UV light as the visualizing agent, and phosphomolybdic acid, $p$-anisaldehyde, or $\mathrm{KMnO}_{4}$ and heat as developing agents. NMR spectra were recorded on Bruker DRX-600, DRX-500, and AMX-400 instruments and are calibrated using residual undeuterated solvent (Acetone, $\mathrm{CHCl}_{3}, \mathrm{CH}_{2} \mathrm{Cl}_{2}$, DMSO, $\mathrm{MeOH}$ at 2.05, 7.26, 5.32, 2.50 and $3.31 \mathrm{ppm}$ for ${ }^{1} \mathrm{H}$ NMR, respectively, and 29.84/206.3, 77.2, 53.8, 39.5 and $49.0 \mathrm{ppm}$ for ${ }^{13} \mathrm{C} \mathrm{NMR}$, respectively). The following abbreviations were used to explain multiplicities: $\mathrm{s}=$ singlet, $\mathrm{d}=$ doublet, $\mathrm{t}=$ triplet, $\mathrm{q}=$ quartet, $\mathrm{m}=$ multiplet, $\mathrm{br}=$ broad. Column chromatography was performed using E. Merck silica gel (60, particle size 0.043$0.063 \mathrm{~mm}$ ), and preparative TLC was performed on Merck silica plates (60F-254). High-resolution mass spectra (HRMS) were recorded on an Agilent LC/MSD TOF mass spectrometer by electrospray ionization time of flight reflectron experiments. 


\section{Methods}

\section{A. LC/MSD TOF}

One microliter of the peptide solution was analyzed on a Waters I-Class LC connected to a Waters G2-XS TOF. Compounds were separated on a Waters BEH C18 column $(1.7 \mu \mathrm{m}, 2.1 \times 55 \mathrm{~mm})$ using a gradient $(0.8 \mathrm{~mL} / \mathrm{min}, 10-99 \% \mathrm{~B}$ over 2.5 minutes; $\mathrm{A}=$ $0.1 \%$ aqueous formic acid, $\mathrm{B}=0.1 \%$ formic acid in acetonitrile) at $35{ }^{\circ} \mathrm{C}$.

ESI-MS: \% Conversion for labeling of tetrapeptides was calculated based on the following formula.

$\%$ Conversion $=I_{\text {desired product }} / \mathrm{I}_{\text {all relevant species }}$

$\mathrm{I}_{\text {desired product }}=$ Peak intensity of labeled peptide

$\mathrm{I}_{\text {all relevant species }}=$ The sum of the peak intensities of starting material peptide and double addition product.

\section{B. HPLC/MS}

HPLC analysis were conducted on a Waters Autopurification LC with a Waters XBridge C18 column $(4.6 \times 150 \mathrm{~mm}, 3.5 \mathrm{~mm})$. Fractionation was triggered by a Waters QDa single quadruple mass spec in $\mathrm{ESI}^{+}$single ion or $\mathrm{ESI}^{-}$single ions recoding modes. UV detection was monitored at $261 \mathrm{~nm}$.

Solvent A: 0.1 M aqueous triethylammonium acetate Solvent B: acetonitrile

$$
1.5 \mathrm{~mL} / \mathrm{min}, 25^{\circ} \mathrm{C} \text {. }
$$

Gradient: 5-90\% B over 12 minutes

\section{ESI-MS}

Mass spectrometry: Waters SQ Detector 2 mass spectrometer coupled to Acquity UPLC system was used for ESI-MS data. $\mathrm{H}_{2} \mathrm{O}$ was buffered with $0.1 \%$ formic acid and $\mathrm{MeCN}: \mathrm{H}_{2} \mathrm{O}$ were buffered with $0.075 \%$ formic acid and used as the mobile phase. Method A and Method B were used to record the ESI-MS data for proteins and LC-ESI-MS data for peptides respectively.

ESI-MS: \% Conversion for labeling of proteins was calculated based on the following formula. 
$\%$ Conversion $=\mathrm{I}_{\text {desired product }} / \mathrm{I}_{\mathrm{all}}$ relevant species

$I_{\text {desired product }}=$ Peak intensity of labeled protein,

$\mathrm{I}_{\text {all relevant species }}=$ The sum of the peak intensities of protein and labeled protein in the deconvoluted mass spectra.

Method A (Column: Acquity UPLC, Protein BEH C4 300, $1.7 \mu \mathrm{M}, 2.1 \times 50 \mathrm{~mm}$, flow rate $0.2 \mathrm{ml} / \mathrm{min}$ )

\begin{tabular}{|c|c|c|}
\hline Time (min) & $\mathbf{H}_{\mathbf{2}} \mathbf{O}(\boldsymbol{\%})$ & Acetonitrile: $\mathrm{H}_{2} \mathbf{O}(\mathbf{7 1 : 2 9 ,} \mathbf{\% )}$ \\
\hline 0 & 72 & 28 \\
\hline 12 & 28.8 & 71.2 \\
\hline 13 & 0 & 100 \\
\hline 16 & 0 & 100 \\
\hline 16.5 & 72 & 100 \\
\hline 20 & 72 & 28 \\
\hline
\end{tabular}

Method B (Column: Acquity UPLC, BEH C18 $1.7 \mu \mathrm{M}, 2.1 \times 50 \mathrm{~mm}$, flow rate 0.2 $\mathrm{ml} / \mathbf{m i n})$

\begin{tabular}{|c|c|c|}
\hline Time (min) & $\mathbf{H}_{2} \mathbf{O}(\boldsymbol{\%})$ & Acetonitrile: $\mathrm{H}_{2} \mathbf{O}(\mathbf{7 1 : 2 9 ,} \mathbf{\% )}$ \\
\hline 0 & 100 & 0 \\
\hline 5 & 100 & 0 \\
\hline 10 & 50 & 50 \\
\hline 15 & 0 & 100 \\
\hline 16 & 100 & 0 \\
\hline 20 & 100 & 0 \\
\hline
\end{tabular}

\section{LC-MS/MS}

All LC-MS/MS experiments were performed using a Dionex Ultimate 3000 RSLC nanoUPLC (Thermo Fisher Scientific Inc, Waltham, MA, USA) system and a QExactive Orbitrap mass spectrometer (Thermo Fisher Scientific Inc, Waltham, MA, USA). Separation of peptides was performed by reverse-phase chromatography at a flow rate of $300 \mathrm{~nL} / \mathrm{min}$ and a Thermo Scientific reverse-phase nano Easy-spray column (Thermo Scientific PepMap C18, $2 \mu \mathrm{m}$ particle size, 100A pore size, $75 \mu \mathrm{m}$ i.d. x 50cm length). Peptides were loaded onto a pre-column (Thermo Scientific 
PepMap $100 \mathrm{C} 18,5 \mu \mathrm{m}$ particle size, 100A pore size, $300 \mu \mathrm{m}$ i.d. x $5 \mathrm{~mm}$ length) from the Ultimate 3000 autosampler with $0.1 \%$ formic acid for 3 minutes at a flow rate of $10 \mu \mathrm{L} / \mathrm{min}$. After this period, the column valve was switched to allow elution of peptides from the pre-column onto the analytical column. Solvent A was water + $0.1 \%$ formic acid and solvent $\mathrm{B}$ was $80 \%$ acetonitrile, $20 \%$ water $+0.1 \%$ formic acid. The linear gradient employed was $2-40 \%$ B in 30 minutes. Wash and re-equilibration steps were then performed, and the total LC-MS/MS time was 60 minutes.

The LC eluant was sprayed into the mass spectrometer by means of an Easy-spray source (Thermo Fisher Scientific Inc.). All $\mathrm{m} / \mathrm{z}$ values of eluting ions were measured in an Orbitrap mass analyzer, set at a resolution of 70000. Data dependent scans (Top 20) were employed to automatically isolate and generate fragment ions by higher energy collisional dissociation (HCD) in the quadrupole mass analyser and measurement of the resulting fragment ions was performed in the Orbitrap analyser, set at a resolution of 17500 . Peptide ions with charge states of $2+$ and above were selected for fragmentation.

Post-run, all data were converted to mgf files and these were submitted to the Mascot search algorithm (Matrix Science, London UK) and searched against a custom database containing the ubiquitin sequence and a common contaminant database (125 sequences; 41129 residues) and applying a fixed modification of cabamidomethyl (C) and variable modifications of oxidation (M), deamidation (NQ) and a custom modification of $176 \mathrm{Da}(\mathrm{S} / \mathrm{T})$, using a peptide tolerance of $5 \mathrm{ppm}$ for both MS and MS/MS data. Peptide identifications were accepted if they could be established at greater than $99.0 \%$ probability. In addition, a minimum of 3 spectral counts was required, peptides were rejected if a modified site was adjacent to an arginine or lysine residue without a missed-cleavage occurring and finally, MS/MS data were manually inspected as a final quality control check.

\section{D. ${ }^{31}$ P NMR}

All ${ }^{31} \mathrm{P}$ NMR spectra were acquired on a Brucker AMX-400 instrument using $\mathrm{P}(=\mathrm{O})(\mathrm{OPh})_{3}$ as an internal standard (referenced at $\left.-17.7 \mathrm{ppm}\right)$. 


\section{General Procedure A for the Synthesis of $\Psi$-modules (P(V)-X)}

Protocol adapted from: K. W. Knouse, J. N. deGruyter, M. A. Schmidt, B. Zheng, J. C. Vantourout, C. Kingston, S. E. Mercer, I. M. McDonald, R. E. Olson, Y. Zhu, C. Hang,

J. Zhu, C. Yuan, Q. Wang, P. Park, M. D. Eastgate and P. S. Baran, Science, 2018, 361, 1234.

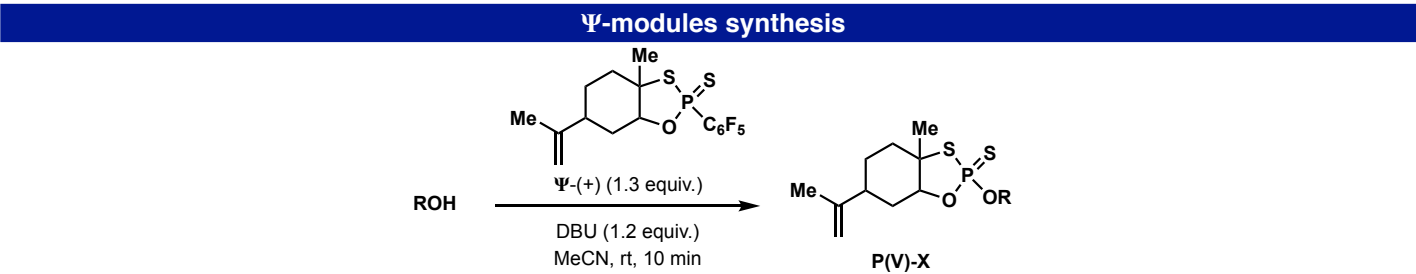

The $\Psi$-modules were prepared as follow unless otherwise stated. Alcohol (1.0 equiv) and (+)- $\Psi$ (1.3 equiv) were dissolved in anhydrous $\mathrm{MeCN}(0.1 \mathrm{M})$ in a flame-dried round-bottom flask. DBU (1.2 equiv) was added dropwise to the reaction mixture while stirring. After 5-10 minutes, the crude reaction mixture was diluted with EtOAc or $\mathrm{Et}_{2} \mathrm{O}$ and transferred to a separatory funnel. The organic layer was washed with $\mathrm{H}_{2} \mathrm{O}$, saturated aqueous $\mathrm{KH}_{2} \mathrm{PO}_{4}$ and brine. After drying over $\mathrm{MgSO}_{4}$ and filtration, the solvent was removed in vacuo. The crude product was purified by silica gel column chromatography unless otherwise stated to afford the $\mathbf{P}(\mathbf{V})-\mathbf{X}$ product. 


\section{General Procedure B for Solid Phase Peptide Synthesis (SPPS)}

\section{Methods for peptide synthesis}

HPLC analysis were conducted on a Waters Autopurification LC with a Waters XBridge C18 column $(4.6 \times 150 \mathrm{~mm}, 3.5 \mathrm{~mm})$. Fractionation was triggered by a Waters QDa single quadruple mass spec in $\mathrm{ESI}^{+}$single ion or $\mathrm{ESI}^{-}$single ions recoding modes. UV detection was monitored at $261 \mathrm{~nm}$.

Solvent A: 0.1 M aqueous triethylammonium acetate Solvent B: acetonitrile

$$
1.5 \mathrm{~mL} / \mathrm{min}, 25^{\circ} \mathrm{C} \text {. }
$$

Gradient: 5-90\% B over 12 minutes

Preparative HPLC were conducted on the same instrument as above and were based on the HPLC analysis using the methods describe below:

\section{RT: Method: \%B:}

0-2 min Narrow 0 5-20\%B

2-4 min Narrow 1 10-25\%B

4-5 min Narrow 2 15-35\%B

5-6 min Narrow $325-45 \% B$

6-7 min Narrow 4 35-55\%B

7-8 min Narrow $545-65 \% \mathrm{~B}$

8-9 min Narrow $655-75 \% \mathrm{~B}$

9-11 min Narrow $765-95 \%$ B 


\section{Materials}

Protocol adapted from: Kawamata, Y.; Vantourout, J. C.; Hickey, D. P.; Bai, P.; Chen, L.; Hou, Q.; Qiao, W.; Barman, K.; Edwards, M. A.; Garrido-Castro, A. F.; deGruyter, J. N.; Nakamura, H.; Knouse, K.; Qin, C.; Clay, K. J.; Bao, D.; Li, C.; Starr, J. T.; Garcia-Irizarry, C.; Sach, N.; White, H. S.; Neurock, M.; Minteer, S. D.; Baran, P. S. Electrochemically Driven, Ni-Catalyzed Aryl Amination: Scope, Mechanism, and Applications. J. Am. Chem. Soc. 2019, 141, 6392.

Commercial materials were used as received unless otherwise noted. Amino acids and coupling reagents were obtained from Novabiochem or Combi-blocks. Rink amide resin was purchased from Chem Impex $(0.8 \mathrm{mmol} / \mathrm{g})$. Solid-phase reaction vessels and pressure caps were purchased from Torviq. An Innova 2000 portable platform shaker (operating at 145-170 rpm) was used for the general mixing and agitation of solid-phase reactions.

\section{Solid phase peptide synthesis}

\section{Preloading Rink Amide resin}

Rink amide resin $(1.0$ equiv, substitution $=0.8 \mathrm{mmol} / \mathrm{g})$ was swollen in dry DCM for 10 min then washed with DCM (5 x $3 \mathrm{~mL})$ and DMF $(5 \times 3 \mathrm{~mL})$. The Fmoc group was deprotected upon treatment with $20 \%$ piperidine/DMF ( $3 \mathrm{~mL}, 2 \times 3 \mathrm{~min}$ ) and the resin washed with DMF (5 x $3 \mathrm{~mL})$, DCM $(5 \times 3 \mathrm{~mL})$ and DMF $(5 \times 3 \mathrm{~mL})$. A solution of Fmoc-AA-OH (4.0 equiv), PyBOP or PyAOP (4.0 equiv) and $N$-methylmorpholine (NMM) (8.0 equiv) in DMF (final concentration of $0.1 \mathrm{M}$ with respect to the resin) was added and the resin agitated on an orbital shaker at $\mathrm{rt}$ for 2-3h. The resin was washed with DMF (5 x $3 \mathrm{~mL})$, DCM $(5 \times 3 \mathrm{~mL})$, and DMF $(5 \times 3 \mathrm{~mL})$ and capped with a solution of acetic anhydride/pyridine $(1: 9 \mathrm{v} / \mathrm{v}, 3 \mathrm{~mL})$ for $10 \mathrm{~min}$. The resin was washed with DMF ( $5 \times 3 \mathrm{~mL})$, DCM ( $5 \times 3 \mathrm{~mL})$, and DMF (5 x $3 \mathrm{~mL})$ and subsequently submitted to iterative peptide assembly (Fmoc-SPPS). 


\section{Estimation of amino acid loading}

The loading efficiency was evaluated through treatment of the resin with $20 \%$ piperidine/DMF ( $3 \mathrm{~mL}, 2 \times 3 \mathrm{~min})$ to deprotect the Fmoc group. The combined deprotection solutions were diluted to $10 \mathrm{~mL}$ with 20\% piperidine/DMF. An aliquot of this mixture $(50 \mu \mathrm{L})$ was diluted 200 -fold with $20 \%$ piperidine/DMF and the UV absorbance of the piperidine-fulvene adduct was measured $\left(\lambda=301 \mathrm{~nm}, \varepsilon=7800 \mathrm{M}^{-1}\right.$ $\mathrm{cm}^{-1}$ ) to quantify the amount of amino acid loaded onto the resin. The theoretical maximum for the reported yields of all isolated peptides are based on the numerical value obtained from the resin loading.

\section{General iterative peptide assembly (Fmoc-SPPS)}

Peptides were elongated using iterative Fmoc-solid-phase peptide synthesis (Fmoc-SPPS), according to the following general protocols:

Deprotection: The resin was treated with 20\% piperidine/DMF ( $3 \mathrm{~mL}, 2 \times 3 \mathrm{~min})$ and washed with DMF (5 x $3 \mathrm{~mL}), \mathrm{DCM}(5 \times 3 \mathrm{~mL})$ and DMF (5 x $3 \mathrm{~mL})$.

General amino acid coupling: A preactivated solution of protected amino acid (4 equiv), PyBOP (4 equiv), and N-methylmorpholine (NMM) (8 equiv) in DMF (final concentration $0.1 \mathrm{M}$ ) was added to the resin. After $1 \mathrm{~h}$, the resin was washed with $\operatorname{DMF}(5 \times 3 \mathrm{~mL}), \operatorname{DCM}(5 \times 3 \mathrm{~mL})$ and DMF $(5 \times 3 \mathrm{~mL})$.

Capping: Acetic anhydride/pyridine $(1: 9 \mathrm{v} / \mathrm{v})$ was added to the resin $(3 \mathrm{~mL})$. After 3 min the resin was washed with DMF ( $5 \times 3 \mathrm{~mL}), \mathrm{DCM}(5 \times 3 \mathrm{~mL})$ and DMF $(5 \times 3$ $\mathrm{mL})$.

Cleavage: A mixture of $\mathrm{TFA} / \mathrm{i} \operatorname{Pr}_{3} \mathrm{SiH} /$ water $(90: 5: 5 \mathrm{v} / \mathrm{v} / \mathrm{v}, 3 \mathrm{~mL})$ was added to the resin. After $2 \mathrm{~h}$, the resin was washed with TFA ( $3 \times 2 \mathrm{~mL})$ and DCM $(3 \times 2 \mathrm{~mL})$. 
Work-up: The combined cleavage solution and TFA and DCM washes were concentrated under a stream of nitrogen. The residue was treated with cold $\mathrm{Et}_{2} \mathrm{O}$ to precipitate the crude peptide. The peptide was collected by centrifugation $(3000 \mathrm{x} g, 5$ min) and the crude residue was used directly in the activation step. 


\section{Synthesis of $\Psi$-modules $(\mathrm{P}(\mathrm{V})-\mathrm{X})$}

\section{Synthesis of $P(V)-1$}<smiles>C=C(C)C1CCC2(C)SP(=S)(OCCCCCCNC(=O)OCc3ccccc3)OC2C1</smiles>

Prepared according to General Procedure A using:

tert-butyl (6-hydroxyhexyl)carbamate (10.0 g, $46.0 \mathrm{mmol}),(+)-\Psi(26.7 \mathrm{~g}, 59.6 \mathrm{mmol})$ and DBU $(8.31 \mathrm{~mL}, 55.2 \mathrm{mmol})$ in anhydrous $\mathrm{MeCN}(460 \mathrm{~mL})$. The crude mixture was purified by flash chromatography (30\% EtOAc in hexanes) to afford $\mathbf{P}(\mathbf{V})-\mathbf{1}$ (15.1 g, $32.7 \mathrm{mmol}, 71 \%)$.

Physical State: Colorless Oil.

$\mathbf{R}_{f}=0.28$ (30\% EtOAc in Hexanes).

${ }^{1}$ H NMR (600 MHz, Acetone-d $\left.d_{6}\right): \delta 5.90(\mathrm{~s}, 1 \mathrm{H}), 5.02(\mathrm{~d}, J=1.5 \mathrm{~Hz}, 1 \mathrm{H}), 4.93(\mathrm{dd}, J$ $=2.0,0.9 \mathrm{~Hz}, 1 \mathrm{H}), 4.54-4.35(\mathrm{~m}, 1 \mathrm{H}), 4.22-4.03(\mathrm{~m}, 2 \mathrm{H}), 3.13-3.00(\mathrm{~m}, 2 \mathrm{H})$, $2.66(\mathrm{~d}, J=6.2 \mathrm{~Hz}, 1 \mathrm{H}), 2.28(\mathrm{ddd}, J=13.3,3.7,1.7 \mathrm{~Hz}, 1 \mathrm{H}), 2.14-2.05(\mathrm{~m}, 2 \mathrm{H})$, $2.02-1.93(\mathrm{~m}, 3 \mathrm{H}), 1.92-1.84(\mathrm{~m}, 1 \mathrm{H}), 1.81(\mathrm{~d}, J=1.2 \mathrm{~Hz}, 3 \mathrm{H}), 1.68(\mathrm{~m}, 5 \mathrm{H}), 1.50$ (m, 2H), $1.45-1.32(\mathrm{~m}, 12 \mathrm{H})$.

${ }^{13}$ C NMR (151 MHz, Acetone-d $\left.d_{6}\right): \delta$ 156.8, 146.7, 112.1, 86.6, 78.4, 69.4, 69.3, 66.4, $60.7,41.2,40.0,34.8,34.7,31.0,30.9,28.8,28.4,28.3,27.2,26.3,24.1,23.0,22.1$, 21.0, 14.7 .

${ }^{31}$ P NMR (162 MHz, Acetone-d $\left.d_{6}\right): \delta 102.1$.

HRMS (ESI-TOF): calcd. for $\mathrm{C}_{21} \mathrm{H}_{49} \mathrm{NO}_{4} \mathrm{PS}_{2}[\mathrm{M}+\mathrm{H}]^{+} 464.2858$; found 464.2851. 
Synthesis of P(V)-2a<smiles>C#CCCCOP1(=S)OC2CC(C(=C)C)CCC2(C)S1</smiles>

Prepared according to General Procedure A using:

pent-4-yn-1-ol (1.26 g, $15.0 \mathrm{mmol}),(+)-\Psi(8.70 \mathrm{~g}, 19.5 \mathrm{mmol})$ and DBU (2.71 mL, $18.0 \mathrm{mmol})$ in anhydrous $\mathrm{MeCN}(150 \mathrm{~mL})$. The crude mixture was purified by flash chromatography (15-20\% DCM in hexanes) to afford P(V)-2a (4.56 g, $13.8 \mathrm{mmol}$, $92 \%)$.

Physical State: Colorless Oil.

$\mathbf{R}_{\boldsymbol{f}}=0.46$ (50\% DCM in Hexanes).

${ }^{1}$ H NMR (600 MHz, Chloroform-d): $\delta 5.01$ (q, $\left.J=1.5 \mathrm{~Hz}, 1 \mathrm{H}\right), 4.90-4.86(\mathrm{~m}, 1 \mathrm{H})$, $4.44(\mathrm{dt}, J=12.7,3.3 \mathrm{~Hz}, 1 \mathrm{H}), 4.32-4.25(\mathrm{~m}, 1 \mathrm{H}), 4.27-4.20(\mathrm{~m}, 1 \mathrm{H}), 2.58(\mathrm{t}, J=$ $6.4 \mathrm{~Hz}, 1 \mathrm{H}), 2.30(\mathrm{qd}, J=8.4,7.7,2.3 \mathrm{~Hz}, 3 \mathrm{H}), 2.11(\mathrm{td}, J=13.5,4.3 \mathrm{~Hz}, 1 \mathrm{H}), 1.99-$ $1.84(\mathrm{~m}, 6 \mathrm{H}), 1.80-1.72(\mathrm{~m}, 4 \mathrm{H}), 1.70(\mathrm{~s}, 3 \mathrm{H})$.

${ }^{13}$ C NMR (151 MHz, Chloroform-d): $\delta$ 144.6, 111.3, 85.2, 82.3, 68.7, 66.8, 64.9, $38.4,33.3,28.5,27.3,23.0,22.2,21.2,14.5$.

${ }^{31}$ P NMR (162 MHz, Chloroform-d): $\delta$ 101.3.

HRMS (ESI-TOF): calcd. for $\mathrm{C}_{15} \mathrm{H}_{24} \mathrm{O}_{2} \mathrm{PS}_{2}[\mathrm{M}+\mathrm{H}]^{+}$331.0955; found 331.0949. 
Synthesis of $P(V)-2 b$<smiles>C#CCCCCOP1(=S)OC2CC(C(=C)C)CCC2(C)S1(=O)=S</smiles>

Prepared according to General Procedure A using:

hex-5-yn-1-ol (0.44 mL, $4.00 \mathrm{mmol}),(+)-\Psi(2.3 \mathrm{~g}, 5.2 \mathrm{mmol})$ and DBU (0.72 mL, $4.80 \mathrm{mmol})$ in anhydrous $\mathrm{MeCN}(40 \mathrm{~mL})$. The crude mixture was purified by flash chromatography (20:1 hexanes/Et $2 \mathrm{O})$ to afford $\mathbf{P}(\mathbf{V})-\mathbf{2 b}(1.19 \mathrm{~g}, 3.44 \mathrm{mmol}, 86 \%)$.

Physical State: Colorless oil.

$\mathbf{R}_{\boldsymbol{f}}=0.33(10: 1$ hexanes/Et $2 \mathrm{O}) ; \mathrm{UV}, \mathrm{KMnO}_{4}$.

${ }^{1}$ H NMR (600 MHz, Chloroform-d): $\delta 5.00$ (s, 1H), 4.87 (s, 1H), 4.44 (dt, $J=12.8$, $3.2 \mathrm{~Hz}, 1 \mathrm{H}), 4.24-4.13(\mathrm{~m}, 2 \mathrm{H}), 2.58(\mathrm{~s}, 1 \mathrm{H}), 2.32-2.27(\mathrm{~m}, 1 \mathrm{H}), 2.24(\mathrm{td}, J=7.0$, $2.6 \mathrm{~Hz}, 2 \mathrm{H}), 2.11(\mathrm{td}, J=13.5,4.2 \mathrm{~Hz}, 1 \mathrm{H}), 1.95$ (tq, $J=4.2,2.0 \mathrm{~Hz}, 2 \mathrm{H}), 1.92-1.80$ (m, 4H), $1.78(\mathrm{~s}, 3 \mathrm{H}), 1.77-1.72(\mathrm{~m}, 1 \mathrm{H}), 1.70(\mathrm{~s}, 3 \mathrm{H}), 1.62$ (p, J=7.2 Hz, 2H).

${ }^{13}$ C NMR (151 MHz, Chloroform-d): $\delta$ 145.2, 111.9, 85.7, 83.9, 68.9, 68.4, 65.4, $39.0,33.9,29.2,27.9,24.7,23.6,22.8,21.8,18.1$.

${ }^{31}$ P NMR (162 MHz, Chloroform-d): $\delta$ 101.2.

HRMS (ESI-TOF): calcd. for $\mathrm{C}_{16} \mathrm{H}_{26} \mathrm{O}_{2} \mathrm{PS}_{2}[\mathrm{M}+\mathrm{H}]^{+}$345.1112; found 345.1110. 
Synthesis of $P(V)-3$<smiles>[Y4]C12CCC(C(=C)C)CC1OP(=S)(OCC1OC(n3cc(C)c(=O)[nH]c3=O)C[C@@H]1N)S2</smiles>

Prepared according to General Procedure A using:

1-((2R,4S,5S)-4-azido-5-(hydroxymethyl)tetrahydrofuran-2-yl)-5-methylpyrimidine-2 ,4(1H,3H)-dione (1.34 g, $5.0 \mathrm{mmol}),(+)-\Psi(2.90 \mathrm{~g}, 59.6 \mathrm{mmol})$ and DBU (0.90 mL, 6 mmol) in anhydrous $\mathrm{MeCN}(50 \mathrm{~mL})$. The crude mixture was purified by flash chromatography (25\% EtOAc in hexanes) to afford P(V)-3 (2.08 g, $4.05 \mathrm{mmol}, 81 \%)$. Physical State: White amorphous solid.

$\mathbf{R}_{\boldsymbol{f}}=0.21(25 \%$ EtOAc in hexanes $)$.

${ }^{1}$ H NMR (600 MHz, Acetone-d $d_{\text {) }}: \delta 10.03(\mathrm{~s}, 1 \mathrm{H}), 7.50$ (q, $\left.J=1.3 \mathrm{~Hz}, 1 \mathrm{H}\right), 6.24(\mathrm{t}, J=$ $6.7 \mathrm{~Hz}, 1 \mathrm{H}), 4.97(\mathrm{~m}, 1 \mathrm{H}), 4.91(\mathrm{~m}, 1 \mathrm{H}), 4.59-4.32(\mathrm{~m}, 4 \mathrm{H}), 4.17(\mathrm{~m}, 1 \mathrm{H}), 2.70-2.62$ (m, 1H), $2.54-2.41(\mathrm{~m}, 2 \mathrm{H}), 2.33-2.23(\mathrm{~m}, 1 \mathrm{H}), 2.09$ (td, $J=13.5,4.4 \mathrm{~Hz}, 1 \mathrm{H}), 2.04$ $-1.83(\mathrm{~m}, 7 \mathrm{H}), 1.78(\mathrm{dt}, J=1.5,0.8 \mathrm{~Hz}, 3 \mathrm{H}), 1.71(\mathrm{~s}, 3 \mathrm{H})$.

${ }^{13}$ C NMR (151 MHz, Acetone-d $)$ ): $\delta$ 164.3, 151.3, 151.2, 146.6, 136.4, 112.1, 111.4, 87.2, 85.8, 83.13, 83.1, 68.8, 68.7, 67.1, 62.4, 39.9, 37.7, 34.6, 34.6, 29.6, 28.4, 28.3, $24.1,22.9,22.1,12.9,12.9$.

${ }^{31}$ P NMR (162 MHz, Acetone- $\left.d_{6}\right): \delta$ 103.5.

HRMS (ESI-TOF): calcd. for $\mathrm{C}_{20} \mathrm{H}_{29} \mathrm{~N}_{5} \mathrm{O}_{5} \mathrm{PS}_{2}[\mathrm{M}+\mathrm{H}]^{+}$514.1348; found 514.1352. 


\section{Synthesis of $P(V)-4$}

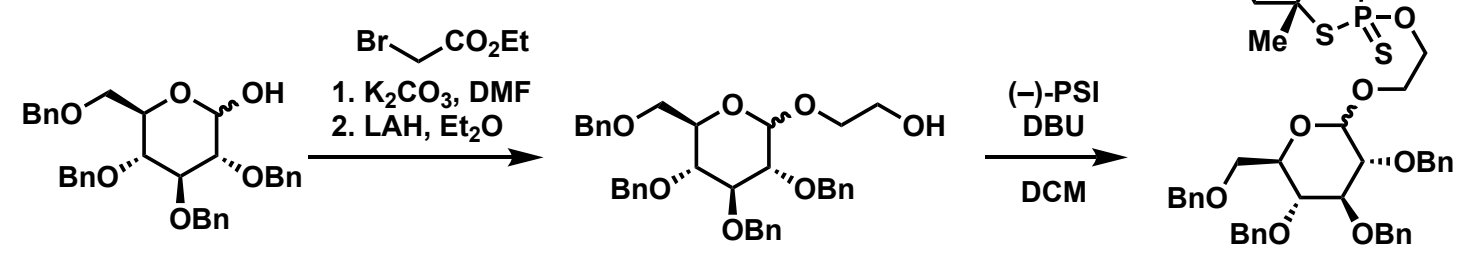

Prepared according to General Procedure A using:

Tetrabenzyl Glucose (0.54 g, $1.0 \mathrm{mmol}, 1$ equiv) was dissolved in DMF (10 mL), to this was added Ethyl Bromoacetate $\left(0.22 \mathrm{~g}, 1.30 \mathrm{mmol}, 1.3\right.$ equiv) and $\mathrm{K}_{2} \mathrm{CO}_{3}(0.276$ g, $2.0 \mathrm{mmol}, 2.0$ equiv) and the reaction was stirred overnight at room temperature. The reaction was diluted with EtOAc $(100 \mathrm{~mL})$ and washed consecutively with water $(3 \times 10 \mathrm{~mL})$ and brine $(3 \times 10 \mathrm{~mL})$. The oragnic layer was dried $\left(\mathrm{MgSO}_{4}\right)$ filtered and concentrated. The crude product was dissolved in THF $(10 \mathrm{~mL})$ and cooled to $0^{\circ} \mathrm{C}$, lithium aluminum hydride ( $0.16 \mathrm{~g}, 4.0 \mathrm{mmol}, 4$ equiv) was added in portions. The reaction was allowed to warm to room temperature overnight. The reaction was quenched by the addition of sodium sulfate heptahydrate (excess), filtered and concentrated to a clear oil $(0.48 \mathrm{~g})$.

The module was prepared according to General Procedure A using ( $0.48 \mathrm{~g}, 0.82$ mmol), (-)- $\Psi(0.476 \mathrm{~g}, 1.06 \mathrm{mmol})$ and DBU $(0.15 \mathrm{~mL}, 0.98 \mathrm{mmol})$ in anhydrous THF $(8 \mathrm{~mL})$. The crude mixture was purified by flash chromatography $(75-100 \%$ DCM in hexanes) to afford P(V)-4 (0.48 g, 58\%).

Physical State: Colorless oil.

$\mathbf{R}_{f}=0.16(75 \%$ DCM in hexanes $)$.

${ }^{1}$ H NMR (600 MHz, Acetone-d $)$ ): $\delta 7.41$ - 7.10 (m, 20H), $5.01-4.86$ (m, 3H), 4.85 $4.75(\mathrm{~m}, 5 \mathrm{H}), 4.75-4.58(\mathrm{~m}, 2 \mathrm{H}), 4.55(\mathrm{q}, J=11.0,10.4 \mathrm{~Hz}, 1 \mathrm{H}), 4.52-4.33(\mathrm{~m}, 5 \mathrm{H})$, $4.32-4.10(\mathrm{~m}, 1 \mathrm{H}), 3.99(\mathrm{t}, J=9.3 \mathrm{~Hz}, 1 \mathrm{H}), 3.88-3.79(\mathrm{~m}, 2 \mathrm{H}), 3.78-3.54(\mathrm{~m}, 5 \mathrm{H})$, $3.50-3.42(\mathrm{~m}, 1 \mathrm{H}), 2.52(\mathrm{dt}, J=22.6,6.0 \mathrm{~Hz}, 1 \mathrm{H}), 2.24(\mathrm{ddt}, J=13.5,3.6,1.8 \mathrm{~Hz}, 1 \mathrm{H})$, $2.04(\mathrm{tt}, J=13.5,3.8 \mathrm{~Hz}, 1 \mathrm{H}), 1.93-1.79(\mathrm{~m}, 3 \mathrm{H}), 1.74-1.68(\mathrm{~m}, 7 \mathrm{H})$. 
${ }^{13}$ C NMR (151 MHz, CDCl $): \delta$ 144.53, 138.44, 138.18, 137.96, 137.91, 137.78, $137.67,137.65,137.51,128.13,128.08,128.04,127.99,127.94,127.92,127.83$, $127.75,127.70,127.52,127.50,127.48,127.46,127.44,127.41,127.36,127.31$, 127.23, 127.20, 127.18, 127.15, 127.12, 111.39, 103.43, 96.91, 85.51, 85.45, 85.32, $84.13,81.50,81.36,79.36,77.26,77.06,75.27,75.23,74.59,74.57,74.43,74.30$ 73.99, 73.08, 73.06, 72.85, 72.65, 70.64, 70.23, 69.91, 68.39, 67.96, 67.88, 67.83, $66.91,66.86,66.71,66.66,66.15,66.10,64.87,64.81,38.45,38.39,33.27,33.21$, 27.36, 27.28, 27.26, 27.18, 22.92, 22.90, 22.23, 22.21, 21.27, 21.24.

${ }^{31}$ P NMR (162 MHz, CDCl 3 ): $\delta$ 102.1, 101.9.

HRMS (ESI-TOF): calcd. for $\mathrm{C}_{46} \mathrm{H}_{56} \mathrm{O}_{8} \mathrm{PS}_{2}[\mathrm{M}+\mathrm{H}]^{+}$831.3154; found 831.3138. 


\section{Serine Coupling: Optimization}

\section{Synthesis of Compound 2}

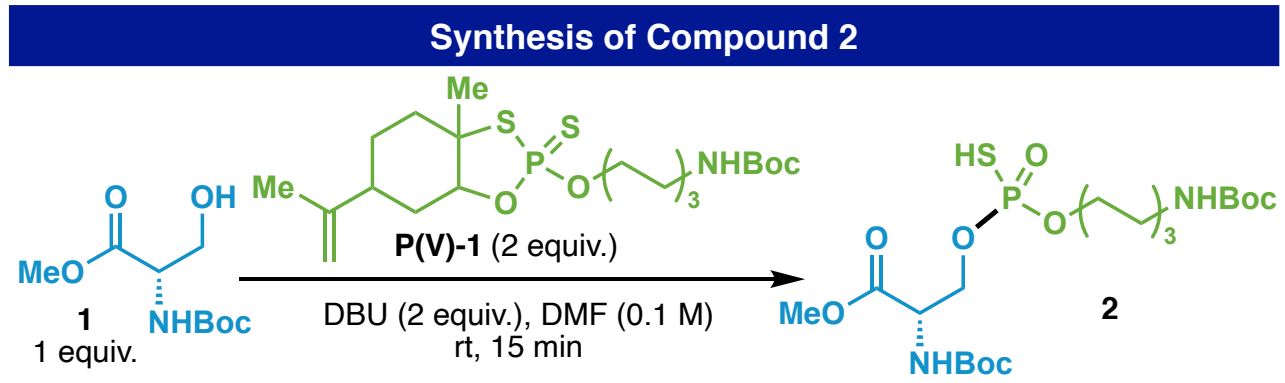

Serine amino acid 1 (22 mg, $0.1 \mathrm{mmol}, 1.0$ equiv) and $\mathbf{P}(\mathbf{V})-1$ (93 mg, $0.2 \mathrm{mmol}, 2$ equiv) were dissolved in DMF ( $1 \mathrm{~mL}, 0.1 \mathrm{M})$ in a $3 \mathrm{~mL}$ HPLC vial. DBU $(30 \mu \mathrm{L}, 0.2$ mmol, 2.0 equiv) was added to the reaction mixture at room temperature while stirring. After 15 minutes, the crude reaction mixture was analyzed by ${ }^{31} \mathrm{P}$ NMR to calculate the conversion using $\mathrm{P}(\mathrm{O})(\mathrm{OPh})_{3}$ as an internal standard. Then the crude mixture was dissolved in EtOAc (4 mL). The organic phase was washed with a $20 \%$ citric acid solution $(1 \times 5 \mathrm{~mL})$, brine $(2 \times 4 \mathrm{~mL})$, and was dried over $\mathrm{Na}_{2} \mathrm{SO}_{4}$. The solvent was removed in vacuo and the crude mixture was purified by silica gel column chromatography $(9: 1, \mathrm{EtOAc} / \mathrm{MeOH})$ to afford compound 2 (35 mg, 0.07 mmol, 69\%) yield.

Physical State: Colorless Oil.

$\mathbf{R}_{\boldsymbol{f}}=0.26(10 \% \mathrm{MeOH}$ in EtOAc).

${ }^{31}$ P NMR (162 MHz, DMF-d): $\delta$ 57.6.

${ }^{31}$ P NMR-coupled (162 MHz, DMF- $d$ ): $\delta 57.6(\mathrm{t}, J=11.8 \mathrm{~Hz})$.

HRMS (ESI-TOF): calcd. for $\mathrm{C}_{20} \mathrm{H}_{40} \mathrm{~N}_{2} \mathrm{O}_{9} \mathrm{PS}[\mathrm{M}+\mathrm{H}]^{+}$515.2192; found 515.2189. 


\section{Optimization Table S1 for the Synthesis of Compound 2}

\section{A. Serine Coupling: Optimization}

\begin{tabular}{|c|c|c|}
\hline 1 equiv. & $\begin{array}{l}\text { DBU (2 equiv.), DMF (0.1 M) } \\
\text { rt, } 15 \mathrm{~min}\end{array}$ & 2 \\
\hline entry & deviation from above & NMR yield (\%) \\
\hline 1 & none & 73 (69 isolated) \\
\hline 2 & MeCN instead of DMF & 53 \\
\hline 3 & THF instead of DMF & 50 \\
\hline 4 & $\mathrm{Et}_{3} \mathrm{~N}$ instead of $\mathrm{DBU}$ & n.r \\
\hline 5 & Imidazole instead of DBU & n.r. \\
\hline 6 & DIPEA instead of DBU & n.r. \\
\hline 7 & $\mathrm{~N}$-methyl imidazole instead of DBU & n.r. \\
\hline 8 & 1 equiv. of $P(V)-1$ instead of 2 equiv. & 43 \\
\hline 9 & 1 equiv. of $D B U$ instead of 2 equiv. & 36 \\
\hline 10 & 3 equiv. of DBU instead of 2 equiv. & 65 \\
\hline
\end{tabular}

Yield determined by ${ }^{31} \mathrm{P} N M R$ with $\mathrm{P}(\mathrm{O})(\mathrm{OPh})_{3}$ as an internal standard. 


\section{Competitive experiment between Serine and nucleophilic amino acids}

\section{General Procedure}

\section{B. Competitive Experiments Between Amino Acids}

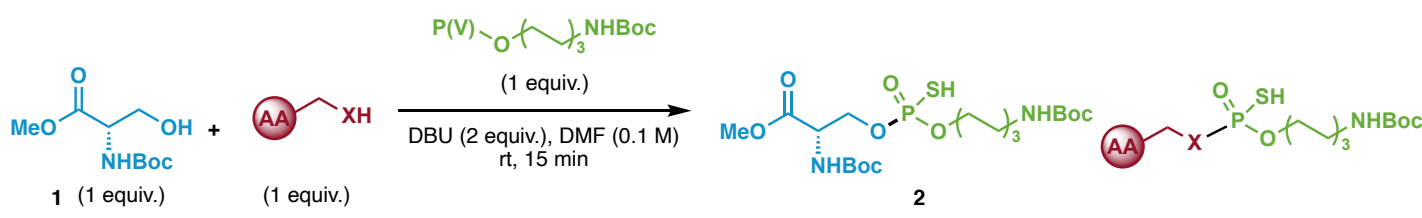

Serine amino acid 1 (22 mg, $0.1 \mathrm{mmol}, 1.0$ equiv), nucleophilic amino acid $\mathbf{X}(0.1$ mmol, 1.0 equiv) and $\mathbf{P}(\mathbf{V})-1$ (46 mg, $0.1 \mathrm{mmol}, 1.0$ equiv) were dissolved in DMF (1 $\mathrm{mL}, 0.1 \mathrm{M})$ in a $3 \mathrm{~mL}$ HPLC vial. DBU ( $30 \mu \mathrm{L}, 0.2 \mathrm{mmol}, 2.0$ equiv) was added to the reaction mixture at room temperature while stirring. After 15 minutes, the crude reaction mixture was analyzed by ${ }^{31} \mathrm{P}$ NMR to calculate the conversion using $\mathrm{P}(\mathrm{O})(\mathrm{OPh})_{3}$ as an internal standard $(0.1 \mathrm{mmol})$. 
Serine vs. Lysine

Compound 2 (Ser)<smiles>COC(=O)NCCCNC(COP(=O)(S)OC(C)(C)C)C(=O)OC</smiles>

${ }^{31}$ P NMR (162 MHz, DMF-d): $\delta$ 56.2.

\section{Compound SI-1 (Lys)}<smiles>COC(=O)C(CCCCNP(=O)(S)OCCNC(=O)OCc1ccccc1)NC(=O)OCc1ccccc1</smiles>

${ }^{31}$ P NMR (162 MHz, DMF- $d$ ): $\delta$ n.a.
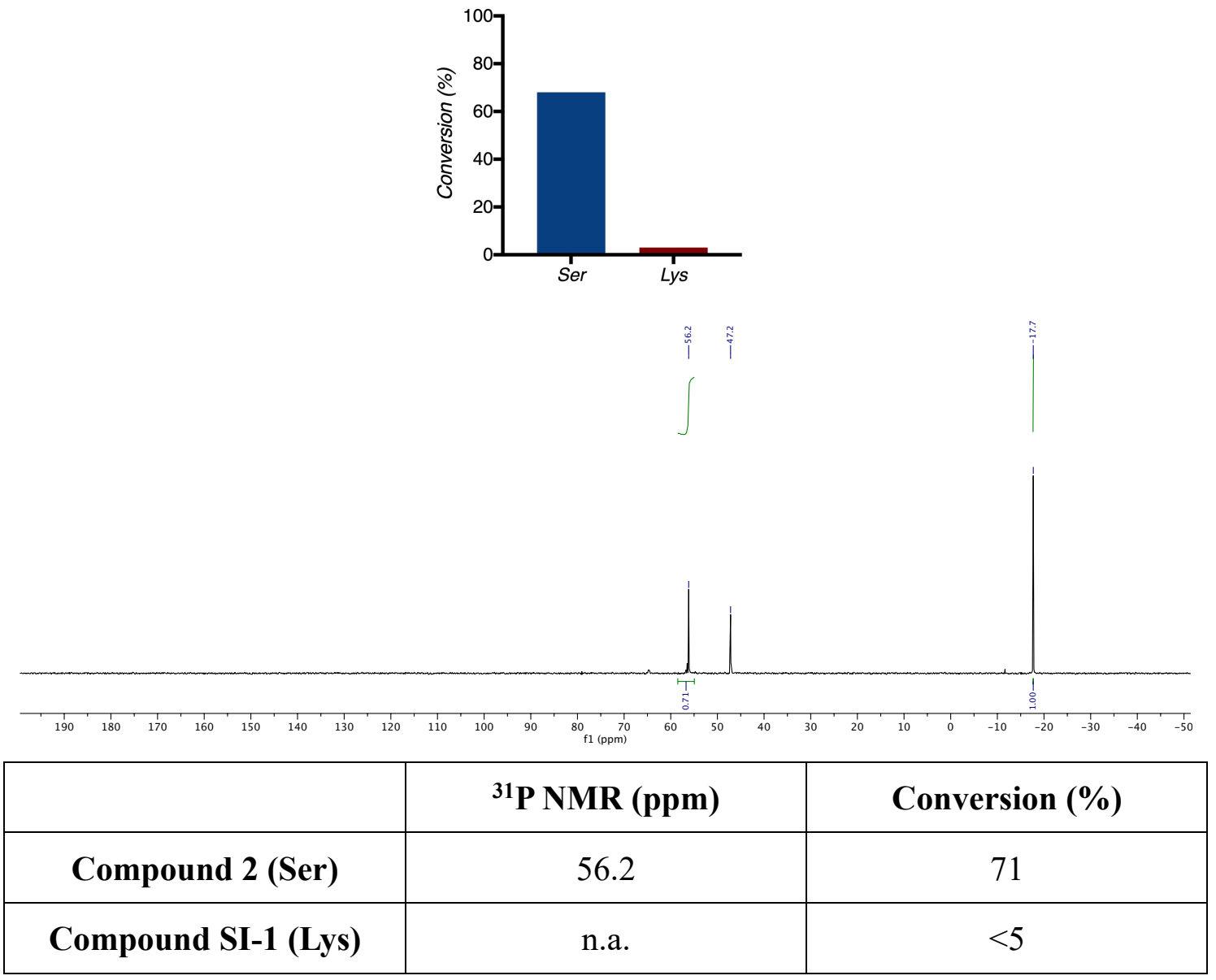
Serine vs. Cysteine

Compound 2 (Ser)

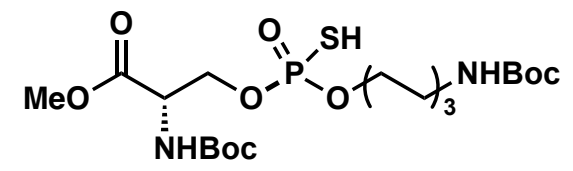

${ }^{31}$ P NMR (162 MHz, DMF-d): $\delta 56.2$.

Compound SI-2 (Cys)

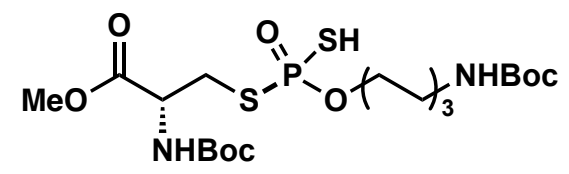

${ }^{31}$ P NMR (162 MHz, DMF-d): $\delta$ n.a.
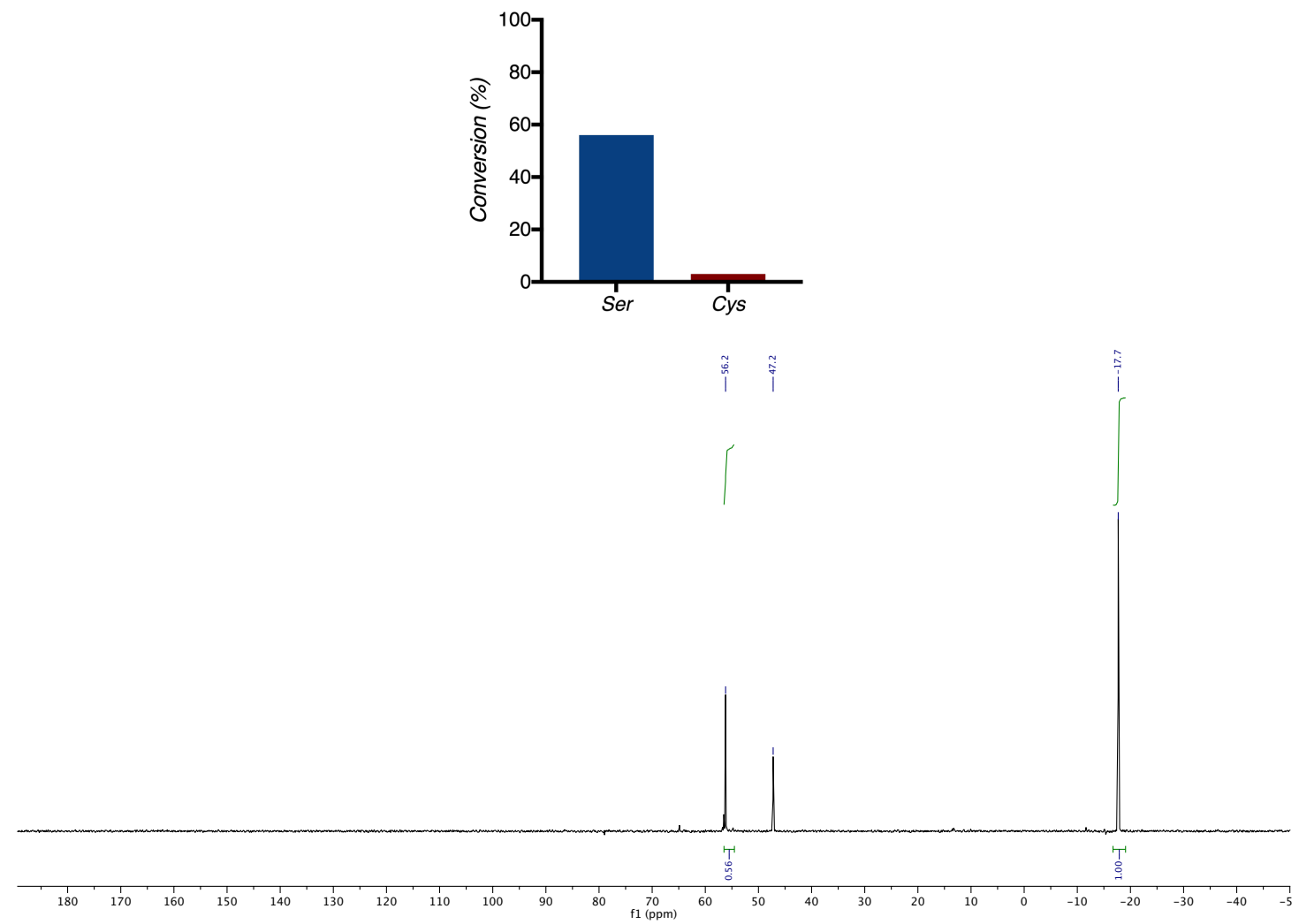

\begin{tabular}{|c|c|c|}
\hline & ${ }^{31}$ P NMR (ppm) & Conversion (\%) \\
\hline Compound 2 (Ser) & 56.2 & 56 \\
\hline Compound SI-2 (Cys) & n.a. & $<5$ \\
\hline
\end{tabular}


Serine vs. Tyrosine

Compound 2 (Ser)

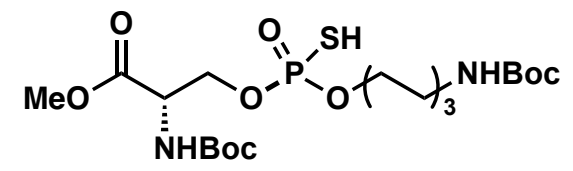

${ }^{31}$ P NMR (162 MHz, DMF-d): $\delta$ 56.1.

Compound SI-3 (Tyr)<smiles>COC(=O)NCCOP(=O)(S)Oc1ccc(C[C@H](NC(=O)OC(C)(C)C)C(=O)OCc2ccccc2)cc1</smiles>

${ }^{31}$ P NMR (162 MHz, DMF-d): $\delta$ n.a.

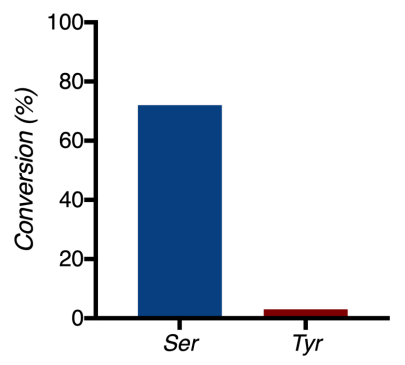

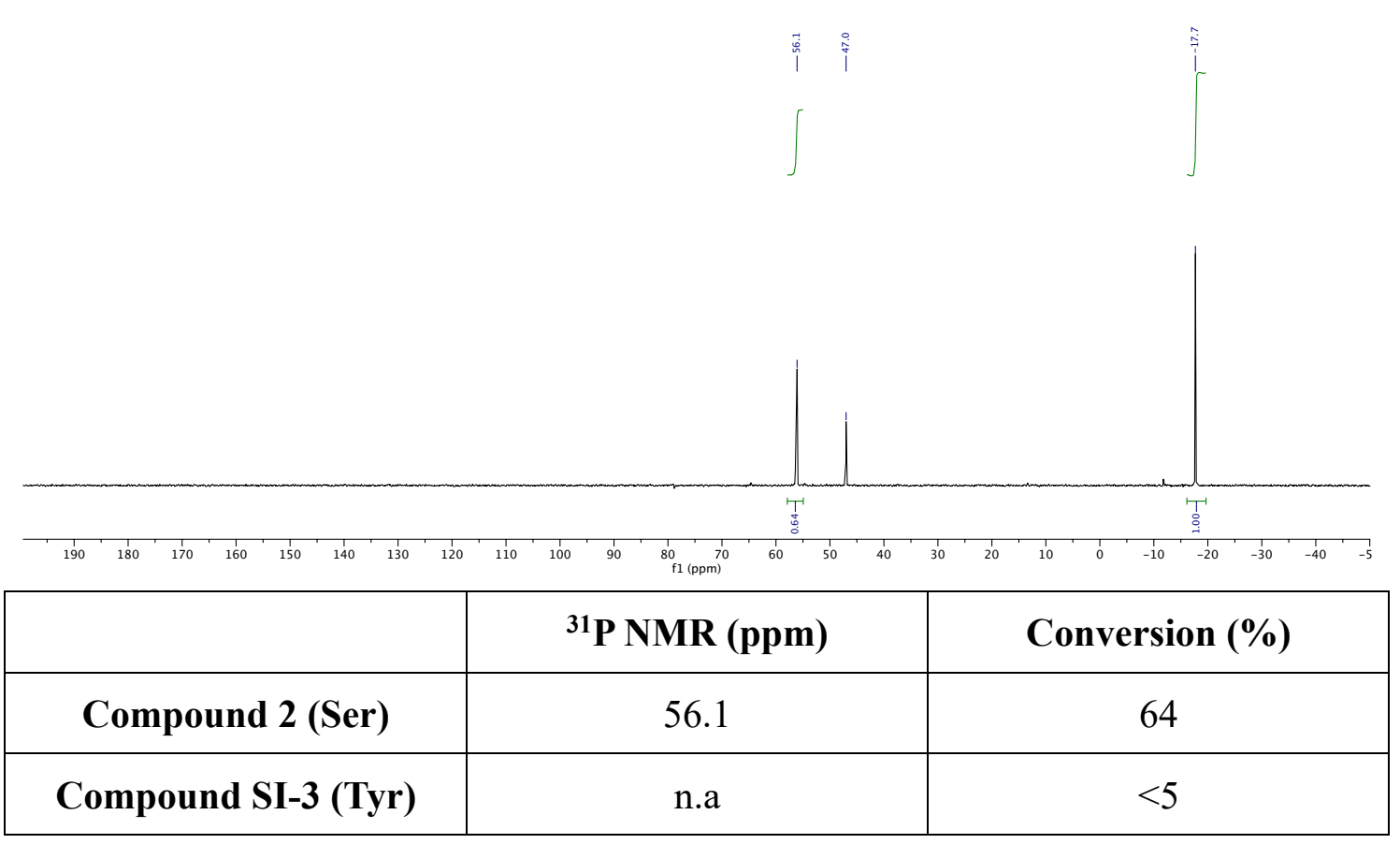


Serine vs. Threonine

Compound 2 (Ser)<smiles>CCCCNC(COP(=O)(S)OCCNC(=O)OCc1ccccc1)C(=O)OC</smiles>

${ }^{31}$ P NMR (162 MHz, DMF-d): $\delta 56.2$.

Compound SI-4 (Thr)

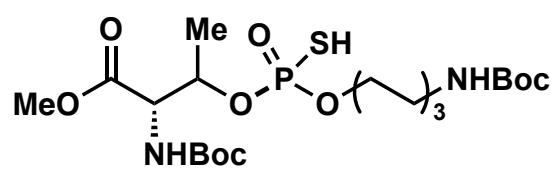

${ }^{31}$ P NMR (162 MHz, DMF- $d$ ): $\delta 56.9$.
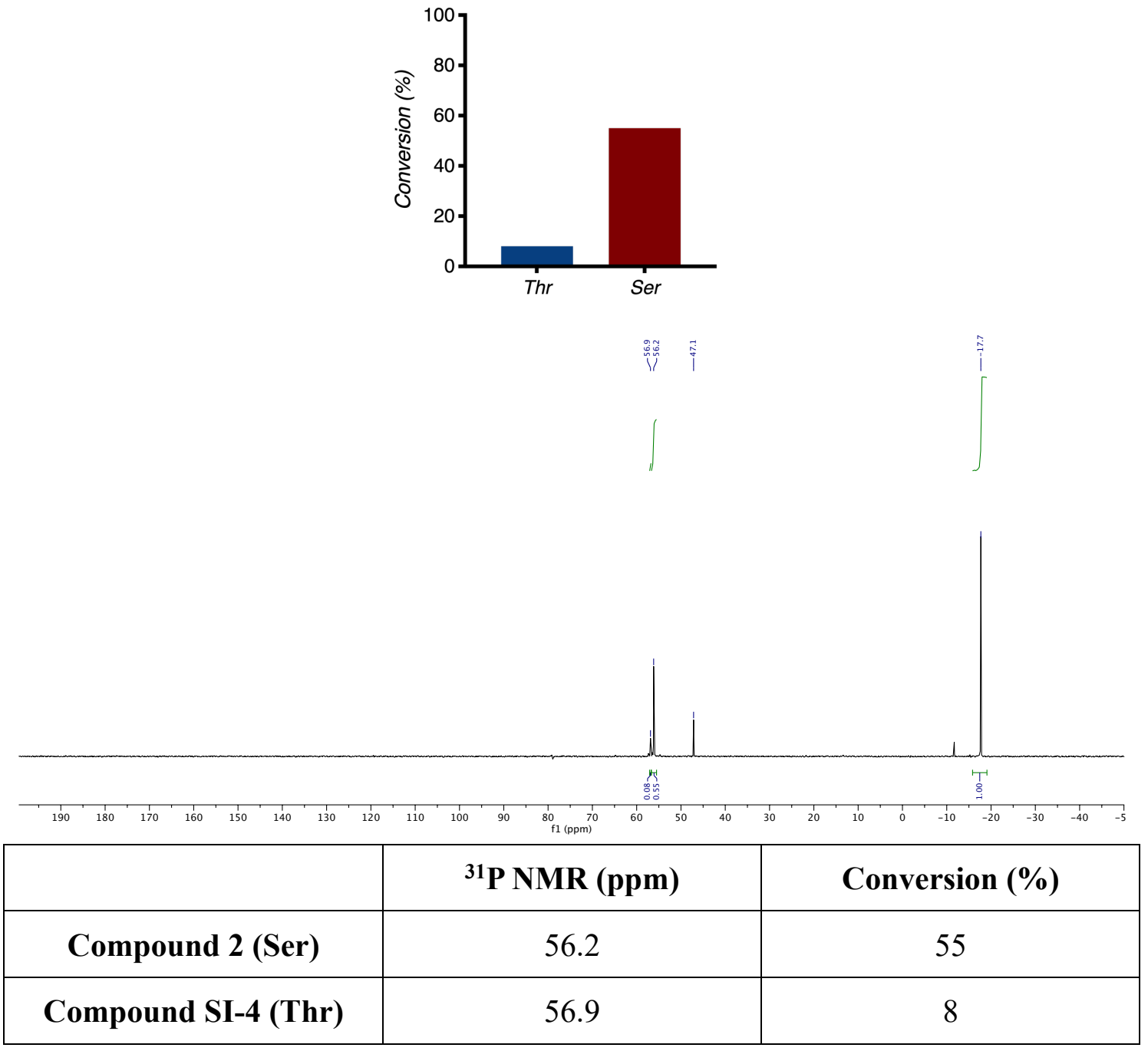
Serine vs. Selenocysteine

Compound 2 (Ser)

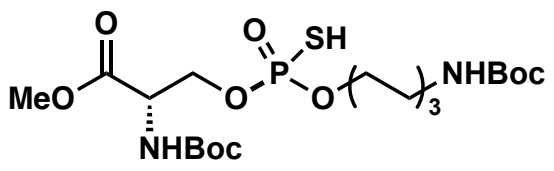

${ }^{31}$ P NMR (162 MHz, DMF-d): $\delta$ 56.2.

Compound SI-5 (Sec)

$\underbrace{\text { NHBoc }}_{\text {NHBoc }}$

${ }^{31}$ P NMR (162 MHz, DMF- $d$ ): $\delta$ n.a.
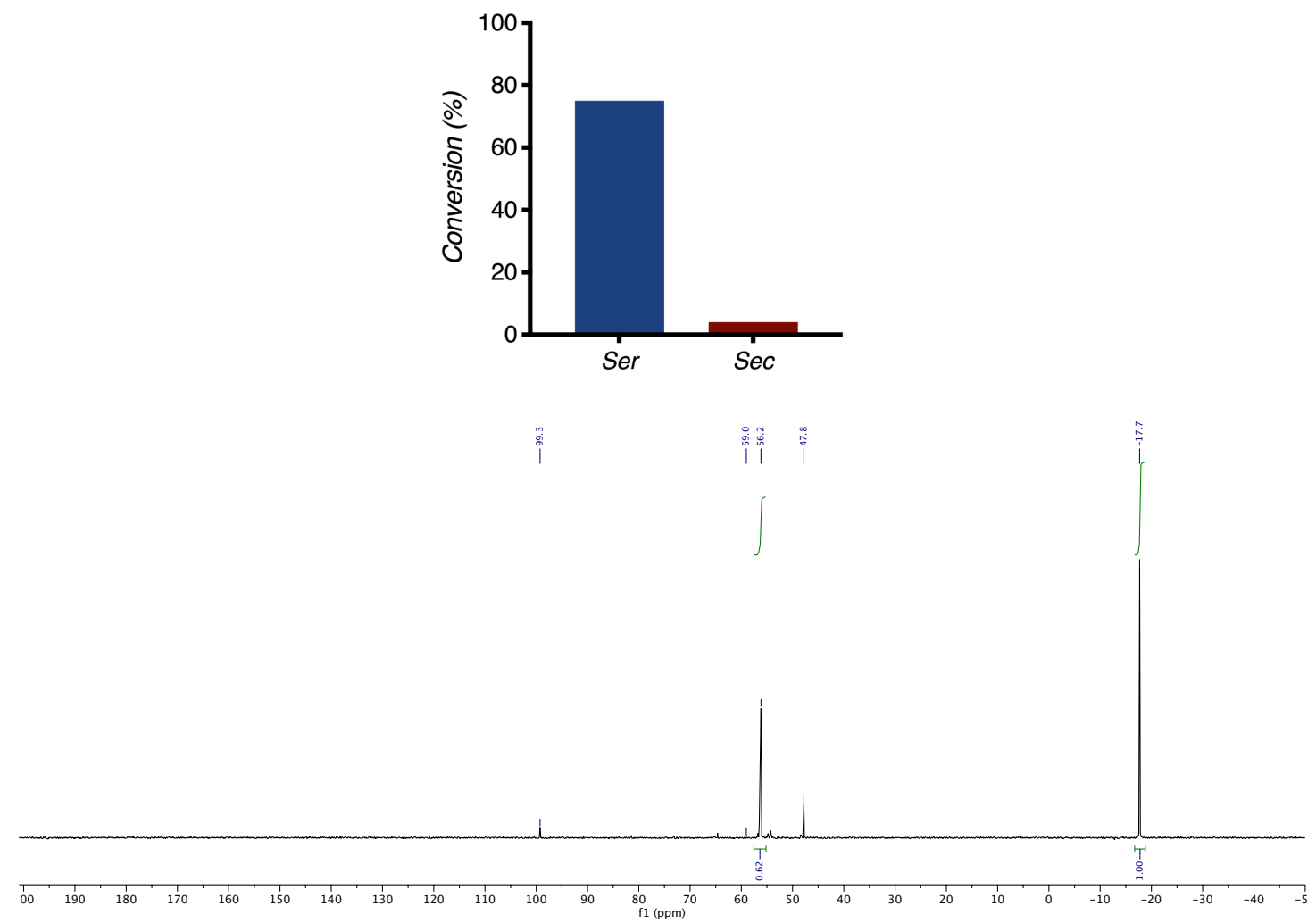

\begin{tabular}{|c|c|c|}
\hline & ${ }^{31}$ P NMR (ppm) & Conversion (\%) \\
\hline Compound 2 (Ser) & 56.2 & 62 \\
\hline Compound SI-5 (Sec) & n.a & $<5 \%$ \\
\hline
\end{tabular}


Competitive experiment between Threonine and nucleophilic amino acids

\section{General Procedure}

Threonine amino acid (23 mg, $0.1 \mathrm{mmol}, 1.0$ equiv), nucleophilic amino acid $\mathbf{X}(0.1$ mmol, 1.0 equiv) and $\mathbf{P ( V ) - 1 ~ ( 4 6 ~ m g , ~} 0.1 \mathrm{mmol}, 1$ equiv) were dissolved in DMF (1 $\mathrm{mL}, 0.1 \mathrm{M})$ in a $3 \mathrm{~mL}$ HPLC vial. DBU $(30 \mu \mathrm{L}, 0.2 \mathrm{mmol}, 2.0$ equiv) was added to the reaction mixture at room temperature while stirring. After 15 minutes, the crude reaction mixture was analyzed by ${ }^{31} \mathrm{P}$ NMR to calculate the conversion using $\mathrm{P}(\mathrm{O})(\mathrm{OPh})_{3}$ as an internal standard $(0.1$ or $0.2 \mathrm{mmol})$. 
Threonine vs. Lysine

Compound SI-4 (Thr)

MeO $\underbrace{\text { Me }}_{\text {NHBoc }}$

${ }^{31}$ P NMR (162 MHz, DMF-d): $\delta$ 56.4.

Compound SI-1 (Lys)<smiles>COC(=O)C(CCCCNP(=O)(S)OCCNC(C)(C)C)NC(=O)OCc1ccccc1</smiles>

${ }^{31}$ P NMR (162 MHz, DMF-d): $\delta$ n.a.
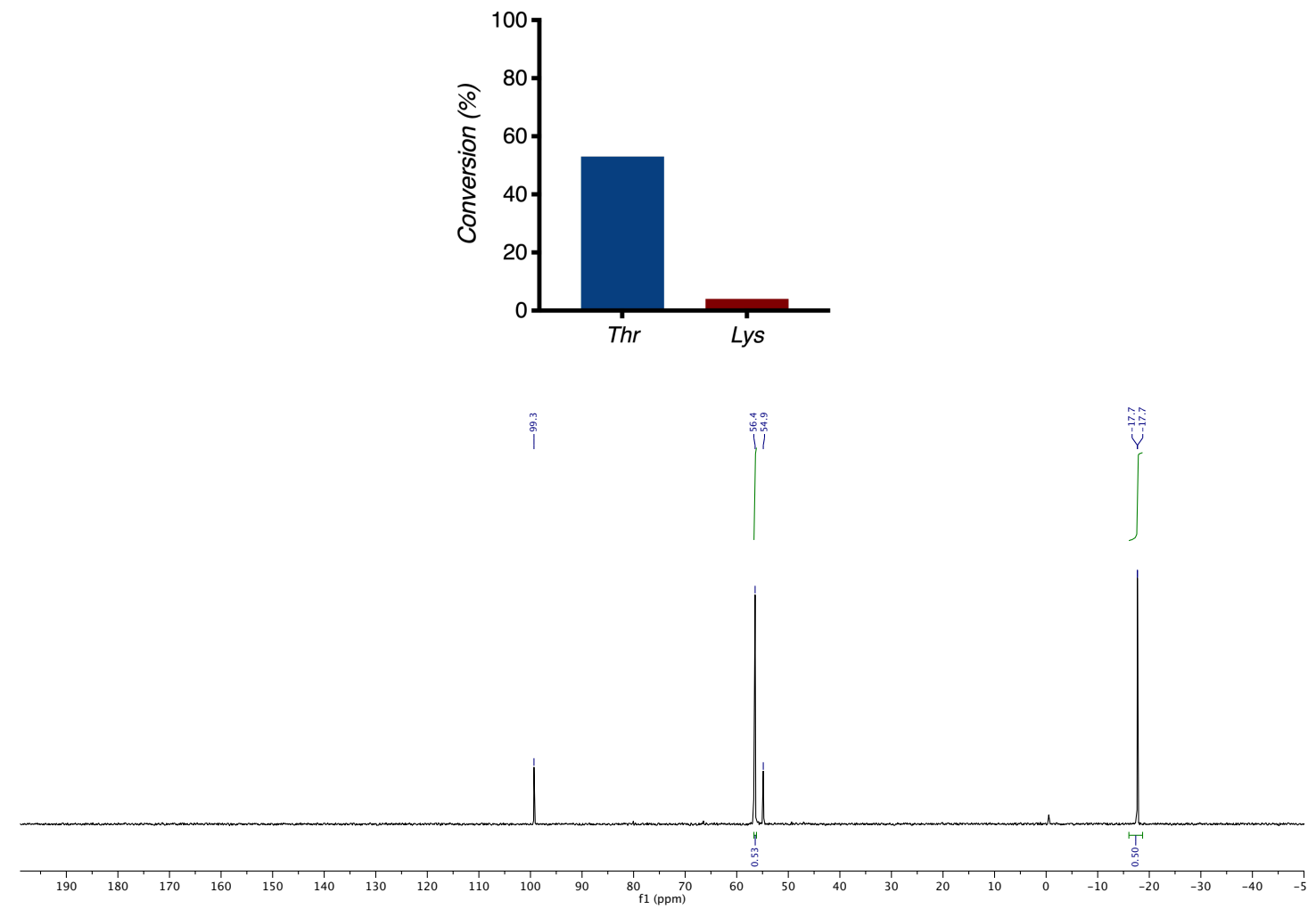

\begin{tabular}{|c|c|c|}
\hline & ${ }^{31}$ P NMR (ppm) & Conversion (\%) \\
\hline Compound 2 (Ser) & 56.4 & 53 \\
\hline Compound SI-1 (Lys) & n.a. & $<5$ \\
\hline
\end{tabular}


Threonine vs. Cysteine

Compound SI-4 (Thr)

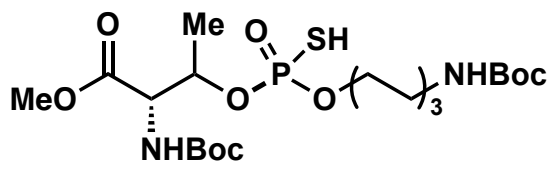

${ }^{31}$ P NMR (162 MHz, DMF-d): $\delta$ 56.4.

Compound SI-2 (Cys)

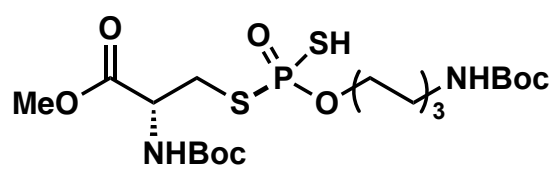

${ }^{31}$ P NMR (162 MHz, DMF-d): $\delta$ n.a.
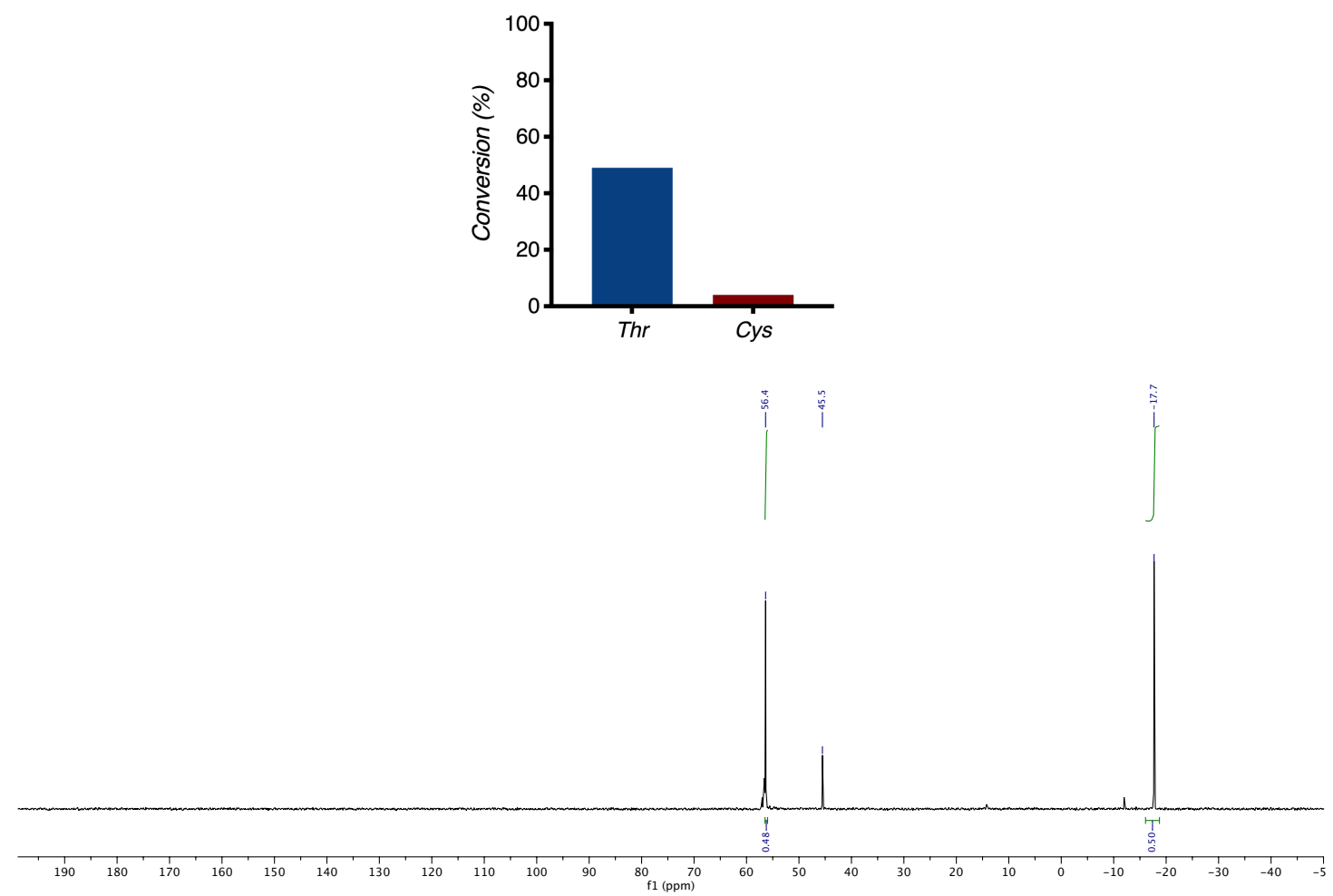

\begin{tabular}{|c|c|c|}
\hline & ${ }^{31}$ P NMR (ppm) & Conversion (\%) \\
\hline Compound 2 (Ser) & 56.4 & 48 \\
\hline Compound SI-2 (Cys) & n.a. & $<5$ \\
\hline
\end{tabular}


Threonine vs. Tyrosine

Compound SI-4 (Thr)

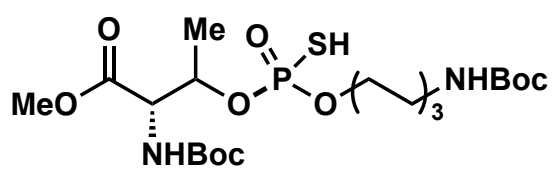

${ }^{31}$ P NMR (162 MHz, DMF-d): $\delta$ 56.4.

Compound SI-3 (Tyr)<smiles>COC(=O)NCCOP(=O)(S)Oc1ccc(C[C@H](NC(=O)OCc2ccccc2)C(=O)OCc2ccccc2)cc1</smiles>

${ }^{31}$ P NMR (162 MHz, DMF- $d$ ): $\delta$ n.a.
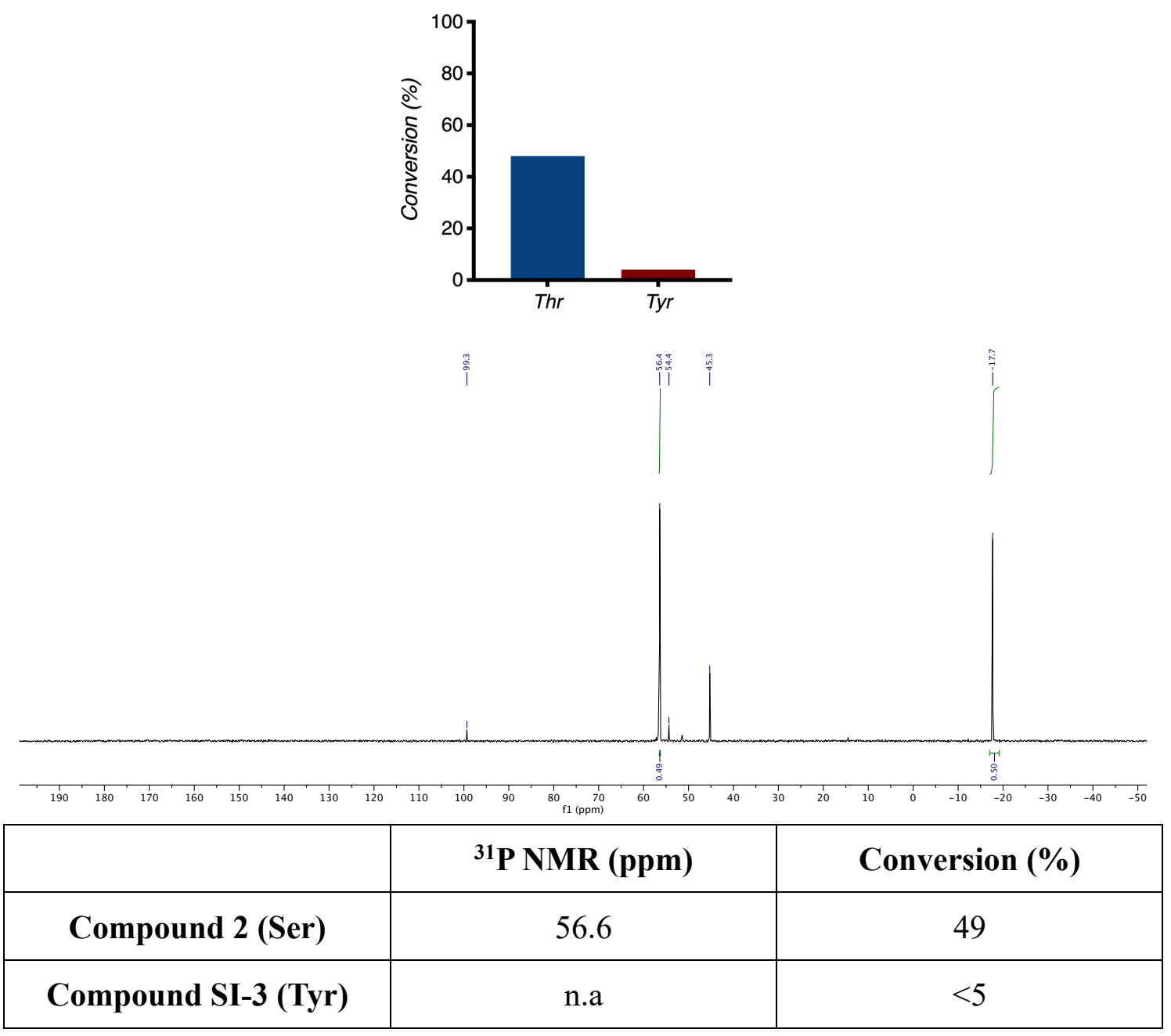
Threonine vs. Selenocysteine

Compound SI-4 (Thr)

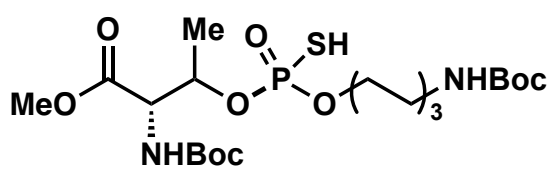

${ }^{31}$ P NMR (162 MHz, DMF-d): $\delta$ 56.4.

Compound SI-5 (Sec)

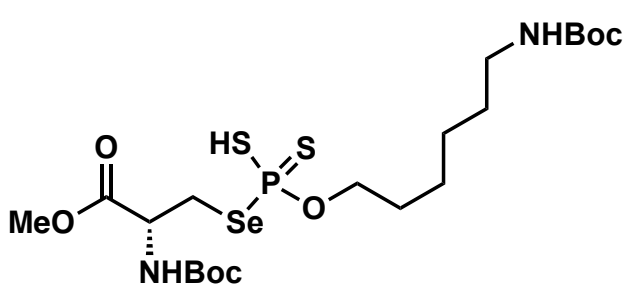

${ }^{31}$ P NMR (162 MHz, DMF- $d$ ): $\delta$ n.a.
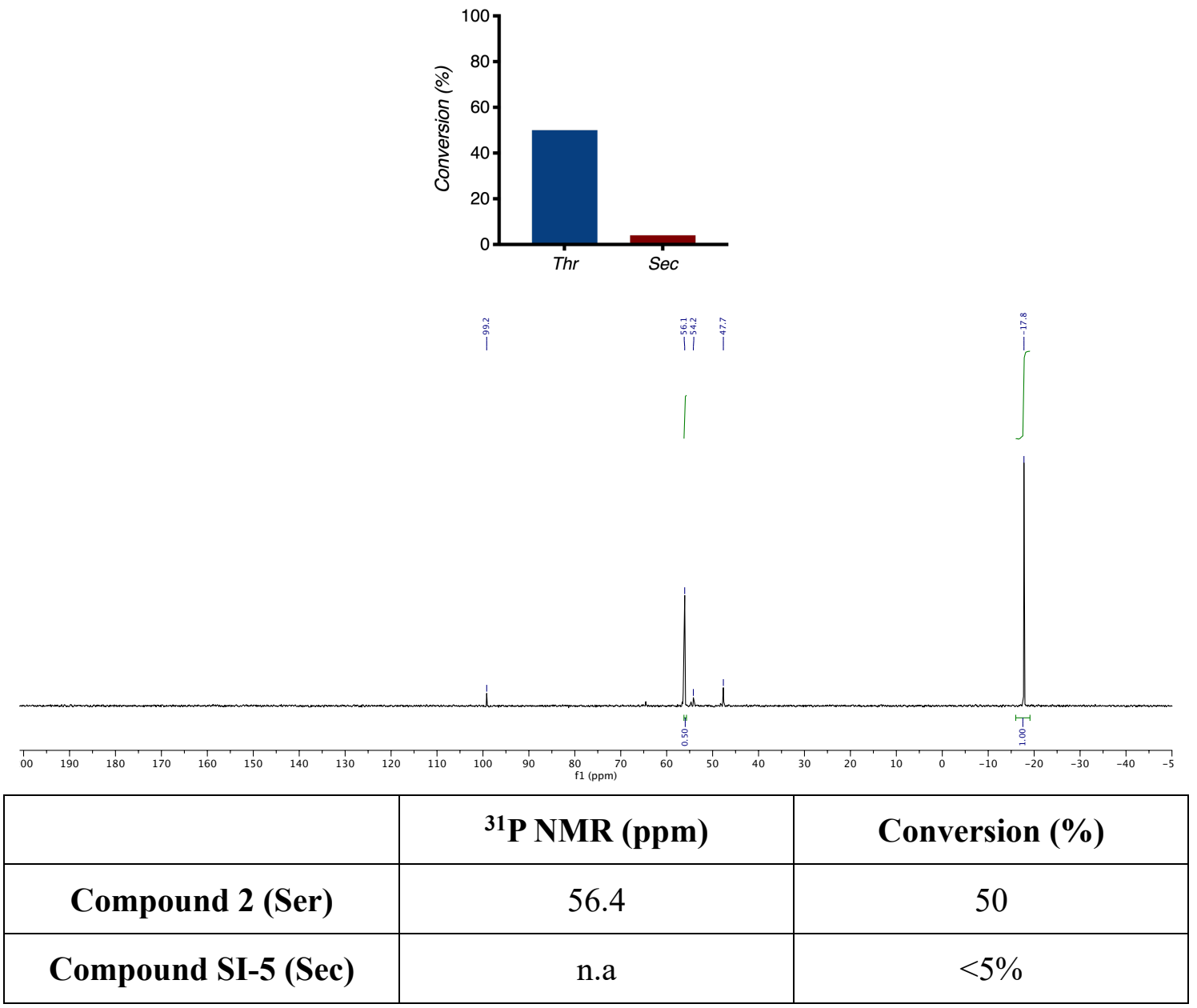


\section{Competitive experiment using tetrapeptide}

\section{Peptide Starting Materials}

The following peptides were used for this study and were prepared following the

General Procedure B (SPPS).

\section{Peptide SI-6}<smiles></smiles>

\begin{tabular}{|c|c|}
\hline LC/MSD TOF Retention time (min) & 0.654 \\
\hline$[2 \mathrm{M}+\mathrm{H}]^{+}\left(\mathrm{ESI}^{+}\right)$ & 1003.8 \\
\hline
\end{tabular}

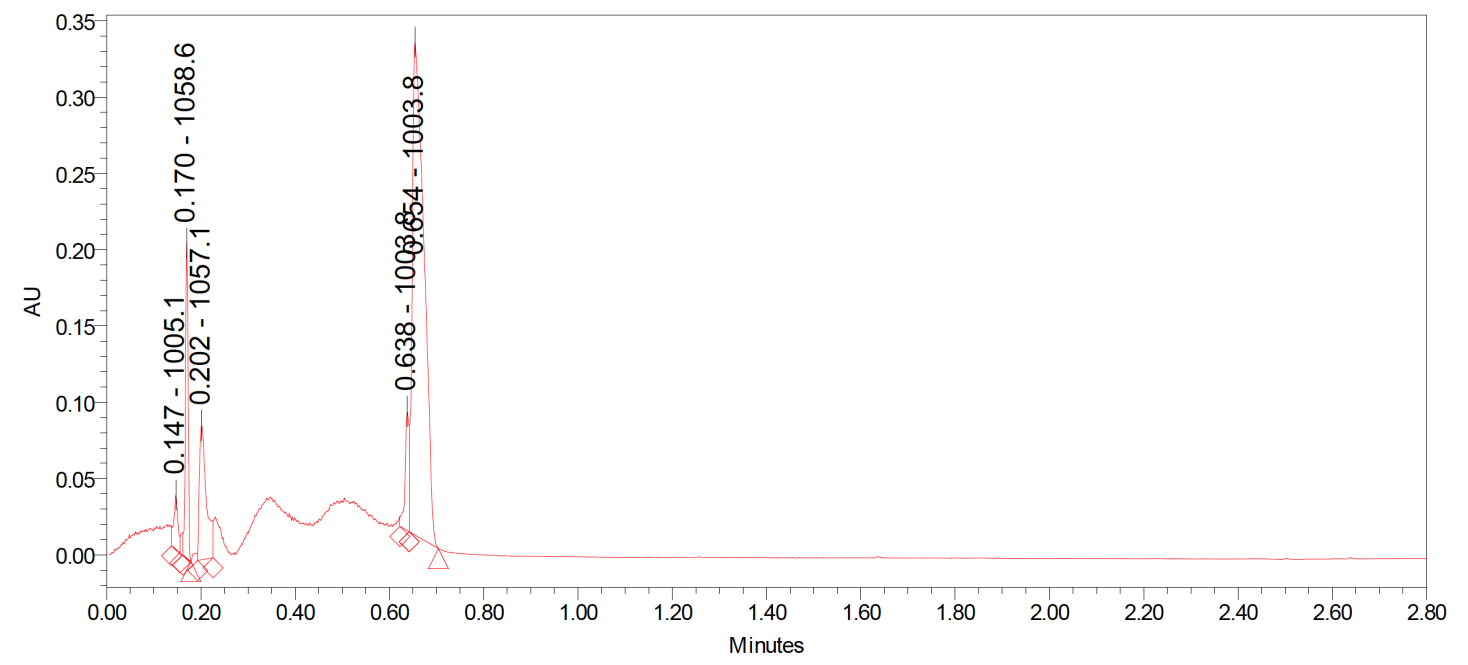

HPLC trace peptide SI-6

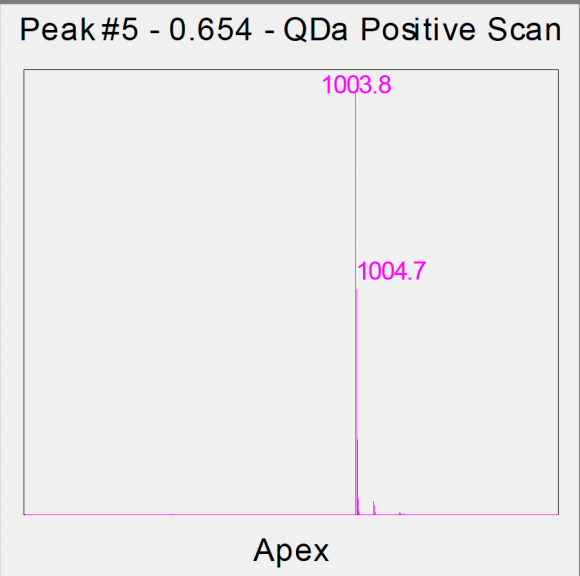

ESI $I^{+}$trace peptide SI-6 
Peptide SI-7

Ac

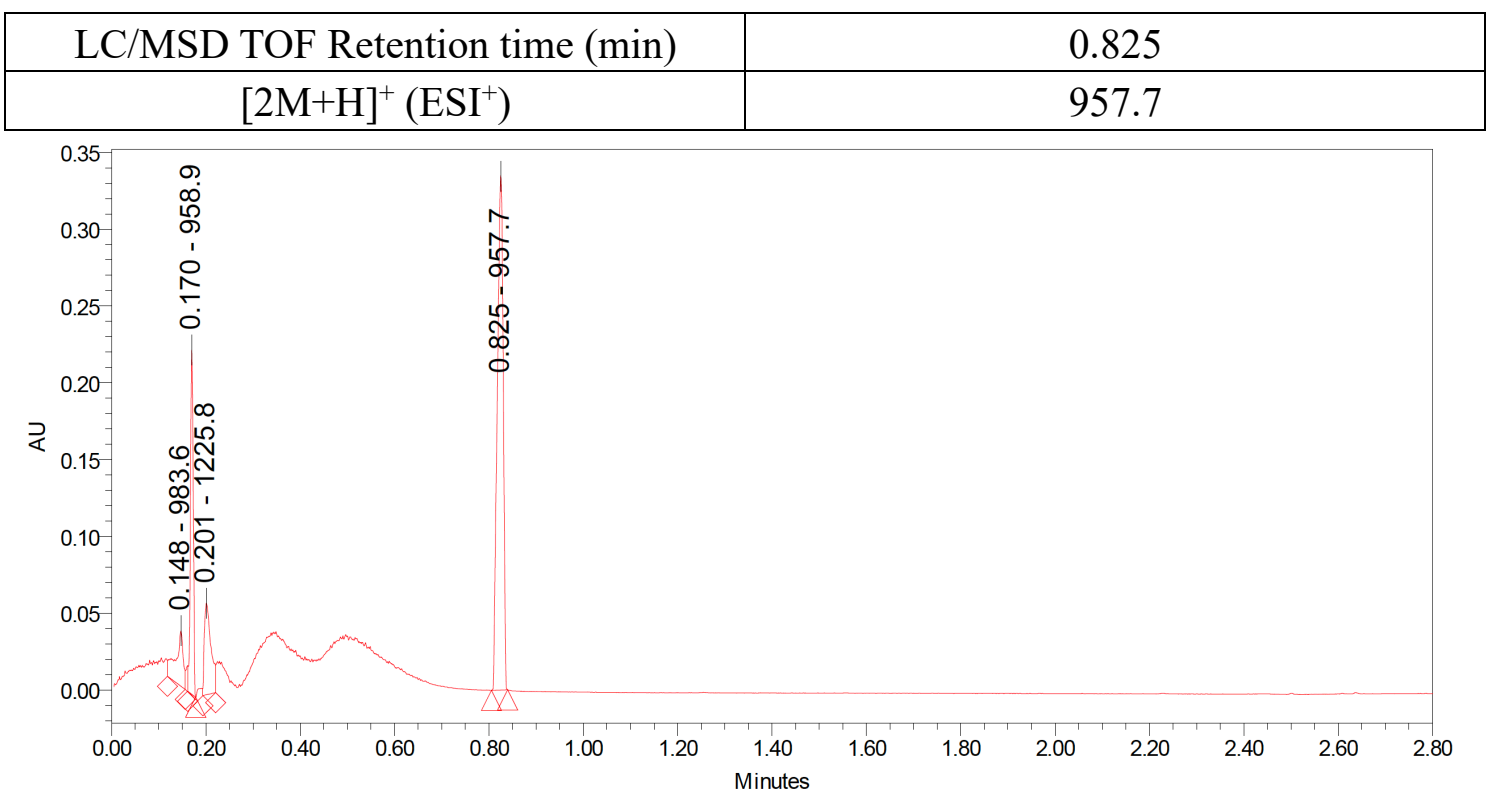

HPLC trace peptide SI-7

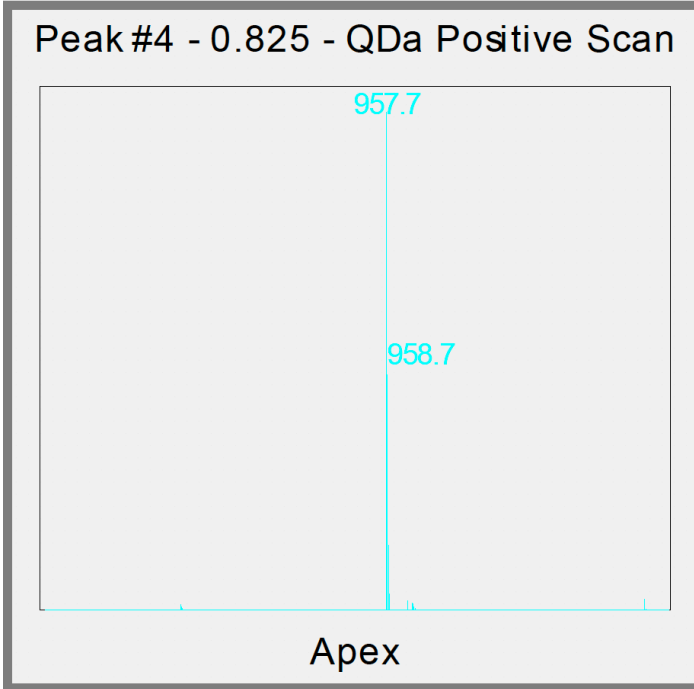

ESI $^{+}$trace peptide SI-7 


\section{Peptide SI-8}

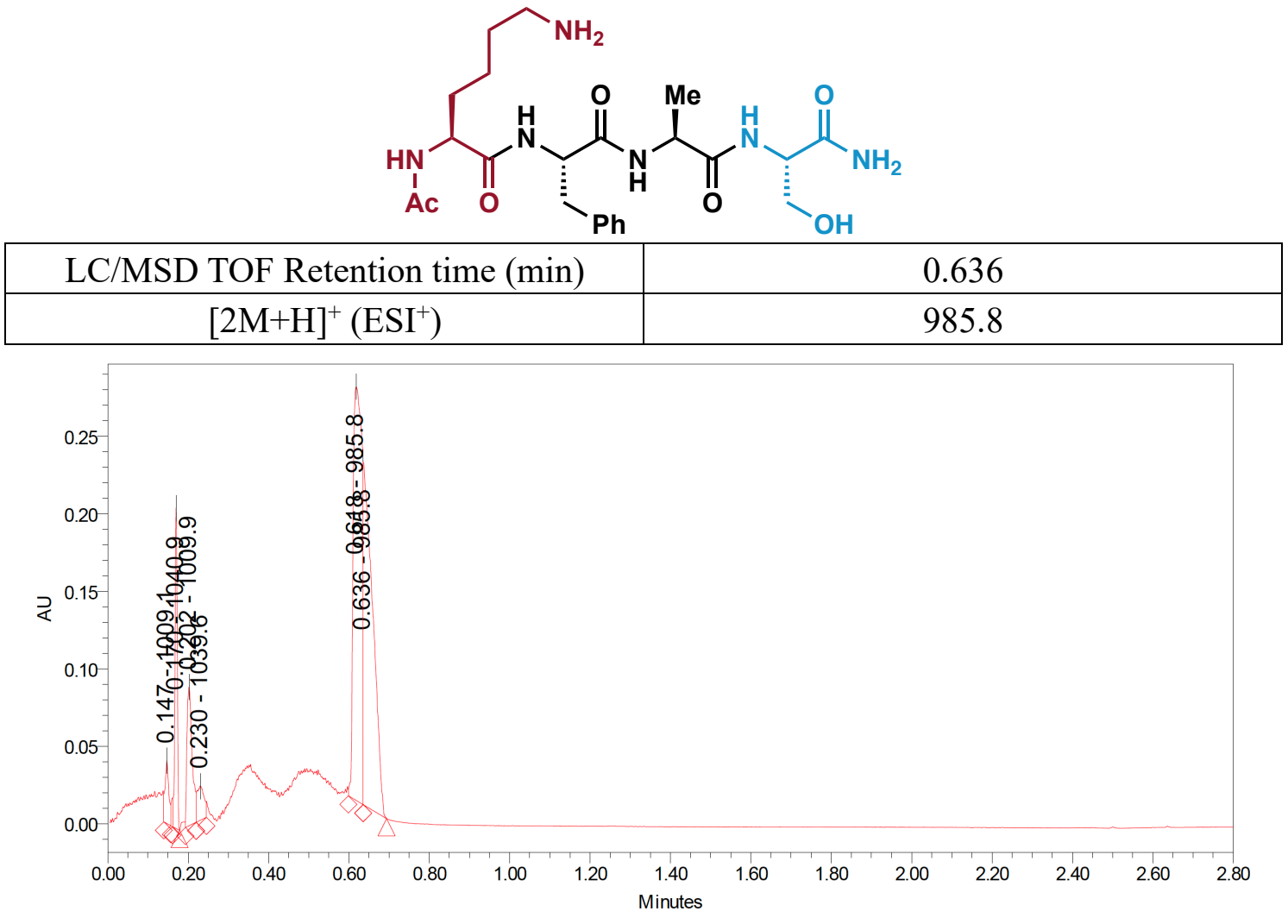

HPLC trace peptide SI-8

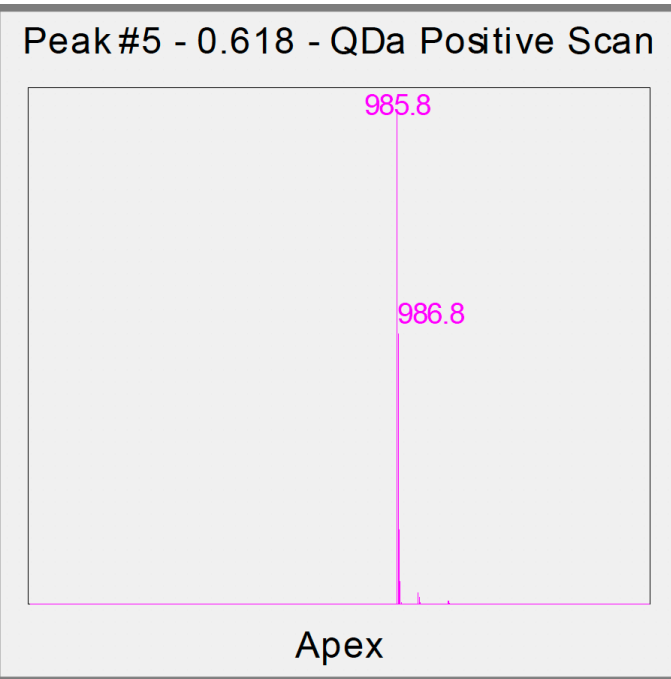

ESI $^{+}$trace peptide SI-8 


\section{Peptide SI-9}<smiles>CC(NC(=O)[C@H](Cc1ccccc1)NC(=O)C(Cc1ccc(O)cc1)N[C@@H](C)C(=O)N[C@@H](CO)C(N)=O)C(=O)N[C@H](Cc1ccccc1)C(N)=O</smiles>

\begin{tabular}{|c|c|}
\hline LC/MSD TOF Retention time (min) & 0.57 \\
\hline$[\mathrm{M}+\mathrm{H}]^{+}\left(\mathrm{ESI}^{+}\right)$ & 528.2 \\
\hline
\end{tabular}

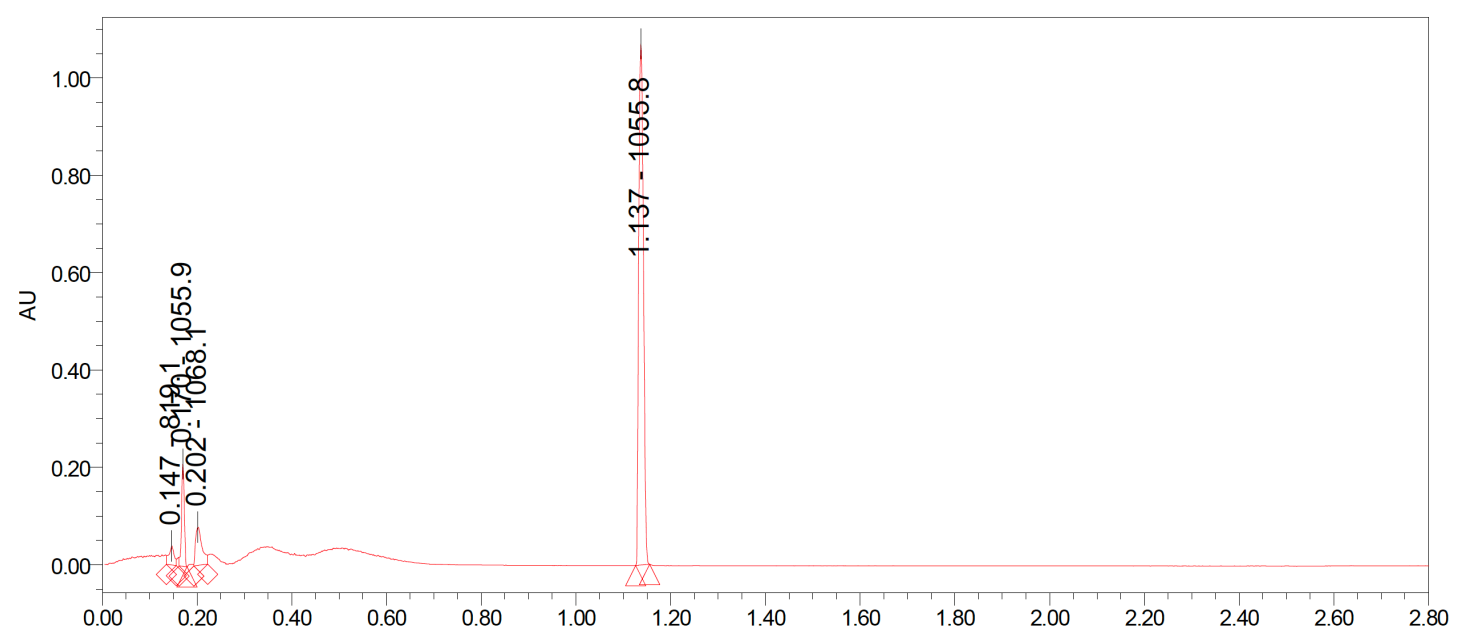

HPLC trace peptide SI-9

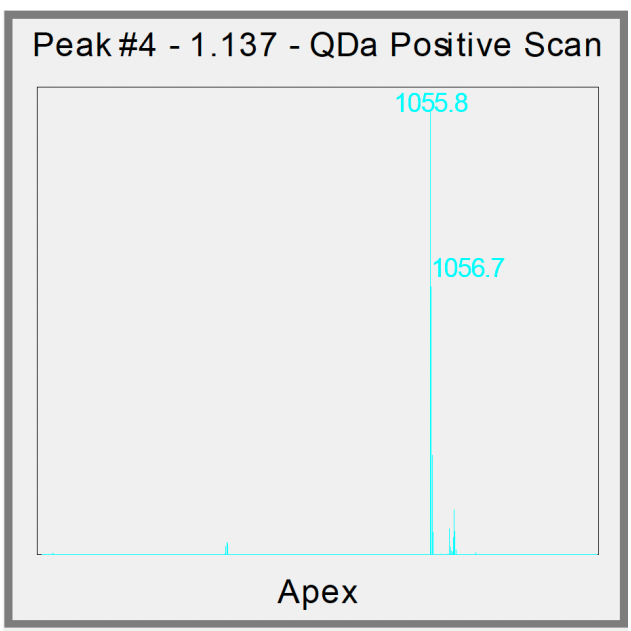

ESI ${ }^{+}$trace peptide SI-9 
Peptide SI-10<smiles>CC(C)NC(=O)C(C)NC(=O)[C@H](Cc1ccccc1)NC(=O)C(NC(=O)N[C@@H](CO)C(N)=O)C(C)O</smiles>

\begin{tabular}{|c|c|}
\hline LC/MSD TOF Retention time (min) & 0.871 \\
\hline$[2 \mathrm{M}+\mathrm{H}]^{+}\left(\mathrm{ESI}^{+}\right)$ & 931.8 \\
\hline
\end{tabular}

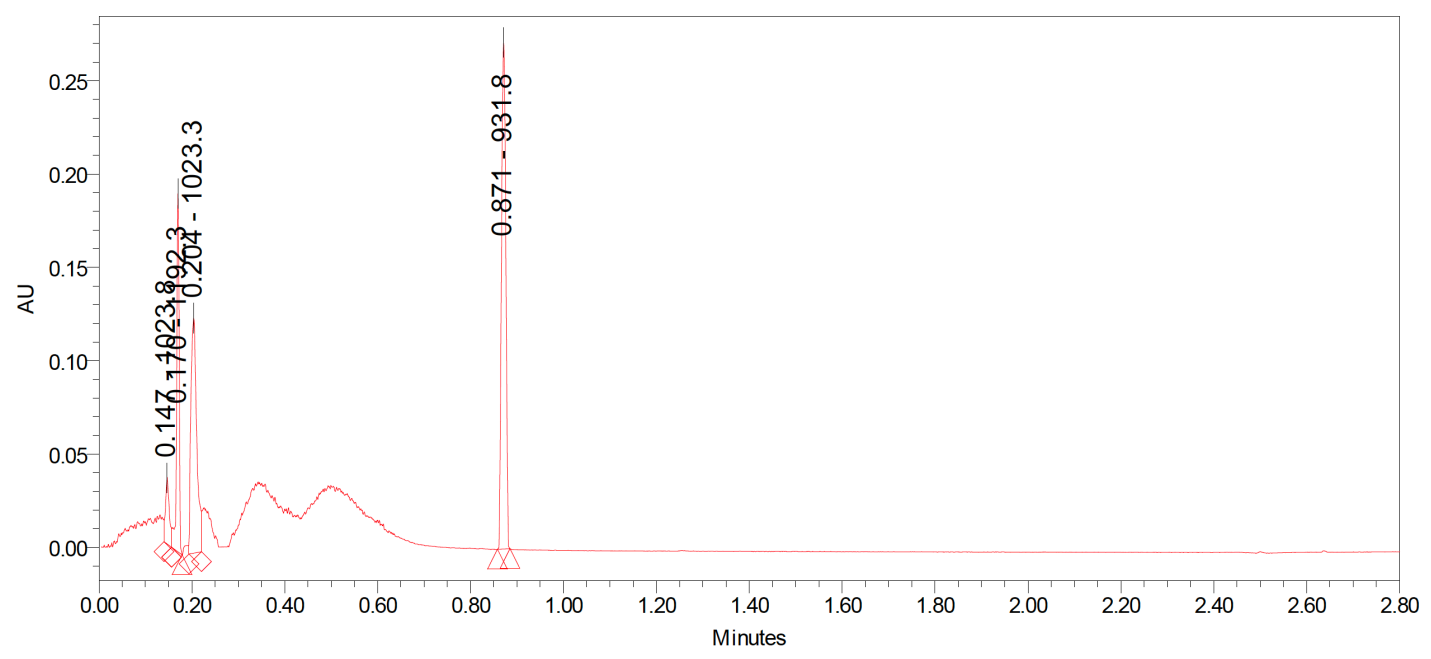

HPLC trace peptide SI-10

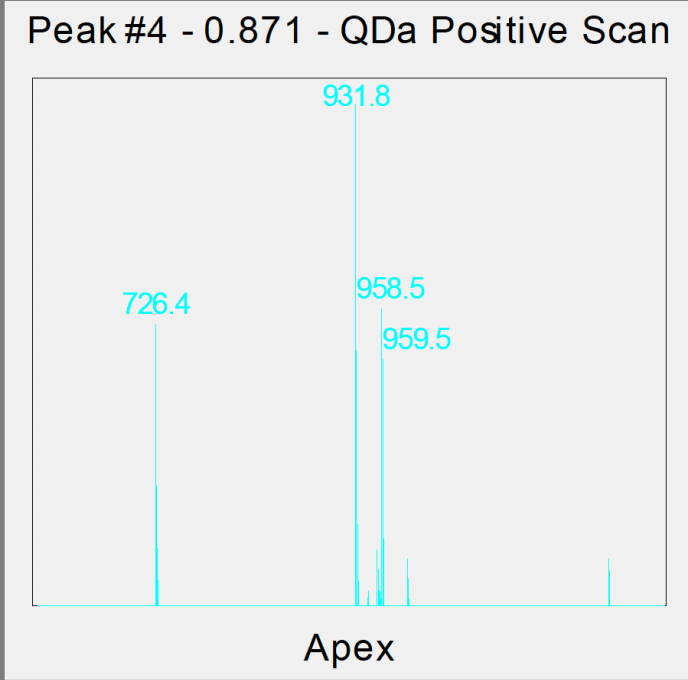

ESI $^{+}$trace peptide SI-10 
Peptide SI-11

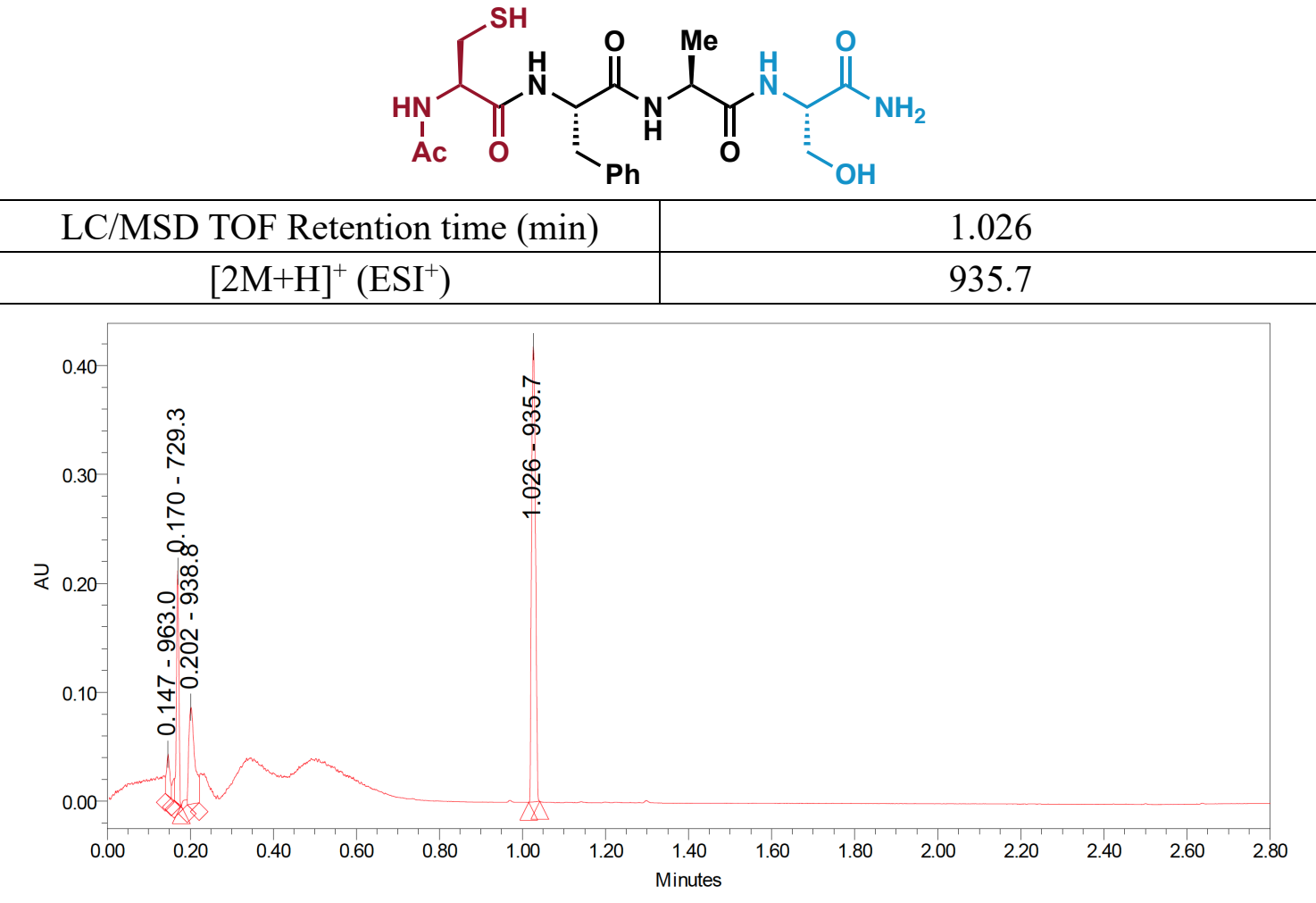

HPLC trace peptide SI-11

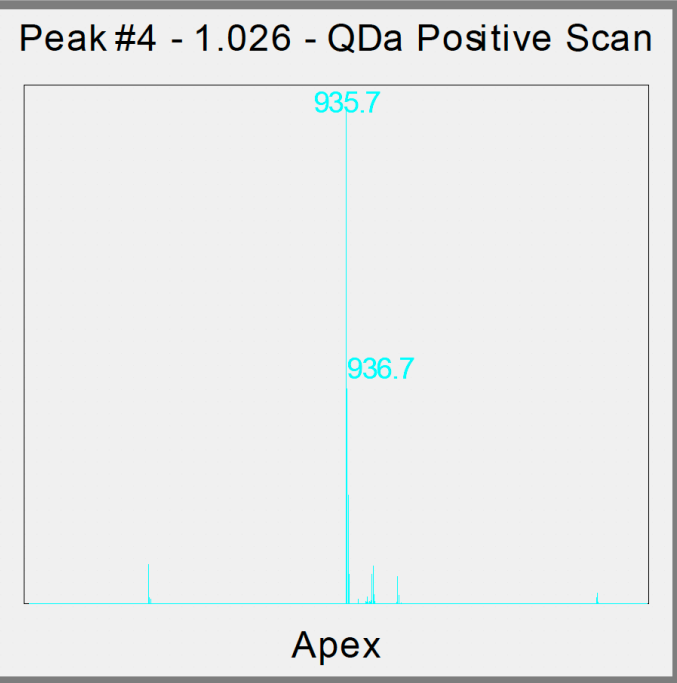

ESI $^{+}$trace peptide SI-11 


\section{Peptide SI-12}

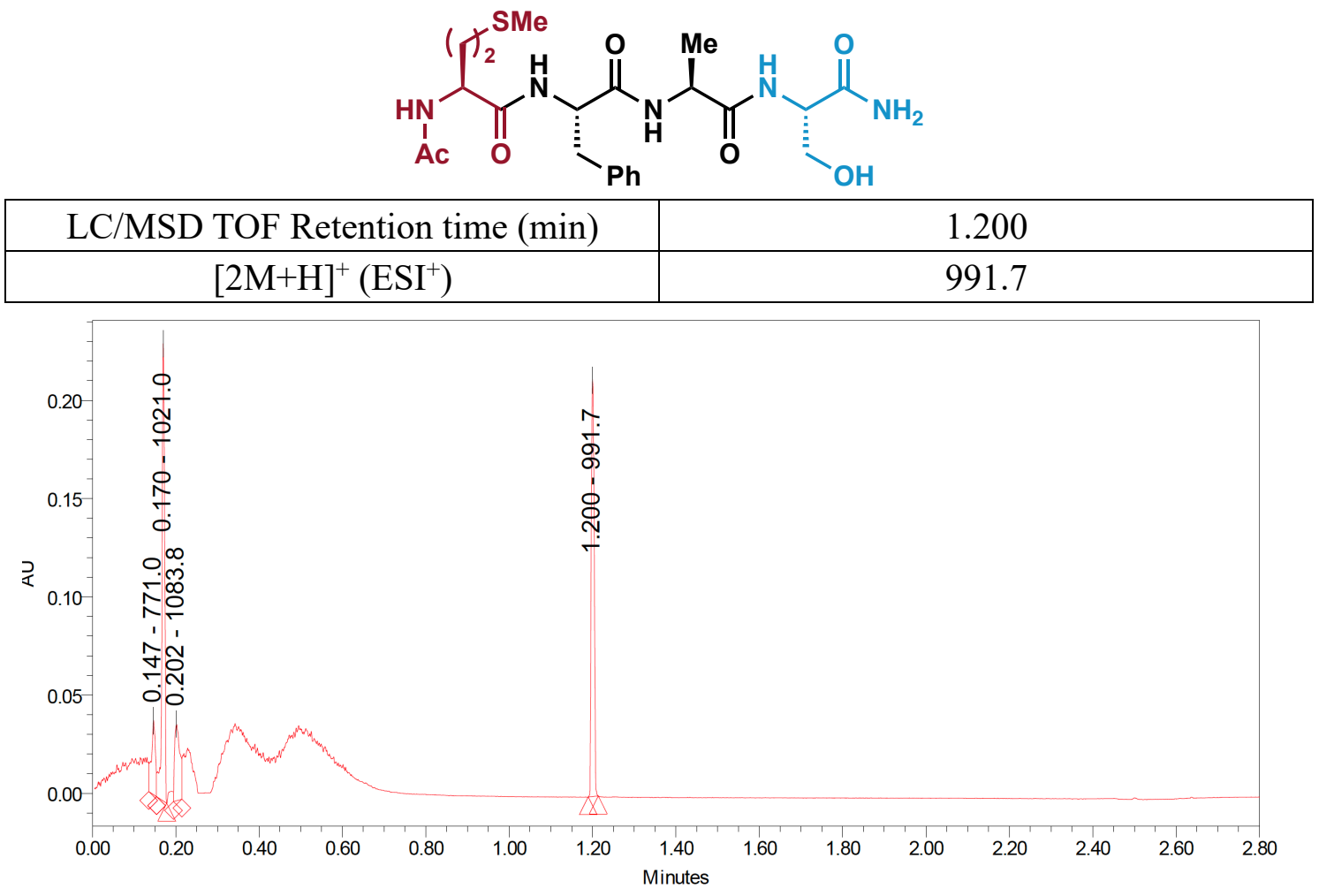

HPLC trace peptide SI-12

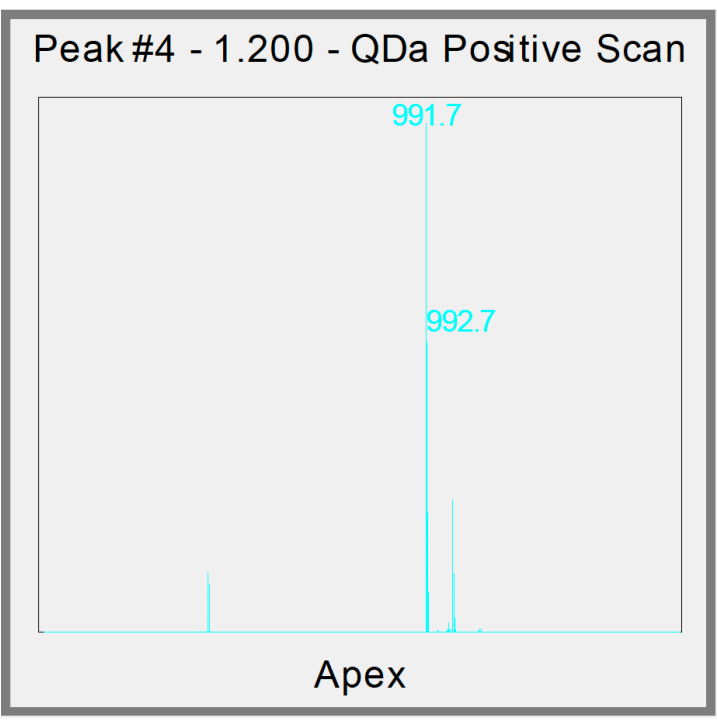

$\mathrm{ESI}^{+}$trace peptide SI-12 
Peptide SI-13
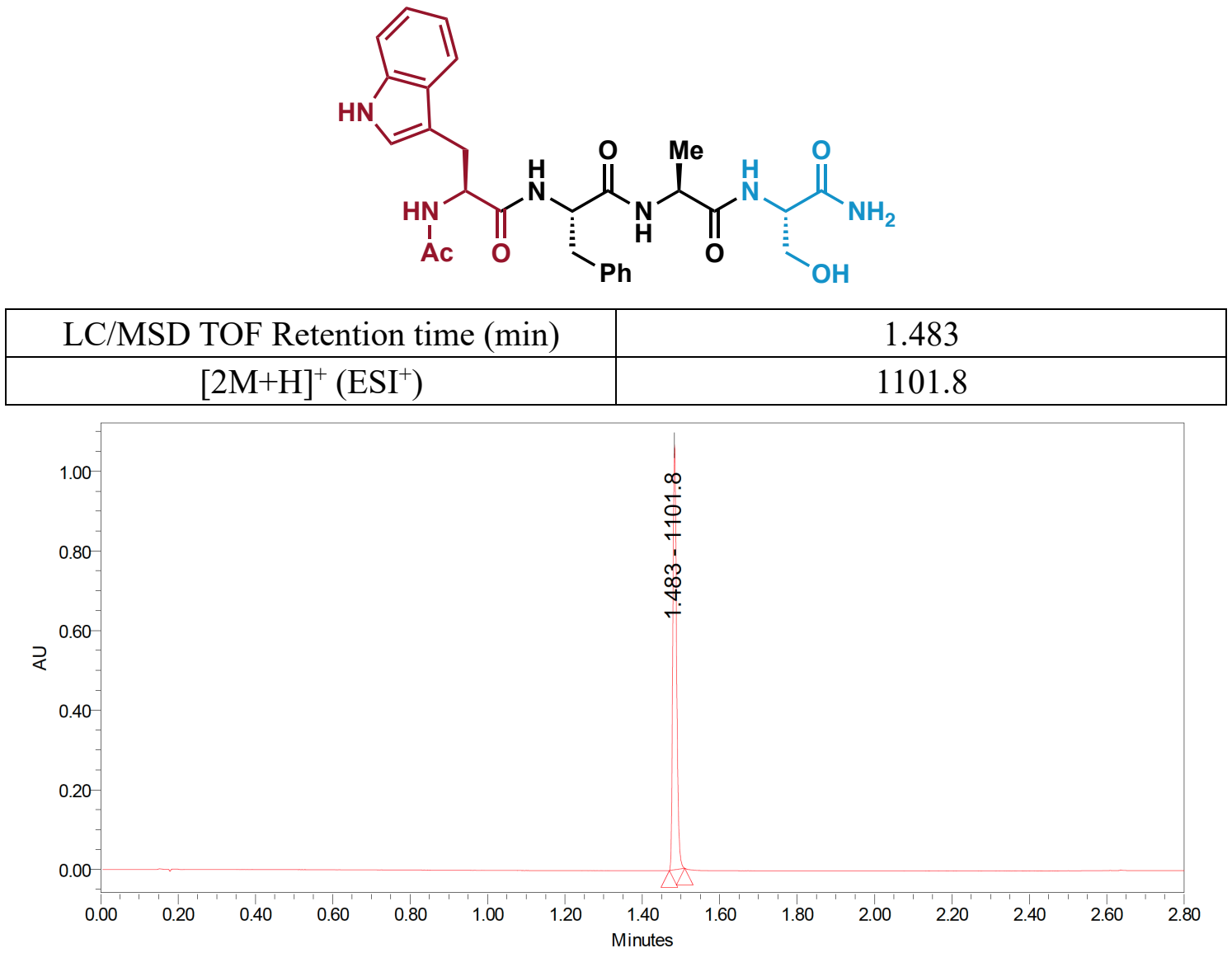

HPL trace peptide SI-13

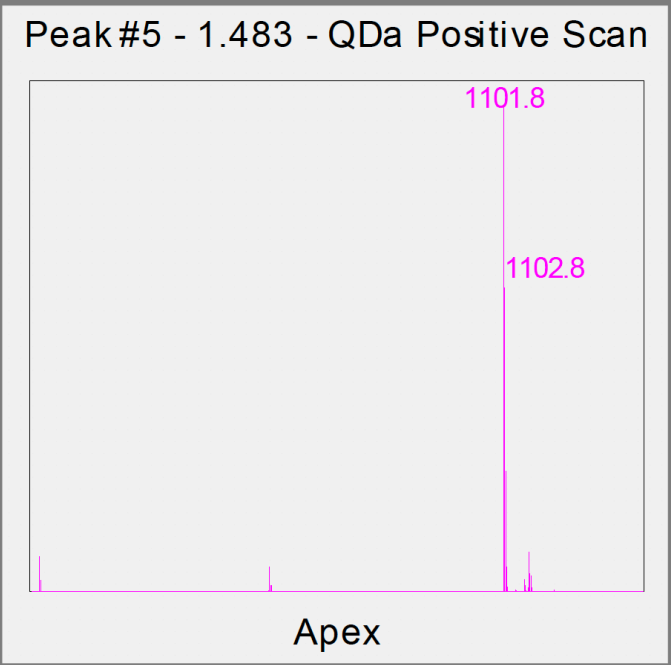

ESI $^{+}$trace peptide SI-13 


\section{General Procedure C for Tetrapeptide Functionalization}

The peptides and proteins were functionalized as follow unless otherwise stated. Tetrapeptide $\mathbf{X}(100 \mu \mathrm{L}$ of a $20 \mathrm{mM}$ solution in DMF, 1.0 equiv) and $\mathbf{P}(\mathbf{V})-\mathbf{X}(100 \mu \mathrm{L}$ of a $100 \mathrm{mM}$ solution in DMF, 5.0 equiv or $100 \mu \mathrm{L}$ of a $200 \mathrm{mM}$ solution in DMF, 10.0 equiv) were added to a $3 \mathrm{~mL}$ HPLC vial. DBU (5.0 equiv or 10.0 equiv) was added to the reaction mixture at room temperature while stirring. After 5-10 minutes, the crude reaction mixture was analyzed by ${ }^{31} \mathrm{P}$ NMR to calculate the conversion and confirm the serine selectivity. LC/MSD TOF was used to confirm the mass.

\section{User Guide for the Analysis for Tetrapeptide Functionalization}

The reaction profile contains the desired product (around $56 \mathrm{ppm}$ ), the $\mathrm{P}(\mathrm{V})$ starting material (around $100 \mathrm{ppm}$ ), the $\mathrm{P}(\mathrm{V})$ hydrolyzed by-product $\mathrm{A}$ (around $50 \mathrm{ppm}$ ) and $\mathrm{P}(\mathrm{V})$ hydrolyzed by-product B (around $15 \mathrm{ppm}$ ). Other small peaks are related to the $\mathrm{P}(\mathrm{V})$ reagent.

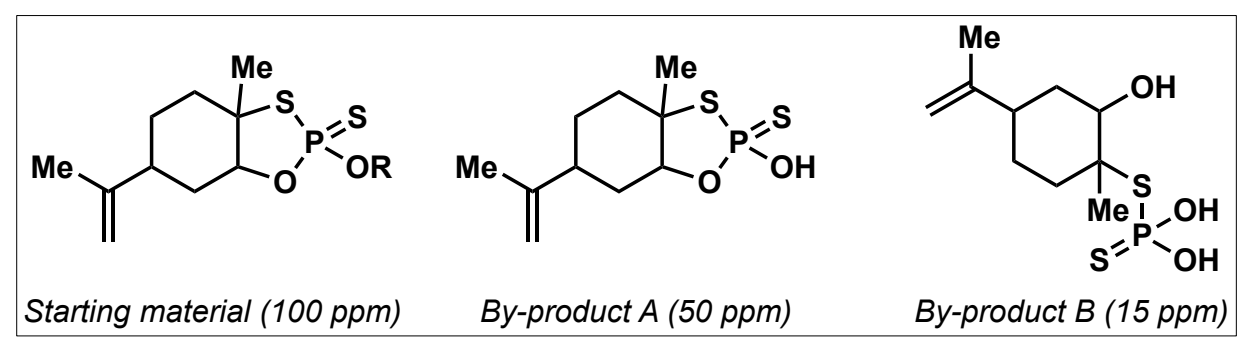

Case 1: Peptide is not UV active.

Analysis was performed using ${ }^{31} \mathrm{P}$ NMR to calculate the conversion and confirm the serine selectivity (using H-coupled mode).

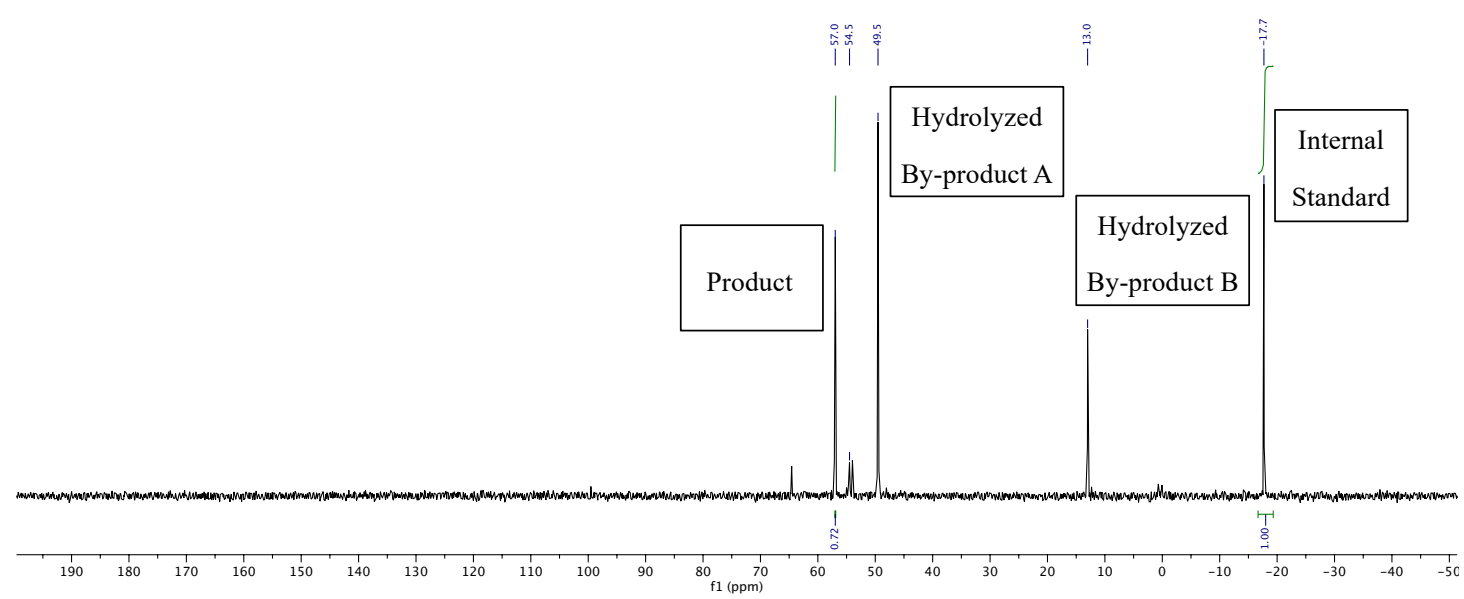


LC/MSD TOF was used to confirm the mass and the conversion.

ESI-MS: \% Conversion for labeling of tetrapeptides was calculated based on the following formula.

$\%$ Conversion $=I_{\text {desired product }} / \mathrm{I}_{\text {all relevant species }}$

$I_{\text {desired product }}=$ Peak intensity of labeled peptide

$\mathrm{I}_{\text {all }}$ relevant species $=$ The sum of the peak intensities of starting material peptide and double addition product.

Case 2: Peptide is UV active.

Analysis of the conversion can be performed using HPLC/MS analysis.

HPLC-MS: \% Conversion for labeling of tetrapeptides was calculated based on the following formula.

\section{$\%$ Conversion $=$ Area $_{\text {desired product }} /$ Area $_{\text {all relevant species }}$}

Areadesired product $=$ Peak intensity of labeled peptide

Areaall relevant species $=$ The sum of the peak intensities of starting material peptide and double addition product.

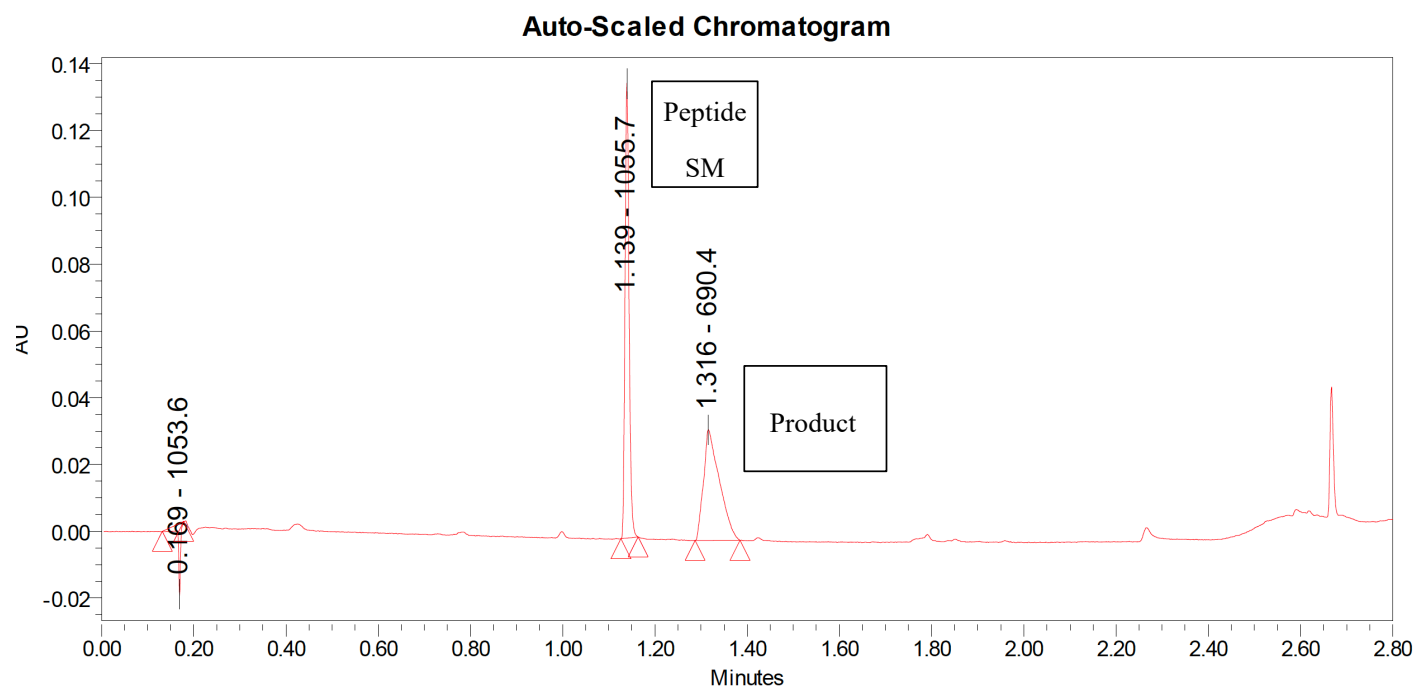




\section{Peptide 3}

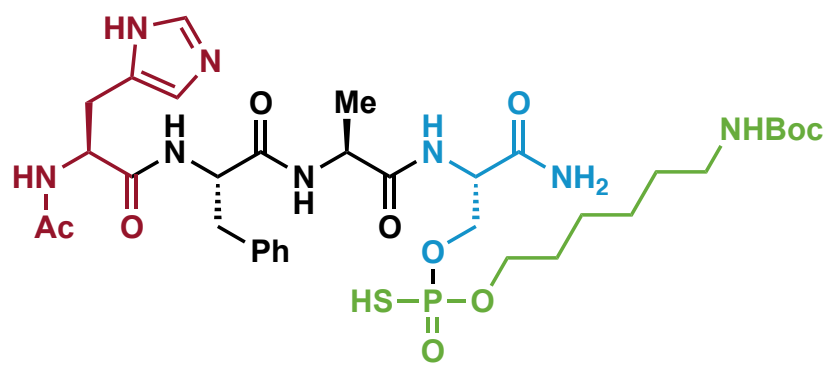

Prepared according to General Procedure $\mathbf{C}$ using:

Peptide SI-6 (100 $\mu \mathrm{L}$ of a $20 \mathrm{mM}$ solution in DMF, 1.0 equiv), P(V)-1 (100 $\mu \mathrm{L}$ of a $100 \mathrm{mM}$ solution in DMF, 5.0 equiv) and DBU (5 equiv). The crude mixture was analyzed by ${ }^{31} \mathrm{P}$ NMR and LC/MSD TOF to afford peptide 3 in $66 \%$ conversion. $[\mathbf{M}+\mathbf{H}]^{+}\left(\mathbf{E S I}^{+}\right):$797.3.

${ }^{31}$ P NMR (162 MHz, DMF-d): $\delta$ 56.0.

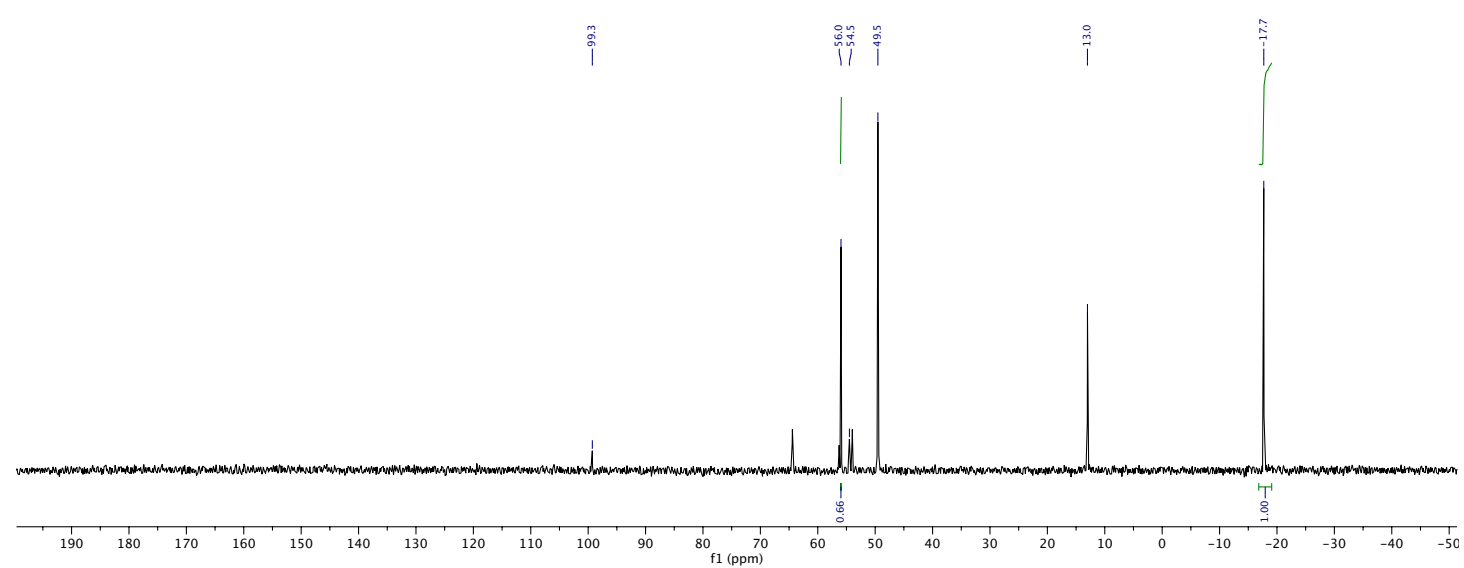

Crude ${ }^{31}$ P NMR spectra peptide 3 


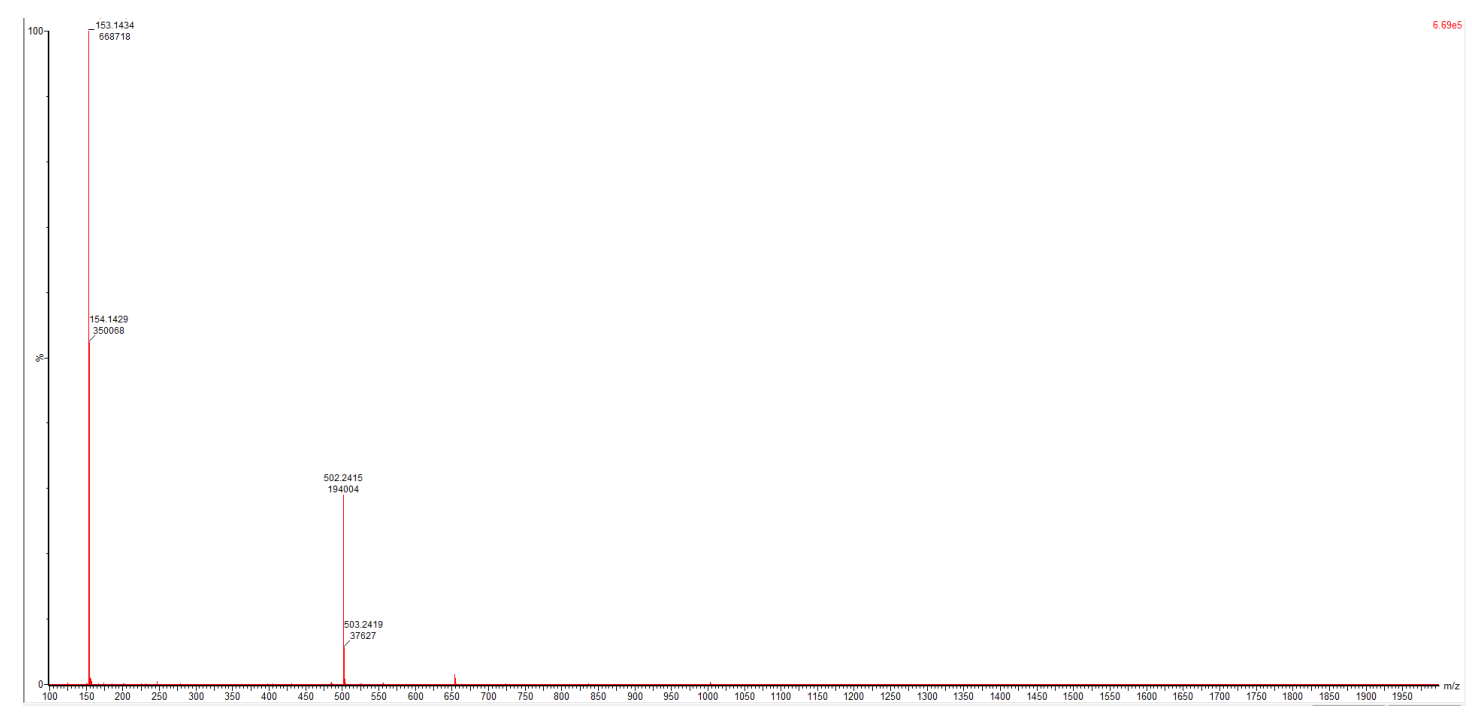

$\mathrm{ESI}^{+}$trace peptide SI-6

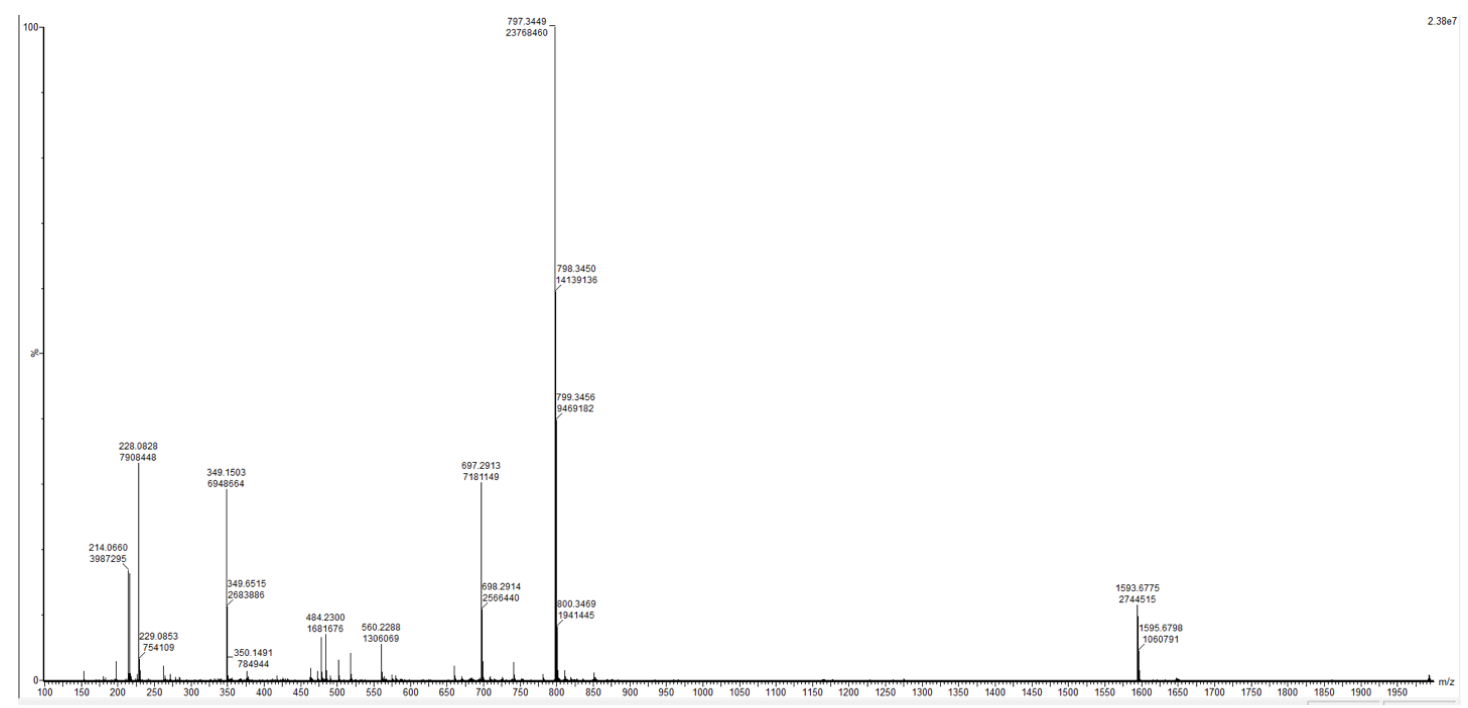

$\mathrm{ESI}^{+}$trace peptide 3 


\section{Peptide 3 bis}

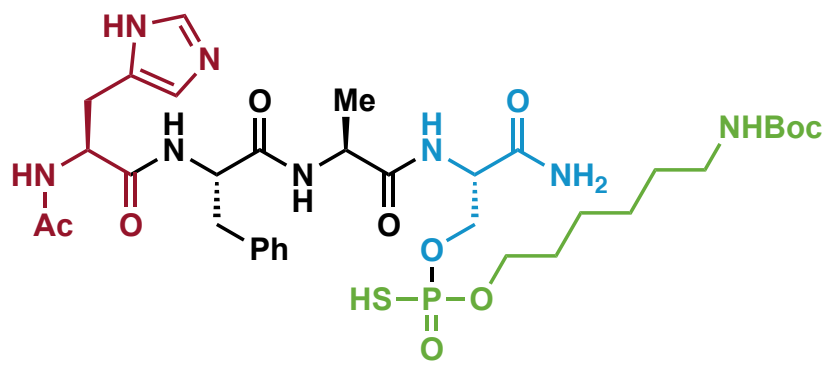

Prepared according to General Procedure C using:

Peptide SI-6 (100 $\mu \mathrm{L}$ of a $20 \mathrm{mM}$ solution in DMF, 1.0 equiv), P(V)-1 (100 $\mu \mathrm{L}$ of a $200 \mathrm{mM}$ solution in DMF, 10.0 equiv) and DBU (10 equiv). The crude mixture was analyzed by ${ }^{31} \mathrm{P}$ NMR and LC/MSD TOF to afford peptide 3 in $77 \%$ conversion. $[\mathbf{M}+\mathbf{H}]^{+}\left(\mathbf{E S I}^{+}\right):$797.3.

${ }^{31}$ P NMR (162 MHz, DMF-d): $\delta 56.0$.

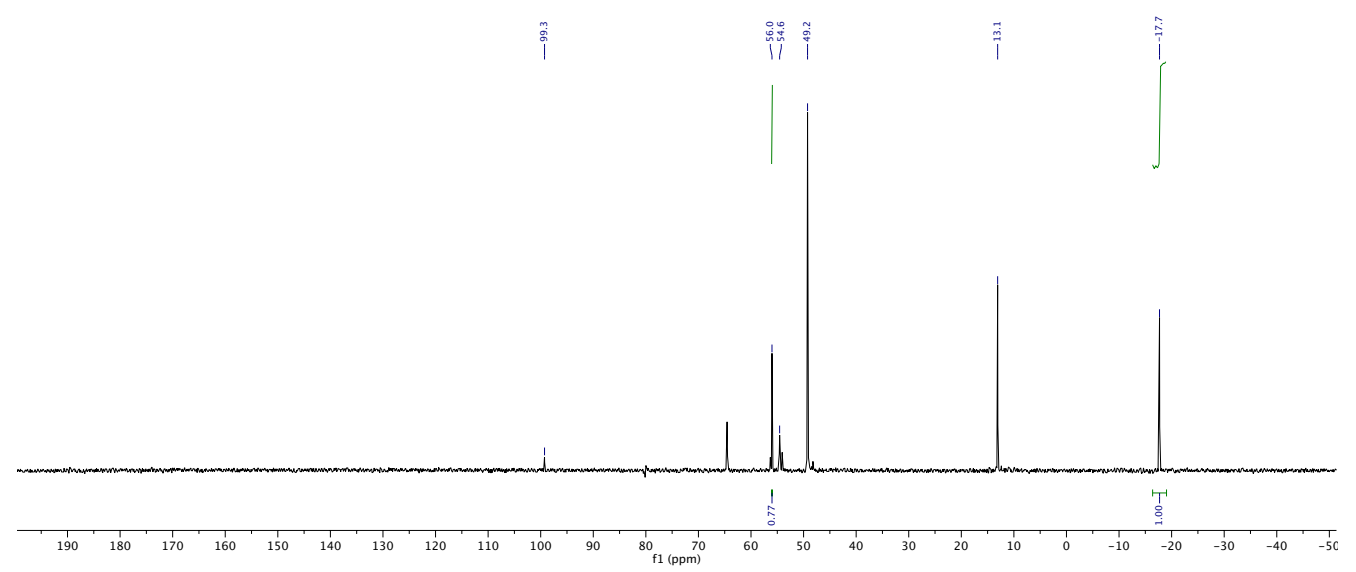

Crude ${ }^{31}$ P NMR spectra peptide 3 


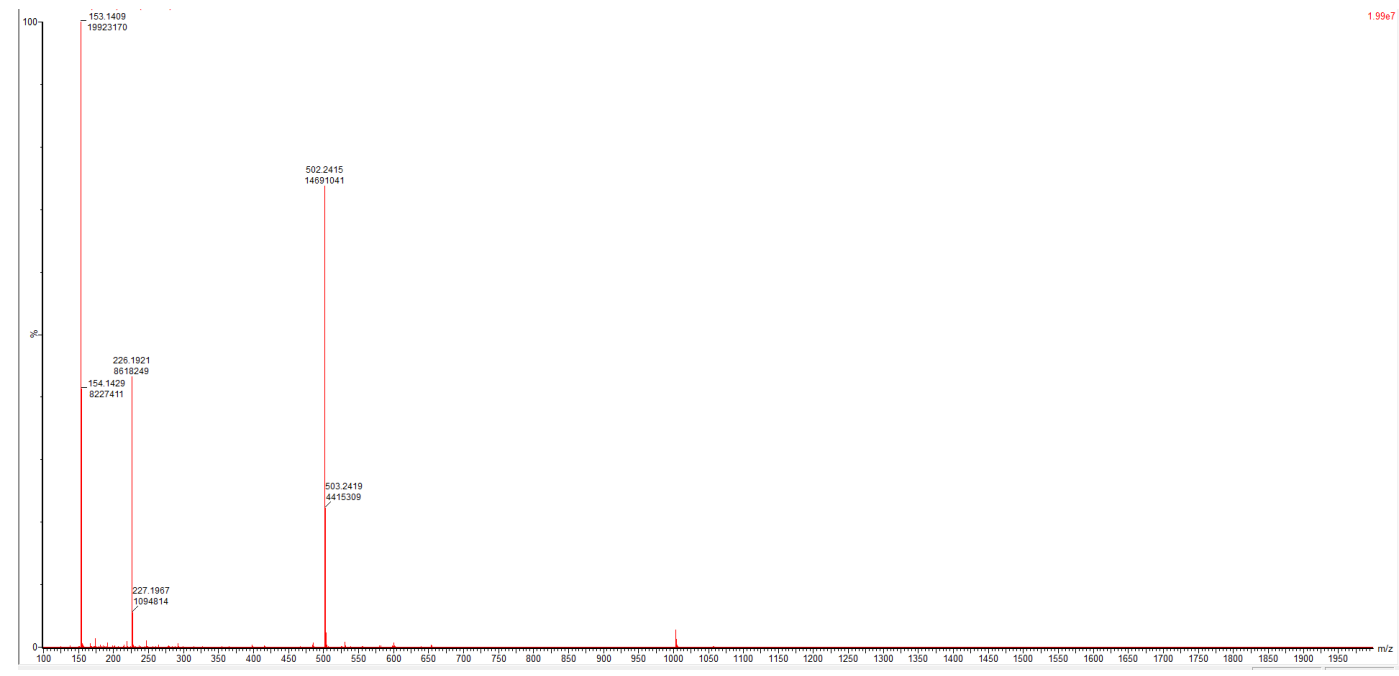

$\mathrm{ESI}^{+}$trace peptide SI-6

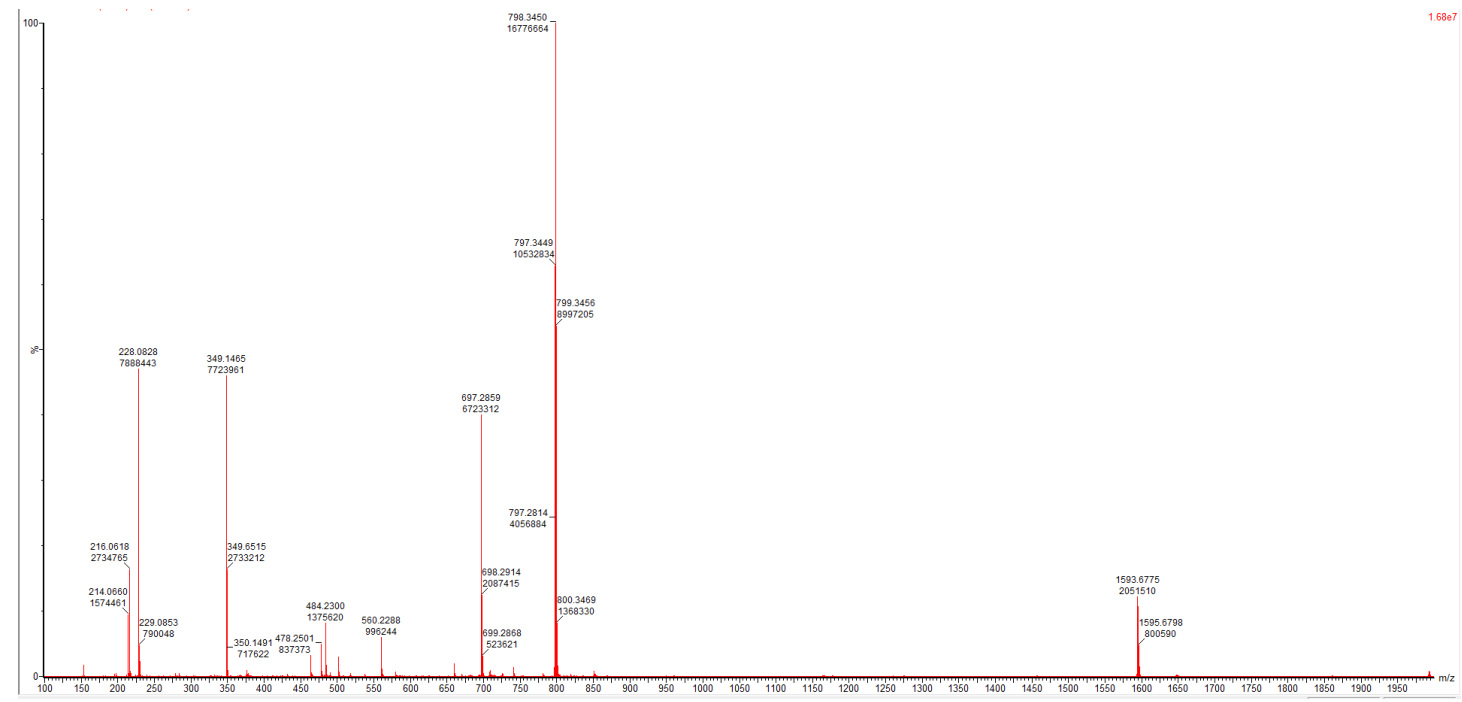

$\mathrm{ESI}^{+}$trace peptide 3 


\section{Peptide 4}

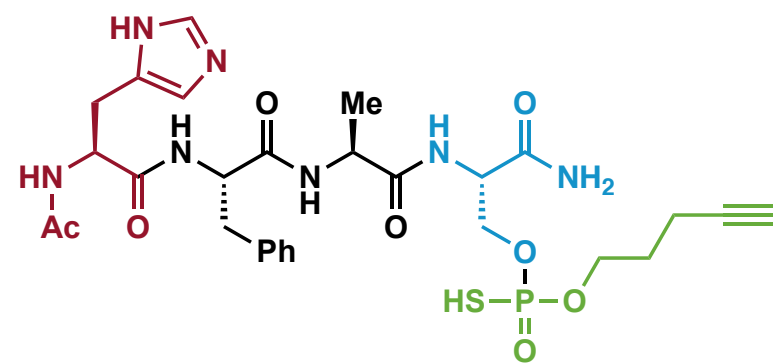

Prepared according to General Procedure $\mathbf{C}$ using:

Peptide SI-6 (100 $\mu \mathrm{L}$ of a $20 \mathrm{mM}$ solution in DMF, 1.0 equiv), P(V)-2a (100 $\mu \mathrm{L}$ of a $100 \mathrm{mM}$ solution in DMF, 5.0 equiv) and DBU (5 equiv). The crude mixture was analyzed by ${ }^{31} \mathrm{P}$ NMR and LC/MSD TOF to afford peptide 4 in $72 \%$ conversion. $[\mathbf{M}+\mathbf{H}]^{+}\left(\mathbf{E S I}^{+}\right): 665.2$.

${ }^{31}$ P NMR (162 MHz, DMF-d): $\delta$ 57.0.

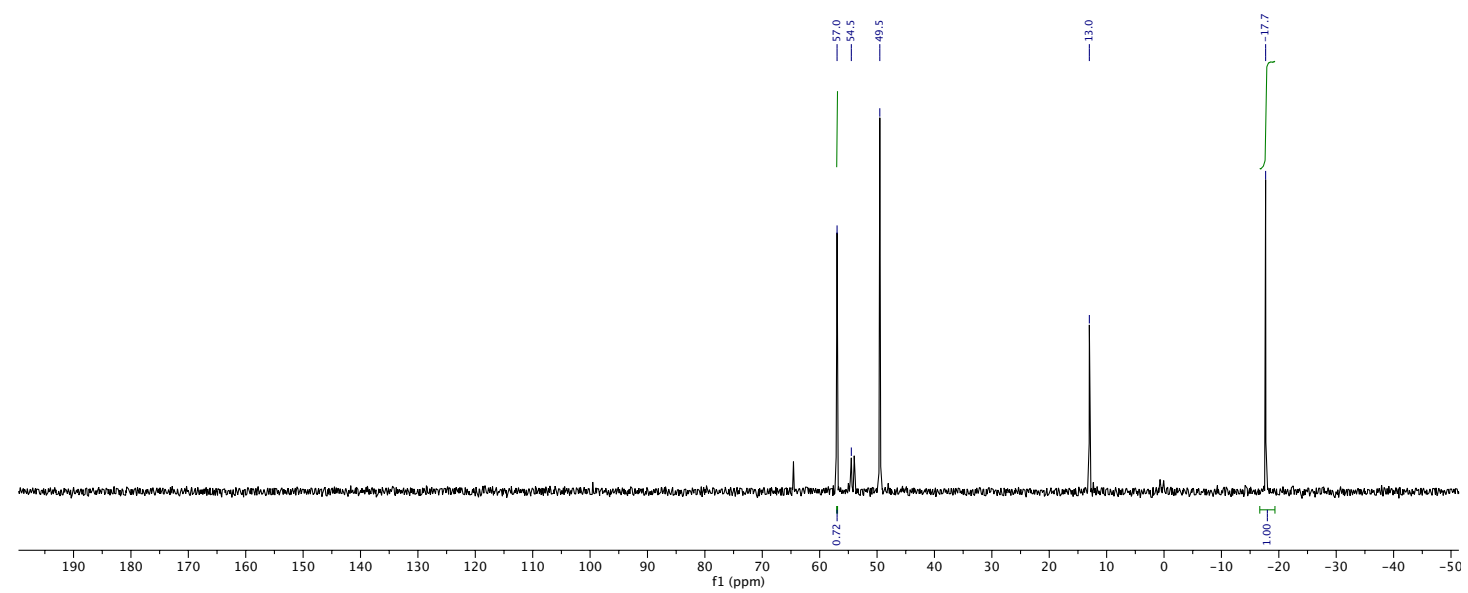

Crude ${ }^{31}$ P NMR spectra peptide 4 


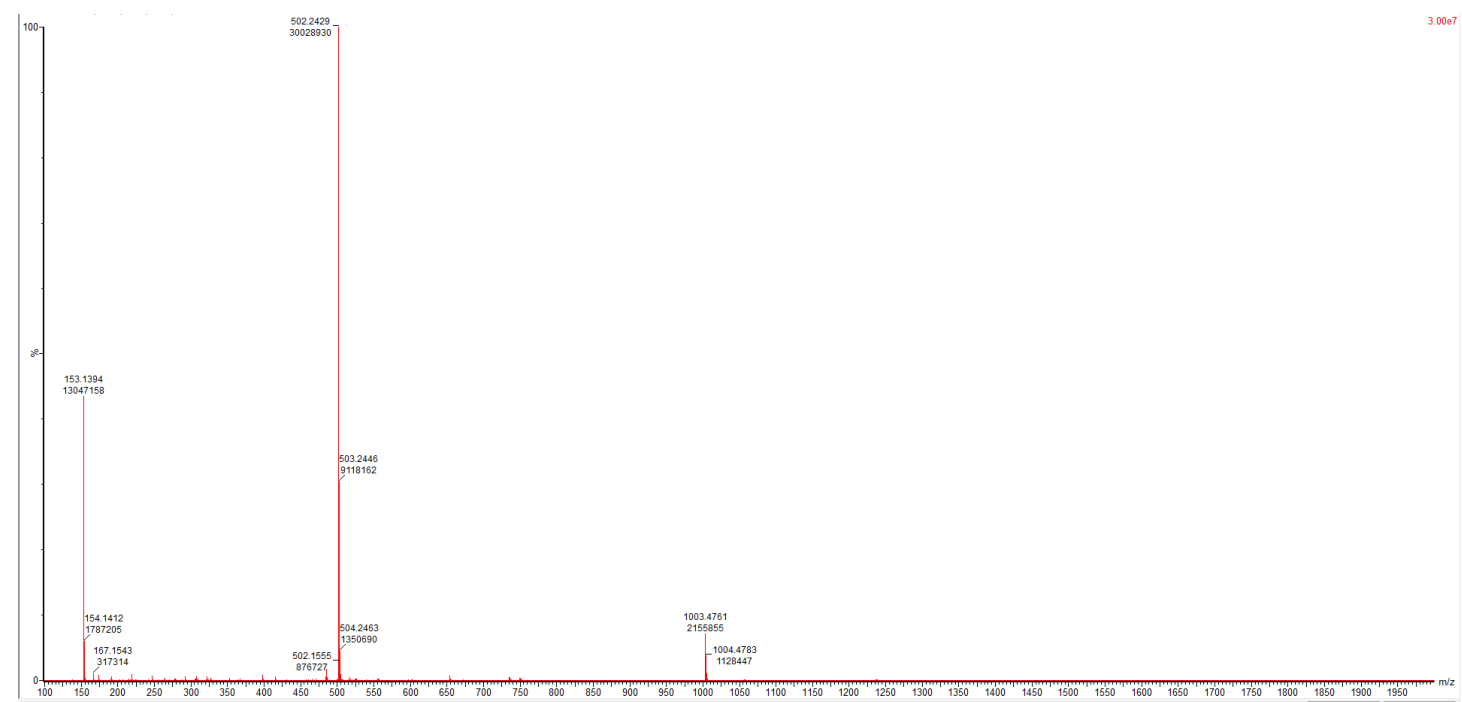

ESI $^{+}$trace peptide SI-6

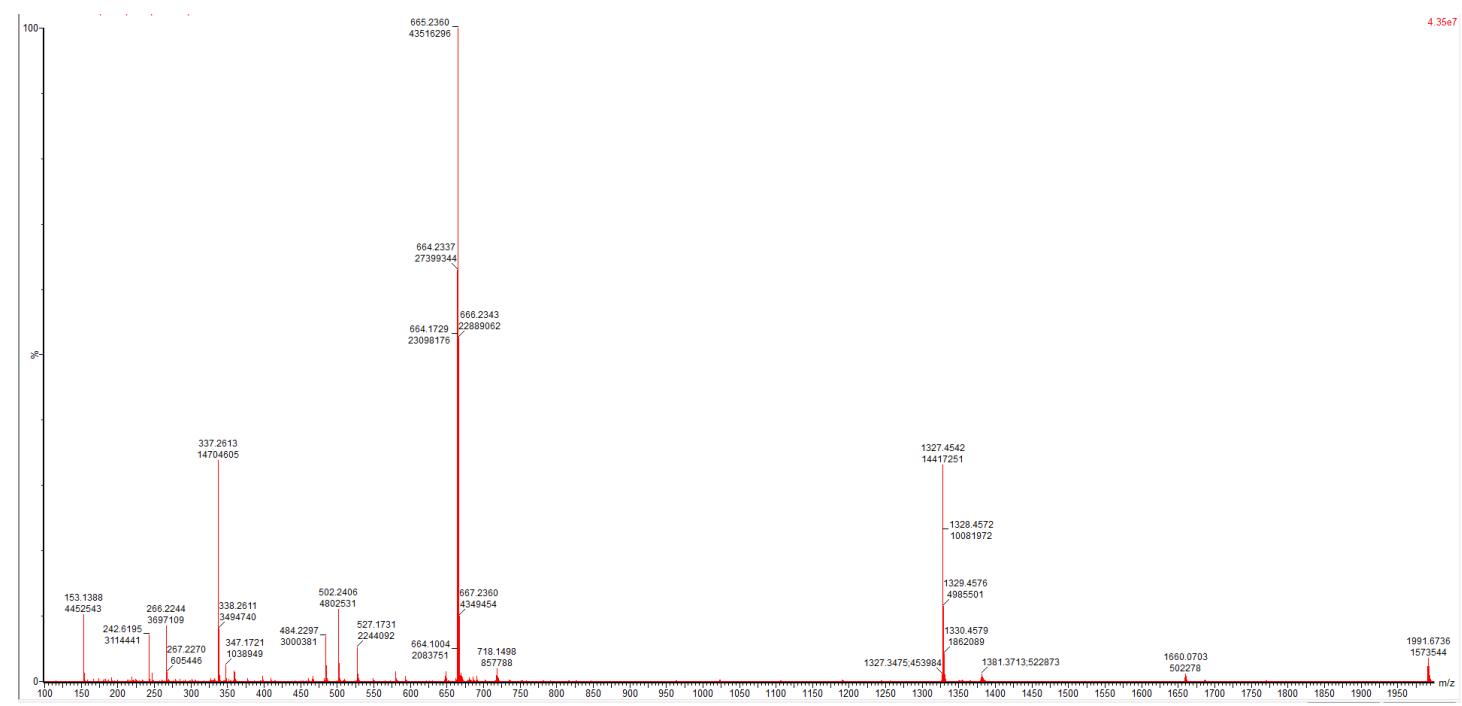

ESI $^{+}$trace peptide 4 


\section{Peptide 5}

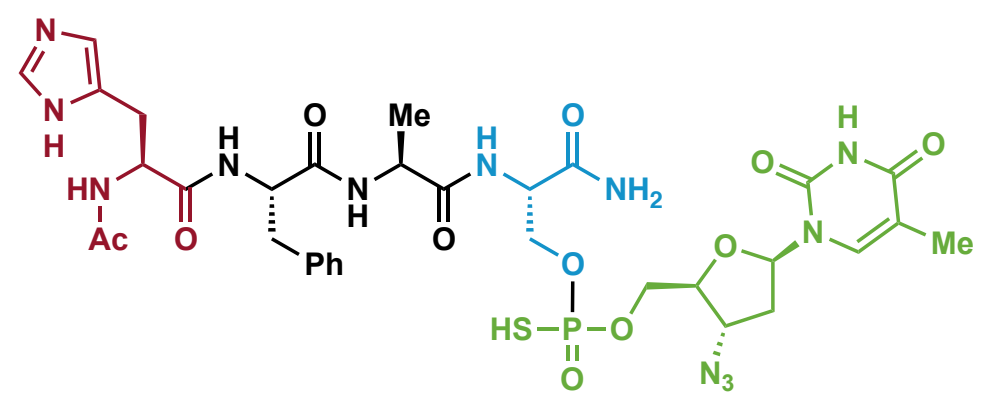

Prepared according to General Procedure C using:

Peptide SI-6 (100 $\mu \mathrm{L}$ of a $20 \mathrm{mM}$ solution in DMF, 1.0 equiv), P(V)-3 (100 $\mu \mathrm{L}$ of a $100 \mathrm{mM}$ solution in DMF, 5.0 equiv) and DBU (5 equiv). The crude mixture was analyzed by ${ }^{31} \mathrm{P}$ NMR and LC/MSD TOF to afford peptide 5 in $87 \%$ conversion. $[\mathbf{M}+\mathbf{H}]^{+}\left(\mathbf{E S I}^{+}\right):$847.3.

${ }^{31}$ P NMR (162 MHz, DMF-d): $\delta 56.0$.

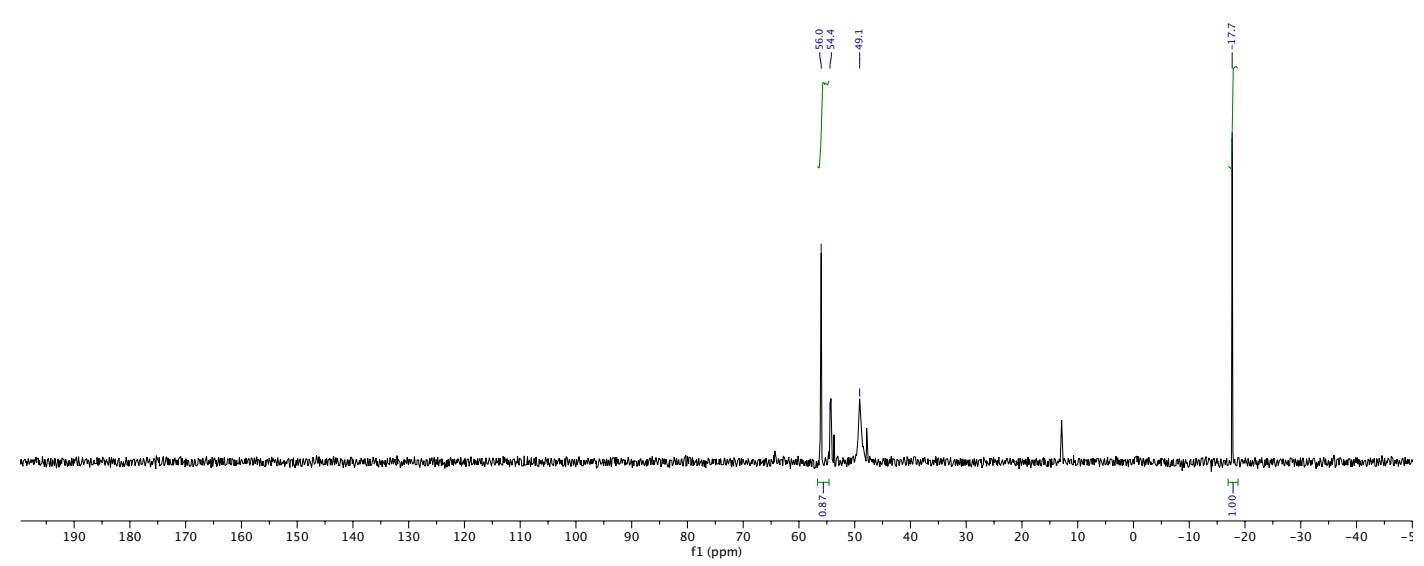

Crude ${ }^{31}$ P NMR spectra peptide 5 


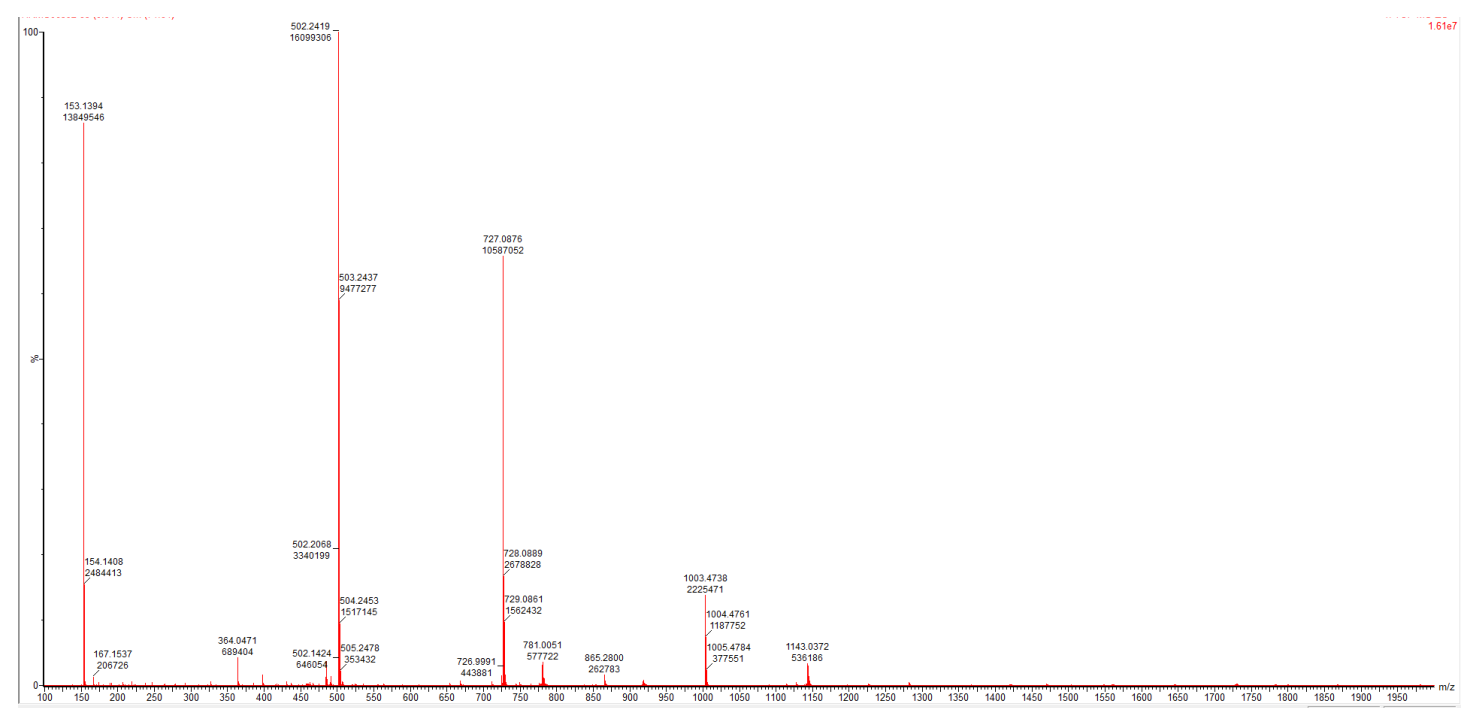

ESI $^{+}$trace peptide SI-6

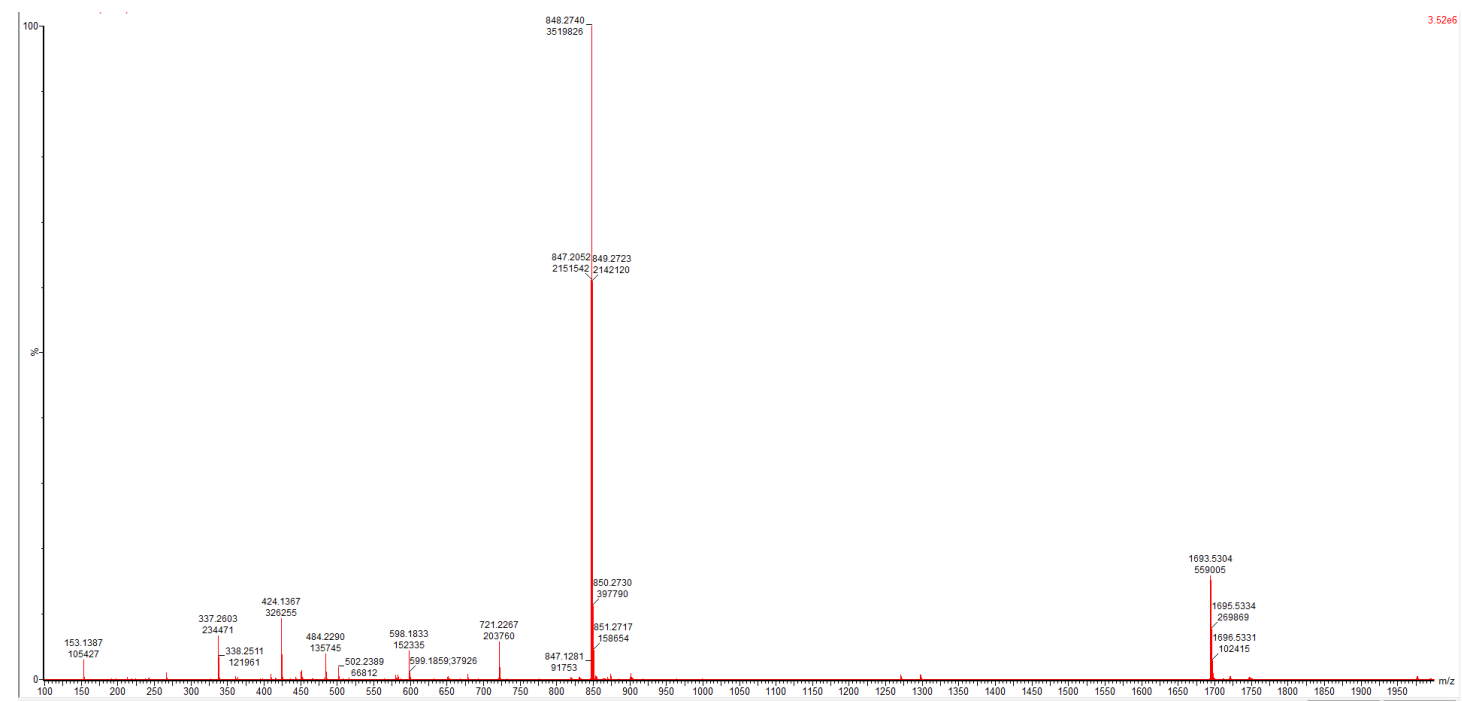

$\mathrm{ESI}^{+}$trace peptide 5 


\section{Peptide 6}

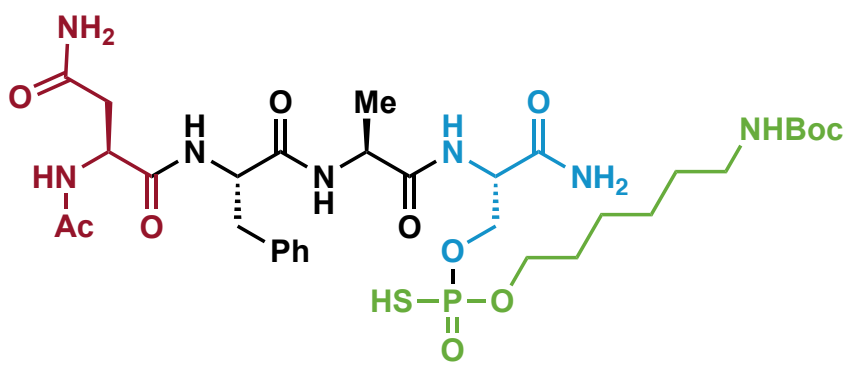

Prepared according to General Procedure $\mathbf{C}$ using:

Peptide SI-7 (100 $\mu \mathrm{L}$ of a $20 \mathrm{mM}$ solution in DMF, 1.0 equiv), P(V)-1 (100 $\mu \mathrm{L}$ of a $100 \mathrm{mM}$ solution in DMF, 5.0 equiv) and DBU (5 equiv). The crude mixture was analyzed by ${ }^{31} \mathrm{P}$ NMR and LC/MSD TOF to afford peptide 6 in $88 \%$ conversion. $[\mathbf{M}+\mathbf{H}]^{+}\left(\mathbf{E S I}^{+}\right): 774.3$.

${ }^{31}$ P NMR (162 MHz, DMF-d): $\delta 54.9$.

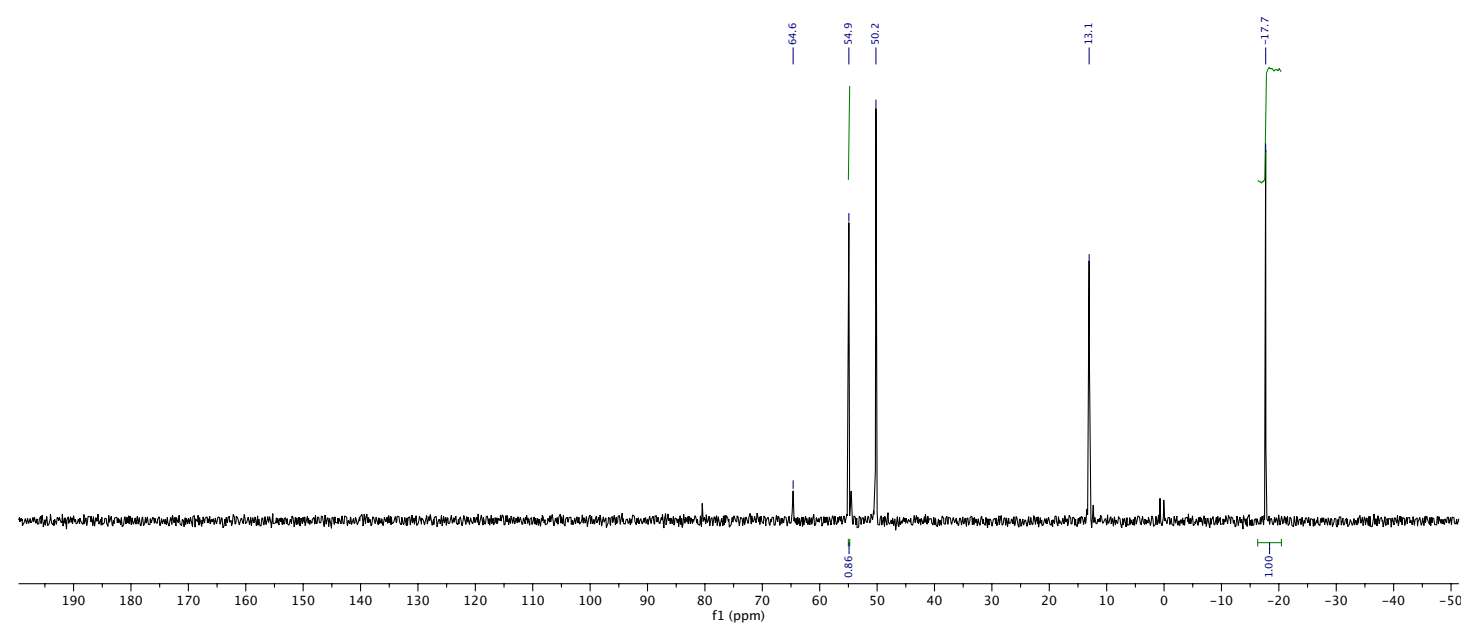

Crude ${ }^{31}$ P NMR spectra peptide 6 


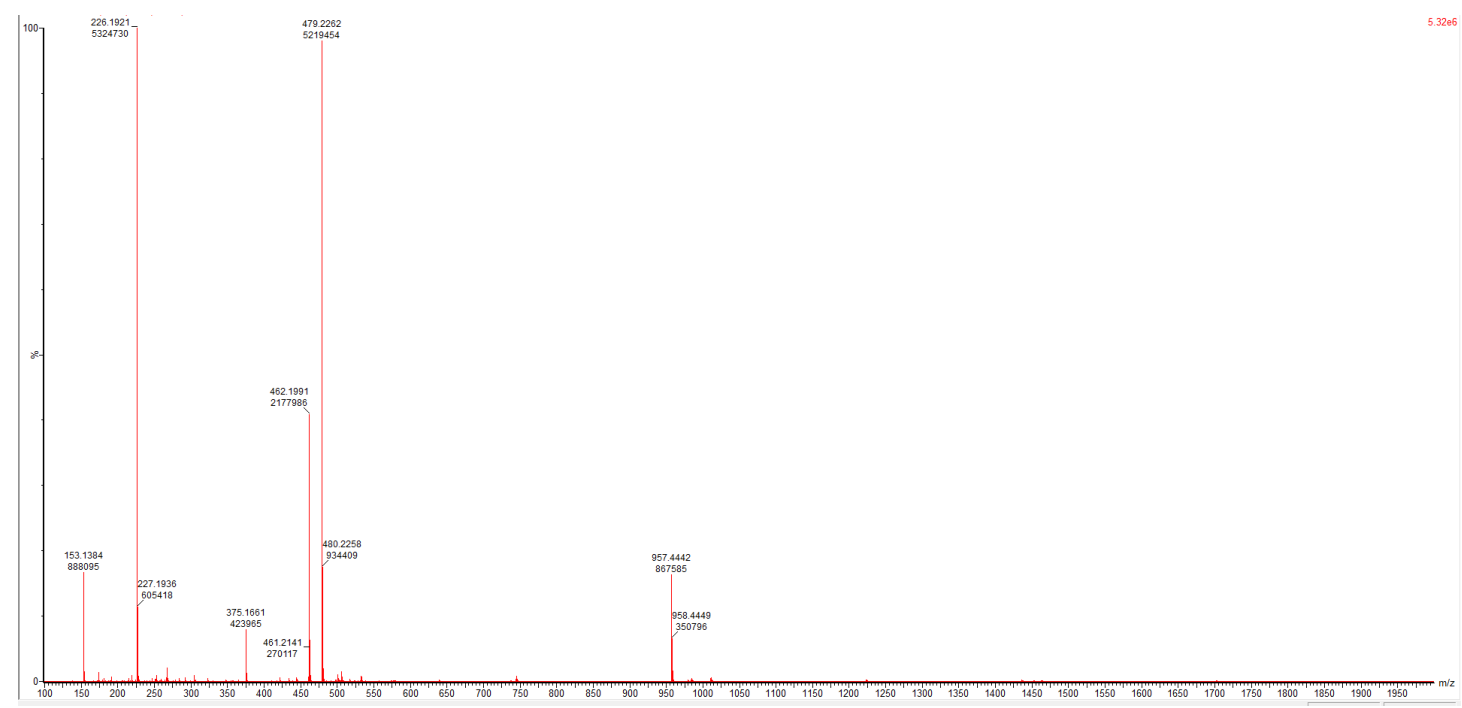

$\mathrm{ESI}^{+}$trace peptide SI-7

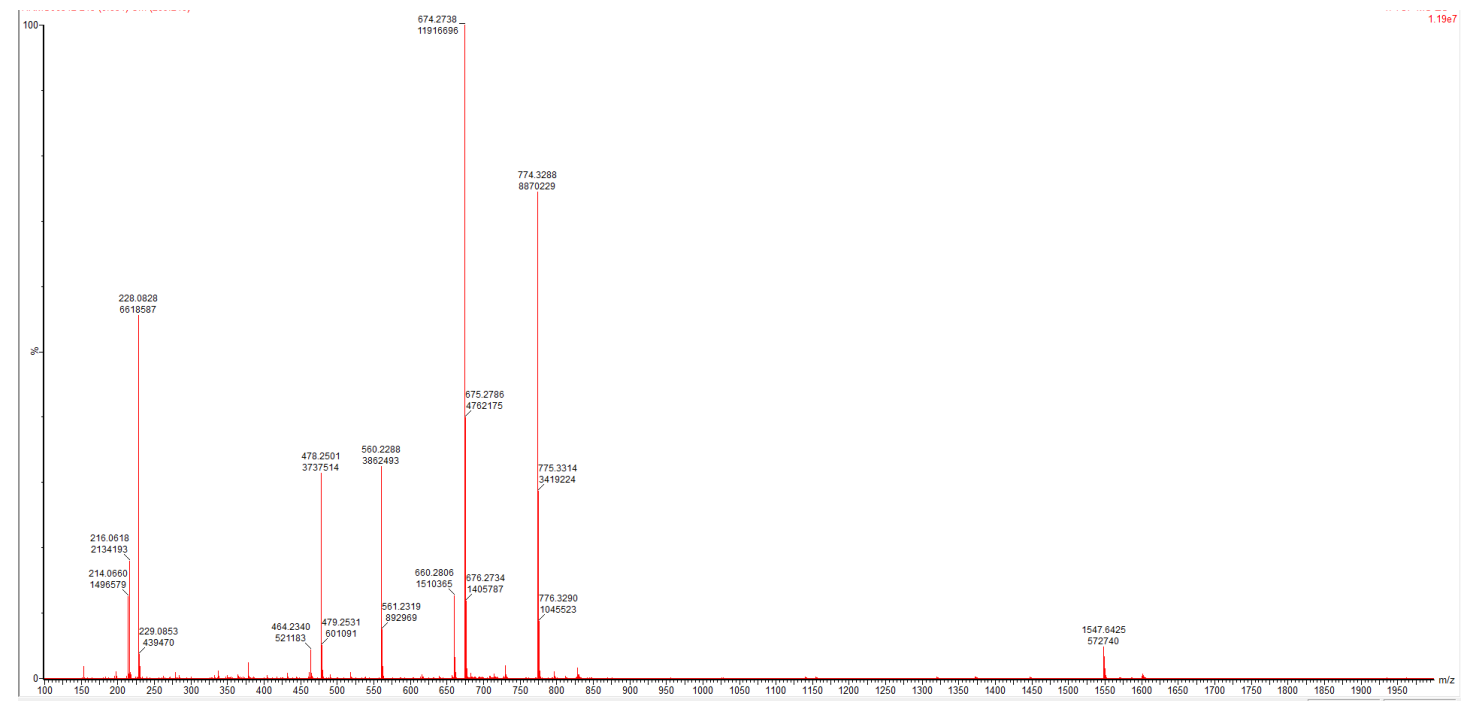

$\mathrm{ESI}^{+}$trace peptide 6 


\section{Peptide 6 bis}

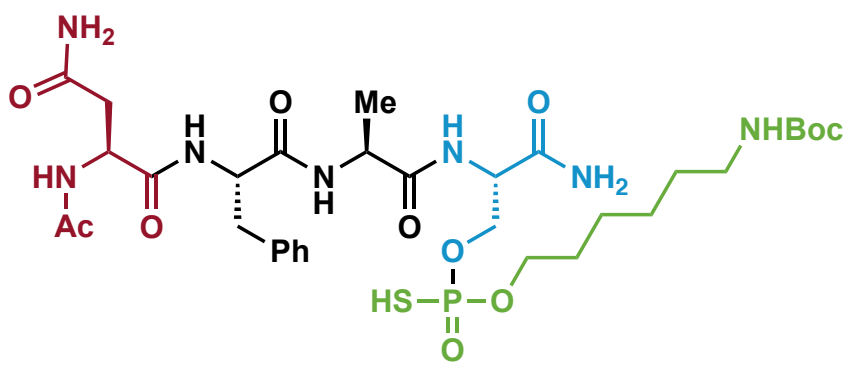

Prepared according to General Procedure C using:

Peptide SI-7 (100 $\mu \mathrm{L}$ of a $20 \mathrm{mM}$ solution in DMF, 1.0 equiv), P(V)-1 (100 $\mu \mathrm{L}$ of a $200 \mathrm{mM}$ solution in DMF, 10.0 equiv) and DBU (10 equiv). The crude mixture was analyzed by ${ }^{31} \mathrm{P}$ NMR and LC/MSD TOF to afford peptide 6 in 94\% conversion. $[\mathbf{M}+\mathbf{H}]^{+}\left(\mathbf{E S I}^{+}\right):$774.3.

${ }^{31}$ P NMR (162 MHz, DMF-d): $\delta 54.6$

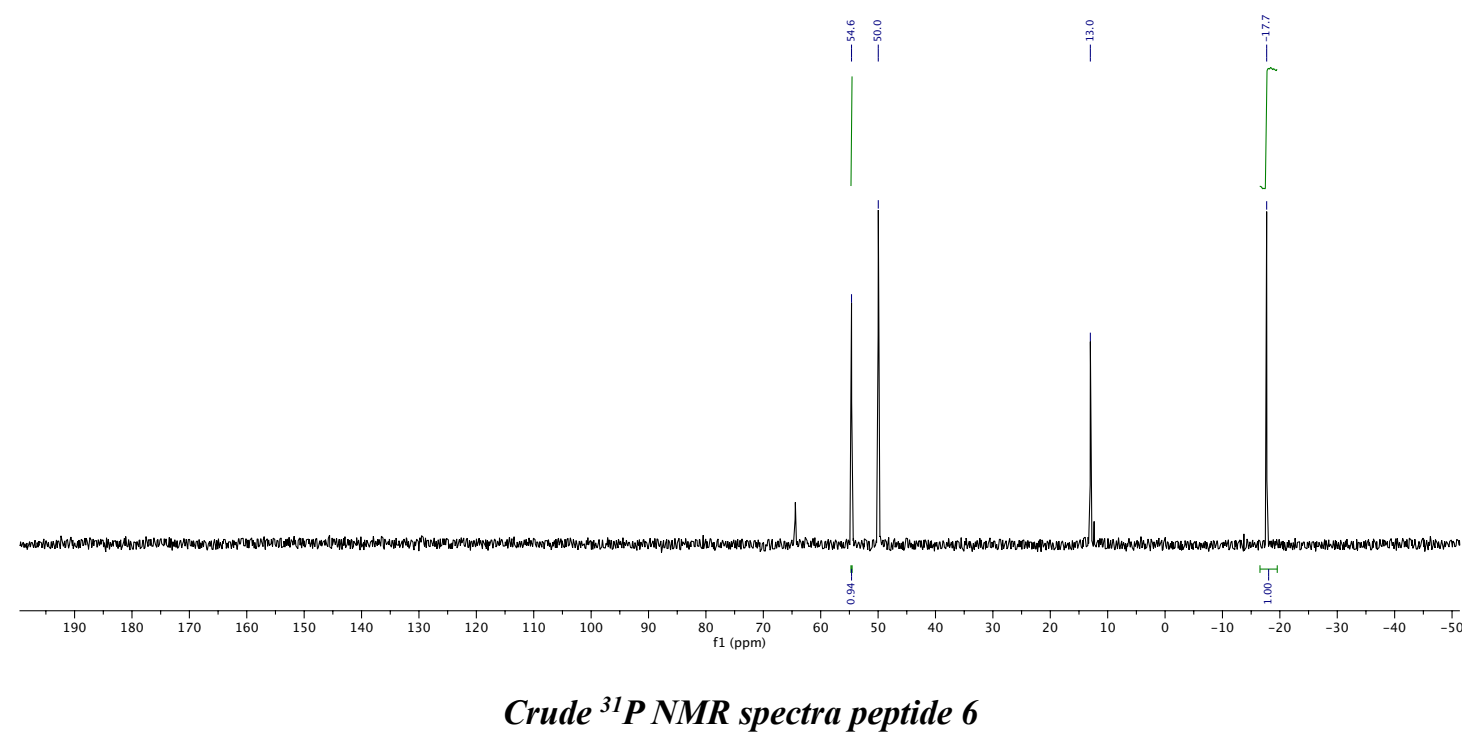




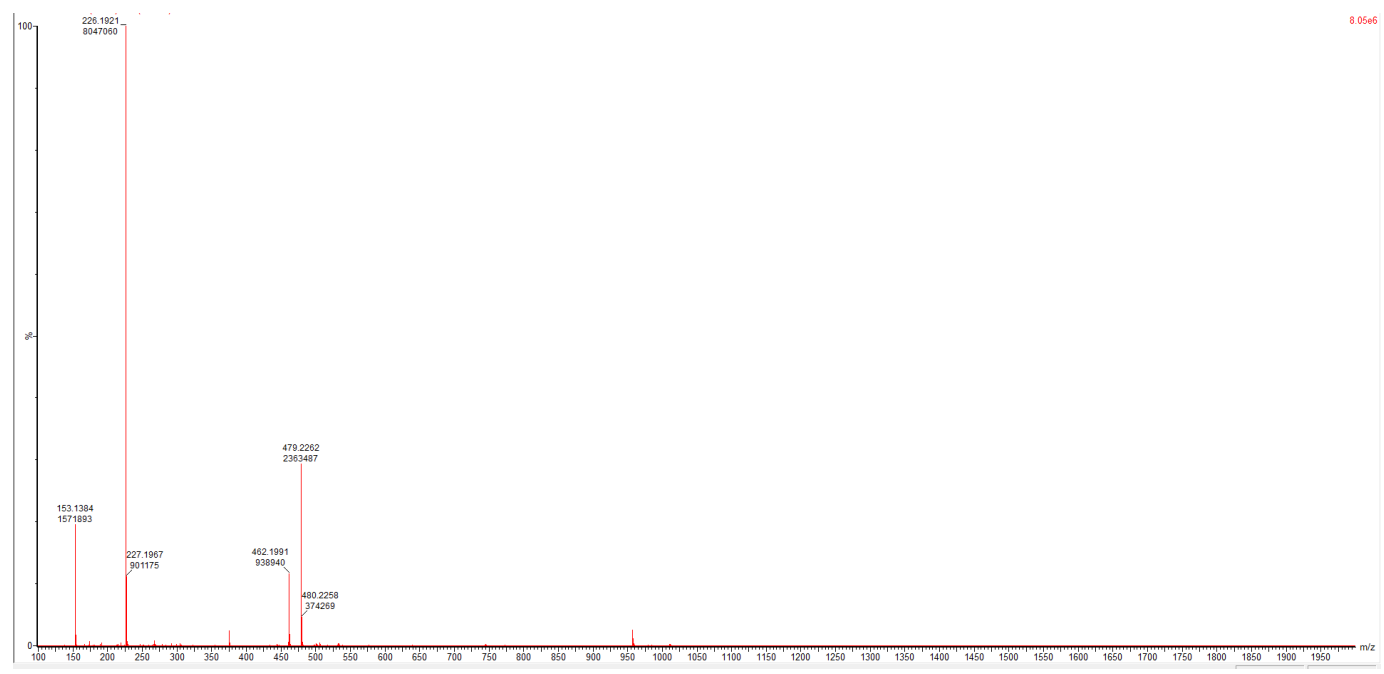

$\mathrm{ESI}^{+}$trace peptide SI-7

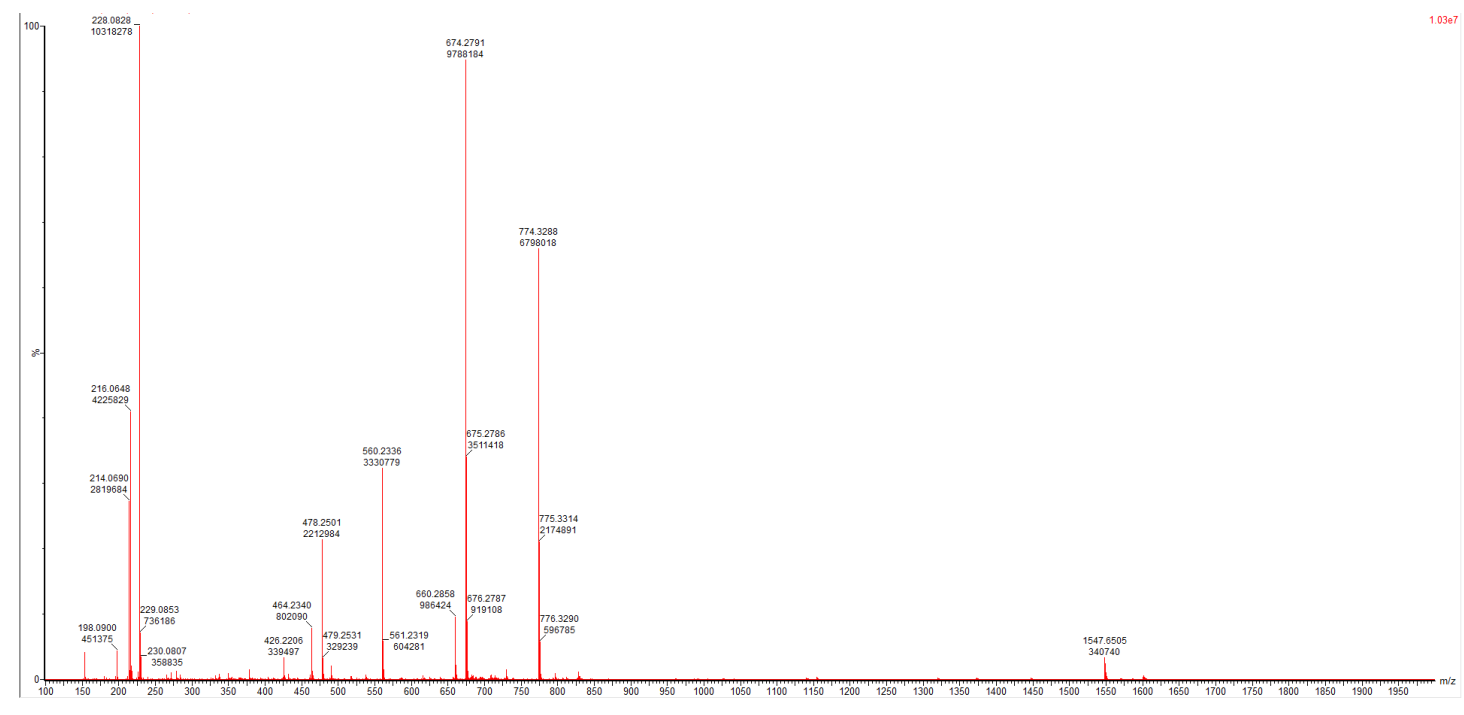

ESI $^{+}$trace peptide 6 


\section{Peptide 7}

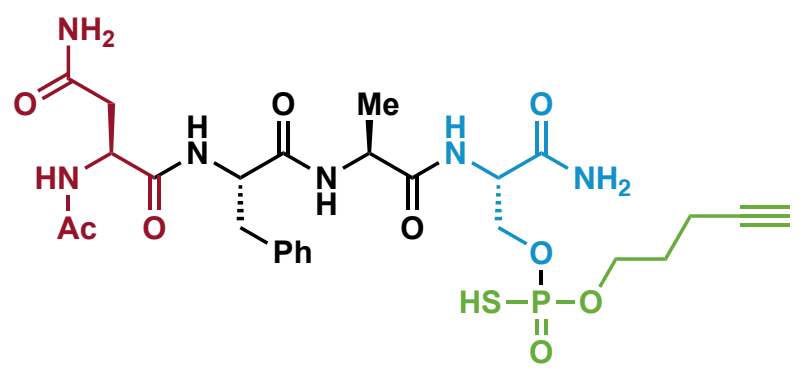

Prepared according to General Procedure $\mathbf{C}$ using:

Peptide SI-7 (100 $\mu \mathrm{L}$ of a $20 \mathrm{mM}$ solution in DMF, 1.0 equiv), P(V)-2a (100 $\mu \mathrm{L}$ of a $100 \mathrm{mM}$ solution in DMF, 5.0 equiv) and DBU (5 equiv). The crude mixture was analyzed by ${ }^{31} \mathrm{P}$ NMR and LC/MSD TOF to afford peptide 7 in $67 \%$ conversion. $[\mathbf{M}+\mathbf{H}]^{+}\left(\mathbf{E S I}^{+}\right): 641.2$.

${ }^{31}$ P NMR (162 MHz, DMF-d): $\delta 56.8$.

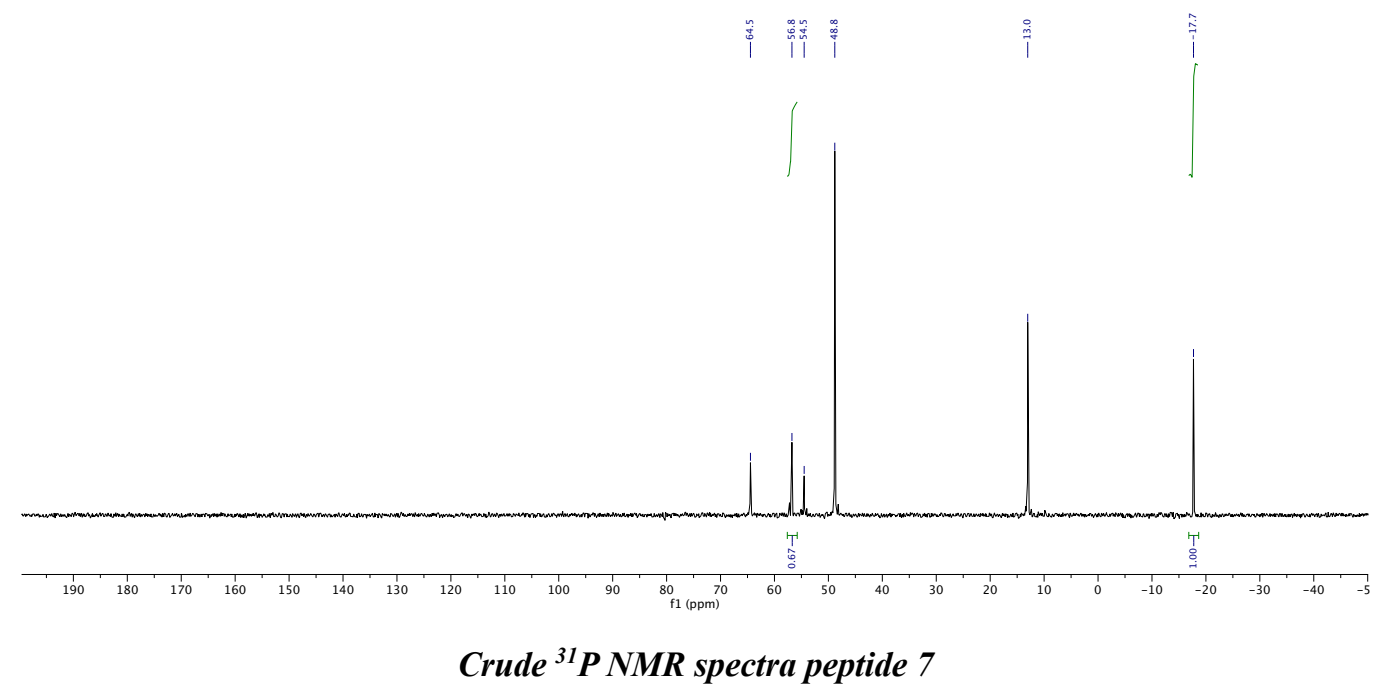




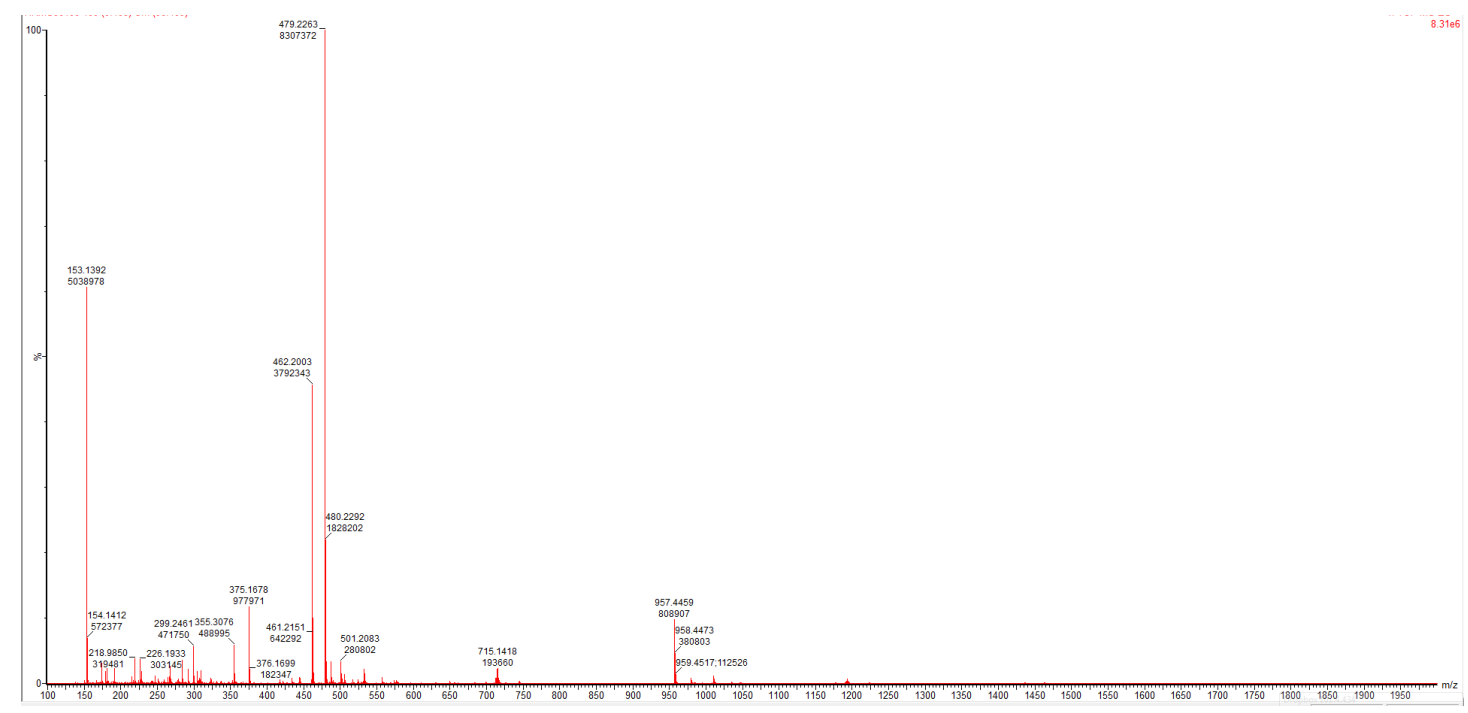

$\mathrm{ESI}^{+}$trace peptide SI-7

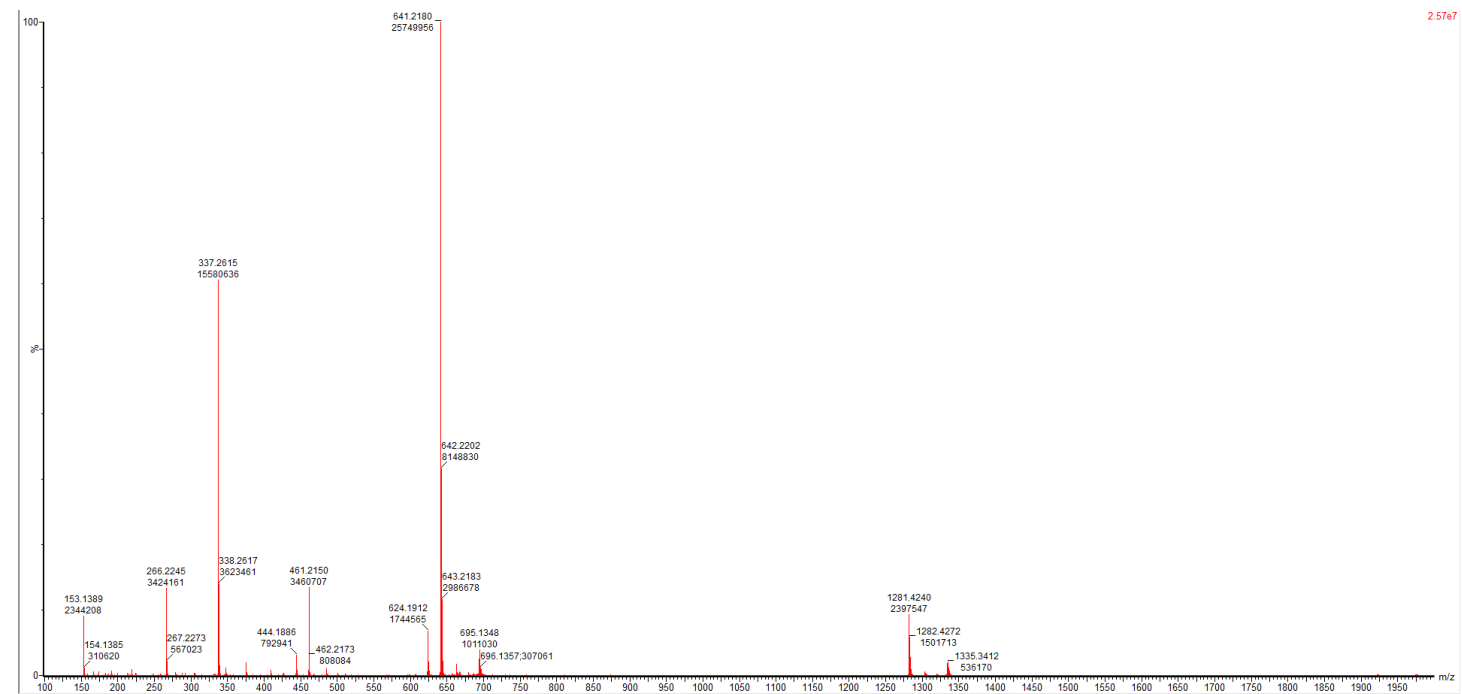

ESI $^{+}$trace peptide 7 


\section{Peptide 8}

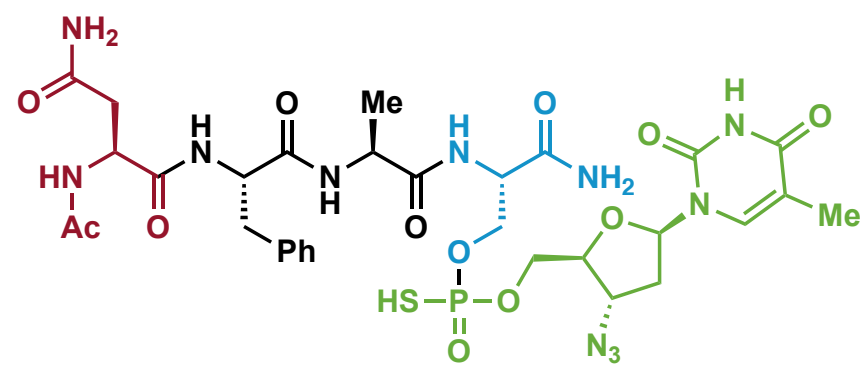

Prepared according to General Procedure $\mathbf{C}$ using:

Peptide SI-7 (100 $\mu \mathrm{L}$ of a $20 \mathrm{mM}$ solution in DMF, 1.0 equiv), P(V)-3 (100 $\mu \mathrm{L}$ of a $100 \mathrm{mM}$ solution in DMF, 5.0 equiv) and DBU (5 equiv). The crude mixture was analyzed by LC/MSD TOF to afford peptide 8 in 54\% conversion.

$[\mathbf{M}+\mathbf{H}]^{+}\left(\mathbf{E S I}^{+}\right): 824.3$.

${ }^{31}$ P NMR (162 MHz, DMF-d): $\delta$ 55.6.

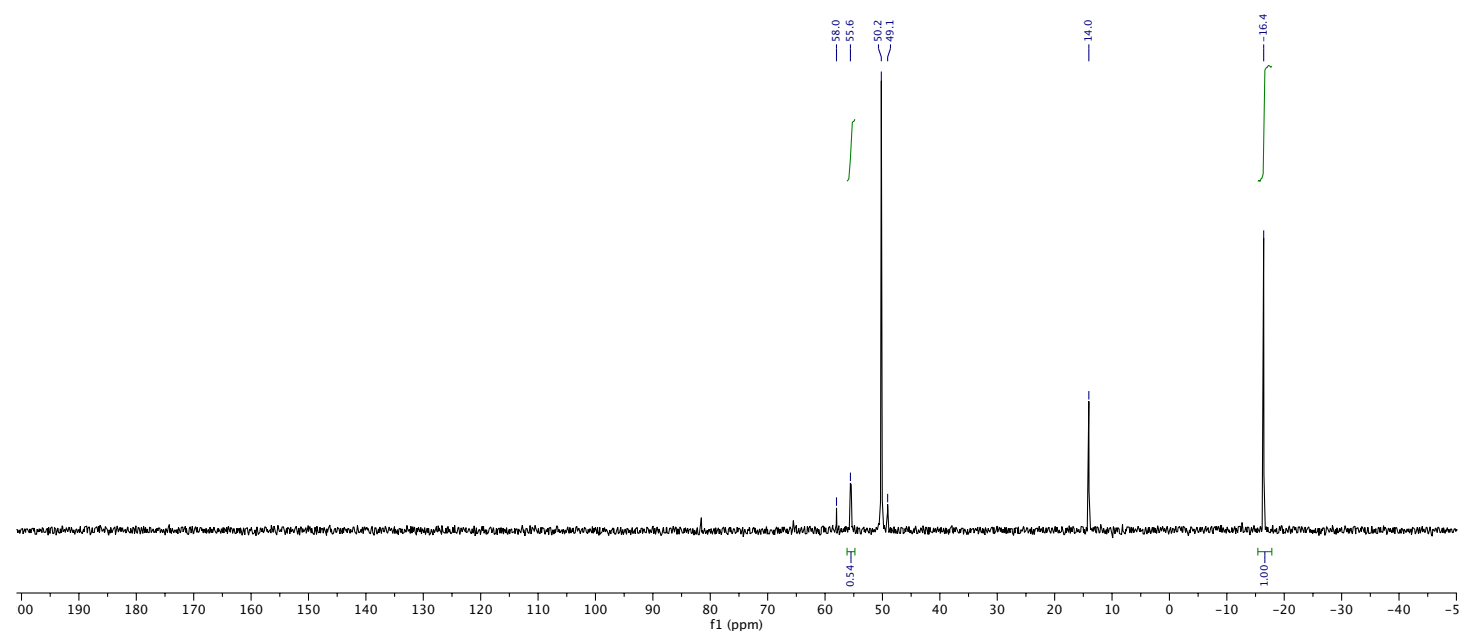

Crude ${ }^{31}$ P NMR spectra peptide 8 


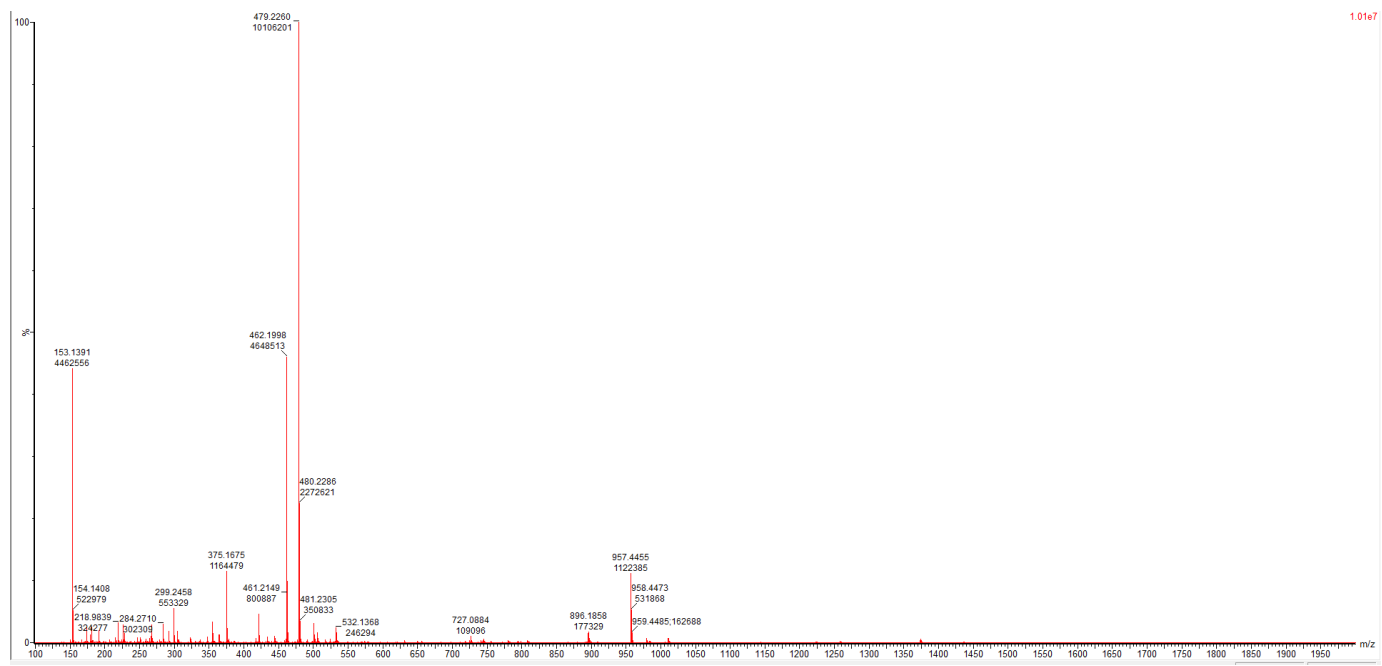

$\mathrm{ESI}^{+}$trace peptide SI-7

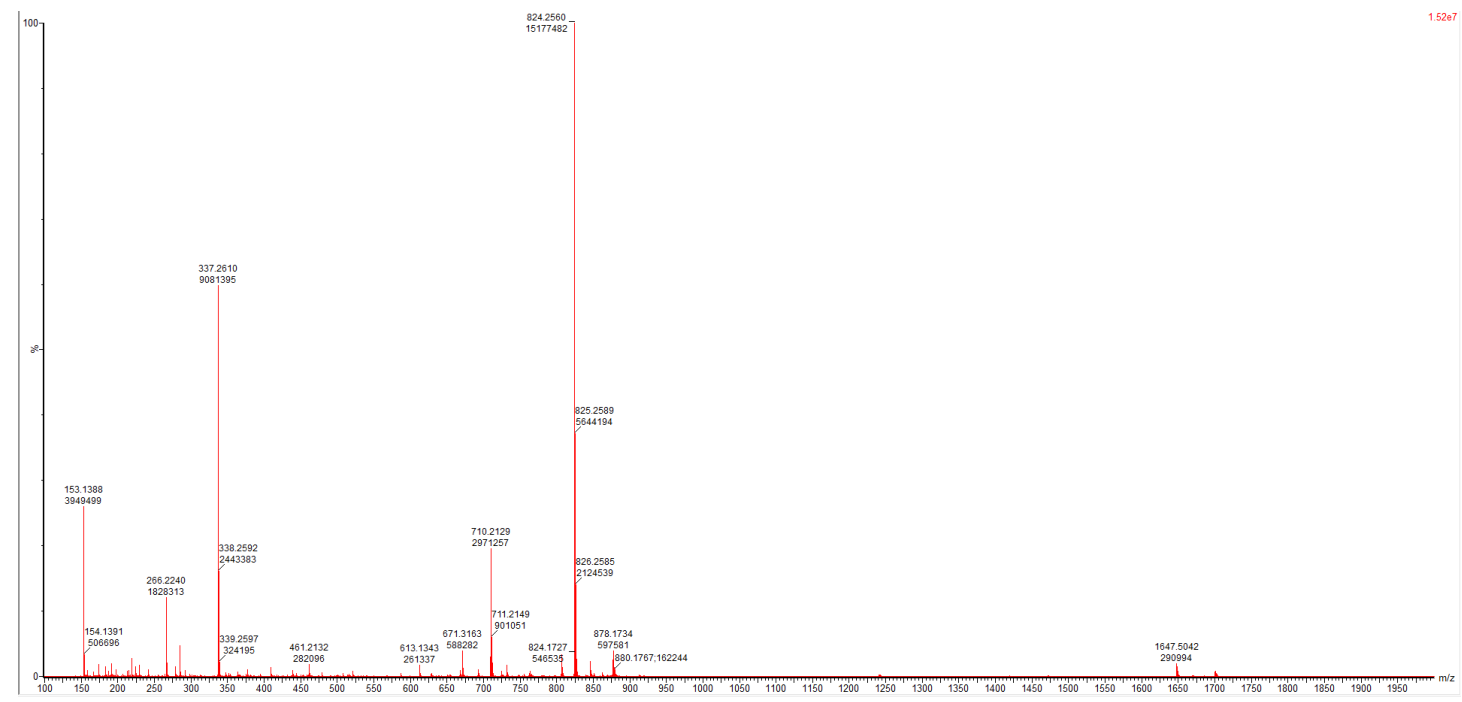

$\mathrm{ESI}^{+}$trace peptide 8 


\section{Peptide 9}

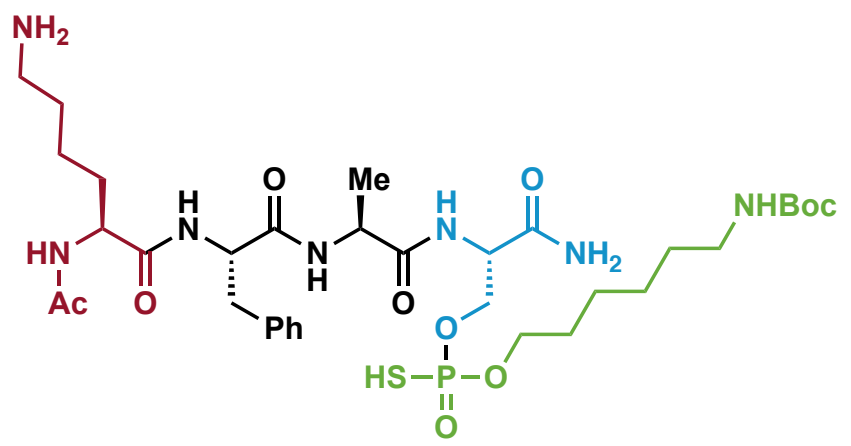

Prepared according to General Procedure C using:

Peptide SI-8 (100 $\mu \mathrm{L}$ of a $20 \mathrm{mM}$ solution in DMF, 1.0 equiv), P(V)-1 (100 $\mu \mathrm{L}$ of a $100 \mathrm{mM}$ solution in DMF, 5.0 equiv) and DBU (5 equiv). The crude mixture was analyzed by ${ }^{31} \mathrm{P}$ NMR and LC/MSD TOF to afford peptide 9 in $83 \%$ conversion.

$[\mathbf{M}+\mathbf{H}]^{+}\left(\mathbf{E S I}^{+}\right):$788.4.

${ }^{31}$ P NMR (162 MHz, DMF-d): $\delta 54.9$.

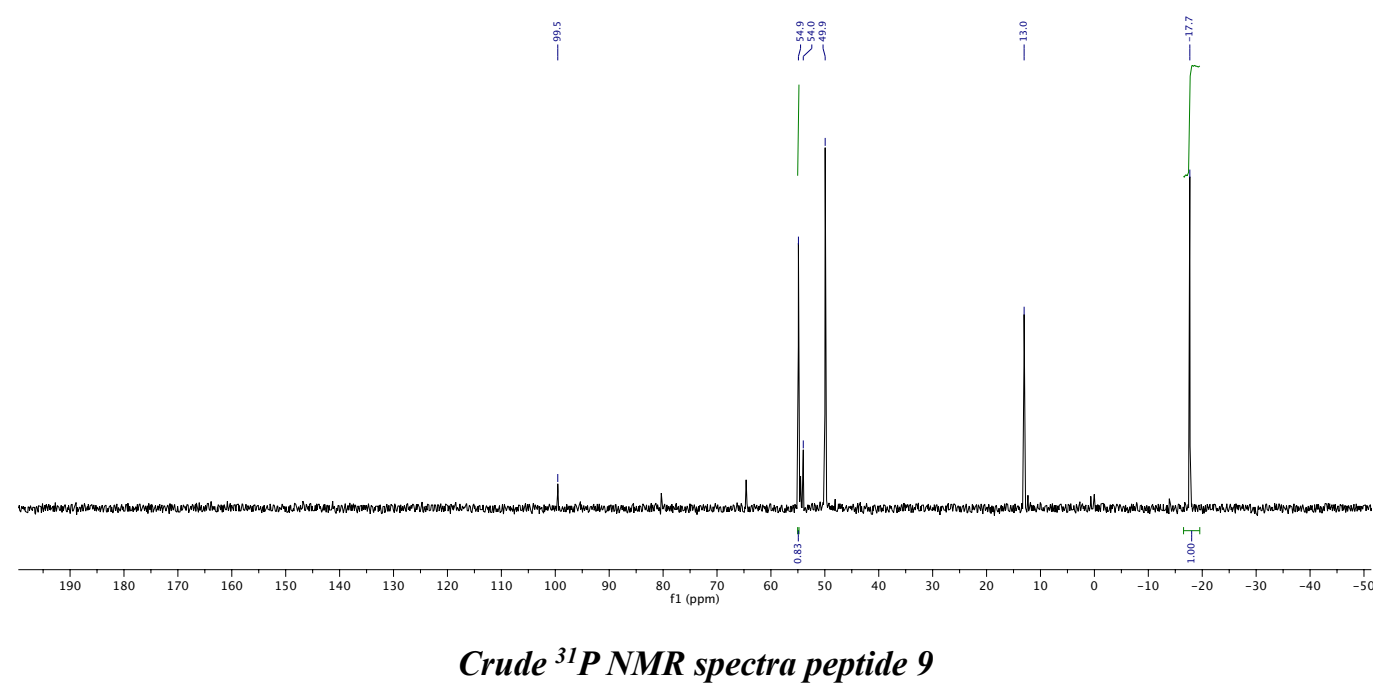




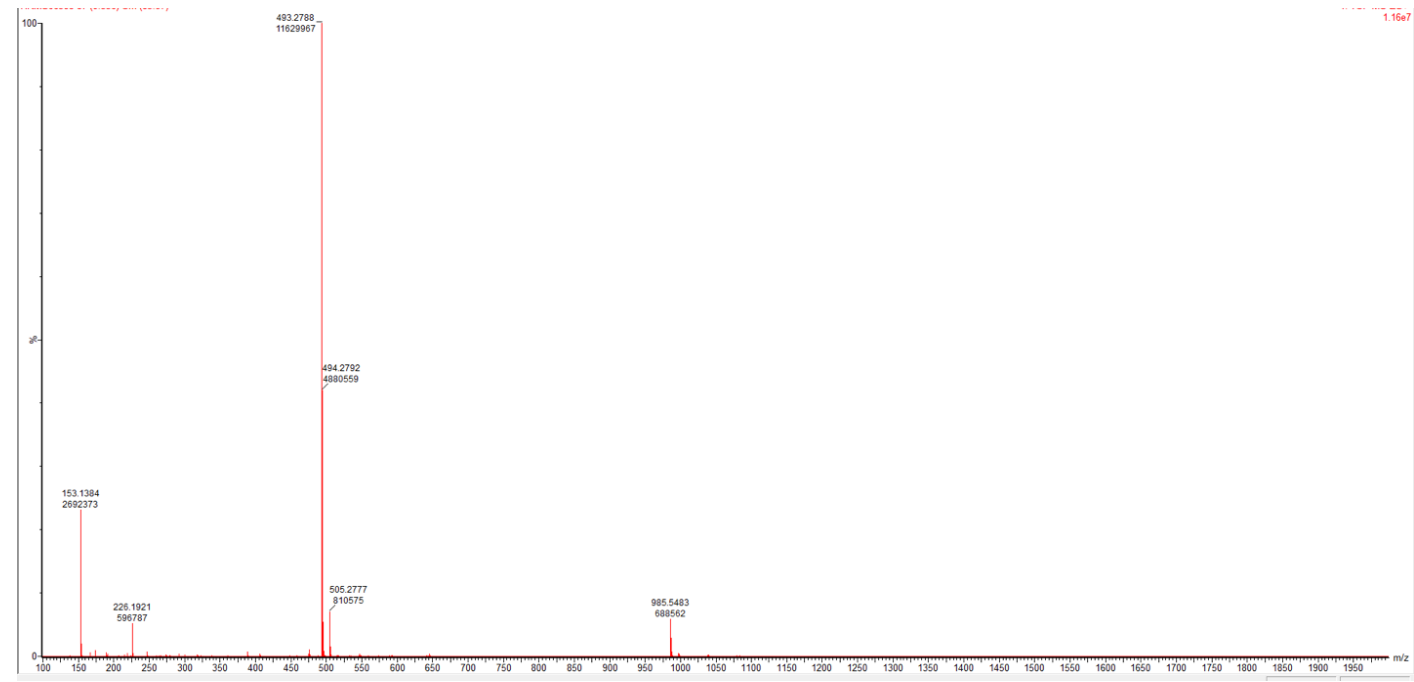

ESI $^{+}$trace peptide SI-8

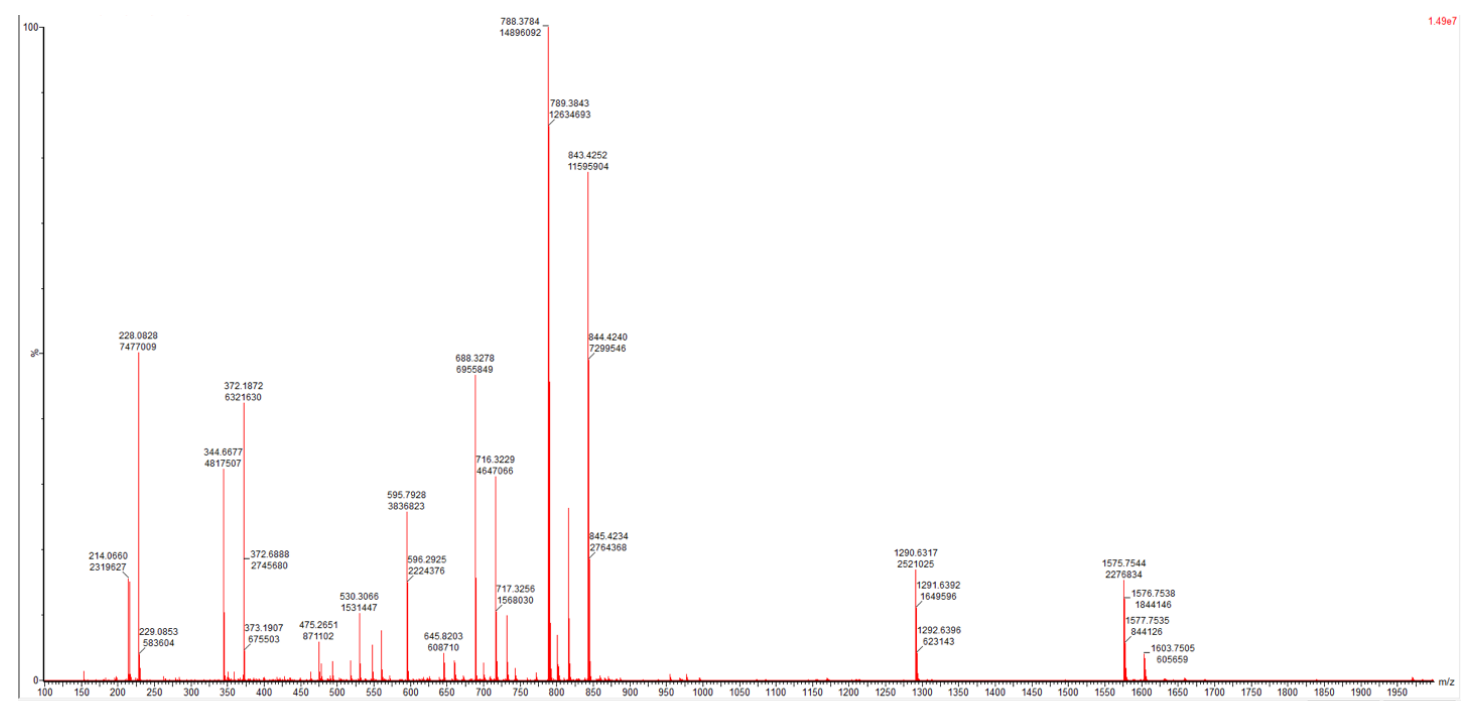

ESI $^{+}$trace peptide 9 


\section{Peptide 9 bis}

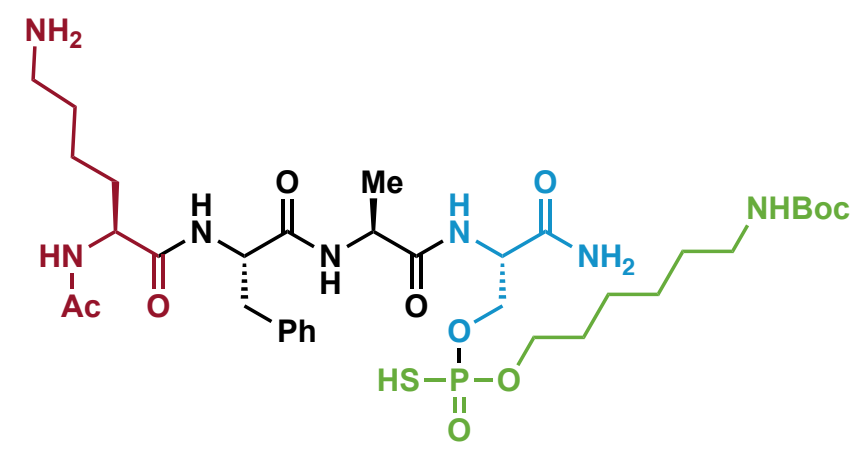

Prepared according to General Procedure C using:

Peptide SI-8 (100 $\mu \mathrm{L}$ of a $20 \mathrm{mM}$ solution in DMF, 1.0 equiv), P(V)-1 (100 $\mu \mathrm{L}$ of a $200 \mathrm{mM}$ solution in DMF, 10.0 equiv) and DBU (10 equiv). The crude mixture was analyzed by ${ }^{31} \mathrm{P}$ NMR and LC/MSD TOF to afford peptide 9 in $94 \%$ conversion.

$[\mathbf{M}+\mathbf{H}]^{+}\left(\mathbf{E S I}^{+}\right):$788.4.

${ }^{31}$ P NMR (162 MHz, DMF-d): $\delta$ 54.6.

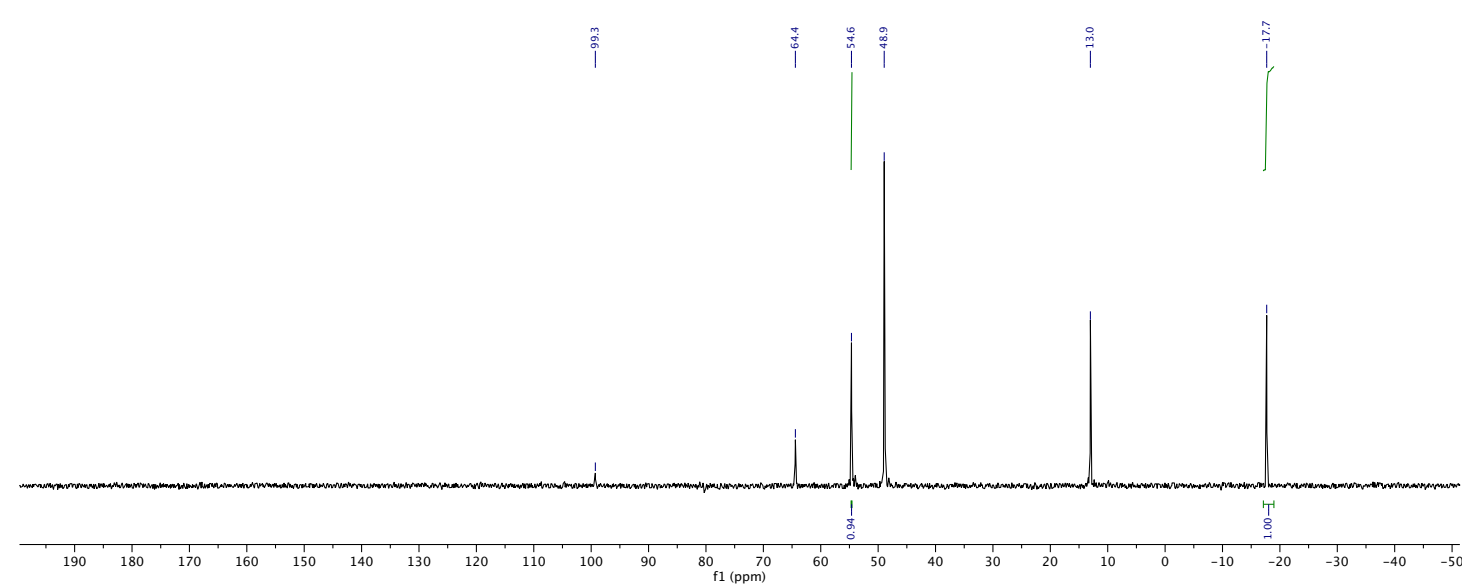

Crude ${ }^{31}$ P NMR spectra peptide 9 


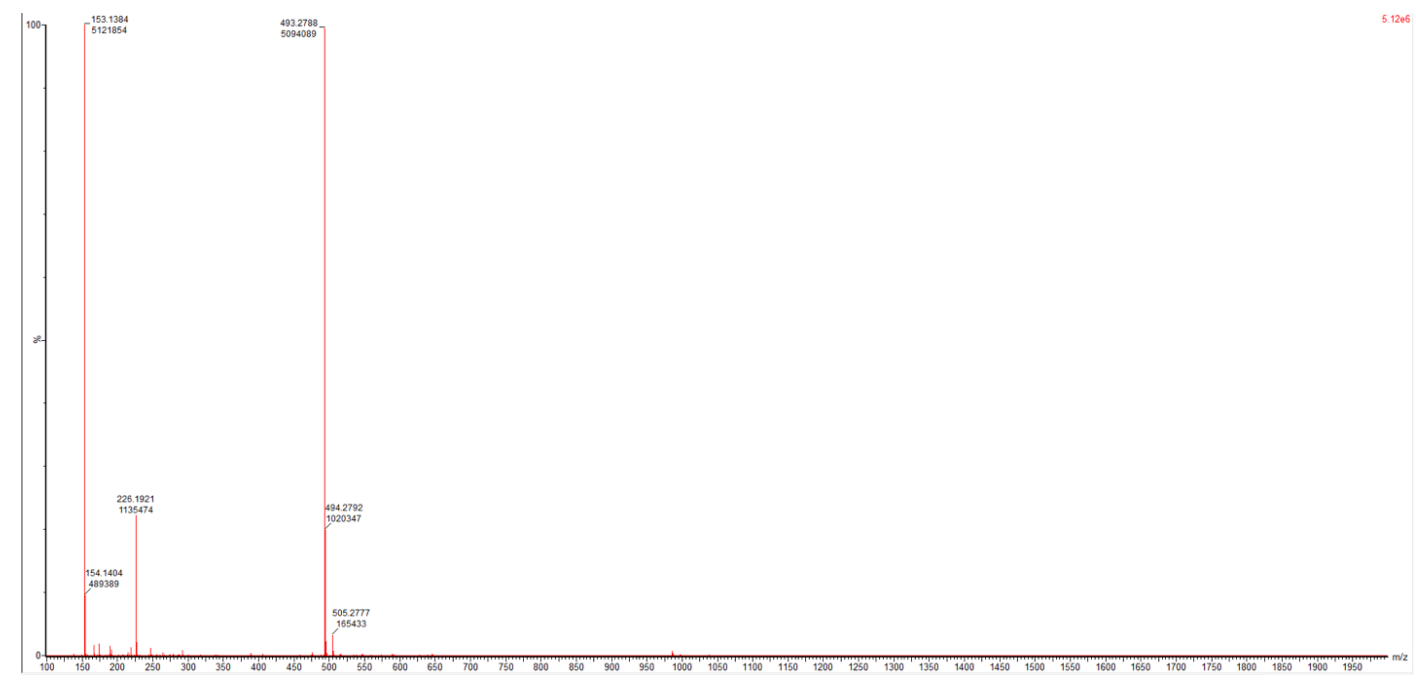

ESI $^{+}$trace peptide SI-8

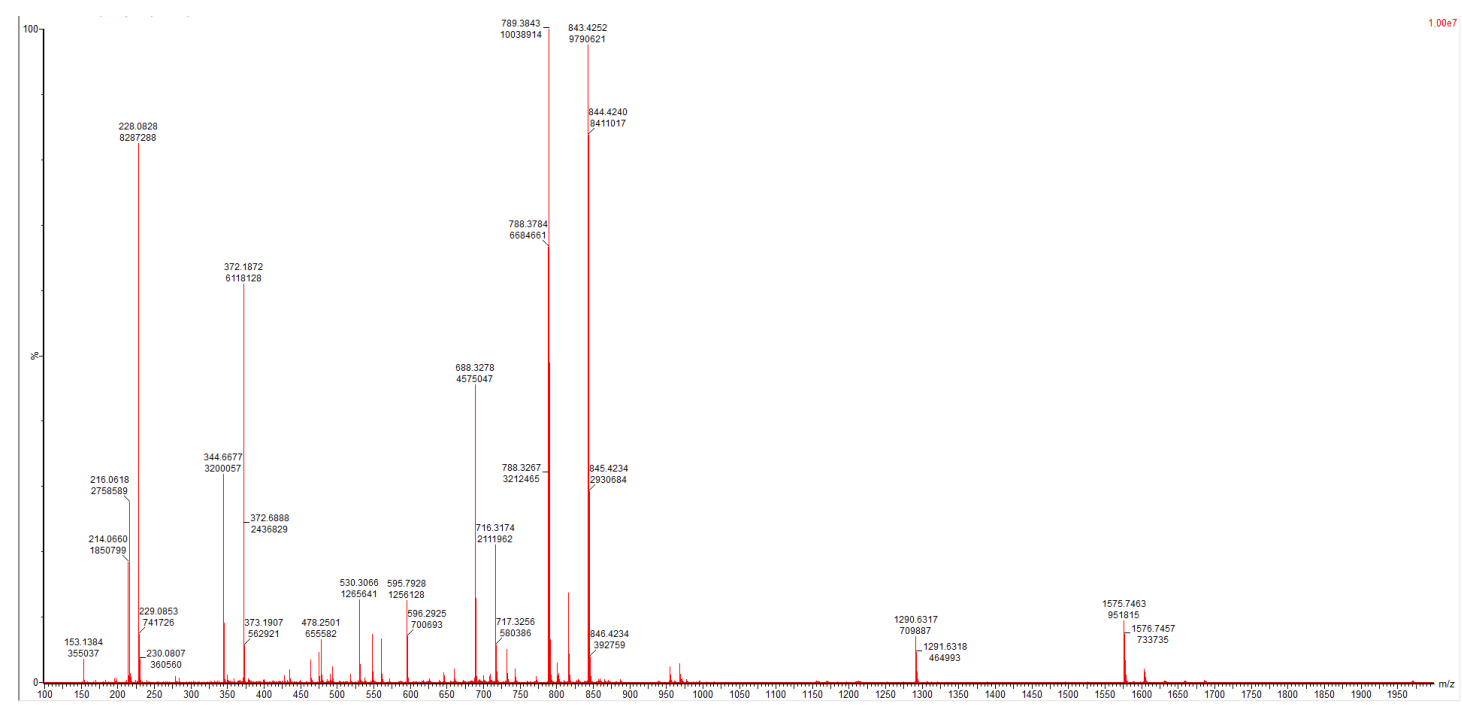

ESI $^{+}$trace peptide 9 


\section{Peptide 10}

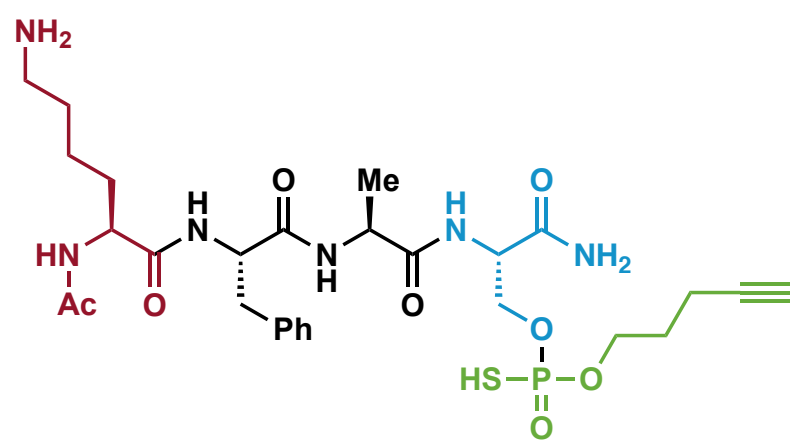

Prepared according to General Procedure C using:

Peptide SI-8 (100 $\mu \mathrm{L}$ of a $20 \mathrm{mM}$ solution in DMF, 1.0 equiv), P(V)-2a (100 $\mu \mathrm{L}$ of a $100 \mathrm{mM}$ solution in DMF, 5.0 equiv) and DBU (5 equiv). The crude mixture was analyzed by ${ }^{31} \mathrm{P}$ NMR and LC/MSD TOF to afford peptide $\mathbf{1 0}$ in $95 \%$ conversion. $[\mathbf{M}+\mathbf{H}]^{+}\left(\mathbf{E S I}^{+}\right): 655.3$.

${ }^{31}$ P NMR (162 MHz, DMF- $d$ ): $\delta$ 54.6.

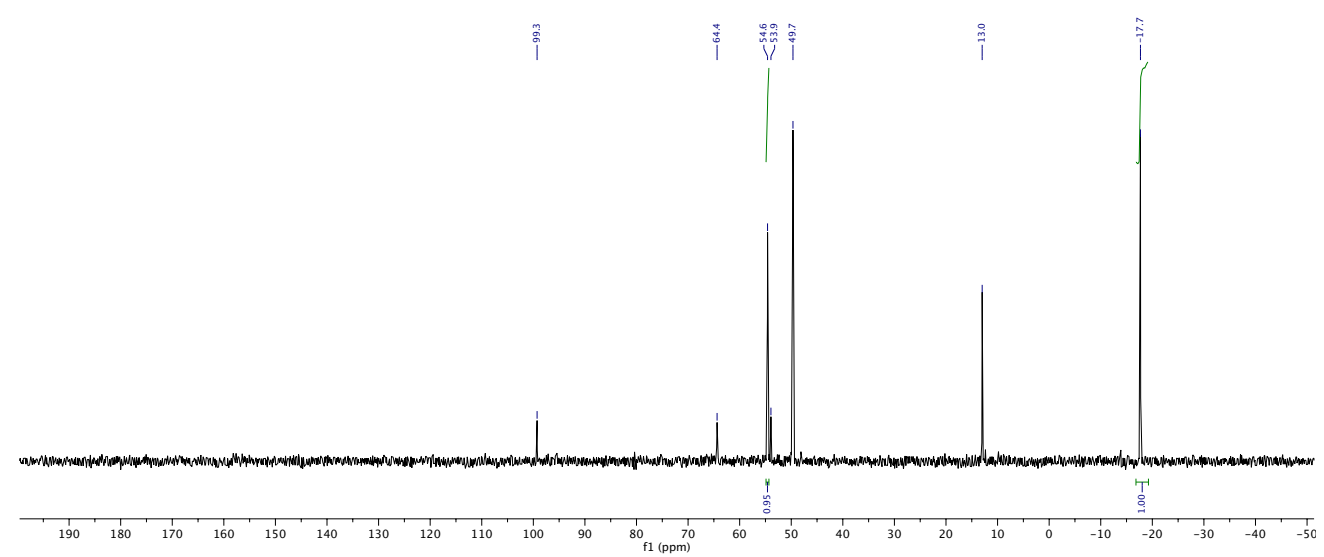

Crude ${ }^{31}$ P NMR spectra peptide 10 


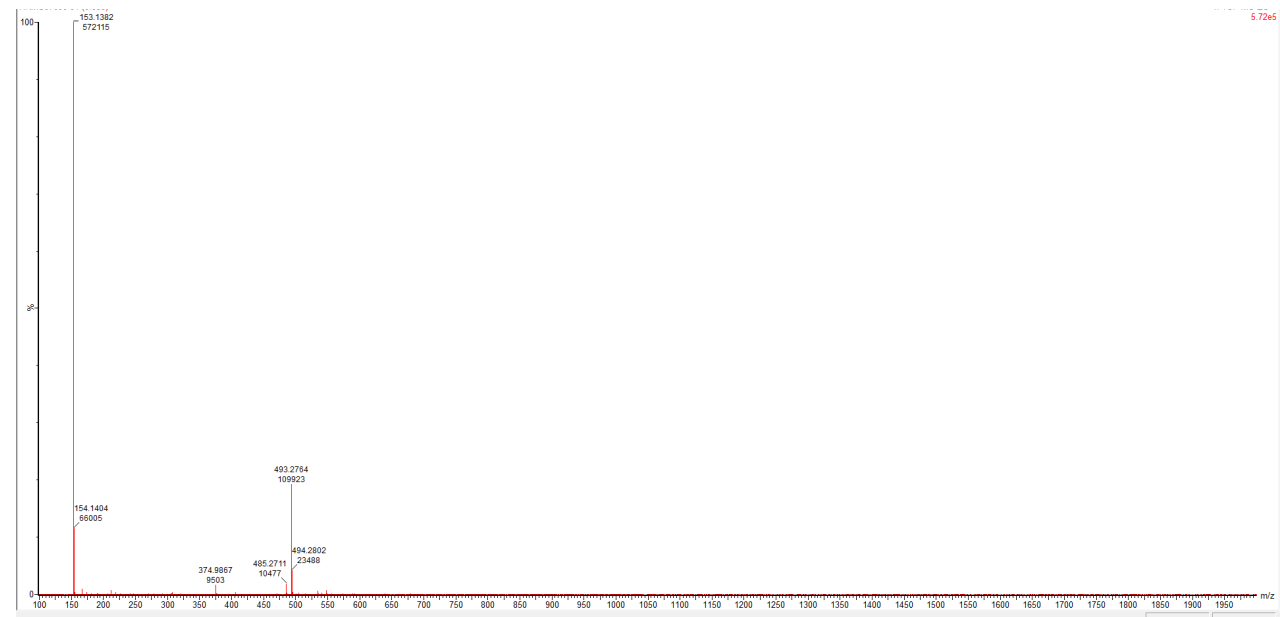

$\mathrm{ESI}^{+}$trace peptide SI-8

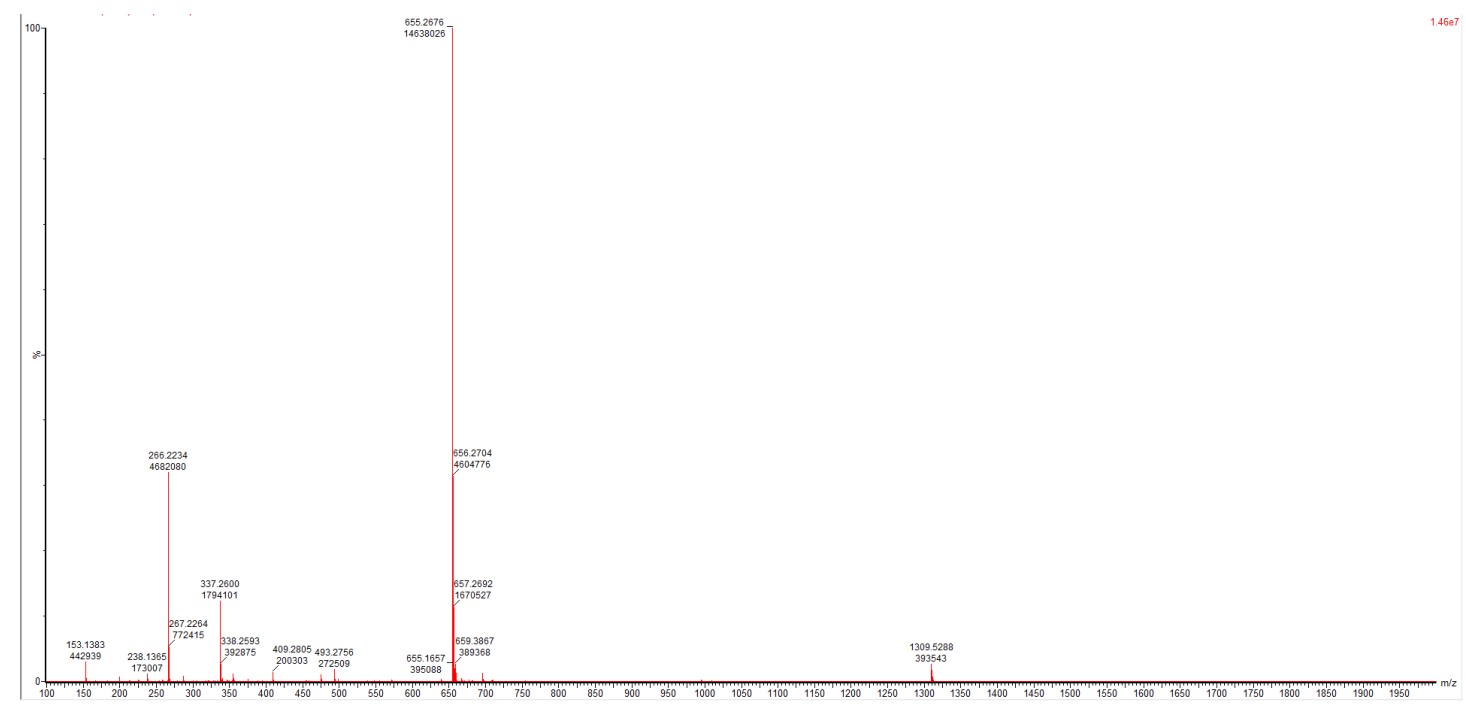

$\mathrm{ESI}^{+}$trace peptide 10 


\section{Peptide 11}

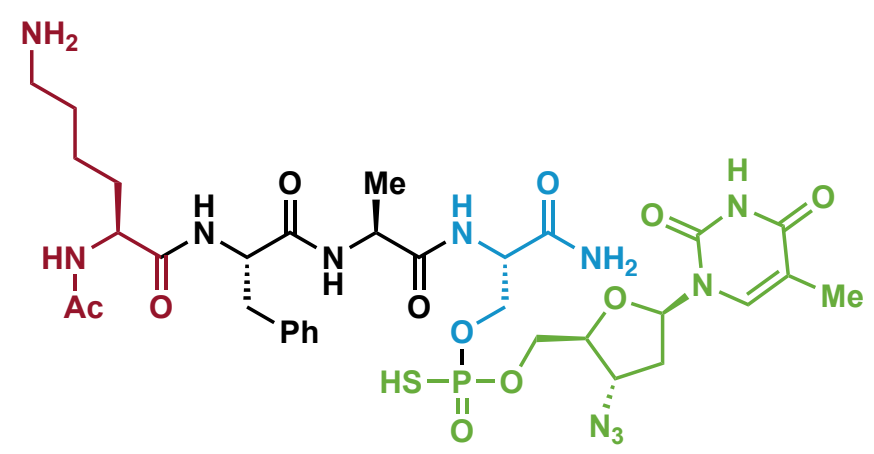

Prepared according to General Procedure C using:

Peptide SI-8 (100 $\mu \mathrm{L}$ of a $20 \mathrm{mM}$ solution in DMF, 1.0 equiv), P(V)-3 (100 $\mu \mathrm{L}$ of a $100 \mathrm{mM}$ solution in DMF, 5.0 equiv) and DBU (5 equiv). The crude mixture was analyzed by ${ }^{31} \mathrm{P}$ NMR and LC/MSD TOF to afford peptide $\mathbf{1 1}$ in $76 \%$ conversion. $[\mathbf{M}+\mathbf{H}]^{+}\left(\mathbf{E S I}^{+}\right): 838.3$.

${ }^{31}$ P NMR (162 MHz, DMF- $d$ ): $\delta 54.8$.

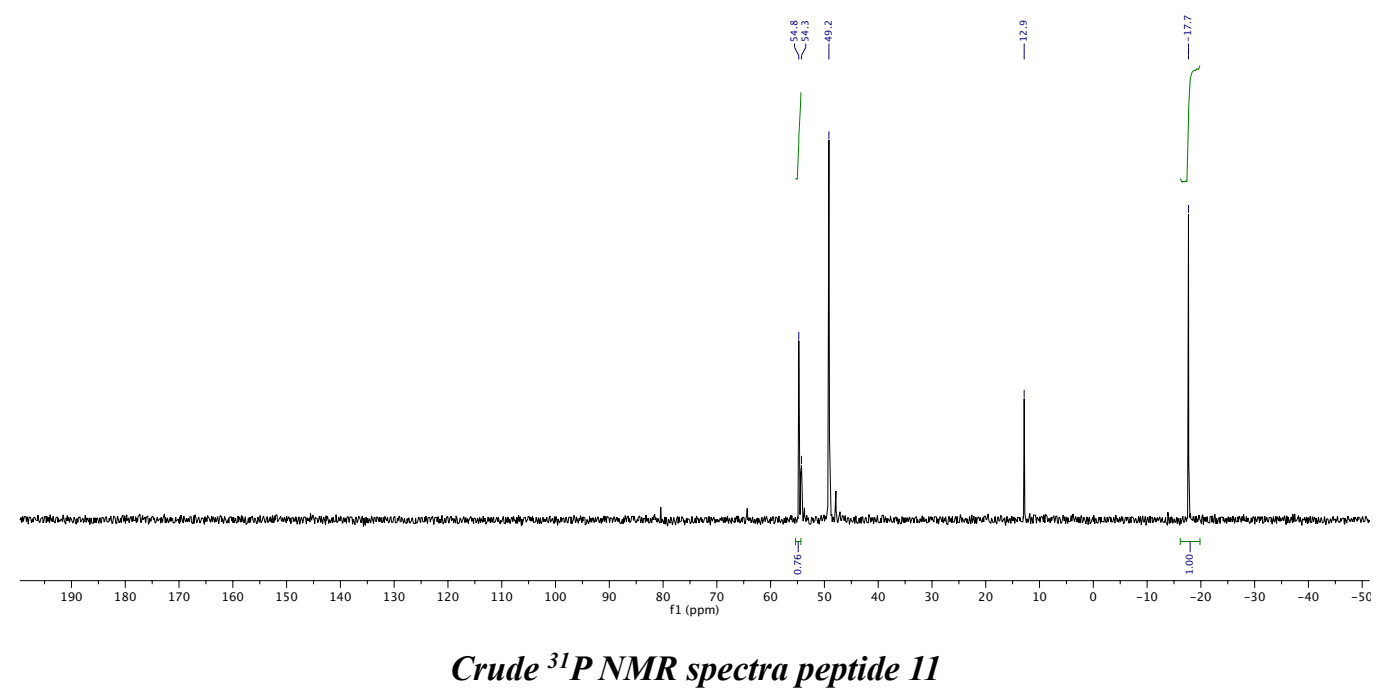




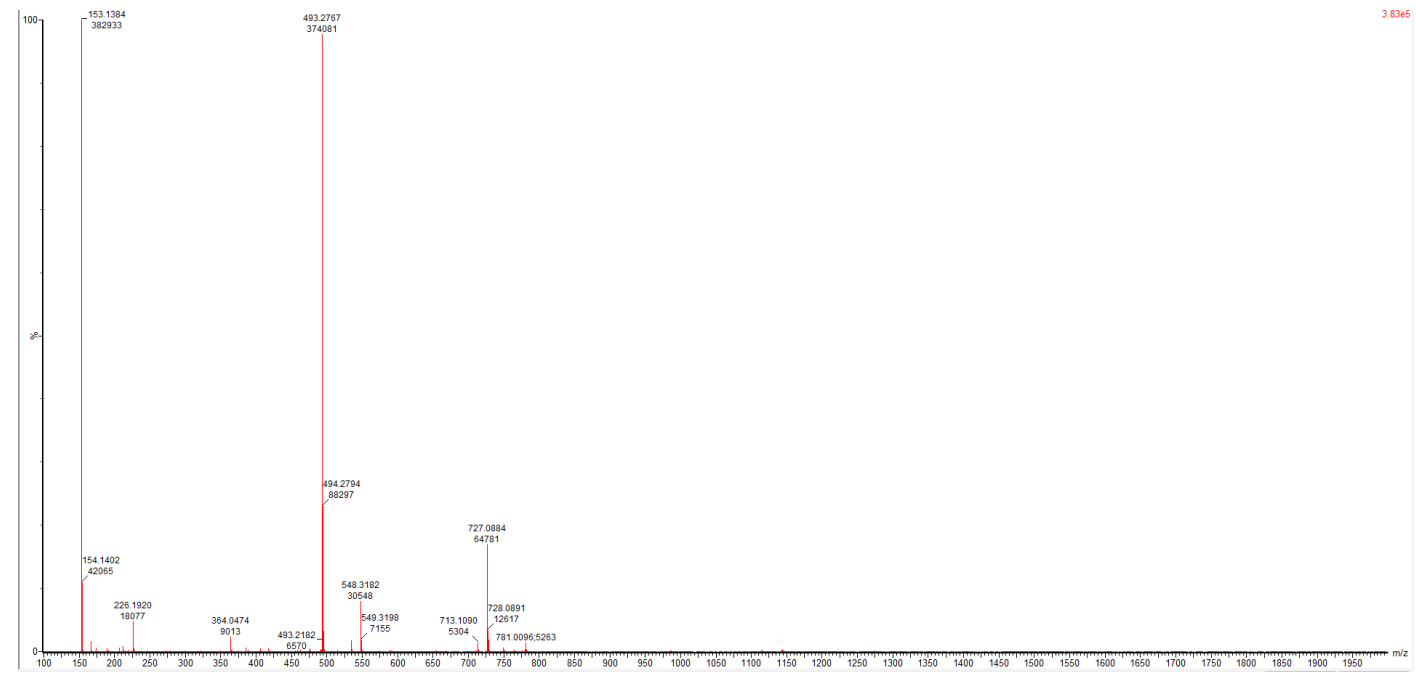

$\mathrm{ESI}^{+}$trace peptide SI-8

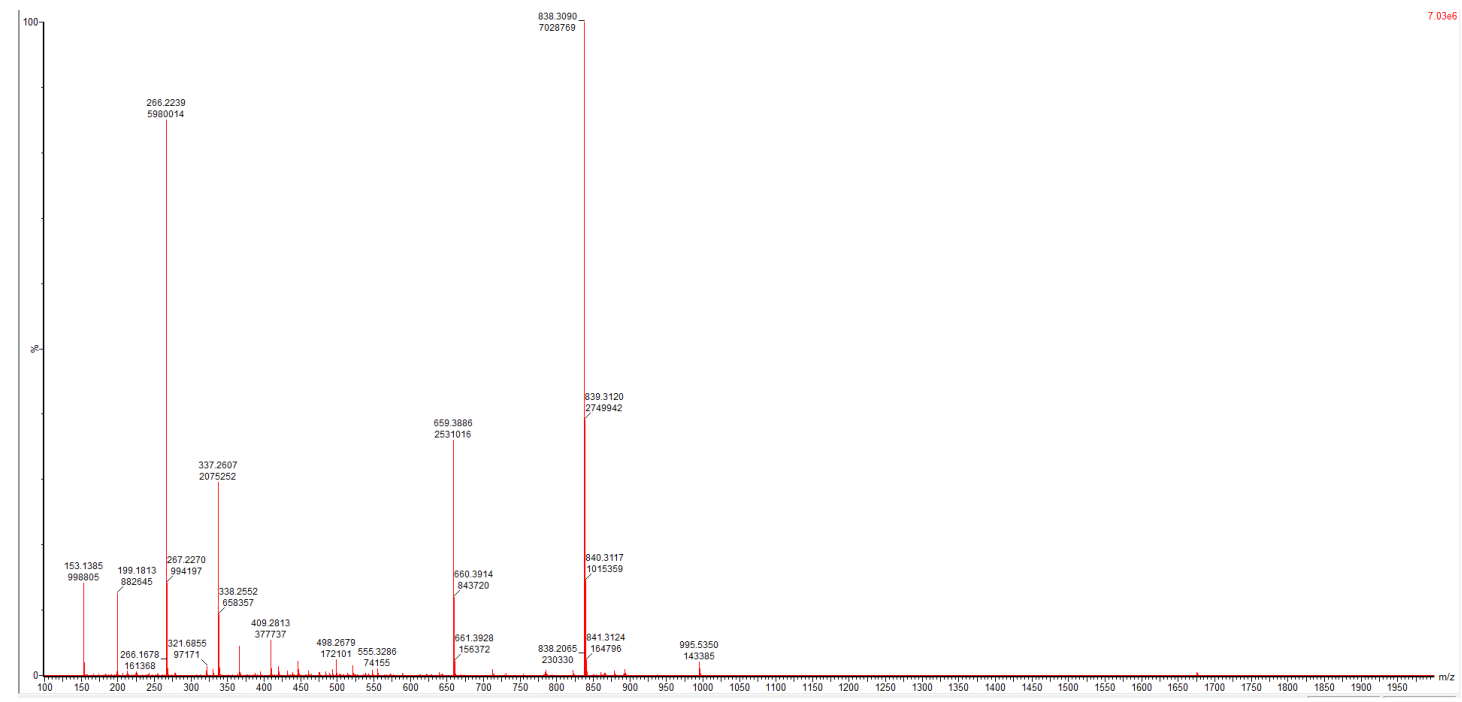

ESI $^{+}$trace peptide 11 


\section{Peptide 12}

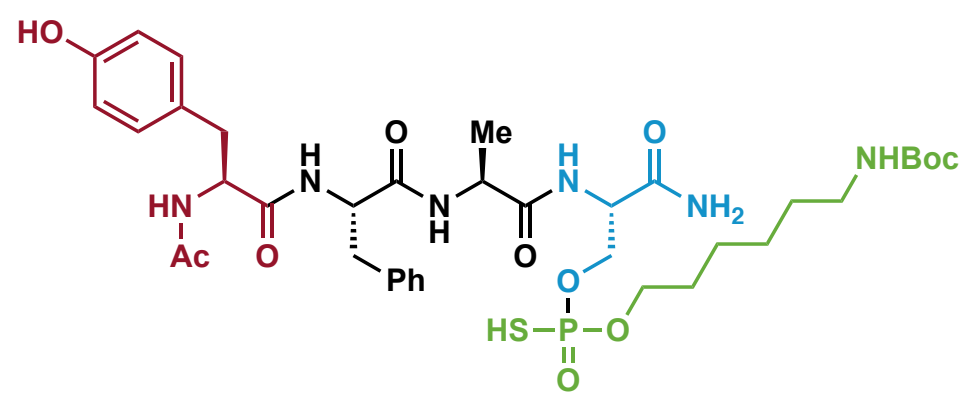

Prepared according to General Procedure C using:

Peptide SI-9 (100 $\mu \mathrm{L}$ of a $20 \mathrm{mM}$ solution in DMF, 1.0 equiv), P(V)-1 (100 $\mu \mathrm{L}$ of a $100 \mathrm{mM}$ solution in DMF, 5.0 equiv) and DBU (5 equiv). The crude mixture was analyzed by ${ }^{31} \mathrm{P}$ NMR and LC/MSD TOF to afford peptide $\mathbf{1 2}$ in $70 \%$ conversion. $[\mathbf{M}+\mathbf{H}]^{+}\left(\mathbf{E S I}^{+}\right): 824.2$.

${ }^{31}$ P NMR (162 MHz, DMF-d): $\delta 54.8$.

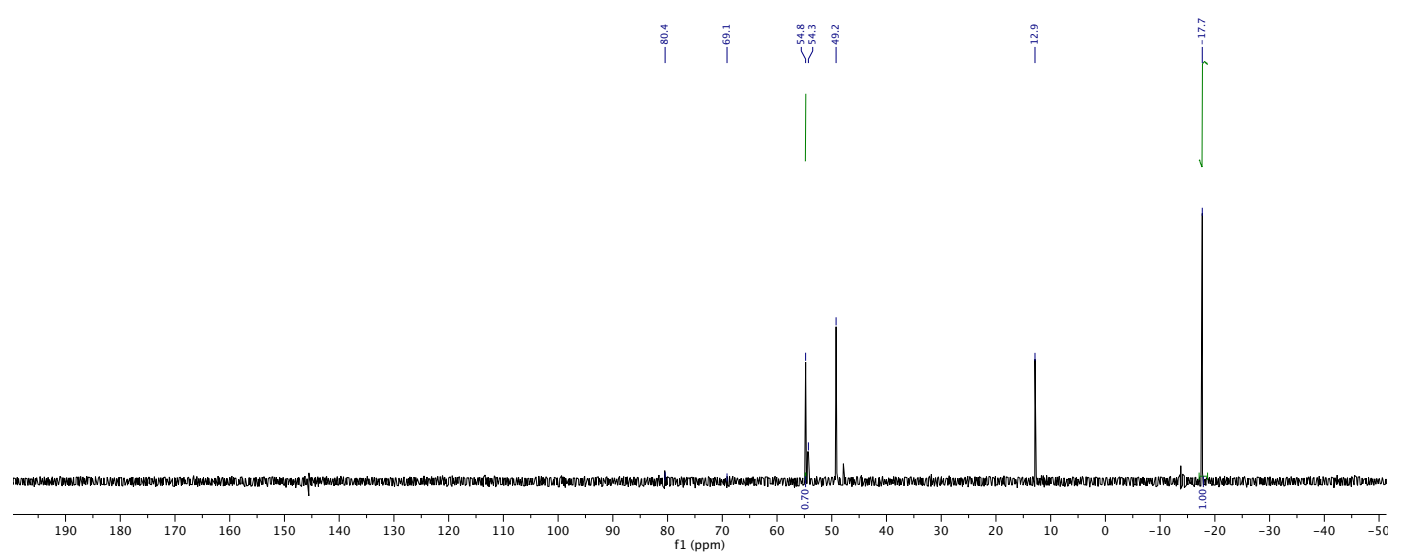

Crude ${ }^{31}$ P NMR spectra peptide 12 


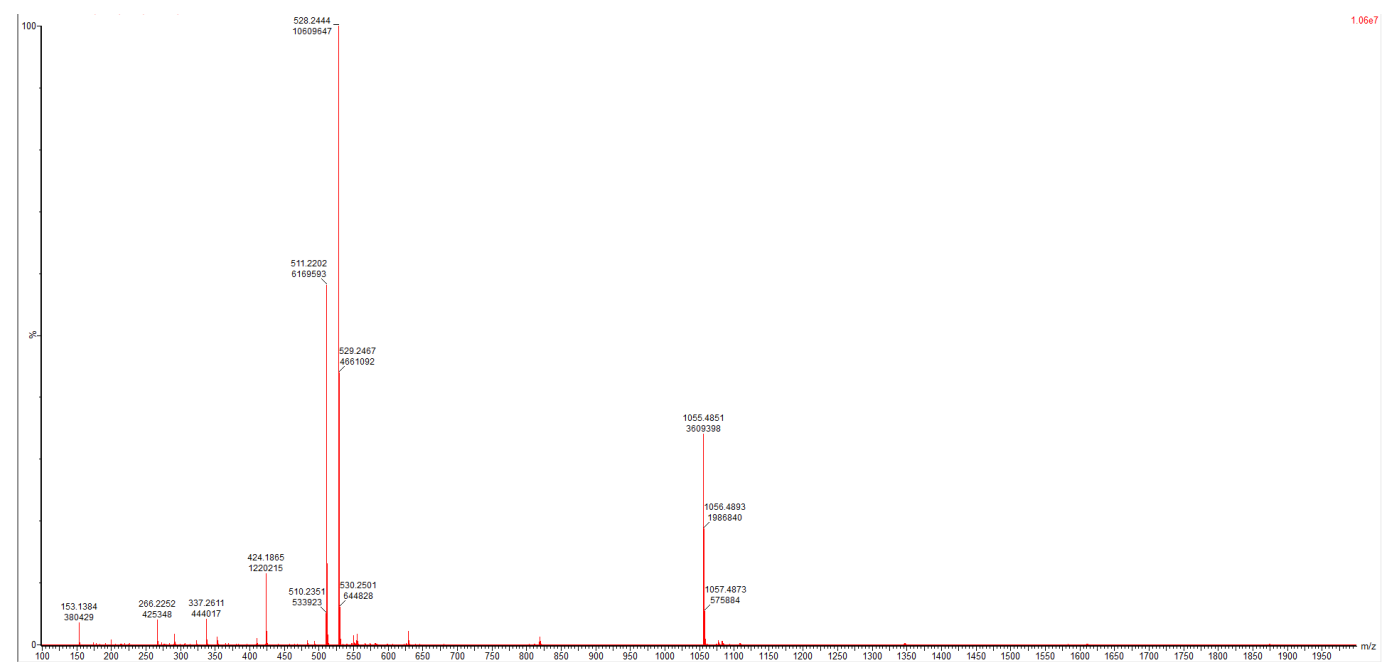

$\mathrm{ESI}^{+}$trace peptide SI-9

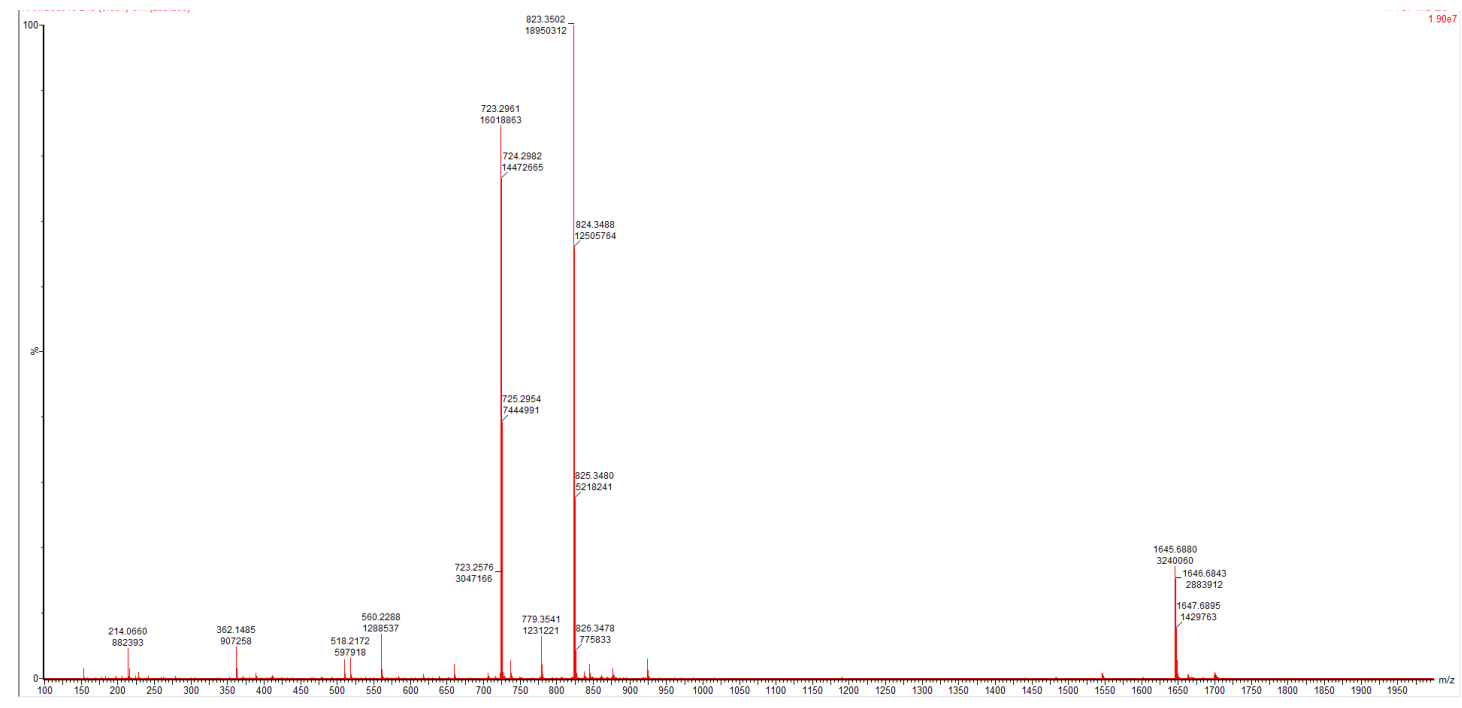

ESI $^{+}$trace peptide 12 


\section{Peptide 12 bis}

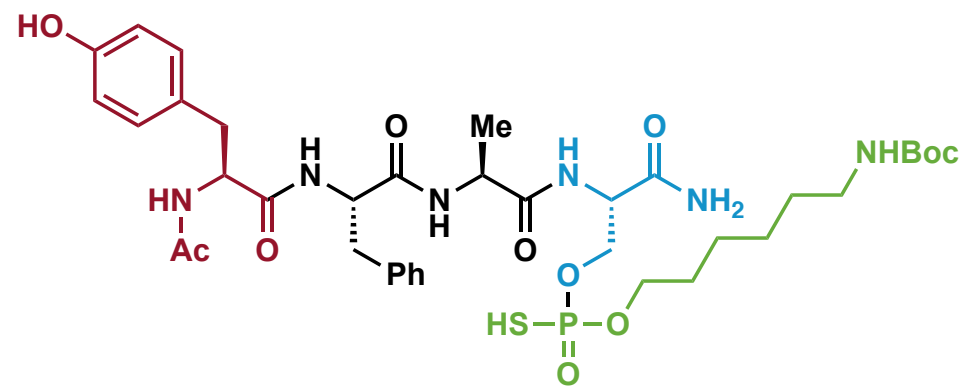

Prepared according to General Procedure $\mathbf{C}$ using:

Peptide SI-9 (100 $\mu \mathrm{L}$ of a $20 \mathrm{mM}$ solution in DMF, 1.0 equiv), P(V)-1 (100 $\mu \mathrm{L}$ of a $200 \mathrm{mM}$ solution in DMF, 10.0 equiv) and DBU (10 equiv). The crude mixture was analyzed by ${ }^{31} \mathrm{P}$ NMR and LC/MSD TOF to afford peptide 12 in $76 \%$ conversion. $[\mathbf{M}+\mathbf{H}]^{+}\left(\mathbf{E S I}^{+}\right):$824.2.

${ }^{31}$ P NMR (162 MHz, DMF-d): $\delta$ 57.0.

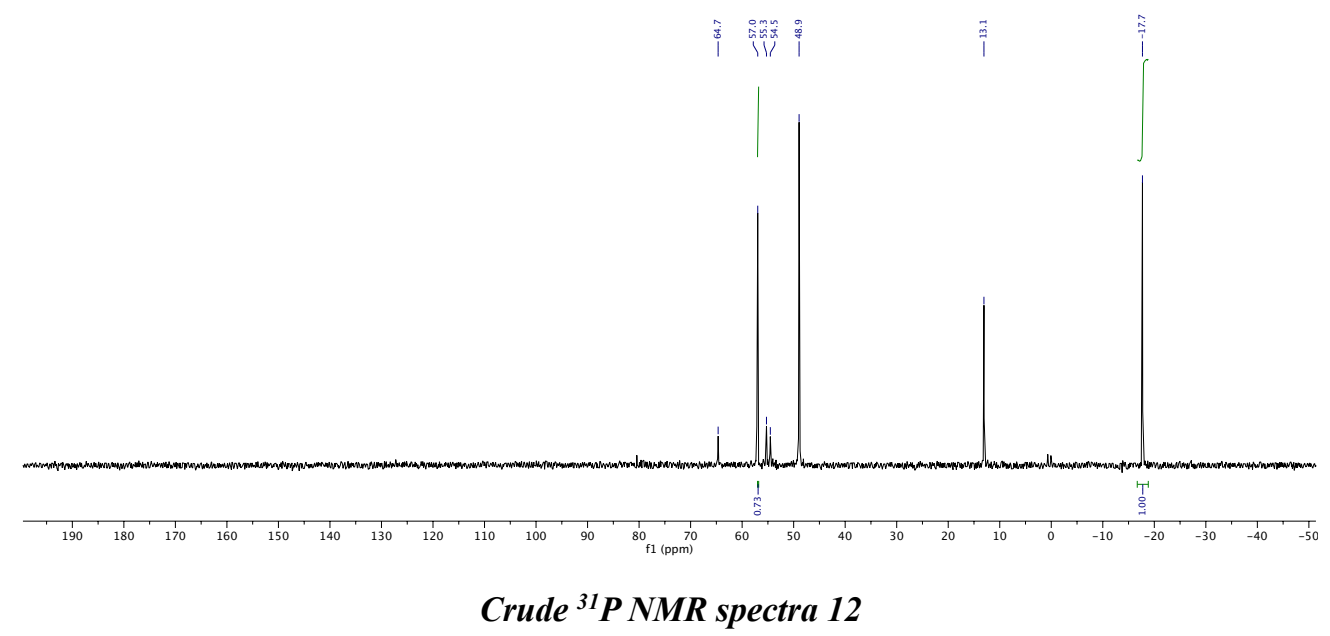




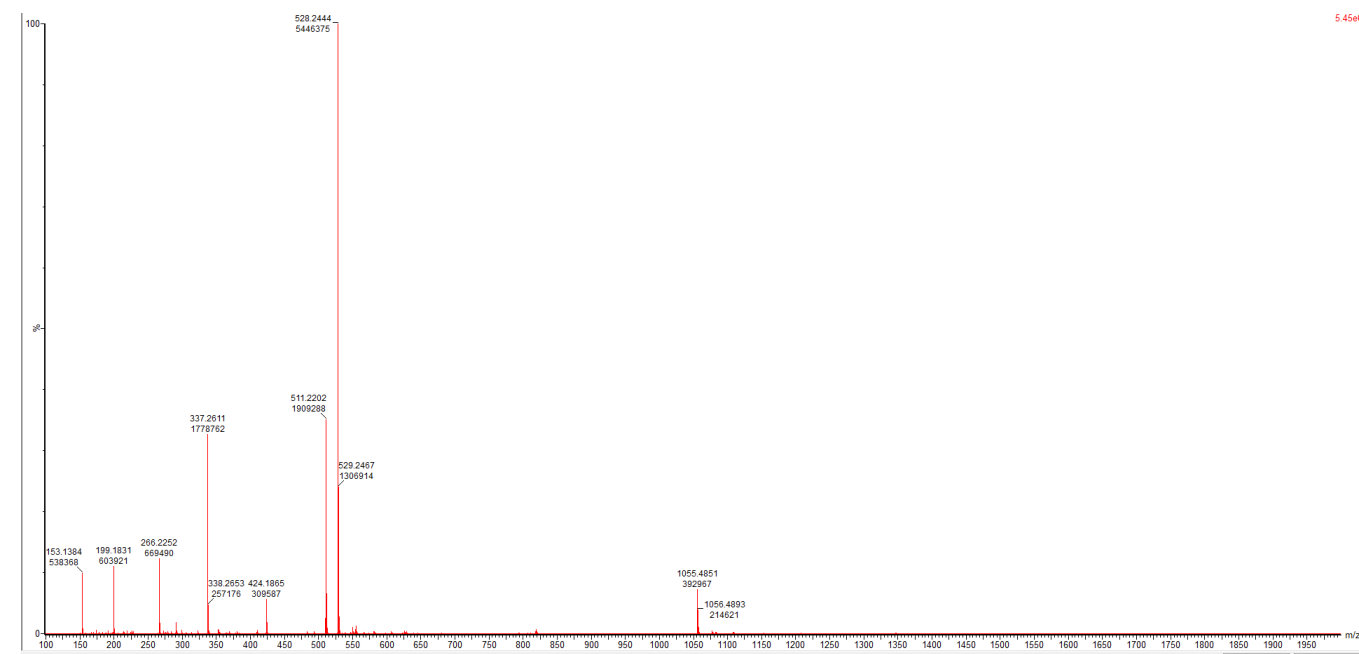

$\mathrm{ESI}^{+}$trace peptide SI-9

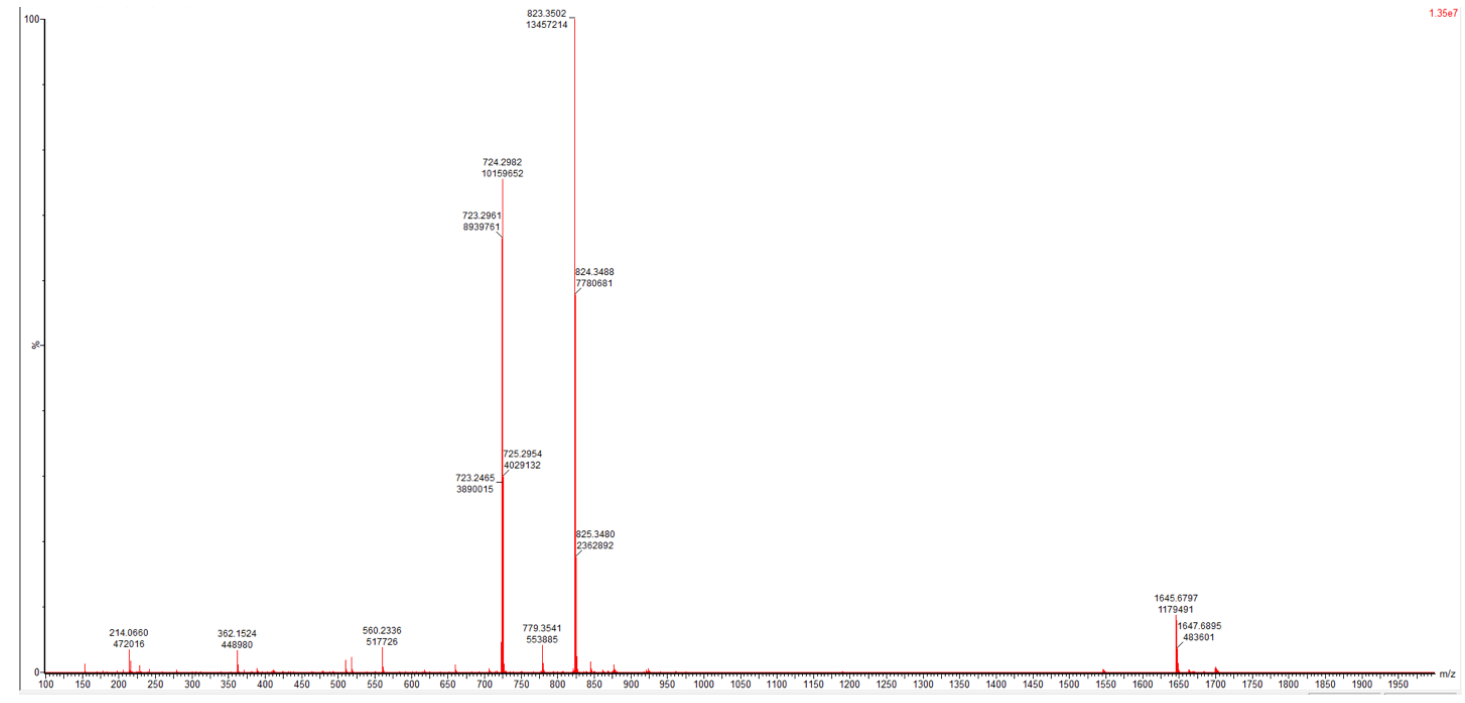

$\mathrm{ESI}^{+}$trace peptide 12 


\section{Peptide 13}

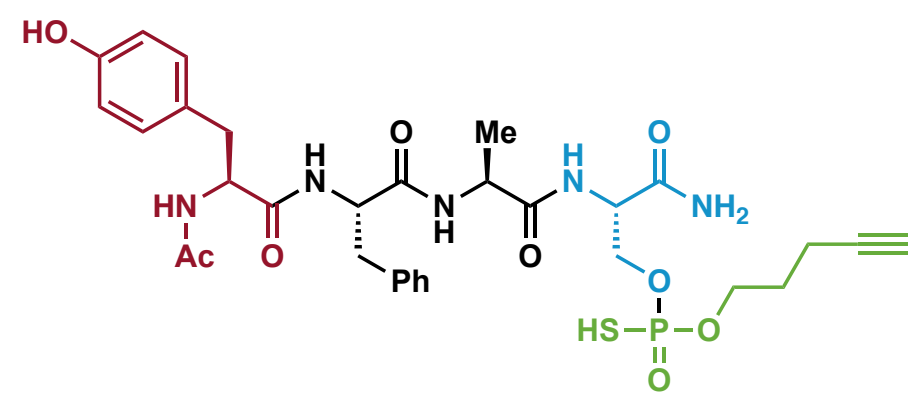

Prepared according to General Procedure $\mathbf{C}$ using:

Peptide SI-9 (100 $\mu \mathrm{L}$ of a $20 \mathrm{mM}$ solution in DMF, 1.0 equiv), P(V)-2a (100 $\mu \mathrm{L}$ of a $100 \mathrm{mM}$ solution in DMF, 5.0 equiv) and DBU (5 equiv). The crude mixture was analyzed by ${ }^{31} \mathrm{P}$ NMR and LC/MSD TOF to afford peptide $\mathbf{1 3}$ in $73 \%$ conversion. $[\mathbf{M}+\mathbf{H}]^{+}\left(\mathbf{E S I}^{+}\right): 690.2$.

${ }^{31}$ P NMR (162 MHz, DMF-d): $\delta 56.0$.

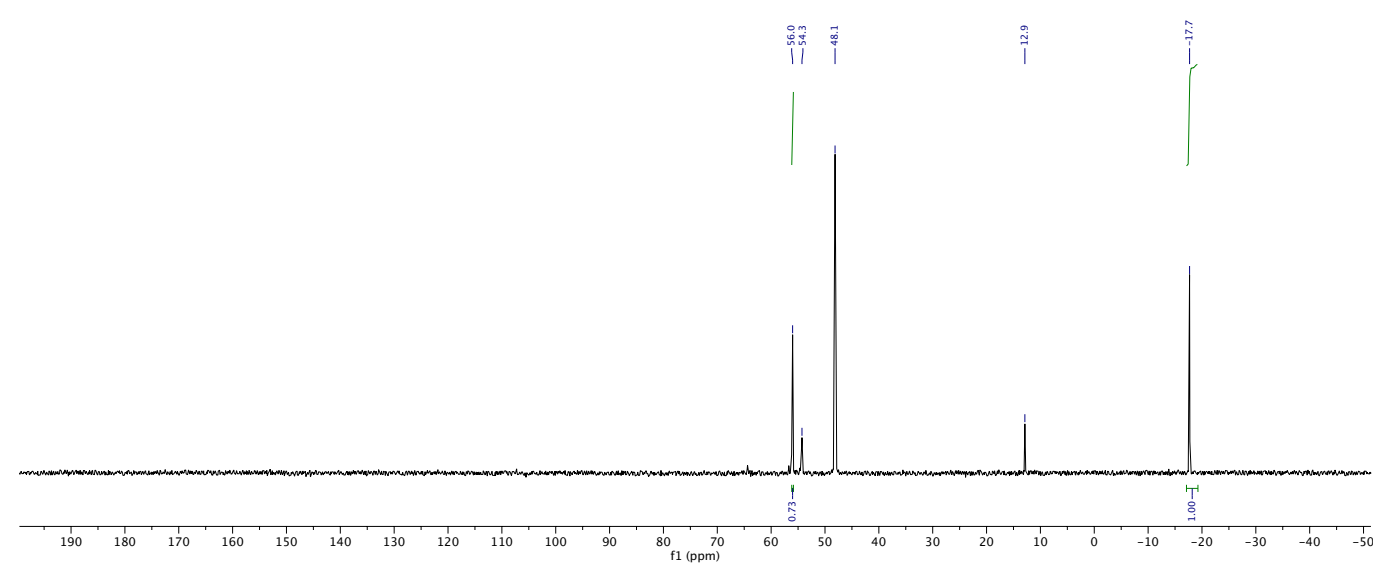

Crude ${ }^{31}$ P NMR spectra peptide 13 


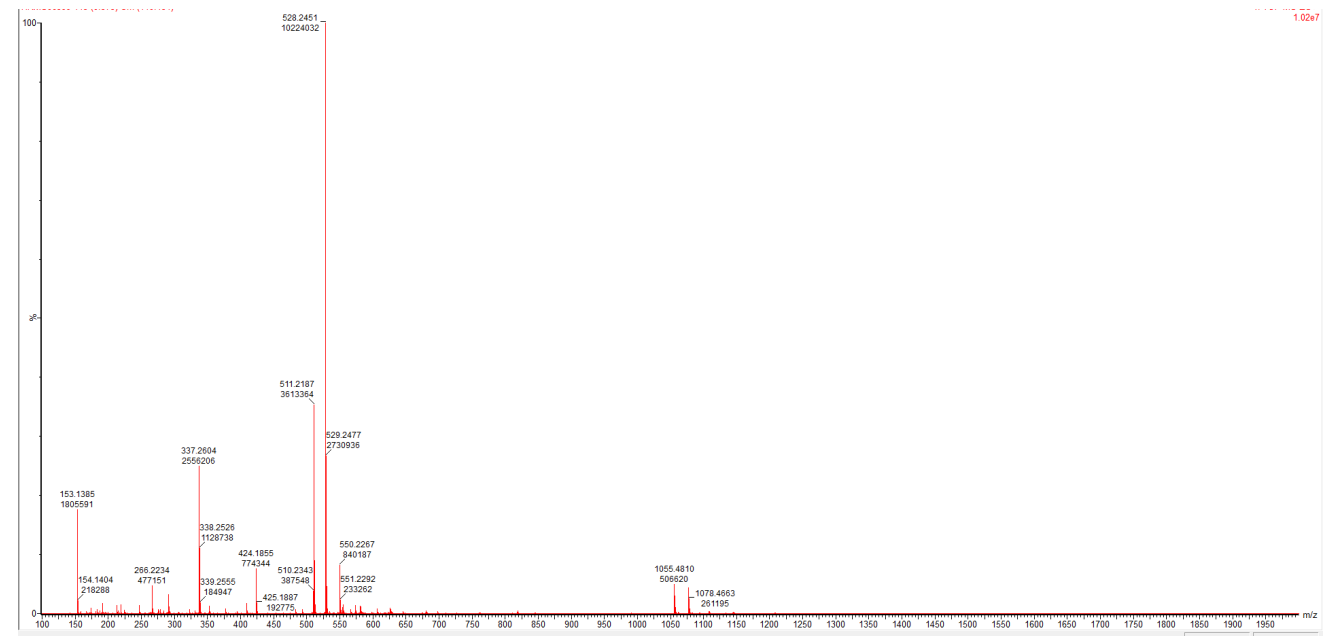

ESI $^{+}$trace peptide SI-9

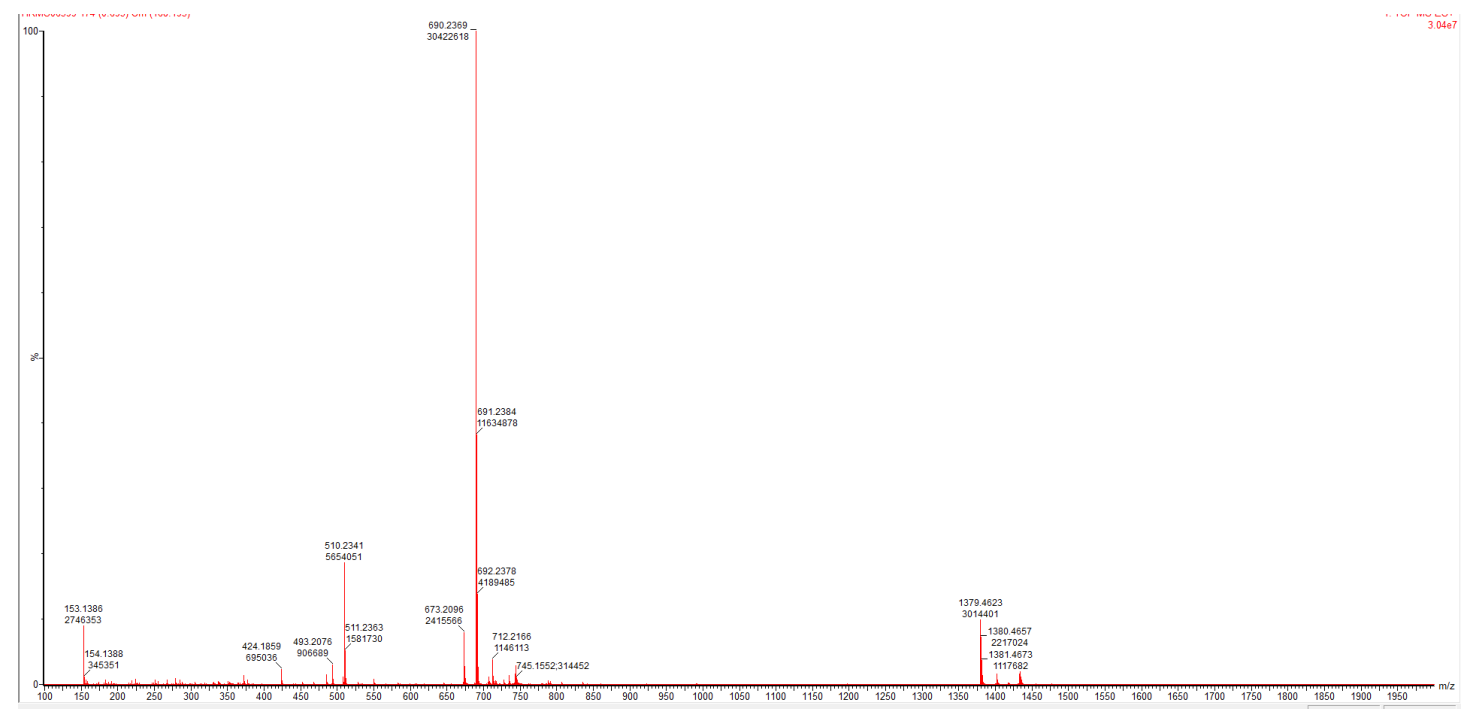

ESI $^{+}$trace peptide 13 


\section{Peptide 14}

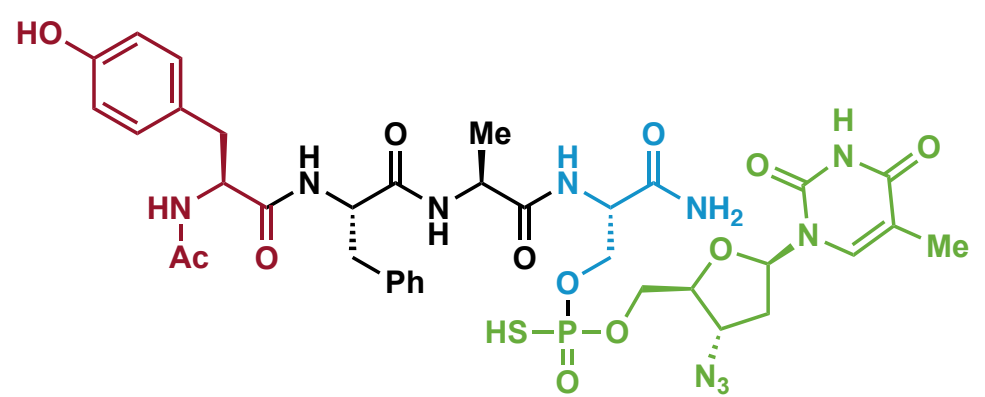

Prepared according to General Procedure C using:

Peptide SI-9 (100 $\mu \mathrm{L}$ of a $20 \mathrm{mM}$ solution in DMF, 1.0 equiv), P(V)-3 (100 $\mu \mathrm{L}$ of a $100 \mathrm{mM}$ solution in DMF, 5.0 equiv) and DBU (5 equiv). The crude mixture was analyzed by ${ }^{31} \mathrm{P}$ NMR and LC/MSD TOF to afford peptide $\mathbf{1 4}$ in $70 \%$ conversion. $[\mathbf{M}+\mathbf{H}]^{+}\left(\mathbf{E S I}^{+}\right):$873.3.

${ }^{31}$ P NMR (162 MHz, DMF-d): $\delta$ 54.6.

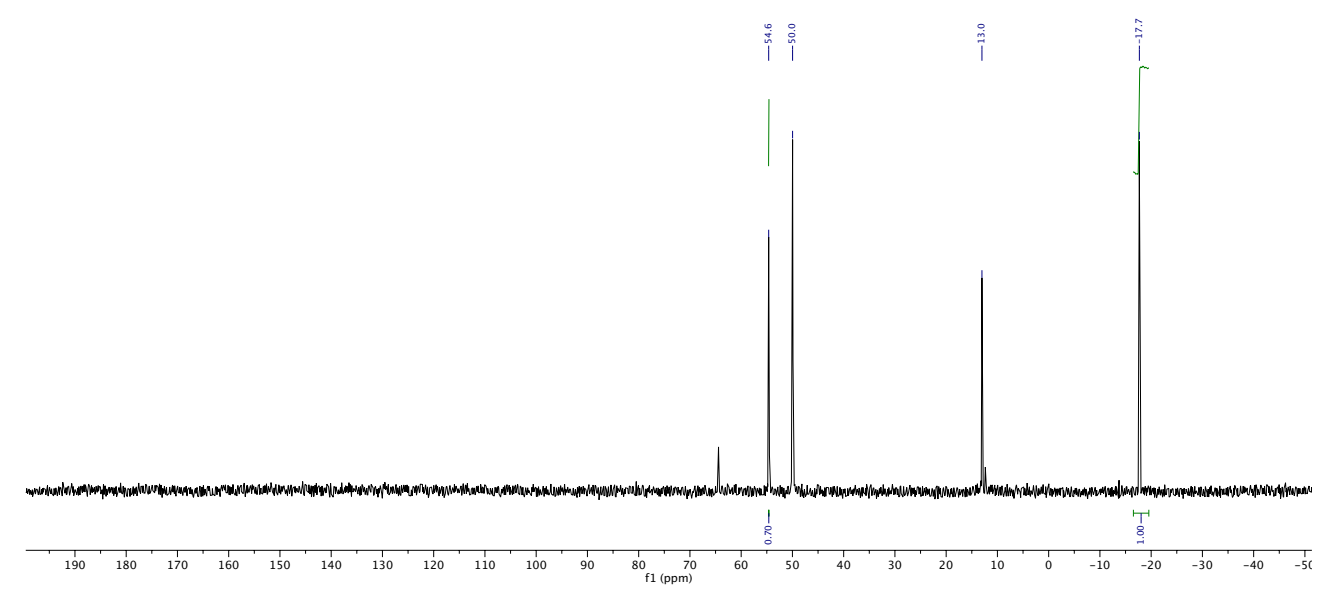

Crude ${ }^{31}$ P NMR spectra peptide 14 


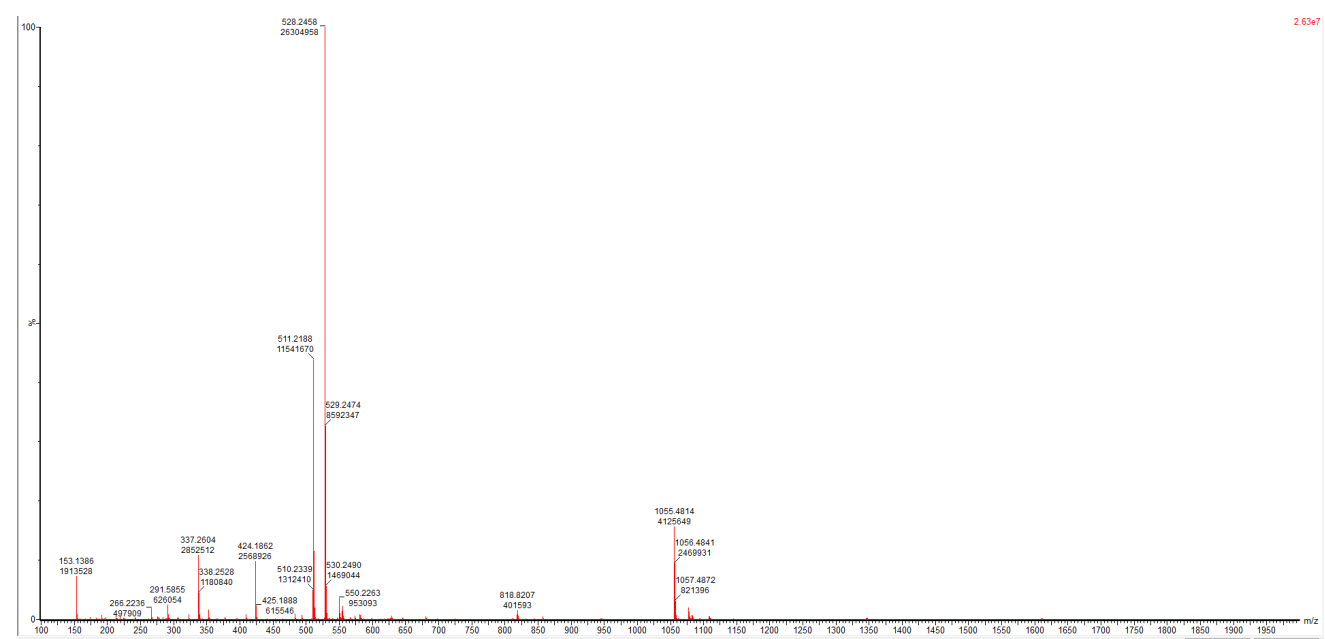

ESI $^{+}$trace peptide SI-9

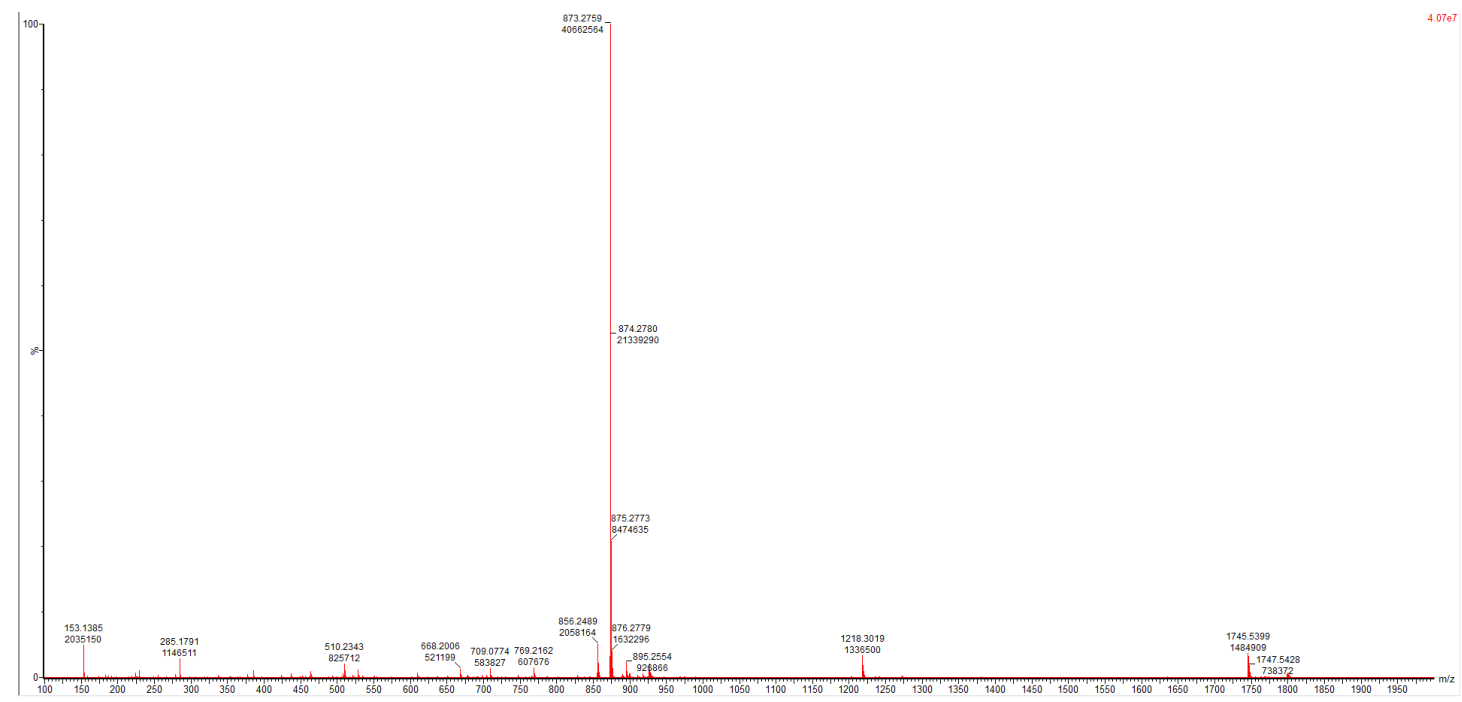

ESI $^{+}$trace peptide 14 


\section{Peptide 15}

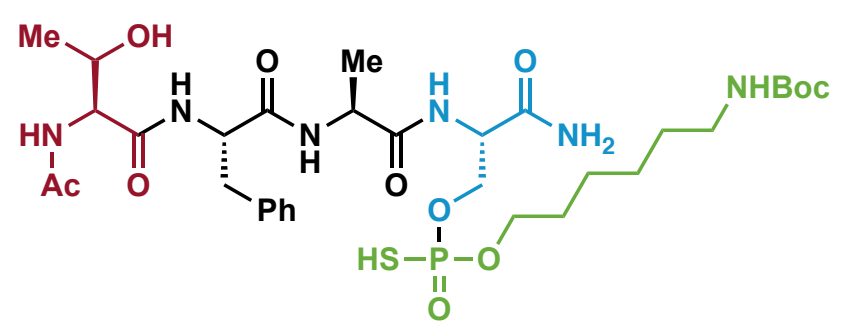

Prepared according to General Procedure C using:

Peptide SI-10 (100 $\mu \mathrm{L}$ of a $20 \mathrm{mM}$ solution in DMF, 1.0 equiv), P(V)-1 (100 $\mu \mathrm{L}$ of a $100 \mathrm{mM}$ solution in DMF, 5.0 equiv) and DBU (5 equiv). The crude mixture was analyzed by ${ }^{31} \mathrm{P}$ NMR and LC/MSD TOF to afford peptide 15 in 95\% conversion (ratio 8:1 Ser/Thr determined by H-coupled ${ }^{31} \mathrm{P}$ NMR).

$[\mathbf{M}+\mathbf{H}]^{+}\left(\mathbf{E S I}^{+}\right):$761.3.

${ }^{31}$ P NMR (162 MHz, DMF-d): $\delta 56.0$.

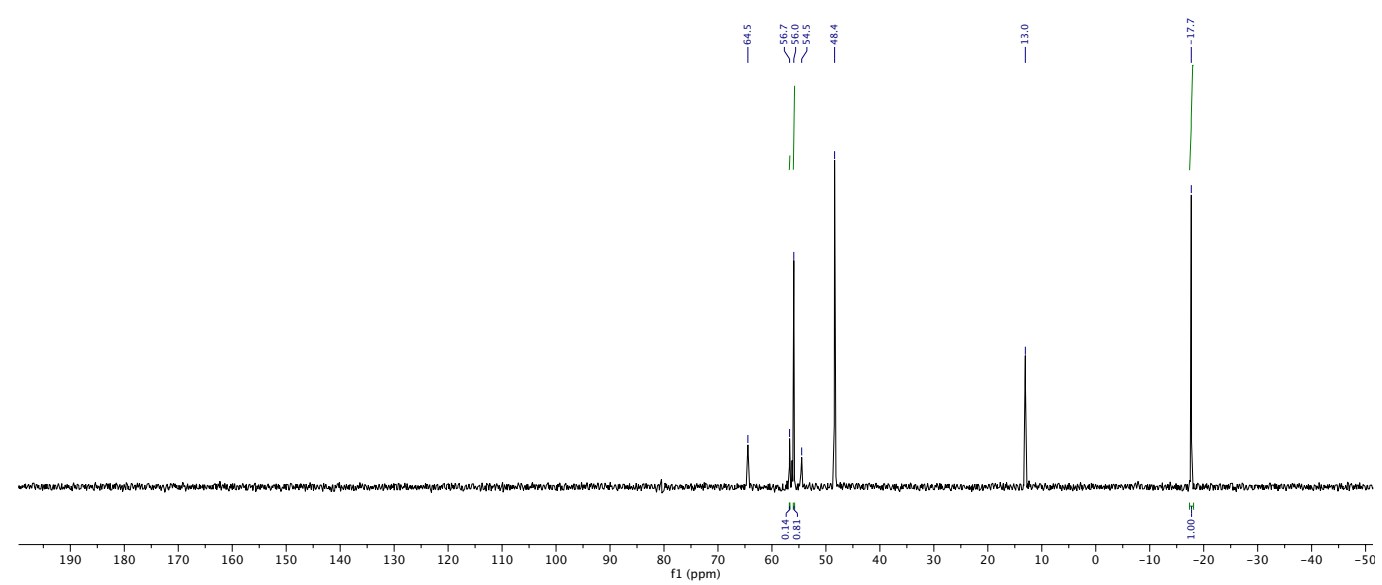

Crude ${ }^{31}$ P NMR spectra peptide 15 


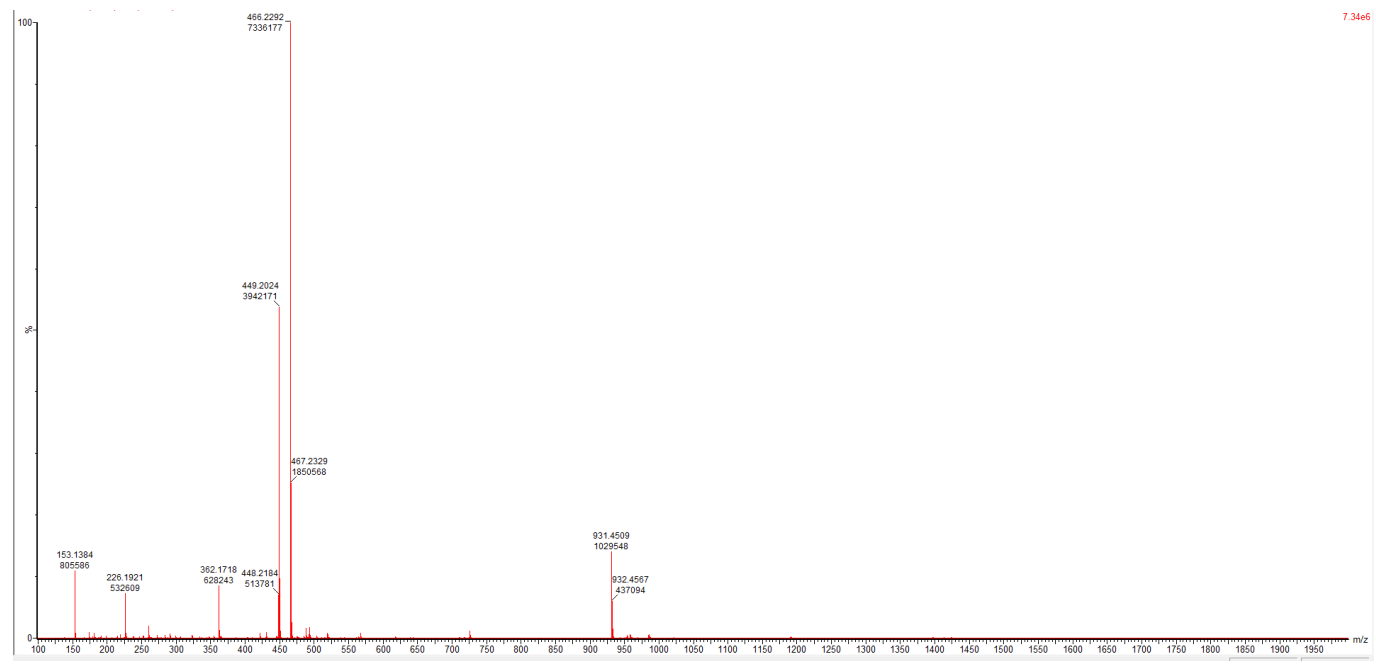

$\mathrm{ESI}^{+}$trace peptide SI-10

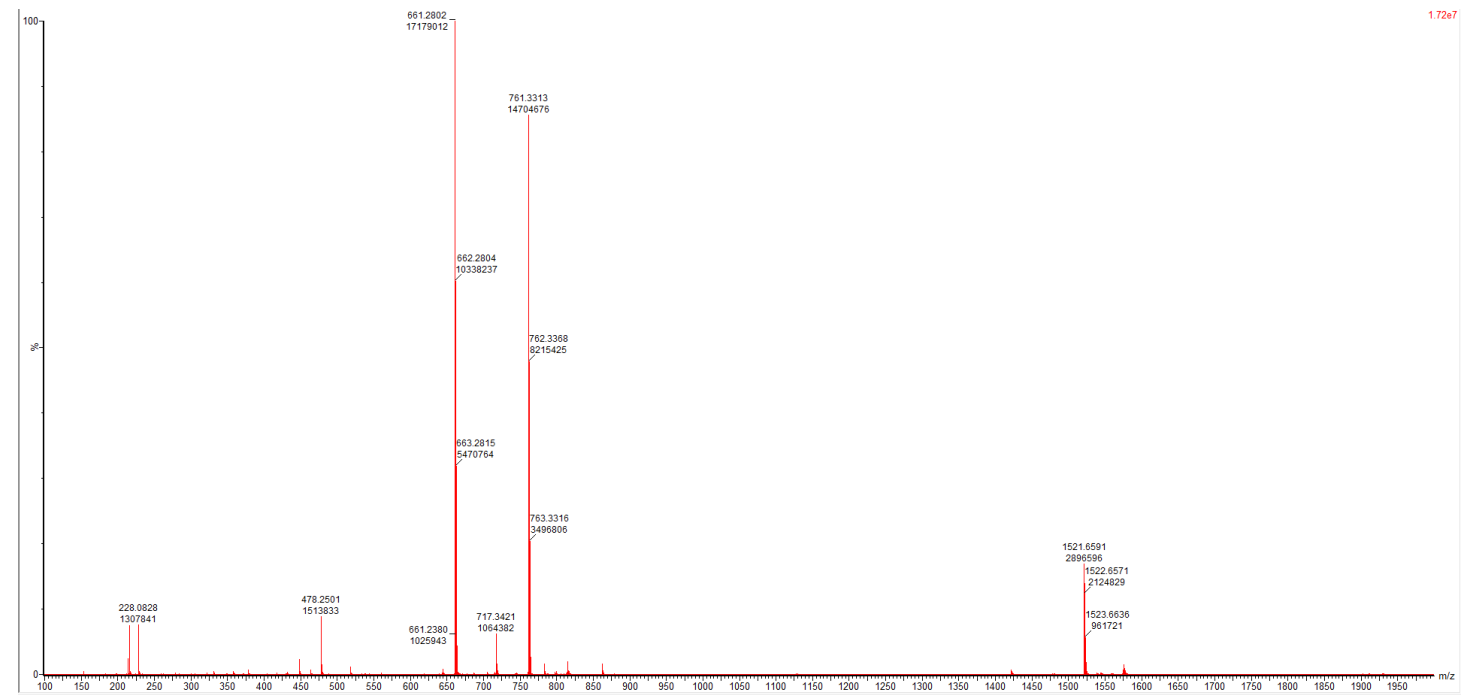

ESI $^{+}$trace peptide 15 


\section{Peptide 15 bis}

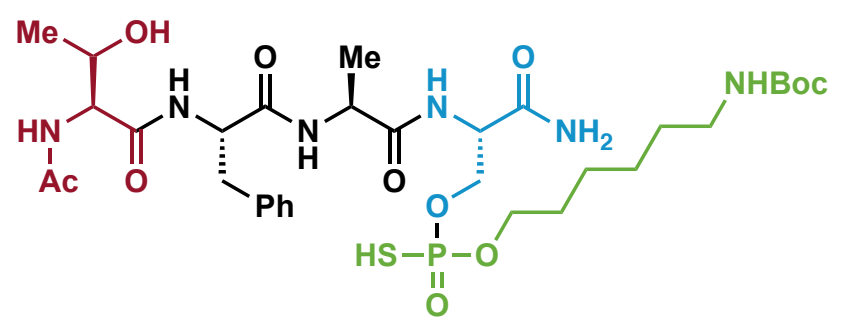

Prepared according to General Procedure C using:

Peptide SI-10 (100 $\mu \mathrm{L}$ of a $20 \mathrm{mM}$ solution in DMF, 1.0 equiv), P(V)-1 (100 $\mu \mathrm{L}$ of a $200 \mathrm{mM}$ solution in DMF, 10.0 equiv) and DBU (10 equiv). The crude mixture was analyzed by ${ }^{31} \mathrm{P}$ NMR and LC/MSD TOF to afford peptide 15 in $100 \%$ conversion (ratio 4:1 Ser/Thr determined by H-coupled ${ }^{31} \mathrm{P}$ NMR).

$[\mathbf{M}+\mathbf{H}]^{+}\left(\mathbf{E S I}^{+}\right):$761.3.

${ }^{31}$ P NMR (162 MHz, DMF-d): $\delta 56.0$.

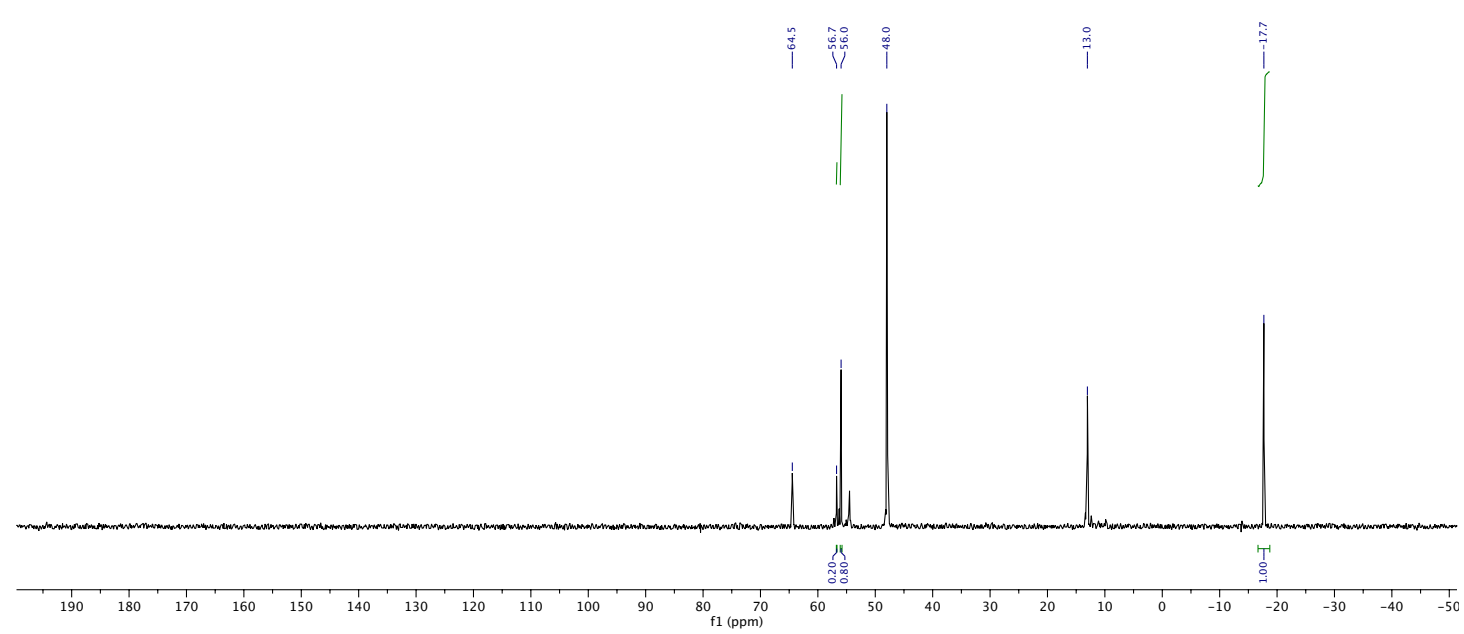

Crude ${ }^{31}$ P NMR spectra peptide 15 


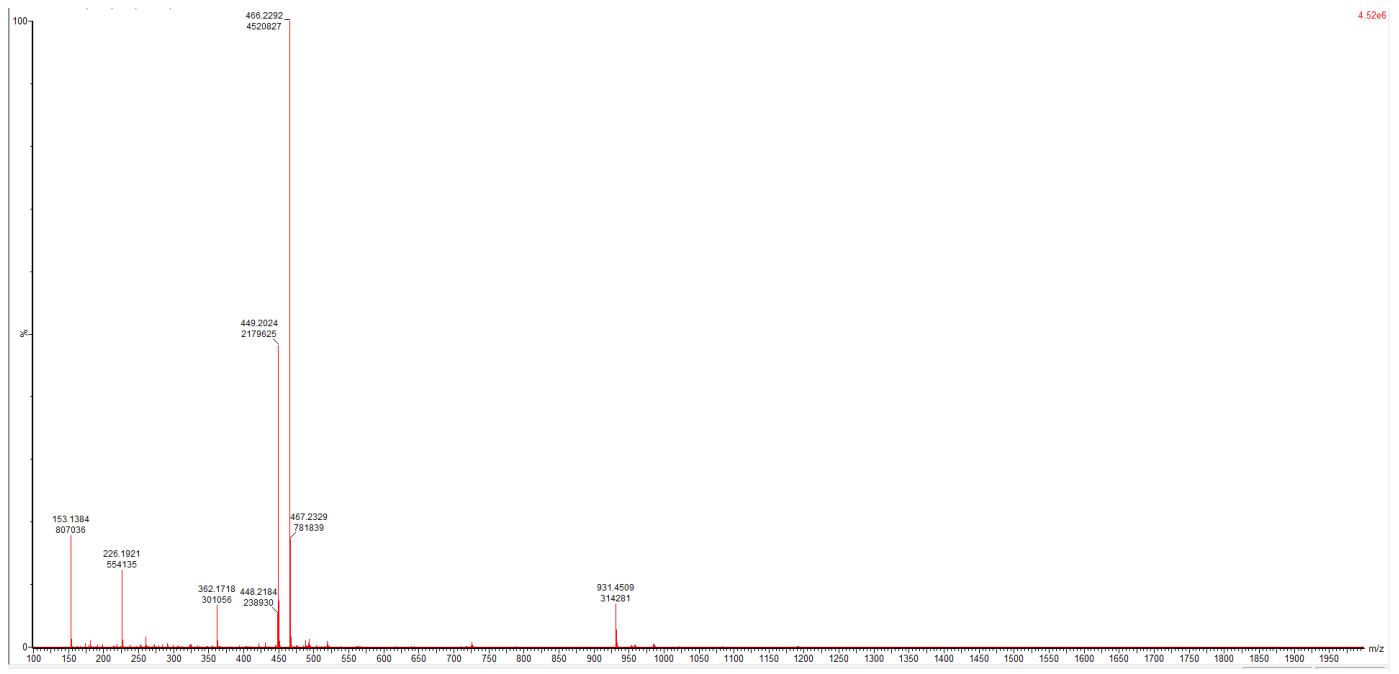

ESI $^{+}$trace peptide SI-10

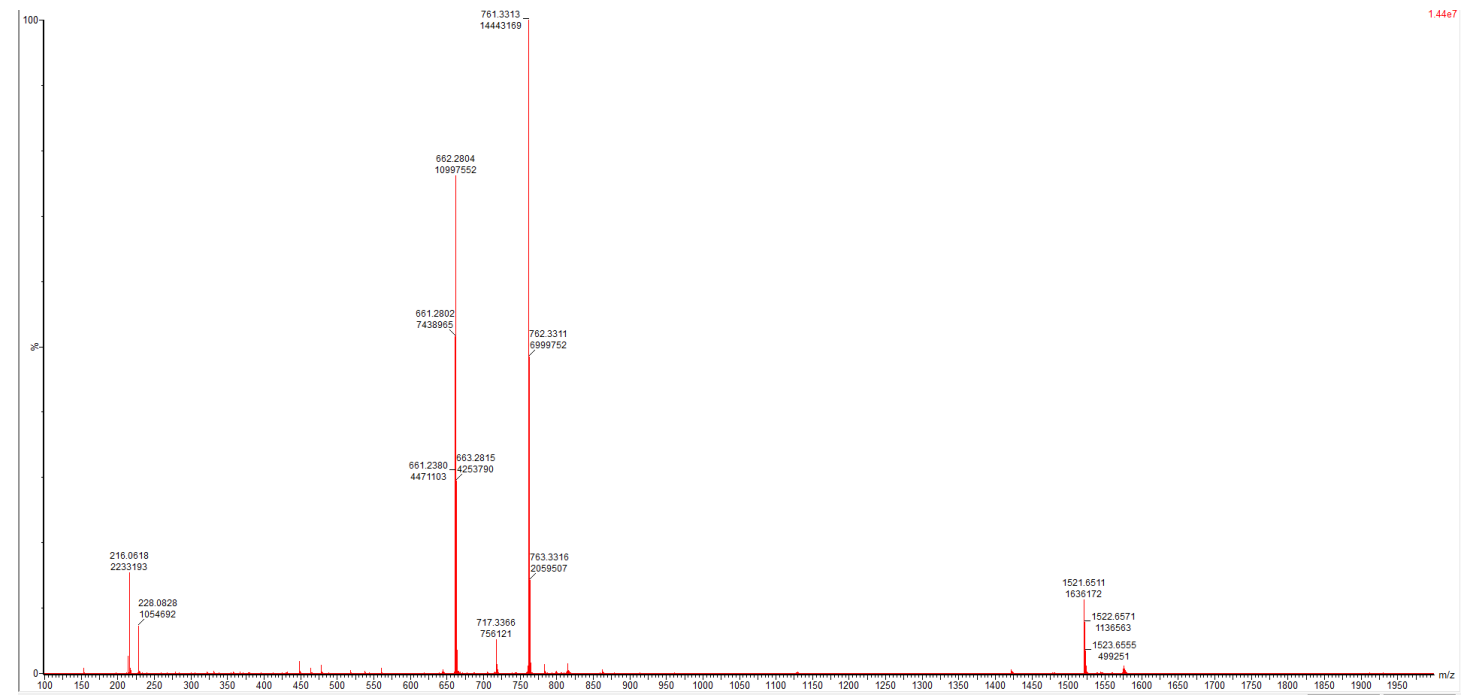

ESI $^{+}$trace peptide 15 


\section{Peptide 16}

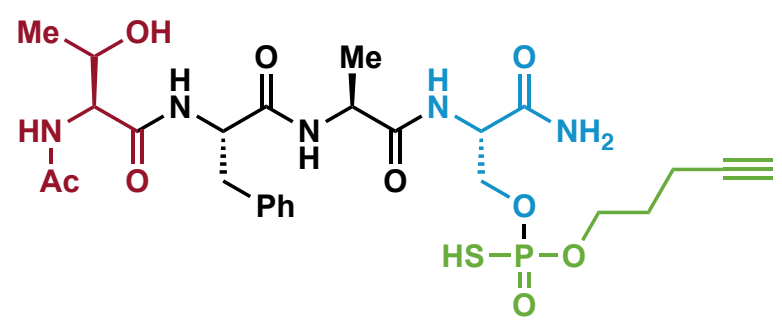

Prepared according to General Procedure C using:

Peptide SI-10 (100 mL of a $20 \mathrm{mM}$ solution in DMF, 1.0 equiv), P(V)-2a (100 $\mu \mathrm{L}$ of a $100 \mathrm{mM}$ solution in DMF, 5.0 equiv) and DBU (5 equiv). The crude mixture was analyzed by ${ }^{31} \mathrm{P}$ NMR and LC/MSD TOF to afford peptide 16 in $72 \%$ conversion (ratio 6:1 Ser/Thr determined by H-coupled ${ }^{31} \mathrm{P}$ NMR).

$[\mathbf{M}+\mathbf{H}]^{+}\left(\mathbf{E S I}^{+}\right): 628.2$.

${ }^{31}$ P NMR (162 MHz, DMF- $d$ ): $\delta$ 54.0.

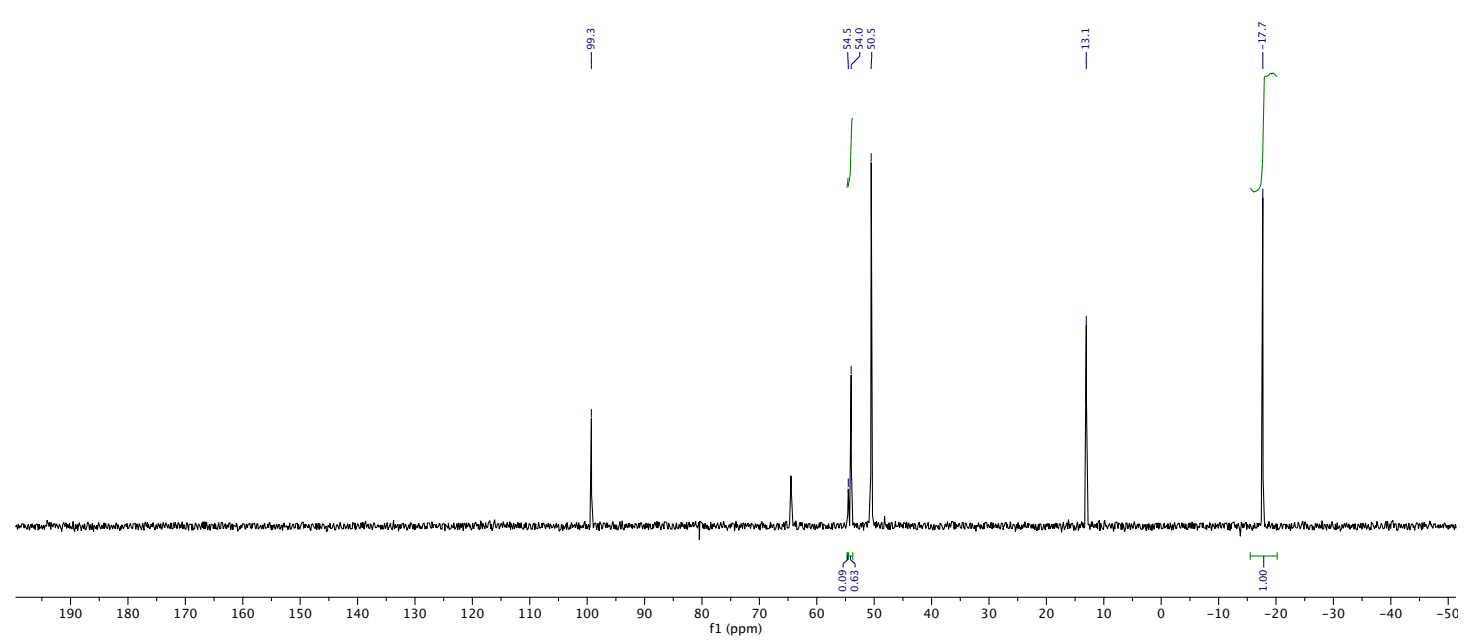

Crude ${ }^{31}$ P NMR spectra peptide 16 


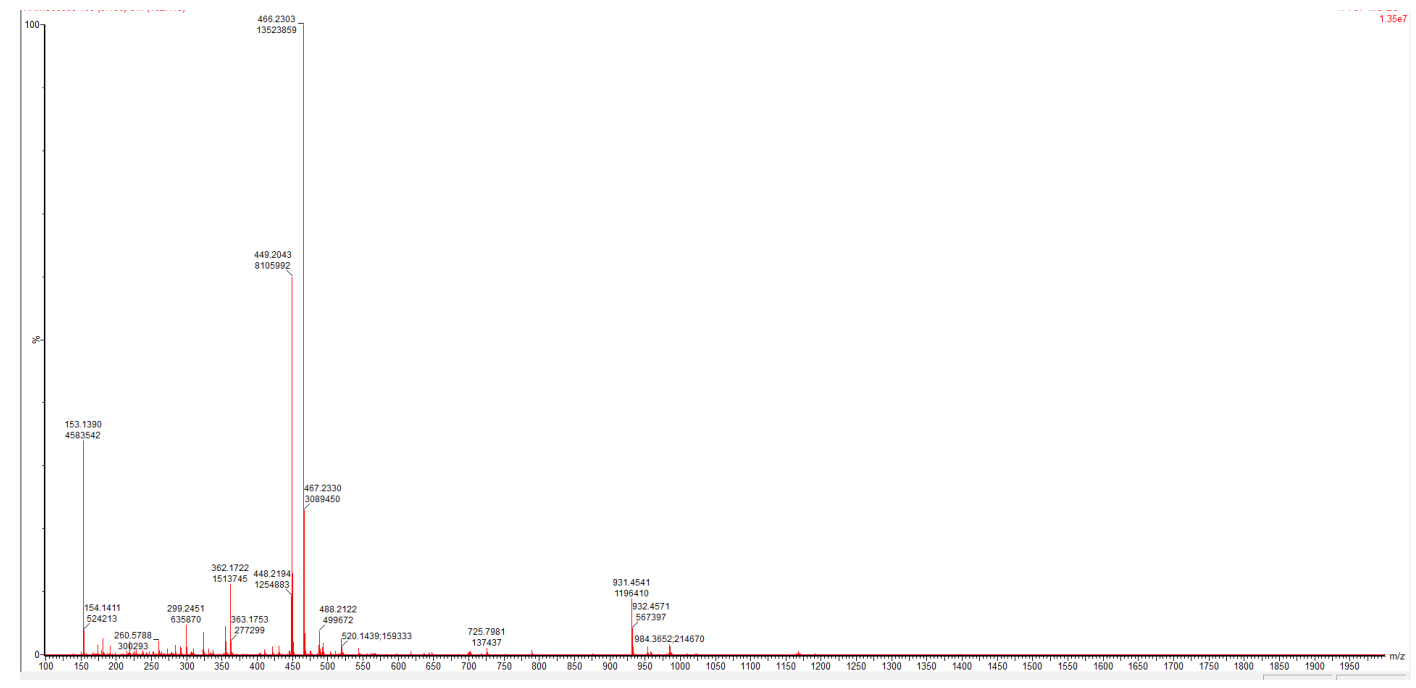

$\mathrm{ESI}^{+}$trace peptide SI-10

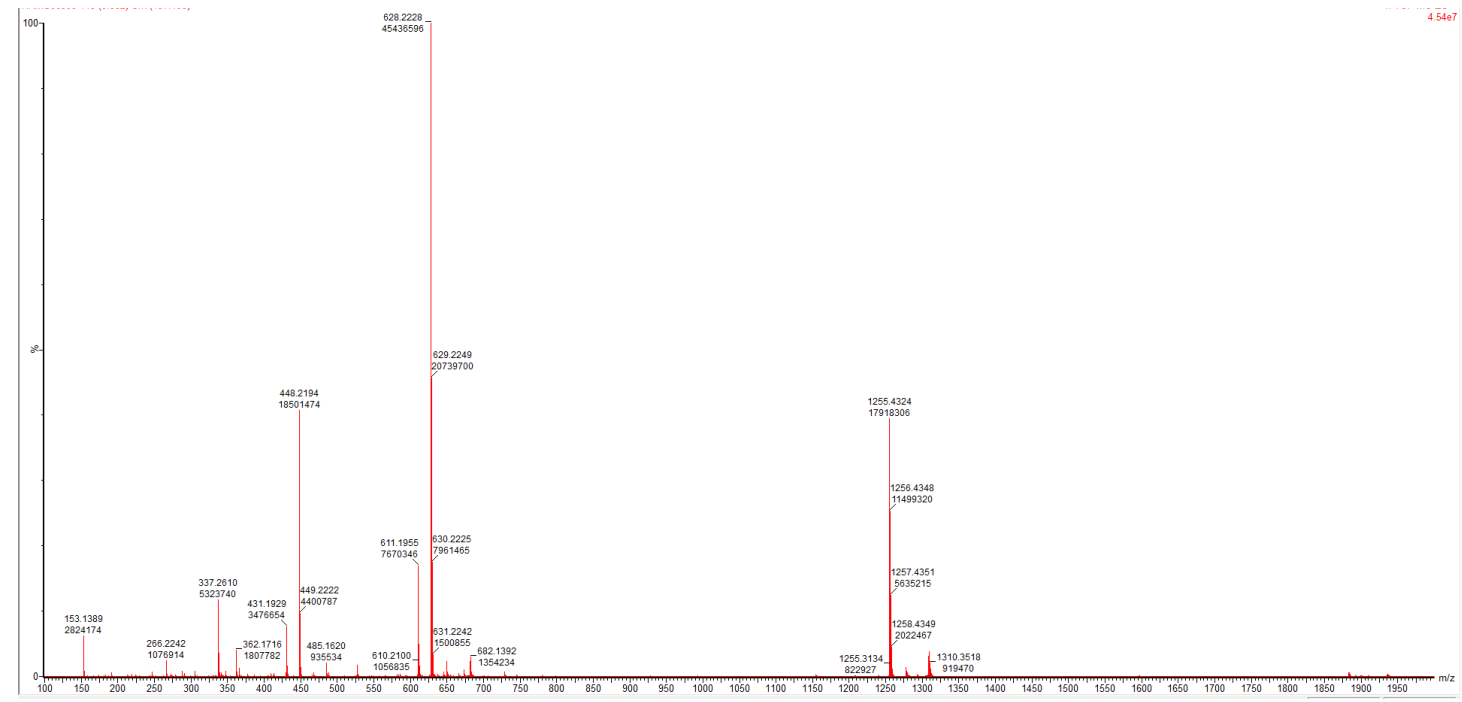

$\mathrm{ESI}^{+}$trace peptide 16 


\section{Peptide 17}

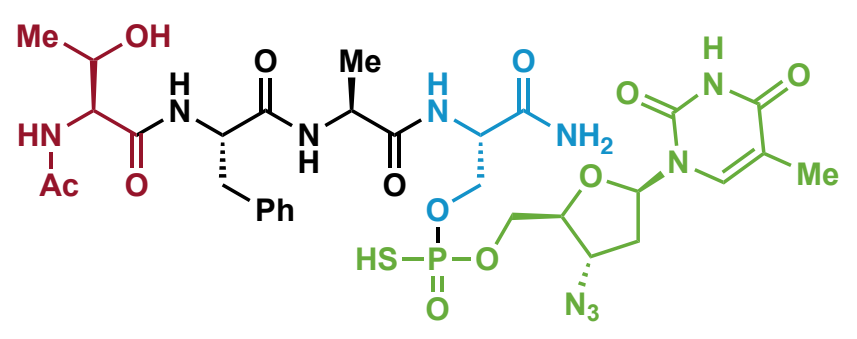

Prepared according to General Procedure C using:

Peptide SI-10 (100 $\mu \mathrm{L}$ of a $20 \mathrm{mM}$ solution in DMF, 1.0 equiv), P(V)-3 (100 $\mu \mathrm{L}$ of a $100 \mathrm{mM}$ solution in DMF, 5.0 equiv) and DBU (5 equiv). The crude mixture was analyzed by ${ }^{31} \mathrm{P}$ NMR and LC/MSD TOF to afford peptide 14 in $94 \%$ conversion (ratio 7:1 Ser/Thr determined by H-coupled ${ }^{31} \mathrm{P}$ NMR).

$[\mathbf{M}+\mathbf{H}]^{+}\left(\mathbf{E S I}^{+}\right):$812.2.

${ }^{31}$ P NMR (162 MHz, DMF-d): $\delta 53.7$.

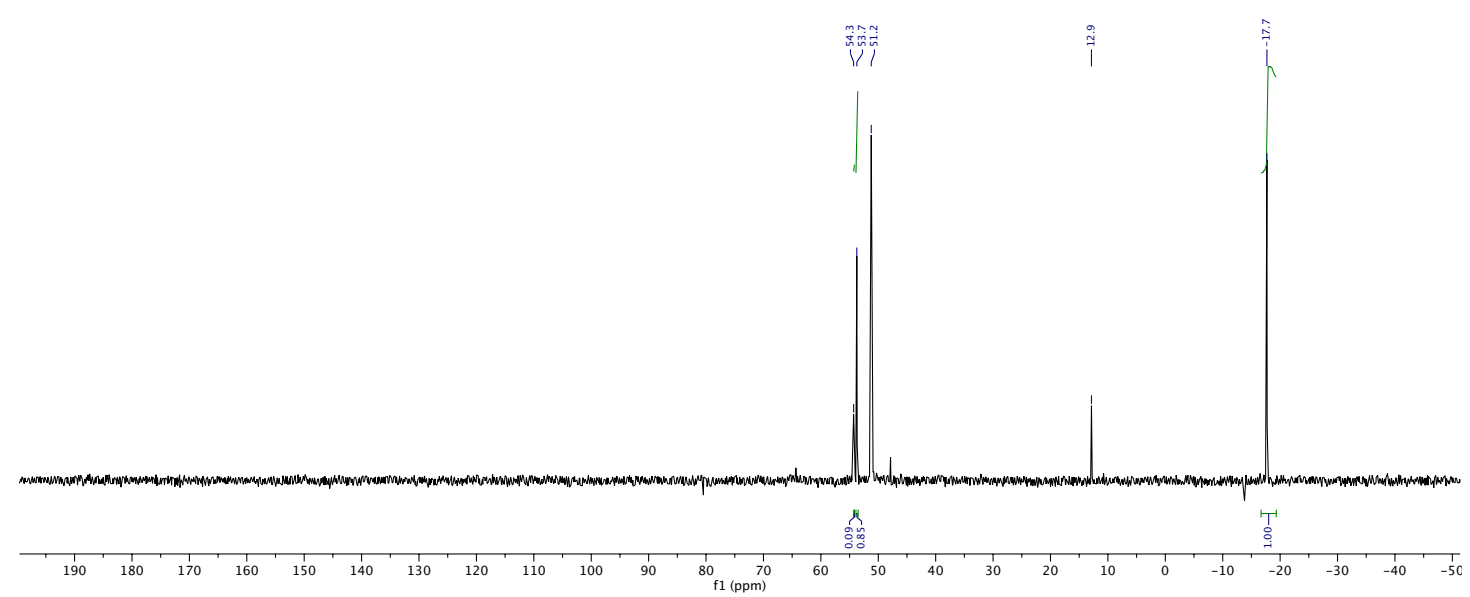

Crude ${ }^{31}$ P NMR spectra peptide 17 


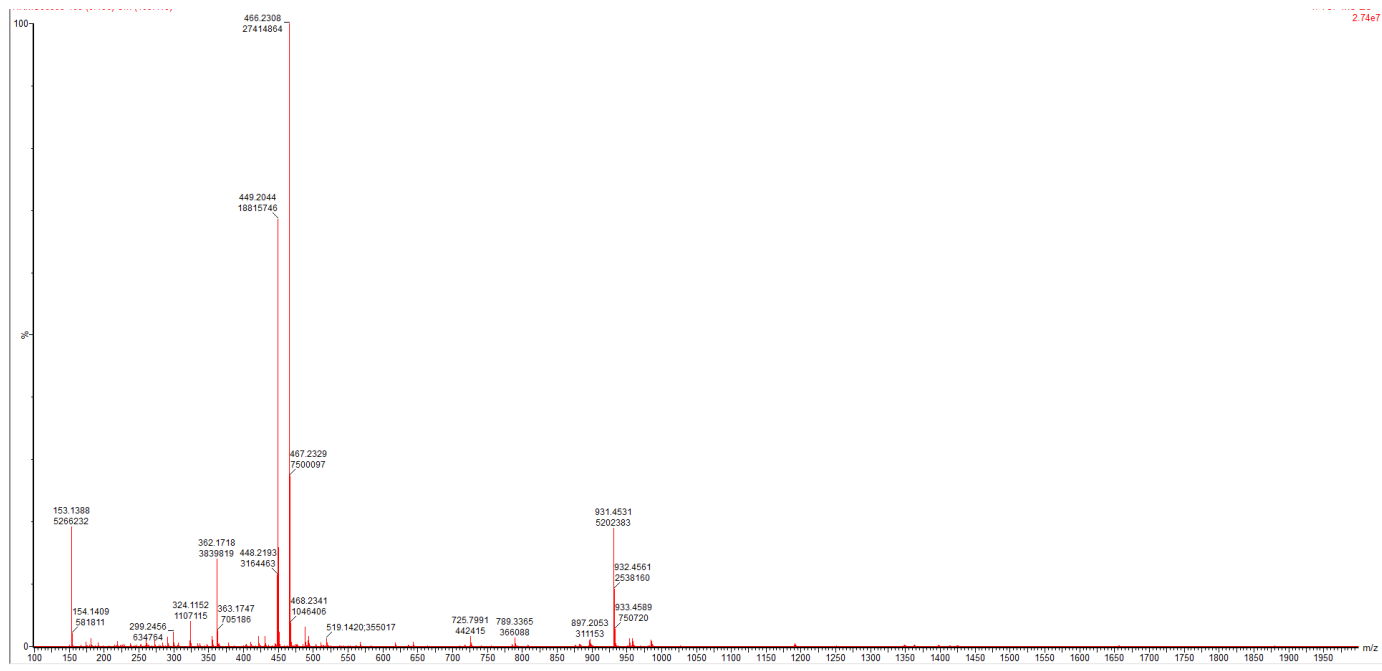

$\mathrm{ESI}^{+}$trace peptide SI-10

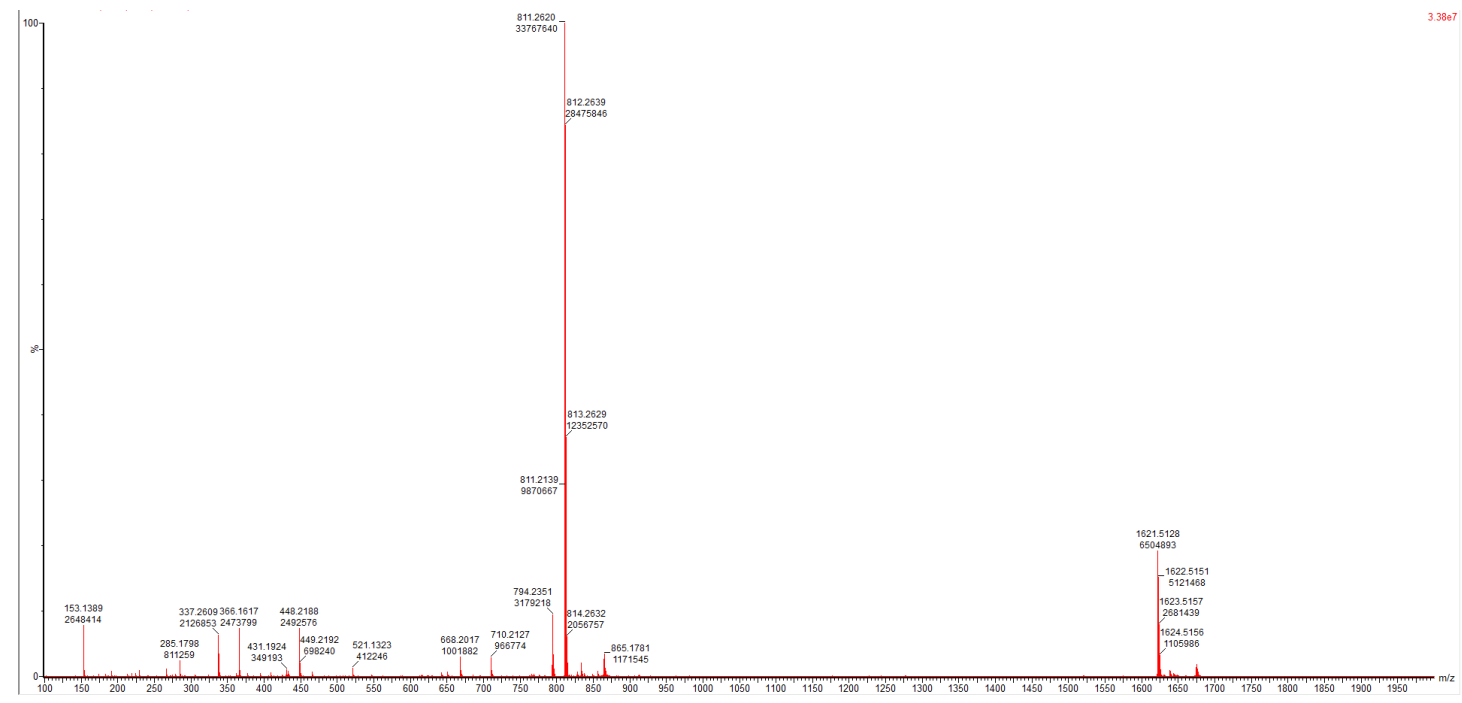

ESI $^{+}$trace peptide 17 


\section{Peptide 18}<smiles>[M]C(NC(=O)[C@H](Cc1ccccc1)NC(=O)C(C)C)C(=O)N[C@@H](COP(=O)(S)OCCCCCCCOC(C)(C)C)C(N)=O</smiles>

Prepared according to General Procedure C using:

Peptide SI-11 (50 $\mu \mathrm{L}$ of a $40 \mathrm{mM}$ solution in DMF, 1.0 equiv) was treated with a solution of EtSH (50 $\mu \mathrm{L}$ of a $200 \mathrm{mM}$ solution in DMF, 5.0 equiv). Then $\mathbf{P ( V ) - 1}$ (100 $\mu \mathrm{L}$ of a $100 \mathrm{mM}$ solution in DMF, 5.0 equiv) and DBU (5 equiv) were added. After 10 minutes, the crude mixture was treated with DTT (to reduce any S-S bond formed during the reaction) and analyzed by ${ }^{31} \mathrm{P}$ NMR and LC/MSD TOF to afford peptide $\mathbf{1 8}$ in $55 \%$ conversion.

$[\mathbf{M}+\mathbf{H}]^{+}\left(\mathbf{E S I}^{+}\right):$763.2.

${ }^{31}$ P NMR (162 MHz, DMF-d): $\delta 54.7$.

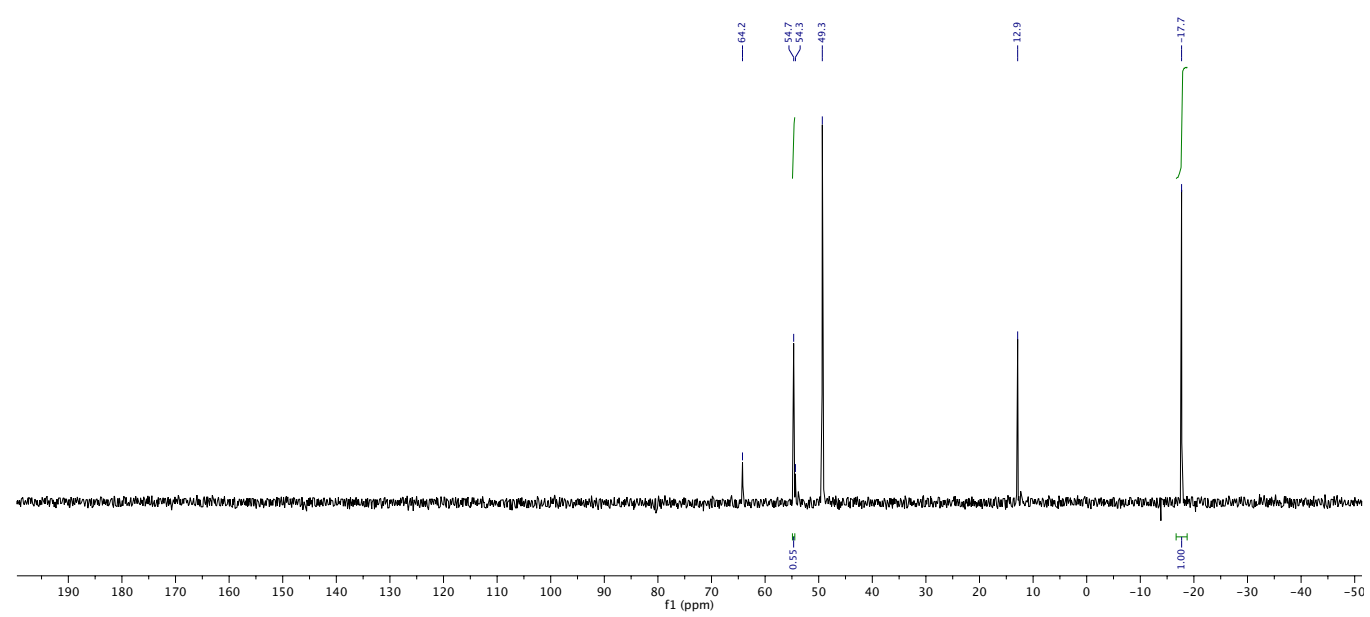

Crude ${ }^{31}$ P NMR spectra peptide 18 


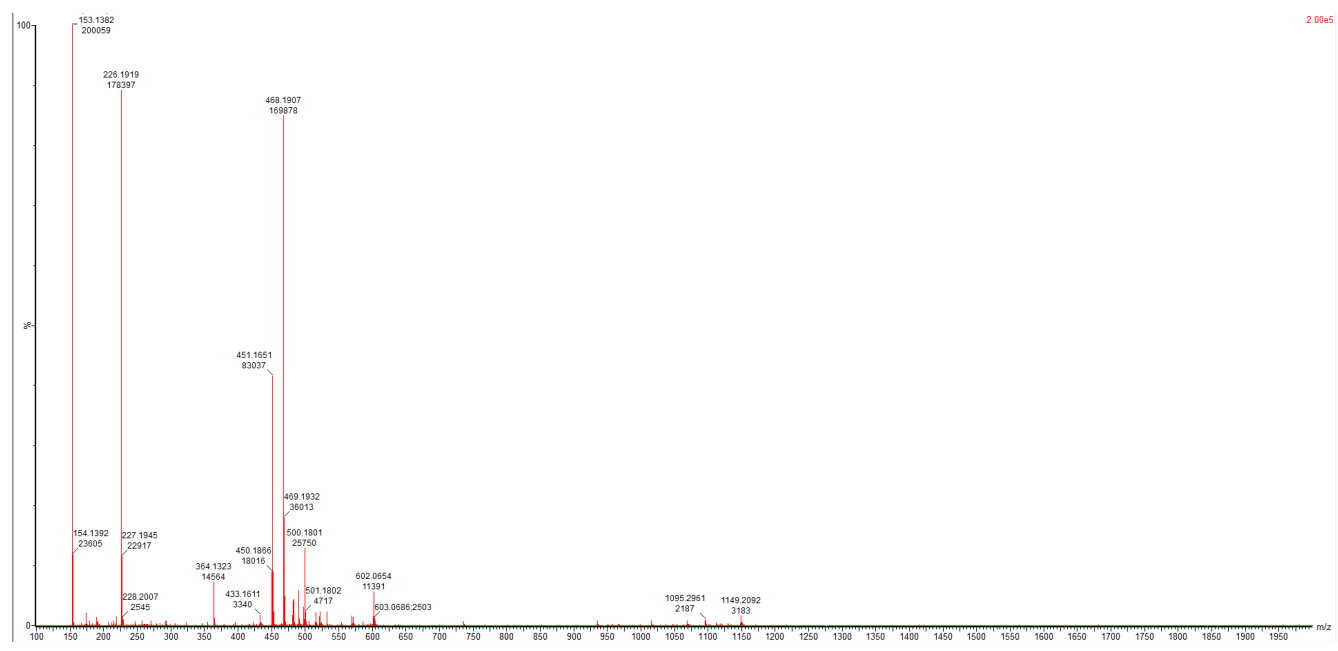

ESI ${ }^{+}$trace peptide SI-11

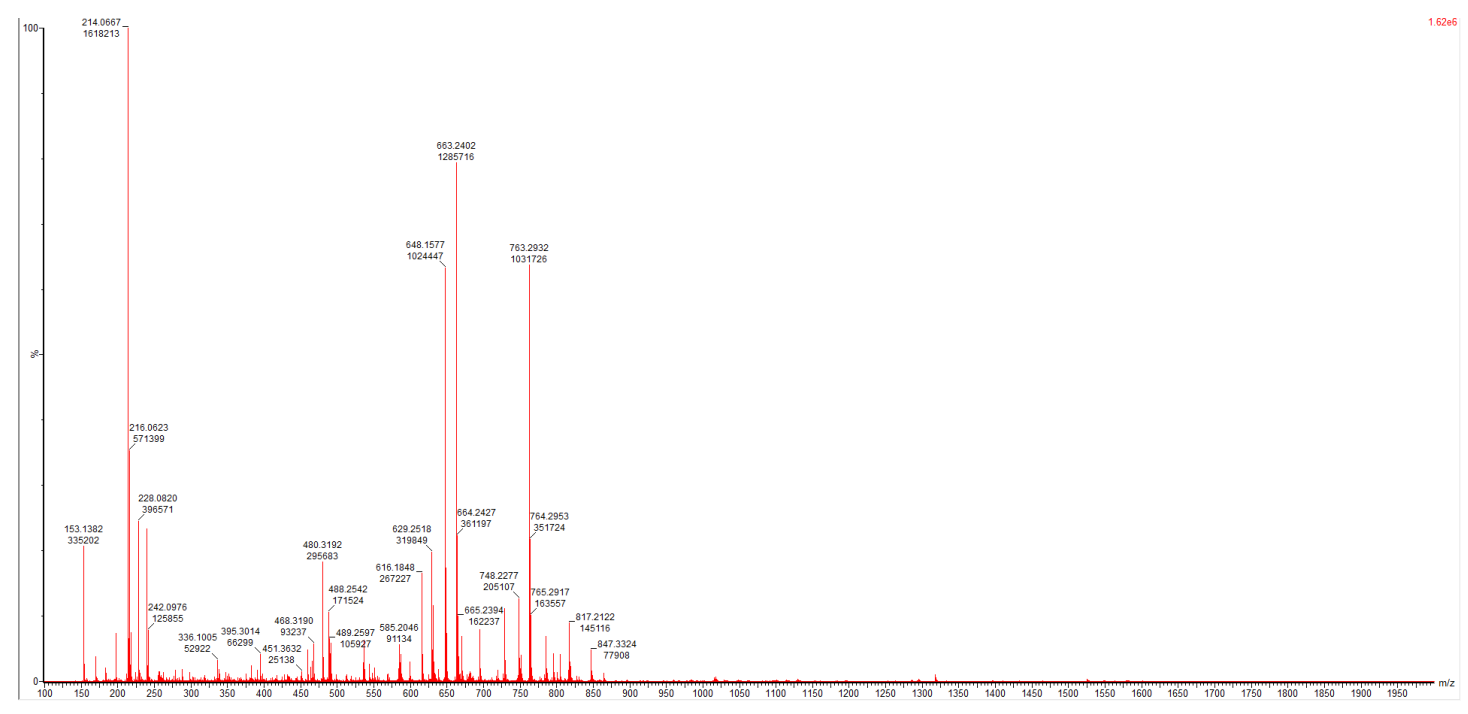

ESI $^{+}$trace peptide 18 


\section{Peptide 12 bis}<smiles>[M]C(NC(=O)[C@H](Cc1ccccc1)NC(=O)C(C)C)C(=O)N[C@@H](COP(=O)(S)OCCCCCCCOC(C)(C)C)C(N)=O</smiles>

Prepared according to General Procedure C using:

Peptide SI-11 (50 $\mu \mathrm{L}$ of a $40 \mathrm{mM}$ solution in DMF, 1.0 equiv) was treated with a solution of EtSH (50 $\mu \mathrm{L}$ of a $200 \mathrm{mM}$ solution in DMF, 5.0 equiv). Then $\mathbf{P ( V ) - 1}$ (100 $\mu \mathrm{L}$ of a $200 \mathrm{mM}$ solution in DMF, 10.0 equiv) and DBU (10 equiv) were added. After 10 minutes, the crude mixture was treated with DTT (to reduce any S-S bond formed during the reaction) and analyzed by ${ }^{31} \mathrm{P}$ NMR and LC/MSD TOF to afford peptide $\mathbf{1 8}$ in $82 \%$ conversion.

$[\mathbf{M}+\mathbf{H}]^{+}\left(\mathbf{E S I}^{+}\right):$763.2.

${ }^{31}$ P NMR (162 MHz, DMF-d): $\delta 54.8$.

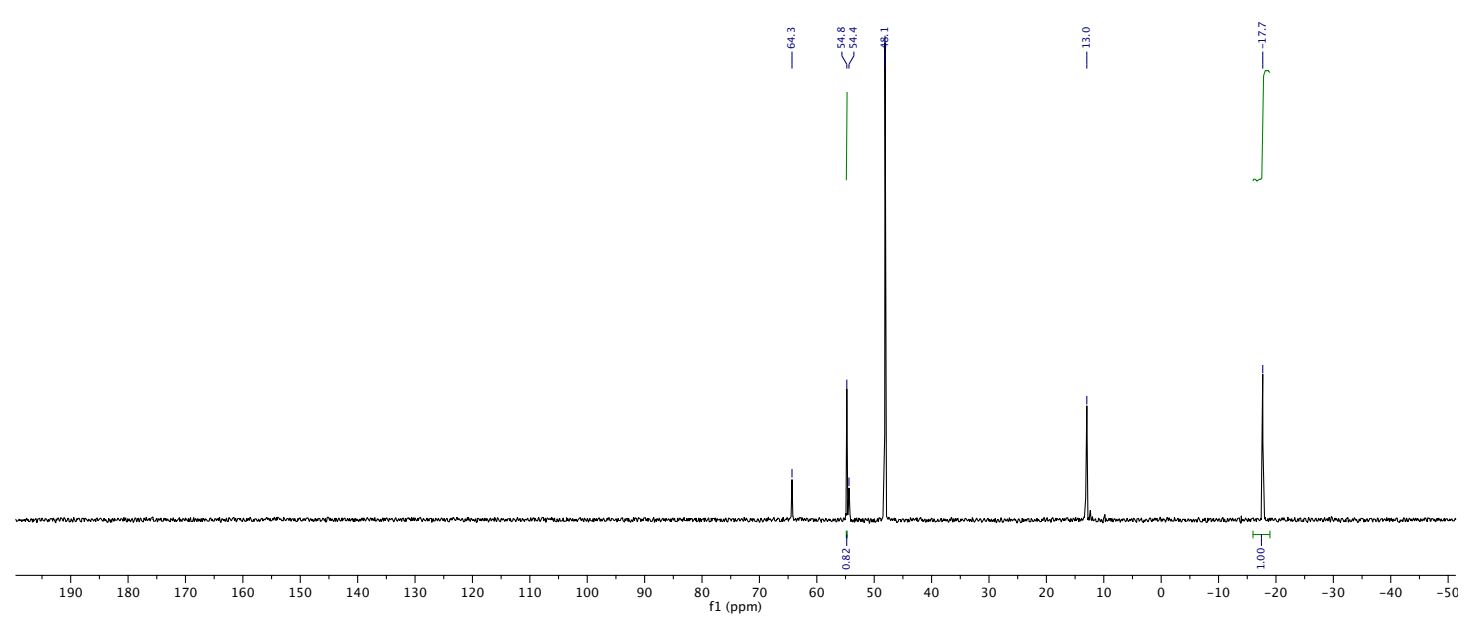

Crude ${ }^{31}$ P NMR spectra peptide 18 


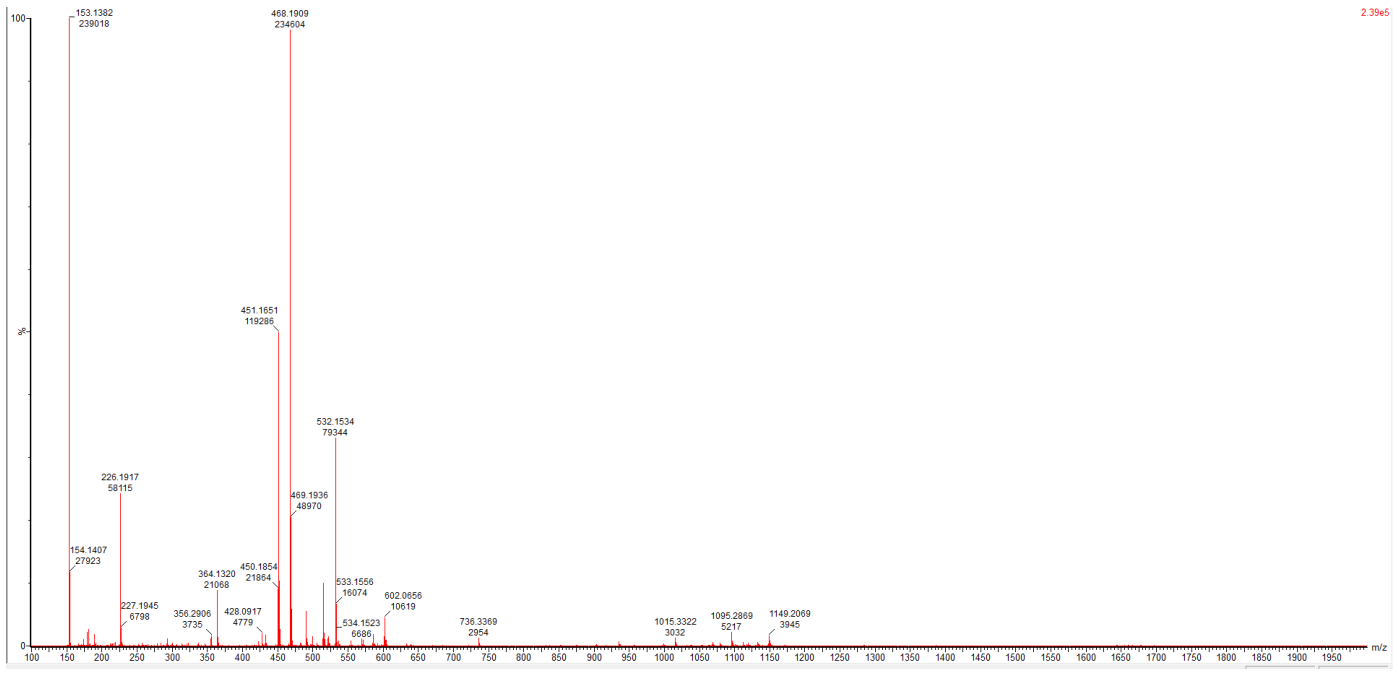

$\mathrm{ESI}^{+}$trace peptide SI-11

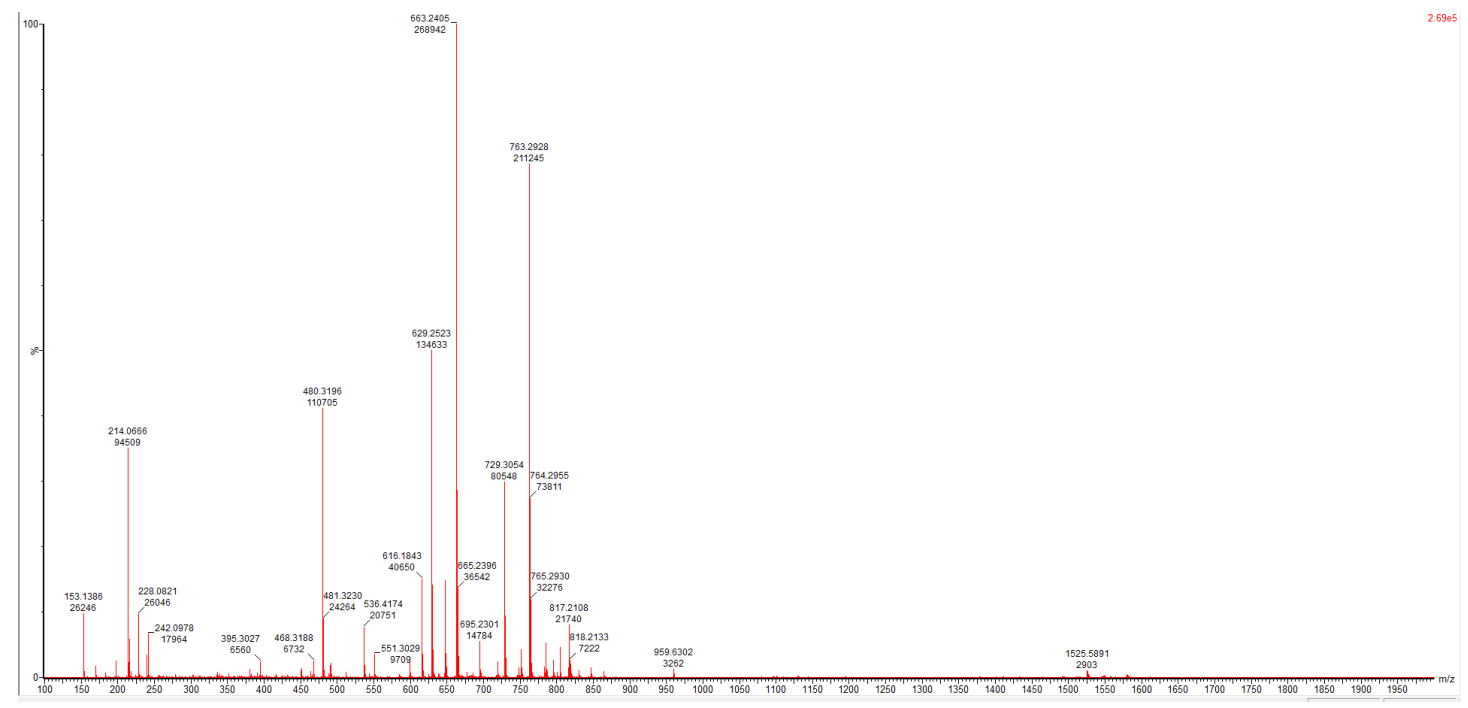

ESI $^{+}$trace peptide 18 


\section{Peptide 19}<smiles>[M]C(NC(=O)[C@H](Cc1ccccc1)NC(=O)C(CS)NC(=O)c1ccccc1)C(=O)N[C@@H](COP(=O)(S)OCCCC#C)C(N)=O</smiles>

Prepared according to General Procedure C using:

Peptide SI-11 (50 $\mu \mathrm{L}$ of a $40 \mathrm{mM}$ solution in DMF, 1.0 equiv) was treated with a solution of EtSH (50 $\mu \mathrm{L}$ of a $200 \mathrm{mM}$ solution in DMF, 5.0 equiv). Then $\mathbf{P ( V ) - 2 a}$ (100 $\mu \mathrm{L}$ of a $100 \mathrm{mM}$ solution in DMF, 5.0 equiv) and DBU (5 equiv) were added. After 10 minutes, the crude mixture was treated with DTT (to reduce any S-S bond formed during the reaction) and analyzed by ${ }^{31} \mathrm{P}$ NMR and LC/MSD TOF to afford peptide 19 in $64 \%$ conversion.

$[\mathbf{M}+\mathbf{H}]^{+}\left(\mathbf{E S I}^{+}\right): 629.1$.

${ }^{31}$ P NMR (162 MHz, DMF-d): $\delta 54.7$.

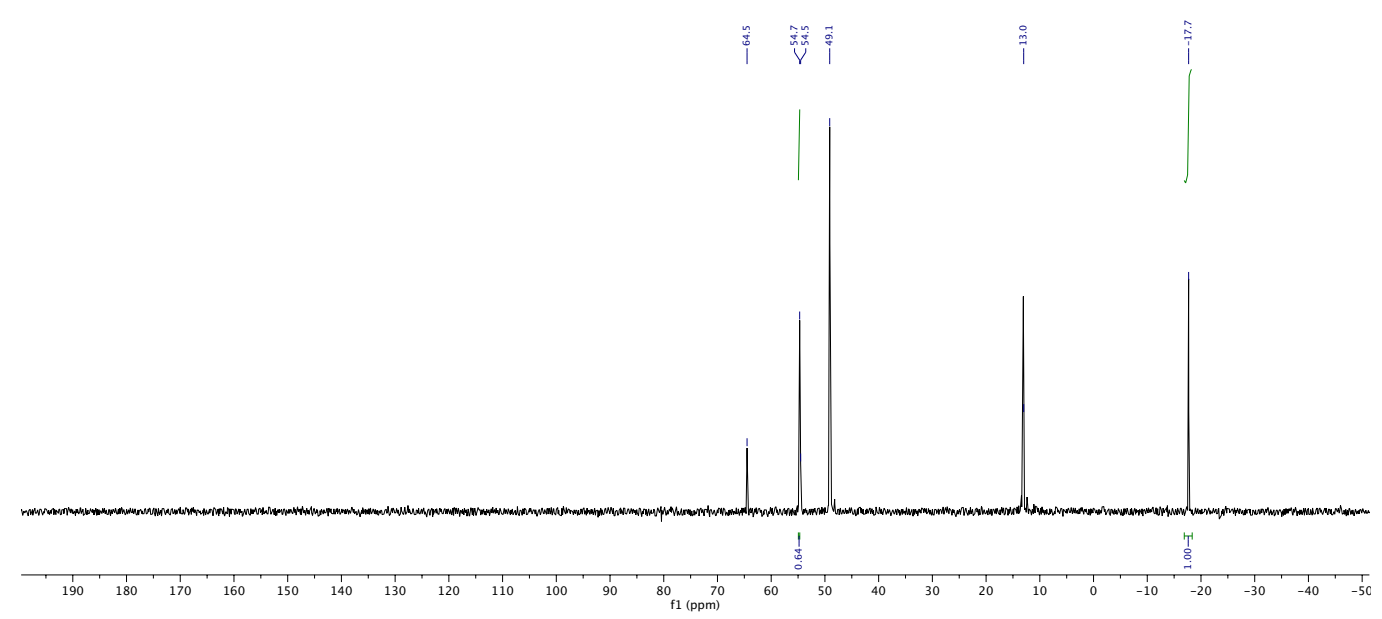

Crude ${ }^{31}$ P NMR spectra peptide 19 


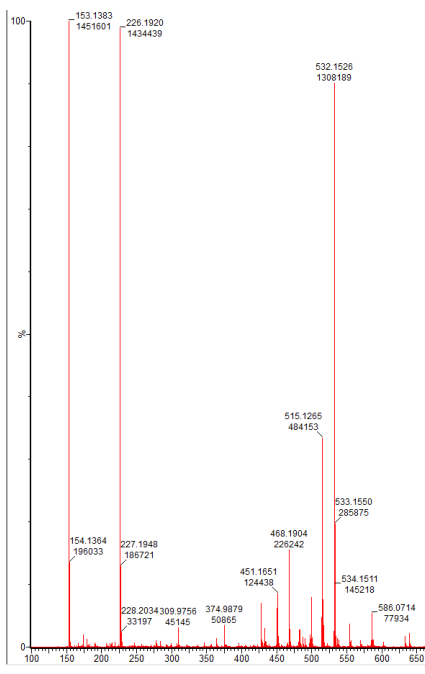

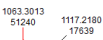

ESI $^{+}$trace peptide SI-11

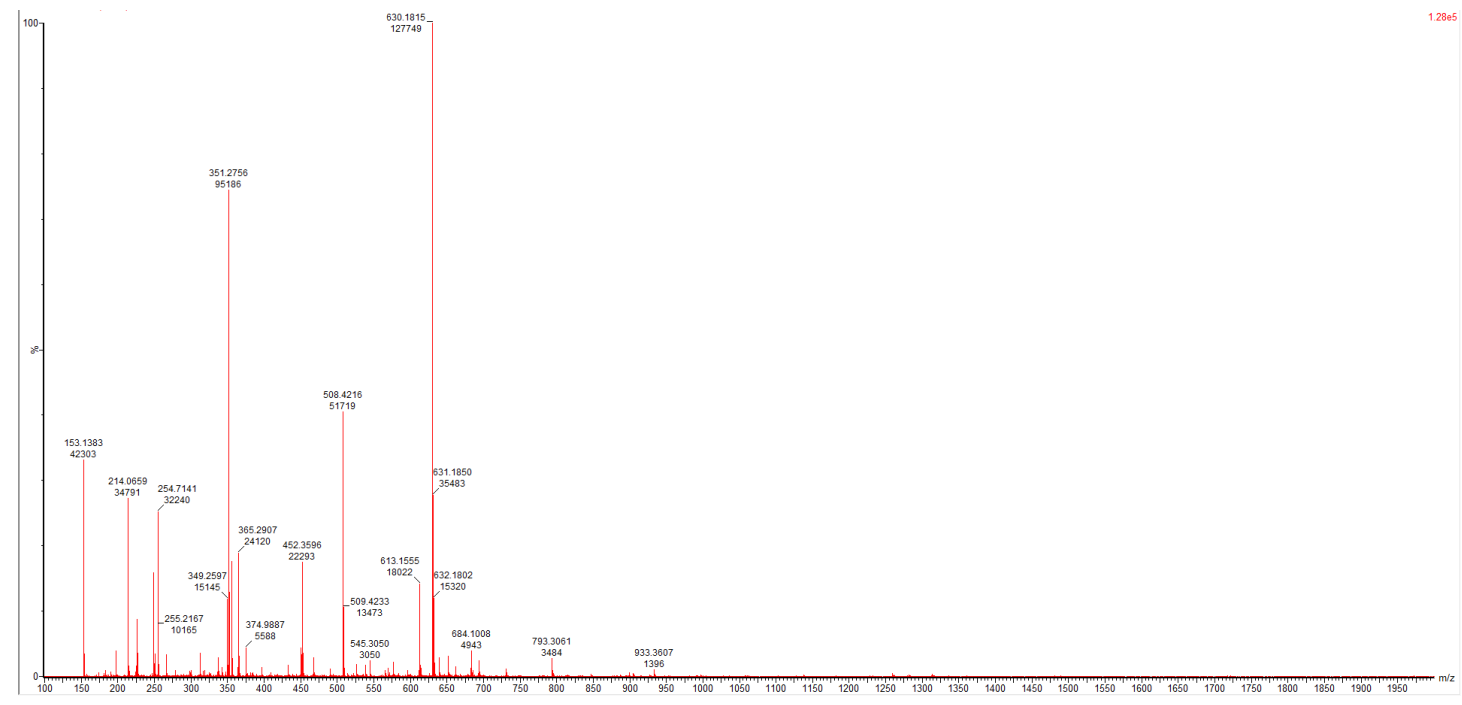

$\mathrm{ESI}^{+}$trace peptide 19 


\section{Peptide 20}<smiles>[M]C(NC(=O)[C@H](Cc1ccccc1)NC(=O)C(CS)NC(C)C)C(=O)N[C@@H](COP(=O)(S)OCC1OC(n2cc(C)c(=O)[nH]c2=O)CC1N)C(N)=O</smiles>

Prepared according to General Procedure C using:

Peptide SI-11 (50 $\mu \mathrm{L}$ of a $40 \mathrm{mM}$ solution in DMF, 1.0 equiv) was treated with a solution of EtSH (50 $\mu \mathrm{L}$ of a $200 \mathrm{mM}$ solution in DMF, 5.0 equiv). Then $\mathbf{P ( V ) - 3 ~ ( 1 0 0 ~}$ $\mu \mathrm{L}$ of a $100 \mathrm{mM}$ solution in DMF, 5.0 equiv) and DBU (5 equiv) were added. After 10 minutes, the crude mixture was treated with DTT (to reduce any S-S bond formed during the reaction) and analyzed by ${ }^{31} \mathrm{P}$ NMR and LC/MSD TOF to afford peptide $\mathbf{2 0}$ in $43 \%$ conversion.

$[\mathbf{M}+\mathbf{H}]^{+}\left(\mathbf{E S I}^{+}\right):$813.2.

${ }^{31}$ P NMR (162 MHz, DMF-d): $\delta 54.7$.

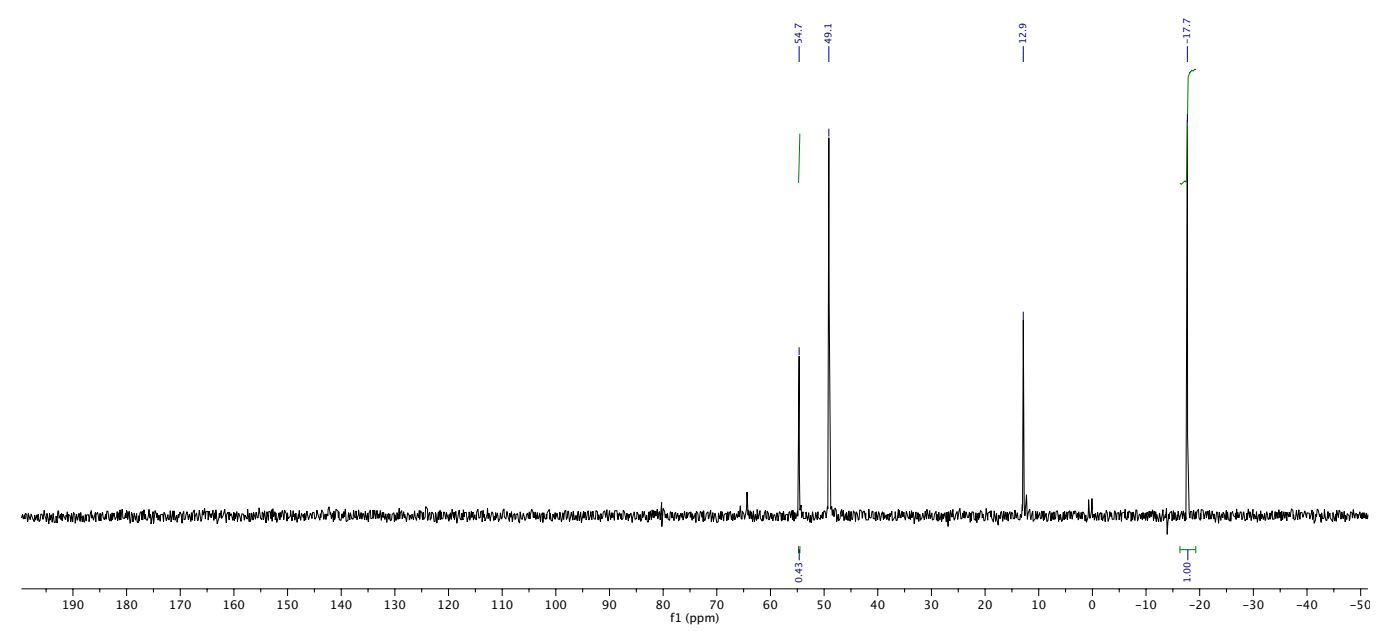

Crude ${ }^{31}$ P NMR spectra peptide 20 


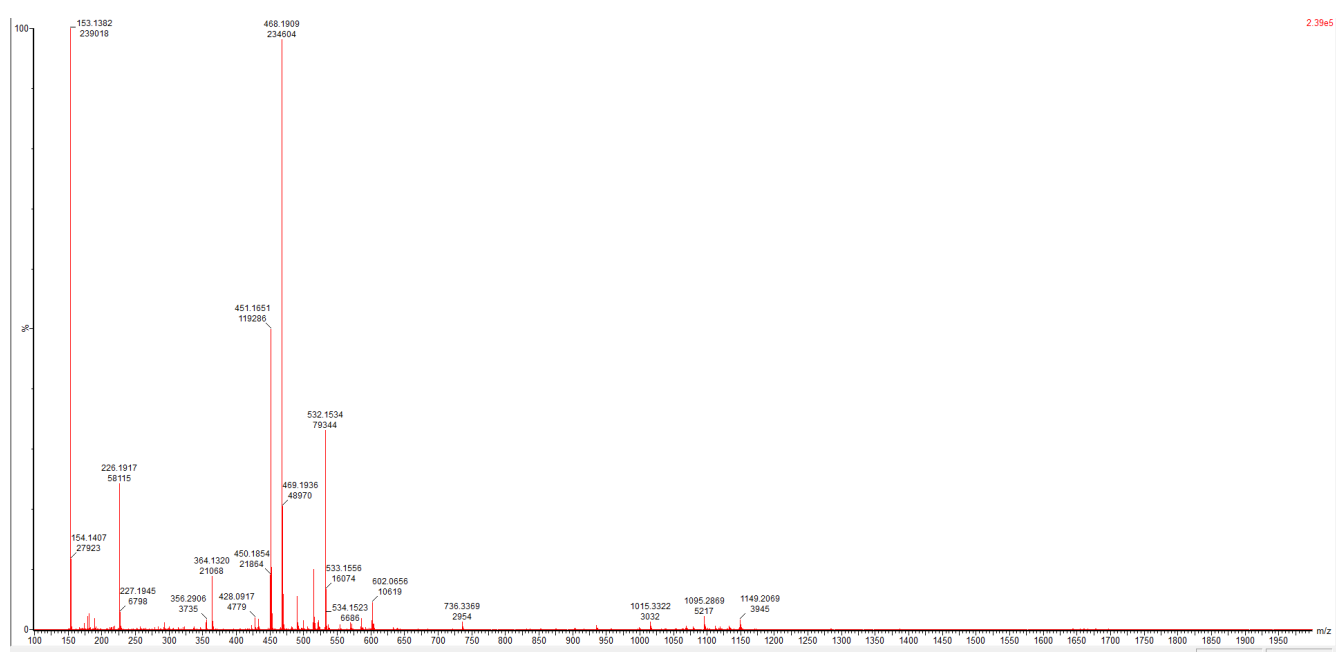

ESI $^{+}$trace peptide SI-11

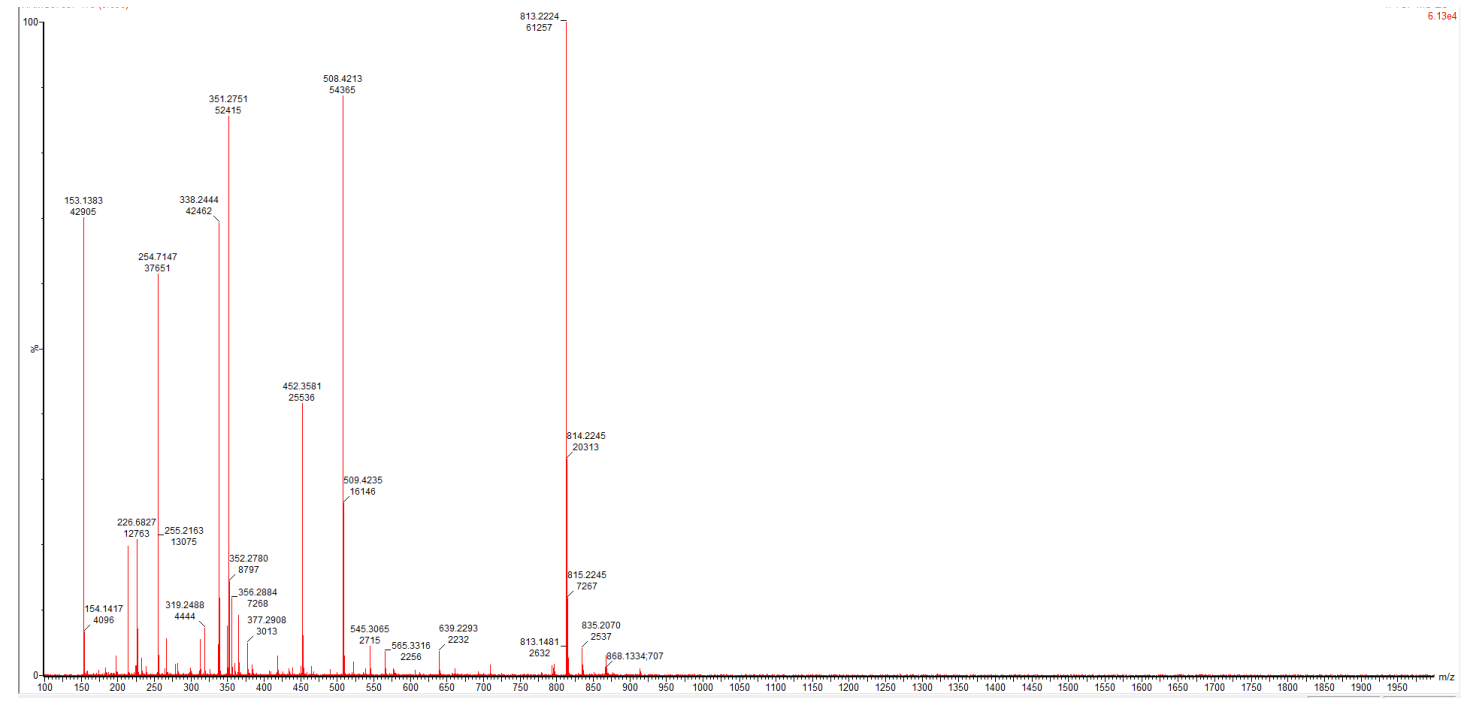

ESI $^{+}$trace peptide 20 


\section{Peptide 21}

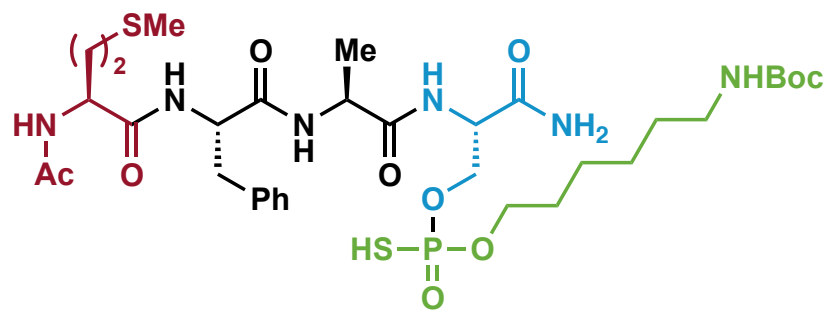

Prepared according to General Procedure C using:

Peptide SI-12 (100 $\mu \mathrm{L}$ of a $20 \mathrm{mM}$ solution in DMF, 1.0 equiv), P(V)-1 (100 $\mu \mathrm{L}$ of a $100 \mathrm{mM}$ solution in DMF, 5.0 equiv) and DBU (5 equiv). The crude mixture was analyzed by ${ }^{31} \mathrm{P}$ NMR and LC/MSD TOF to afford peptide 21 in $60 \%$ conversion.

$[\mathbf{M}+\mathbf{H}]^{+}\left(\mathbf{E S I}^{+}\right):$791.2.

${ }^{31}$ P NMR (162 MHz, DMF- $d$ ): $\delta 54.7$.

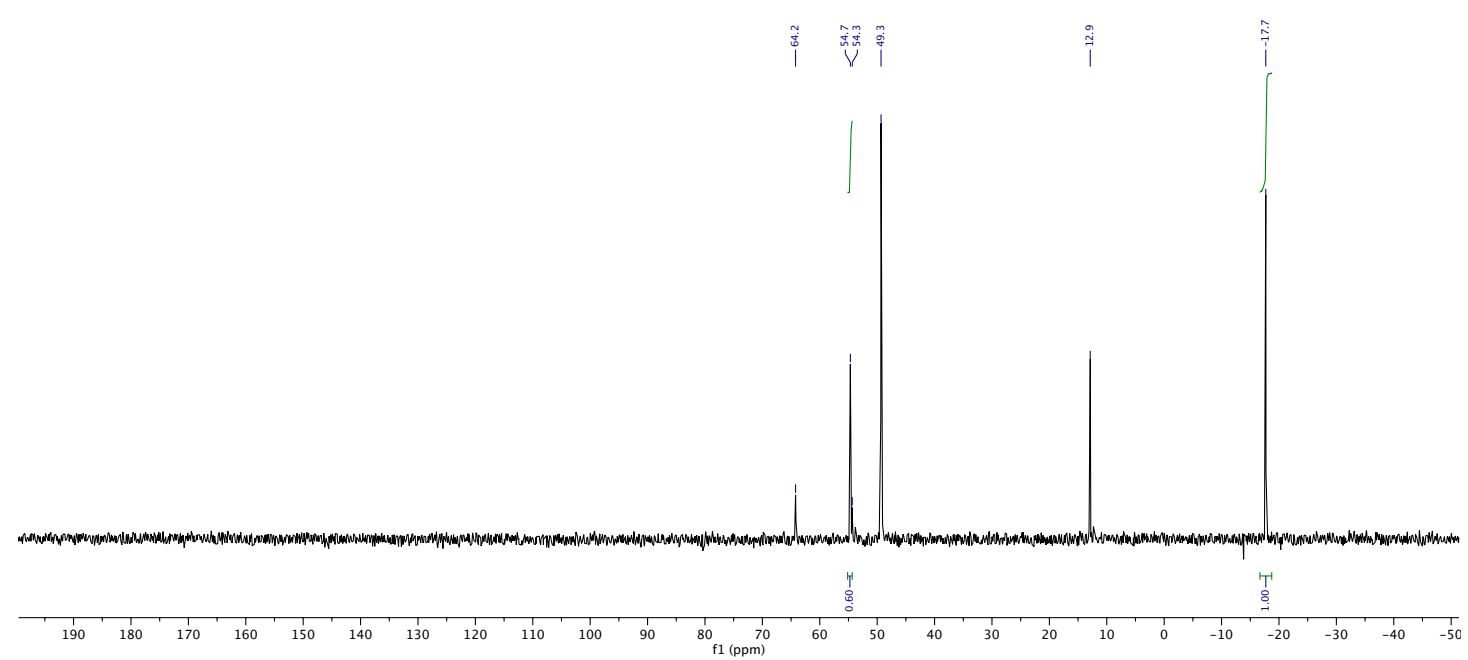

Crude ${ }^{31}$ P NMR spectra peptide 21 


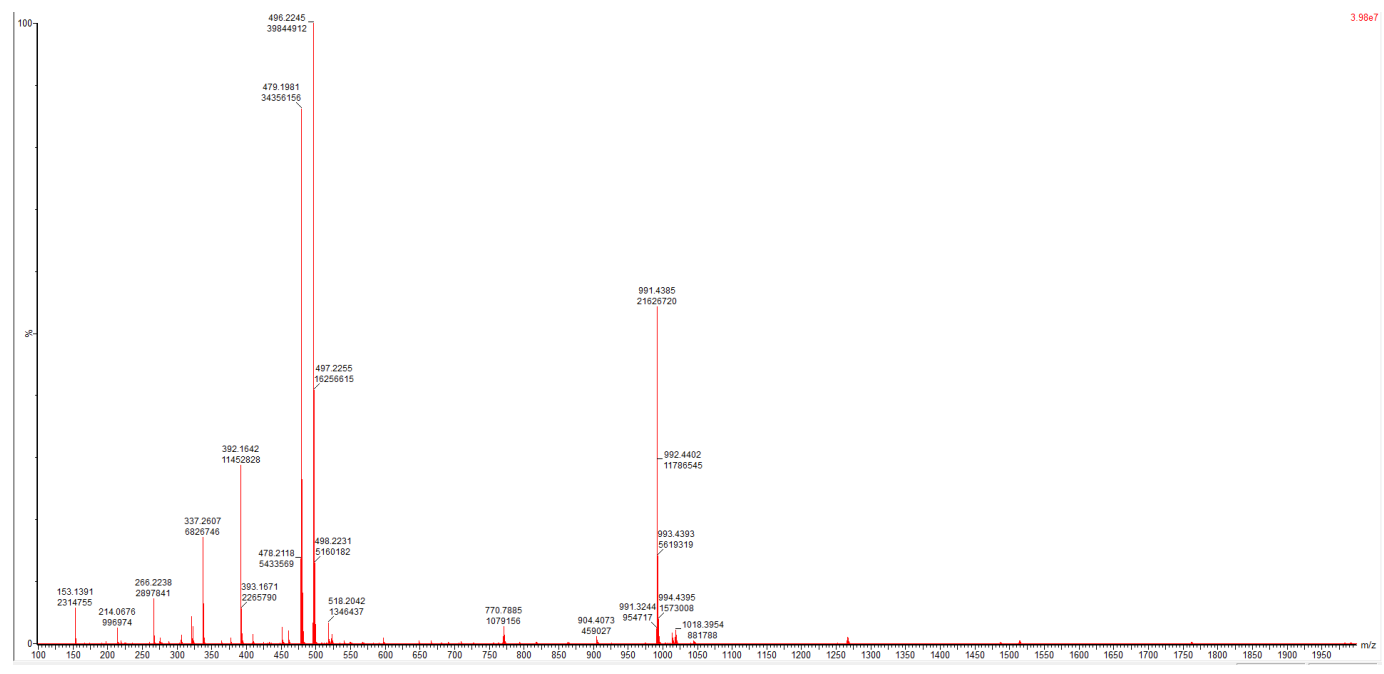

$\mathrm{ESI}^{+}$trace peptide SI-12

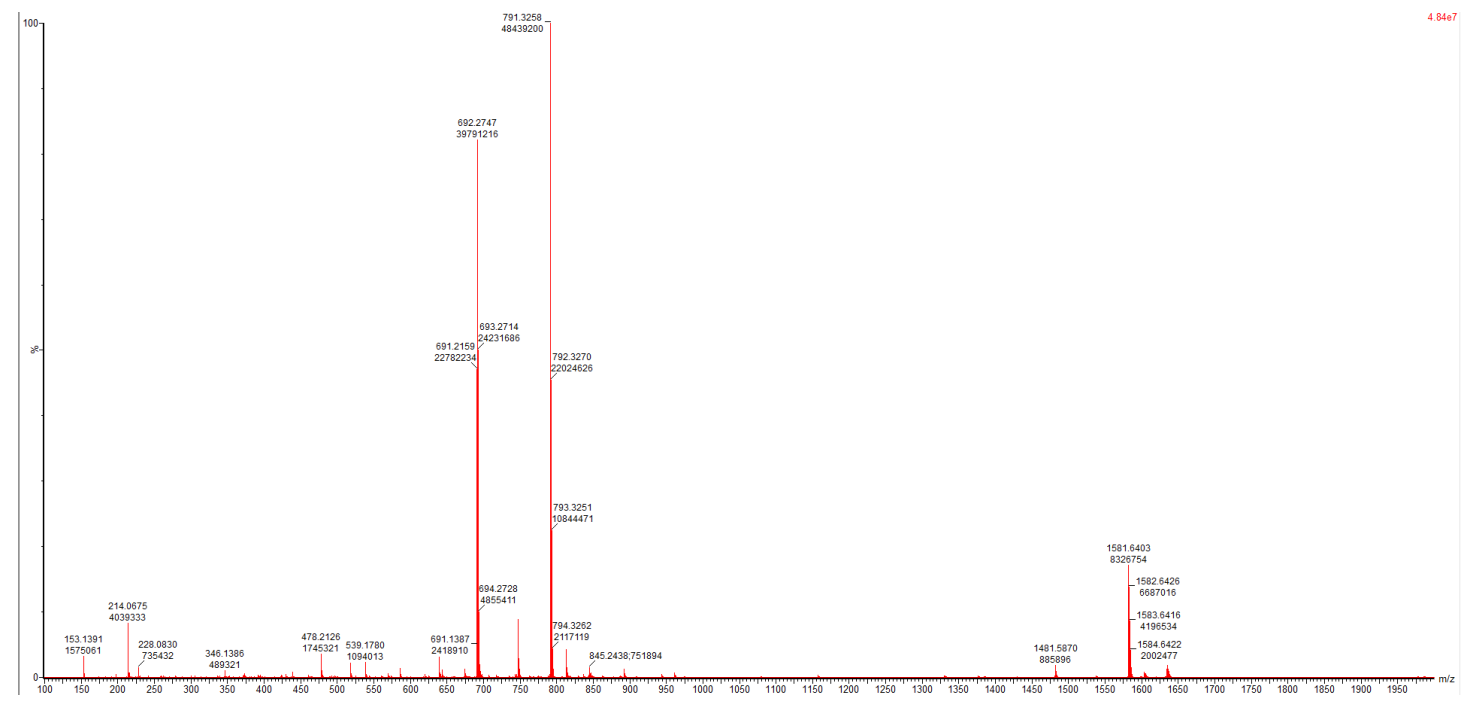

ESI $^{+}$trace peptide 21 


\section{Peptide 21 bis}

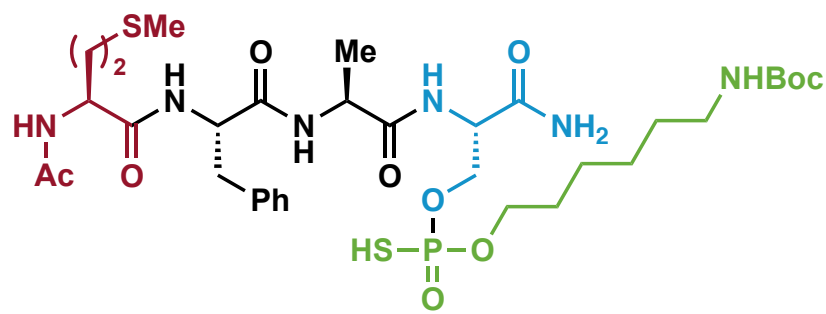

Prepared according to General Procedure C using:

Peptide SI-12 (100 $\mu \mathrm{L}$ of a $20 \mathrm{mM}$ solution in DMF, 1.0 equiv), P(V)-1 (100 $\mu \mathrm{L}$ of a $200 \mathrm{mM}$ solution in DMF, 10.0 equiv) and DBU (10 equiv). The crude mixture was analyzed by ${ }^{31} \mathrm{P}$ NMR and LC/MSD TOF to afford peptide 21 in $73 \%$ conversion. $[\mathbf{M}+\mathbf{H}]^{+}\left(\mathbf{E S I}^{+}\right):$791.2.

${ }^{31}$ P NMR (162 MHz, DMF- $d$ ): $\delta$ 56.0.

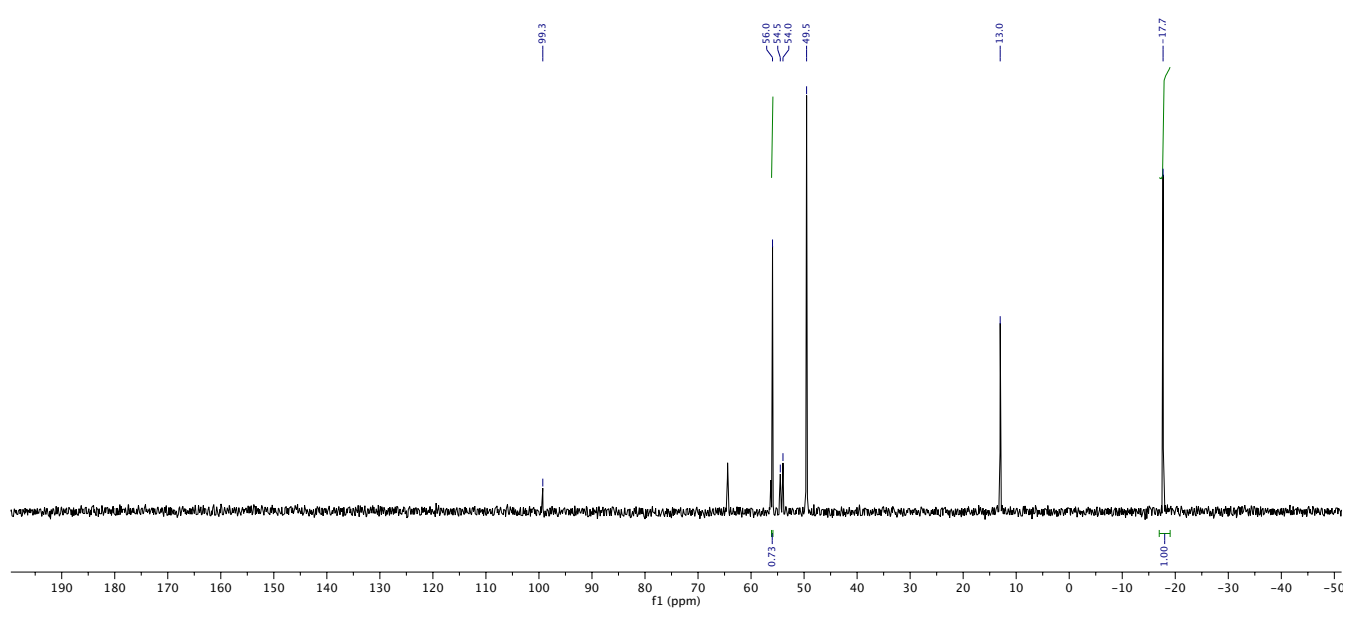

Crude ${ }^{31}$ P NMR spectra peptide 21 


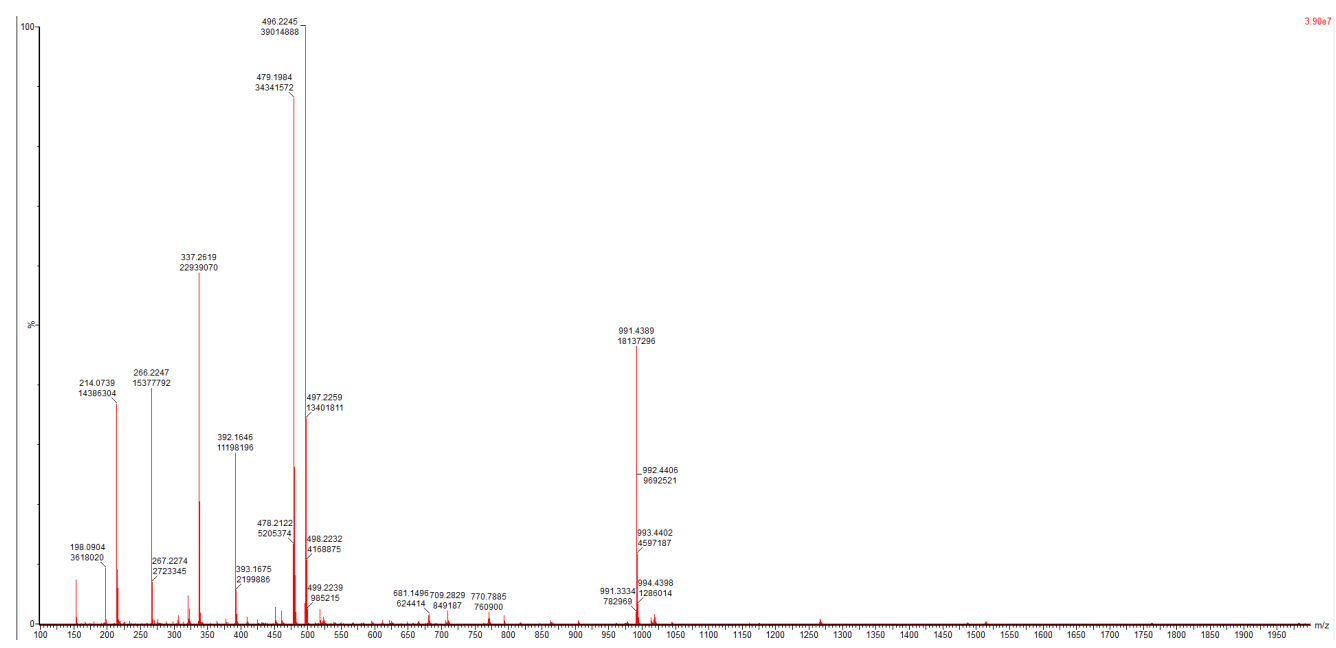

ESI $^{+}$trace peptide SI-12

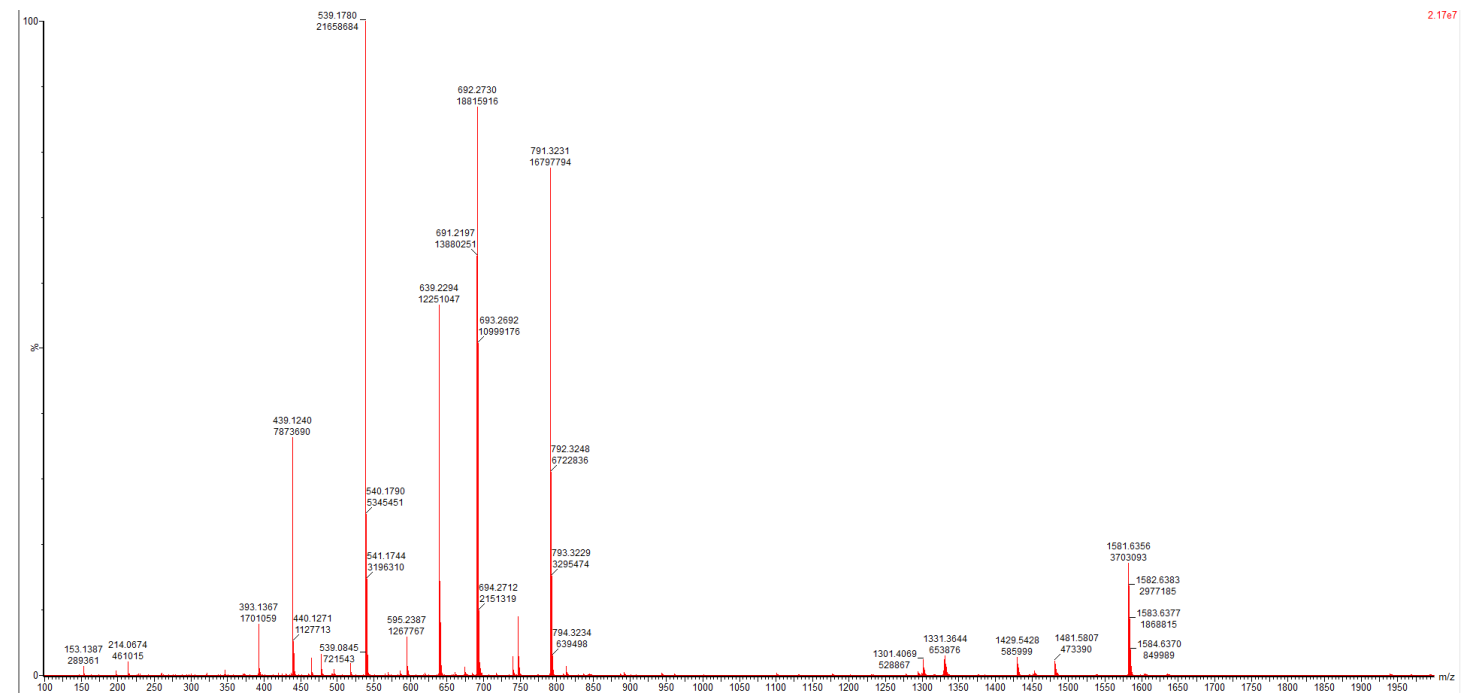

ESI $^{+}$trace peptide 21 


\section{Peptide 22}

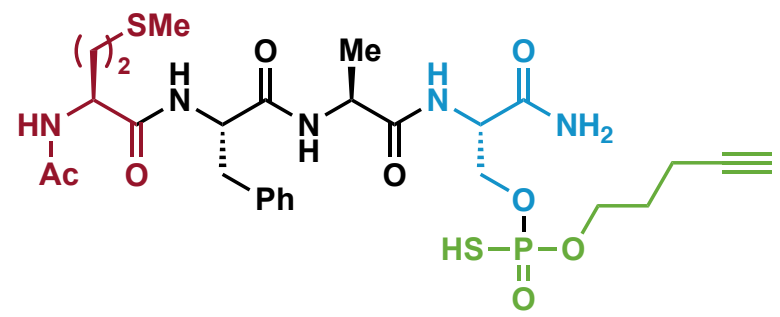

Prepared according to General Procedure C using:

Peptide SI-12 (100 $\mu \mathrm{L}$ of a $20 \mathrm{mM}$ solution in DMF, 1.0 equiv), P(V)-2a (100 $\mu \mathrm{L}$ of a $100 \mathrm{mM}$ solution in DMF, 5.0 equiv) and DBU (5 equiv). The crude mixture was analyzed by ${ }^{31} \mathrm{P}$ NMR and LC/MSD TOF to afford peptide 22 in $63 \%$ conversion. $[\mathbf{M}+\mathbf{H}]^{+}\left(\mathbf{E S I}^{+}\right): 658.2$.

${ }^{31}$ P NMR (162 MHz, DMF- $d$ ): $\delta 54.7$.

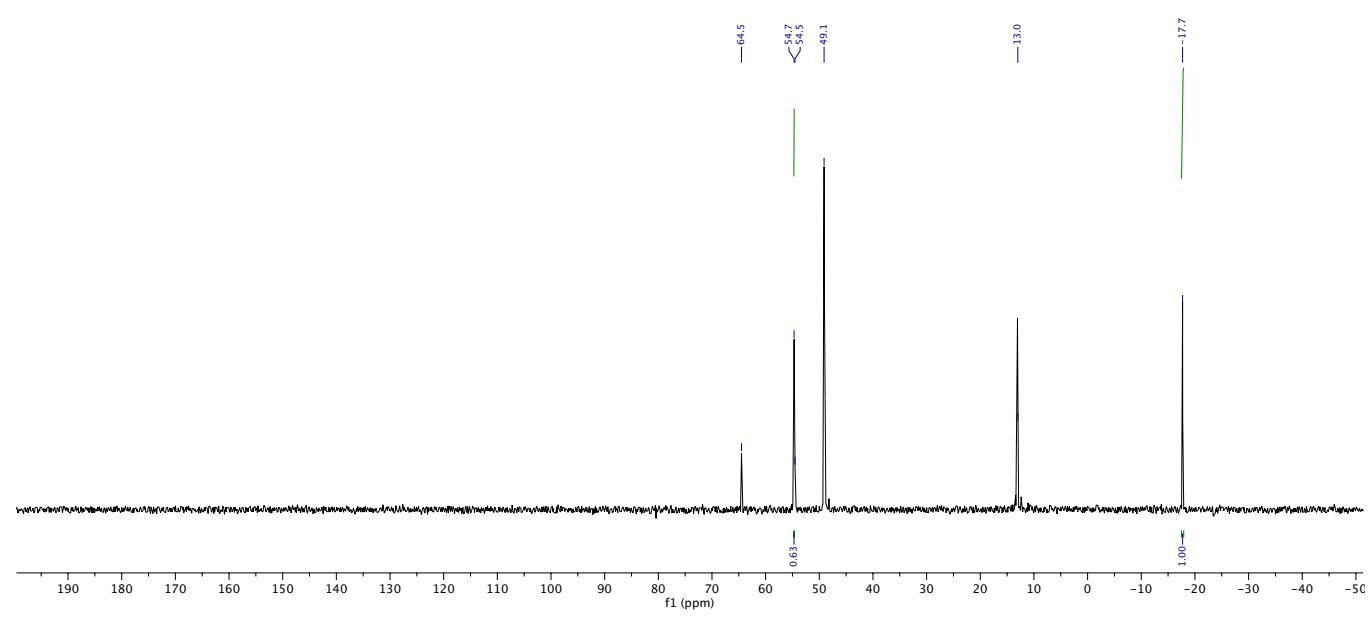

Crude ${ }^{31}$ P NMR spectra peptide 22 


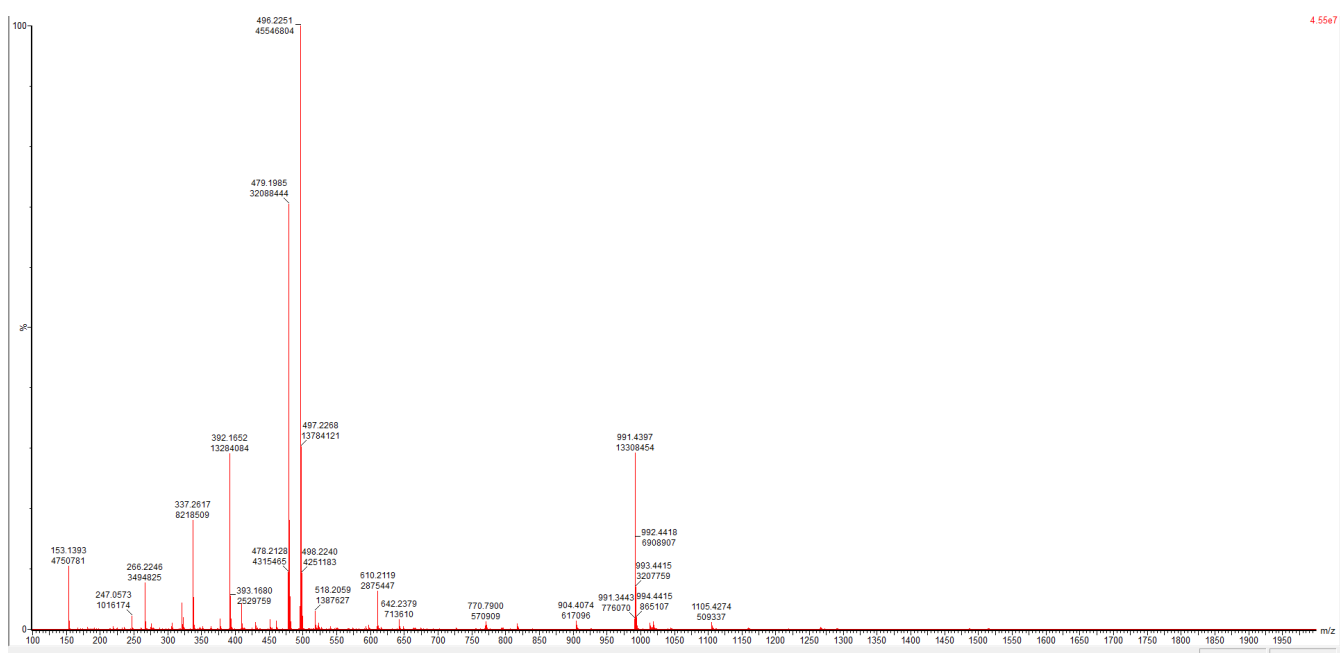

$\mathrm{ESI}^{+}$trace peptide SI-12

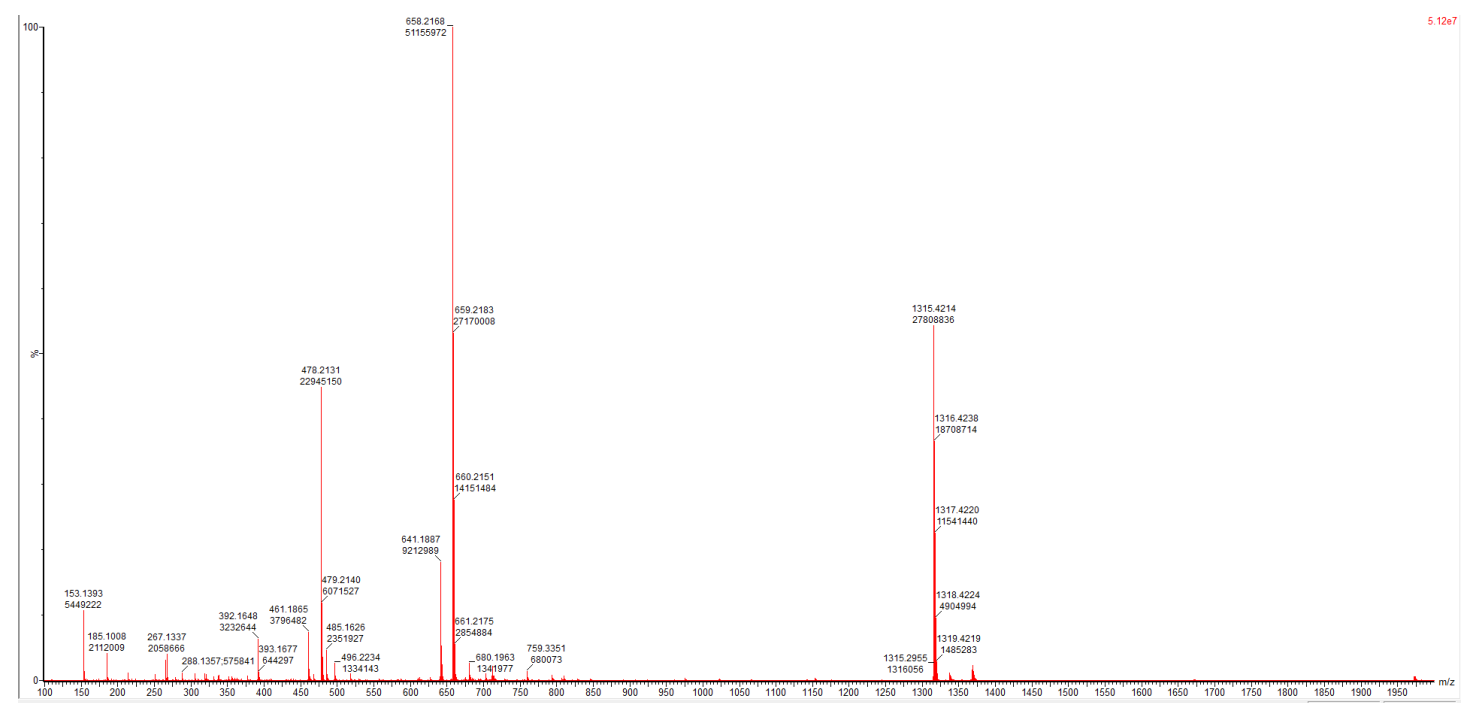

$\mathrm{ESI}^{+}$trace peptide 22 


\section{Peptide 23}

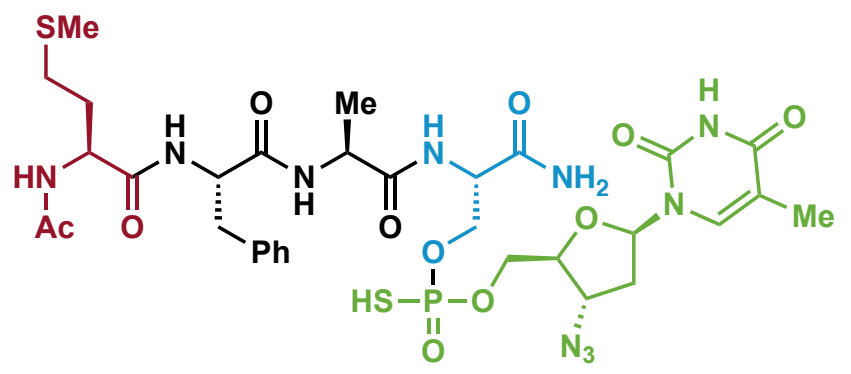

Prepared according to General Procedure $\mathbf{C}$ using:

Peptide SI-12 (100 $\mu \mathrm{L}$ of a $20 \mathrm{mM}$ solution in DMF, 1.0 equiv), P(V)-3 (100 $\mu \mathrm{L}$ of a $100 \mathrm{mM}$ solution in DMF, 5.0 equiv) and DBU (5 equiv). The crude mixture was analyzed by ${ }^{31} \mathrm{P}$ NMR and LC/MSD TOF to afford peptide 23 in 34\% conversion. $[\mathbf{M}+\mathbf{H}]^{+}\left(\mathbf{E S I}^{+}\right):$841.2.

${ }^{31}$ P NMR (162 MHz, DMF-d): $\delta 56.7$.

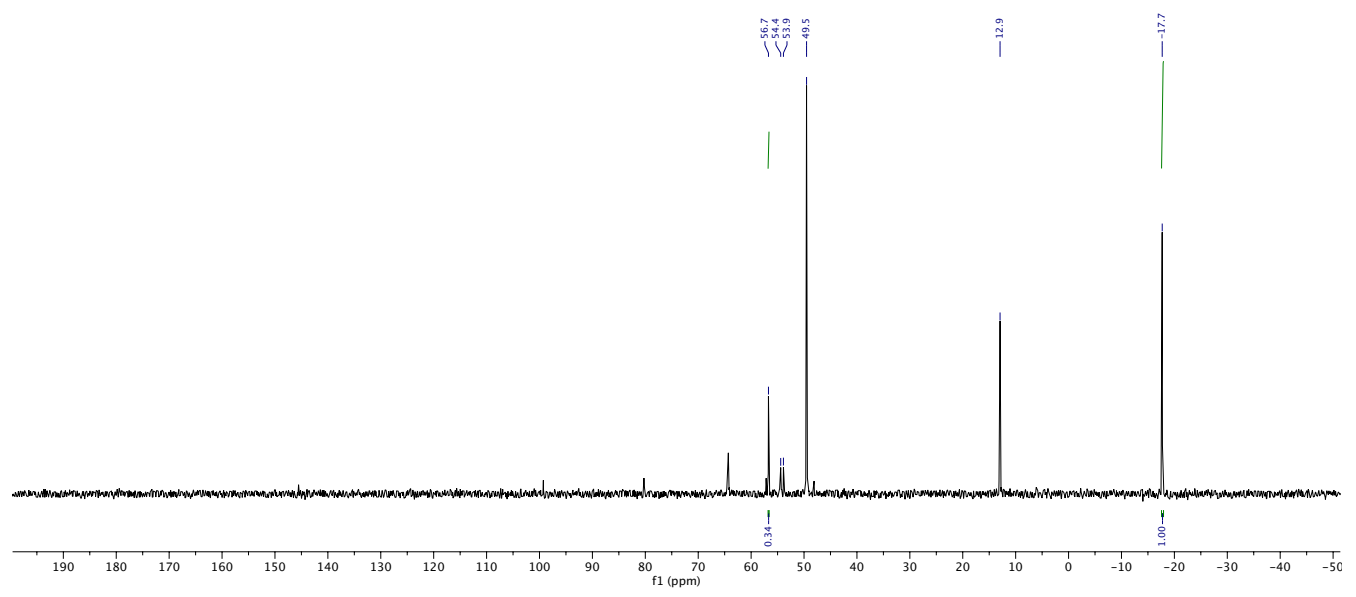

Crude ${ }^{31}$ P NMR spectra peptide 23 


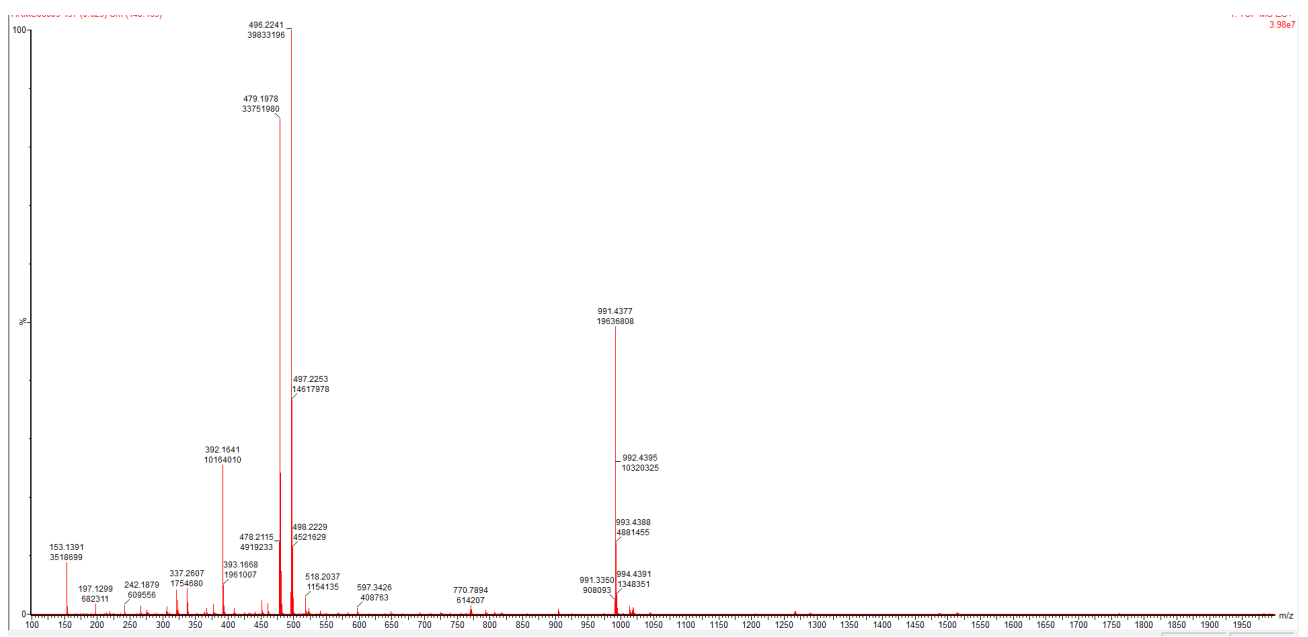

ESI $^{+}$trace peptide SI-12

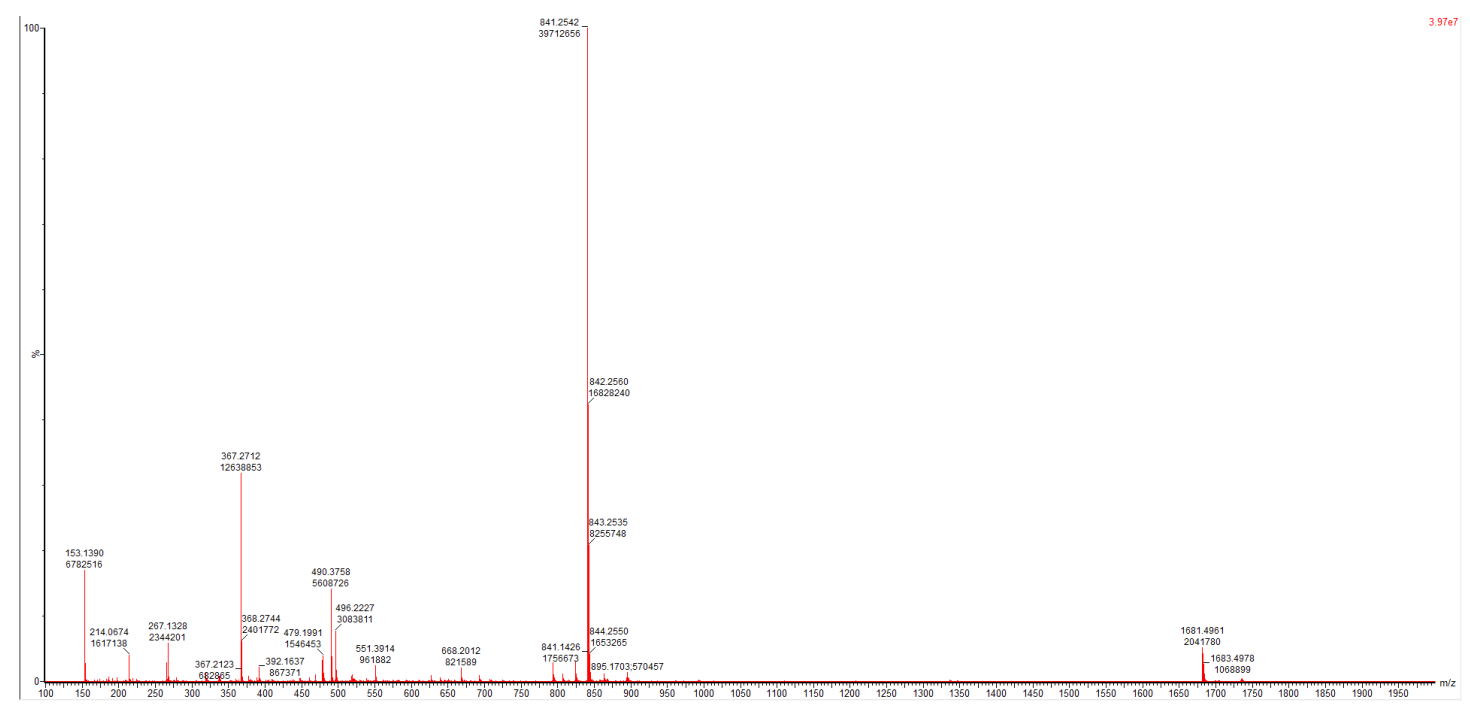

ESI $^{+}$trace peptide 23 


\section{Peptide 24}

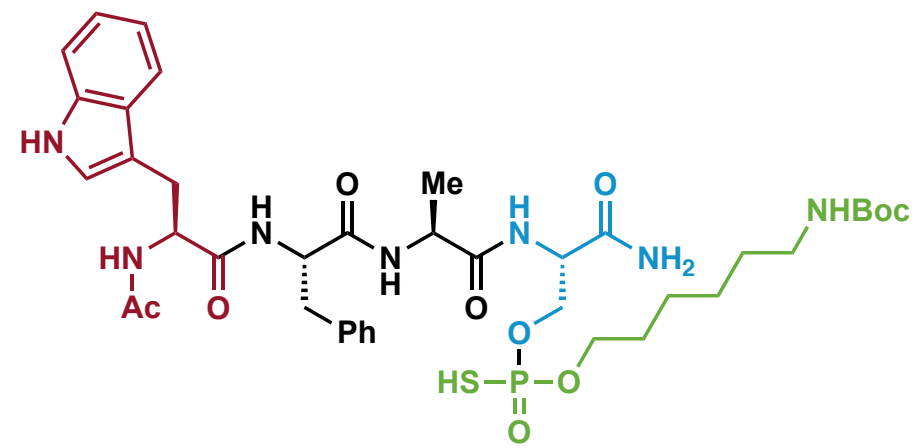

Prepared according to General Procedure C using:

Peptide SI-13 (100 $\mu \mathrm{L}$ of a $20 \mathrm{mM}$ solution in DMF, 1.0 equiv), P(V)-1 (100 $\mu \mathrm{L}$ of a $100 \mathrm{mM}$ solution in DMF, 5.0 equiv) and DBU (5 equiv). The crude mixture was analyzed by ${ }^{31} \mathrm{P}$ NMR and LC/MSD TOF to afford peptide 24 in 30\% conversion. $[\mathbf{M}+\mathbf{H}]^{+}\left(\mathbf{E S I}^{+}\right): 846.4$.

${ }^{31}$ P NMR (162 MHz, DMF-d): $\delta 54.7$.

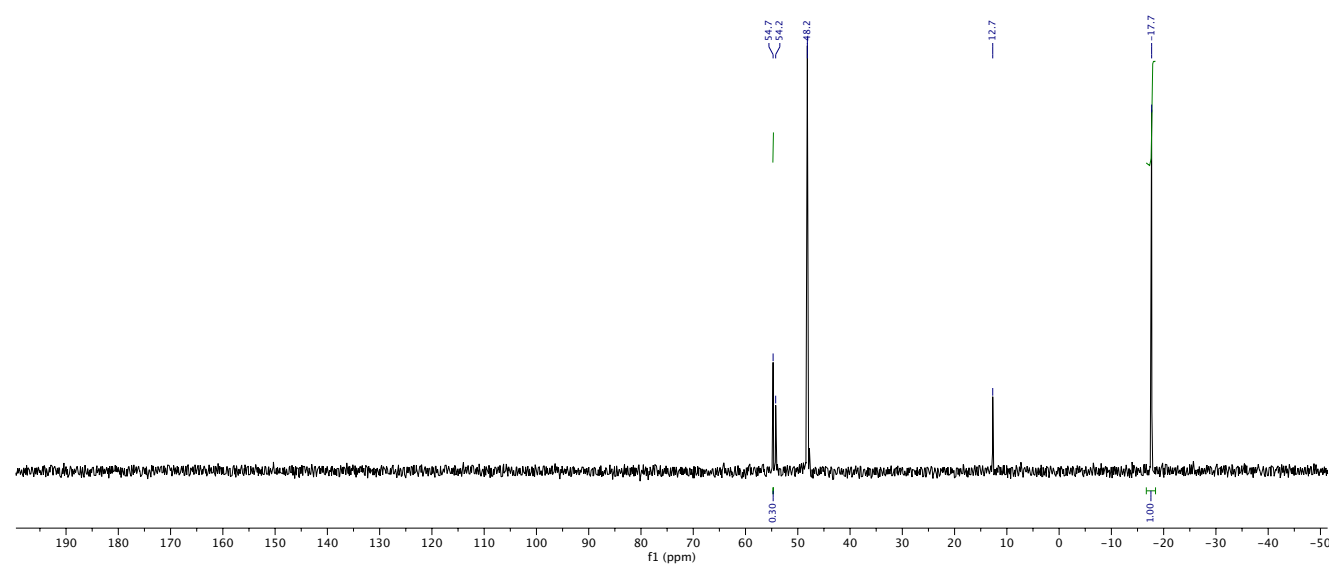

Crude ${ }^{31}$ P NMR spectra peptide 24 


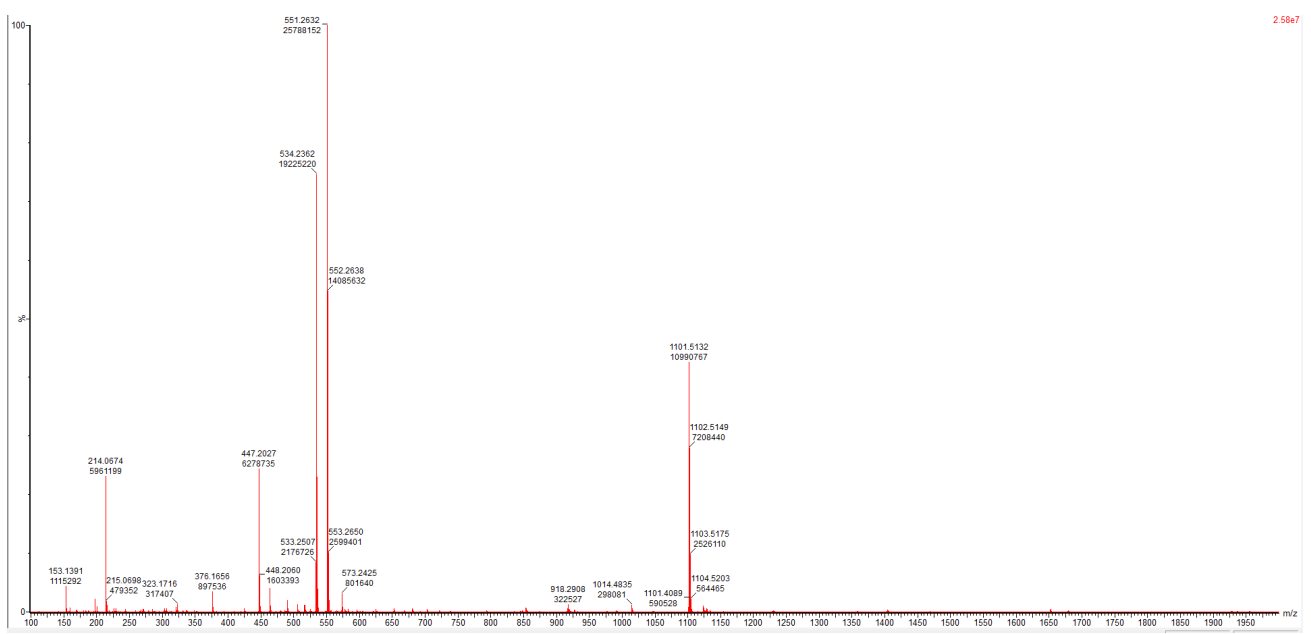

$\mathrm{ESI}^{+}$trace peptide SI-13

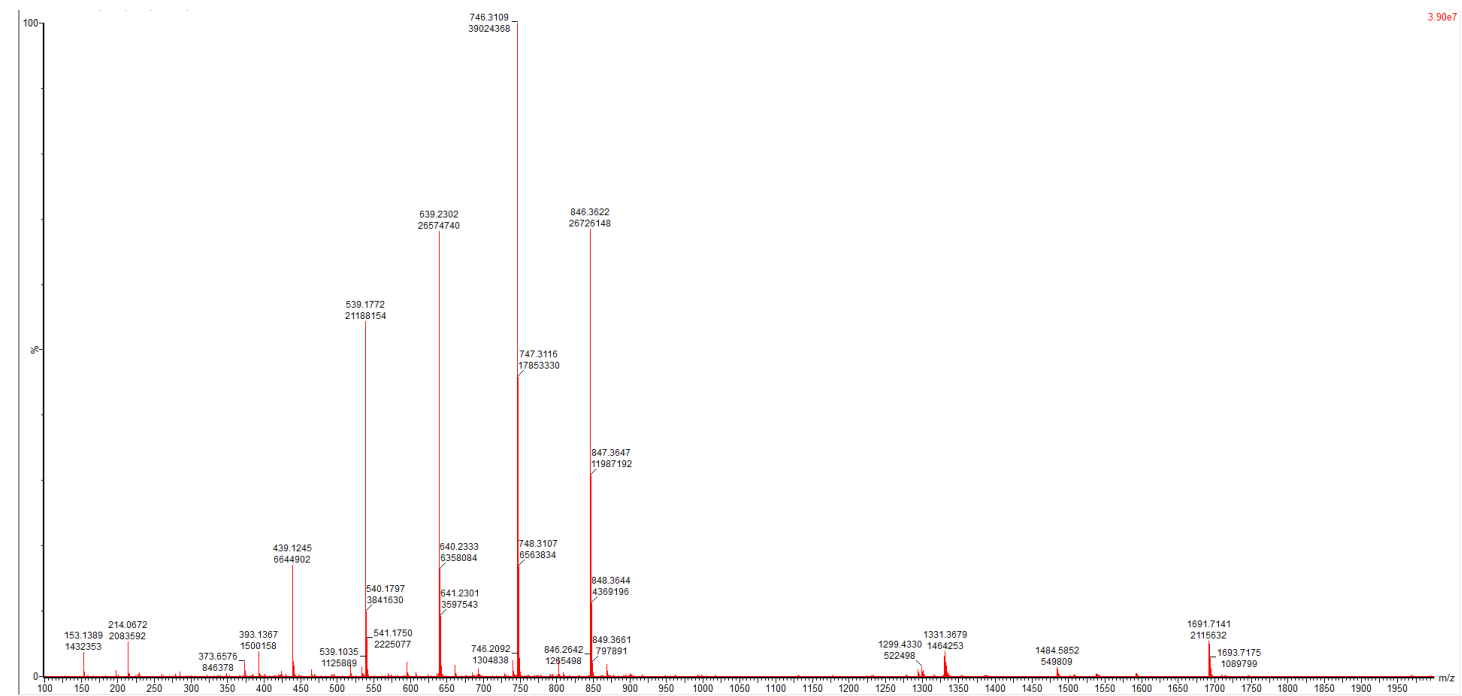

ESI $^{+}$trace peptide 24 


\section{Peptide 24 bis}

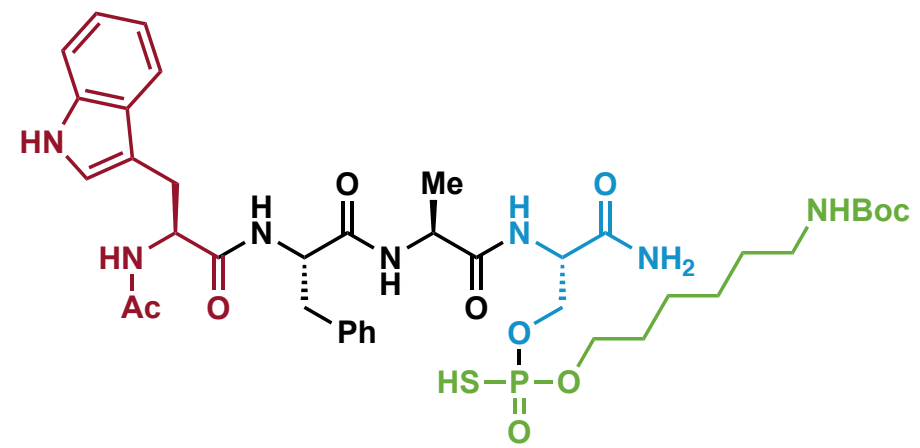

Prepared according to General Procedure C using:

Peptide SI-13 (100 $\mu \mathrm{L}$ of a $20 \mathrm{mM}$ solution in DMF, 1.0 equiv), P(V)-1 (100 $\mu \mathrm{L}$ of a $200 \mathrm{mM}$ solution in DMF, 10.0 equiv) and DBU (10 equiv). The crude mixture was analyzed by ${ }^{31} \mathrm{P}$ NMR and LC/MSD TOF to afford peptide 24 in 35\% conversion. $[\mathbf{M}+\mathbf{H}]^{+}\left(\mathbf{E S I}^{+}\right):$846.4.

${ }^{31}$ P NMR (162 MHz, DMF-d): $\delta 56.7$.

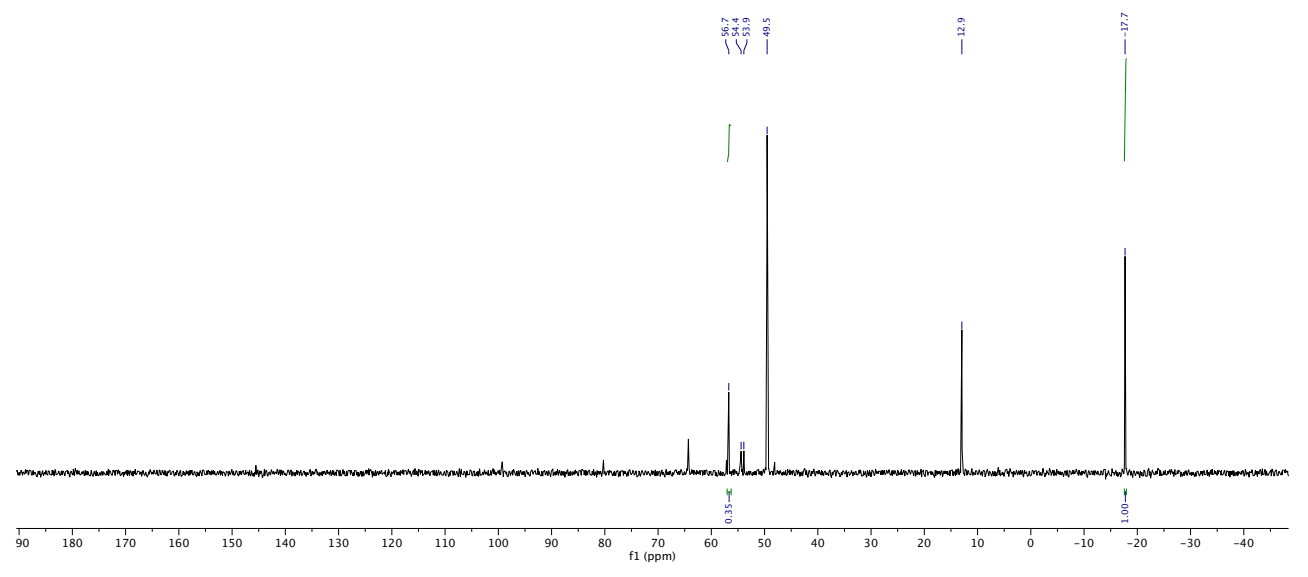

Crude ${ }^{31}$ P NMR spectra peptide 24 


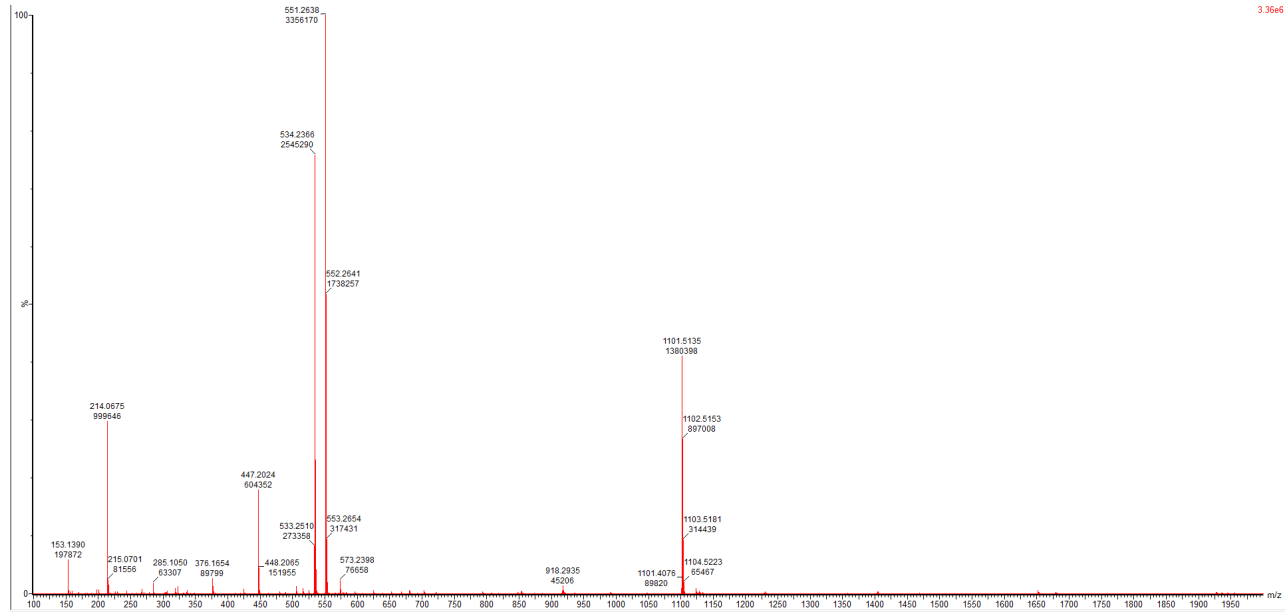

ESI $^{+}$trace peptide SI-13

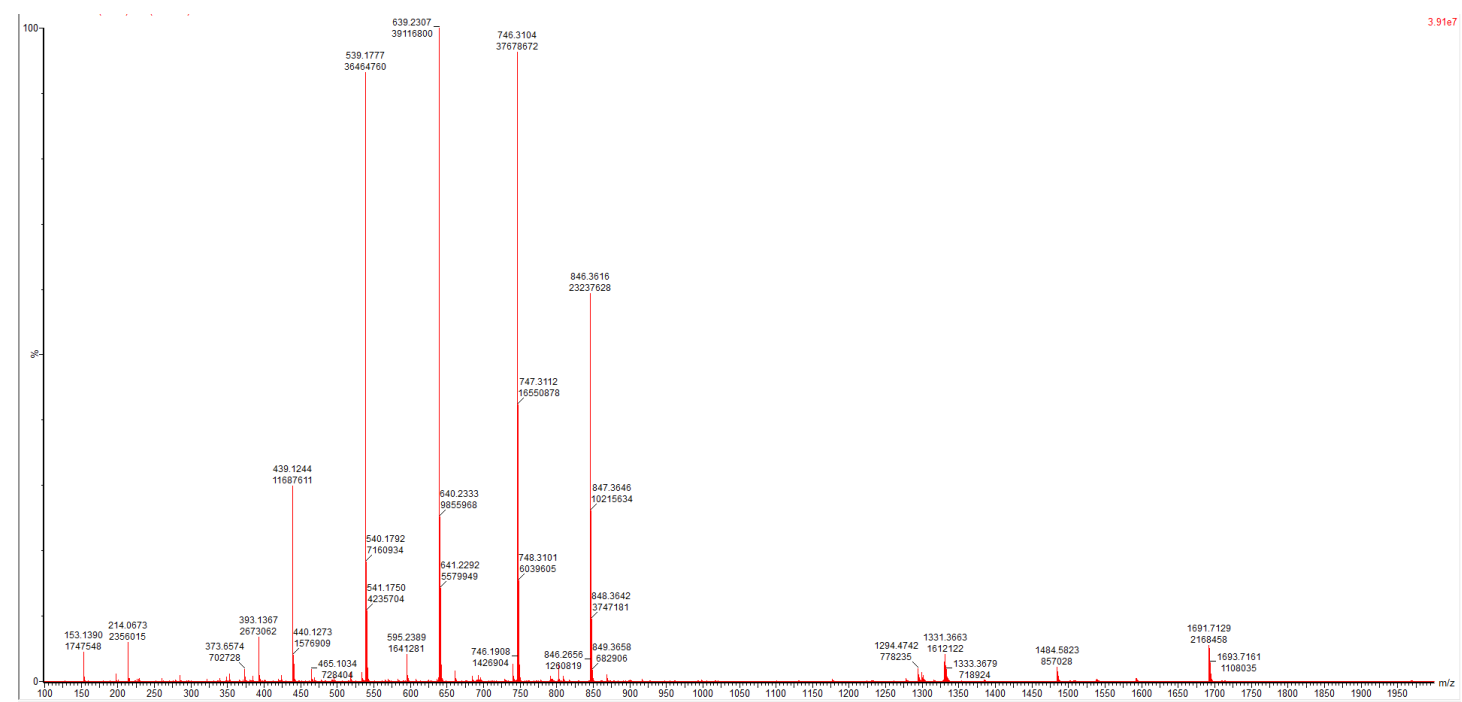

ESI $^{+}$trace peptide 24 


\section{Peptide 25}

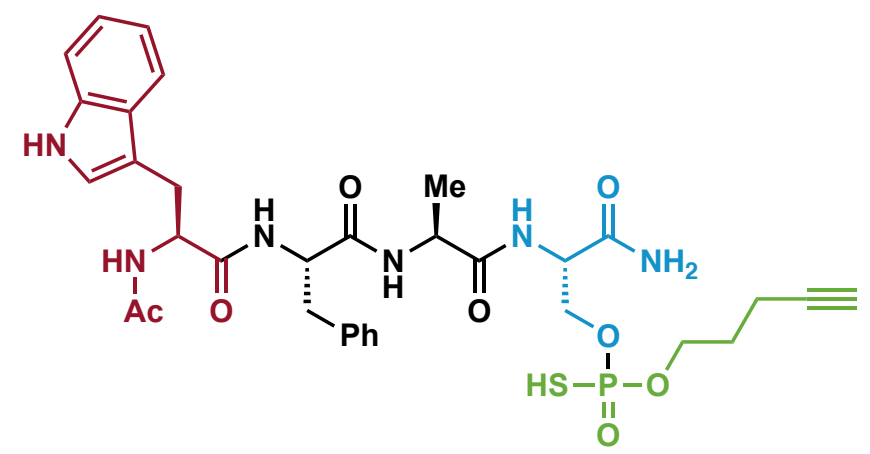

Prepared according to General Procedure C using:

Peptide SI-13 (100 $\mu \mathrm{L}$ of a $20 \mathrm{mM}$ solution in DMF, 1.0 equiv), P(V)-2a (100 $\mu \mathrm{L}$ of a $100 \mathrm{mM}$ solution in DMF, 5.0 equiv) and DBU (5 equiv). The crude mixture was analyzed by ${ }^{31} \mathrm{P}$ NMR and LC/MSD TOF to afford peptide 25 in $78 \%$ conversion. $[\mathbf{M}+\mathbf{H}]^{+}\left(\mathbf{E S I}^{+}\right): 714.3$.

${ }^{31}$ P NMR (162 MHz, DMF- $d$ ): $\delta 56.9$.

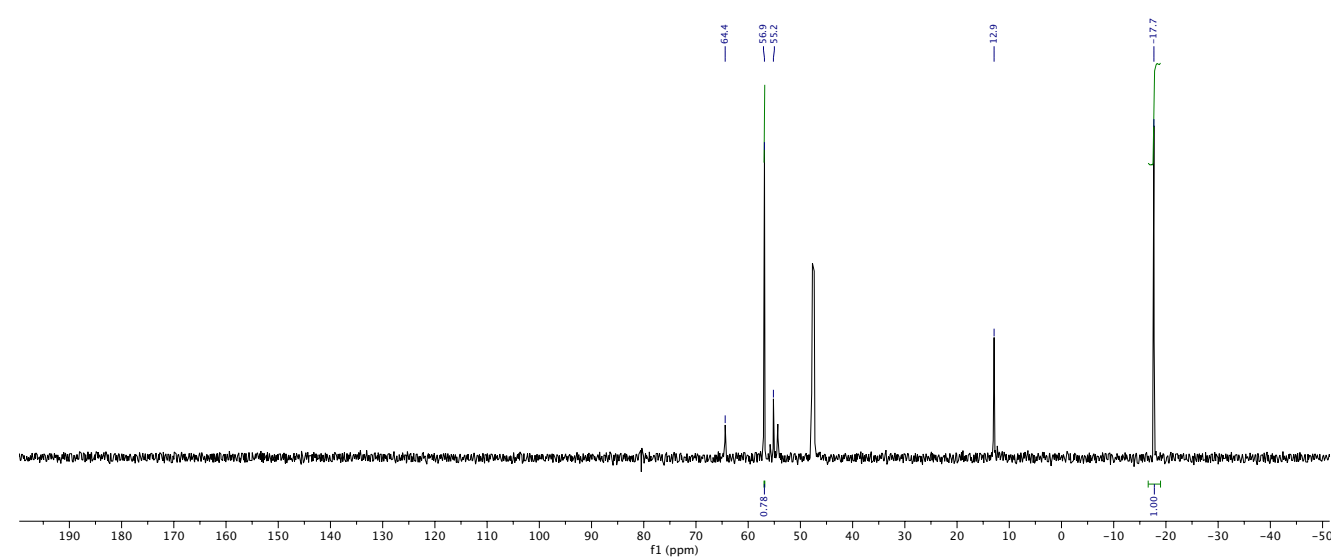

Crude ${ }^{31}$ P NMR spectra peptide 25 


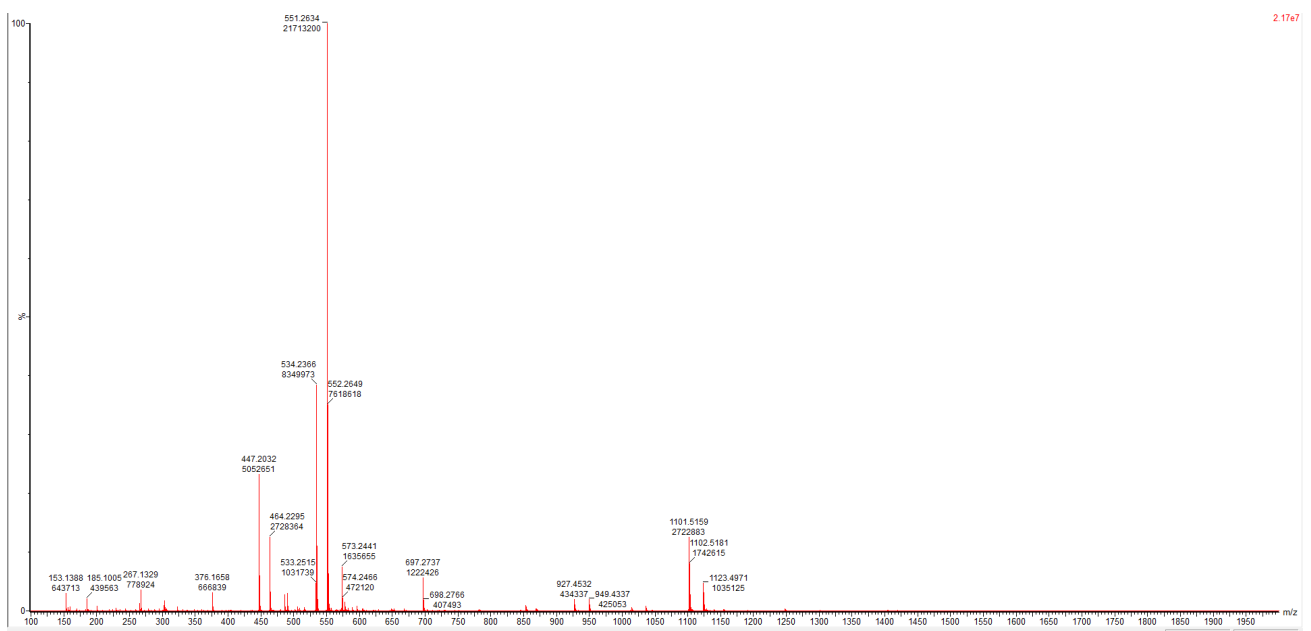

ESI $^{+}$trace peptide SI-13

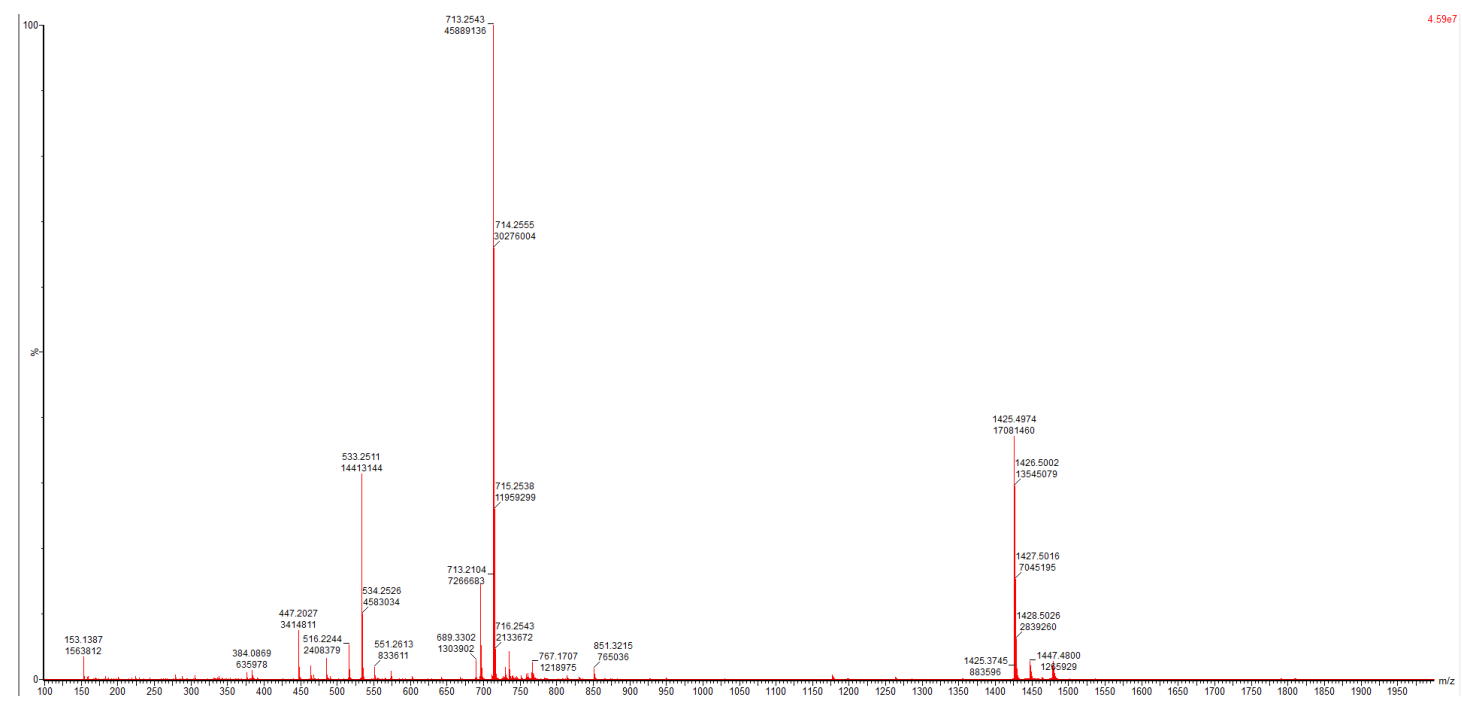

ESI $^{+}$trace peptide 25 


\section{Peptide 26}

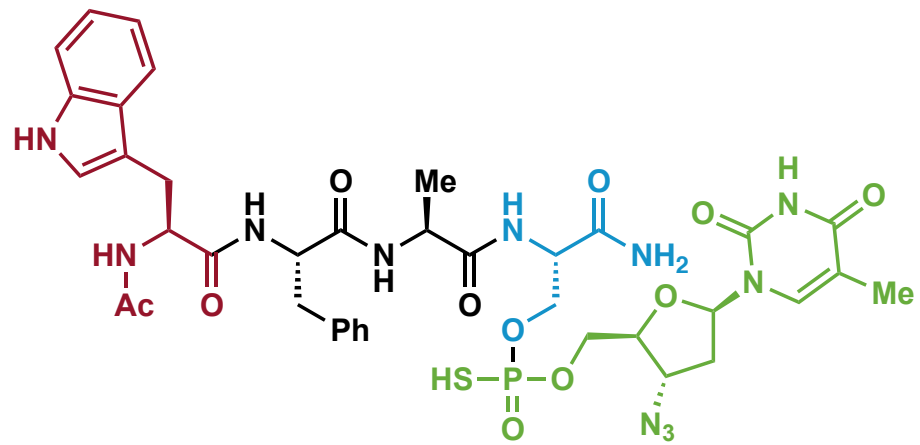

Prepared according to General Procedure C using:

Peptide SI-13 (100 $\mu \mathrm{L}$ of a $20 \mathrm{mM}$ solution in DMF, 1.0 equiv), P(V)-3 (100 $\mu \mathrm{L}$ of a $100 \mathrm{mM}$ solution in DMF, 5.0 equiv) and DBU (5 equiv). The crude mixture was analyzed by ${ }^{31} \mathrm{P}$ NMR and LC/MSD TOF to afford peptide 26 in $45 \%$ conversion. $[\mathbf{M}+\mathbf{H}]^{+}\left(\mathbf{E S I}^{+}\right): 896.3$.

${ }^{31}$ P NMR (162 MHz, DMF-d): $\delta 54.7$.

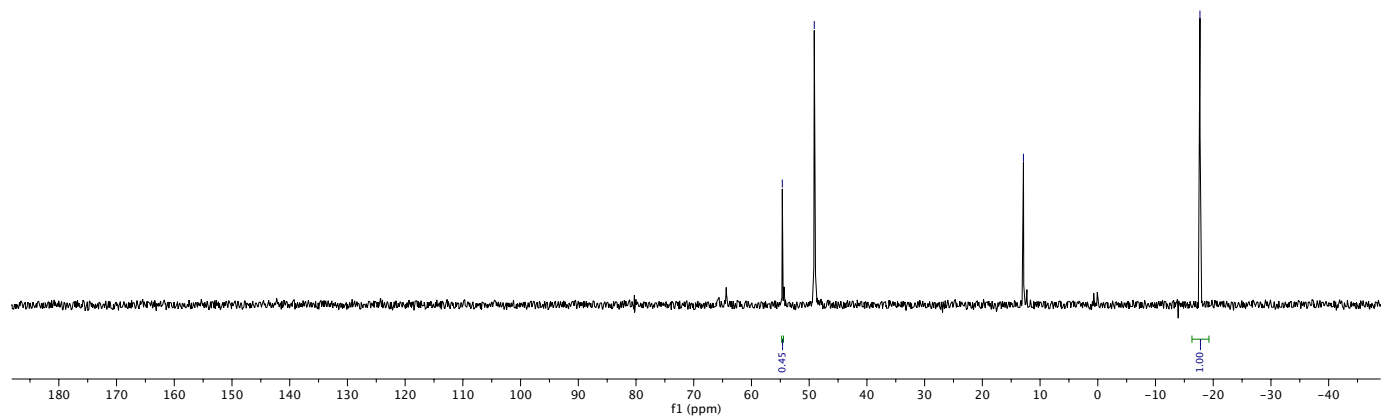

Crude ${ }^{31}$ P NMR spectra peptide 26 


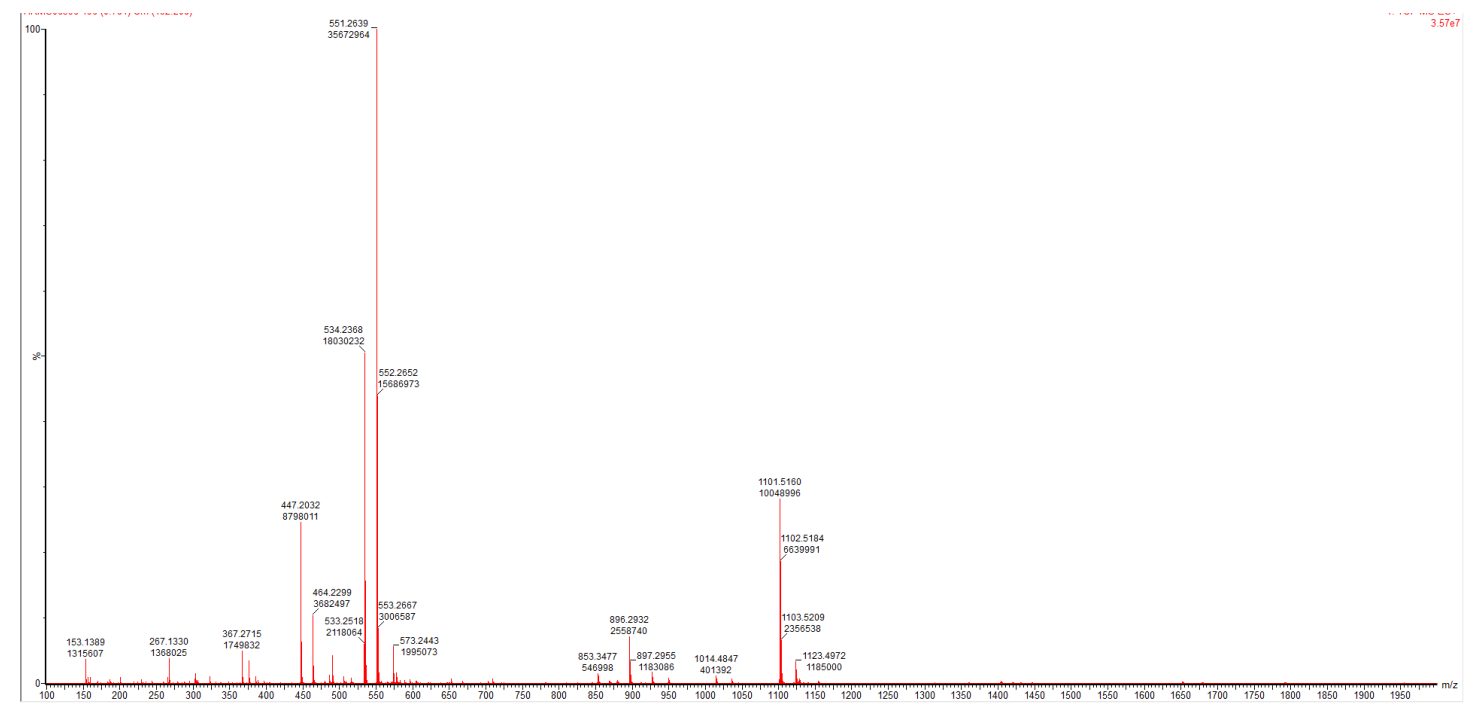

ESI $^{+}$trace peptide SI-13

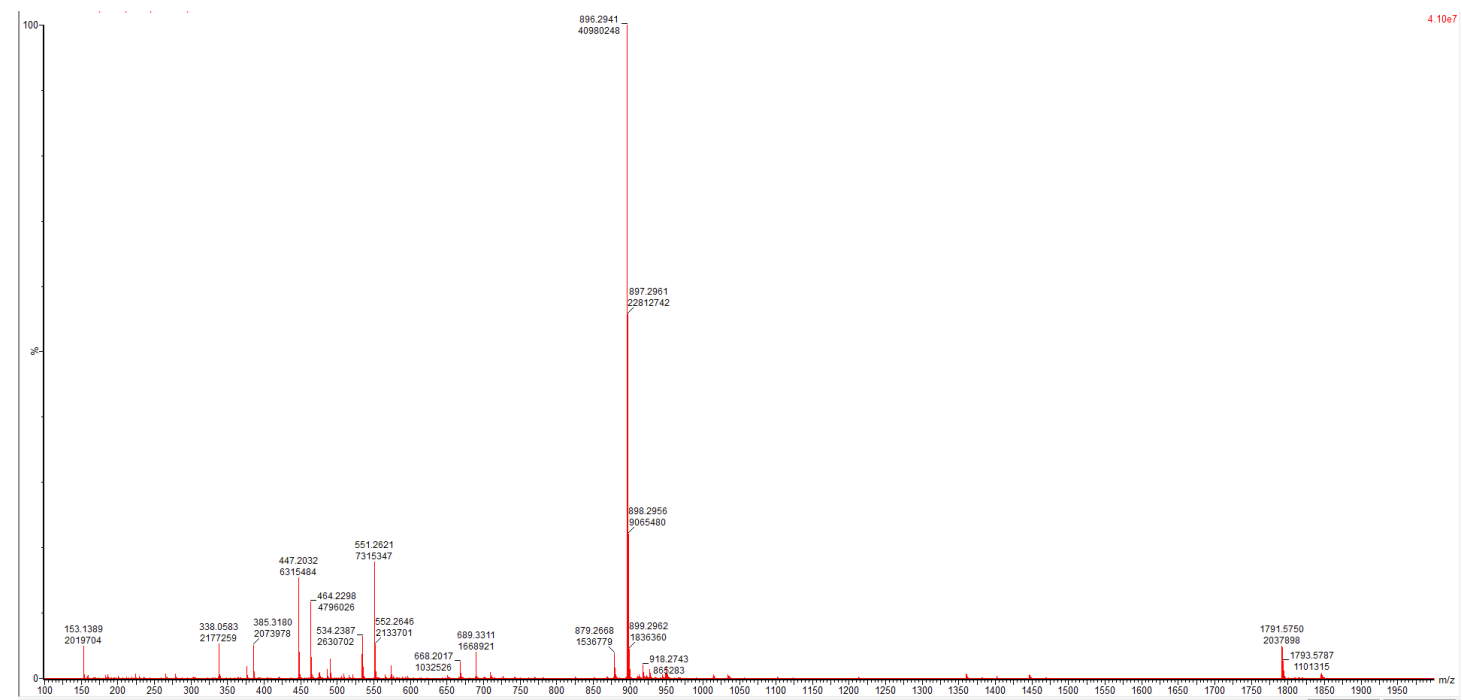

$\mathrm{ESI}^{+}$trace peptide 26 


\section{Linear Peptide Scope}

\section{Starting materials}

The following peptides were used for this study and were prepared following the General Procedure B (SPPS).

\section{Peptide SI-14}

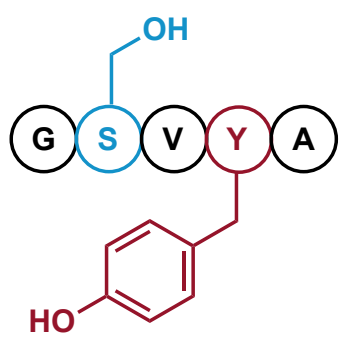

$[\mathbf{M}+\mathbf{H}]^{+}\left(\mathbf{E S I}^{+}\right): 552.6$.

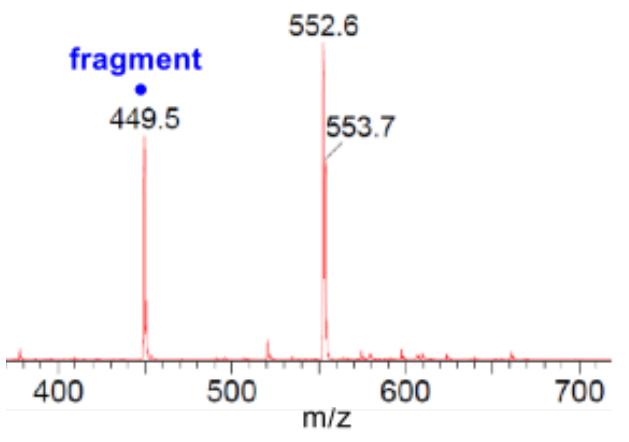

ESI $^{+}$trace peptide SI-14 


\section{Peptide SI-15}

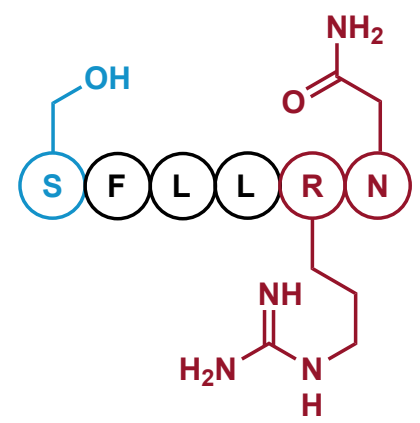

$[\mathbf{M}+\mathbf{H}]^{+}\left(\mathbf{E S I}^{+}\right):$: 749.9 .

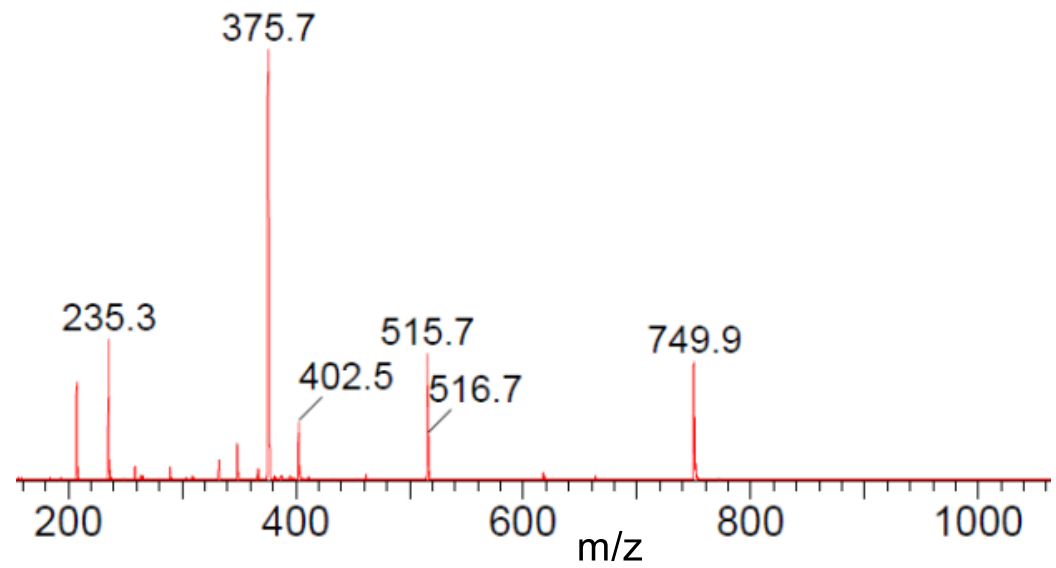

ESI $^{+}$trace peptide SI-15 


\section{Peptide SI-16 (Melittin)}

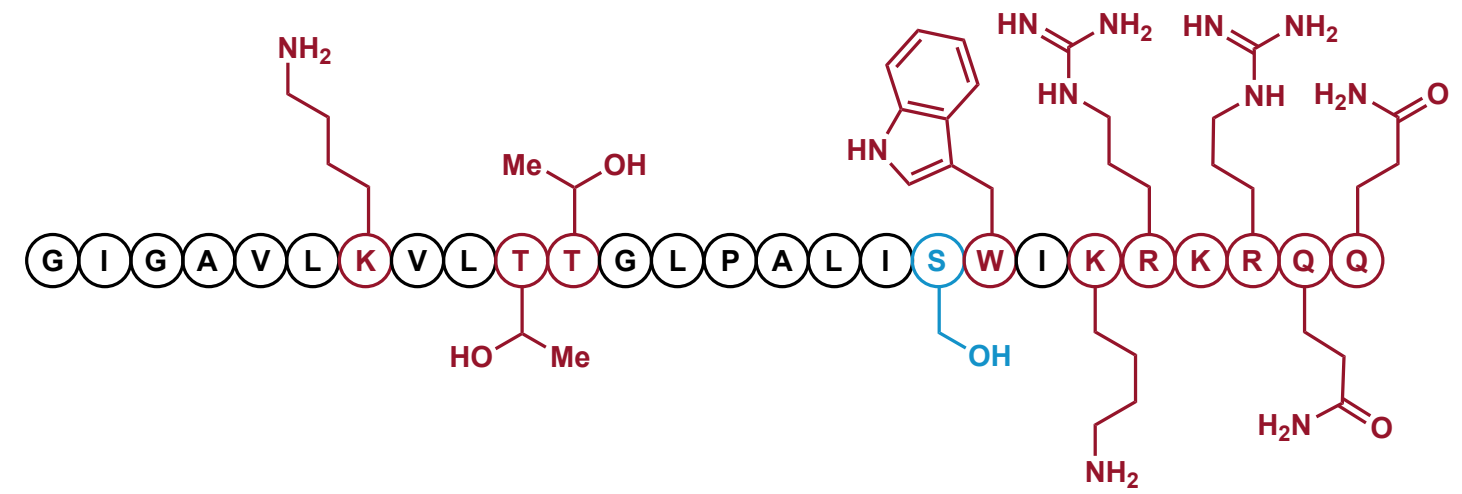

$[\mathbf{M}+\mathbf{H}]^{+}\left(\mathbf{E S I}^{+}\right): 2846$.

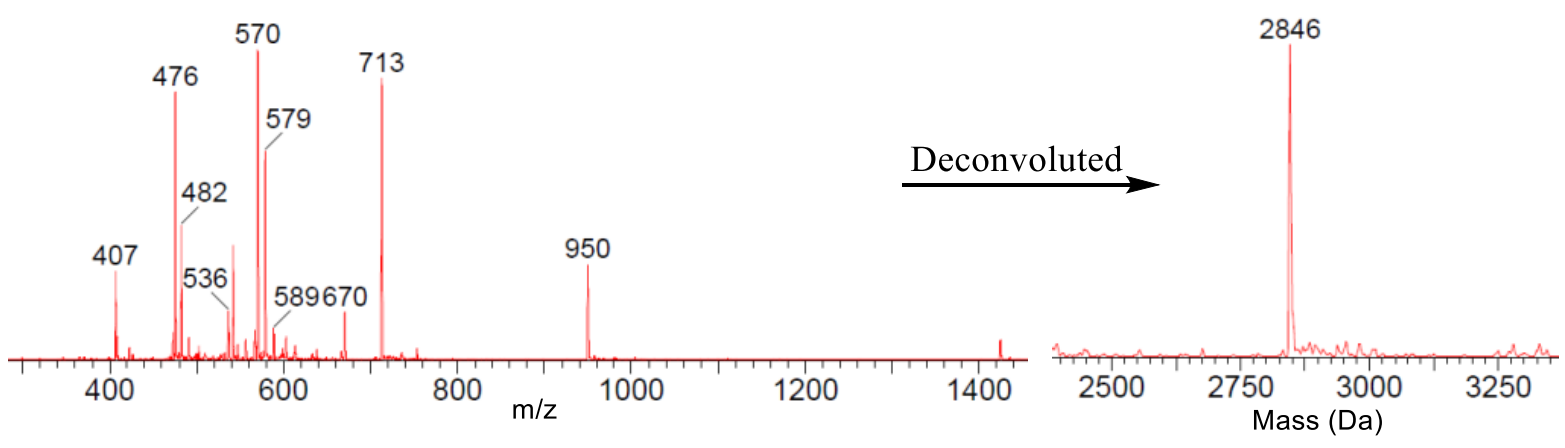

$\mathrm{ESI}^{+}$trace peptide SI-16 


\section{Linear Peptides Functionalization}

\section{Peptide 27}

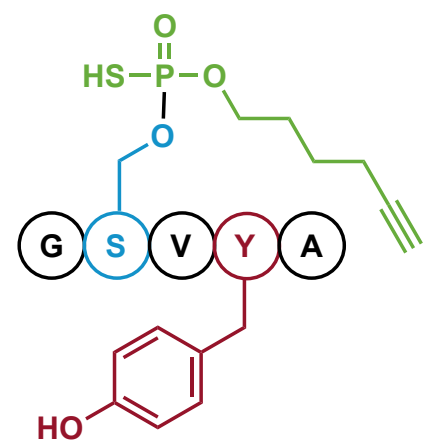

Peptide SI-14 $(2 \mu \mathrm{mol})$ in DMF ( $80 \mu \mathrm{l})$ was taken in a $1.5 \mathrm{ml}$ Eppendorf tube. To this solution, DBU $(6 \mu \mathrm{mol})$ in $\operatorname{DMF}(10 \mu \mathrm{l})$ was added. After mixing the reaction mixture, $\mathbf{P}(\mathbf{V})-\mathbf{2 b}$ reagent $(4 \mu \mathrm{mol})$ in DMF $(10 \mu$, from a freshly prepared stock solution) was added and vortexed at $25{ }^{\circ} \mathrm{C}$. The crude mixture was analyzed by LC-ESI-MS to afford peptide 27 in $40 \%$ conversion.

Retention time: $9.09 \mathrm{~min}$.

$[\mathbf{M}+\mathbf{H}]^{+}\left(\mathbf{E S I}^{+}\right): 728.6$. 
(a)
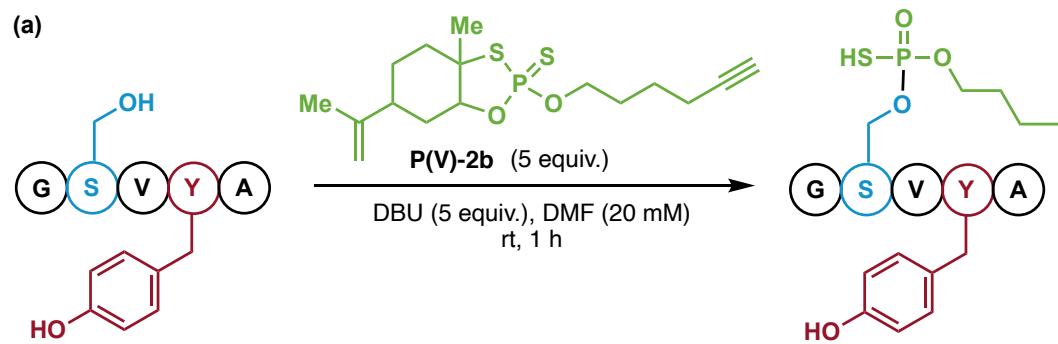

SI-14

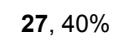

(b)

(b) $\mathrm{SI}-14$

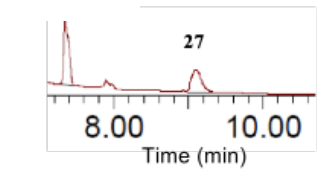

Compound Time $(\mathrm{min}) \quad$ Area $(\%)$

$\begin{array}{lll}\text { SI-14 } & 7.35 & 60.42 \\ 27 & 9.09 & 39.58\end{array}$
SI-14

c)

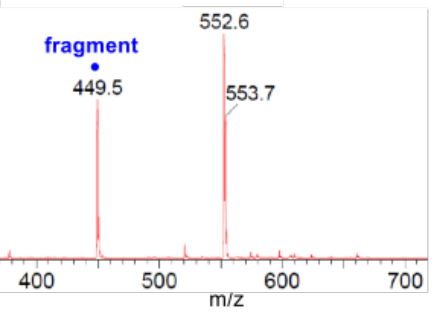

\begin{tabular}{l|l}
$\mid \mathbf{2 7}$ & $\mathbf{2 7}$
\end{tabular}

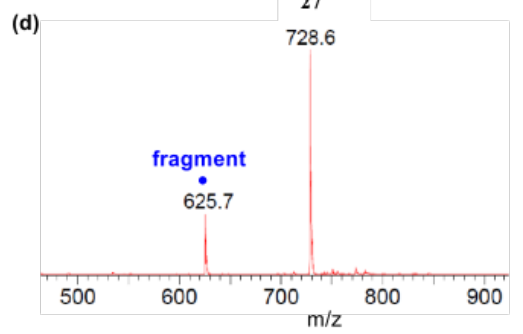

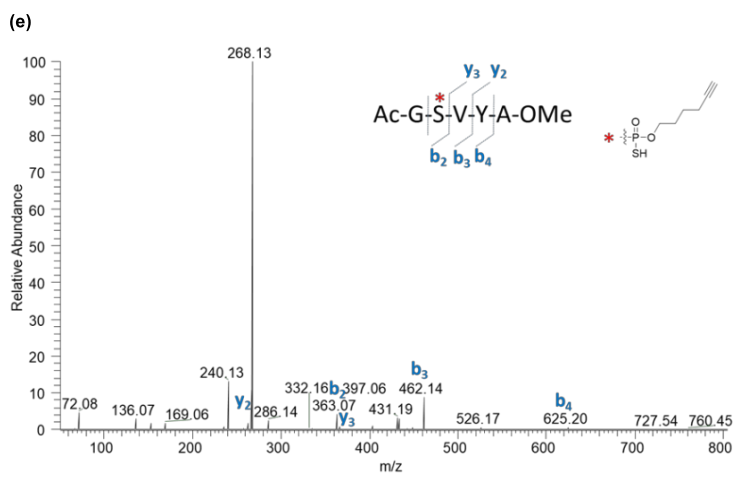

(f)

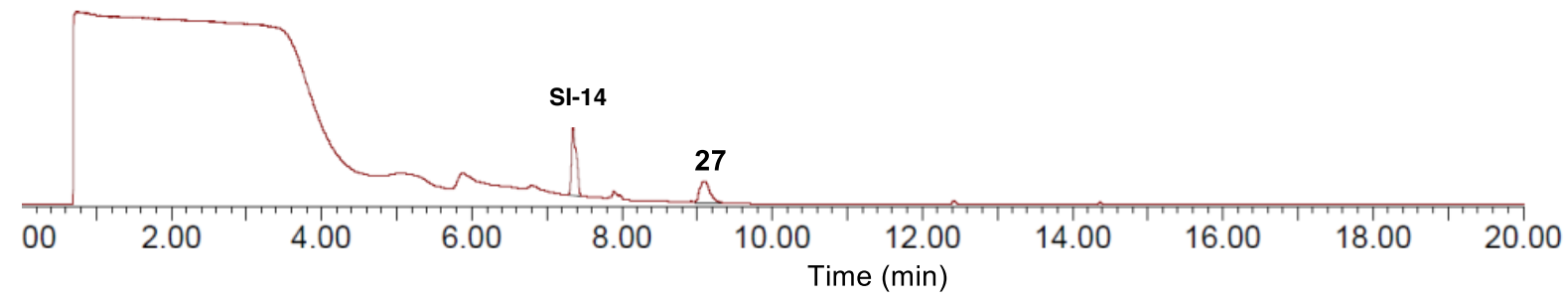

Figure S1. (a) Labeling of peptide SI-14 (Ac-Gly-Ser-Val-Tyr-Ala-OMe) using P(V)-2b reagent. (b) HPLC spectrum for the labeled peptide 27. (c) ESI-MS spectrum for peptide SI-14 (LC peak at $7.35 \mathrm{~min}$ ). (d) ESI-MS spectrum for labeled peptide 27 (LC peak at $9.09 \mathrm{~min}$ ). (e) MS/MS spectrum of labeled peptide 27 (Ac-Gly-Ser*-Val-Tyr-Ala-OMe) confirms the serine labeling. (f) Full HPLC spectrum for the labeled peptide 27. 


\section{Peptide 28}

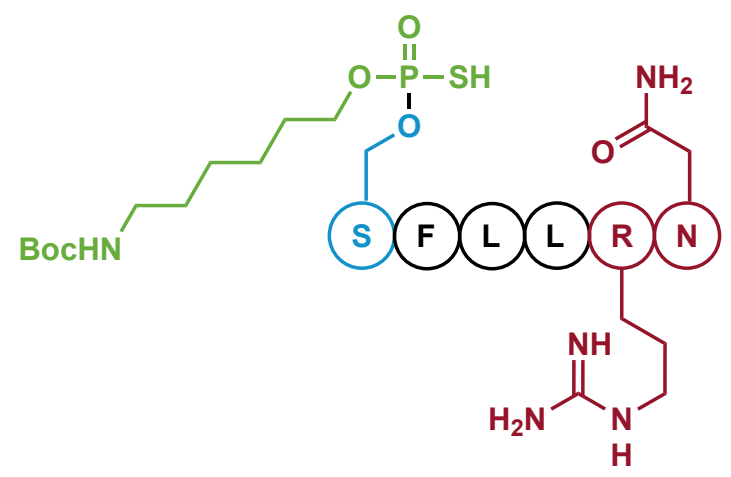

TRAP-6 SI-15 $(0.5 \mu \mathrm{mol})$ in DMF $(15 \mu \mathrm{l})$ was taken in a $0.5 \mathrm{ml}$ Eppendorf tube. To this solution, DBU $(2.5 \mu \mathrm{mol})$ in DMF ( $5 \mu 1$, from a freshly prepared stock solution) was added. After mixing the reaction mixture, $\mathbf{P}(\mathbf{V})-1$ reagent $(2.5 \mu \mathrm{mol})$ in DMF (5 $\mu 1$, from freshly prepared stock solution) was added and vortexed at $25{ }^{\circ} \mathrm{C}$. After $1 \mathrm{~h}$, the crude mixture was analyzed by LC-ESI-MS to afford peptide $\mathbf{2 8}$ in $40 \%$ conversion.

Retention time: $12.80 \mathrm{~min}$.

$[\mathbf{M}+\mathbf{H}]^{+}\left(\mathbf{E S I}^{+}\right): 1044.8$ 

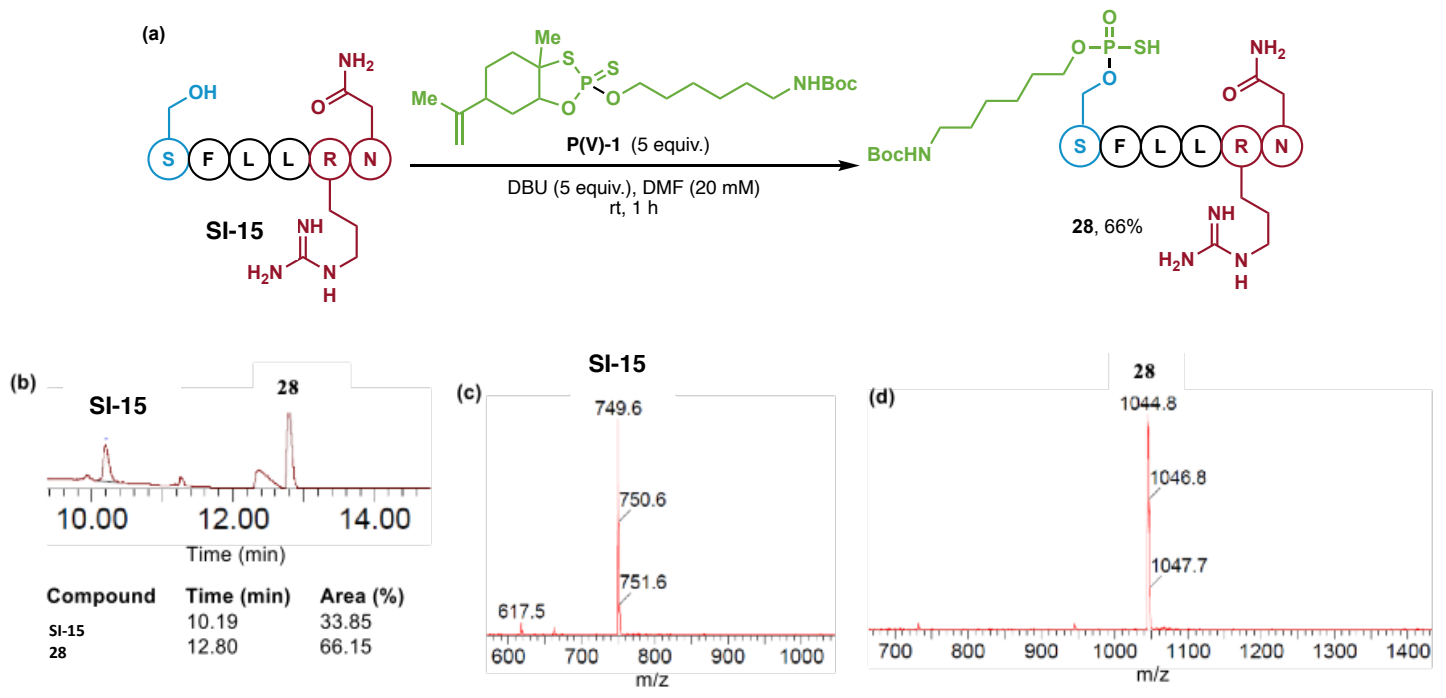

(e)

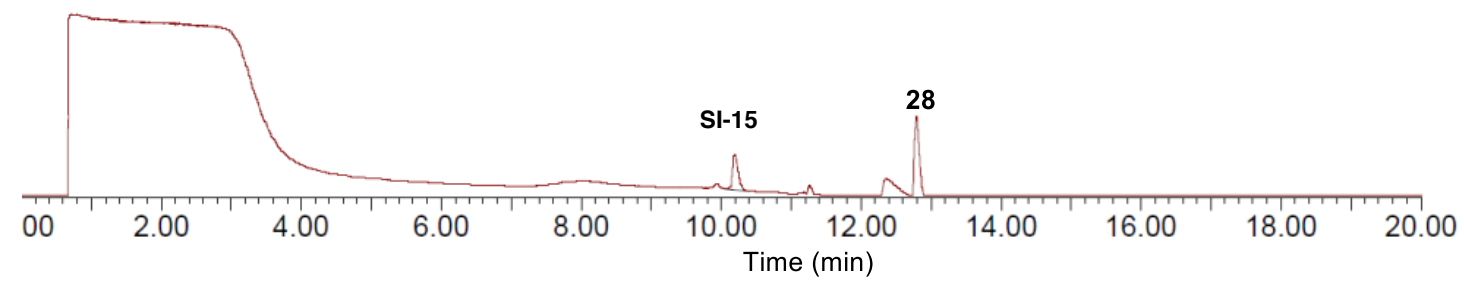

Figure S2. (a) Labeling of TRAP-6 SI-15 using P(V)-1 reagent. (b) HPLC spectrum for the labeled TRAP-6 28. (c) ESI-MS spectrum for TRAP-6 SI-15 (LC peak at $10.19 \mathrm{~min}$ ). (d) ESI-MS spectrum for labeled TRAP-6 28 (LC peak at $12.80 \mathrm{~min}$ ). (e) Full HPLC spectrum for the labeled peptide $\mathbf{2 8 .}$ 


\section{Peptide 29}

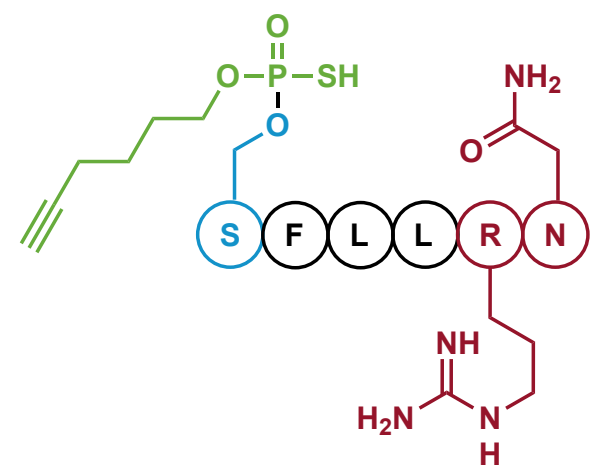

TRAP-6 SI-15 $(0.5 \mu \mathrm{mol})$ in DMF $(15 \mu \mathrm{l})$ was taken in a $0.5 \mathrm{ml}$ Eppendorf tube. To this solution, DBU $(2.5 \mu \mathrm{mol})$ in DMF ( $5 \mu 1$, from a freshly prepared stock solution) was added. After mixing the reaction mixture, $\mathbf{P}(\mathbf{V})-\mathbf{2 b}$ reagent $(2.5 \mu \mathrm{mol})$ in DMF (5 $\mu 1$, from freshly prepared stock solution) was added and vortexed at $25^{\circ} \mathrm{C}$. After $1 \mathrm{~h}$, the crude mixture was analyzed by LC-ESI-MS to afford peptide 29 in $80 \%$ conversion.

Retention time: $11.94 \mathrm{~min}$.

$[\mathbf{M}+\mathbf{H}]^{+}\left(\mathbf{E S I}^{+}\right): 925.7$. 
(a)
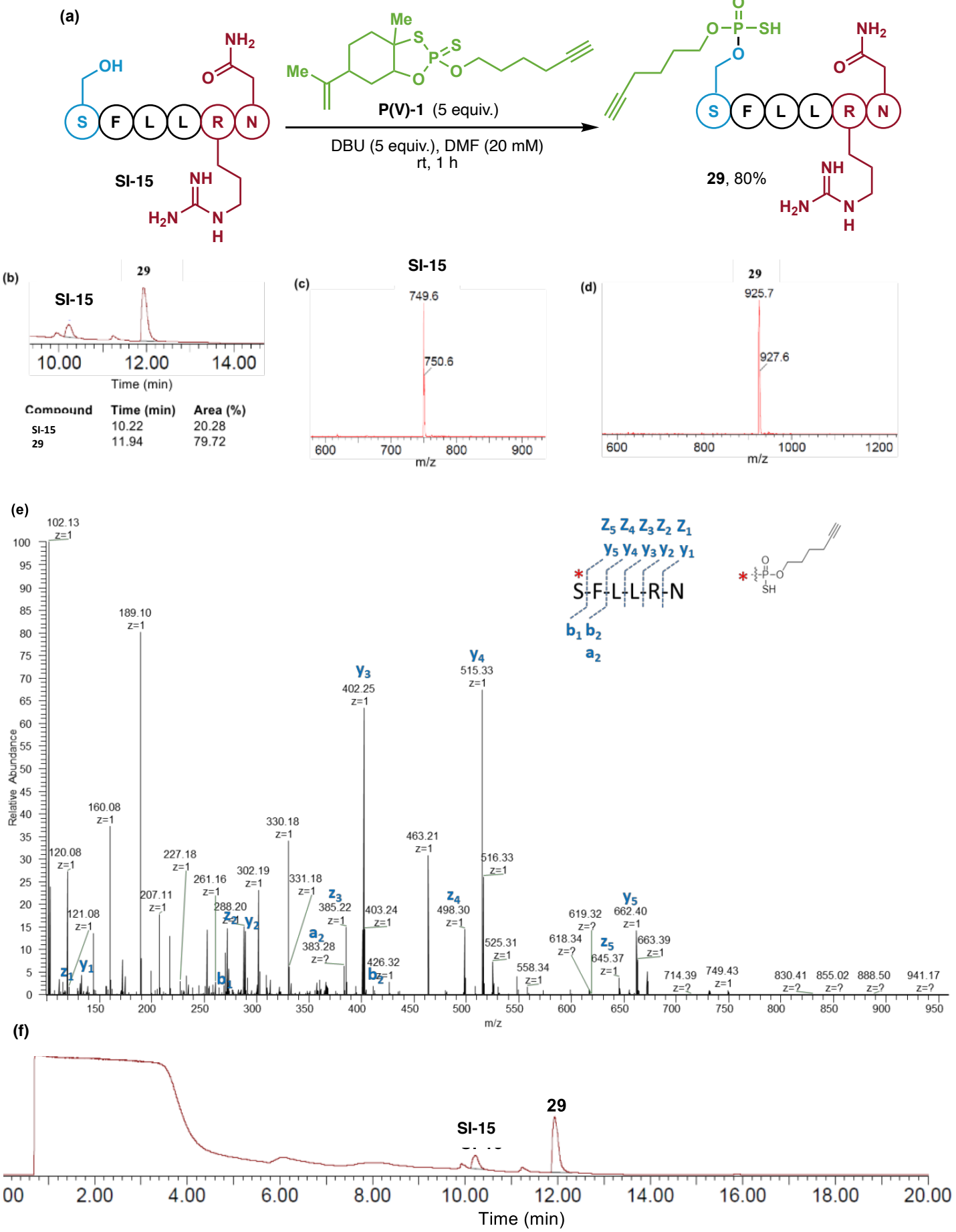

Figure S3. (a) Labeling of TRAP-6 SI-15 (Ser-Phe-Leu-Leu-Arg-Asn) using P(V)-2b reagent. (b) HPLC spectrum for the labeled TRAP-6 29. (c) ESI-MS spectrum for TRAP-6 SI-15 (LC peak at $10.22 \mathrm{~min}$ ). (d) ESI-MS spectrum for labeled TRAP-6 29 (LC peak at $11.94 \mathrm{~min}$ ). (e) MS/MS spectrum of labeled TRAP-6 29 (Ser*-Phe-Leu-Leu-Arg-Asn) confirms the serine labeling. (f) Full HPLC spectrum for the labeled peptide 29. 


\section{Peptide 30}

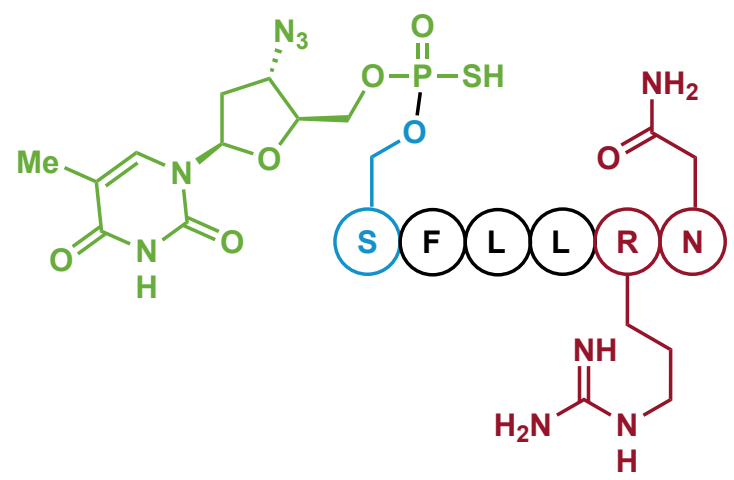

TRAP-6 SI-15 $(0.5 \mu \mathrm{mol})$ in DMF $(15 \mu \mathrm{l})$ was taken in a $0.5 \mathrm{ml}$ Eppendorf tube. To this solution, DBU $(2.5 \mu \mathrm{mol})$ in DMF ( $5 \mu 1$, from a freshly prepared stock solution) was added. After mixing the reaction mixture, $\mathbf{P}(\mathbf{V})-3$ reagent $(2.5 \mu \mathrm{mol})$ in DMF (5 $\mu 1$, from freshly prepared stock solution) was added and vortexed at $25{ }^{\circ} \mathrm{C}$. After $1 \mathrm{~h}$, the crude mixture was analyzed by LC-ESI-MS to afford peptide $\mathbf{3 0}$ in $58 \%$ conversion.

Retention time: $11.61 \mathrm{~min}$.

$[\mathbf{M}+\mathbf{H}]^{+}\left(\mathbf{E S I}^{+}\right): 1094.7$. 

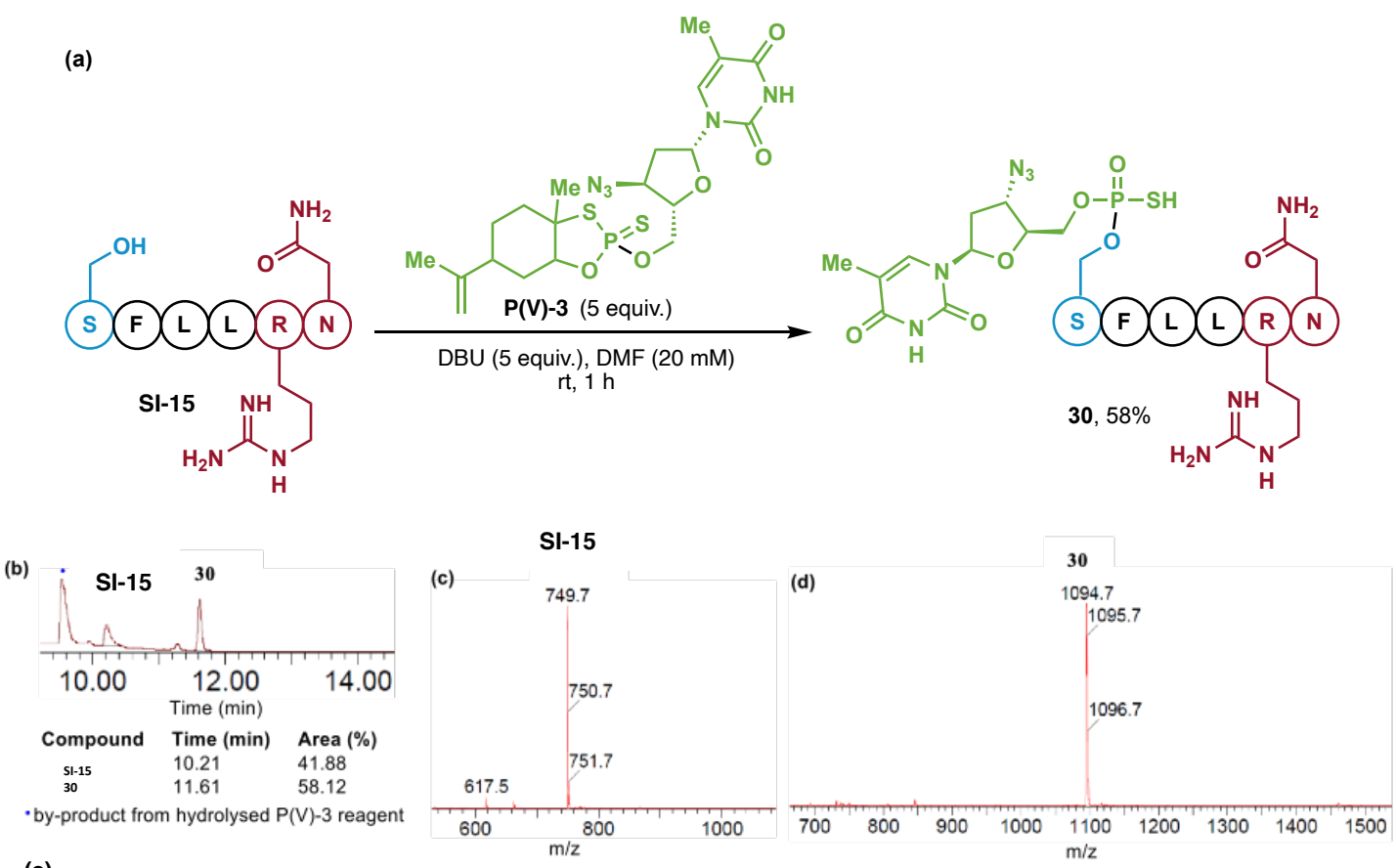

(e)

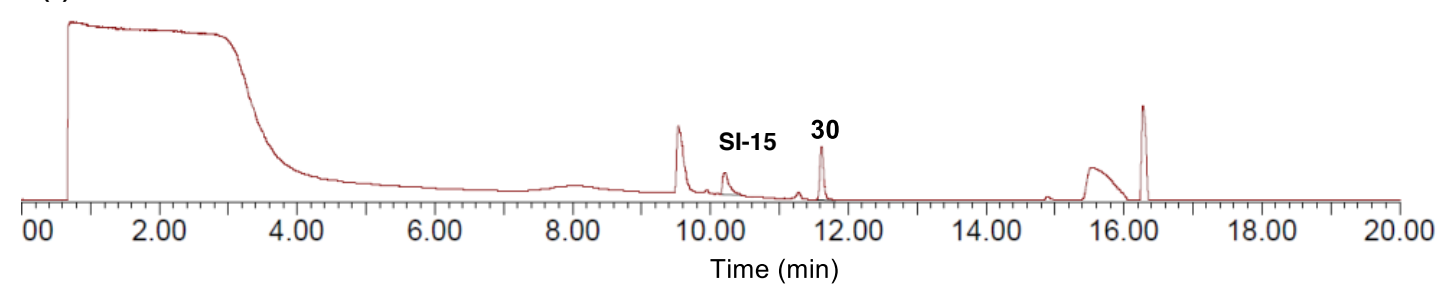

Figure S4. (a) Labeling of TRAP-6 SI-15 using P(V)-3 reagent. (b) HPLC spectrum for the labeled TRAP-6 30. (c) ESI-MS spectrum for TRAP-6 SI-15 (LC peak at $10.21 \mathrm{~min}$ ). (d) ESI-MS spectrum for labeled TRAP-6 30 (LC peak at $11.61 \mathrm{~min}$ ). (e) Full HPLC spectrum for the labeled peptide 30. 


\section{Peptide 31}

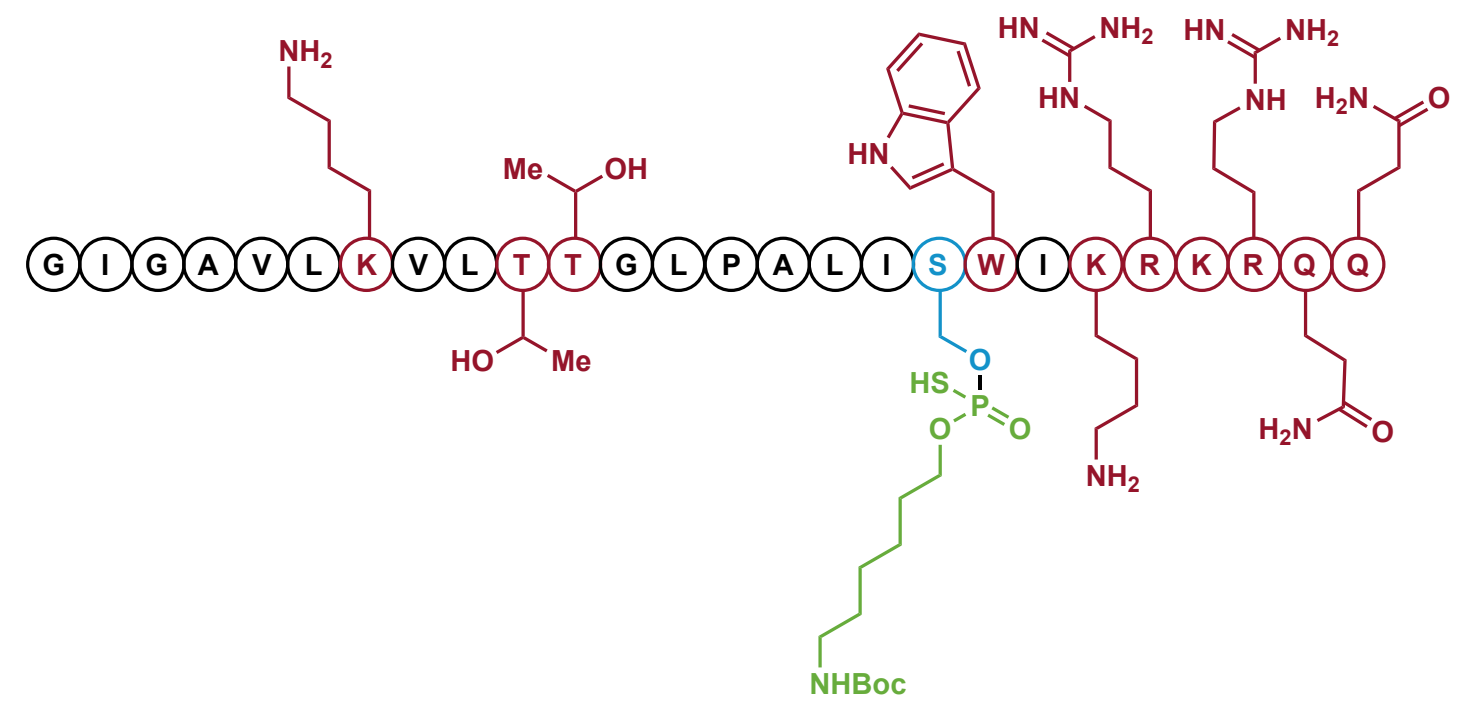

Melittin SI-16 $(0.1 \mu \mathrm{mol})$ in $\mathrm{H}_{2} \mathrm{O}$ :DMF $(10 \mu 1,2: 3)$ was taken in a $0.5 \mathrm{ml}$ Eppendorf tube. To this solution, DBU $(1 \mu \mathrm{mol})$ in DMF $(5 \mu$, from freshly prepared stock solution) was added. After mixing the reaction mixture, $\mathbf{P}(\mathbf{V})-\mathbf{1}$ reagent $(1 \mu \mathrm{mol})$ in DMF ( $5 \mu 1$, from a freshly prepared stock solution) was added and vortexed at $25{ }^{\circ} \mathrm{C}$. After 2-3 h, the crude mixture was analyzed by ESI-MS to afford peptide 31 in $23 \%$ conversion.

$\left[\mathbf{M}+\mathbf{H}^{+}\left(\mathbf{E S I}^{+}\right): 3141\right.$.

(a)

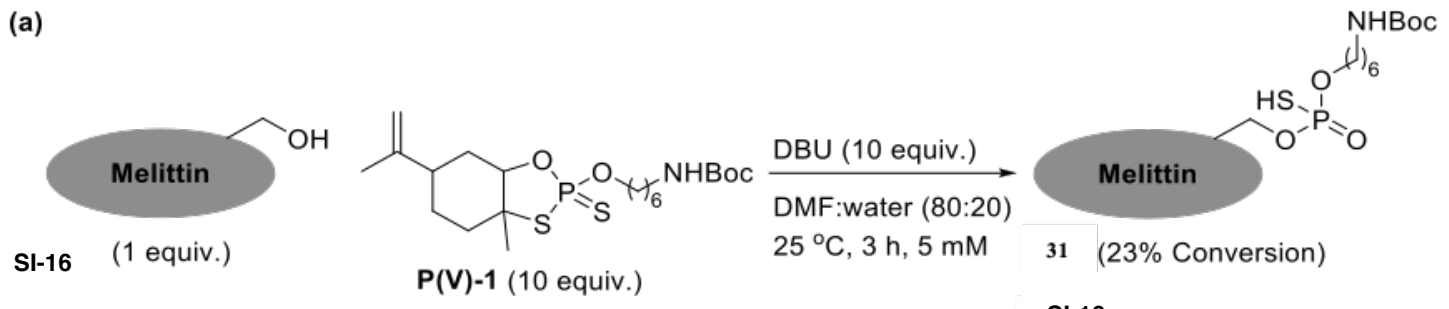

(b)

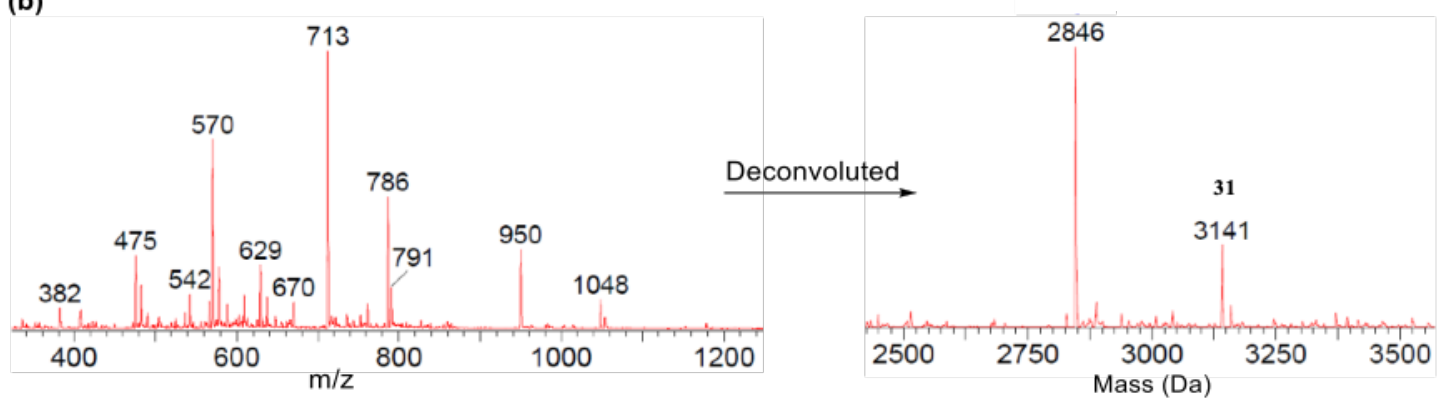

Figure S5. (a) Labeling of melittin SI-16 using P(V)-1 reagent. (b) ESI-MS spectrum for mono-labeled melittin 31. 


\section{Peptide 32}

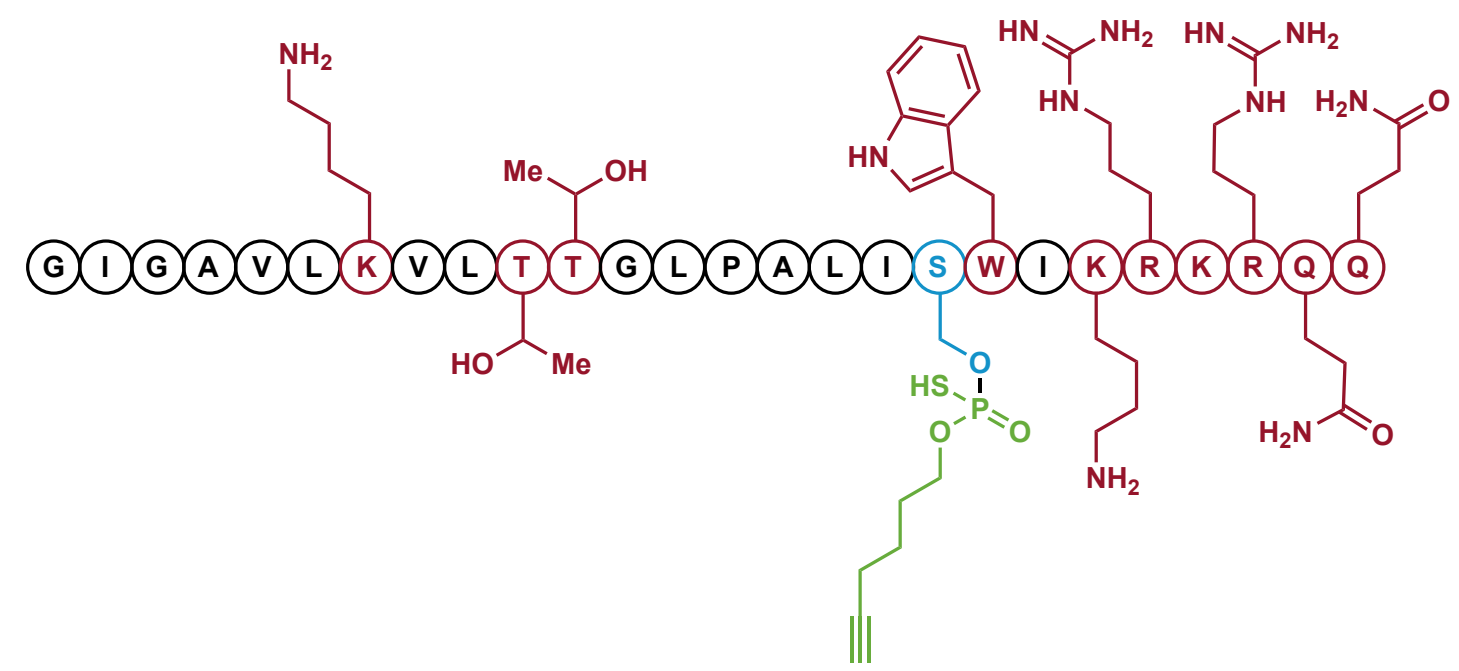

Melittin SI-16 $(0.1 \mu \mathrm{mol})$ in $\mathrm{H}_{2} \mathrm{O}$ :DMF $(10 \mu 1,2: 3)$ was taken in a $0.5 \mathrm{ml}$ Eppendorf tube. To this solution, DBU $(1 \mu \mathrm{mol})$ in DMF $(5 \mu 1$, from freshly prepared stock solution) was added. After mixing the reaction mixture, $\mathbf{P}(\mathbf{V})-\mathbf{2 b}$ reagent $(1 \mu \mathrm{mol})$ in DMF ( $5 \mu 1$, from a freshly prepared stock solution) was added and vortexed at $25{ }^{\circ} \mathrm{C}$. After 2-3 h, the crude mixture was analyzed by ESI-MS to afford peptide 32 in $36 \%$ conversion.

$[\mathbf{M}+\mathbf{H}]^{+}\left(\mathbf{E S I}^{+}\right): 3022$.

(a)

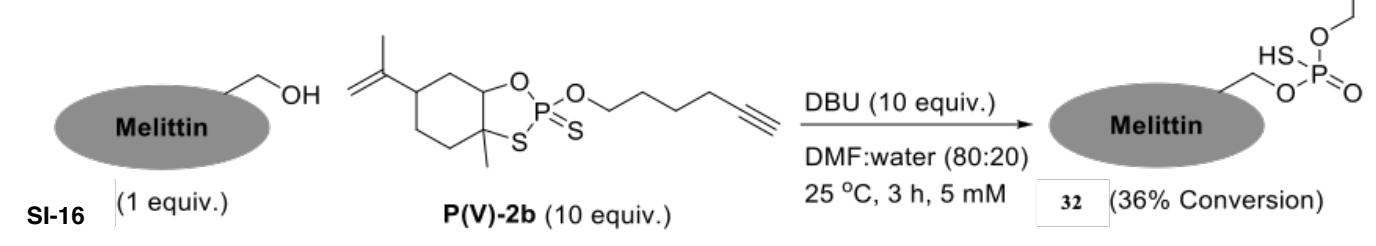

(b)

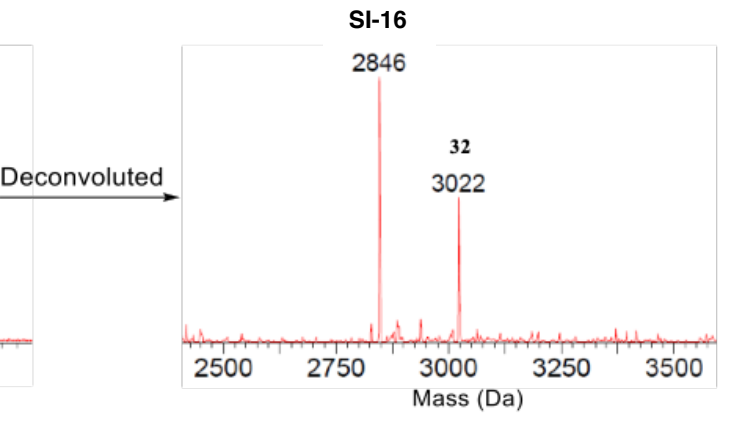




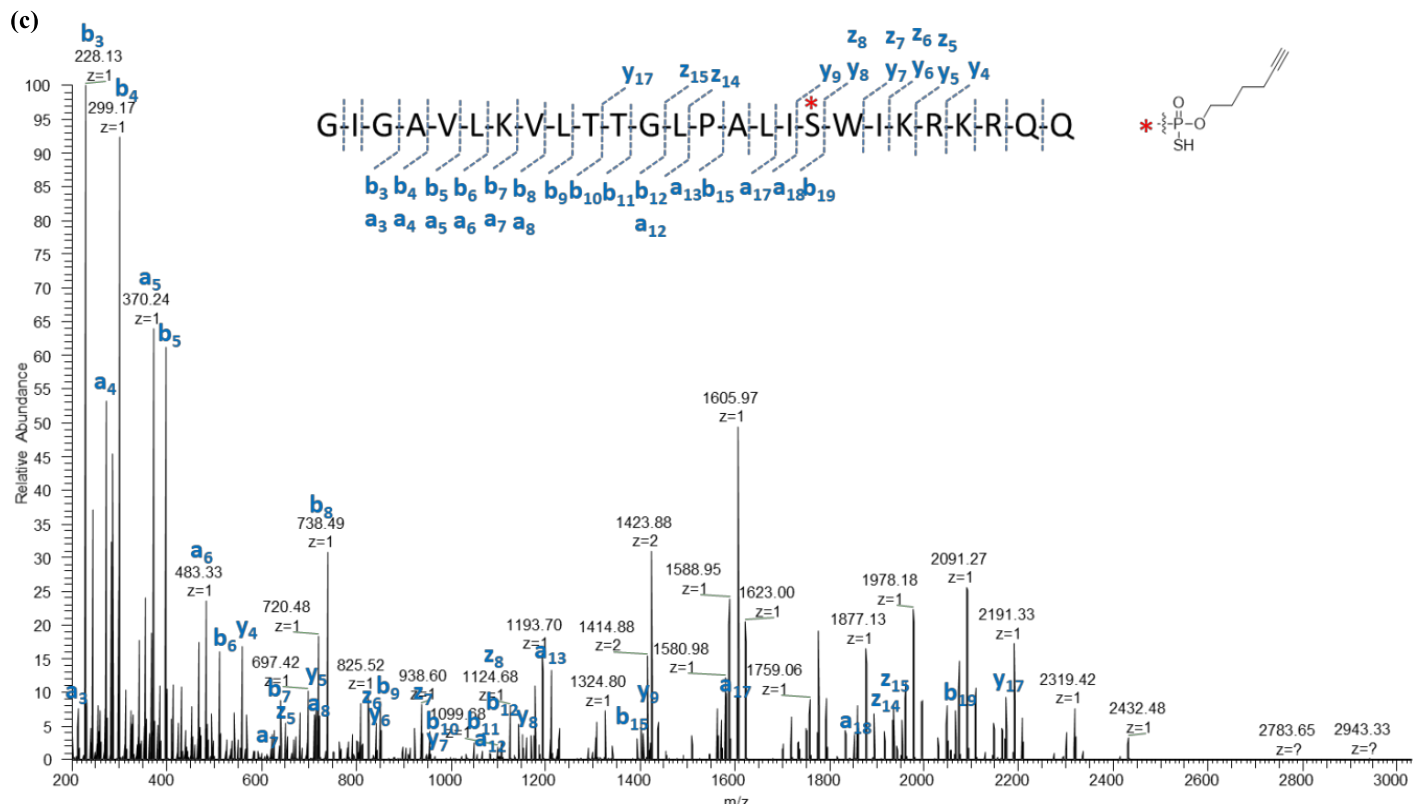

Figure S6. (a) Labeling of melittin SI-16 using P(V)-2b reagent. (b) ESI-MS spectrum for mono-labeled melittin 32. (c) MS/MS spectrum of labeled melittin 32 confirms the serine (S18) labeling. 


\section{Peptide 33}

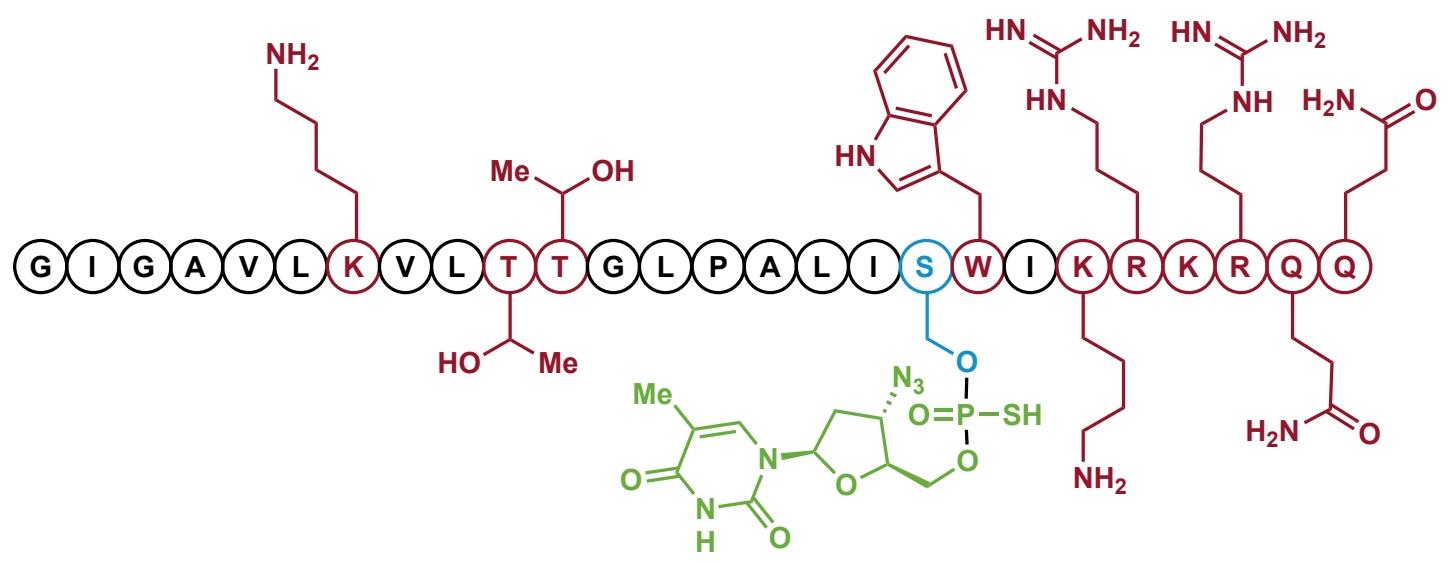

Melittin SI-16 $(0.1 \mu \mathrm{mol})$ in $\mathrm{H}_{2} \mathrm{O}$ :DMF $(10 \mu \mathrm{l}, 2: 3)$ was taken in a $0.5 \mathrm{ml}$ Eppendorf tube. To this solution, DBU $(1 \mu \mathrm{mol})$ in DMF $(5 \mu$, from freshly prepared stock solution) was added. After mixing the reaction mixture, $\mathbf{P}(\mathbf{V})-3$ reagent $(1 \mu \mathrm{mol})$ in DMF ( $5 \mu 1$, from a freshly prepared stock solution) was added and vortexed at $25{ }^{\circ} \mathrm{C}$. After 2-3 h, the crude mixture was analyzed by ESI-MS to afford peptide 33 in $36 \%$ conversion.

$\left[\mathbf{M}+\mathbf{H}^{+}\left(\mathbf{E S I}^{+}\right): 3192\right.$.

(a)

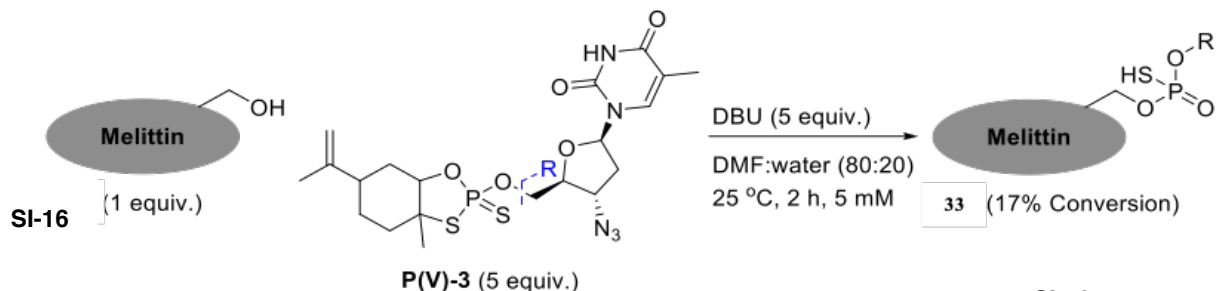

(b)

$\mathbf{P}(\mathbf{V})-3$ (5 equiv.)

SI-16
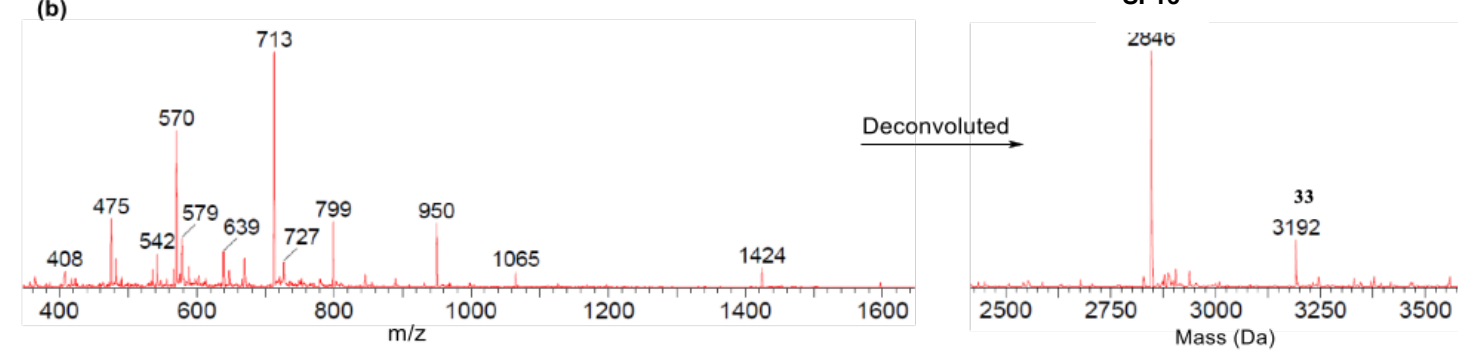

Figure S7. (a) Labeling of melittin SI-16 using P(V)-3 reagent. (b) ESI-MS spectrum for mono-labeled melittin 33. 


\section{Cyclic Peptide Scope}

\section{Starting materials}

\section{Peptide SI-17}

Peptide SI-17 was provided by BMS and was synthesized according to the general procedure reported in the following paper: Kheirabadi, M.; Creech, G. S.; Qiao, J. X.; Nirschl, D. S.; Leahy, D. K.; Boy, K. M.; Carter, P. H.; Eastgate, M. D. Leveraging a "catch-Release" Logic Gate Process for the Synthesis and Nonchromatographic Purification of Thioether- or Amine-Bridged Macrocyclic Peptides. J. Org. Chem. 2018, $83,4323$.

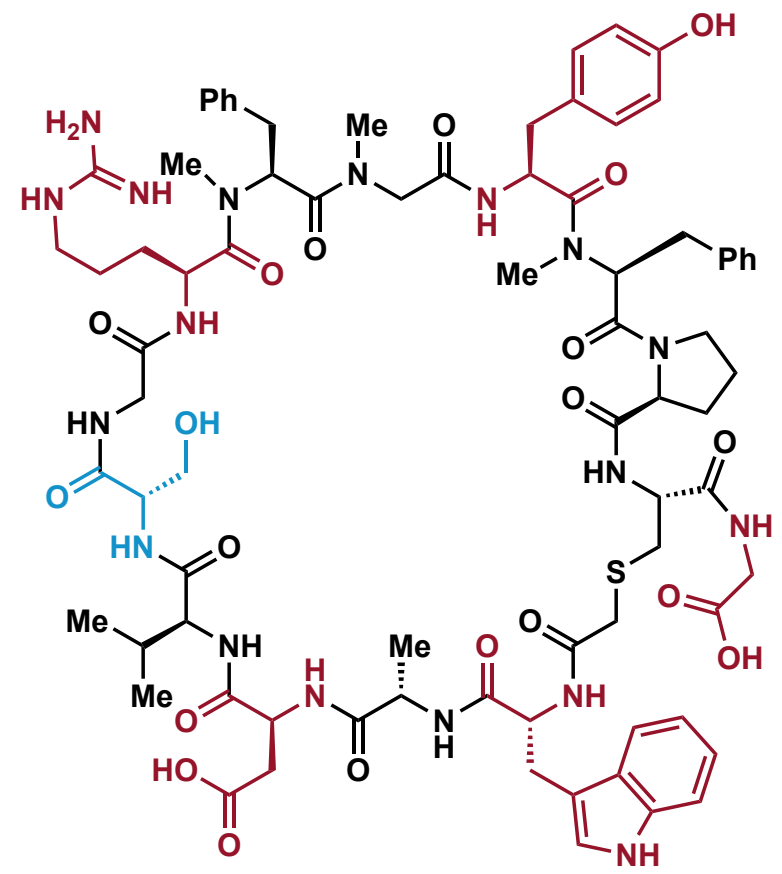

$[\mathbf{M}+\mathbf{2 H}] / \mathbf{2}^{+}\left(\mathbf{E S I}^{+}\right): 823$.

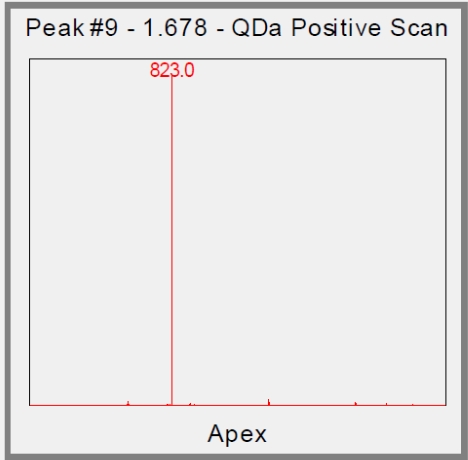

ESI ${ }^{+}$trace peptide SI-17 


\section{Peptide SI-18 (oxytocin derivative)}

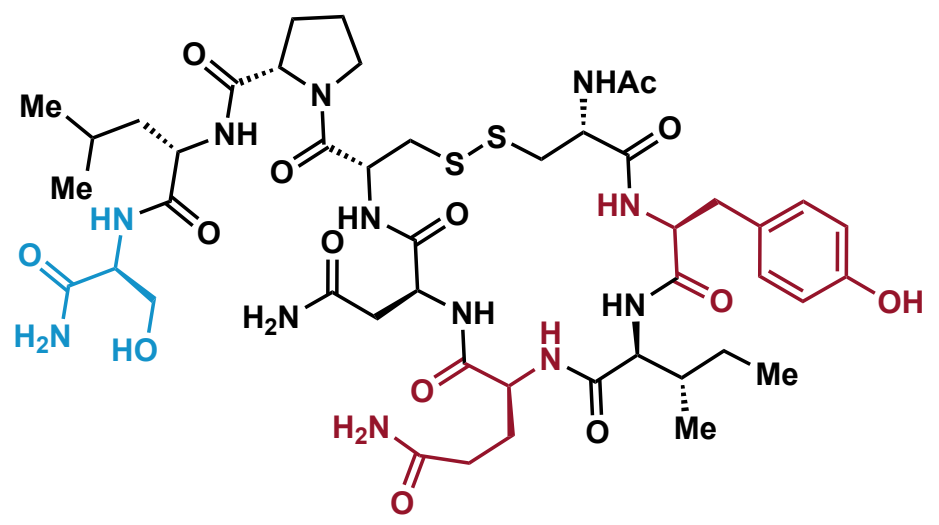

Peptide SI-18 was chain assembled on polystyrene rink amide resin following the standard SPPS protocol. The $N$-terminal residue was acylated with $\mathrm{Ac}_{2} \mathrm{O}$ in $\mathrm{DMF}$ (20\%, twice for 2 minutes) and the resin was solvent exchanged into DCM. Oxidative deprotection and disulfide formation was performed with $\mathrm{I}_{2}(5 \mathrm{eq})$ in $20 \% \mathrm{MeOH}$ in DCM (20 minutes). The reaction was quenched by washing the resin with saturated sodium ascorbate in DMF until the resin returned to its original color (60 seconds). The resin was washed with DMF and DCM and cleaved as previously described. $[\mathbf{M}+\mathbf{H}]^{+}\left(\mathbf{E S I}^{+}\right): 1079.6$.

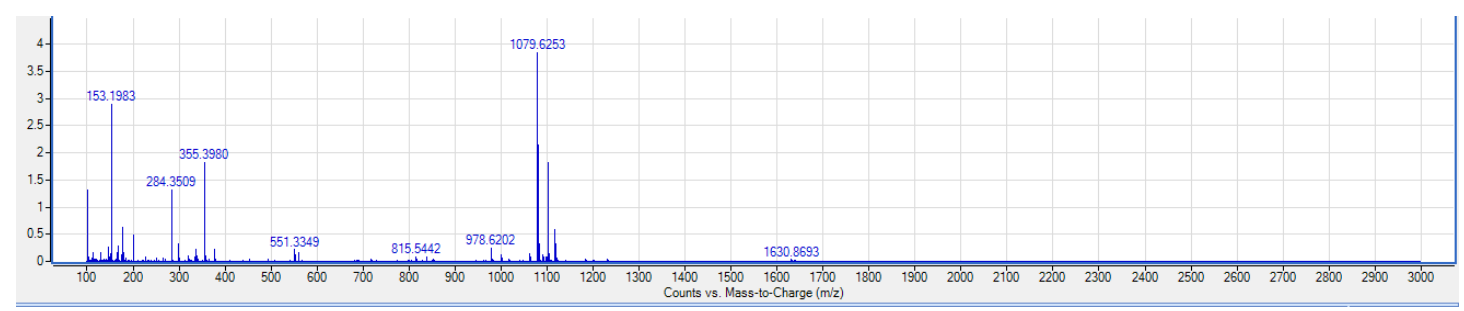

ESI $^{+}$trace peptide SI-18 


\section{Peptide SI-19 (vancomycin)}

This peptide was bought from Chem-Impex (Cat\# 00315) as the $\mathrm{HCl}$ salt.

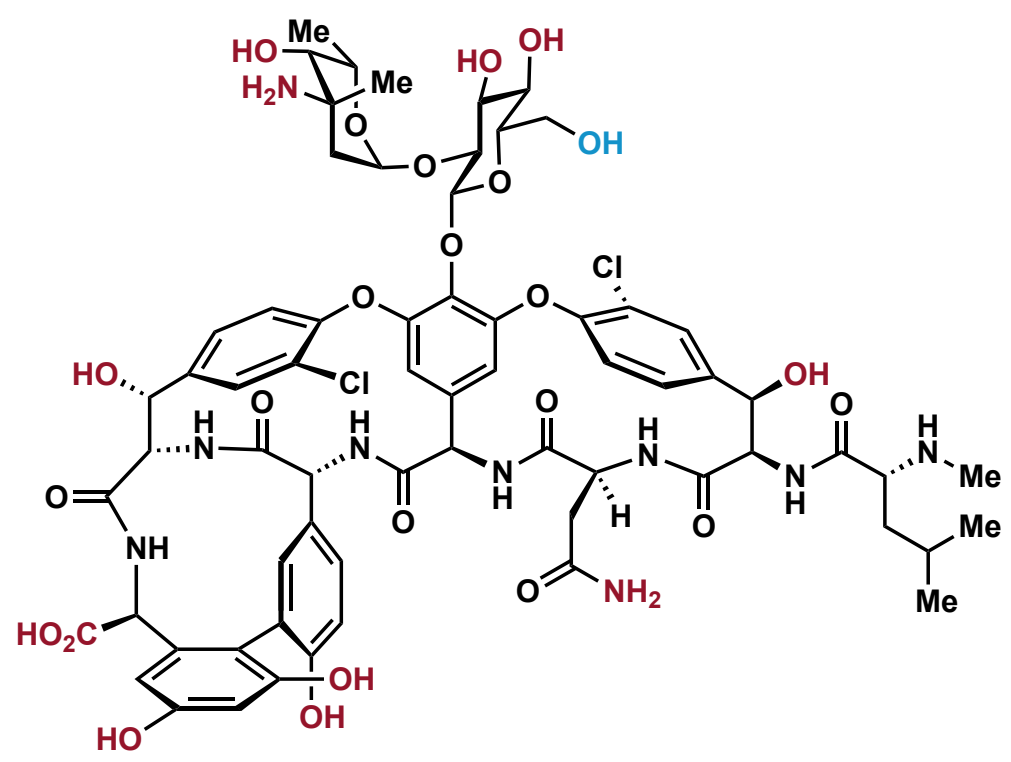

$[\mathbf{M}+\mathbf{H}]^{+}\left(\mathbf{E S I}^{+}\right): 1450.4$

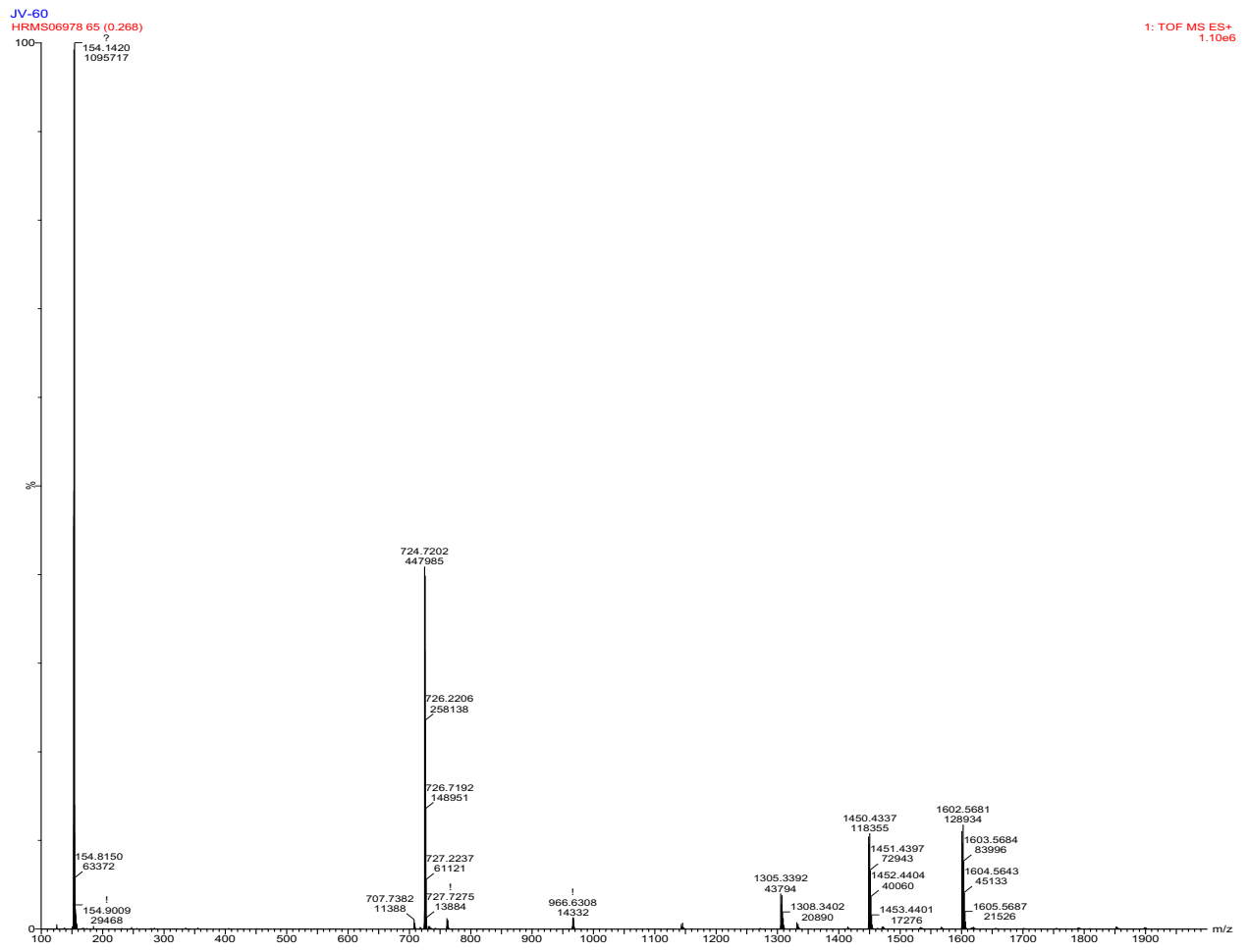

ESI ${ }^{+}$trace peptide SI-19 


\section{Cyclic Peptides Functionalization}

\section{Peptide 34}

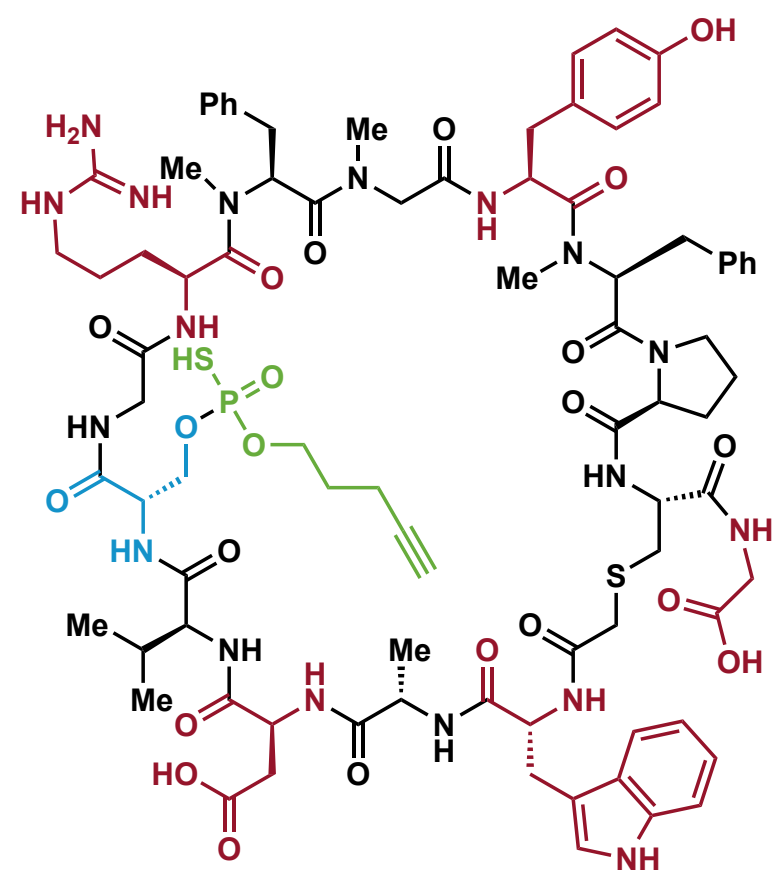

Cyclic peptide SI-17 (100 $\mu \mathrm{L}$ of a $20 \mathrm{mM}$ solution in DMF, 1.0 equiv) and $\mathbf{P ( V ) - 2 a}$ (100 $\mu \mathrm{L}$ of a $100 \mathrm{mM}$ solution in DMF, 5.0 equiv) were added to a $3 \mathrm{~mL} \mathrm{HPLC}$ vial. DBU (10.0 equiv) was added to the reaction mixture at room temperature while stirring. After 5-10 minutes, the crude reaction mixture was purified by HPLC (method Narrow 4) to afford the desired product 34 in 61\% isolated yield.

${ }^{1}$ H NMR (500 MHz, DMSO-d $)$ ): $\delta 10.79$ (s, 1H), 9.44 - $9.05(\mathrm{~m}, 1 \mathrm{H}), 8.50$ - 7.65 (m, $10 \mathrm{H}), 7.56(\mathrm{t}, J=9.2 \mathrm{~Hz}, 1 \mathrm{H}), 7.46-6.70(\mathrm{~m}, 20 \mathrm{H}), 6.69-6.45(\mathrm{~m}, 2 \mathrm{H}), 5.53-4.92$ (m, 1H), $4.92-4.77(\mathrm{~m}, 1 \mathrm{H}), 4.75-4.49(\mathrm{~m}, 3 \mathrm{H}), 4.45(\mathrm{~d}, J=4.7 \mathrm{~Hz}, 1 \mathrm{H}), 4.42-$ $4.09(\mathrm{~m}, 6 \mathrm{H}), 4.08-3.96(\mathrm{~m}, 1 \mathrm{H}), 3.93(\mathrm{dd}, J=10.5,2.6 \mathrm{~Hz}, 1 \mathrm{H}), 3.90-3.81(\mathrm{~m}$, $1 \mathrm{H}), 3.81-3.73(\mathrm{~m}, 3 \mathrm{H}), 3.71(\mathrm{dd}, J=10.6,3.7 \mathrm{~Hz}, 1 \mathrm{H}), 3.67-3.47(\mathrm{~m}, 1 \mathrm{H}), 3.45-$ $3.41(\mathrm{~m}, 2 \mathrm{H}), 3.21-2.60(\mathrm{~m}, 27 \mathrm{H}), 2.19(\mathrm{qd}, J=6.9,2.6 \mathrm{~Hz}, 2 \mathrm{H}), 2.12-1.74(\mathrm{~m}$, 5H), $1.74-1.54(\mathrm{~m}, 4 \mathrm{H}), 1.35(\mathrm{~d}, J=105.2 \mathrm{~Hz}, 4 \mathrm{H}), 1.15-0.96(\mathrm{~m}, 3 \mathrm{H}), 0.98-0.63$ $(\mathrm{m}, 6 \mathrm{H})$

${ }^{31}$ P NMR (202 MHz, DMSO-d $\left.{ }_{6}\right): \delta 56.0$.

ESI-HRMS: Calcd for $\mathrm{C}_{83} \mathrm{H}_{111} \mathrm{~N}_{18} \mathrm{O}_{22} \mathrm{PS}_{2}\left([\mathrm{M}+2 \mathrm{H}]^{2+}\right) / 2=903.3644$, found 903.3666, mass difference $2.4 \mathrm{ppm}$. 


\section{HPLC Conversion:}

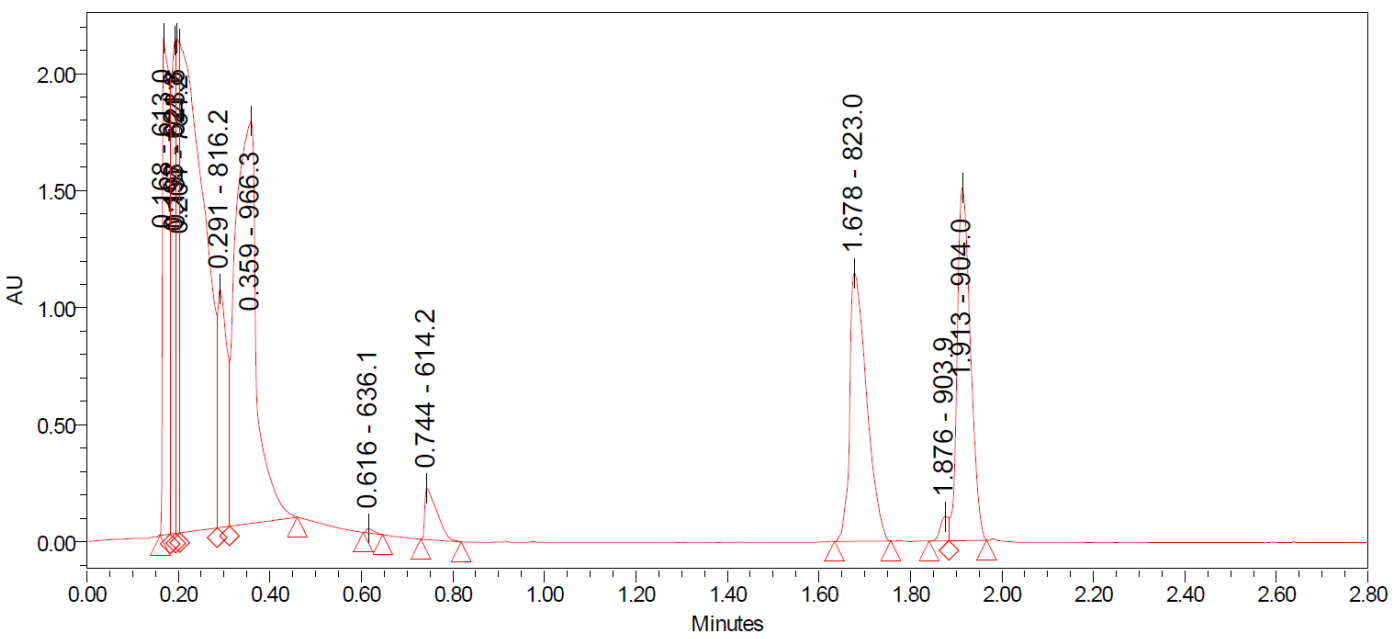

HPLC trace Peptide 34 (Crude)

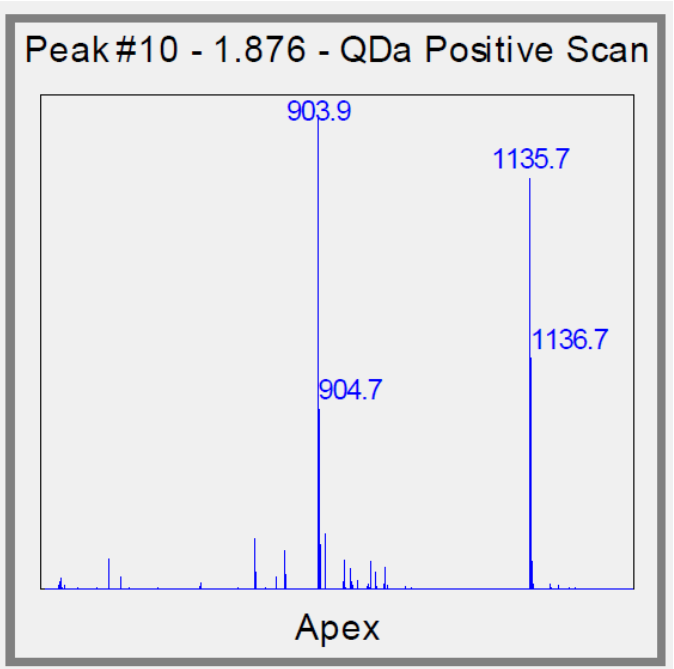

ESI-MS Peptide 34 (Crude) 


\section{HPLC purity:}

The purity of the compounds was checked using the following two HPLC conditions: Method A: A linear gradient using solvent A (5\% acetonitrile, 95\% water, 0.05\% TFA) and solvent B (95\% acetonitrile, $5 \%$ water, $0.05 \%$ TFA); $10-100 \%$ of solvent B over $10 \mathrm{~min}$ and then $100 \%$ of solvent B over 5 min. Column: Sunfire C18 $3.5 \mu \mathrm{m}(3.0 \mathrm{x}$ $150 \mathrm{~mm}$ ). Flow rate was $0.5 \mathrm{ml} / \mathrm{min}$, and UV detection was set to 220 and $254 \mathrm{~nm}$. The LC column was maintained at room temperature.

Method B: A linear gradient using solvent A (5\% acetonitrile, 95\% water, $0.05 \%$ TFA) and solvent B (95\% acetonitrile, 5\% water, $0.05 \%$ TFA); $10-100 \%$ of solvent B over 10 min and then $100 \%$ of solvent B over 5 min. Column: Xbridge Phenyl $3.5 \mu \mathrm{m}$ (3.0 x $150 \mathrm{~mm}$ ). Flow rate was $0.5 \mathrm{ml} / \mathrm{min}$, and UV detection was set to 220 and 254 $\mathrm{nm}$. The LC column was maintained at room temperature.

MS-ESI: $\left([\mathrm{M}+2 \mathrm{H}]^{2+}\right) / 2=903.1(98.3 \%)$, retention time $=1.33 \min ($ Method A); MS-ESI: $[\mathrm{M}+\mathrm{H}]^{+}=1806.5,(99.1 \%)$, retention time $=1.50 \min ($ Method B).

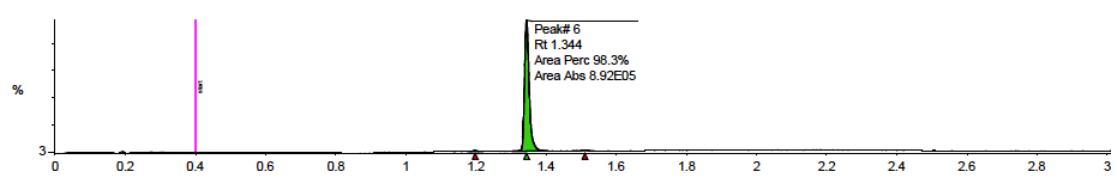

HPLC trace Peptide 34 (Method A)

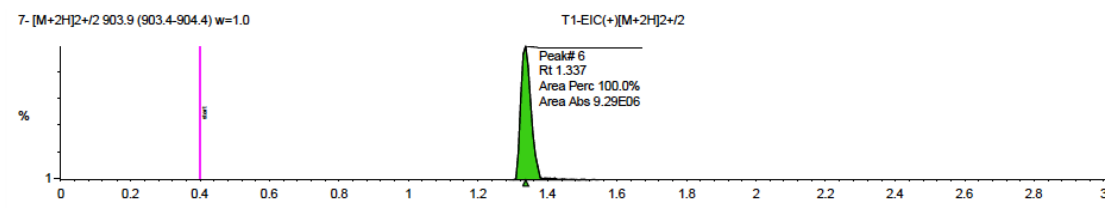

ESI-MS trace Peptide 34 (Method A)

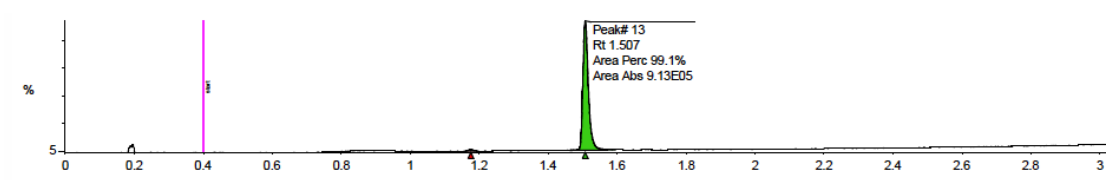

HPLC trace Peptide 34 (Method B)

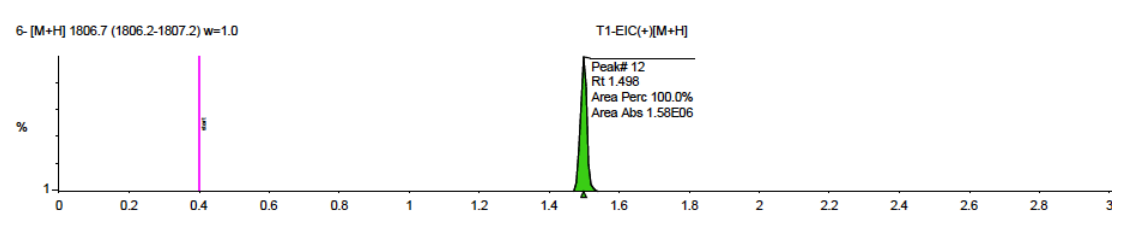

ESI-MS trace Peptide 34 (Method B) 


\section{Peptide 35}

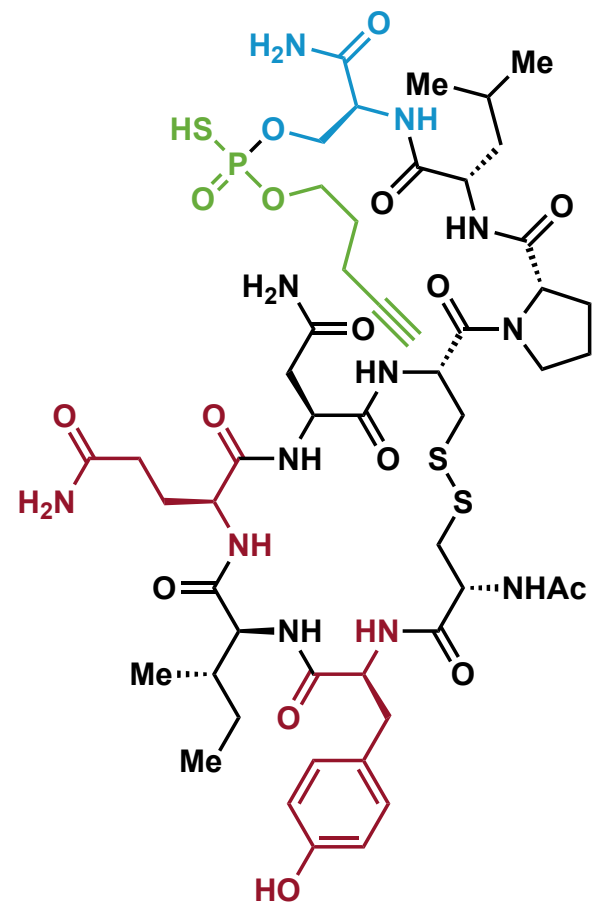

Cyclic peptide SI-18 (100 $\mu \mathrm{L}$ of a $20 \mathrm{mM}$ solution in DMF, 1.0 equiv) and $\mathbf{P ( V ) - 2 a}$ (100 $\mu \mathrm{L}$ of a $200 \mathrm{mM}$ solution in DMF, 10.0 equiv) were added to a $3 \mathrm{~mL}$ HPLC vial. DBU (10.0 equiv) was added to the reaction mixture at room temperature while stirring. After 5-10 minutes, the crude reaction mixture was purified by HPLC (method Narrow 2) to afford the desired product 35 in $42 \%$ isolated yield (1.04 $\mathrm{mg}$ ).

${ }^{31}$ P NMR (202 MHz, DMSO- $\left.d_{6}\right): \delta 58.1$.

${ }^{31}$ P NMR H-coupled (202 MHz, DMSO- $\left.\boldsymbol{d}_{6}\right): \delta 58.1(\mathrm{t}, J=10.9 \mathrm{~Hz})$.

Retention time LCMS: $3.25 \mathrm{~min}$.

Retention time HPLC: $4.11 \mathrm{~min}$.

$[\mathbf{M}+]^{+}\left(\mathbf{E S I}^{+}\right): 1241.6$.

ESI-HRMS: Calcd for $\mathrm{C}_{51} \mathrm{H}_{78} \mathrm{~N}_{12} \mathrm{O}_{16} \mathrm{PS}_{3}[\mathrm{M}+\mathrm{H}]^{+}=1241.4558$, found 1241.4560. 

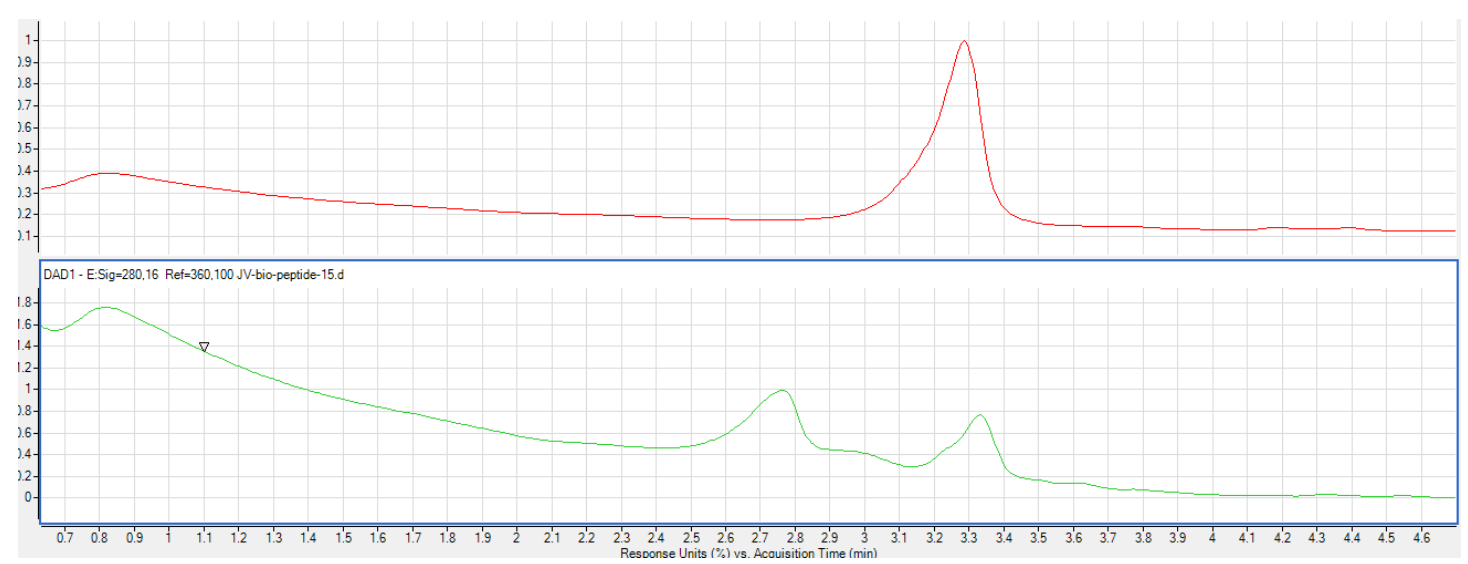

LCMS trace Peptide 35 (top: purified, bottom: crude)

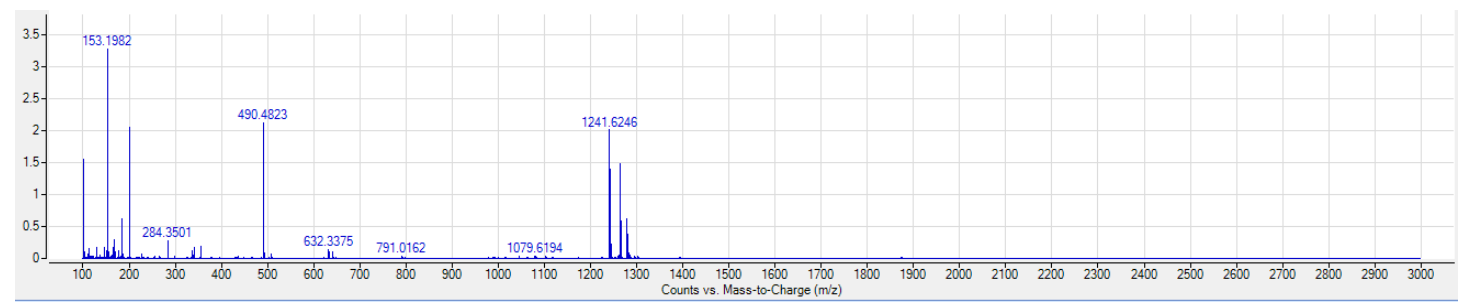

ESI-MS trace Peptide 35

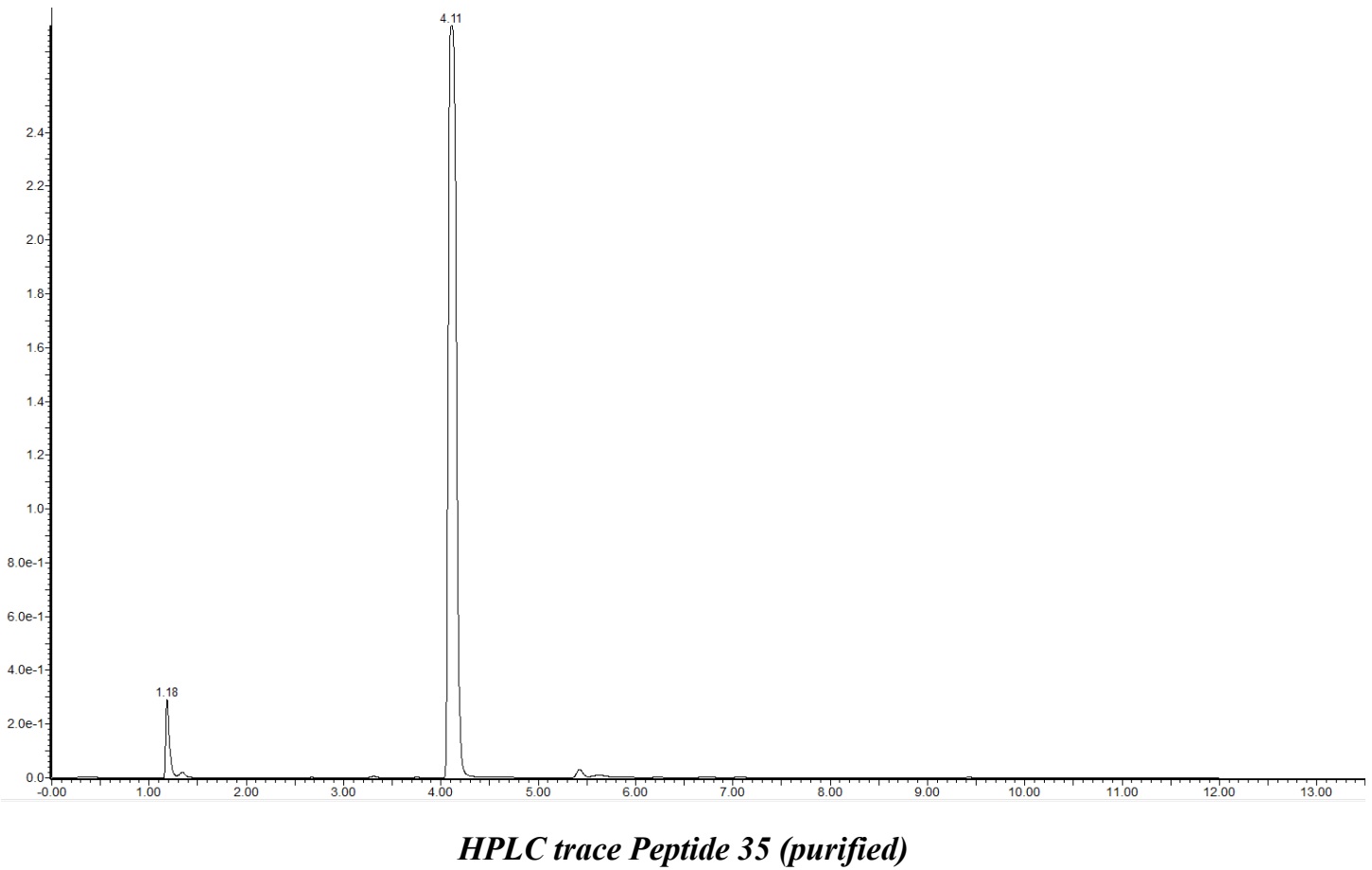




\section{Peptide 36}

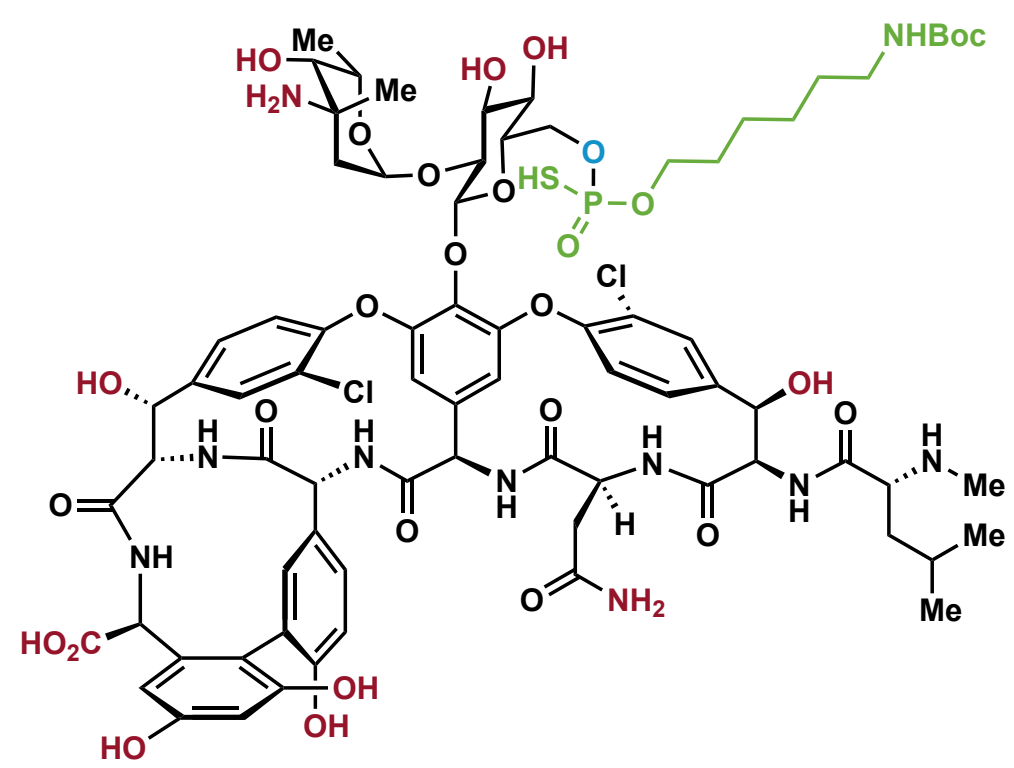

Cyclic peptide SI-19 (100 $\mu \mathrm{L}$ of a $20 \mathrm{mM}$ solution in DMF, 1.0 equiv) and $\mathbf{P ( V ) - 1}$ (100 $\mu \mathrm{L}$ of a $80 \mathrm{mM}$ solution in DMF, 4.0 equiv) were added to a $3 \mathrm{~mL}$ HPLC vial. DBU (5.0 equiv) was added to the reaction mixture at room temperature while stirring. After 5-10 minutes, the crude reaction mixture was purified by HPLC (method Narrow 1) to afford the desired product 36 in $19 \%$ isolated yield $(0.66 \mathrm{mg})$.

${ }^{31}$ P NMR (202 MHz, DMSO-d $): \delta 59.1$.

${ }^{31}$ P NMR H-coupled (202 MHz, DMSO-d $\mathbf{d}_{\text {): }} \delta 59.1(\mathrm{t}, J=10.8 \mathrm{~Hz})$.

Retention time: 3.54 min.

$[\mathbf{M}+\mathbf{H}]^{+}\left(\mathbf{E S I}^{+}\right): 1745.4$.

ESI-HRMS: Calcd for $\mathrm{C}_{79} \mathrm{H}_{102} \mathrm{Cl}_{2} \mathrm{~N}_{10} \mathrm{O}_{28} \mathrm{PS}[\mathrm{M}+\mathrm{H}]^{+}=1745.5400$, found 1745.5400 . 


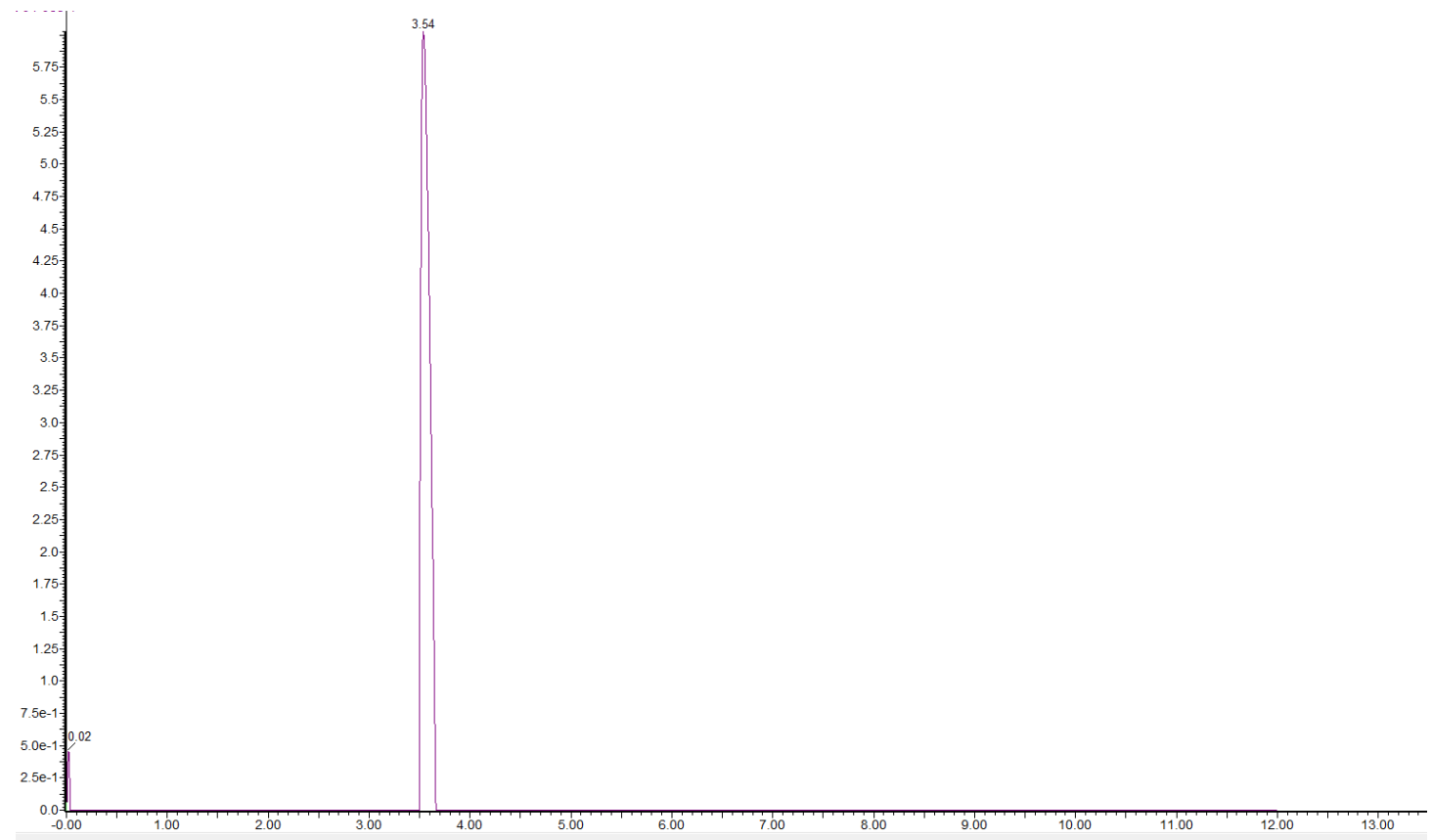

HPLC trace Peptide 36 (purified)

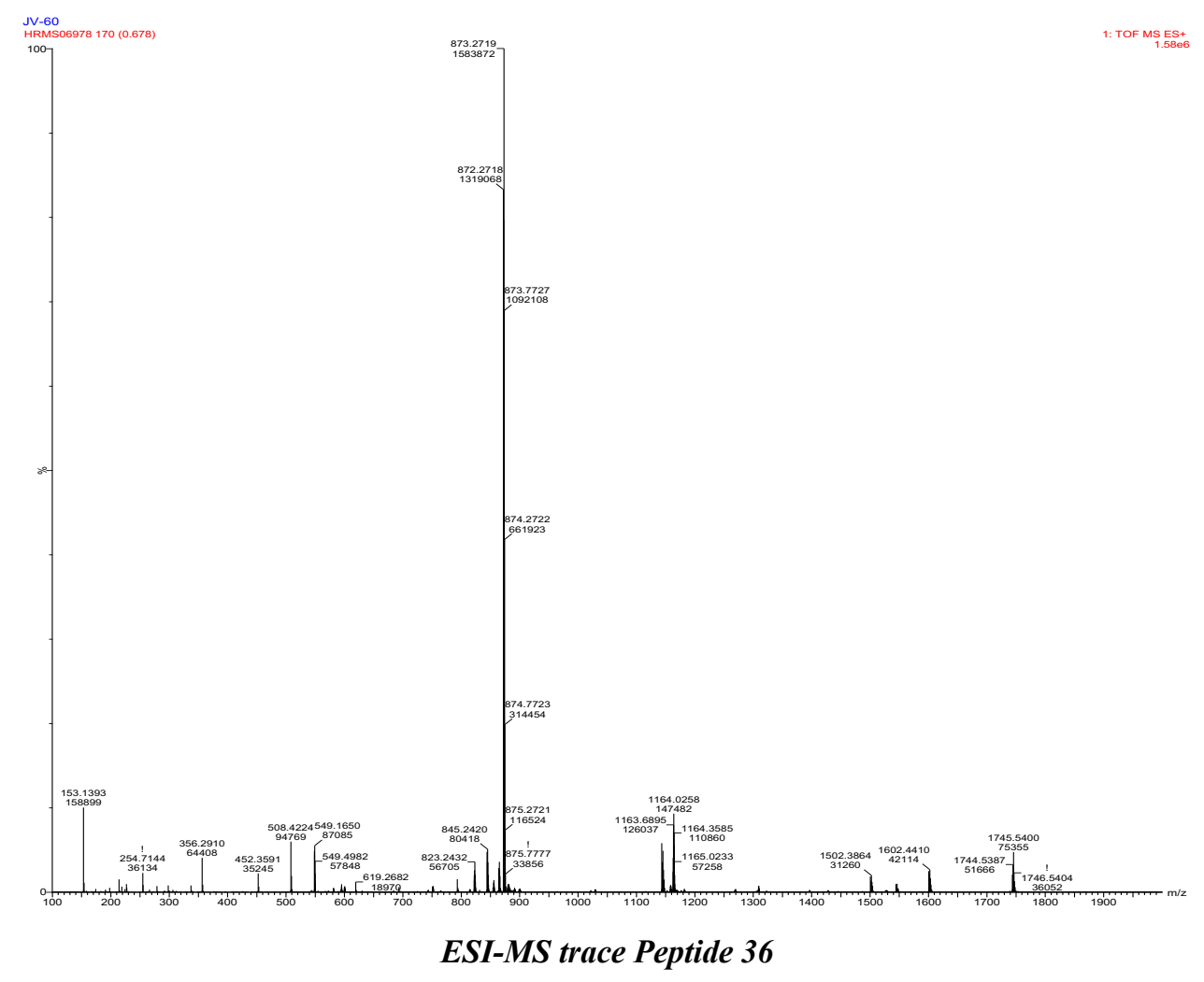




\section{Peptide 37}

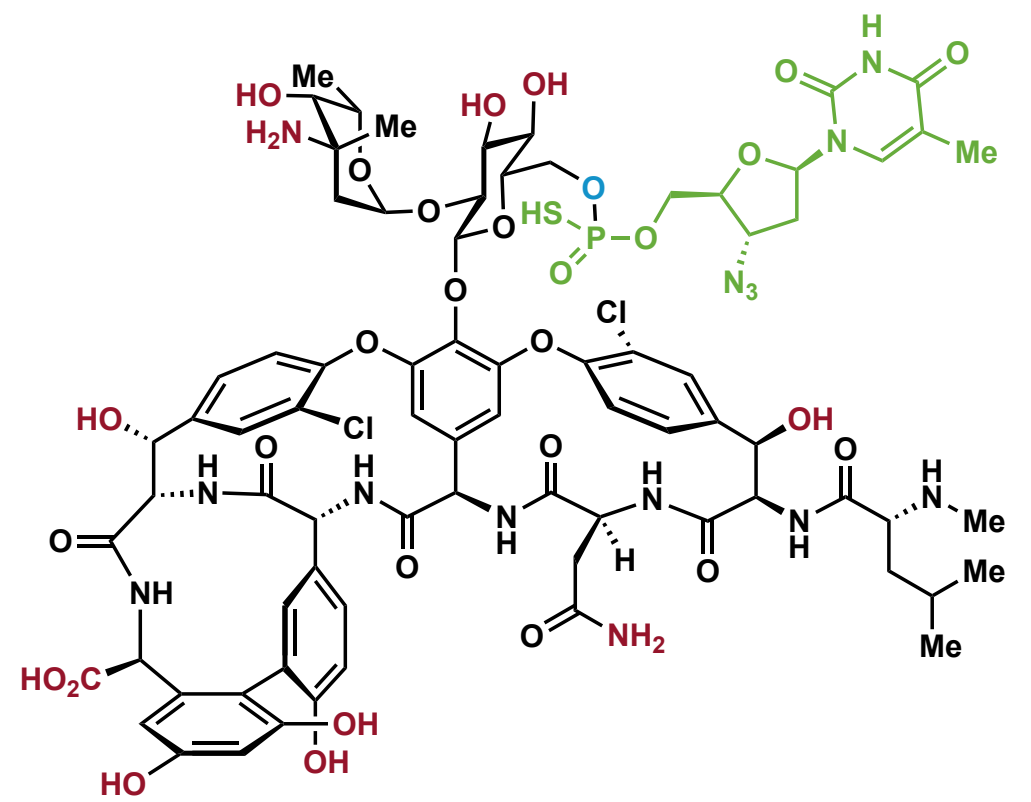

Cyclic peptide SI-19 (100 $\mu \mathrm{L}$ of a $20 \mathrm{mM}$ solution in DMF, 1.0 equiv) and $\mathbf{P}(\mathbf{V})-3$ (100 $\mu \mathrm{L}$ of a $80 \mathrm{mM}$ solution in DMF, 4.0 equiv) were added to a $3 \mathrm{~mL}$ HPLC vial. DBU (5.0 equiv) was added to the reaction mixture at room temperature while stirring. After 5-10 minutes, the crude reaction mixture was purified by HPLC (method Narrow 0$)$ to afford the desired product 37 in $21 \%$ isolated yield $(0.75 \mathrm{mg})$.

${ }^{31}$ P NMR (202 MHz, DMSO- $\left.\boldsymbol{d}_{6}\right): \delta 58.7$

${ }^{31}$ P NMR H-coupled (202 MHz, DMSO- $\left.\boldsymbol{d}_{6}\right): \delta 58.7(\mathrm{t}, J=11.1 \mathrm{~Hz})$;

Retention time: $1.52 \mathrm{~min}$.

$[\mathbf{M}+\mathbf{H}]^{+}\left(\mathbf{E S I}^{+}\right):$1793.4.

ESI-HRMS: Calcd for $\mathrm{C}_{78} \mathrm{H}_{92} \mathrm{Cl}_{2} \mathrm{~N}_{14} \mathrm{O}_{29} \mathrm{PS}[\mathrm{M}+\mathrm{H}]^{+}=1793.4560$, found 1793.4556. 


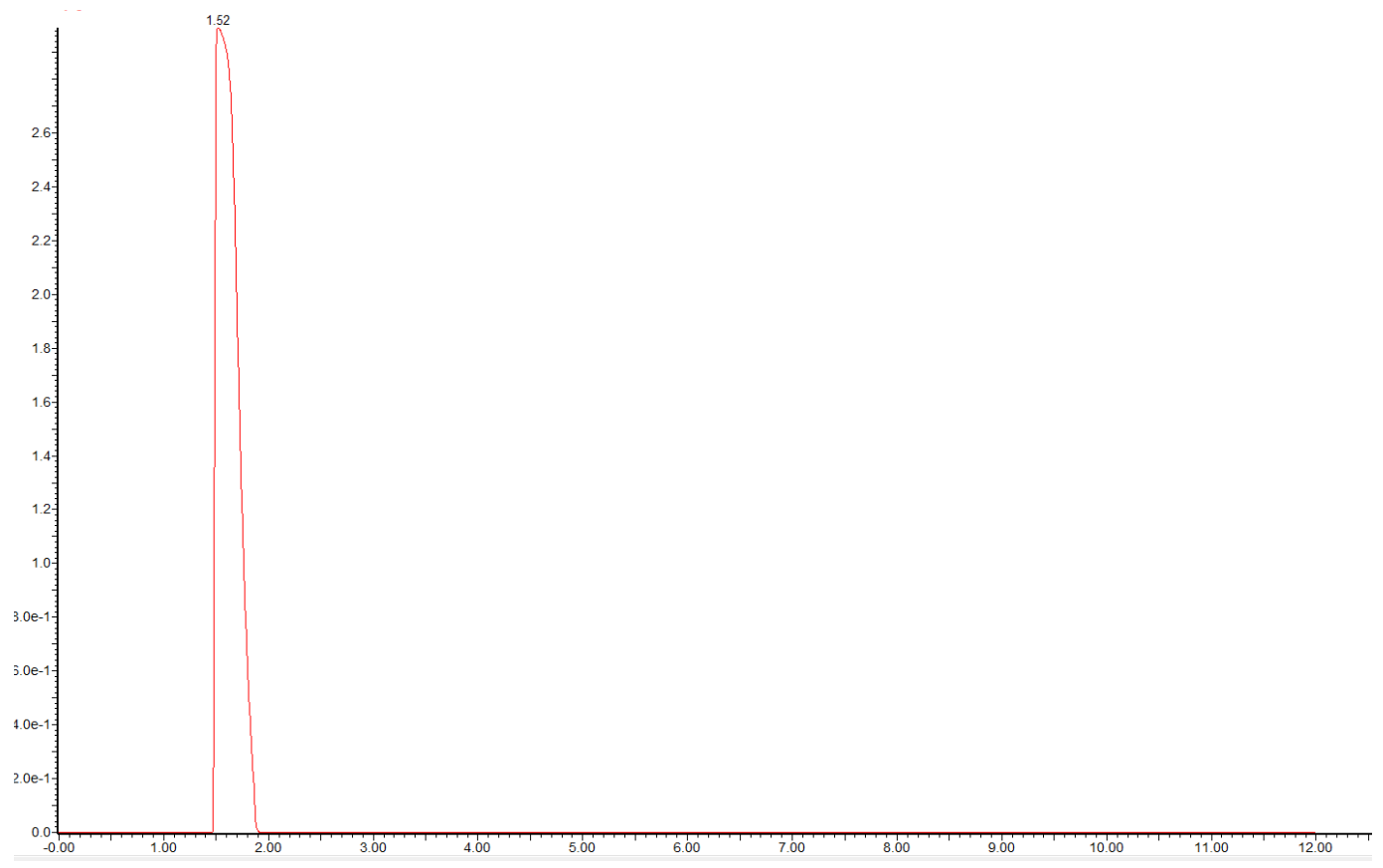

HPLC trace Peptide 37 (purified)

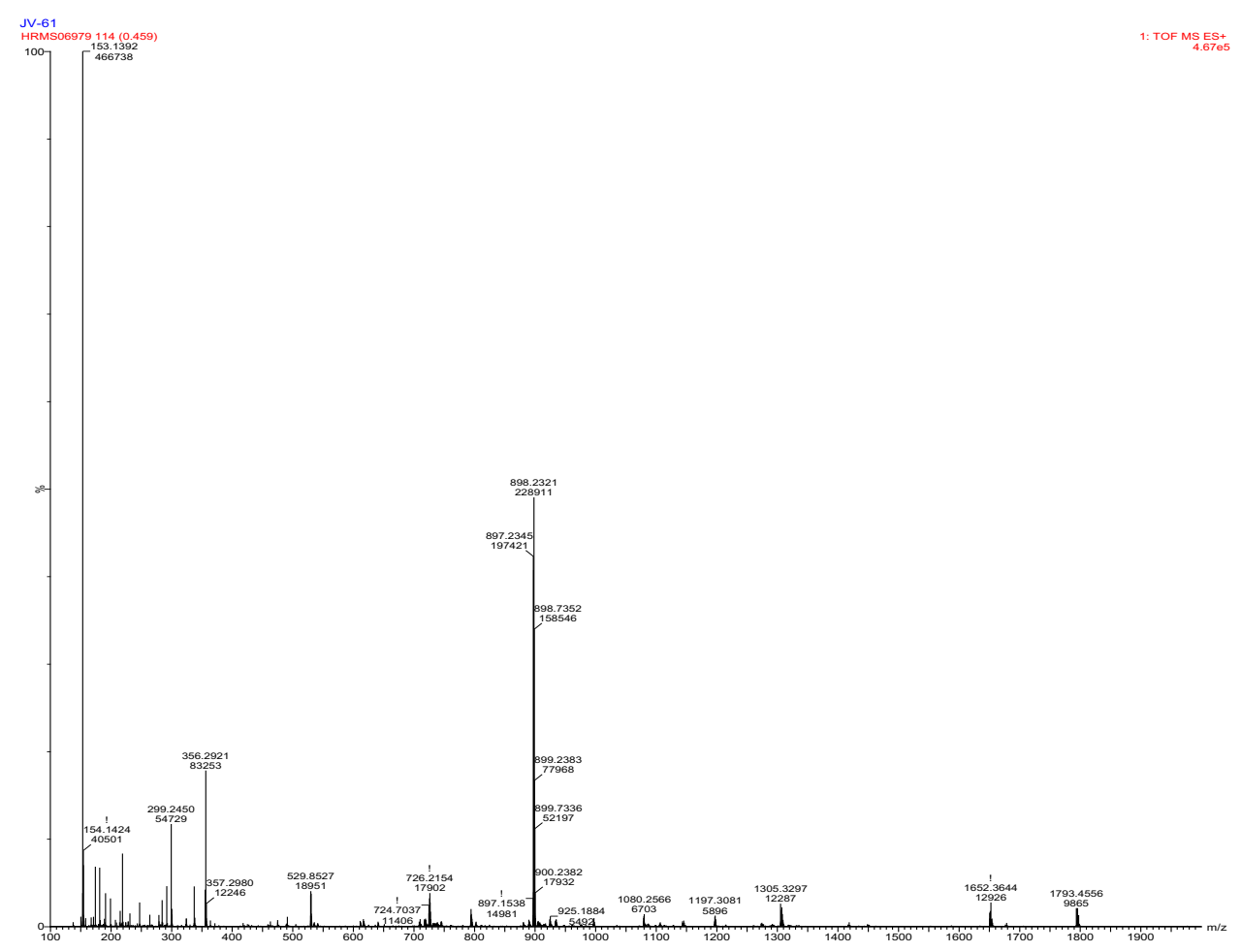

ESI-MS trace Peptide 37 


\section{Protein Functionalization}

\section{Starting materials}

\section{Ubiquitin 38}

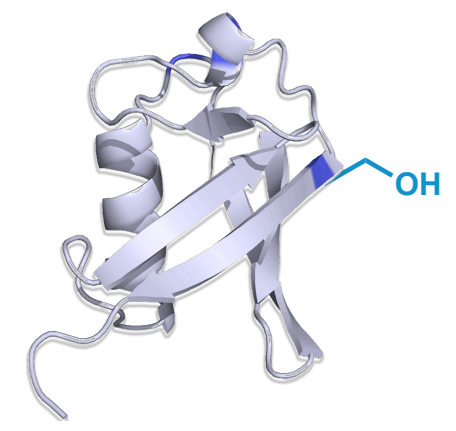

Amino acid sequence:

MQIFVKTLTGKTITLEVEPSDTIENVKAKIQDKEGIPPDQQRLIFAGKQLEDGRT LSDYNIQKESTLHLVLRLRGG

MW (average mass): $8565 \mathrm{Da}$.

(a)

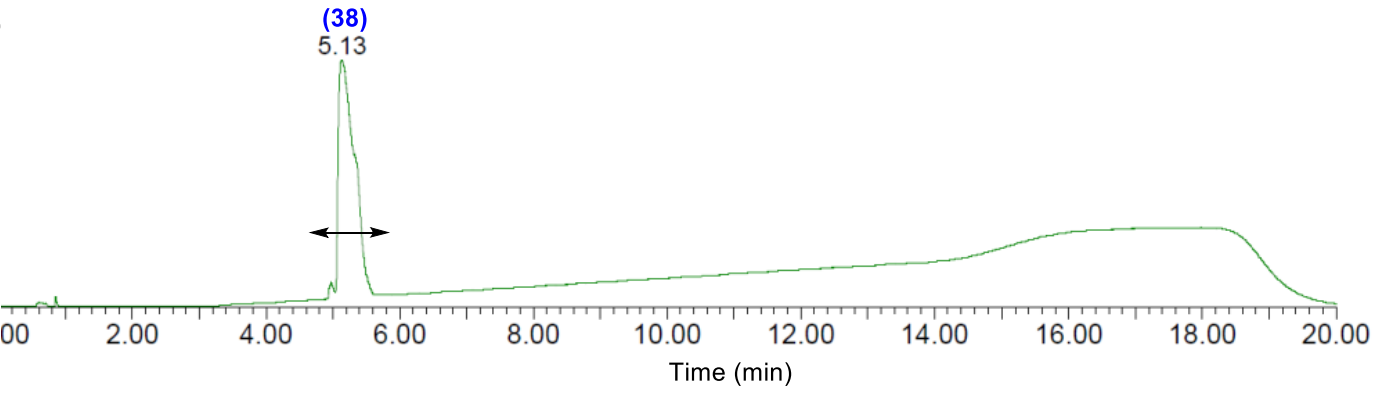

(b)

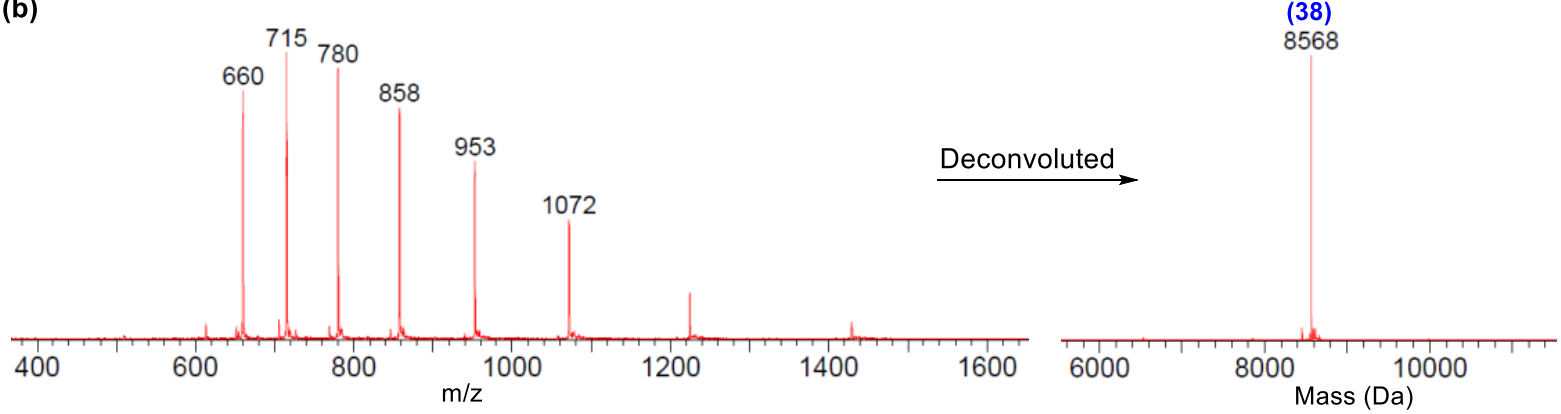

Figure S8. (a) HPLC spectrum of ubiquitin (38). (b) ESI-MS spectrum of ubiquitin (38). 


\section{Repressor 43}

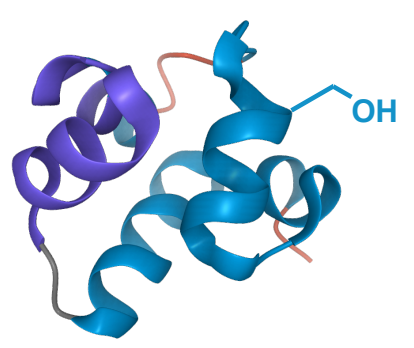

Amino acid sequence:

GSHMSISSRVKSKRIQLGLNQAELAQKVGTTQQSIEQLENGKTKRPRFLPELAS

\section{ALGVSV DWLLNGTSDSNVR}

MW (average mass): 7963 Da.

(a)

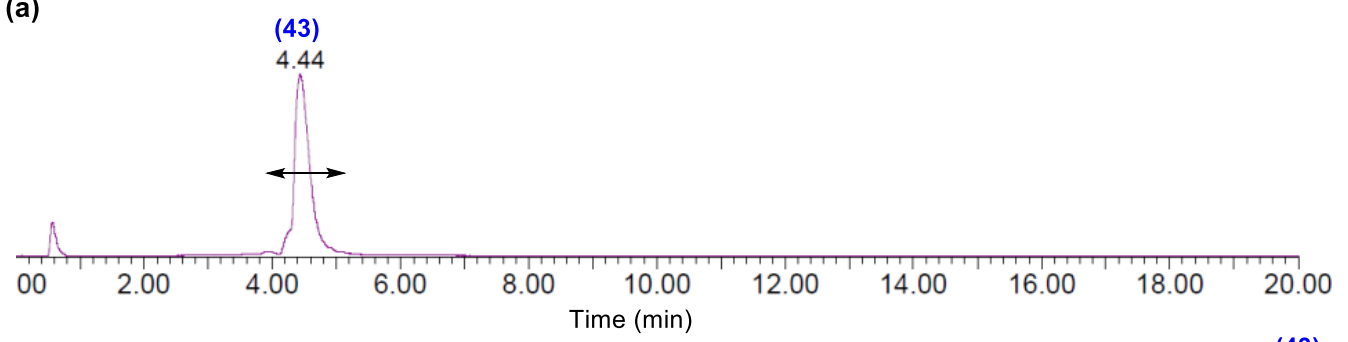

(b)

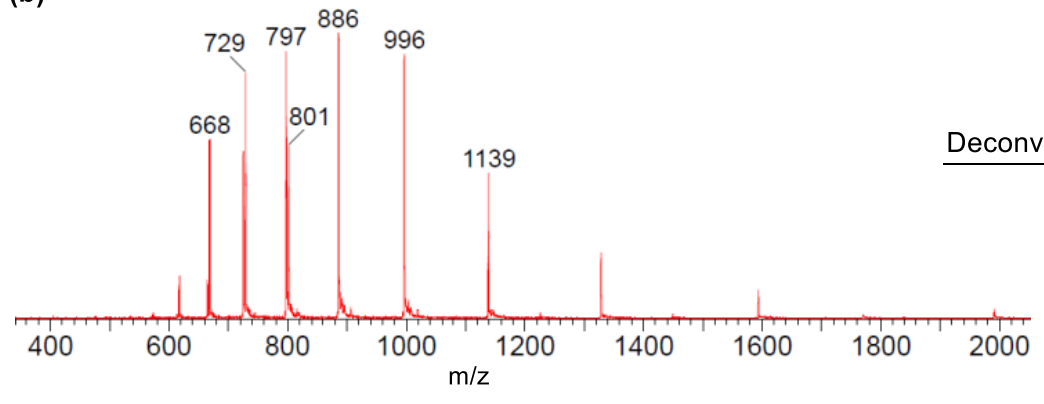

(43)

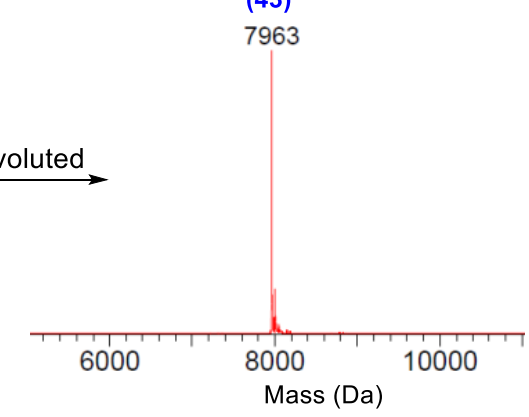

Figure S9. (a) HPLC spectrum of 434 repressor (43). (b) ESI-MS spectrum of 434 repressor (43). 


\section{Functionalization of Ubiquitin}

\section{Ubiquitin 39}

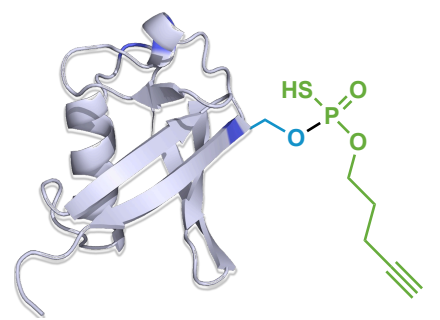

In a $0.5 \mathrm{ml}$ Eppendorf tube, ubiquitin $38(20 \mathrm{nmol})$ in water $(4 \mu \mathrm{l})$ was taken. To this solution, DBU (100 nmol, $200 \mathrm{nmol}, 500 \mathrm{nmol}$ or $1 \mu \mathrm{mol})$ in DMF $(8 \mu \mathrm{l}$, from a freshly prepared stock solution) was added. After mixing the reaction mixture, $\mathbf{P}(\mathbf{V})-2 \mathbf{b}$ reagent $(100 \mathrm{nmol}, 200 \mathrm{nmol}, 500 \mathrm{nmol}$ or $1 \mu \mathrm{mol})$ in DMF $(8 \mu \mathrm{l}$, from a freshly prepared stock solution) was added and vortexed at $25{ }^{\circ} \mathrm{C}$. After $3 \mathrm{~h}$, the crude mixtures were analyzed by ESI-MS. The best conversion was obtained when the overall concentration of ubiquitin 38, DBU, and $\mathrm{P}(\mathrm{V})-2 \mathrm{~b}$ reagent was $1 \mathrm{mM}, 50 \mathrm{mM}$, and $50 \mathrm{mM}$ respectively. Under these conditions compound 39 was obtained in $37 \%$ coversion.

$[\mathbf{M}+\mathbf{H}]^{+}\left(\mathbf{E S I}^{+}\right): 8741$;

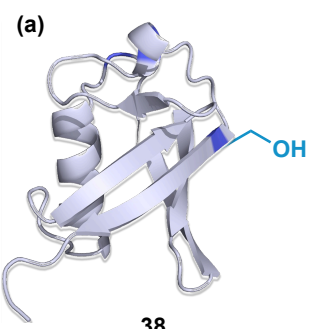

38

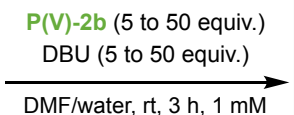

DMF/water, rt, $3 \mathrm{~h}, 1 \mathrm{mM}$

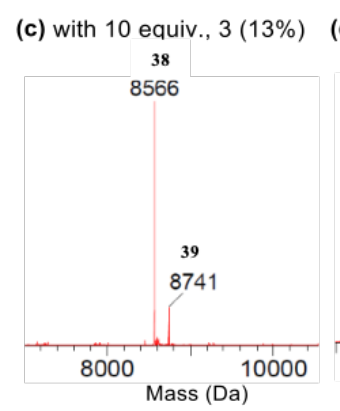

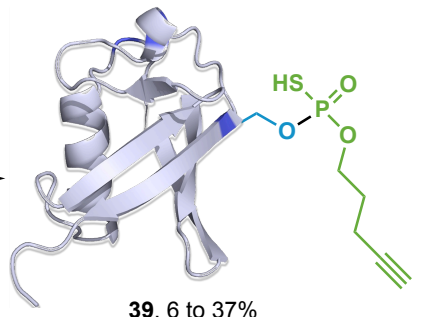

39,6 to $37 \%$
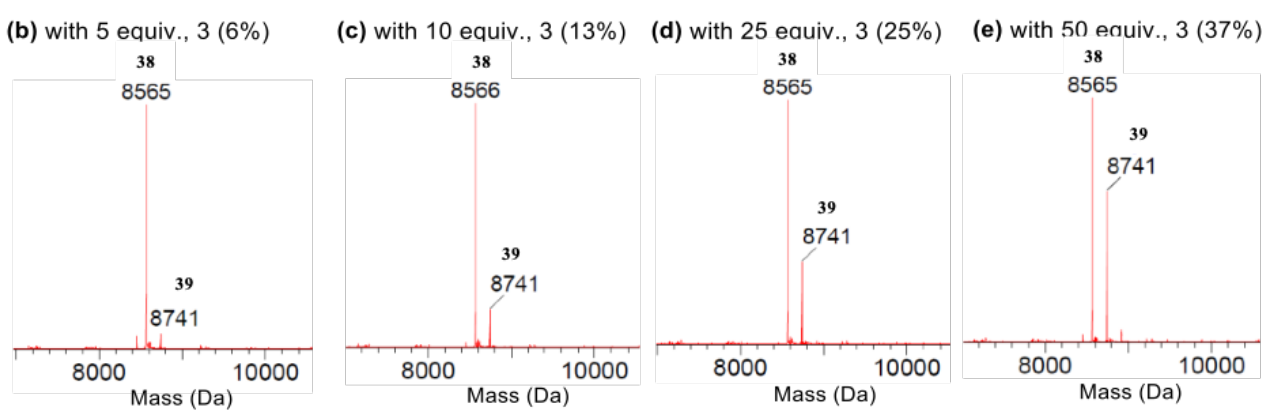

Figure S10. (a) Labeling of ubiquitin 38 using $\mathbf{P ( V ) - 2 b}$ reagent. ESI-MS spectra for mono-labeled ubiquitin 39 by using (b) P(V)-2b (5 equiv) and DBU (5 equiv); (c) $\mathbf{P}(\mathbf{V})-2 \mathbf{b}$ (10 equiv) and DBU (10 equiv); (d) P(V)-2b (25 equiv) and DBU (25 equiv) and (e) $\mathbf{P ( V ) - 2 b}$ (50 equiv) and DBU (50 equiv) 


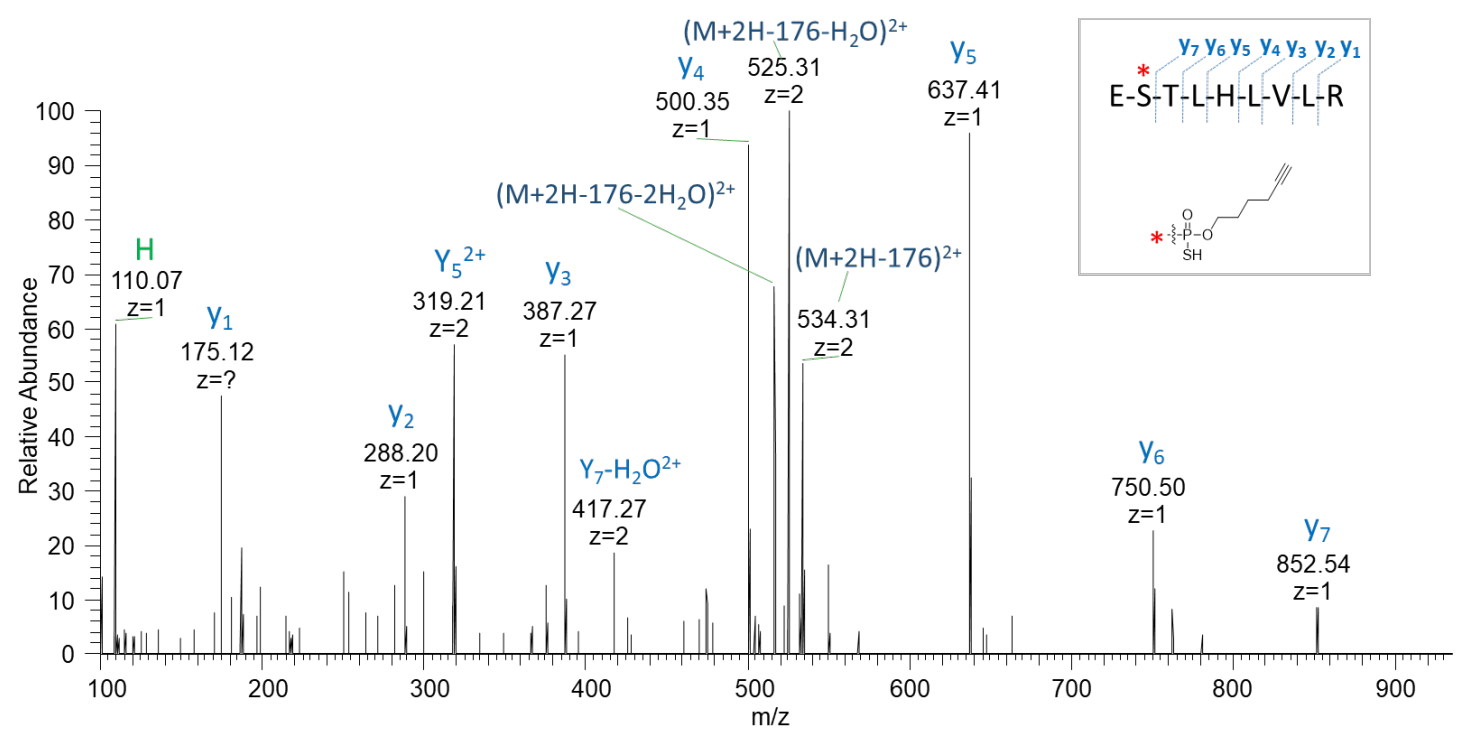

Figure S11. MS-MS spectrum of labeled ESTLHLVLR (E64-R72, m/z 622.31 $[\mathrm{M}+2 \mathrm{H}]^{2+}$ ) after the digestion of 39 with trypsin. Losses of $176 \mathrm{Da}$ (the MW of the label) are observed from the peptide precursor ion. The site of modification in mono-labeled ubiquitin 39 is $\mathrm{S} 65$.

The resulting MS/MS data were searched using the Mascot search algorithm using a variable modification of $176 \mathrm{Da}$ and a database containing the ubiquitin sequence. The resulting data was then filtered using stringent criteria and the MS/MS spectrum of the best match is shown which corresponds to a modified serine residue on the peptide ESTLHLVLR.

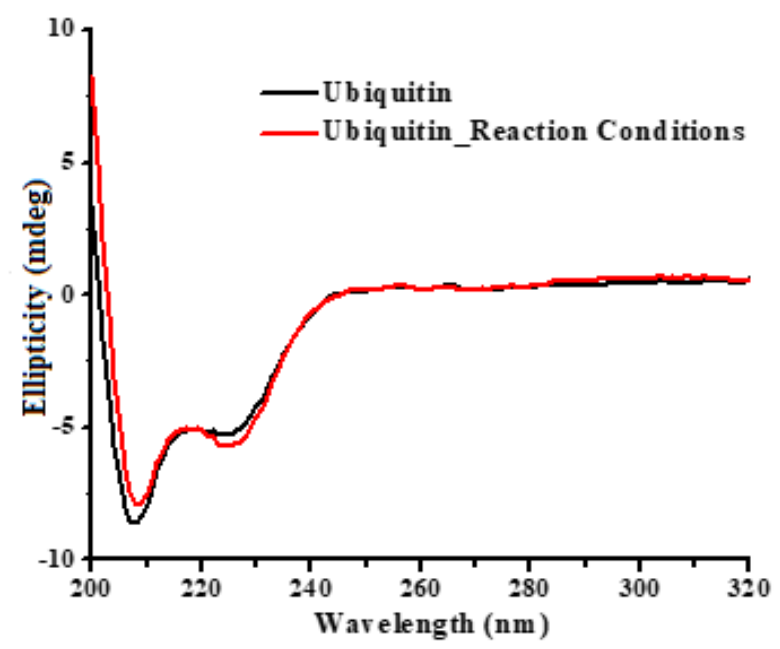

Figure S12. Effect of the reaction conditions on the circular dichroism (CD) spectrum of ubiquitin. Circular dichroism (CD) spectra of ubiquitin (black line) and ubiquitin under the reaction conditions (red line) at concentration $0.2 \mathrm{mg} / \mathrm{ml}$ in water. Ubiquitin 
was vortexed under the same solvent conditions [DMF:water $(4: 1)]$ at $25{ }^{\circ} \mathrm{C} . \mathrm{CD}$ measurements were recorded on a Chirascan spectrophotometer equipped with a Quantum TC125 temperature control unit. CD spectra were measured using a $10 \mathrm{~mm}$ path length cuvette with a response time of $1 \mathrm{~s}$ and bandwidth $1 \mathrm{~nm}$. Each spectrum is an average of 3 scans. 


\section{Ubiquitin 40}

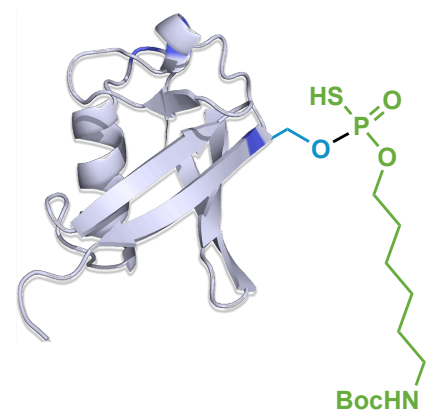

In a $0.5 \mathrm{ml}$ Eppendorf tube, ubiquitin $38(20 \mathrm{nmol})$ in water $(4 \mu \mathrm{l})$ was taken. To this solution, DBU (1 $\mu \mathrm{mol})$ in DMF ( $8 \mu$, from a freshly prepared stock solution) was added. After mixing the reaction mixture, $\mathbf{P}(\mathbf{V})-1$ reagent $(1 \mu \mathrm{mol})$ in DMF $(8 \mu 1$, from a freshly prepared stock solution) was added and vortexed at $25^{\circ} \mathrm{C}$. After $1 \mathrm{~h}$, the crude mixture was analyzed by ESI-MS to afford compound $\mathbf{4 0}$ in $32 \%$ conversion.

$[\mathbf{M}+\mathbf{H}]^{+}\left(\mathbf{E S I}^{+}\right): 8860$.
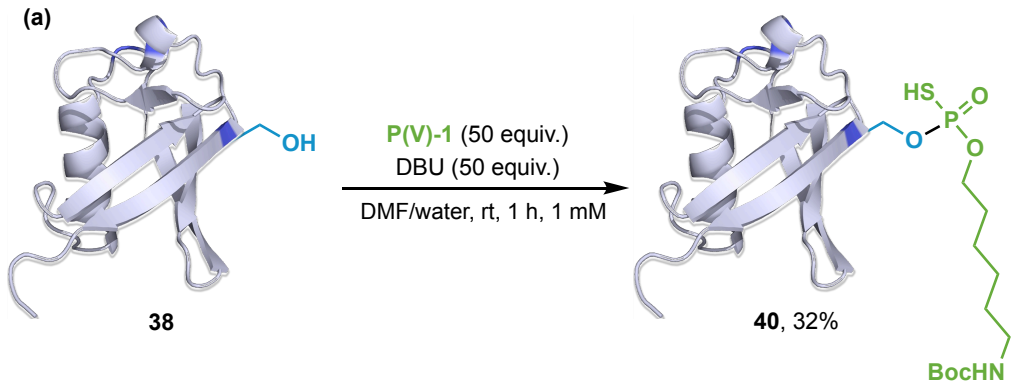

(b)

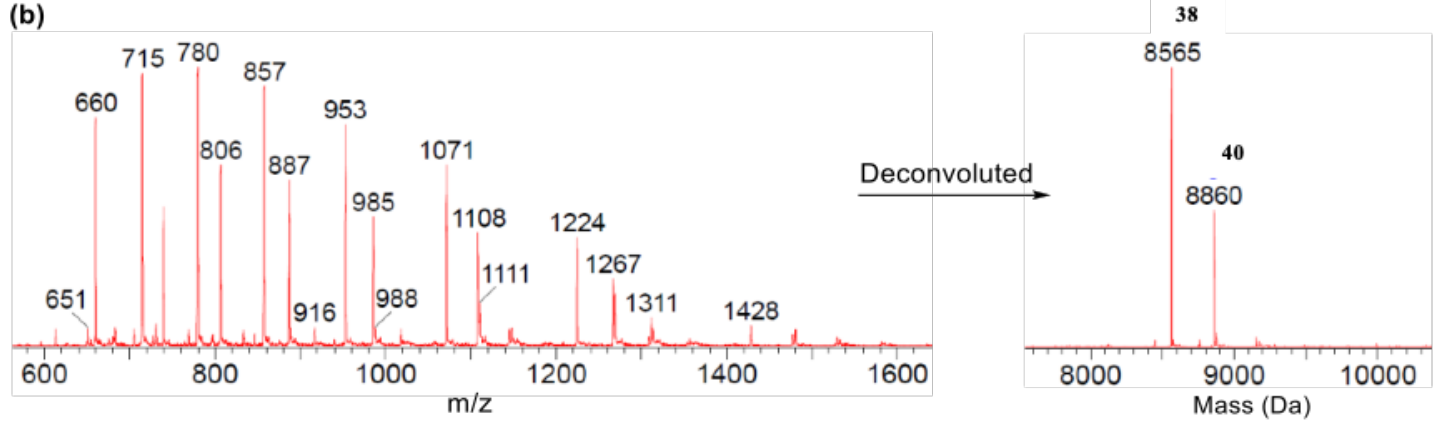

Figure S13. (a) Labeling of ubiquitin 38 using $\mathbf{P ( V ) - 1}$ reagent. (b) ESI-MS spectrum for mono-labeled ubiquitin $\mathbf{4 0 .}$ 


\section{Ubiquitin 41}

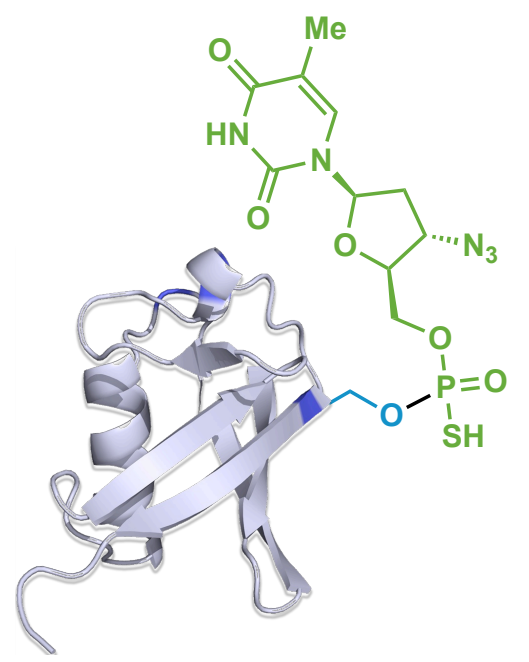

In a $0.5 \mathrm{ml}$ Eppendorf tube, ubiquitin $38(20 \mathrm{nmol})$ in water $(4 \mu \mathrm{l})$ was taken. To this solution, DBU (1 $\mu \mathrm{mol})$ in DMF ( $8 \mu \mathrm{l}$, from a freshly prepared stock solution) was added. After mixing the reaction mixture, $\mathbf{P}(\mathbf{V})-1$ reagent $(1 \mu \mathrm{mol})$ in DMF $(8 \mu \mathrm{l}$, from a freshly prepared stock solution) was added and vortexed at $25^{\circ} \mathrm{C}$. After $1 \mathrm{~h}$, the crude mixture was analyzed by ESI-MS to afford compound $\mathbf{4 1}$ in $40 \%$ conversion.

$[\mathbf{M}+\mathbf{H}]^{+}\left(\mathbf{E S I}^{+}\right): 8910$.

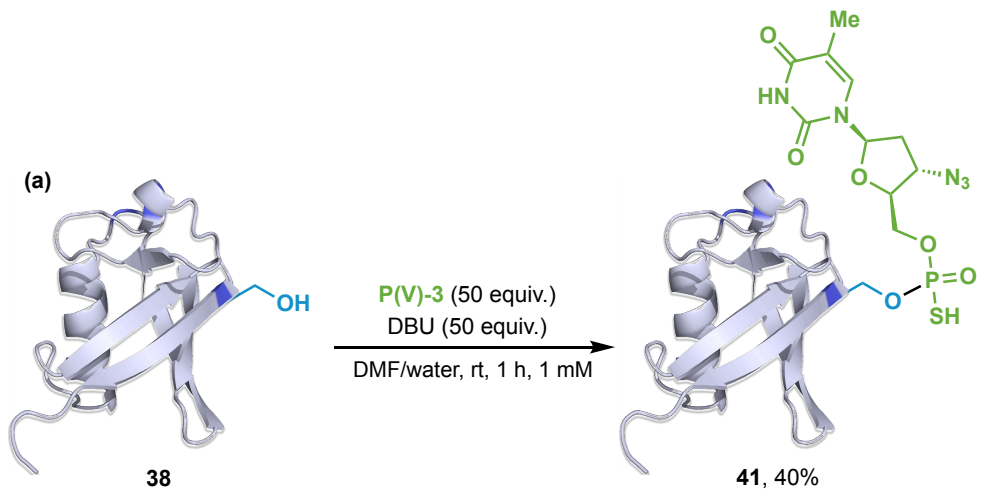

(b)
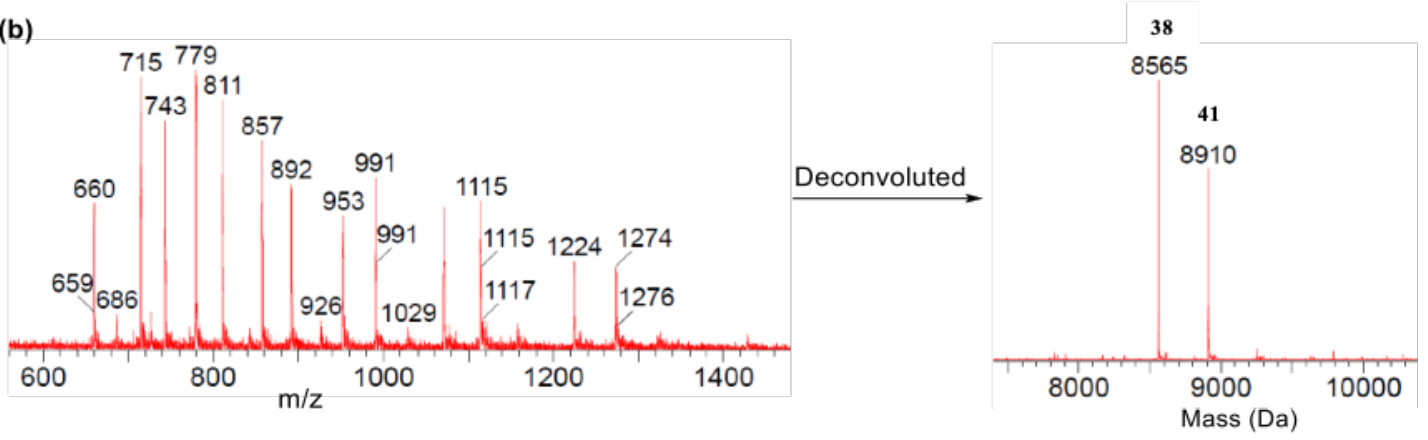

Figure S14. (a) Labeling of ubiquitin 38 using $\mathbf{P ( V ) - 3 ~ r e a g e n t . ~ ( b ) ~ E S I - M S ~ s p e c t r u m ~}$ 
for mono-labeled ubiquitin 41.

\section{Ubiquitin 42}

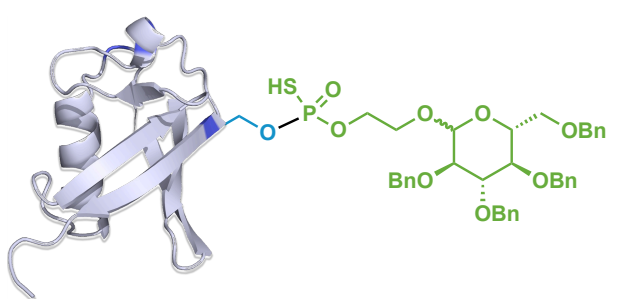

In a $0.5 \mathrm{ml}$ Eppendorf tube, ubiquitin $38(20 \mathrm{nmol})$ in water $(4 \mu \mathrm{l})$ was taken. To this solution, DBU ( $1 \mu \mathrm{mol})$ in DMF ( $8 \mu 1$, from a freshly prepared stock solution) was added. After mixing the reaction mixture, $\mathbf{P}(\mathbf{V})-1$ reagent $(1 \mu \mathrm{mol})$ in DMF $(8 \mu 1$, from a freshly prepared stock solution) was added and vortexed at $25^{\circ} \mathrm{C}$. After $1 \mathrm{~h}$, the crude mixture was analyzed by ESI-MS to afford compound $\mathbf{4 2}$ in $40 \%$ conversion.

$[\mathbf{M}+\mathbf{H}]^{+}\left(\mathbf{E S I}^{+}\right): 9228$;

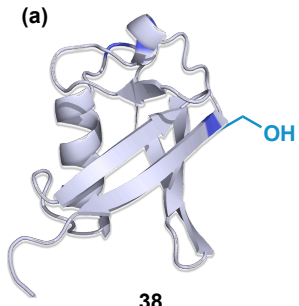

38

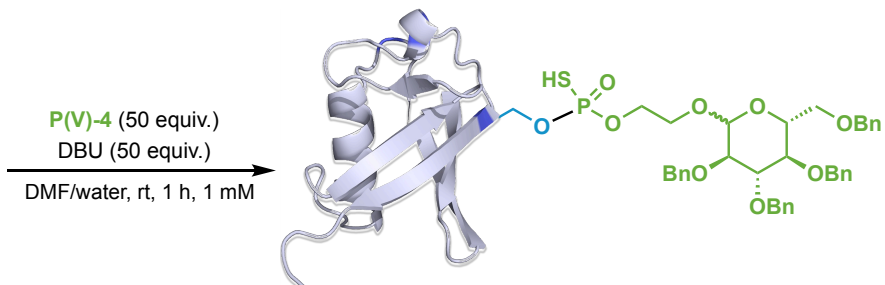

42, $20 \%$

(b)
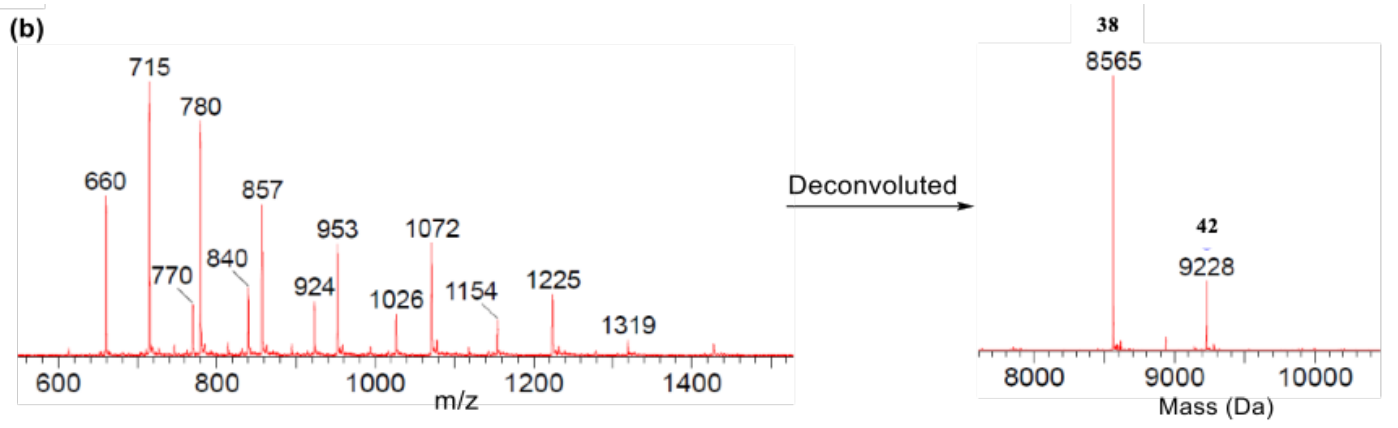

Figure S15. (a) Labeling of ubiquitin 38 using $\mathbf{P ( V ) - 4}$ reagent. (b) ESI-MS spectrum for mono-labeled ubiquitin $\mathbf{4 2}$. 


\section{Functionalization of 434 Repressor Protein}

\section{Repressor Protein 44}

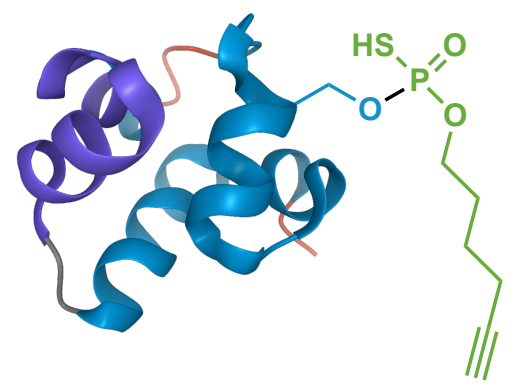

In a $0.5 \mathrm{ml}$ Eppendorf tube, 434 repressor protein $43(2 \mathrm{nmol})$ in water $(4 \mu \mathrm{l})$ was taken. To this solution, DBU (100 nmol) in DMF $(8 \mu \mathrm{l})$ from a freshly prepared stock solution was added. After mixing the reaction mixture, $\mathbf{P ( V ) - 2 b}$ reagent $(100 \mathrm{nmol})$ in DMF $(8 \mu 1)$ was added and vortexed at $25{ }^{\circ} \mathrm{C}$. The overall concentration of 434 repressor 43, DBU, and $\mathrm{P}(\mathrm{V})-2 \mathrm{~b}$ reagent was $100 \mu \mathrm{M}, 5 \mathrm{mM}$ and $5 \mathrm{mM}$ respectively. After $1 \mathrm{~h}$, modification of 434 repressor was analyzed by ESI-MS to afford compound 44 in $35 \%$ conversion.

$[\mathbf{M}+\mathbf{H}]^{+}\left(\mathbf{E S I}^{+}\right): 8140$

(a)

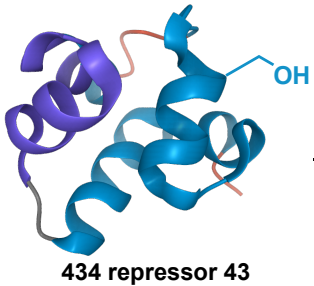

$\mathrm{P}(\mathrm{V})-2 \mathrm{~b}$ (50 equiv.) $\underset{\mathrm{DMF} / \text { water, rt, } 1 \mathrm{~h}, 0.1 \mathrm{mM}}{\longrightarrow}$

434 repressor 43

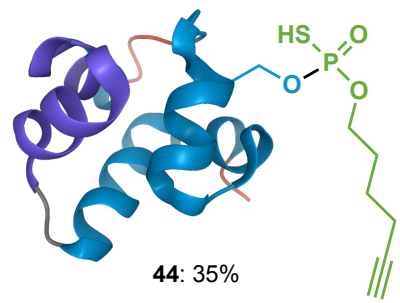

(b)
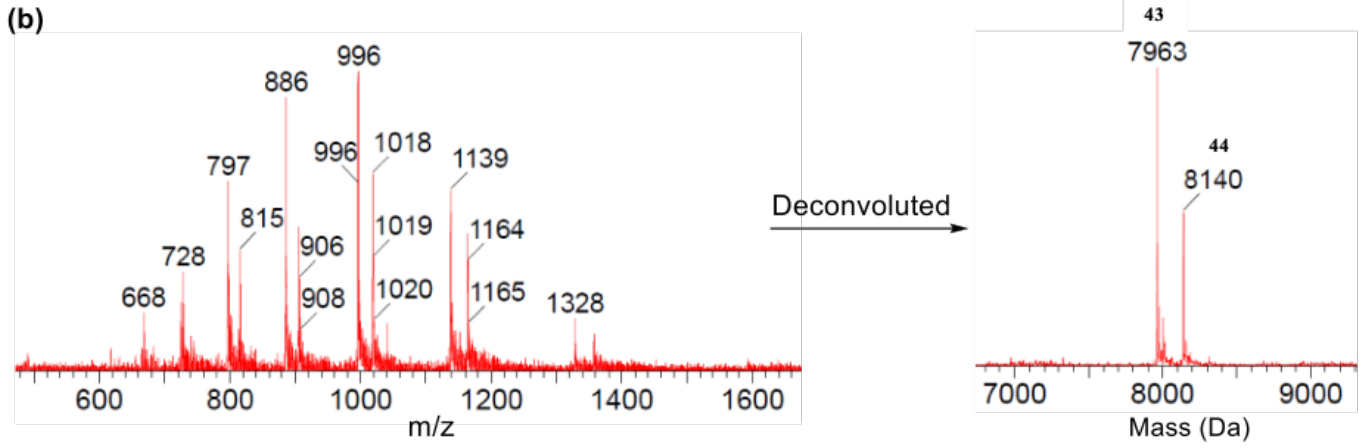

Figure S16. (a) Labeling of 434 repressor 43 using $\mathbf{P ( V ) - 2 b}$ reagent. (b) ESI-MS spectrum for mono-labeled 434 repressor 44. 


\section{DFT Computational Studies}

\section{A. General Computational Information}

A systematic search for the lowest energy conformers of the Boc-protected amino acids was performed using the Spartan Conformer Distribution tool, ${ }^{4}$ and the resulting structures were fully optimized in Gaussian $09^{5}$ at the B3LYP/6-31G(d) level of theory. ${ }^{6}$ Ion-pair interaction energies $\left(\Delta \Delta G_{\text {int }}=\Delta G_{\mathrm{AB}}-\Delta G_{\mathrm{A}}-\Delta G_{\mathrm{B}}\right)$ were estimated by optimizing isolated (e.g. $\left.\mathrm{A}^{-}, \mathrm{B}^{+}\right)$and contact ion-pair geometries (e.g. $\mathrm{A}^{-} \mathrm{B}^{+}$) at the B3LYP/6-31G(d) level of theory including B3LYP-D3 single point corrections for dispersion. $^{7}$ The resulting $\Delta G_{\text {int }}$ values represent approximate energies for ion-pair stabilization $^{8}$ and enable a continuous analysis of the reaction coordinate initiated by DBU as a general base catalyst. Frequency calculations for all stationary points were performed at the same level of theory to describe them either as minima $(i=0)$ or as first-order transition states $(i=1)$. Intrinsic reaction coordinate (IRC) calculations were performed to confirm that the optimized transition structures connect with their corresponding minima. ${ }^{9}$ We have used the Cylview program to generate ball and stick geometries of the optimized structures. ${ }^{10}$ Treatment of the potential ionization of the side chain in the presence of DBU considered the $\mathrm{p} K_{\mathrm{a}}$ values of the corresponding functional groups reported in water, MeCN, and DMSO (Table S2). p $K_{\mathrm{a}}$ measurements indicate that DBU can partially deprotonate the side chains of Tyr and Cys in water but will only be able to deprotonate Cys in $\mathrm{MeCN}$. The dissociation constants of neutral acids are orders of magnitude lower in aprotic solvents compared with water due to their limited capacity to solvate both anions and cations. ${ }^{11}$ 


$\begin{array}{ccccc}\text { entry } & \text { compound } & \mathrm{p} K_{\mathrm{a}}(\text { water }) & \mathrm{p} K_{\mathrm{a}}(\mathrm{MeCN}) & \mathrm{p} K_{\mathrm{a}}(\mathrm{DMSO}) \\ 1 & \mathrm{DBU}-\mathrm{H}^{+} & 11.5^{12} & 24.3^{13} & 13.9^{14} \\ 2 & \mathrm{EtOH} & 15.5^{15} & 28.7^{16} & 29.8^{16} \\ 3 & \mathrm{PhOH} & 10.0^{17} & 29.1^{18} & 18.0^{16} \\ 4 & \text { EtSH } & 10.6^{19} & 23.1^{16} & 17.8^{20}\end{array}$

Table S2. $\mathrm{p} K_{\mathrm{a}}$ values reported for functional groups in amino acids with ionizable side chains. See reference ${ }^{21}$ for the $\mathrm{p} K_{\mathrm{a}}$ value of the side chains of Cys ad Tyr in water.

Free energy values $(\Delta G, 298.15 \mathrm{~K}, 1.0 \mathrm{~atm})$ result from the corresponding equilibria arbitrarily balanced relative to the $\mathrm{MeO}-\mathrm{P}(\mathrm{V})$ reagent with $R_{\mathrm{P}}$ configuration at the phosphorus $\left[\Delta \Delta G=\left(\Delta G_{\mathrm{NuP}(\mathrm{V})-}+\Delta G_{\mathrm{DBUH}}\right)-\left(\Delta G_{\mathrm{P}(\mathrm{V})}+\Delta G_{\mathrm{Nu}}+\Delta G_{\mathrm{DBU}}\right)\right]$. The free energy for the reaction of the ionized Boc-Cys thiolate was balanced considering the initial side chain deprotonation by DBU.

\section{B. Computational Results}

DFT studies support a stepwise $A_{N}+D_{N}$ phosphorylation mechanism with limiting barriers for the formation or collapse of a trigonal bipyramidal pentacoordinated (TBP) intermediate, which are significantly higher than the barriers calculated for the downstream generation of the cyclohexene sulfide and phosphorylated products. Overall, the calculations endorse a process that occurs with retention of configuration at the phosphorus atom. ${ }^{22}$

Amino acids with alcohol side chains display a rate-limiting formation of the trigonal bipyramidal intermediate (Figure S17) with barriers that increase in the order Boc-Ser $<$ Boc-Thr $<<$ Boc-Tyr (Figure S18). A $\Delta \Delta \mathrm{G}^{\ddagger}$ of $0.6 \mathrm{kcal} / \mathrm{mol}$ between BocSer and BocThr is in qualitative agreement with the lower but competitive reactivity of Boc-Thr, whereas a $\Delta \Delta \mathrm{G}^{\ddagger}$ of $4.9 \mathrm{kcal} / \mathrm{mol}$ between Boc-Ser and Boc-Tyr is consistent with the limited reactivity of Boc-Tyr. The transition structures leading to the TBP, TS1, display a hydrogen-bonded four-centered addition with the nucleophile 
approaching the backside of the P-O ring bond. TS1-Ser represents a late, intermediate-like arrangement with a large extent of SerO-P bond formation and concomitant proton transfer to the nitrogen atom of DBU acting as a general base. A search for the transition structures corresponding to the collapse of the TBP intermediates led to structures TS2, which depict the dissociation of the ring S-P bond accompanied by pseudorotation ${ }^{23}$ and reduction of the $\mathrm{O}-\mathrm{P}-\mathrm{O}$ angle as the tetrahedral phosphorylated $\mathrm{P}(\mathrm{V})$ product forms (Figure S19). The formation of a strong $\mathrm{O}-\mathrm{P}$ and the axial arrangement of the methoxy group facilitate the dissociation of the weaker S-P bond (Table S3). ${ }^{24}$ For amino acids with alcohol side chains, transition structures TS2 leading to the collapse of the TBP intermediates are $\approx 8$ $\mathrm{kcal} / \mathrm{mol}$ more stable than the transition structures TS1 forming the TBP intermediates. The remaining steps of the reaction coordinate involve a ring flip of the limonene skeleton (TS3) followed by $\mathrm{S}_{\mathrm{N}} 2$ displacement of the phosphorylated amino acid and simultaneous release of the cyclohexene sulfide (TS4) with an exothermic balance $(\Delta G \approx-37 \mathrm{kcal} / \mathrm{mol}) .{ }^{25}$ Transition structures $\mathbf{T S 3}$ represent the highest barrier within the sequence of conformational distorsions ${ }^{26}$ required to transform chair INT2 into chair INT3. ${ }^{27}$

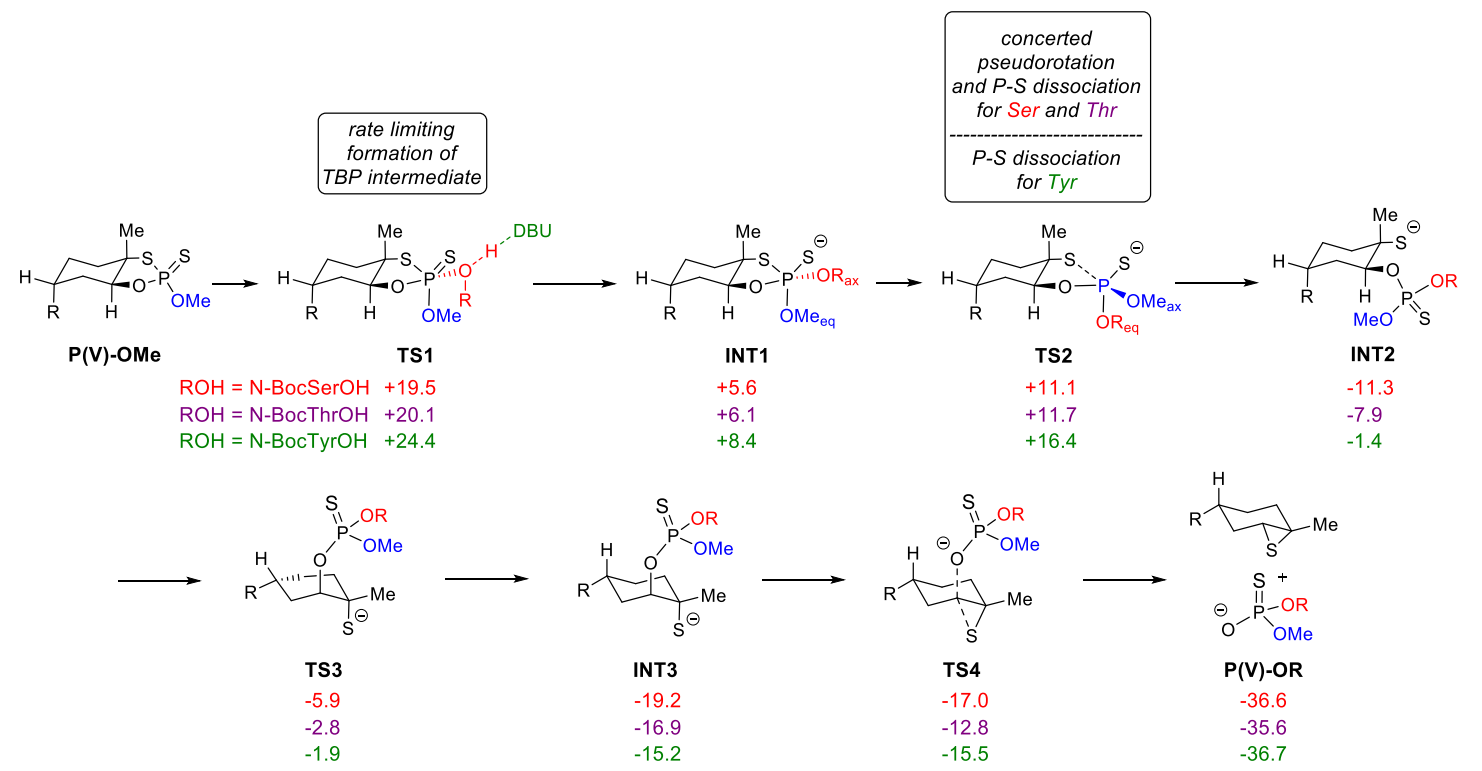

Figure S17. DFT reaction coordinate for the phosphorylation of amino acids with a ROH side chain $(\Delta G$ in $\mathrm{kcal} / \mathrm{mol})$ 


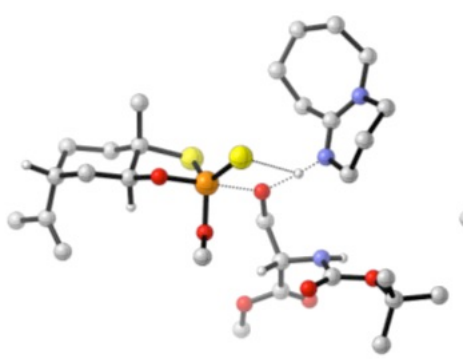

TS1-Ser

$\Delta G^{\ddagger}=+19.5 \mathrm{kcal} / \mathrm{mol}$

SerO-P $2.302 \AA$

$\mathrm{O}-\mathrm{H} \quad 1.428 \AA$

S-H $\quad 3.036 \AA$

$\mathrm{N}-\mathrm{H} \quad 1.122 \AA$

ring O-P $1.694 \AA$

ring S-P $2.141 \AA$

S-P $1.978 \AA$

O-P-O $166.5^{\circ}$

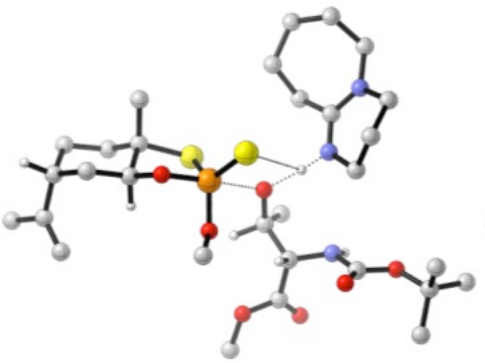

TS1-Thr

$\Delta G^{\ddagger}=+20.1 \mathrm{kcal} / \mathrm{mol}$

Thro-P $2.392 \AA$

$\mathrm{O}-\mathrm{H} \quad 1.445 \AA$

$\mathrm{S}-\mathrm{H} \quad 3.119 \AA$

$\mathrm{N}-\mathrm{H} \quad 1.119 \AA$

ring O-P $1.687 \AA$

ring S-P $2.138 \AA$

S-P $\quad 1.873 \AA$

O-P-O $164.1^{\circ}$

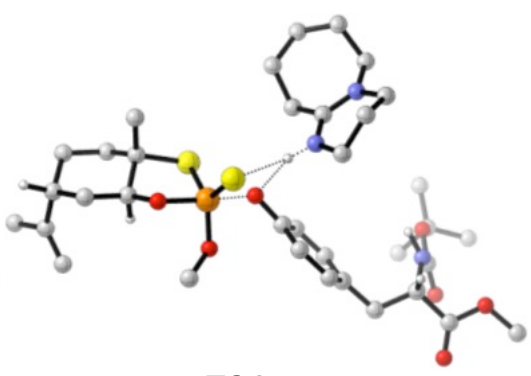

TS1-Tyr

$\Delta G^{\ddagger}=+24.5 \mathrm{kcal} / \mathrm{mol}$

Tyro-P $1.900 \AA$

$\mathrm{O}-\mathrm{H} \quad 2.113 \AA$

S-H $2.380 \AA$

$\mathrm{N}-\mathrm{H} \quad 1.038 \AA$

ring O-P $1.729 \AA$

ring S-P $2.181 \AA$

S-P $2.028 \AA$

O-P-O $167.9^{\circ}$

Figure S18. Transition structures for the formation of the TBP intermediates from amino acids with a

ROH side chain

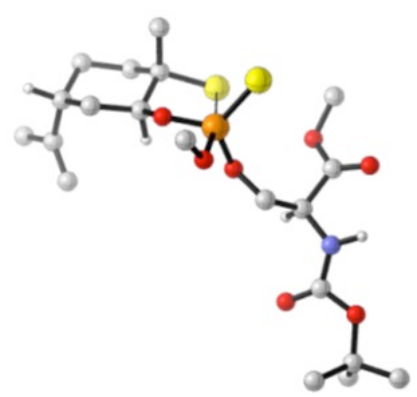

TS2-Ser

$\Delta G^{\ddagger}=+11.1 \mathrm{kcal} / \mathrm{mol}$

SerO-P $1.635 \AA$

ring O-P $1.623 \AA$

ring S-P $3.044 \AA$

S-P $\quad 1.978 \AA$

O-P-O $111.2^{\circ}$

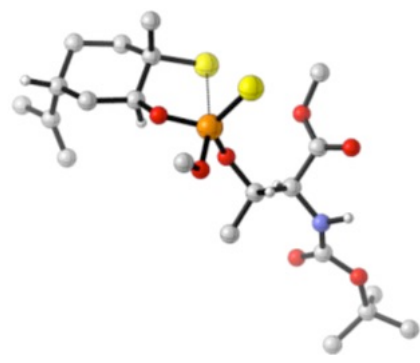

TS2-Thr

$\Delta G^{\ddagger}=+11.7 \mathrm{kcal} / \mathrm{mol}$

$\begin{array}{ll}\text { ThrO-P } & 1.632 \AA \\ \text { ring O-P } & 1.675 \AA \\ \text { ring S-P } & 3.110 \AA \\ \text { S-P } & 1.974 \AA \\ \text { O-P-O } & 111.0^{\circ}\end{array}$

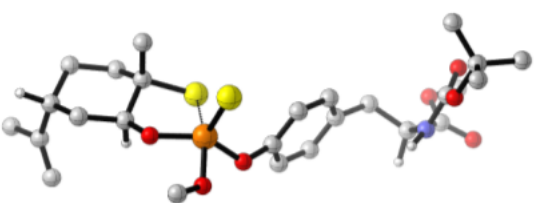

TS2-Tyr

$\Delta G^{\ddagger}=+16.4 \mathrm{kcal} / \mathrm{mol}$

Tyro-P $1.749 \AA$

ring O-P $1.733 \AA$

ring S-P $2.416 \AA$

S-P $\quad 2.013 \AA$

O-P-O $137.4^{\circ}$

Figure S19. Transition structures for the collapse of the TBP intermediates of amino acids with a ROH side chain

\begin{tabular}{ccc|}
\hline entry & bond & $\Delta H f_{298}(\mathrm{kcal} / \mathrm{mol})$ \\
1 & $\mathrm{P}-\mathrm{N}$ & 147.6 \\
2 & $\mathrm{P}-\mathrm{O}$ & 142.7 \\
3 & $\mathrm{P}-\mathrm{S}$ & 82.7
\end{tabular}

Table S3. Bond dissociation energies for a bond A-B broken through the reaction AB

$$
\rightarrow \mathrm{A}+\mathrm{B}^{28}
$$


In contrast with the reaction coordinate for the alcohol nucleophiles, the collapse of the TBP-Cys intermediate is disfavored relative to its formation (cf. TS1-Cys and TS2-Cys, Figure S20). The existence of a low barrier for decomposition of the TBP intermediate back to reactants has been used to explain the slow thiolysis of phosphate triesters. ${ }^{29}$ In agreement with experiment, the limiting barrier for the phosphorylation of Cys (TS2-Cys, $\Delta G^{\ddagger}=+22.2 \mathrm{kcal} / \mathrm{mol}$ ) is estimated to be 2.7 $\mathrm{kcal} / \mathrm{mol}$ higher than the limiting barrier for the phosphorylation of Ser (TS1-Ser, $\Delta G^{\ddagger}$ $=+19.5 \mathrm{kcal} / \mathrm{mol}$ ). A comparison of TS2-Cys and TS2-Ser geometries (Figures S19 and S21) shows the reluctance of Cys to pseudorotate (S-P-Oring 147.0 in TS2-Cys versus $\mathrm{O}-\mathrm{P}-\mathrm{Oring} 111.2^{\circ}$ in TS2-Ser), become equatorial, and stabilize ring $\mathrm{P}-\mathrm{S}$ dissociation via the axial-axial arrangement of the OMe group and the ring P-S bond. The higher pseudorotation barrier of Cys relative to Ser is consistent with the preference of good leaving groups (e.g. Cys) to occupy an axial position. ${ }^{30} \mathrm{~A}$ heightened barrier for the pseudorotation of Tyr may also explain the higher activation energy of TS2-Tyr relative to TS2-Ser and TS2-Thr (Figure S19). ${ }^{31,32}$

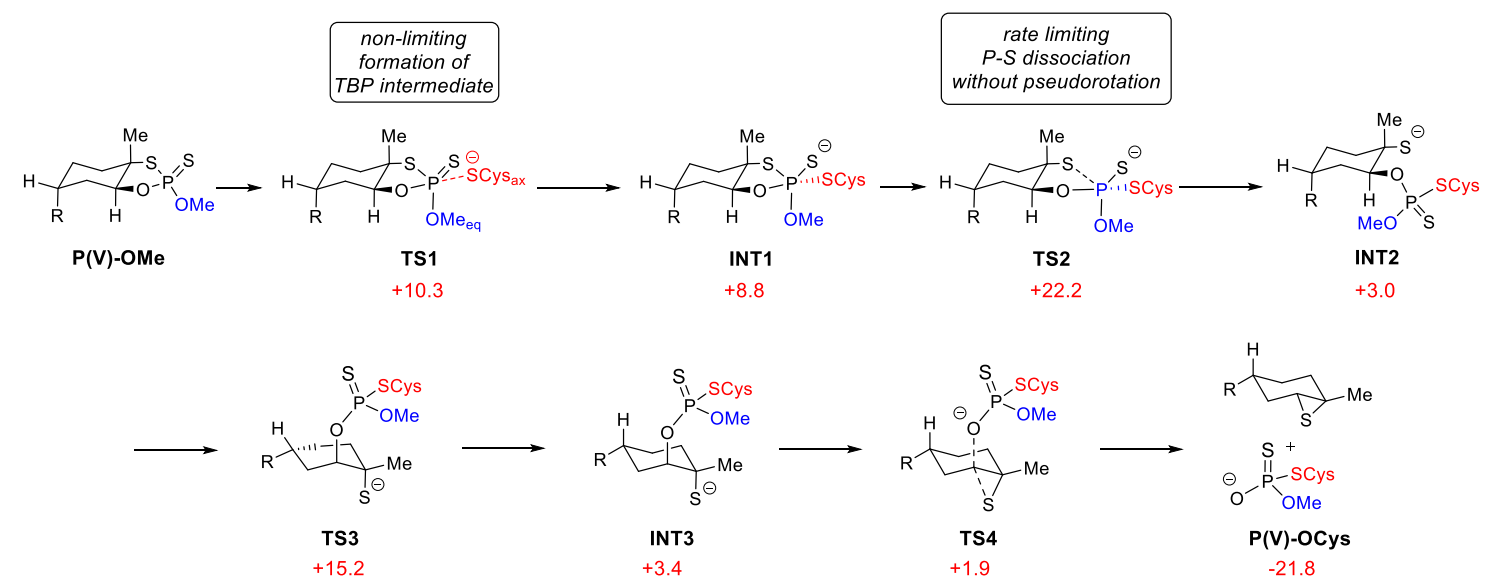

Figure S20. DFT reaction coordinate for the phosphorylation of the Cys nucleophile $(\Delta G$ in $\mathrm{kcal} / \mathrm{mol})$ 


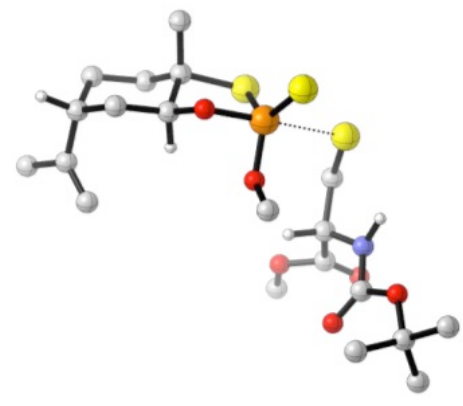

TS1-Cys

$\Delta G^{\ddagger}=+10.3 \mathrm{kcal} / \mathrm{mol}$

$\begin{array}{ll}\text { CysS-P } & 2.586 \AA \\ \text { ring O-P } & 1.737 \AA \\ \text { ring S-P } & 2.174 \AA \\ \text { S-P } & 1.990 \AA \\ \text { S-P-Oring } & 170.8^{\circ}\end{array}$

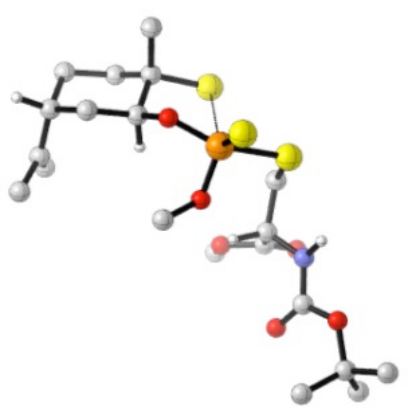

TS2-Cys

$\Delta G^{\ddagger}=+22.2 \mathrm{kcal} / \mathrm{mol}$

$$
\begin{array}{ll}
\text { CysS-P } & 2.207 \AA \\
\text { ring O-P } & 1.654 \AA \\
\text { ring S-P } & 3.209 \AA \\
\text { S-P } & 1.982 \AA \\
\text { S-P-Oring } & 147.0^{\circ}
\end{array}
$$

Figure S21. Transition structures for the formation and collapse of the Cys TBP intermediates

Structures TS1-Lys and TS2-Lys were located for the $A_{N}+D_{N}$ phosphorylation of $N$-Boc-Lys. TS1-Lys $\left(\Delta G^{\ddagger}=+28.8 \mathrm{kcal} / \mathrm{mol}\right.$, Figure S22) represents a rate-limiting nucleophilic attack of the primary amine to the backside of the P-O assisted by DBU as a general base catalyst. ${ }^{33}$ TS1-Ser is favored relative to TS1-Lys by $\approx 9 \mathrm{kcal} / \mathrm{mol}$ in agreement with the lower acidity of the primary amine and greater steric congestion during the partial deprotonation by DBU. P-S bond dissociation from INT1-Lys leads to a non-limiting transition structure $\left(\Delta G^{\ddagger}=+25.6 \mathrm{kcal} / \mathrm{mol}\right)$ located in a shallow potential energy surface that includes $\mathrm{H}$-bond formation between the $-\mathrm{P}(\mathrm{S})-\mathrm{NHR}$ moiety and the negatively charged sulfur atom. ${ }^{34}$

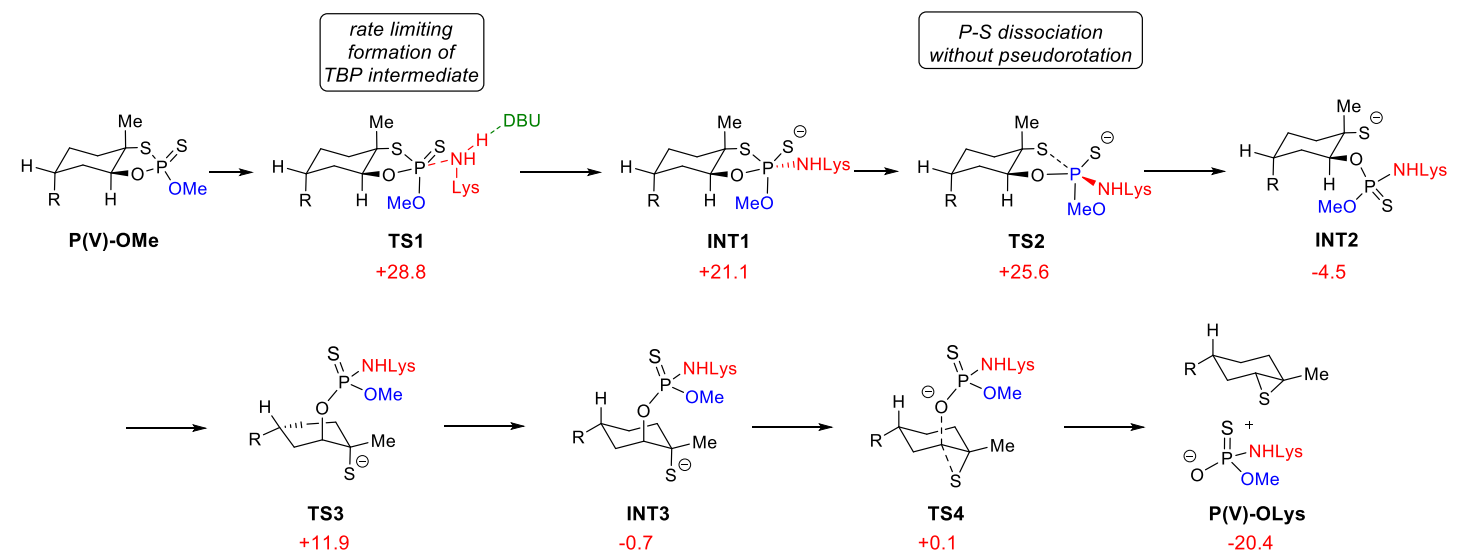

Figure S22. Transition structures for the formation and collapse of the Lys TBP intermediates 


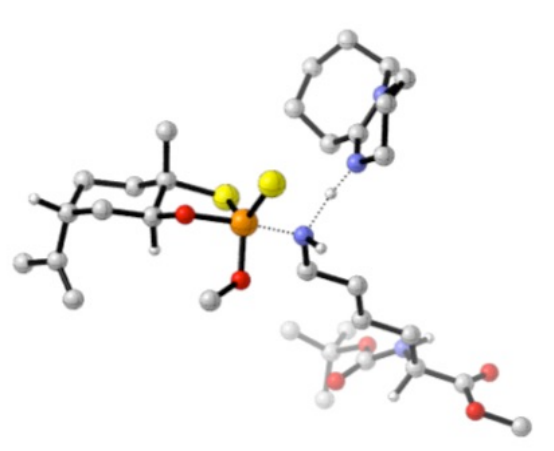

TS1-Lys

$\Delta G^{\ddagger}=+28.8 \mathrm{kcal} / \mathrm{mol}$

$\begin{array}{ll}\text { LysN-P } & 1.938 \AA \\ \text { ring O-P } & 1.752 \AA \\ \text { ring S-P } & 2.213 \AA \\ \text { S-P } & 2.020 \AA \\ \text { S-P-Oring } & 116.4^{\circ}\end{array}$

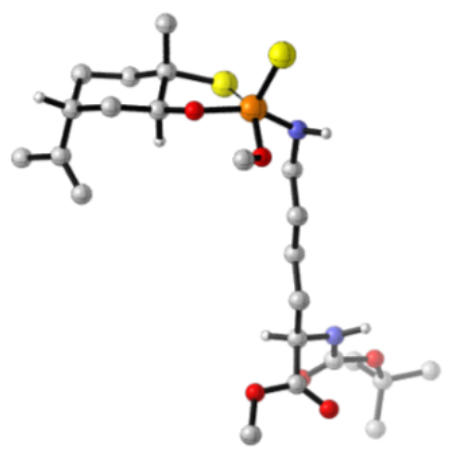

TS2-Lys

$\Delta G^{\ddagger}=+25.6 \mathrm{kcal} / \mathrm{mol}$

$\begin{array}{ll}\text { LysN-P } & 1.795 \AA \\ \text { ring O-P } & 1.735 \AA \\ \text { ring S-P } & 2.326 \AA \\ \text { S-P } & 2.013 \AA \\ \text { S-P-Oring } & 143.5^{\circ}\end{array}$

Figure S23. Transition structures for the formation and collapse of the Lys TBP intermediates

Note:

We also employed the polarizable continuum model (PCM) to evaluate the effect of solvation on the activation energies of transition structures TS1. These calculations use DMF as solvent $(\varepsilon=37.781)$ and consider the formation a hydrogen bond between DBU and the nucleophilic function of the amino acid along the reaction coordinate. Moreover, we included a diffused function for the estimation of the activation barrier of TS1-Cys and TS2-Cys, which involve anionic character. The results for the fully optimized geometries using the different methods are shown in the Table below. The inclusion of solvation or diffused functions promote limited changes in energies and do not change the relative energy profiles shown in Figure 5.

\begin{tabular}{|c|c|c|c|}
\hline $\begin{array}{c}\text { Transition } \\
\text { Structure }\end{array}$ & $\begin{array}{c}\Delta \Delta G^{\ddagger} 6-31 \mathrm{G}(\mathrm{d}) \\
(\mathrm{kcal} / \mathrm{mol})\end{array}$ & $\begin{array}{r}\Delta \Delta G^{\ddagger} \\
6-31 \mathrm{G}(\mathrm{d}) / \mathrm{PCM}, \\
(\mathrm{kcal} / \mathrm{mol})\end{array}$ & $\begin{array}{c}\Delta \Delta G^{\ddagger} 6-31+\mathrm{G}(\mathrm{d}) \\
(\mathrm{kcal} / \mathrm{mol})\end{array}$ \\
\hline TS1-Ser & 19.5 & 19.9 & --- \\
\hline TS1-Thr & 20.1 & 21.2 & --- \\
\hline TS1-Tyr & 24.5 & 23.0 & --- \\
\hline TS1-Lys & 28.8 & 26.6 & --- \\
\hline
\end{tabular}




\begin{tabular}{|c|c|c|c|}
\hline TS1-Cys & 10.3 & --- & 13.4 \\
\hline TS2-Cys & 22.2 & --- & 24.8 \\
\hline
\end{tabular}

\section{Cartesian Coordinates for Stationary Points}

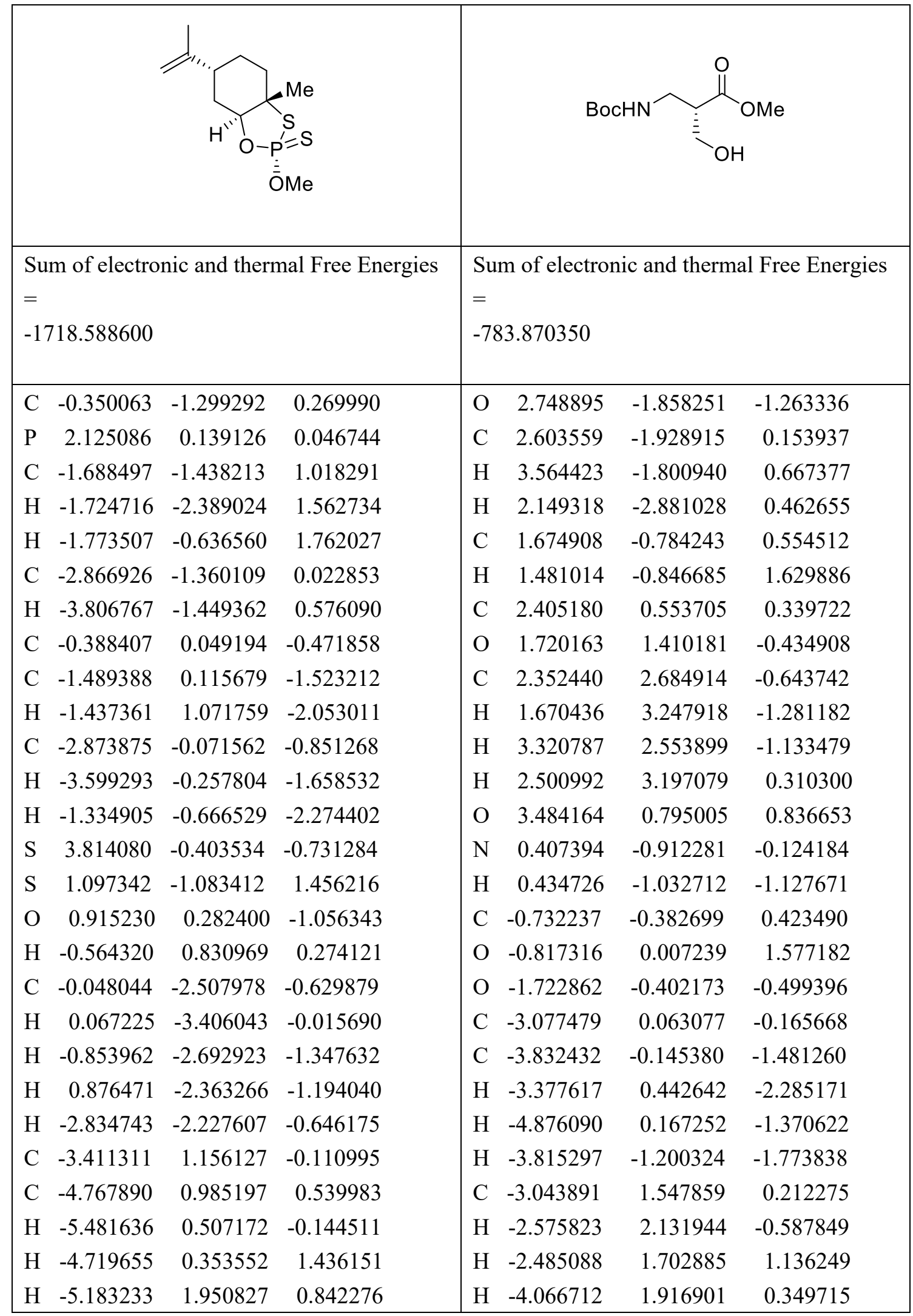




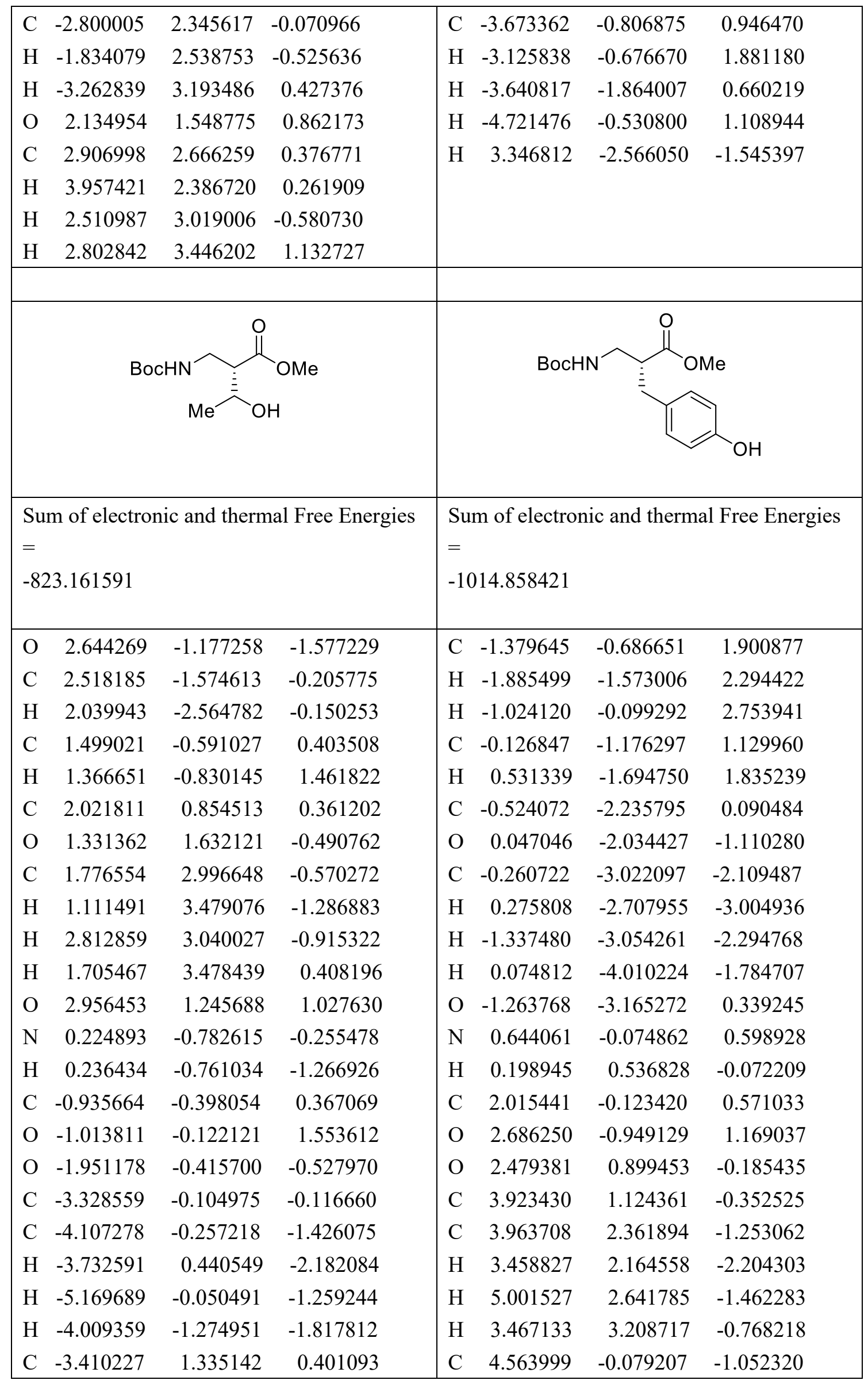




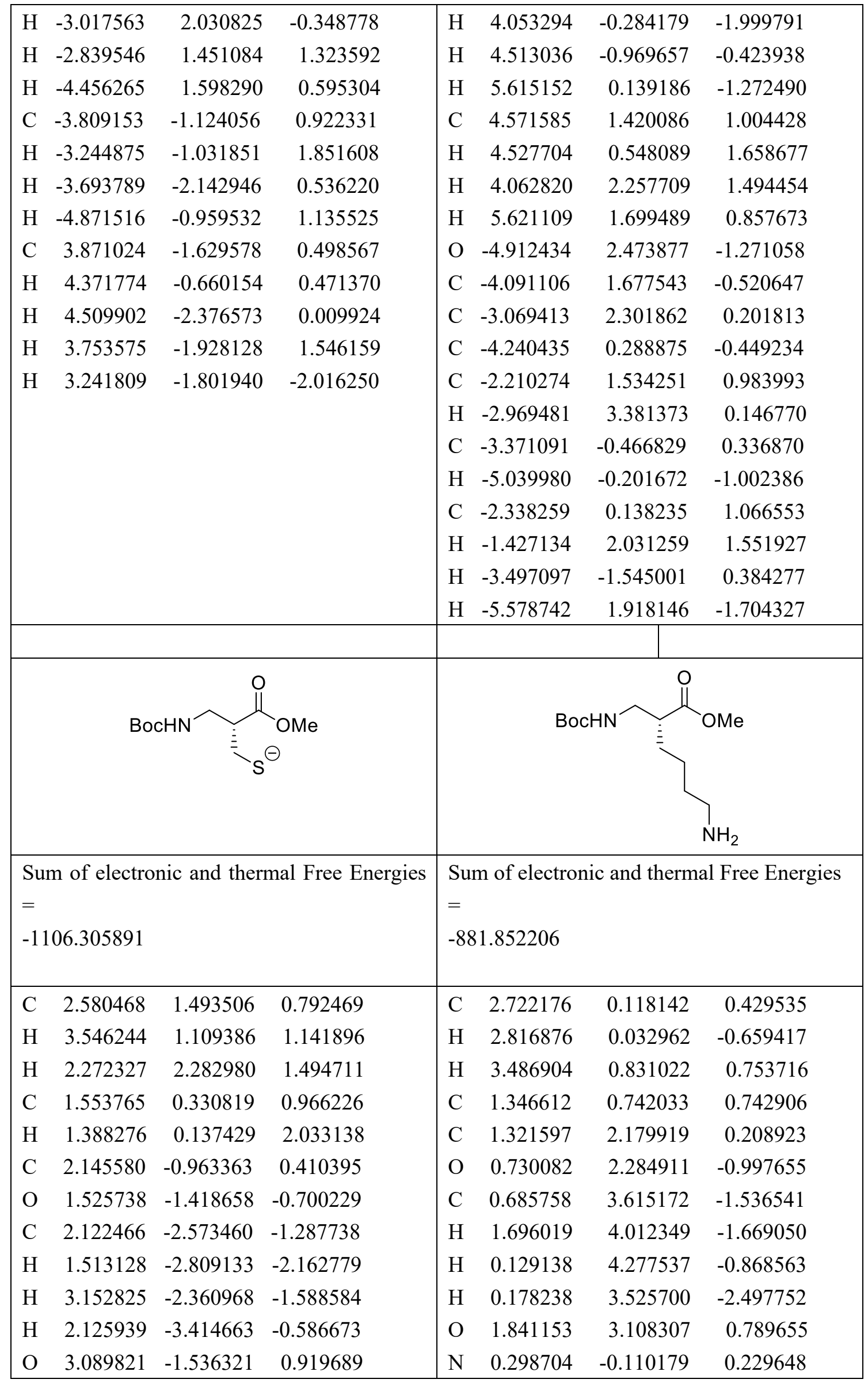




\begin{tabular}{|c|c|c|c|c|c|c|c|}
\hline $\mathrm{N}$ & 0.307144 & 0.729696 & 0.356538 & $\mathrm{H}$ & 0.547692 & -0.829938 & -0.457141 \\
\hline $\mathrm{H}$ & 0.452818 & 1.349505 & -0.452809 & $\mathrm{C}$ & -1.003004 & 0.164785 & 0.505396 \\
\hline $\mathrm{C}$ & -0.856177 & 0.095549 & 0.580786 & $\mathrm{O}$ & -1.373807 & 1.077336 & 1.231690 \\
\hline $\mathrm{O}$ & -1.048762 & -0.791485 & 1.409415 & $\mathrm{O}$ & -1.807286 & -0.729758 & -0.133676 \\
\hline $\mathrm{O}$ & -1.831448 & 0.615004 & -0.242687 & $\mathrm{C}$ & -3.264979 & -0.657515 & 0.002084 \\
\hline $\mathrm{C}$ & -3.185501 & 0.098612 & -0.201339 & $\mathrm{C}$ & -3.739997 & -1.824905 & -0.868513 \\
\hline $\mathrm{C}$ & -3.901450 & 0.938136 & -1.266630 & $\mathrm{H}$ & -3.414583 & -1.690713 & -1.905549 \\
\hline $\mathrm{H}$ & -3.427566 & 0.799767 & -2.244018 & $\mathrm{H}$ & -4.833255 & -1.888089 & -0.853790 \\
\hline $\mathrm{H}$ & -4.955392 & 0.645085 & -1.342022 & $\mathrm{H}$ & -3.333423 & -2.772277 & -0.498867 \\
\hline $\mathrm{H}$ & -3.850813 & 2.002177 & -1.012532 & $\mathrm{C}$ & -3.785110 & 0.674635 & -0.551187 \\
\hline $\mathrm{C}$ & -3.210851 & -1.387494 & -0.588147 & $\mathrm{H}$ & -3.442523 & 0.816326 & -1.582410 \\
\hline $\mathrm{H}$ & -2.729556 & -1.528943 & -1.562452 & $\mathrm{H}$ & -3.433932 & 1.510981 & 0.054766 \\
\hline $\mathrm{H}$ & -2.678404 & -1.983028 & 0.154564 & $\mathrm{H}$ & -4.881266 & 0.672175 & -0.553220 \\
\hline $\mathrm{H}$ & -4.247391 & -1.740820 & -0.661263 & $\mathrm{C}$ & -3.673358 & -0.873687 & 1.464107 \\
\hline $\mathrm{C}$ & -3.817179 & 0.337871 & 1.178267 & $\mathrm{H}$ & -3.315213 & -0.056289 & 2.091424 \\
\hline $\mathrm{H}$ & -3.292468 & -0.238047 & 1.941645 & $\mathrm{H}$ & -3.258611 & -1.816277 & 1.838980 \\
\hline $\mathrm{H}$ & -3.760093 & 1.401334 & 1.437621 & $\mathrm{H}$ & -4.765513 & -0.928584 & 1.540193 \\
\hline $\mathrm{H}$ & -4.874606 & 0.044274 & 1.164923 & $\mathrm{C}$ & 2.949068 & -1.260035 & 1.103508 \\
\hline \multirow[t]{12}{*}{ S } & 2.671576 & 2.126651 & -0.927898 & $\mathrm{H}$ & 2.026040 & -1.583529 & 1.600506 \\
\hline & & & & $\mathrm{H}$ & 3.694109 & -1.141617 & 1.898963 \\
\hline & & & & $\mathrm{C}$ & 3.418871 & -2.386133 & 0.160116 \\
\hline & & & & $\mathrm{H}$ & 4.146250 & -1.988425 & -0.563796 \\
\hline & & & & $\mathrm{H}$ & 3.963119 & -3.140306 & 0.743651 \\
\hline & & & & $\mathrm{C}$ & 2.304242 & -3.131521 & -0.585068 \\
\hline & & & & $\mathrm{H}$ & 1.606001 & -3.551413 & 0.149724 \\
\hline & & & & $\mathrm{H}$ & 2.749191 & -3.985360 & -1.123595 \\
\hline & & & & $\mathrm{N}$ & 1.518156 & -2.253472 & -1.471890 \\
\hline & & & & $\mathrm{H}$ & 0.767909 & -2.787758 & -1.908323 \\
\hline & & & & $\mathrm{H}$ & 1.235782 & 0.850066 & 1.828012 \\
\hline & & & & $\mathrm{H}$ & 2.104649 & -1.914689 & -2.234473 \\
\hline & & & & & & $\mathrm{H}$ & \\
\hline \multicolumn{4}{|c|}{$\begin{array}{l}\text { Sum of electronic and thermal Free Energies } \\
= \\
-461.877431\end{array}$} & \multicolumn{4}{|c|}{$\begin{array}{l}\text { Sum of electronic and thermal Free Energies } \\
= \\
-462.281041\end{array}$} \\
\hline $\mathrm{C}$ & -2.035798 & 0.078247 & 1.096104 & $\mathrm{C}$ & -2.086042 & 0.059416 & 1.097134 \\
\hline $\mathrm{C}$ & -2.131873 & -1.244033 & 0.315668 & $\mathrm{C}$ & -2.155407 & -1.257506 & 0.305920 \\
\hline $\mathrm{C}$ & -0.970868 & -1.523959 & -0.686206 & $\mathrm{C}$ & -0.976406 & -1.518666 & -0.688128 \\
\hline
\end{tabular}




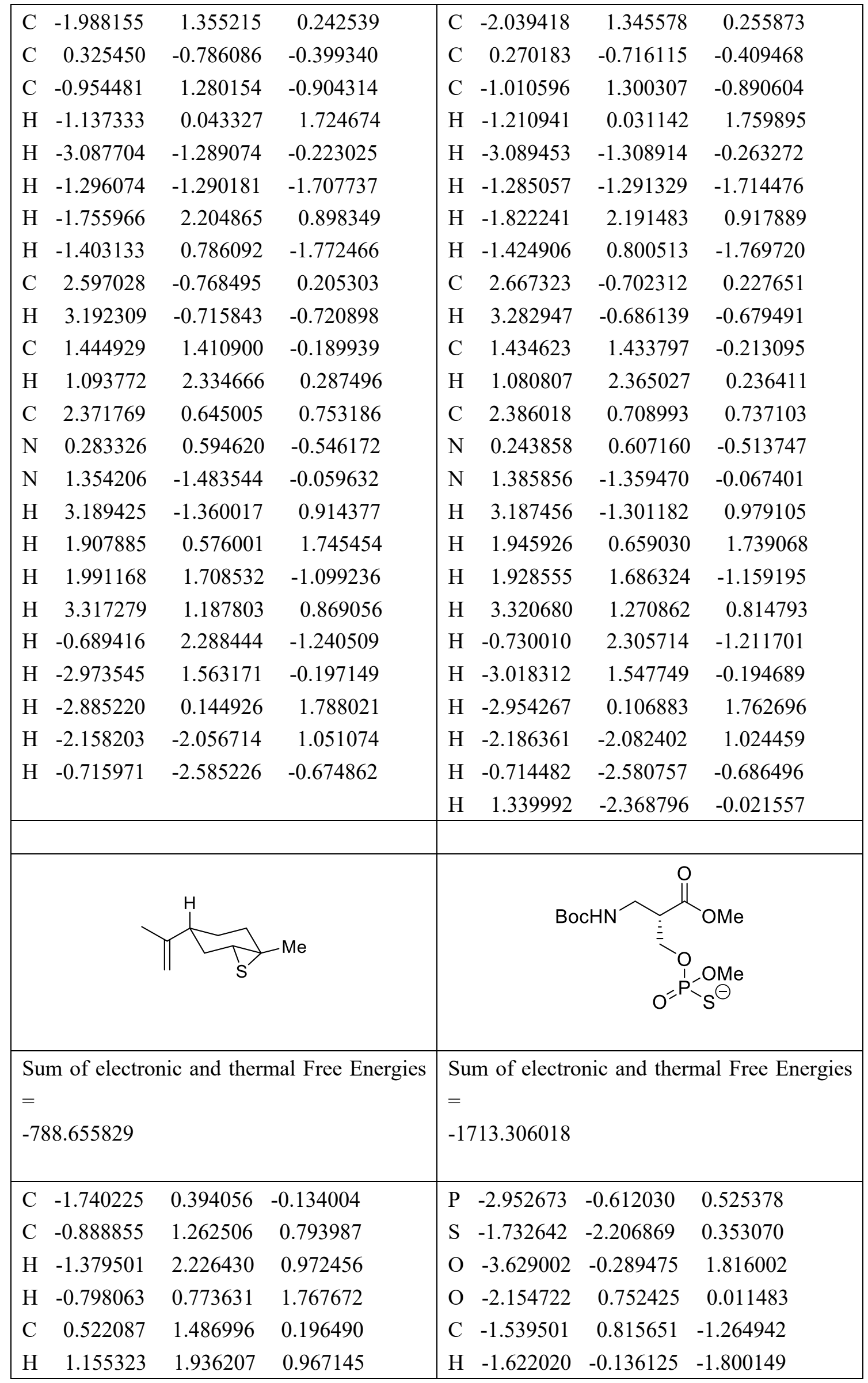




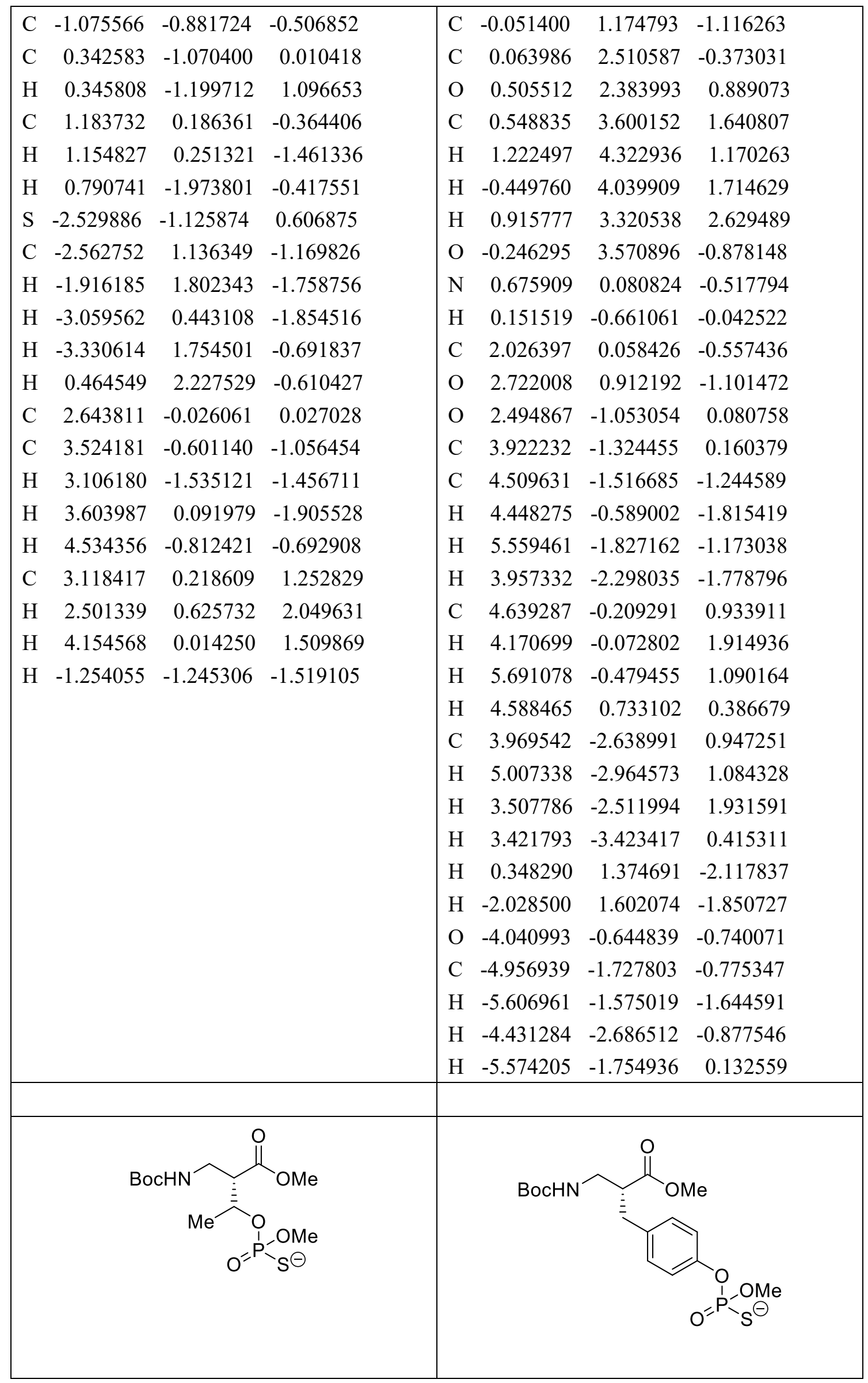




\begin{tabular}{|c|c|c|c|c|c|c|c|}
\hline \multicolumn{4}{|c|}{$\begin{array}{l}\text { Sum of electronic and thermal Free Energies } \\
= \\
-1752.598706\end{array}$} & \multicolumn{4}{|c|}{$\begin{array}{l}\text { Sum of electronic and thermal Free Energies } \\
= \\
-1944.288211\end{array}$} \\
\hline $\mathrm{P}$ & -2.975645 & -0.916926 & 0.440090 & $\mathrm{P}$ & -4.337129 & 0.944940 & -0.450768 \\
\hline S & -1.654227 & -1.937573 & 1.535845 & $\mathrm{~S}$ & -3.253584 & 0.580461 & -2.073885 \\
\hline $\mathrm{O}$ & -4.066280 & -0.098708 & 1.069708 & $\mathrm{O}$ & -5.829917 & 0.899435 & -0.407255 \\
\hline $\mathrm{O}$ & -2.119136 & 0.059523 & -0.636340 & $\mathrm{C}$ & 2.161233 & -2.007072 & 0.293153 \\
\hline $\mathrm{C}$ & -1.542268 & 1.255452 & -0.119661 & $\mathrm{C}$ & 1.259650 & -2.787118 & -0.662013 \\
\hline $\mathrm{C}$ & -0.082072 & 1.289175 & -0.642839 & $\mathrm{O}$ & 0.571232 & -1.964256 & -1.465387 \\
\hline $\mathrm{C}$ & 0.608419 & 2.592729 & -0.240368 & $\mathrm{C}$ & -0.524160 & -2.514923 & -2.227768 \\
\hline $\mathrm{O}$ & 1.092361 & 2.550045 & 1.020950 & $\mathrm{H}$ & -0.151367 & -2.866305 & -3.195004 \\
\hline $\mathrm{C}$ & 1.751731 & 3.742132 & 1.453981 & $\mathrm{H}$ & -0.974203 & -3.345061 & -1.681874 \\
\hline $\mathrm{H}$ & 2.607437 & 3.962131 & 0.808790 & $\mathrm{H}$ & -1.238091 & -1.698368 & -2.350622 \\
\hline $\mathrm{H}$ & 1.067505 & 4.596160 & 1.435581 & $\mathrm{O}$ & 1.134208 & -3.993438 & -0.619558 \\
\hline $\mathrm{H}$ & 2.083741 & 3.541125 & 2.473946 & $\mathrm{~N}$ & 2.493340 & -0.700918 & -0.247126 \\
\hline $\mathrm{O}$ & 0.654191 & 3.585086 & -0.936541 & $\mathrm{H}$ & 1.769342 & -0.190912 & -0.734716 \\
\hline $\mathrm{N}$ & 0.612380 & 0.113415 & -0.159325 & $\mathrm{C}$ & 3.642049 & -0.057989 & 0.089042 \\
\hline $\mathrm{H}$ & 0.075215 & -0.623281 & 0.311377 & $\mathrm{O}$ & 4.542794 & -0.540760 & 0.763616 \\
\hline $\mathrm{C}$ & 1.917624 & -0.075562 & -0.447581 & $\mathrm{O}$ & 3.632588 & 1.191662 & -0.454299 \\
\hline $\mathrm{O}$ & 2.619186 & 0.727740 & -1.059489 & $\mathrm{C}$ & 4.756053 & 2.107325 & -0.259241 \\
\hline $\mathrm{O}$ & 2.339584 & -1.273543 & 0.048077 & $\mathrm{C}$ & 4.929735 & 2.424449 & 1.231509 \\
\hline $\mathrm{C}$ & 3.717049 & -1.711438 & -0.118751 & $\mathrm{H}$ & 5.226751 & 1.533236 & 1.786444 \\
\hline $\mathrm{C}$ & 4.049960 & -1.875274 & -1.608185 & $\mathrm{H}$ & 5.697053 & 3.197135 & 1.360126 \\
\hline $\mathrm{H}$ & 4.018914 & -0.911191 & -2.118202 & $\mathrm{H}$ & 3.990478 & 2.804461 & 1.648478 \\
\hline $\mathrm{H}$ & 5.050338 & -2.310740 & -1.722841 & $\mathrm{C}$ & 6.031951 & 1.521688 & -0.876859 \\
\hline $\mathrm{H}$ & 3.326919 & -2.548759 & -2.081788 & $\mathrm{H}$ & 5.862910 & 1.276489 & -1.931406 \\
\hline $\mathrm{C}$ & 4.677921 & -0.740135 & 0.580726 & $\mathrm{H}$ & 6.842231 & 2.258578 & -0.823403 \\
\hline $\mathrm{H}$ & 4.394527 & -0.624800 & 1.632972 & $\mathrm{H}$ & 6.337501 & 0.617296 & -0.348697 \\
\hline $\mathrm{H}$ & 5.701264 & -1.133745 & 0.542199 & $\mathrm{C}$ & 4.307307 & 3.354709 & -1.027110 \\
\hline $\mathrm{H}$ & 4.652217 & 0.238915 & 0.100023 & $\mathrm{H}$ & 5.072969 & 4.135748 & -0.961190 \\
\hline $\mathrm{C}$ & 3.722844 & -3.072715 & 0.585582 & $\mathrm{H}$ & 4.140616 & 3.117695 & -2.082916 \\
\hline $\mathrm{H}$ & 4.720219 & -3.524916 & 0.532698 & $\mathrm{H}$ & 3.372312 & 3.746492 & -0.613964 \\
\hline $\mathrm{H}$ & 3.442550 & -2.960192 & 1.637755 & $\mathrm{H}$ & 3.094367 & -2.561957 & 0.412543 \\
\hline $\mathrm{H}$ & 3.003254 & -3.749856 & 0.114730 & $\mathrm{O}$ & -3.787470 & 2.395758 & 0.165532 \\
\hline $\mathrm{H}$ & -0.111952 & 1.304718 & -1.739135 & $\mathrm{C}$ & -4.529939 & 2.944374 & 1.250700 \\
\hline $\mathrm{H}$ & -1.500421 & 1.215043 & 0.976750 & $\mathrm{H}$ & -4.133175 & 3.949326 & 1.433810 \\
\hline $\mathrm{O}$ & -3.569870 & -1.948031 & -0.704246 & $\mathrm{H}$ & -5.595891 & 3.001933 & 1.007626 \\
\hline $\mathrm{C}$ & -4.592173 & -1.447476 & -1.560223 & $\mathrm{H}$ & -4.409610 & 2.340161 & 2.160782 \\
\hline $\mathrm{H}$ & -5.023420 & -2.309008 & -2.082049 & $\mathrm{C}$ & 1.455763 & -1.929400 & 1.690874 \\
\hline $\mathrm{H}$ & -5.371844 & -0.935115 & -0.985770 & $\mathrm{O}$ & -3.856369 & -0.089780 & 0.828810 \\
\hline $\mathrm{H}$ & -4.177423 & -0.749483 & -2.299551 & $\mathrm{C}$ & -2.575902 & -0.470972 & 1.082790 \\
\hline
\end{tabular}




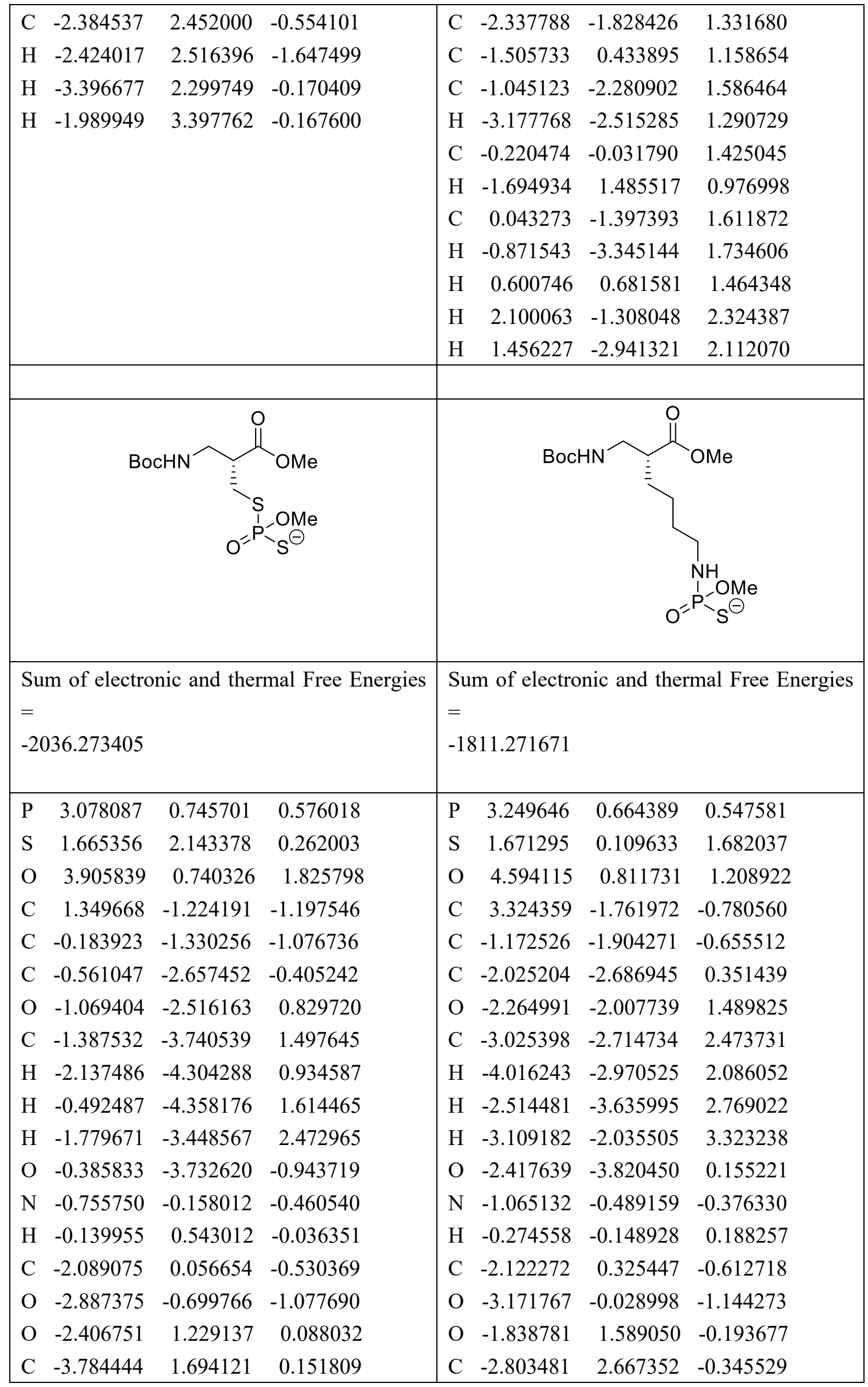




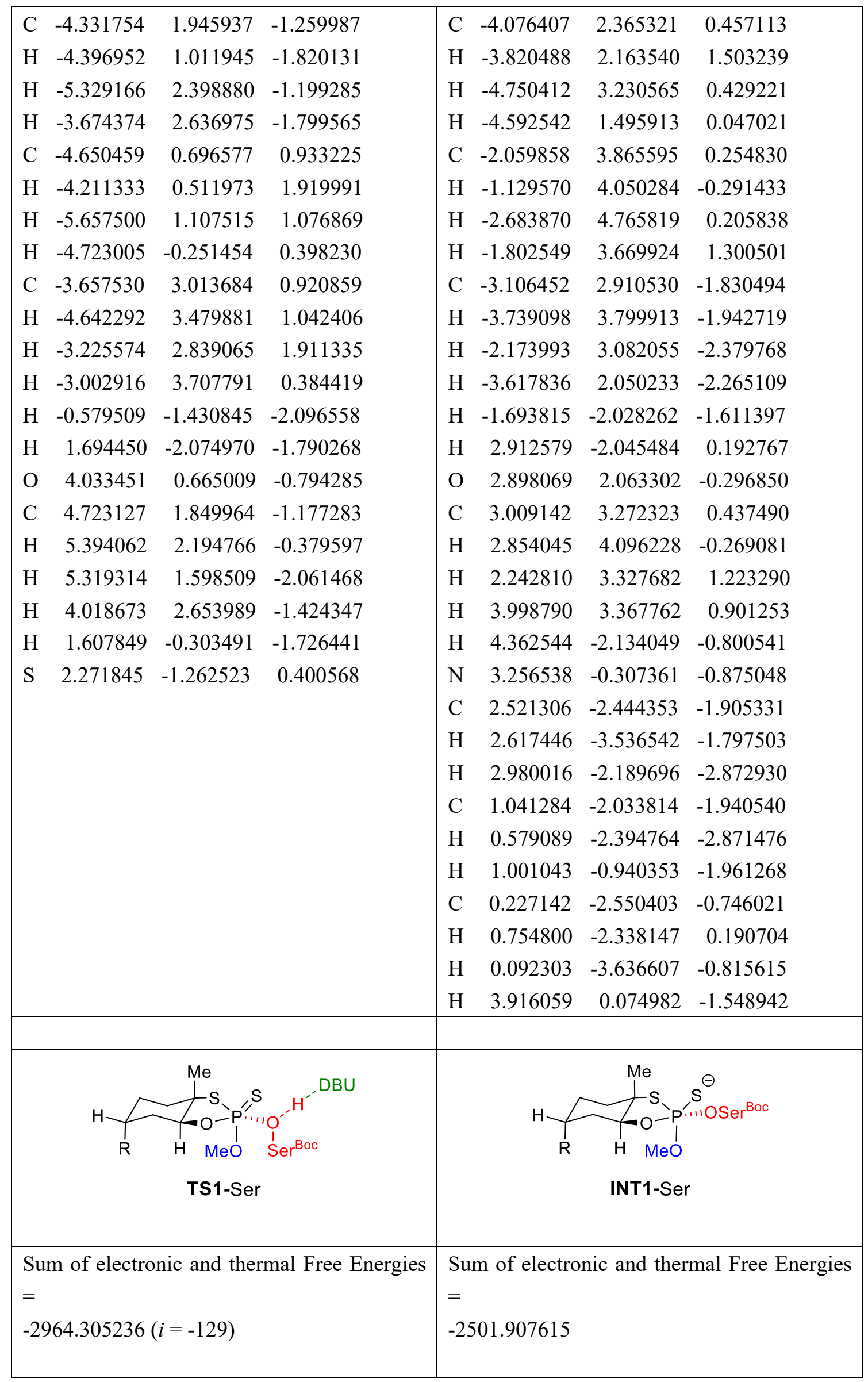




\begin{tabular}{|c|c|c|c|c|c|c|c|}
\hline $\mathrm{C}$ & -3.946061 & 1.081143 & -0.112206 & $\mathrm{C}$ & 3.622963 & -0.722455 & -0.868583 \\
\hline $\mathrm{P}$ & -1.321820 & 0.203909 & 0.896824 & $\mathrm{P}$ & 1.060134 & -0.399643 & 0.742350 \\
\hline $\mathrm{C}$ & -5.100351 & 0.728818 & -1.067541 & $\mathrm{C}$ & 4.558028 & -0.096752 & -1.918101 \\
\hline $\mathrm{H}$ & -5.174688 & 1.467423 & -1.875683 & $\mathrm{H}$ & 4.544989 & -0.679080 & -2.849272 \\
\hline $\mathrm{H}$ & -4.897414 & -0.241571 & -1.537743 & $\mathrm{H}$ & 4.196293 & 0.909368 & -2.166514 \\
\hline $\mathrm{C}$ & -6.436768 & 0.669549 & -0.296205 & $\mathrm{C}$ & 6.002121 & -0.017310 & -1.382586 \\
\hline $\mathrm{H}$ & -7.241666 & 0.401307 & -0.988348 & $\mathrm{H}$ & 6.652277 & 0.438506 & -2.138919 \\
\hline $\mathrm{C}$ & -3.917072 & 0.004706 & 0.988008 & $\mathrm{C}$ & 3.686007 & 0.155682 & 0.398651 \\
\hline $\mathrm{C}$ & -5.195703 & -0.012768 & 1.821227 & $\mathrm{C}$ & 5.099098 & 0.200117 & 0.991824 \\
\hline $\mathrm{H}$ & -5.110025 & -0.761038 & 2.615854 & $\mathrm{H}$ & 5.099701 & 0.809681 & 1.902514 \\
\hline $\mathrm{C}$ & -6.426047 & -0.301070 & 0.923324 & $\mathrm{C}$ & 6.135233 & 0.740379 & -0.025867 \\
\hline $\mathrm{H}$ & -7.322444 & -0.051031 & 1.513312 & $\mathrm{H}$ & 7.137248 & 0.487419 & 0.361301 \\
\hline $\mathrm{H}$ & -5.324786 & 0.954370 & 2.319838 & $\mathrm{H}$ & 5.389529 & -0.810627 & 1.301136 \\
\hline $\mathrm{C}$ & 2.269974 & 2.824217 & -0.802641 & $S$ & 0.536713 & -1.938202 & 1.948373 \\
\hline $\mathrm{C}$ & 3.308629 & 1.183654 & 0.666179 & $\mathrm{~S}$ & 1.842234 & -0.586375 & -1.322331 \\
\hline $\mathrm{C}$ & 1.113024 & 3.158506 & -1.714435 & $\mathrm{O}$ & 2.754247 & -0.328993 & 1.323291 \\
\hline $\mathrm{H}$ & 4.154384 & 0.687904 & 0.173824 & $\mathrm{H}$ & 3.418491 & 1.177180 & 0.079675 \\
\hline $\mathrm{C}$ & 3.762347 & 2.387893 & 1.484717 & $\mathrm{C}$ & 3.947873 & -2.202972 & -0.596423 \\
\hline $\mathrm{C}$ & 0.164716 & 4.232521 & -1.134337 & $\mathrm{H}$ & 3.773022 & -2.794308 & -1.502591 \\
\hline $\mathrm{H}$ & 1.492414 & 3.474956 & -2.696056 & $\mathrm{H}$ & 4.990217 & -2.361214 & -0.289528 \\
\hline $\mathrm{C}$ & 3.147746 & 5.118385 & -1.076192 & $\mathrm{H}$ & 3.299878 & -2.585261 & 0.196027 \\
\hline $\mathrm{H}$ & 4.592946 & 2.118997 & 2.145456 & $\mathrm{H}$ & 6.386976 & -1.034045 & -1.236854 \\
\hline $\mathrm{C}$ & 1.982685 & 6.008081 & -0.616794 & $\mathrm{C}$ & 6.165677 & 2.261200 & -0.190448 \\
\hline $\mathrm{H}$ & 3.145149 & 5.023750 & -2.169238 & $\mathrm{C}$ & 7.242031 & 2.800092 & -1.110930 \\
\hline $\mathrm{C}$ & 4.195261 & 3.515649 & 0.551604 & $\mathrm{H}$ & 8.217616 & 2.340550 & -0.897761 \\
\hline $\mathrm{N}$ & 2.335646 & 1.603526 & -0.338545 & $\mathrm{H}$ & 7.022675 & 2.592088 & -2.166057 \\
\hline $\mathrm{N}$ & 3.164498 & 3.780308 & -0.466179 & $\mathrm{H}$ & 7.346279 & 3.884859 & -1.005042 \\
\hline $\mathrm{H}$ & 0.555285 & 2.230112 & -1.854980 & $\mathrm{C}$ & 5.367470 & 3.115294 & 0.460084 \\
\hline $\mathrm{H}$ & -0.798198 & 4.123208 & -1.645432 & $\mathrm{H}$ & 4.574073 & 2.794925 & 1.125910 \\
\hline $\mathrm{H}$ & 4.101692 & 5.582600 & -0.810916 & $\mathrm{H}$ & 5.477361 & 4.190313 & 0.332284 \\
\hline $\mathrm{H}$ & 5.144753 & 3.269728 & 0.054384 & $\mathrm{O}$ & -0.399695 & -0.193965 & -0.204438 \\
\hline $\mathrm{H}$ & 4.350567 & 4.441161 & 1.116274 & $\mathrm{C}$ & -1.633856 & 0.063516 & 0.402421 \\
\hline $\mathrm{H}$ & 2.928905 & 2.725277 & 2.110707 & $\mathrm{H}$ & -1.651710 & -0.261667 & 1.450380 \\
\hline $\mathrm{H}$ & 2.805728 & 0.447422 & 1.297014 & $\mathrm{C}$ & -2.751332 & -0.692400 & -0.369597 \\
\hline $\mathrm{S}$ & -0.108081 & 1.259321 & 2.048042 & $\mathrm{C}$ & -2.614776 & -2.197247 & -0.176399 \\
\hline $\mathrm{S}$ & -2.265405 & 0.879684 & -0.902702 & $\mathrm{O}$ & -1.696367 & -2.724087 & -0.987497 \\
\hline $\mathrm{O}$ & -2.759913 & 0.228369 & 1.791654 & $\mathrm{C}$ & -1.289106 & -4.068118 & -0.681624 \\
\hline $\mathrm{H}$ & -3.818439 & -0.966563 & 0.486681 & $\mathrm{H}$ & -0.610856 & -4.352529 & -1.487016 \\
\hline $\mathrm{C}$ & -4.045408 & 2.517024 & 0.430665 & $\mathrm{H}$ & -0.762885 & -4.066370 & 0.276413 \\
\hline $\mathrm{H}$ & -3.929225 & 3.233925 & -0.389345 & $\mathrm{H}$ & -2.154631 & -4.736284 & -0.645269 \\
\hline $\mathrm{H}$ & -5.009688 & 2.715126 & 0.911577 & $\mathrm{O}$ & -3.271373 & -2.828801 & 0.633467 \\
\hline $\mathrm{H}$ & -3.258307 & 2.704222 & 1.165181 & $\mathrm{~N}$ & -4.068303 & -0.318324 & 0.122431 \\
\hline
\end{tabular}




\begin{tabular}{|c|c|c|c|c|c|c|c|}
\hline $\mathrm{H}$ & -6.685805 & 1.672125 & 0.070708 & $\mathrm{H}$ & -4.472464 & -0.933264 & 0.817608 \\
\hline $\mathrm{C}$ & -6.617508 & -1.766908 & 0.526181 & $\mathrm{C}$ & -4.840715 & 0.629965 & -0.456935 \\
\hline $\mathrm{C}$ & -7.844599 & -2.063706 & -0.310676 & $\mathrm{O}$ & -4.510055 & 1.346247 & -1.391516 \\
\hline $\mathrm{H}$ & -8.737745 & -1.574948 & 0.102108 & $\mathrm{O}$ & -6.058180 & 0.664761 & 0.175625 \\
\hline $\mathrm{H}$ & -7.738108 & -1.703566 & -1.341962 & $\mathrm{C}$ & -7.079241 & 1.620693 & -0.235030 \\
\hline $\mathrm{H}$ & -8.038142 & -3.139513 & -0.357883 & $\mathrm{C}$ & -8.232615 & 1.315401 & 0.727201 \\
\hline $\mathrm{C}$ & -5.826918 & -2.770920 & 0.922413 & $\mathrm{H}$ & -7.916727 & 1.463887 & 1.765136 \\
\hline $\mathrm{H}$ & -4.937297 & -2.627329 & 1.525908 & $\mathrm{H}$ & -9.083067 & 1.975810 & 0.523309 \\
\hline $\mathrm{H}$ & -6.051238 & -3.798959 & 0.648386 & $\mathrm{H}$ & -8.562440 & 0.277121 & 0.615008 \\
\hline $\mathrm{O}$ & 0.294570 & 0.132038 & -0.740033 & $\mathrm{C}$ & -6.581241 & 3.058488 & -0.035305 \\
\hline $\mathrm{C}$ & 0.396616 & -0.881190 & -1.681908 & $\mathrm{H}$ & -5.743932 & 3.273260 & -0.700559 \\
\hline $\mathrm{H}$ & -0.596602 & -1.248776 & -1.979620 & $\mathrm{H}$ & -7.393787 & 3.766140 & -0.240504 \\
\hline $\mathrm{C}$ & 1.205791 & -2.123196 & -1.195215 & $\mathrm{H}$ & -6.254499 & 3.203921 & 1.000520 \\
\hline $\mathrm{C}$ & 1.176806 & -3.197038 & -2.274833 & $\mathrm{C}$ & -7.507118 & 1.357768 & -1.685364 \\
\hline $\mathrm{O}$ & -0.008865 & -3.835715 & -2.312829 & $\mathrm{H}$ & -6.679819 & 1.548099 & -2.370344 \\
\hline $\mathrm{C}$ & -0.153616 & -4.810869 & -3.358015 & $\mathrm{H}$ & -7.829210 & 0.316503 & -1.800978 \\
\hline $\mathrm{H}$ & -1.160457 & -5.213530 & -3.244216 & $\mathrm{H}$ & -8.349973 & 2.007720 & -1.950379 \\
\hline $\mathrm{H}$ & -0.034549 & -4.343742 & -4.339373 & $\mathrm{H}$ & -2.670599 & -0.436075 & -1.428478 \\
\hline $\mathrm{H}$ & 0.592080 & -5.603050 & -3.249346 & $\mathrm{H}$ & -1.880271 & 1.134450 & 0.358490 \\
\hline $\mathrm{O}$ & 2.086397 & -3.419055 & -3.050697 & $\mathrm{O}$ & 0.770790 & 1.150031 & 1.343395 \\
\hline $\mathrm{N}$ & 2.591585 & -1.801352 & -0.889263 & $\mathrm{C}$ & 1.345052 & 1.565751 & 2.573793 \\
\hline $\mathrm{H}$ & 3.204197 & -1.738861 & -1.694330 & $\mathrm{H}$ & 1.337730 & 0.757548 & 3.313637 \\
\hline $\mathrm{C}$ & 3.187811 & -2.277833 & 0.249086 & $\mathrm{H}$ & 2.376243 & 1.917618 & 2.449130 \\
\hline $\mathrm{O}$ & 2.599492 & -2.720307 & 1.223013 & $\mathrm{H}$ & 0.725008 & 2.395828 & 2.935359 \\
\hline $\mathrm{O}$ & 4.538267 & -2.131254 & 0.136871 & & & & \\
\hline $\mathrm{C}$ & 5.441983 & -2.649076 & 1.172924 & & & & \\
\hline $\mathrm{C}$ & 6.824790 & -2.324954 & 0.600041 & & & & \\
\hline $\mathrm{H}$ & 6.939150 & -1.245791 & 0.451914 & & & & \\
\hline $\mathrm{H}$ & 7.607159 & -2.664607 & 1.287012 & & & & \\
\hline $\mathrm{H}$ & 6.969524 & -2.821621 & -0.364780 & & & & \\
\hline $\mathrm{C}$ & 5.217175 & -1.911572 & 2.497820 & & & & \\
\hline $\mathrm{H}$ & 4.218213 & -2.107395 & 2.889437 & & & & \\
\hline $\mathrm{H}$ & 5.958965 & -2.241673 & 3.234199 & & & & \\
\hline $\mathrm{H}$ & 5.338499 & -0.831069 & 2.358718 & & & & \\
\hline $\mathrm{C}$ & 5.261342 & -4.164534 & 1.319295 & & & & \\
\hline $\mathrm{H}$ & 4.273308 & -4.405161 & 1.714622 & & & & \\
\hline $\mathrm{H}$ & 5.384820 & -4.656726 & 0.348289 & & & & \\
\hline $\mathrm{H}$ & 6.020951 & -4.562220 & 2.001864 & & & & \\
\hline $\mathrm{H}$ & 1.469513 & 0.914928 & -0.523291 & & & & \\
\hline $\mathrm{C}$ & 0.647743 & 5.679647 & -1.299349 & & & & \\
\hline $\mathrm{H}$ & 0.742514 & 5.901608 & -2.373323 & & & & \\
\hline $\mathrm{H}$ & -0.123074 & 6.359480 & -0.915070 & & & & \\
\hline
\end{tabular}




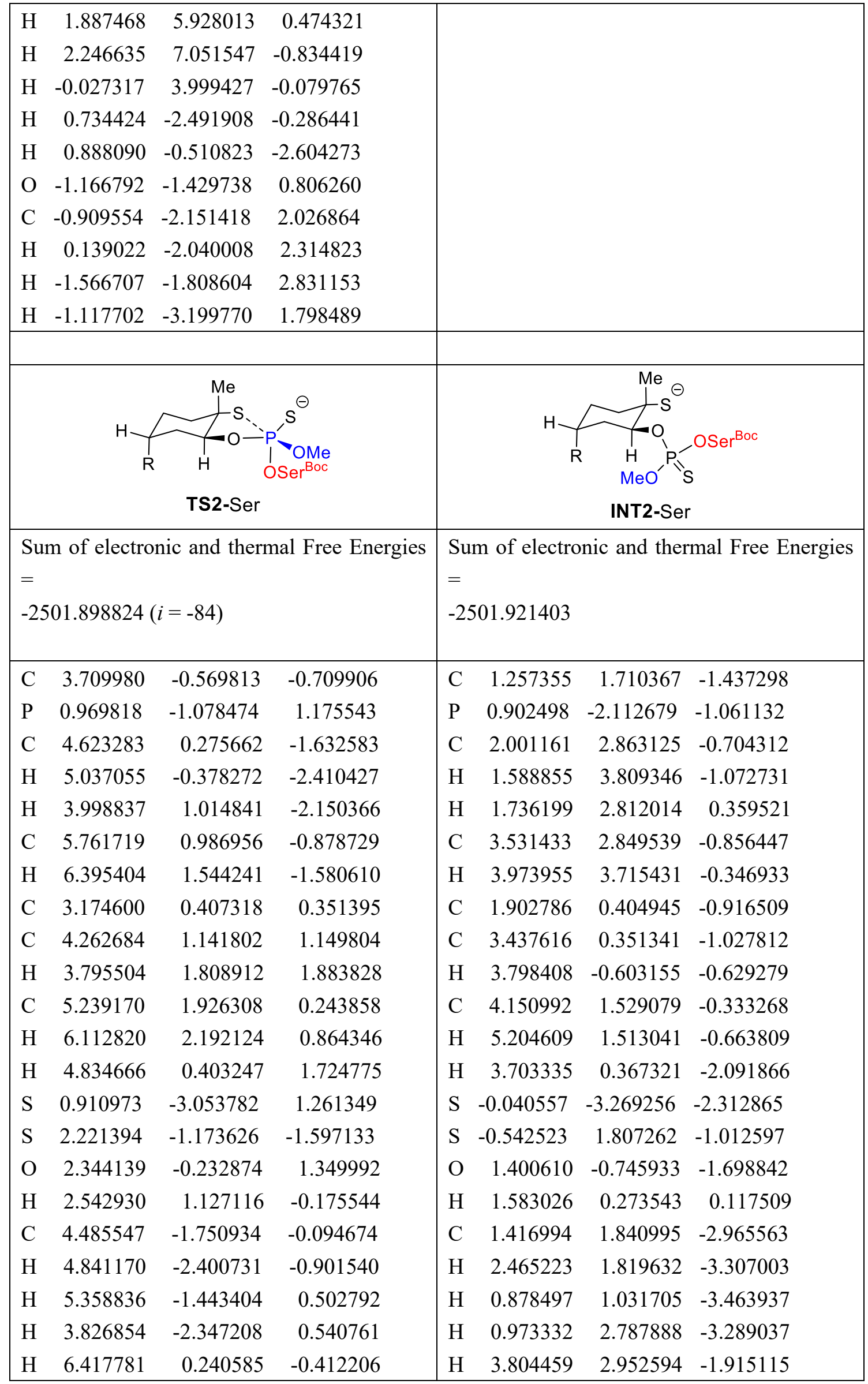




\begin{tabular}{|c|c|c|c|c|c|c|c|}
\hline $\mathrm{C}$ & 4.717981 & 3.264378 & -0.279907 & $\mathrm{C}$ & 4.222621 & 1.442833 & 1.191181 \\
\hline $\mathrm{C}$ & 5.697260 & 4.068312 & -1.109880 & $\mathrm{C}$ & 4.893443 & 2.610962 & 1.882286 \\
\hline $\mathrm{H}$ & 6.681459 & 4.125173 & -0.623210 & $\mathrm{H}$ & 5.844441 & 2.871107 & 1.396121 \\
\hline $\mathrm{H}$ & 5.862204 & 3.617160 & -2.096494 & $\mathrm{H}$ & 4.268946 & 3.512581 & 1.850211 \\
\hline $\mathrm{H}$ & 5.336317 & 5.089749 & -1.269403 & $\mathrm{H}$ & 5.098521 & 2.385353 & 2.934077 \\
\hline $\mathrm{C}$ & 3.511162 & 3.772353 & -0.004942 & $\mathrm{C}$ & 3.801697 & 0.396683 & 1.912509 \\
\hline $\mathrm{H}$ & 2.763738 & 3.242967 & 0.575334 & $\mathrm{H}$ & 3.309428 & -0.467672 & 1.480269 \\
\hline $\mathrm{H}$ & 3.219765 & 4.753247 & -0.375001 & $\mathrm{H}$ & 3.937317 & 0.375477 & 2.992348 \\
\hline $\mathrm{O}$ & -0.124112 & -0.251046 & 0.284721 & $\mathrm{O}$ & 0.160833 & -1.687967 & 0.299745 \\
\hline $\mathrm{C}$ & -1.514167 & -0.330561 & 0.608111 & $\mathrm{C}$ & -1.015258 & -2.327731 & 0.824833 \\
\hline $\mathrm{H}$ & -1.726087 & -1.146790 & 1.304753 & $\mathrm{H}$ & -1.696608 & -2.585035 & 0.010891 \\
\hline $\mathrm{C}$ & -2.342325 & -0.528785 & -0.685644 & $\mathrm{C}$ & -1.692081 & -1.330627 & 1.771946 \\
\hline $\mathrm{C}$ & -2.134815 & -1.926568 & -1.270133 & $\mathrm{C}$ & -0.765133 & -1.061580 & 2.962462 \\
\hline $\mathrm{O}$ & -0.996032 & -2.005403 & -1.936059 & $\mathrm{O}$ & -0.595993 & 0.244212 & 3.217954 \\
\hline $\mathrm{C}$ & -0.546855 & -3.314790 & -2.339345 & $\mathrm{C}$ & 0.301785 & 0.549982 & 4.291007 \\
\hline $\mathrm{H}$ & 0.511302 & -3.184328 & -2.562992 & $\mathrm{H}$ & 0.292783 & 1.637153 & 4.375340 \\
\hline $\mathrm{H}$ & -0.677511 & -4.019151 & -1.516816 & $\mathrm{H}$ & -0.033808 & 0.084961 & 5.222850 \\
\hline $\mathrm{H}$ & -1.115980 & -3.644912 & -3.215130 & $\mathrm{H}$ & 1.309461 & 0.195136 & 4.057130 \\
\hline $\mathrm{O}$ & -2.929699 & -2.837719 & -1.102168 & $\mathrm{O}$ & -0.249158 & -1.950376 & 3.611818 \\
\hline $\mathrm{N}$ & -3.759062 & -0.411015 & -0.385549 & $\mathrm{~N}$ & -2.163572 & -0.145194 & 1.108166 \\
\hline $\mathrm{H}$ & -4.275318 & -1.281332 & -0.343373 & $\mathrm{H}$ & -1.494996 & 0.472985 & 0.600715 \\
\hline $\mathrm{C}$ & -4.411663 & 0.774366 & -0.315575 & $\mathrm{C}$ & -3.480792 & -0.047709 & 0.783788 \\
\hline $\mathrm{O}$ & -3.889257 & 1.874347 & -0.426409 & $\mathrm{O}$ & -4.337341 & -0.894610 & 1.034492 \\
\hline $\mathrm{O}$ & -5.742912 & 0.542108 & -0.098862 & $\mathrm{O}$ & -3.709156 & 1.144957 & 0.181558 \\
\hline $\mathrm{C}$ & -6.676600 & 1.654430 & 0.056134 & $\mathrm{C}$ & -4.819790 & 1.326044 & -0.745906 \\
\hline $\mathrm{C}$ & -8.012513 & 0.939949 & 0.287555 & $\mathrm{C}$ & -4.761816 & 0.250597 & -1.837837 \\
\hline $\mathrm{H}$ & -7.961414 & 0.309154 & 1.181203 & $\mathrm{H}$ & -4.946325 & -0.742171 & -1.419556 \\
\hline $\mathrm{H}$ & -8.816600 & 1.671895 & 0.422930 & $\mathrm{H}$ & -5.520482 & 0.452884 & -2.603779 \\
\hline $\mathrm{H}$ & -8.261348 & 0.302910 & -0.567726 & $\mathrm{H}$ & -3.774596 & 0.259335 & -2.311595 \\
\hline $\mathrm{C}$ & -6.300488 & 2.500736 & 1.279216 & $\mathrm{C}$ & -6.154491 & 1.315428 & 0.010875 \\
\hline $\mathrm{H}$ & -5.337831 & 2.991566 & 1.129281 & $\mathrm{H}$ & -6.140600 & 2.068623 & 0.807219 \\
\hline $\mathrm{H}$ & -7.067799 & 3.264560 & 1.453663 & $\mathrm{H}$ & -6.976161 & 1.558118 & -0.675109 \\
\hline $\mathrm{H}$ & -6.238944 & 1.868268 & 2.172003 & $\mathrm{H}$ & -6.334556 & 0.337018 & 0.459200 \\
\hline $\mathrm{C}$ & -6.729116 & 2.490977 & -1.228742 & $\mathrm{C}$ & -4.530541 & 2.708766 & -1.339208 \\
\hline $\mathrm{H}$ & -5.771180 & 2.980189 & -1.409894 & $\mathrm{H}$ & -5.284278 & 2.963317 & -2.094416 \\
\hline $\mathrm{H}$ & -6.967249 & 1.851658 & -2.086401 & $\mathrm{H}$ & -4.552635 & 3.471988 & -0.553532 \\
\hline $\mathrm{H}$ & -7.511458 & 3.254882 & -1.144394 & $\mathrm{H}$ & -3.535301 & 2.720161 & -1.794623 \\
\hline $\mathrm{H}$ & -2.039392 & 0.230762 & -1.411072 & $\mathrm{H}$ & -2.574388 & -1.843406 & 2.174514 \\
\hline $\mathrm{H}$ & -1.825722 & 0.613857 & 1.064806 & $\mathrm{H}$ & -0.718252 & -3.228295 & 1.370012 \\
\hline $\mathrm{O}$ & 0.338135 & -0.541973 & 2.632149 & $\mathrm{O}$ & 2.228869 & -2.798615 & -0.379569 \\
\hline $\mathrm{C}$ & 0.911056 & -0.969801 & 3.856041 & $\mathrm{C}$ & 3.180032 & -3.461987 & -1.216748 \\
\hline $\mathrm{H}$ & 0.922696 & -2.064369 & 3.925790 & $\mathrm{H}$ & 3.954840 & -3.851403 & -0.551519 \\
\hline
\end{tabular}




\begin{tabular}{|c|c|c|c|c|c|c|c|}
\hline $\begin{array}{l}\mathrm{H} \\
\mathrm{H}\end{array}$ & $\begin{array}{l}1.935540 \\
0.289762\end{array}$ & \multicolumn{2}{|c|}{$\begin{array}{ll}-0.590623 & 3.965791 \\
-0.558483 & 4.659535 \\
\end{array}$} & $\begin{array}{l}\mathrm{H} \\
\mathrm{H} \\
\end{array}$ & $\begin{array}{l}2.706082 \\
3.630690 \\
\end{array}$ & $\begin{array}{l}-4.284624 \\
-2.764150 \\
\end{array}$ & $\begin{array}{l}-1.762101 \\
-1.931900 \\
\end{array}$ \\
\hline \multicolumn{4}{|c|}{ 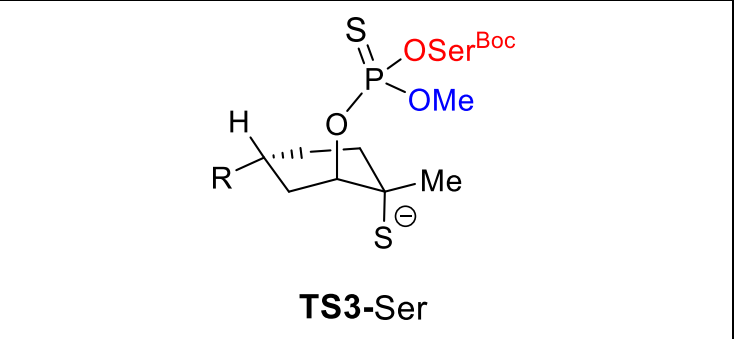 } & \multicolumn{4}{|c|}{ SI, OSer ${ }^{\mathrm{Boc}}$} \\
\hline \multicolumn{4}{|c|}{$\begin{array}{l}\text { Sum of electronic and thermal Free Energies } \\
= \\
-2501.912628(i=-178)\end{array}$} & \multicolumn{4}{|c|}{$\begin{array}{l}\text { Sum of electronic and thermal Free Energies } \\
= \\
-2501.934011\end{array}$} \\
\hline $\mathrm{C}$ & -1.658327 & -1.711985 & -0.621405 & $\mathrm{C}$ & -1.674568 & -1.859223 & -0.448552 \\
\hline $\mathrm{P}$ & -1.126725 & 2.088612 & -0.579697 & $\mathrm{P}$ & -1.141858 & 1.949096 & -0.549603 \\
\hline $\mathrm{C}$ & -2.634865 & -1.985190 & -1.800957 & $\mathrm{C}$ & -2.691647 & -2.237934 & -1.551344 \\
\hline $\mathrm{H}$ & -2.166329 & -1.616689 & -2.724536 & $\mathrm{H}$ & -2.574765 & -1.547229 & -2.403505 \\
\hline $\mathrm{H}$ & -2.708033 & -3.070980 & -1.899187 & $\mathrm{H}$ & -2.445276 & -3.243838 & -1.910421 \\
\hline $\mathrm{C}$ & -4.064188 & -1.361928 & -1.750675 & $\mathrm{C}$ & -4.151284 & -2.201805 & -1.081645 \\
\hline $\mathrm{H}$ & -4.793994 & -2.146173 & -1.977755 & $\mathrm{H}$ & -4.288682 & -2.953278 & -0.296246 \\
\hline $\mathrm{C}$ & -2.032382 & -0.414917 & 0.094117 & $\mathrm{C}$ & -2.091041 & -0.528082 & 0.193769 \\
\hline $\mathrm{C}$ & -3.454483 & -0.388292 & 0.622156 & $\mathrm{C}$ & -3.553267 & -0.458618 & 0.627645 \\
\hline $\mathrm{H}$ & -3.485182 & -1.178785 & 1.371361 & $\mathrm{H}$ & -3.653384 & -1.182354 & 1.441399 \\
\hline $\mathrm{C}$ & -4.547752 & -0.616637 & -0.451398 & $\mathrm{C}$ & -4.521600 & -0.807088 & -0.514906 \\
\hline $\mathrm{H}$ & -4.862224 & 0.380108 & -0.787989 & $\mathrm{H}$ & -4.356731 & -0.078345 & -1.324817 \\
\hline $\mathrm{H}$ & -3.638970 & 0.562594 & 1.138327 & $\mathrm{H}$ & -3.769545 & 0.538827 & 1.029816 \\
\hline $\mathrm{S}$ & -0.974069 & 3.342658 & -2.067547 & $\mathrm{~S}$ & -0.952695 & 3.144309 & -2.081931 \\
\hline $\mathrm{S}$ & -1.723015 & -3.050189 & 0.683811 & $\mathrm{~S}$ & -1.657019 & -3.098368 & 0.942626 \\
\hline $\mathrm{O}$ & -1.906525 & 0.759413 & -0.903632 & $\mathrm{O}$ & -1.913450 & 0.609167 & -0.843810 \\
\hline $\mathrm{H}$ & -1.317799 & -0.212488 & 0.890512 & $\mathrm{H}$ & -1.421272 & -0.287129 & 1.017487 \\
\hline $\mathrm{C}$ & -0.225938 & -1.637049 & -1.180639 & $\mathrm{C}$ & -0.272516 & -1.761715 & -1.071863 \\
\hline $\mathrm{H}$ & -0.113340 & -0.830251 & -1.920715 & $\mathrm{H}$ & -0.235098 & -1.039947 & -1.901530 \\
\hline $\mathrm{H}$ & 0.492126 & -1.486267 & -0.368318 & $\mathrm{H}$ & 0.462490 & -1.473066 & -0.313480 \\
\hline $\mathrm{H}$ & 0.020340 & -2.588639 & -1.663388 & $\mathrm{H}$ & 0.016872 & -2.747554 & -1.450134 \\
\hline $\mathrm{H}$ & -4.134960 & -0.640059 & -2.572217 & $\mathrm{H}$ & -4.814709 & -2.461050 & -1.918840 \\
\hline $\mathrm{C}$ & -5.791666 & -1.288720 & 0.136484 & $\mathrm{C}$ & -5.992168 & -0.716300 & -0.137064 \\
\hline $\mathrm{C}$ & -7.110482 & -0.642896 & -0.216980 & $\mathrm{C}$ & -6.954984 & -0.592483 & -1.297066 \\
\hline $\mathrm{H}$ & -7.157789 & 0.393751 & 0.148667 & $\mathrm{H}$ & -6.748402 & 0.314811 & -1.882441 \\
\hline $\mathrm{H}$ & -7.244977 & -0.588751 & -1.307517 & $\mathrm{H}$ & -6.858390 & -1.436715 & -1.992114 \\
\hline $\mathrm{H}$ & -7.962215 & -1.190987 & 0.201690 & $\mathrm{H}$ & -7.996108 & -0.550887 & -0.958567 \\
\hline $\mathrm{C}$ & -5.732303 & -2.407264 & 0.867531 & $\mathrm{C}$ & -6.446426 & -0.740459 & 1.121616 \\
\hline $\mathrm{H}$ & -4.783577 & -2.893403 & 1.091923 & $\mathrm{H}$ & -5.784877 & -0.825851 & 1.977581 \\
\hline
\end{tabular}




\begin{tabular}{|c|c|c|c|c|c|c|c|}
\hline $\mathrm{H}$ & -6.639116 & -2.884133 & 1.237906 & $\mathrm{H}$ & -7.511969 & -0.687376 & 1.338156 \\
\hline $\mathrm{O}$ & 0.260576 & 1.532043 & 0.050428 & $\mathrm{O}$ & 0.231975 & 1.421588 & 0.133900 \\
\hline $\mathrm{C}$ & 1.246206 & 2.387165 & 0.648665 & $\mathrm{C}$ & 1.202264 & 2.314066 & 0.704013 \\
\hline $\mathrm{H}$ & 1.640016 & 3.075531 & -0.106389 & $\mathrm{H}$ & 1.543291 & 3.021882 & -0.058766 \\
\hline $\mathrm{C}$ & 2.354152 & 1.466436 & 1.163656 & $\mathrm{C}$ & 2.364092 & 1.439931 & 1.177656 \\
\hline $\mathrm{C}$ & 1.788116 & 0.614775 & 2.318441 & $\mathrm{C}$ & 1.868079 & 0.548793 & 2.334948 \\
\hline $\mathrm{O}$ & 1.706828 & -0.676986 & 1.998810 & $\mathrm{O}$ & 1.871757 & -0.744272 & 2.012870 \\
\hline $\mathrm{C}$ & 1.059355 & -1.585184 & 2.927223 & $\mathrm{C}$ & 1.288257 & -1.694639 & 2.942316 \\
\hline $\mathrm{H}$ & 1.824167 & -2.276769 & 3.292306 & $\mathrm{H}$ & 2.067136 & -2.425166 & 3.176971 \\
\hline $\mathrm{H}$ & 0.632404 & -1.019339 & 3.756057 & $\mathrm{H}$ & 0.964890 & -1.173993 & 3.844384 \\
\hline $\mathrm{H}$ & 0.285563 & -2.117386 & 2.357988 & $\mathrm{H}$ & 0.445215 & -2.173875 & 2.425276 \\
\hline $\mathrm{O}$ & 1.439880 & 1.121330 & 3.365890 & $\mathrm{O}$ & 1.501037 & 1.029716 & 3.388178 \\
\hline $\mathrm{N}$ & 2.925894 & 0.714375 & 0.069010 & $\mathrm{~N}$ & 2.942863 & 0.730192 & 0.058903 \\
\hline $\mathrm{H}$ & 2.286507 & 0.160237 & -0.488175 & $\mathrm{H}$ & 2.316841 & 0.157153 & -0.493801 \\
\hline $\mathrm{C}$ & 4.229093 & 0.307350 & 0.112376 & $\mathrm{C}$ & 4.265079 & 0.389483 & 0.059120 \\
\hline $\mathrm{O}$ & 5.060568 & 0.720935 & 0.908301 & $\mathrm{O}$ & 5.097583 & 0.832313 & 0.838027 \\
\hline $\mathrm{O}$ & 4.451971 & -0.586122 & -0.885262 & $\mathrm{O}$ & 4.503773 & -0.476741 & -0.959319 \\
\hline $\mathrm{C}$ & 5.770656 & -1.189821 & -1.078528 & $\mathrm{C}$ & 5.846749 & -1.002001 & -1.205366 \\
\hline $\mathrm{C}$ & 6.802841 & -0.109059 & -1.424017 & $\mathrm{C}$ & 6.805609 & 0.140385 & -1.563354 \\
\hline $\mathrm{H}$ & 6.952078 & 0.568846 & -0.582240 & $\mathrm{H}$ & 6.943827 & 0.811404 & -0.714272 \\
\hline $\mathrm{H}$ & 7.760727 & -0.578675 & -1.677951 & $\mathrm{H}$ & 7.779199 & -0.270815 & -1.855849 \\
\hline $\mathrm{H}$ & 6.467193 & 0.471304 & -2.290796 & $\mathrm{H}$ & 6.409859 & 0.714828 & -2.408367 \\
\hline $\mathrm{C}$ & 6.170687 & -1.996979 & 0.162447 & $\mathrm{C}$ & 6.331397 & -1.806518 & 0.007037 \\
\hline $\mathrm{H}$ & 5.394208 & -2.731964 & 0.400598 & $\mathrm{H}$ & 5.604376 & -2.586879 & 0.256709 \\
\hline $\mathrm{H}$ & 7.105132 & -2.536596 & -0.032557 & $\mathrm{H}$ & 7.286914 & -2.290577 & -0.227732 \\
\hline $\mathrm{H}$ & 6.312218 & -1.342363 & 1.023781 & $\mathrm{H}$ & 6.465407 & -1.159513 & 0.875288 \\
\hline $\mathrm{C}$ & 5.539070 & -2.118354 & -2.274623 & $\mathrm{C}$ & 5.628312 & -1.921701 & -2.410820 \\
\hline $\mathrm{H}$ & 6.465820 & -2.643979 & -2.530613 & $\mathrm{H}$ & 6.573489 & -2.391905 & -2.704477 \\
\hline $\mathrm{H}$ & 4.768753 & -2.860123 & -2.041453 & $\mathrm{H}$ & 4.906681 & -2.708168 & -2.168351 \\
\hline $\mathrm{H}$ & 5.209544 & -1.546163 & -3.148003 & $\mathrm{H}$ & 5.241424 & -1.353617 & -3.263130 \\
\hline $\mathrm{H}$ & 3.147084 & 2.083867 & 1.593809 & $\mathrm{H}$ & 3.138063 & 2.089164 & 1.595723 \\
\hline $\mathrm{H}$ & 0.804480 & 2.943345 & 1.479507 & $\mathrm{H}$ & 0.763677 & 2.846650 & 1.551683 \\
\hline $\mathrm{O}$ & -1.755609 & 2.737284 & 0.782353 & $\mathrm{O}$ & -1.803990 & 2.649433 & 0.770318 \\
\hline $\mathrm{C}$ & -2.933990 & 3.547326 & 0.714461 & $\mathrm{C}$ & -2.968853 & 3.472362 & 0.642658 \\
\hline $\mathrm{H}$ & -3.120366 & 3.901031 & 1.731132 & $\mathrm{H}$ & -3.170977 & 3.871432 & 1.639337 \\
\hline $\mathrm{H}$ & -2.779367 & 4.396459 & 0.041072 & $\mathrm{H}$ & -2.786786 & 4.289815 & -0.062264 \\
\hline $\mathrm{H}$ & -3.791462 & 2.958753 & 0.370199 & $\mathrm{H}$ & -3.827775 & 2.881938 & 0.305789 \\
\hline
\end{tabular}




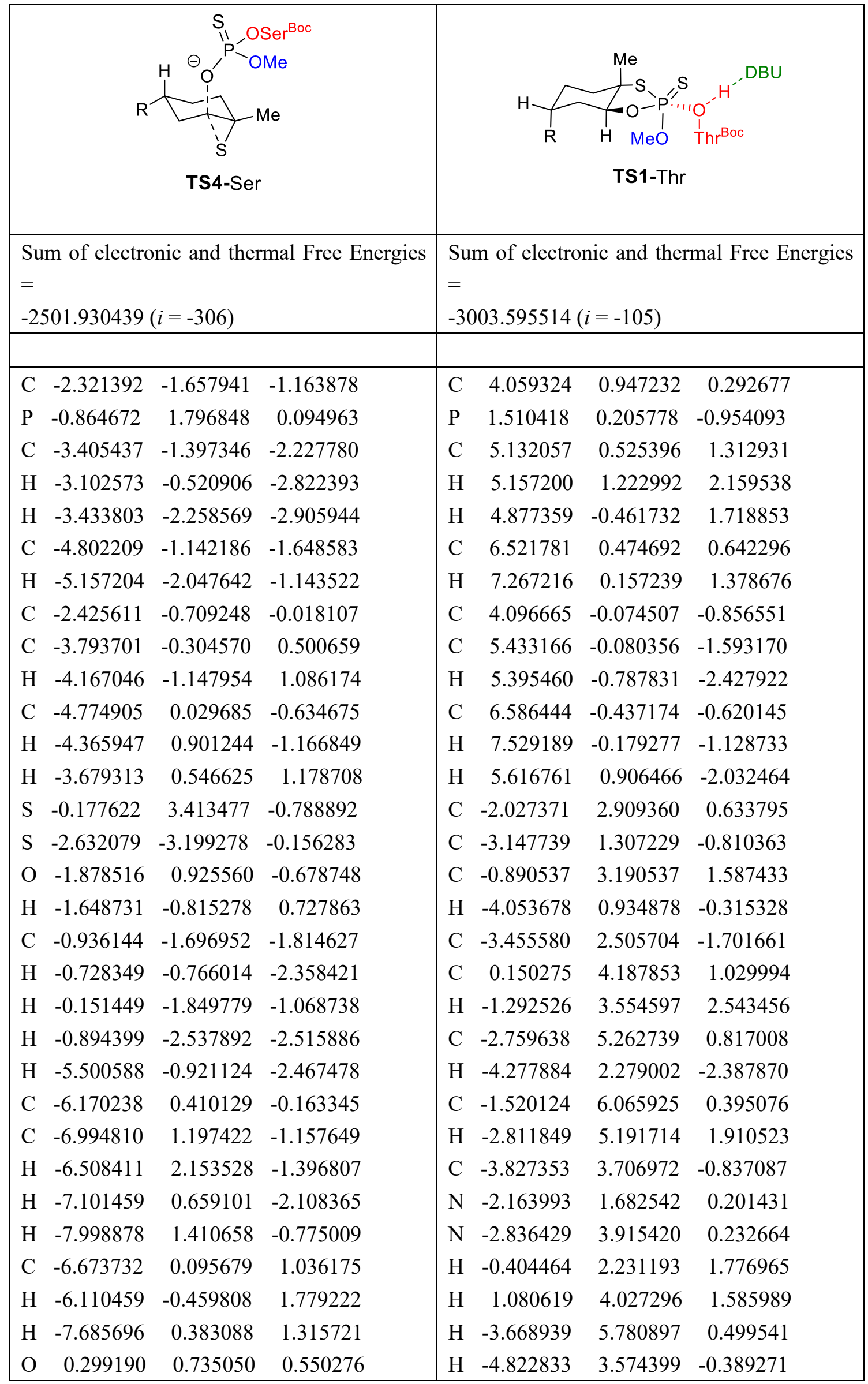




\begin{tabular}{|c|c|c|c|c|c|c|c|}
\hline $\mathrm{C}$ & 1.177127 & 0.998065 & 1.649034 & $\mathrm{H}$ & -3.859200 & 4.619340 & -1.442704 \\
\hline $\mathrm{H}$ & 1.539788 & 2.031391 & 1.612278 & $\mathrm{H}$ & -2.568747 & 2.738420 & -2.300931 \\
\hline $\mathrm{C}$ & 2.358948 & 0.038983 & 1.513704 & $\mathrm{H}$ & -2.719081 & 0.484042 & -1.385324 \\
\hline $\mathrm{C}$ & 1.891049 & -1.427850 & 1.404700 & $\mathrm{~S}$ & 0.393081 & 1.356388 & -2.102905 \\
\hline $\mathrm{O}$ & 1.039808 & -1.735571 & 2.395055 & $\mathrm{~S}$ & 2.320419 & 0.740038 & 0.950728 \\
\hline $\mathrm{C}$ & 0.462900 & -3.064271 & 2.346028 & $\mathrm{O}$ & 3.005312 & 0.209999 & -1.735771 \\
\hline $\mathrm{H}$ & -0.282510 & -3.125808 & 1.543930 & $\mathrm{H}$ & 3.941885 & -1.066088 & -0.412355 \\
\hline $\mathrm{H}$ & 1.249039 & -3.806872 & 2.191017 & $\mathrm{C}$ & 4.225927 & 2.404987 & -0.169128 \\
\hline $\mathrm{H}$ & -0.015258 & -3.200957 & 3.317122 & $\mathrm{H}$ & 4.061270 & 3.082887 & 0.675350 \\
\hline $\mathrm{O}$ & 2.264511 & -2.194372 & 0.545800 & $\mathrm{H}$ & 5.227146 & 2.605814 & -0.566093 \\
\hline $\mathrm{N}$ & 3.175790 & 0.397924 & 0.377009 & $\mathrm{H}$ & 3.500501 & 2.647282 & -0.949717 \\
\hline $\mathrm{H}$ & 2.710108 & 0.429817 & -0.521472 & $\mathrm{H}$ & 6.815454 & 1.487843 & 0.343889 \\
\hline $\mathrm{C}$ & 4.515725 & 0.138042 & 0.374095 & $\mathrm{C}$ & 6.720439 & -1.924005 & -0.281489 \\
\hline $\mathrm{O}$ & 5.173896 & -0.134241 & 1.368048 & $\mathrm{C}$ & 7.869640 & -2.285928 & 0.636260 \\
\hline $\mathrm{O}$ & 4.998269 & 0.282229 & -0.888141 & $\mathrm{H}$ & 8.041657 & -3.366342 & 0.644402 \\
\hline $\mathrm{C}$ & 6.421596 & 0.109472 & -1.173925 & $\mathrm{H}$ & 8.801233 & -1.795218 & 0.322888 \\
\hline $\mathrm{C}$ & 7.244942 & 1.161053 & -0.419519 & $\mathrm{H}$ & 7.683995 & -1.975013 & 1.672291 \\
\hline $\mathrm{H}$ & 7.180672 & 1.003297 & 0.658097 & $\mathrm{C}$ & 5.948601 & -2.891480 & -0.789773 \\
\hline $\mathrm{H}$ & 8.295827 & 1.101161 & -0.727123 & $\mathrm{H}$ & 5.114379 & -2.700798 & -1.456193 \\
\hline $\mathrm{H}$ & 6.877598 & 2.166821 & -0.652472 & $\mathrm{H}$ & 6.132676 & -3.935942 & -0.550231 \\
\hline $\mathrm{C}$ & 6.861639 & -1.320947 & -0.838467 & $\mathrm{O}$ & -0.229117 & 0.076088 & 0.682734 \\
\hline $\mathrm{H}$ & 6.220495 & -2.043410 & -1.354894 & $\mathrm{C}$ & -0.406742 & -1.094042 & 1.414095 \\
\hline $\mathrm{H}$ & 7.894745 & -1.478111 & -1.171221 & $\mathrm{H}$ & 0.543199 & -1.647647 & 1.455299 \\
\hline $\mathrm{H}$ & 6.801437 & -1.504981 & 0.235056 & $\mathrm{C}$ & -1.407914 & -2.075658 & 0.704034 \\
\hline $\mathrm{C}$ & 6.490266 & 0.353897 & -2.684895 & $\mathrm{C}$ & -1.275406 & -3.489972 & 1.260157 \\
\hline $\mathrm{H}$ & 7.522883 & 0.254254 & -3.037619 & $\mathrm{O}$ & -0.175825 & -4.110309 & 0.781234 \\
\hline $\mathrm{H}$ & 5.866966 & -0.369967 & -3.219645 & $\mathrm{C}$ & 0.066120 & -5.425853 & 1.304166 \\
\hline $\mathrm{H}$ & 6.132895 & 1.359732 & -2.928561 & $\mathrm{H}$ & 0.987482 & -5.764910 & 0.829549 \\
\hline $\mathrm{H}$ & 2.987096 & 0.124888 & 2.406310 & $\mathrm{H}$ & 0.183496 & -5.392962 & 2.390752 \\
\hline $\mathrm{H}$ & 0.647000 & 0.824372 & 2.588368 & $\mathrm{H}$ & -0.762448 & -6.095378 & 1.057601 \\
\hline $\mathrm{O}$ & -1.459669 & 2.106772 & 1.602160 & $\mathrm{O}$ & -2.033511 & -3.997320 & 2.063000 \\
\hline $\mathrm{C}$ & -2.362183 & 3.196567 & 1.793212 & $\mathrm{~N}$ & -2.792519 & -1.637983 & 0.809987 \\
\hline $\mathrm{H}$ & -2.569918 & 3.244226 & 2.865860 & $\mathrm{H}$ & -3.182303 & -1.644932 & 1.744339 \\
\hline $\mathrm{H}$ & -1.911655 & 4.136012 & 1.455678 & $\mathrm{C}$ & -3.693092 & -1.973049 & -0.170199 \\
\hline \multirow[t]{8}{*}{$\mathrm{H}$} & -3.301041 & 3.029984 & 1.251763 & $\mathrm{O}$ & -3.398722 & -2.336318 & -1.297545 \\
\hline & & & & $\mathrm{O}$ & -4.955709 & -1.772148 & 0.298170 \\
\hline & & & & $\mathrm{C}$ & -6.127555 & -2.155812 & -0.499939 \\
\hline & & & & $\mathrm{C}$ & -7.291366 & -1.827717 & 0.439814 \\
\hline & & & & $\mathrm{H}$ & -7.290532 & -0.763659 & 0.699119 \\
\hline & & & & $\mathrm{H}$ & -8.245268 & -2.066283 & -0.042487 \\
\hline & & & & $\mathrm{H}$ & -7.215189 & -2.407212 & 1.365439 \\
\hline & & & & $\mathrm{C}$ & -6.205921 & -1.309659 & -1.775924 \\
\hline
\end{tabular}




\begin{tabular}{|c|c|c|c|}
\hline & $\begin{array}{lr}\mathrm{H} & -5.357646 \\
\mathrm{H} & -7.133262 \\
\mathrm{H} & -6.216123 \\
\mathrm{C} & -6.087007 \\
\mathrm{H} & -5.253652 \\
\mathrm{H} & -5.982136 \\
\mathrm{H} & -7.022078 \\
\mathrm{H} & -1.364473 \\
\mathrm{C} & -0.242411 \\
\mathrm{H} & -0.371206 \\
\mathrm{H} & 0.588464 \\
\mathrm{H} & -1.380572 \\
\mathrm{H} & -1.725213 \\
\mathrm{H} & 0.371910 \\
\mathrm{H} & -1.139329 \\
\mathrm{O} & 1.247581 \\
\mathrm{C} & 1.241630 \\
\mathrm{H} & 0.481287 \\
\mathrm{H} & 2.221874 \\
\mathrm{H} & 0.994725 \\
\mathrm{C} & -0.834612 \\
\mathrm{H} & -1.752493 \\
\mathrm{H} & -1.007113 \\
\mathrm{H} & -0.048155 \\
\end{array}$ & $\begin{array}{r}-1.513210 \\
-1.537925 \\
-0.242328 \\
-3.657380 \\
-3.900613 \\
-4.230614 \\
-3.960105 \\
0.936944 \\
5.666751 \\
5.918071 \\
6.286172 \\
5.955164 \\
7.128810 \\
3.920214 \\
-2.085166 \\
-1.412869 \\
-2.115168 \\
-1.701962 \\
-2.061477 \\
-3.149328 \\
-0.792816 \\
-0.192033 \\
-1.707217 \\
-0.213597 \\
\end{array}$ & $\begin{array}{r}-2.430834 \\
-2.313906 \\
-1.525487 \\
-0.806279 \\
-1.467286 \\
0.121296 \\
-1.291182 \\
0.438972 \\
1.145749 \\
2.209724 \\
0.785140 \\
-0.688553 \\
0.579744 \\
-0.010381 \\
-0.350437 \\
-0.954561 \\
-2.207995 \\
-2.878527 \\
-2.691196 \\
-1.959618 \\
2.861452 \\
2.882568 \\
3.443701 \\
3.355581 \\
\end{array}$ \\
\hline 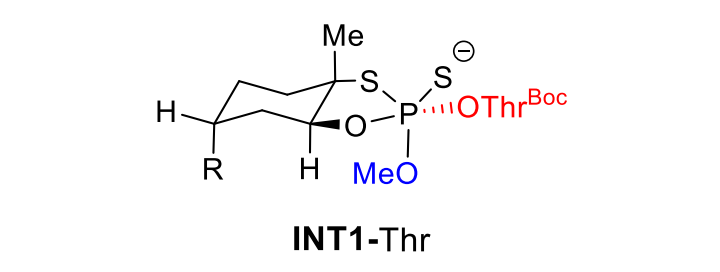 & \multicolumn{3}{|c|}{ TS2-Thr } \\
\hline $\begin{array}{l}\text { Sum of electronic and thermal Free Energies } \\
= \\
-2541.196744\end{array}$ & \multicolumn{3}{|c|}{$\begin{array}{l}\text { Sum of electronic and thermal Free Energies } \\
= \\
-2541.187813(i=-74)\end{array}$} \\
\hline $\begin{array}{llll}\mathrm{C} & -3.624935 & 0.863433 & -0.845461\end{array}$ & C 3.716446 & -0.446955 & -1.001865 \\
\hline $\begin{array}{llll}\mathrm{P} & -1.150868 & 0.198141 & 0.806946\end{array}$ & $\mathrm{P} \quad 1.145556$ & -1.283297 & 1.045919 \\
\hline $\begin{array}{llll}\text { C } & -4.587721 & 0.393130 & -1.949759\end{array}$ & C 4.568159 & 0.554380 & -1.822301 \\
\hline $\mathrm{H} \quad-4.493330 \quad 1.023683 \quad-2.844135$ & $\mathrm{H} \quad 4.899884$ & 0.056385 & -2.741830 \\
\hline H $\quad-4.318611 \quad-0.627596 \quad-2.250841$ & 3.918948 & 1.381453 & -2.137243 \\
\hline $\begin{array}{llll}\text { C } & -6.046701 & 0.425834 & -1.450038\end{array}$ & C $\quad 5.780355$ & 1.107262 & -1.051343 \\
\hline $\begin{array}{llll}\mathrm{H} & -6.718298 & 0.083270 & -2.246217\end{array}$ & H $\quad 6.364478$ & 1.783135 & -1.689246 \\
\hline
\end{tabular}




\begin{tabular}{|c|c|c|c|c|c|c|c|}
\hline $\mathrm{C}$ & -3.808814 & -0.066711 & 0.371977 & $\mathrm{C}$ & 3.299891 & 0.304533 & 0.276291 \\
\hline $\mathrm{C}$ & -5.236985 & -0.008964 & 0.925899 & $\mathrm{C}$ & 4.470410 & 0.875807 & 1.092549 \\
\hline $\mathrm{H}$ & -5.321387 & -0.662149 & 1.801860 & $\mathrm{H}$ & 4.085532 & 1.386475 & 1.983314 \\
\hline $\mathrm{C}$ & -6.287275 & -0.394663 & -0.146322 & $\mathrm{C}$ & 5.367927 & 1.822292 & 0.264713 \\
\hline $\mathrm{H}$ & -7.273598 & -0.074515 & 0.231413 & $\mathrm{H}$ & 6.294807 & 1.979416 & 0.843793 \\
\hline $\mathrm{H}$ & -5.442757 & 1.007214 & 1.282129 & $\mathrm{H}$ & 5.084196 & 0.042005 & 1.454780 \\
\hline $\mathrm{S}$ & -0.503761 & 1.594174 & 2.117643 & $\mathrm{~S}$ & 1.037890 & -3.234641 & 0.769980 \\
\hline $\mathrm{S}$ & -1.853875 & 0.571959 & -1.262795 & $\mathrm{~S}$ & 2.151040 & -0.860657 & -1.866594 \\
\hline $\mathrm{O}$ & -2.863036 & 0.282718 & 1.342154 & $\mathrm{O}$ & 2.567663 & -0.527504 & 1.212465 \\
\hline $\mathrm{H}$ & -3.627040 & -1.091320 & 0.006257 & $\mathrm{H}$ & 2.626514 & 1.108058 & -0.032897 \\
\hline $\mathrm{C}$ & -3.808796 & 2.352896 & -0.499937 & $\mathrm{C}$ & 4.514630 & -1.729936 & -0.697233 \\
\hline $\mathrm{H}$ & -3.541891 & 2.971250 & -1.364632 & $\mathrm{H}$ & 4.786955 & -2.210301 & -1.643079 \\
\hline $\mathrm{H}$ & -4.840597 & 2.600352 & -0.217422 & $\mathrm{H}$ & 5.441607 & -1.552875 & -0.127573 \\
\hline $\mathrm{H}$ & -3.155975 & 2.622501 & 0.333593 & $\mathrm{H}$ & 3.896594 & -2.434523 & -0.136305 \\
\hline $\mathrm{H}$ & -6.333549 & 1.464817 & -1.247687 & $\mathrm{H}$ & 6.458313 & 0.284797 & -0.788100 \\
\hline $\mathrm{C}$ & -6.448316 & -1.893874 & -0.405389 & $\mathrm{C}$ & 4.810278 & 3.227724 & 0.040496 \\
\hline $\mathrm{C}$ & -7.529733 & -2.275519 & -1.395863 & $\mathrm{C}$ & 5.702602 & 4.169257 & -0.741186 \\
\hline $\mathrm{H}$ & -8.468134 & -1.741466 & -1.189632 & $\mathrm{H}$ & 6.737425 & 4.140410 & -0.371240 \\
\hline $\mathrm{H}$ & -7.248487 & -2.025605 & -2.427014 & $\mathrm{H}$ & 5.743058 & 3.900785 & -1.804408 \\
\hline $\mathrm{H}$ & -7.735319 & -3.350427 & -1.362573 & $\mathrm{H}$ & 5.344691 & 5.202002 & -0.674017 \\
\hline $\mathrm{C}$ & -5.756602 & -2.854051 & 0.218443 & $\mathrm{C}$ & 3.646821 & 3.671934 & 0.529321 \\
\hline $\mathrm{H}$ & -4.964213 & -2.645701 & 0.928451 & $\mathrm{H}$ & 2.959632 & 3.043275 & 1.084614 \\
\hline $\mathrm{H}$ & -5.956748 & -3.905301 & 0.021399 & $\mathrm{H}$ & 3.329105 & 4.700305 & 0.369512 \\
\hline $\mathrm{O}$ & 0.303526 & -0.114001 & -0.126438 & $\mathrm{O}$ & 0.022083 & -0.282898 & 0.413199 \\
\hline $\mathrm{C}$ & 1.543113 & -0.452326 & 0.454327 & $\mathrm{C}$ & -1.338614 & -0.263768 & 0.896731 \\
\hline $\mathrm{H}$ & 1.545727 & -0.205824 & 1.524201 & $\mathrm{H}$ & -1.523996 & -1.136114 & 1.531579 \\
\hline $\mathrm{C}$ & 2.637192 & 0.428376 & -0.235568 & $\mathrm{C}$ & -2.269080 & -0.356975 & -0.347964 \\
\hline $\mathrm{C}$ & 2.413070 & 1.919400 & 0.013145 & $\mathrm{C}$ & -2.087004 & -1.692909 & -1.076974 \\
\hline $\mathrm{O}$ & 1.516308 & 2.443385 & -0.824155 & $\mathrm{O}$ & -1.120509 & -1.636780 & -1.977033 \\
\hline $\mathrm{C}$ & 1.093446 & 3.782195 & -0.520937 & $\mathrm{C}$ & -0.707221 & -2.879900 & -2.581321 \\
\hline $\mathrm{H}$ & 0.379744 & 4.040408 & -1.304090 & $\mathrm{H}$ & 0.244709 & -2.651818 & -3.058164 \\
\hline $\mathrm{H}$ & 0.606977 & 3.789197 & 0.457316 & $\mathrm{H}$ & -0.564471 & -3.633805 & -1.806370 \\
\hline $\mathrm{H}$ & 1.946912 & 4.467664 & -0.528529 & $\mathrm{H}$ & -1.463385 & -3.208009 & -3.302940 \\
\hline $\mathrm{O}$ & 3.021268 & 2.551407 & 0.858962 & $\mathrm{O}$ & -2.776092 & -2.668754 & -0.828083 \\
\hline $\mathrm{N}$ & 3.973243 & 0.122660 & 0.262129 & $\mathrm{~N}$ & -3.669322 & -0.291666 & 0.049663 \\
\hline $\mathrm{H}$ & 4.284754 & 0.707000 & 1.029234 & $\mathrm{H}$ & -4.118920 & -1.193686 & 0.160014 \\
\hline $\mathrm{C}$ & 4.919025 & -0.501042 & -0.483167 & $\mathrm{C}$ & -4.455564 & 0.792050 & -0.188329 \\
\hline $\mathrm{O}$ & 4.735943 & -1.055554 & -1.557627 & $\mathrm{O}$ & -4.060242 & 1.893159 & -0.540432 \\
\hline $\mathrm{O}$ & 6.120966 & -0.433059 & 0.175287 & $\mathrm{O}$ & -5.759341 & 0.456736 & 0.055698 \\
\hline $\mathrm{C}$ & 7.311128 & -1.061867 & -0.383837 & $\mathrm{C}$ & -6.822565 & 1.448417 & -0.085535 \\
\hline $\mathrm{C}$ & 8.381096 & -0.752530 & 0.669236 & $\mathrm{C}$ & -8.076273 & 0.650994 & 0.289182 \\
\hline $\mathrm{H}$ & 8.101678 & -1.181094 & 1.637494 & $\mathrm{H}$ & -7.999407 & 0.271499 & 1.313497 \\
\hline
\end{tabular}




\begin{tabular}{|c|c|c|c|c|c|c|}
\hline $\mathrm{H}$ & 9.346446 & -1.173941 & 0.366441 & H $\quad-8.965787$ & 1.286902 & 0.218438 \\
\hline $\mathrm{H}$ & 8.496120 & 0.329257 & 0.794419 & H $\quad-8.203737$ & -0.203102 & -0.384075 \\
\hline $\mathrm{C}$ & 7.108952 & -2.577586 & -0.512288 & C -6.607986 & 2.606356 & 0.897617 \\
\hline $\mathrm{H}$ & 6.331523 & -2.802817 & -1.243453 & H $\quad-5.703314$ & 3.163041 & 0.649360 \\
\hline $\mathrm{H}$ & 8.046165 & -3.053500 & -0.825772 & H $\quad-7.467136$ & 3.287193 & 0.864260 \\
\hline $\mathrm{H}$ & 6.816708 & -3.002014 & 0.454860 & H $\quad-6.516828$ & 2.221991 & 1.919862 \\
\hline $\mathrm{C}$ & 7.676670 & -0.415035 & -1.726687 & C -6.908640 & 1.934101 & -1.538294 \\
\hline $\mathrm{H}$ & 6.902555 & -0.609079 & -2.470348 & H $\quad-6.005930$ & 2.478619 & -1.818566 \\
\hline $\mathrm{H}$ & 7.786317 & 0.668726 & -1.605689 & H $\quad-7.030726$ & 1.080733 & -2.214878 \\
\hline $\mathrm{H}$ & 8.631006 & -0.816819 & -2.088712 & Н $\quad-7.776539$ & 2.593351 & -1.660036 \\
\hline $\mathrm{H}$ & 2.603713 & 0.225201 & -1.308614 & H $\quad-2.038831$ & 0.473331 & -1.018603 \\
\hline $\mathrm{O}$ & -1.057160 & -1.403006 & 1.334942 & 0.680647 & -1.011951 & 2.632648 \\
\hline $\mathrm{C}$ & -1.709454 & -1.802721 & 2.532769 & C 1.360418 & -1.668628 & 3.690900 \\
\hline $\mathrm{H}$ & -1.640415 & -1.028249 & 3.304454 & 1.350827 & -2.755835 & 3.549523 \\
\hline $\mathrm{H}$ & -2.767055 & -2.038715 & 2.365454 & 2.399402 & -1.322465 & 3.763743 \\
\hline $\mathrm{H}$ & -1.190826 & -2.706728 & 2.876084 & 0.831202 & -1.414042 & 4.615753 \\
\hline $\mathrm{C}$ & 1.838543 & -1.941128 & 0.249297 & C -1.557539 & 1.021264 & 1.687620 \\
\hline $\mathrm{H}$ & 1.879840 & -2.177915 & -0.819821 & Н -1.374193 & 1.893961 & 1.052735 \\
\hline $\mathrm{H}$ & 2.791310 & -2.230539 & 0.706328 & H $\quad-2.582094$ & 1.077528 & 2.068232 \\
\hline $\mathrm{H}$ & 1.029291 & -2.516700 & 0.703101 & H $\quad-0.861945$ & 1.035945 & 2.529809 \\
\hline \multicolumn{4}{|c|}{ INT2-Thr } & \multicolumn{3}{|c|}{$\mathrm{S}_{\text {II }}, \mathrm{OThr}{ }^{\mathrm{BOC}}$} \\
\hline \multicolumn{4}{|c|}{$\begin{array}{l}\text { Sum of electronic and thermal Free Energies } \\
= \\
-2541.210351\end{array}$} & \multicolumn{3}{|c|}{$\begin{array}{l}\text { Sum of electronic and thermal Free Energies } \\
= \\
-2541.202167(i=-170)\end{array}$} \\
\hline $\mathrm{C}$ & -1.365341 & -1.617501 & -1.669947 & C -1.533806 & -1.790129 & -0.719685 \\
\hline $\mathrm{P}$ & -1.379471 & 2.162166 & -0.808346 & $\mathrm{P} \quad-1.256995$ & 2.063099 & -0.630371 \\
\hline $\mathrm{C}$ & -1.857271 & -2.931075 & -0.997230 & C $\quad-2.568177$ & -2.060886 & -1.847988 \\
\hline $\mathrm{H}$ & -1.423658 & -3.769936 & -1.553542 & H $\quad-2.175612$ & -1.633707 & -2.781882 \\
\hline $\mathrm{H}$ & -1.421044 & -2.977883 & 0.008794 & H $\quad-2.600045$ & -3.144184 & -1.988069 \\
\hline $\mathrm{C}$ & -3.384936 & -3.081408 & -0.904944 & C -4.015535 & -1.503985 & -1.680019 \\
\hline $\mathrm{H}$ & -3.648056 & -4.048351 & -0.456418 & H $\quad-4.725915$ & -2.308728 & -1.897902 \\
\hline $\mathrm{C}$ & -2.034248 & -0.473449 & -0.874485 & C -1.909294 & -0.520982 & 0.046109 \\
\hline $\mathrm{C}$ & -3.564062 & -0.586189 & -0.739294 & C -3.287949 & -0.578544 & 0.679783 \\
\hline $\mathrm{H}$ & -3.943623 & 0.262828 & -0.160641 & H $\quad-3.226221$ & -1.385311 & 1.409125 \\
\hline $\mathrm{C}$ & -4.033847 & -1.916204 & -0.115512 & C -4.443852 & -0.837614 & -0.319742 \\
\hline
\end{tabular}




\begin{tabular}{|c|c|c|c|c|c|c|c|}
\hline $\mathrm{H}$ & -5.124167 & -1.984773 & -0.277565 & $\mathrm{H}$ & -4.839278 & 0.148960 & -0.594354 \\
\hline $\mathrm{H}$ & -4.001392 & -0.504013 & -1.741855 & $\mathrm{H}$ & -3.481371 & 0.350634 & 1.230504 \\
\hline $\mathrm{S}$ & -0.677525 & 3.541218 & -1.992714 & $\mathrm{~S}$ & -1.639110 & 3.430976 & -1.973256 \\
\hline $\mathrm{S}$ & 0.481936 & -1.553648 & -1.554855 & $\mathrm{~S}$ & -1.479311 & -3.169625 & 0.543216 \\
\hline $\mathrm{O}$ & -1.777396 & 0.816781 & -1.552410 & $\mathrm{O}$ & -1.926778 & 0.668054 & -0.932110 \\
\hline $\mathrm{H}$ & -1.556425 & -0.436543 & 0.104705 & $\mathrm{H}$ & -1.144203 & -0.294002 & 0.787973 \\
\hline $\mathrm{C}$ & -1.774789 & -1.579050 & -3.156426 & $\mathrm{C}$ & -0.138367 & -1.652815 & -1.354282 \\
\hline $\mathrm{H}$ & -2.863528 & -1.642739 & -3.322391 & $\mathrm{H}$ & -0.081324 & -0.804670 & -2.053034 \\
\hline $\mathrm{H}$ & -1.412176 & -0.656587 & -3.615408 & $\mathrm{H}$ & 0.617962 & -1.534803 & -0.570969 \\
\hline $\mathrm{H}$ & -1.302307 & -2.418811 & -3.675553 & $\mathrm{H}$ & 0.101432 & -2.571342 & -1.900256 \\
\hline $\mathrm{H}$ & -3.822431 & -3.088780 & -1.912182 & $\mathrm{H}$ & -4.167238 & -0.750095 & -2.460543 \\
\hline $\mathrm{C}$ & -3.862769 & -2.022522 & 1.399680 & $\mathrm{C}$ & -5.602823 & -1.602548 & 0.325102 \\
\hline $\mathrm{C}$ & -4.298575 & -3.334183 & 2.017692 & $\mathrm{C}$ & -6.979691 & -1.045219 & 0.049779 \\
\hline $\mathrm{H}$ & -5.287516 & -3.641275 & 1.648714 & $\mathrm{H}$ & -7.079079 & -0.018721 & 0.433117 \\
\hline $\mathrm{H}$ & -3.606190 & -4.148424 & 1.769295 & $\mathrm{H}$ & -7.174042 & -0.987624 & -1.031497 \\
\hline $\mathrm{H}$ & -4.349093 & -3.261287 & 3.109174 & $\mathrm{H}$ & -7.768784 & -1.656411 & 0.502524 \\
\hline $\mathrm{C}$ & -3.433027 & -1.027677 & 2.186376 & $\mathrm{C}$ & -5.430590 & -2.722904 & 1.035185 \\
\hline $\mathrm{H}$ & -3.100974 & -0.067066 & 1.807852 & $\mathrm{H}$ & -4.441939 & -3.150029 & 1.198758 \\
\hline $\mathrm{H}$ & -3.396424 & -1.148656 & 3.267452 & $\mathrm{H}$ & -6.284107 & -3.262920 & 1.443920 \\
\hline $\mathrm{O}$ & -0.491313 & 1.703664 & 0.451568 & $\mathrm{O}$ & 0.297185 & 1.663872 & -0.388895 \\
\hline $\mathrm{C}$ & 0.702489 & 2.387351 & 0.918454 & $\mathrm{C}$ & 1.280194 & 2.512863 & 0.260375 \\
\hline $\mathrm{H}$ & 1.207446 & 2.815922 & 0.048176 & $\mathrm{C}$ & 2.271361 & 1.540755 & 0.931914 \\
\hline $\mathrm{C}$ & 1.638446 & 1.293248 & 1.473157 & $\mathrm{C}$ & 1.592286 & 0.865245 & 2.138443 \\
\hline $\mathrm{C}$ & 0.959768 & 0.467887 & 2.581373 & $\mathrm{O}$ & 1.435741 & -0.446965 & 1.958623 \\
\hline $\mathrm{O}$ & 1.014097 & -0.846889 & 2.336476 & $\mathrm{C}$ & 0.734506 & -1.205578 & 2.974684 \\
\hline $\mathrm{C}$ & 0.372905 & -1.692826 & 3.297164 & $\mathrm{H}$ & 1.479261 & -1.675092 & 3.625368 \\
\hline $\mathrm{H}$ & 0.561664 & -2.710172 & 2.953701 & $\mathrm{H}$ & 0.099069 & -0.538865 & 3.559831 \\
\hline $\mathrm{H}$ & 0.791368 & -1.532014 & 4.295394 & $\mathrm{H}$ & 0.144371 & -1.952425 & 2.429878 \\
\hline $\mathrm{H}$ & -0.702175 & -1.494619 & 3.318936 & $\mathrm{O}$ & 1.239396 & 1.501530 & 3.110943 \\
\hline $\mathrm{O}$ & 0.457220 & 0.948264 & 3.580127 & $\mathrm{~N}$ & 2.827489 & 0.626898 & -0.040774 \\
\hline $\mathrm{N}$ & 2.192298 & 0.500600 & 0.405101 & $\mathrm{H}$ & 2.169979 & 0.048854 & -0.551568 \\
\hline $\mathrm{H}$ & 1.559772 & -0.080135 & -0.190722 & $\mathrm{C}$ & 4.095417 & 0.139505 & 0.109782 \\
\hline $\mathrm{C}$ & 3.524299 & 0.233522 & 0.402234 & $\mathrm{O}$ & 4.925753 & 0.587850 & 0.888032 \\
\hline $\mathrm{O}$ & 4.343614 & 0.704878 & 1.190865 & $\mathrm{O}$ & 4.287374 & -0.881065 & -0.763818 \\
\hline $\mathrm{O}$ & 3.817817 & -0.609783 & -0.618354 & $\mathrm{C}$ & 5.551061 & -1.617705 & -0.801795 \\
\hline $\mathrm{C}$ & 5.167793 & -1.104712 & -0.835302 & $\mathrm{C}$ & 6.695792 & -0.683874 & -1.213991 \\
\hline $\mathrm{C}$ & 6.118513 & 0.054997 & -1.162968 & $\mathrm{H}$ & 6.865003 & 0.080884 & -0.454402 \\
\hline $\mathrm{H}$ & 6.224849 & 0.721200 & -0.305332 & $\mathrm{H}$ & 7.616879 & -1.263404 & -1.349325 \\
\hline $\mathrm{H}$ & 7.105282 & -0.337268 & -1.439454 & $\mathrm{H}$ & 6.459258 & -0.192664 & -2.164627 \\
\hline $\mathrm{H}$ & 5.729100 & 0.629734 & -2.010686 & $\mathrm{C}$ & 5.811665 & -2.291656 & 0.550835 \\
\hline $\mathrm{C}$ & 5.642880 & -1.909359 & 0.382398 & $\mathrm{H}$ & 4.955712 & -2.914200 & 0.832606 \\
\hline $\mathrm{H}$ & 4.925207 & -2.706287 & 0.606095 & $\mathrm{H}$ & 6.695703 & -2.936392 & 0.478505 \\
\hline
\end{tabular}




\begin{tabular}{|c|c|c|c|c|c|c|c|}
\hline $\mathrm{H}$ & 6.614873 & -2.371472 & 0.169177 & $\mathrm{H}$ & 5.978644 & -1.547784 & 1.331467 \\
\hline $\mathrm{H}$ & 5.738772 & -1.264735 & 1.257864 & $\mathrm{C}$ & 5.290563 & -2.667971 & -1.886014 \\
\hline $\mathrm{C}$ & 4.991525 & -2.020421 & -2.051488 & $\mathrm{H}$ & 6.173500 & -3.303608 & -2.016719 \\
\hline $\mathrm{H}$ & 5.947570 & -2.486116 & -2.319766 & $\mathrm{H}$ & 4.440628 & -3.300374 & -1.611408 \\
\hline $\mathrm{H}$ & 4.258198 & -2.802724 & -1.834541 & $\mathrm{H}$ & 5.063124 & -2.185583 & -2.842318 \\
\hline $\mathrm{H}$ & 4.622121 & -1.448697 & -2.908322 & $\mathrm{H}$ & 3.098536 & 2.126049 & 1.342088 \\
\hline $\mathrm{H}$ & 2.479584 & 1.801538 & 1.958025 & $\mathrm{H}$ & 0.785599 & 3.085051 & 1.049771 \\
\hline $\mathrm{O}$ & -2.713939 & 2.622819 & 0.030969 & $\mathrm{O}$ & -1.631670 & 2.498342 & 0.897828 \\
\hline $\mathrm{C}$ & -3.813090 & 3.201844 & -0.677676 & $\mathrm{C}$ & -2.803989 & 3.267862 & 1.186048 \\
\hline $\mathrm{H}$ & -4.567035 & 3.449158 & 0.074015 & $\mathrm{H}$ & -2.755836 & 3.503645 & 2.251543 \\
\hline $\mathrm{H}$ & -3.497401 & 4.108786 & -1.203909 & $\mathrm{H}$ & -2.816620 & 4.187239 & 0.592755 \\
\hline $\mathrm{H}$ & -4.235683 & 2.492010 & -1.397979 & $\mathrm{H}$ & -3.710612 & 2.688812 & 0.980760 \\
\hline $\mathrm{C}$ & 0.316778 & 3.489329 & 1.897312 & $\mathrm{C}$ & 1.946244 & 3.432840 & -0.754995 \\
\hline $\mathrm{H}$ & 1.219719 & 3.986000 & 2.272182 & $\mathrm{H}$ & 2.463887 & 2.846398 & -1.519198 \\
\hline $\mathrm{H}$ & -0.297205 & 4.235598 & 1.383350 & $\mathrm{H}$ & 1.197125 & 4.061654 & -1.242493 \\
\hline $\mathrm{H}$ & -0.233078 & 3.081303 & 2.746636 & $\mathrm{H}$ & 2.677705 & 4.075465 & -0.250303 \\
\hline & & INT3-Thr & & & & TS4-Thr & \\
\hline \multicolumn{4}{|c|}{$\begin{array}{l}\text { Sum of electronic and thermal Free Energies } \\
= \\
-2541.224679\end{array}$} & \multicolumn{4}{|c|}{$\begin{array}{l}\text { Sum of electronic and thermal Free Energies } \\
= \\
-2541.218131(i=-314)\end{array}$} \\
\hline $\mathrm{C}$ & -1.365341 & -1.617501 & -1.669947 & $\mathrm{C}$ & 2.234106 & -1.919406 & 0.995737 \\
\hline $\mathrm{P}$ & -1.379471 & 2.162166 & -0.808346 & $\mathrm{P}$ & 0.987938 & 1.825410 & 0.281592 \\
\hline $\mathrm{C}$ & -1.857271 & -2.931075 & -0.997230 & $\mathrm{C}$ & 3.358343 & -1.827895 & 2.044825 \\
\hline $\mathrm{H}$ & -1.423658 & -3.769936 & -1.553542 & $\mathrm{H}$ & 3.104566 & -1.021946 & 2.750890 \\
\hline $\mathrm{H}$ & -1.421044 & -2.977883 & 0.008794 & $\mathrm{H}$ & 3.375961 & -2.766860 & 2.611046 \\
\hline $\mathrm{C}$ & -3.384936 & -3.081408 & -0.904944 & $\mathrm{C}$ & 4.745484 & -1.549018 & 1.452814 \\
\hline $\mathrm{H}$ & -3.648056 & -4.048351 & -0.456418 & $\mathrm{H}$ & 5.051771 & -2.396821 & 0.829644 \\
\hline $\mathrm{C}$ & -2.034248 & -0.473449 & -0.874485 & $\mathrm{C}$ & 2.340319 & -0.848375 & -0.031552 \\
\hline $\mathrm{C}$ & -3.564062 & -0.586189 & -0.739294 & $\mathrm{C}$ & 3.704391 & -0.422555 & -0.543759 \\
\hline $\mathrm{H}$ & -3.943623 & 0.262828 & -0.160641 & $\mathrm{H}$ & 4.034777 & -1.193878 & -1.243195 \\
\hline $\mathrm{C}$ & -4.033847 & -1.916204 & -0.115512 & $\mathrm{C}$ & 4.730860 & -0.261690 & 0.590383 \\
\hline $\mathrm{H}$ & -5.124167 & -1.984773 & -0.277565 & $\mathrm{H}$ & 4.369549 & 0.550490 & 1.237821 \\
\hline $\mathrm{H}$ & -4.001392 & -0.504013 & -1.741855 & $\mathrm{H}$ & 3.596117 & 0.509167 & -1.105969 \\
\hline S & -0.677525 & 3.541218 & -1.992714 & $\mathrm{~S}$ & 0.662047 & 3.395820 & 1.423522 \\
\hline
\end{tabular}




\begin{tabular}{|c|c|c|c|c|c|c|c|}
\hline$S$ & 0.481936 & -1.553648 & -1.554855 & $\mathrm{~S}$ & 2.465413 & -3.325521 & -0.211522 \\
\hline $\mathrm{O}$ & -1.777396 & 0.816781 & -1.552410 & $\mathrm{O}$ & 1.889800 & 0.722486 & 0.873873 \\
\hline $\mathrm{H}$ & -1.556425 & -0.436543 & 0.104705 & $\mathrm{H}$ & 1.526931 & -0.810484 & -0.744784 \\
\hline $\mathrm{C}$ & -1.774789 & -1.579050 & -3.156426 & C & 0.866375 & -1.995050 & 1.677769 \\
\hline $\mathrm{H}$ & -2.863528 & -1.642739 & -3.322391 & $\mathrm{H}$ & 0.703978 & -1.127743 & 2.330711 \\
\hline $\mathrm{H}$ & -1.412176 & -0.656587 & -3.615408 & $\mathrm{H}$ & 0.059791 & -2.037408 & 0.940630 \\
\hline $\mathrm{H}$ & -1.302307 & -2.418811 & -3.675553 & $\mathrm{H}$ & 0.814472 & -2.910843 & 2.277380 \\
\hline $\mathrm{H}$ & -3.822431 & -3.088780 & -1.912182 & $\mathrm{H}$ & 5.475117 & -1.452709 & 2.268475 \\
\hline $\mathrm{C}$ & -3.862769 & -2.022522 & 1.399680 & C & 6.122858 & 0.131400 & 0.119533 \\
\hline $\mathrm{C}$ & -4.298575 & -3.334183 & 2.017692 & C & 7.015956 & 0.738795 & 1.178797 \\
\hline $\mathrm{H}$ & -5.287516 & -3.641275 & 1.648714 & $\mathrm{H}$ & 6.571545 & 1.659278 & 1.582343 \\
\hline $\mathrm{H}$ & -3.606190 & -4.148424 & 1.769295 & $\mathrm{H}$ & 7.148944 & 0.060432 & 2.031445 \\
\hline $\mathrm{H}$ & -4.349093 & -3.261287 & 3.109174 & $\mathrm{H}$ & 8.007818 & 0.982494 & 0.782706 \\
\hline $\mathrm{C}$ & -3.433027 & -1.027677 & 2.186376 & C & 6.567549 & -0.022163 & -1.133557 \\
\hline $\mathrm{H}$ & -3.100974 & -0.067066 & 1.807852 & $\mathrm{H}$ & 5.955328 & -0.445020 & -1.923568 \\
\hline $\mathrm{H}$ & -3.396424 & -1.148656 & 3.267452 & $\mathrm{H}$ & 7.578488 & 0.269417 & -1.412403 \\
\hline $\mathrm{O}$ & -0.491313 & 1.703664 & 0.451568 & $\mathrm{O}$ & -0.370822 & 1.041585 & -0.208145 \\
\hline $\mathrm{C}$ & 0.702489 & 2.387351 & 0.918454 & $\mathrm{C}$ & -1.150712 & 1.365983 & -1.379309 \\
\hline $\mathrm{H}$ & 1.207446 & 2.815922 & 0.048176 & C & -2.278890 & 0.318453 & -1.404287 \\
\hline $\mathrm{C}$ & 1.638446 & 1.293248 & 1.473157 & C & -1.758162 & -1.126579 & -1.532338 \\
\hline $\mathrm{C}$ & 0.959768 & 0.467887 & 2.581373 & $O$ & -0.895410 & -1.245127 & -2.553464 \\
\hline $\mathrm{O}$ & 1.014097 & -0.846889 & 2.336476 & $\mathrm{C}$ & -0.351489 & -2.572319 & -2.767024 \\
\hline $\mathrm{C}$ & 0.372905 & -1.692826 & 3.297164 & $\mathrm{H}$ & 0.332884 & -2.843233 & -1.954263 \\
\hline $\mathrm{H}$ & 0.561664 & -2.710172 & 2.953701 & $\mathrm{H}$ & -1.165089 & -3.298973 & -2.834541 \\
\hline $\mathrm{H}$ & 0.791368 & -1.532014 & 4.295394 & $\mathrm{H}$ & 0.188311 & -2.505596 & -3.712816 \\
\hline $\mathrm{H}$ & -0.702175 & -1.494619 & 3.318936 & $O$ & -2.124477 & -2.040029 & -0.827146 \\
\hline $\mathrm{O}$ & 0.457220 & 0.948264 & 3.580127 & $\mathrm{~N}$ & -3.124955 & 0.440110 & -0.238384 \\
\hline $\mathrm{N}$ & 2.192298 & 0.500600 & 0.405101 & $\mathrm{H}$ & -2.667182 & 0.309476 & 0.655316 \\
\hline $\mathrm{H}$ & 1.559772 & -0.080135 & -0.190722 & $\mathrm{C}$ & -4.448211 & 0.107599 & -0.305502 \\
\hline $\mathrm{C}$ & 3.524299 & 0.233522 & 0.402234 & $\mathrm{O}$ & -5.084800 & -0.013976 & -1.342066 \\
\hline $\mathrm{O}$ & 4.343614 & 0.704878 & 1.190865 & $\mathrm{O}$ & -4.944663 & -0.010635 & 0.954159 \\
\hline $\mathrm{O}$ & 3.817817 & -0.609783 & -0.618354 & $\mathrm{C}$ & -6.346984 & -0.357275 & 1.180778 \\
\hline $\mathrm{C}$ & 5.167793 & -1.104712 & -0.835302 & C & -7.261895 & 0.737697 & 0.617926 \\
\hline $\mathrm{C}$ & 6.118513 & 0.054997 & -1.162968 & $\mathrm{H}$ & -7.180326 & 0.789291 & -0.468801 \\
\hline $\mathrm{H}$ & 6.224849 & 0.721200 & -0.305332 & $\mathrm{H}$ & -8.303516 & 0.526915 & 0.888629 \\
\hline $\mathrm{H}$ & 7.105282 & -0.337268 & -1.439454 & $\mathrm{H}$ & -6.989776 & 1.711723 & 1.039953 \\
\hline $\mathrm{H}$ & 5.729100 & 0.629734 & -2.010686 & C & -6.656237 & -1.735029 & 0.582174 \\
\hline $\mathrm{C}$ & 5.642880 & -1.909359 & 0.382398 & $\mathrm{H}$ & -5.951924 & -2.480084 & 0.967460 \\
\hline $\mathrm{H}$ & 4.925207 & -2.706287 & 0.606095 & $\mathrm{H}$ & -7.670814 & -2.041909 & 0.863596 \\
\hline $\mathrm{H}$ & 6.614873 & -2.371472 & 0.169177 & $\mathrm{H}$ & -6.580201 & -1.712722 & -0.505858 \\
\hline $\mathrm{H}$ & 5.738772 & -1.264735 & 1.257864 & C & -6.436043 & -0.401594 & 2.709618 \\
\hline $\mathrm{C}$ & 4.991525 & -2.020421 & -2.051488 & $\mathrm{H}$ & -7.455454 & -0.653648 & 3.022579 \\
\hline
\end{tabular}




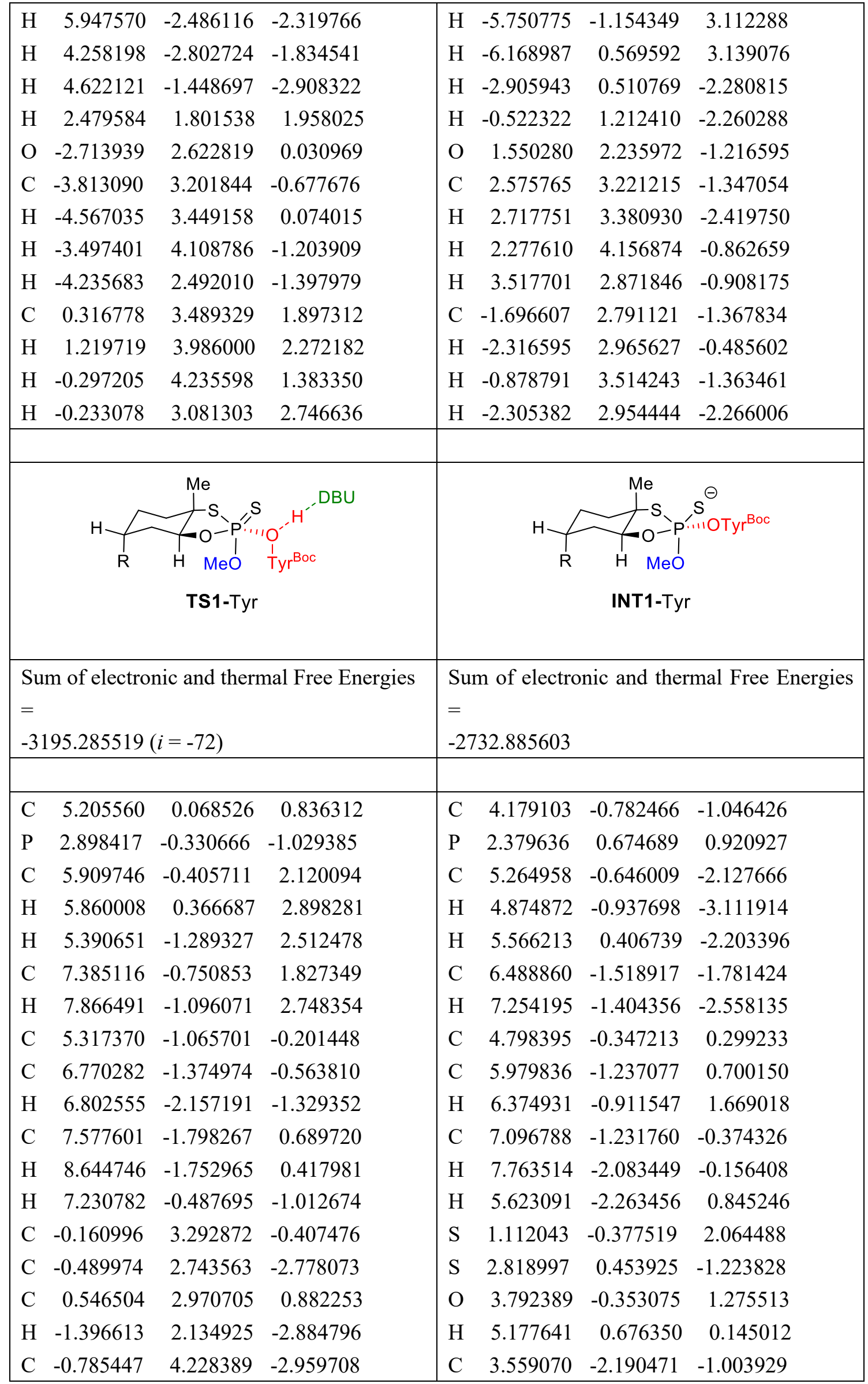




\begin{tabular}{|c|c|c|c|c|c|c|c|}
\hline $\mathrm{C}$ & 1.525811 & 4.074368 & 1.340615 & $\mathrm{H}$ & 3.017672 & -2.387572 & -1.936120 \\
\hline $\mathrm{H}$ & -0.205439 & 2.786562 & 1.661608 & $\mathrm{H}$ & 4.310208 & -2.981034 & -0.879474 \\
\hline $\mathrm{C}$ & -1.326463 & 5.164525 & 0.692413 & $\mathrm{H}$ & 2.853797 & -2.261023 & -0.172324 \\
\hline $\mathrm{H}$ & -1.341819 & 4.400758 & -3.885897 & $\mathrm{H}$ & 6.195272 & -2.575188 & -1.810034 \\
\hline $\mathrm{C}$ & -0.170609 & 6.031640 & 1.214490 & $\mathrm{C}$ & 8.020393 & -0.012503 & -0.360383 \\
\hline $\mathrm{H}$ & -1.705757 & 4.510911 & 1.486741 & $\mathrm{C}$ & 9.175922 & -0.054266 & -1.339761 \\
\hline $\mathrm{C}$ & -1.599766 & 4.742404 & -1.774004 & $\mathrm{H}$ & 9.695096 & -1.022455 & -1.304173 \\
\hline $\mathrm{N}$ & 0.075967 & 2.526953 & -1.450016 & $\mathrm{H}$ & 8.842609 & 0.083419 & -2.376375 \\
\hline $\mathrm{N}$ & -0.986186 & 4.350824 & -0.490190 & $\mathrm{H}$ & 9.906372 & 0.731729 & -1.122487 \\
\hline $\mathrm{H}$ & 1.077452 & 2.027536 & 0.735450 & $\mathrm{C}$ & 7.907799 & 1.020379 & 0.482361 \\
\hline $\mathrm{H}$ & 2.240309 & 3.603659 & 2.024163 & $\mathrm{H}$ & 7.101727 & 1.112165 & 1.201337 \\
\hline $\mathrm{H}$ & -2.163332 & 5.798005 & 0.387733 & $\mathrm{H}$ & 8.630709 & 1.833466 & 0.469534 \\
\hline $\mathrm{H}$ & -2.628867 & 4.359803 & -1.810722 & $\mathrm{O}$ & 1.217418 & 1.937299 & 0.242951 \\
\hline $\mathrm{H}$ & -1.653585 & 5.835411 & -1.793991 & $\mathrm{C}$ & -4.310794 & 1.757758 & -1.128008 \\
\hline $\mathrm{H}$ & 0.157559 & 4.782383 & -3.029266 & $\mathrm{H}$ & -4.642387 & 2.716910 & -1.541956 \\
\hline $\mathrm{H}$ & 0.249668 & 2.373441 & -3.492181 & $\mathrm{H}$ & -4.544266 & 0.990361 & -1.873618 \\
\hline $\mathrm{S}$ & 2.696765 & 0.972601 & -2.569978 & $\mathrm{C}$ & -5.150349 & 1.469197 & 0.141030 \\
\hline S & 3.367162 & 0.198031 & 1.034229 & $\mathrm{C}$ & -6.676433 & 1.562639 & -0.021733 \\
\hline $\mathrm{O}$ & 4.558790 & -0.700896 & -1.338840 & $\mathrm{O}$ & -7.034581 & 2.028065 & -1.238943 \\
\hline $\mathrm{H}$ & 4.881741 & -1.962171 & 0.263573 & $\mathrm{C}$ & -8.446686 & 2.135062 & -1.448761 \\
\hline $\mathrm{C}$ & 5.740815 & 1.420111 & 0.332570 & $\mathrm{H}$ & -8.564842 & 2.523402 & -2.461685 \\
\hline $\mathrm{H}$ & 5.518259 & 2.204145 & 1.064915 & $\mathrm{H}$ & -8.919072 & 1.153234 & -1.356273 \\
\hline $\mathrm{H}$ & 6.825703 & 1.407367 & 0.179062 & $\mathrm{H}$ & -8.898570 & 2.815276 & -0.720700 \\
\hline $\mathrm{H}$ & 5.269919 & 1.687952 & -0.616462 & $\mathrm{O}$ & -7.472731 & 1.327295 & 0.858917 \\
\hline $\mathrm{H}$ & 7.918980 & 0.162671 & 1.540236 & $\mathrm{~N}$ & -4.823333 & 0.194082 & 0.768392 \\
\hline $\mathrm{C}$ & 7.358059 & -3.239091 & 1.157522 & $\mathrm{H}$ & -3.961509 & 0.156511 & 1.297671 \\
\hline $\mathrm{C}$ & 8.174827 & -3.670731 & 2.357919 & $\mathrm{C}$ & -5.231654 & -0.978579 & 0.199599 \\
\hline $\mathrm{H}$ & 9.226898 & -3.371686 & 2.253993 & $\mathrm{O}$ & -6.071166 & -1.057024 & -0.688659 \\
\hline $\mathrm{H}$ & 7.810442 & -3.218366 & 3.289139 & $\mathrm{O}$ & -4.593088 & -2.016364 & 0.792447 \\
\hline $\mathrm{H}$ & 8.142012 & -4.756770 & 2.486690 & $\mathrm{C}$ & -4.834947 & -3.398828 & 0.373496 \\
\hline $\mathrm{C}$ & 6.566469 & -4.125386 & 0.543016 & $\mathrm{C}$ & -3.892019 & -4.191040 & 1.283958 \\
\hline $\mathrm{H}$ & 5.960481 & -3.881860 & -0.322873 & $\mathrm{H}$ & -4.145084 & -4.026458 & 2.336420 \\
\hline $\mathrm{H}$ & 6.496760 & -5.151577 & 0.895605 & $\mathrm{H}$ & -3.971813 & -5.262566 & 1.069123 \\
\hline $\mathrm{O}$ & 1.173669 & 0.007785 & -0.307233 & $\mathrm{H}$ & -2.854659 & -3.878725 & 1.129300 \\
\hline $\mathrm{C}$ & -4.952776 & -1.580371 & -1.324275 & $\mathrm{C}$ & -6.296738 & -3.779475 & 0.638629 \\
\hline $\mathrm{C}$ & -6.259637 & -2.241364 & -1.782782 & $\mathrm{H}$ & -6.549303 & -3.600278 & 1.689650 \\
\hline $\mathrm{O}$ & -7.285992 & -1.368175 & -1.781562 & $\mathrm{H}$ & -6.971247 & -3.194899 & 0.010870 \\
\hline $\mathrm{C}$ & -8.550143 & -1.923414 & -2.174741 & $\mathrm{H}$ & -6.445756 & -4.845275 & 0.428000 \\
\hline $\mathrm{H}$ & -9.260134 & -1.096757 & -2.127397 & $\mathrm{C}$ & -4.445535 & -3.582787 & -1.098151 \\
\hline $\mathrm{H}$ & -8.497723 & -2.328865 & -3.188877 & $\mathrm{H}$ & -5.100128 & -3.003476 & -1.751268 \\
\hline $\mathrm{H}$ & -8.841989 & -2.719887 & -1.485278 & $\mathrm{H}$ & -3.410292 & -3.262142 & -1.257354 \\
\hline $\mathrm{O}$ & -6.339031 & -3.377546 & -2.191526 & $\mathrm{H}$ & -4.519884 & -4.642488 & -1.369760 \\
\hline
\end{tabular}




\begin{tabular}{|c|c|c|c|c|c|c|c|}
\hline $\mathrm{N}$ & -5.162158 & -0.714758 & -0.168461 & $\mathrm{C}$ & -0.074639 & 1.814545 & -0.083843 \\
\hline $\mathrm{H}$ & -4.457657 & -0.008071 & -0.005752 & $\mathrm{C}$ & -0.881224 & 2.962973 & 0.057424 \\
\hline $\mathrm{C}$ & -5.792180 & -1.188958 & 0.952462 & $\mathrm{C}$ & -0.672942 & 0.654811 & -0.616772 \\
\hline $\mathrm{O}$ & -6.454483 & -2.214492 & 0.984000 & $\mathrm{C}$ & -2.223839 & 2.948947 & -0.306423 \\
\hline $\mathrm{O}$ & -5.584960 & -0.332117 & 1.983200 & $\mathrm{H}$ & -0.417487 & 3.859857 & 0.458045 \\
\hline $\mathrm{C}$ & -6.199376 & -0.570035 & 3.298554 & $\mathrm{C}$ & -2.020306 & 0.656659 & -0.970073 \\
\hline $\mathrm{C}$ & -5.706223 & 0.627460 & 4.115537 & $\mathrm{H}$ & -0.076703 & -0.238957 & -0.746439 \\
\hline $\mathrm{H}$ & -6.042586 & 1.567338 & 3.665252 & $\mathrm{C}$ & -2.829431 & 1.792260 & -0.820156 \\
\hline $\mathrm{H}$ & -6.096921 & 0.573044 & 5.137060 & $\mathrm{H}$ & -2.816865 & 3.856327 & -0.185884 \\
\hline $\mathrm{H}$ & -4.612285 & 0.638002 & 4.163293 & $\mathrm{H}$ & -2.455552 & -0.253857 & -1.380971 \\
\hline $\mathrm{C}$ & -7.726941 & -0.551340 & 3.176326 & $\mathrm{H}$ & -4.905341 & 2.233618 & 0.889583 \\
\hline $\mathrm{H}$ & -8.081594 & -1.391283 & 2.577218 & $\mathrm{O}$ & 3.116937 & 2.027061 & 1.562000 \\
\hline $\mathrm{H}$ & -8.176987 & -0.613244 & 4.173682 & $\mathrm{C}$ & 3.890324 & 1.902909 & 2.747494 \\
\hline $\mathrm{H}$ & -8.059623 & 0.382618 & 2.709823 & $\mathrm{H}$ & 3.946511 & 2.910269 & 3.176372 \\
\hline $\mathrm{C}$ & -5.679764 & -1.883211 & 3.893885 & $\mathrm{H}$ & 3.418329 & 1.227304 & 3.469386 \\
\hline $\mathrm{H}$ & -6.009232 & -2.739161 & 3.303246 & $\mathrm{H}$ & 4.905248 & 1.542002 & 2.541913 \\
\hline $\mathrm{H}$ & -4.584595 & -1.877587 & 3.930510 & & & & \\
\hline $\mathrm{H}$ & -6.052568 & -1.996111 & 4.918278 & & & & \\
\hline $\mathrm{H}$ & 0.801748 & 1.787860 & -1.382361 & & & & \\
\hline $\mathrm{C}$ & 0.862463 & 5.262212 & 2.050253 & & & & \\
\hline $\mathrm{H}$ & 0.369484 & 4.896290 & 2.963025 & & & & \\
\hline $\mathrm{H}$ & 1.639268 & 5.961446 & 2.383248 & & & & \\
\hline $\mathrm{H}$ & 0.312951 & 6.525614 & 0.360841 & & & & \\
\hline $\mathrm{H}$ & -0.603965 & 6.828586 & 1.832411 & & & & \\
\hline $\mathrm{H}$ & 2.113235 & 4.417123 & 0.479152 & & & & \\
\hline $\mathrm{H}$ & -4.661243 & -0.911297 & -2.145349 & & & & \\
\hline $\mathrm{O}$ & 2.375085 & -1.885259 & -1.217211 & & & & \\
\hline $\mathrm{C}$ & 2.977855 & -2.750491 & -2.181961 & & & & \\
\hline $\mathrm{H}$ & 3.170306 & -2.227329 & -3.123740 & & & & \\
\hline $\mathrm{H}$ & 3.915940 & -3.172579 & -1.809150 & & & & \\
\hline $\mathrm{H}$ & 2.254519 & -3.553941 & -2.347885 & & & & \\
\hline $\mathrm{C}$ & 0.029315 & -0.677499 & -0.538864 & & & & \\
\hline $\mathrm{C}$ & -0.427219 & -1.007610 & -1.829467 & & & & \\
\hline $\mathrm{C}$ & -0.783159 & -1.006484 & 0.558826 & & & & \\
\hline $\mathrm{C}$ & -1.655374 & -1.643703 & -1.997124 & & & & \\
\hline $\mathrm{H}$ & 0.198611 & -0.772831 & -2.684018 & & & & \\
\hline $\mathrm{C}$ & -2.012827 & -1.637244 & 0.373036 & & & & \\
\hline $\mathrm{H}$ & -0.420931 & -0.774225 & 1.556412 & & & & \\
\hline $\mathrm{C}$ & -2.477801 & -1.970012 & -0.907401 & & & & \\
\hline $\mathrm{H}$ & -1.980468 & -1.903855 & -3.003904 & & & & \\
\hline $\mathrm{H}$ & -2.614199 & -1.893400 & 1.243614 & & & & \\
\hline $\mathrm{C}$ & -3.827747 & -2.620526 & -1.119797 & & & & \\
\hline
\end{tabular}




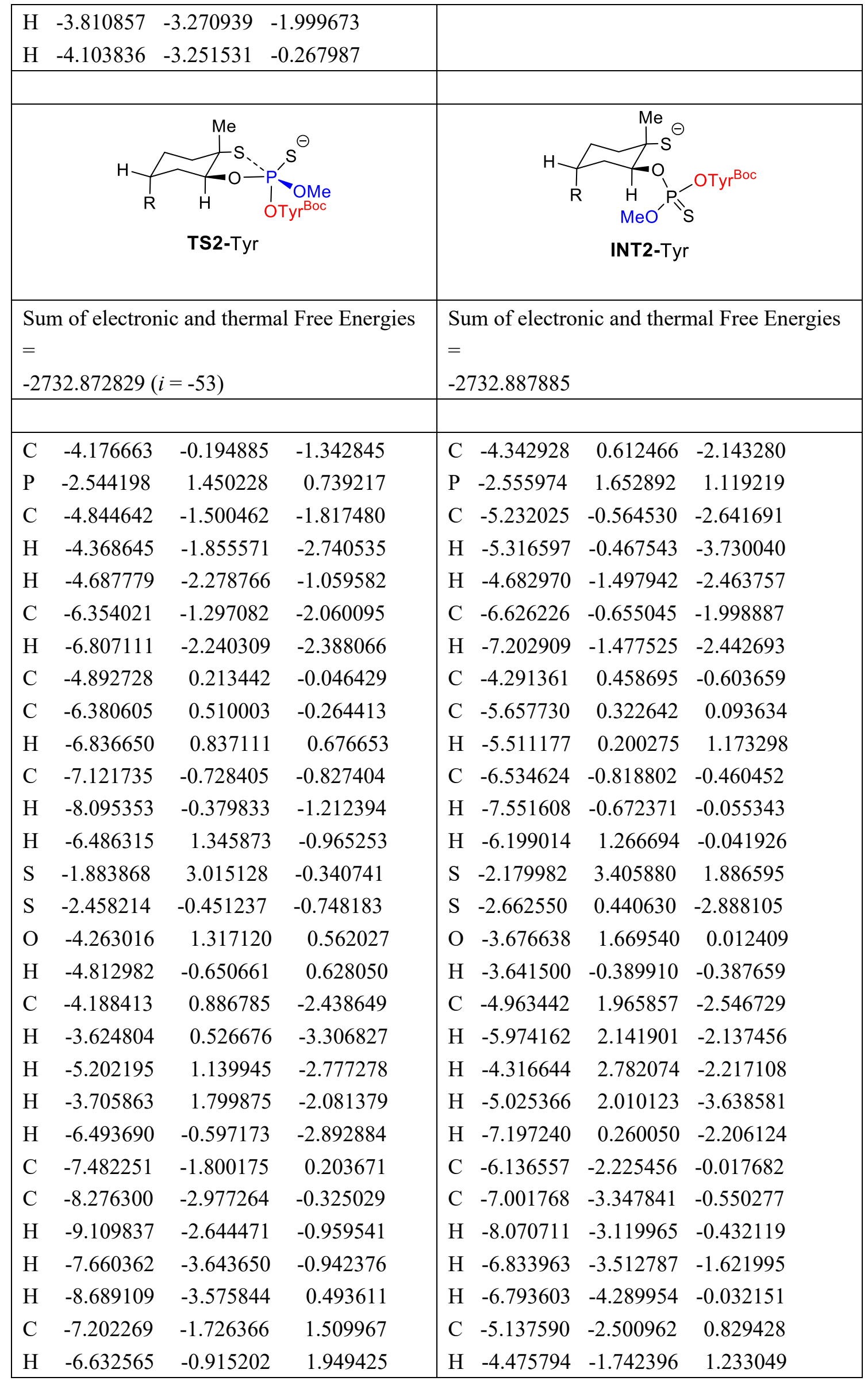




\begin{tabular}{|c|c|c|c|c|c|c|c|}
\hline $\mathrm{H}$ & -7.533172 & -2.502787 & 2.196738 & $\mathrm{H}$ & -4.935250 & -3.524878 & 1.138315 \\
\hline $\mathrm{O}$ & -1.269974 & 0.609931 & 1.593198 & $\mathrm{O}$ & -1.336407 & 0.866750 & 0.397232 \\
\hline $\mathrm{C}$ & 3.462074 & -2.066377 & -0.095816 & $\mathrm{C}$ & 3.558124 & -1.078117 & 2.561806 \\
\hline $\mathrm{H}$ & 3.314702 & -3.151809 & -0.116649 & $\mathrm{C}$ & 4.558906 & -1.406544 & 1.419111 \\
\hline $\mathrm{H}$ & 3.785229 & -1.769059 & -1.098699 & $\mathrm{C}$ & 4.008822 & -2.571867 & 0.583672 \\
\hline $\mathrm{C}$ & 4.609133 & -1.756661 & 0.896071 & $\mathrm{O}$ & 3.756331 & -2.226053 & -0.688214 \\
\hline $\mathrm{C}$ & 5.913506 & -2.544695 & 0.685840 & $\mathrm{C}$ & 3.145613 & -3.243331 & -1.502022 \\
\hline $\mathrm{O}$ & 5.787926 & -3.497706 & -0.261681 & $\mathrm{H}$ & 3.025775 & -2.794388 & -2.487717 \\
\hline $\mathrm{C}$ & 6.973049 & -4.264512 & -0.505611 & $\mathrm{H}$ & 3.785071 & -4.128586 & -1.549725 \\
\hline $\mathrm{H}$ & 6.703698 & -4.981795 & -1.282309 & $\mathrm{H}$ & 2.172344 & -3.520314 & -1.089888 \\
\hline $\mathrm{H}$ & 7.781371 & -3.612637 & -0.847860 & $\mathrm{O}$ & 3.800113 & -3.674238 & 1.047599 \\
\hline $\mathrm{H}$ & 7.294928 & -4.782455 & 0.402569 & $\mathrm{~N}$ & 4.883144 & -0.221944 & 0.653466 \\
\hline $\mathrm{O}$ & 6.916305 & -2.387917 & 1.345096 & $\mathrm{H}$ & 4.111134 & 0.289558 & 0.243670 \\
\hline $\mathrm{N}$ & 4.929520 & -0.336458 & 0.979493 & $\mathrm{C}$ & 6.093635 & -0.103810 & 0.025060 \\
\hline $\mathrm{H}$ & 4.292947 & 0.243199 & 1.509846 & $\mathrm{O}$ & 7.058650 & -0.823097 & 0.236702 \\
\hline $\mathrm{C}$ & 5.599639 & 0.281629 & -0.038949 & $\mathrm{O}$ & 6.050649 & 0.952693 & -0.825057 \\
\hline $\mathrm{O}$ & 6.180340 & -0.311761 & -0.937969 & $\mathrm{C}$ & 7.219457 & 1.331035 & -1.625042 \\
\hline $\mathrm{O}$ & 5.542160 & 1.625070 & 0.130526 & $\mathrm{C}$ & 8.379919 & 1.733980 & -0.707517 \\
\hline $\mathrm{C}$ & 6.174512 & 2.538969 & -0.826689 & $\mathrm{H}$ & 8.735109 & 0.879055 & -0.130119 \\
\hline $\mathrm{C}$ & 5.837525 & 3.914568 & -0.243771 & $\mathrm{H}$ & 9.207934 & 2.126618 & -1.309461 \\
\hline $\mathrm{H}$ & 6.253158 & 4.018580 & 0.764054 & $\mathrm{H}$ & 8.059588 & 2.520767 & -0.015345 \\
\hline $\mathrm{H}$ & 6.256045 & 4.705039 & -0.876369 & $\mathrm{C}$ & 7.600369 & 0.187980 & -2.573009 \\
\hline $\mathrm{H}$ & 4.753463 & 4.053199 & -0.184597 & $\mathrm{H}$ & 6.737271 & -0.100641 & -3.182768 \\
\hline $\mathrm{C}$ & 7.690891 & 2.312626 & -0.845798 & $\mathrm{H}$ & 8.399769 & 0.517254 & -3.247177 \\
\hline $\mathrm{H}$ & 8.099349 & 2.398730 & 0.167226 & $\mathrm{H}$ & 7.945194 & -0.683473 & -2.014151 \\
\hline $\mathrm{H}$ & 7.931950 & 1.323752 & -1.238816 & $\mathrm{C}$ & 6.705918 & 2.539823 & -2.412761 \\
\hline $\mathrm{H}$ & 8.169887 & 3.073134 & -1.473882 & $\mathrm{H}$ & 7.495204 & 2.928393 & -3.065611 \\
\hline $\mathrm{C}$ & 5.544076 & 2.370198 & -2.213869 & $\mathrm{H}$ & 5.847707 & 2.260301 & -3.032013 \\
\hline $\mathrm{H}$ & 5.760038 & 1.382319 & -2.623692 & $\mathrm{H}$ & 6.391967 & 3.338360 & -1.732785 \\
\hline $\mathrm{H}$ & 4.458166 & 2.501163 & -2.155255 & $\mathrm{H}$ & 5.491296 & -1.766706 & 1.861912 \\
\hline $\mathrm{H}$ & 5.942273 & 3.131370 & -2.894998 & $\mathrm{O}$ & -2.958483 & 0.505721 & 2.219427 \\
\hline $\mathrm{C}$ & -0.183861 & -0.019564 & 1.088053 & $\mathrm{C}$ & -3.670565 & 0.847217 & 3.413275 \\
\hline $\mathrm{C}$ & 0.162321 & -1.257684 & 1.655865 & $\mathrm{H}$ & -3.738091 & -0.073106 & 3.998464 \\
\hline $\mathrm{C}$ & 0.658178 & 0.541807 & 0.114406 & $\mathrm{H}$ & -3.133367 & 1.616184 & 3.975945 \\
\hline $\mathrm{C}$ & 1.325784 & -1.912365 & 1.264892 & $\mathrm{H}$ & -4.679239 & 1.206728 & 3.181633 \\
\hline $\mathrm{H}$ & -0.503699 & -1.685782 & 2.398636 & $\mathrm{C}$ & -0.182992 & 0.430274 & 1.015961 \\
\hline $\mathrm{C}$ & 1.813810 & -0.134615 & -0.272037 & $\mathrm{C}$ & -0.019215 & -0.940548 & 1.220441 \\
\hline $\mathrm{H}$ & 0.380066 & 1.491497 & -0.329332 & $\mathrm{C}$ & 0.837767 & 1.324044 & 1.340660 \\
\hline $\mathrm{C}$ & 2.176690 & -1.366056 & 0.291792 & $\mathrm{C}$ & 1.180605 & -1.418176 & 1.742141 \\
\hline $\mathrm{H}$ & 1.570940 & -2.875313 & 1.712931 & $\mathrm{H}$ & -0.829162 & -1.609992 & 0.951915 \\
\hline $\mathrm{H}$ & 2.449840 & 0.306406 & -1.038160 & $\mathrm{C}$ & 2.030495 & 0.830626 & 1.870953 \\
\hline $\mathrm{H}$ & 4.275142 & -2.040295 & 1.902463 & $\mathrm{H}$ & 0.686720 & 2.384994 & 1.177574 \\
\hline
\end{tabular}




\begin{tabular}{|c|c|c|c|c|c|c|}
\hline $\mathrm{O}$ & -2.825517 & 2.025650 & 2.305806 & $\begin{array}{ll}\text { C } & 2.229220\end{array}$ & -0.543868 & 2.068595 \\
\hline $\mathrm{C}$ & -3.771960 & 3.052437 & 2.528579 & 1.310315 & -2.487356 & 1.891780 \\
\hline $\mathrm{H}$ & -3.548418 & 3.470767 & 3.518555 & H 2.822642 & 1.529019 & 2.133502 \\
\hline $\mathrm{H}$ & -3.685414 & 3.850018 & 1.779271 & 3.411532 & -1.998974 & 3.135056 \\
\hline $\mathrm{H}$ & -4.799813 & 2.669437 & 2.523218 & 4.045232 & -0.348463 & 3.218059 \\
\hline & & ${ }_{S}{ }^{\rho}$ & Tyr ${ }^{B o c}$ & & $\begin{array}{c}S^{\ominus} \\
\text { INT3-Tyr }\end{array}$ & \\
\hline & $\begin{array}{l}\text { n of electror } \\
32.888645\end{array}$ & $\begin{array}{l}\text { aic and therm } \\
(i=-172)\end{array}$ & nal Free Energies & $\begin{array}{l}\text { Sum of electro } \\
= \\
-2732.909902\end{array}$ & nic and therm & al Free Energies \\
\hline $\mathrm{C}$ & 4.001328 & 2.202769 & -0.014447 & C 3.872312 & 2.369388 & -0.051239 \\
\hline $\mathrm{P}$ & 2.553965 & $-1.203116-$ & -1.142228 & 2.624167 & -1.153209 & -1.104886 \\
\hline $\mathrm{C}$ & 5.171160 & 2.440269 & -1.009024 & C $\quad 5.201344$ & 2.616864 & -0.803855 \\
\hline $\mathrm{H}$ & 4.760313 & 2.441996 & -2.029143 & 5.160576 & 2.122080 & -1.789375 \\
\hline $\mathrm{H}$ & 5.540967 & 3.450370 & -0.816997 & 5.293845 & 3.694437 & -0.982282 \\
\hline $\mathrm{C}$ & 6.360850 & 1.431386 & -1.012905 & C $\quad 6.436577$ & 2.112961 & -0.046761 \\
\hline $\mathrm{H}$ & 7.298426 & 1.996058 & -0.969603 & 6.525548 & 2.672698 & 0.890759 \\
\hline $\mathrm{C}$ & 3.895591 & 0.724495 & 0.336771 & C $\quad 3.789507$ & 0.901096 & 0.368838 \\
\hline $\mathrm{C}$ & 5.153692 & 0.130115 & 0.941333 & C $\quad 5.026432$ & 0.360984 & 1.080746 \\
\hline $\mathrm{H}$ & 5.267952 & 0.643240 & 1.895184 & 5.069835 & 0.896802 & 2.032938 \\
\hline $\mathrm{C}$ & 6.431612 & 0.299445 & 0.078988 & C $\quad 6.314935$ & 0.601173 & 0.276235 \\
\hline $\mathrm{H}$ & 6.549103 & -0.636245 & -0.483880 & 6.208217 & 0.077108 & -0.687302 \\
\hline $\mathrm{H}$ & 4.992655 & -0.934371 & 1.155192 & H $\quad 4.894164$ & -0.706909 & 1.293680 \\
\hline S & 2.445822 & $-2.016219-$ & -2.912116 & 2.628765 & -2.021904 & -2.851336 \\
\hline $\mathrm{S}$ & 4.246673 & 3.078184 & 1.617086 & 3.772911 & 3.317414 & 1.546841 \\
\hline $\mathrm{O}$ & 3.632052 & -0.077988 & -0.981734 & 3.650426 & 0.015879 & -0.926023 \\
\hline $\mathrm{H}$ & 3.025836 & 0.547020 & 0.969314 & 2.878092 & 0.721564 & 0.936559 \\
\hline $\mathrm{C}$ & 2.695723 & 2.703530 & -0.655891 & C $\quad 2.693352$ & 2.751720 & -0.959132 \\
\hline $\mathrm{H}$ & 2.468351 & 2.183415 & -1.598739 & H 2.718330 & 2.221071 & -1.922932 \\
\hline $\mathrm{H}$ & 1.856156 & 2.570622 & 0.033863 & 1.742231 & 2.534157 & -0.462574 \\
\hline $\mathrm{H}$ & 2.786648 & 3.775562 & -0.861283 & 2.727337 & 3.829687 & -1.148637 \\
\hline $\mathrm{H}$ & 6.358745 & 0.928693 & -1.986831 & 7.339809 & 2.301904 & -0.644319 \\
\hline $\mathrm{C}$ & 7.690878 & 0.444148 & 0.938389 & C $\quad 7.571994$ & 0.052664 & 0.933854 \\
\hline $\mathrm{C}$ & 8.862967 & -0.412627 & 0.520541 & C $\quad 8.752356$ & -0.151250 & 0.010024 \\
\hline $\mathrm{H}$ & 8.614821 & -1.483439 & 0.572760 & 8.507198 & -0.867473 & -0.787114 \\
\hline
\end{tabular}




\begin{tabular}{|c|c|c|c|c|c|c|c|}
\hline $\mathrm{H}$ & 9.145044 & -0.215140 & -0.524414 & $\mathrm{H}$ & 9.035482 & 0.783263 & -0.491400 \\
\hline $\mathrm{H}$ & 9.744886 & -0.236242 & 1.146970 & $\mathrm{H}$ & 9.630097 & -0.526212 & 0.548009 \\
\hline $\mathrm{C}$ & 7.782323 & 1.309775 & 1.953919 & $\mathrm{C}$ & 7.671736 & -0.242929 & 2.235441 \\
\hline $\mathrm{H}$ & 6.950702 & 1.959571 & 2.226306 & $\mathrm{H}$ & 6.846258 & -0.110362 & 2.927285 \\
\hline $\mathrm{H}$ & 8.709328 & 1.414494 & 2.517197 & $\mathrm{H}$ & 8.601365 & -0.619344 & 2.658955 \\
\hline $\mathrm{O}$ & 1.194955 & -0.458804 & -0.600916 & $\mathrm{O}$ & 1.213356 & -0.447902 & -0.651209 \\
\hline $\mathrm{C}$ & -3.994328 & -2.726242 & 0.043715 & $\mathrm{C}$ & -3.985462 & -2.763237 & -0.369027 \\
\hline $\mathrm{C}$ & -4.982229 & -1.697195 & 0.657451 & $\mathrm{H}$ & -4.397494 & -2.953769 & -1.365916 \\
\hline $\mathrm{C}$ & -4.574828 & -1.397169 & 2.107881 & $\mathrm{C}$ & -4.969739 & -1.809815 & 0.361383 \\
\hline $\mathrm{O}$ & -4.292571 & -0.100710 & 2.316489 & $\mathrm{C}$ & -4.573837 & -1.699148 & 1.841840 \\
\hline $\mathrm{C}$ & -3.851353 & 0.230557 & 3.644859 & $\mathrm{O}$ & -4.280400 & -0.442670 & 2.213935 \\
\hline $\mathrm{H}$ & -3.673079 & 1.305725 & 3.633054 & $\mathrm{C}$ & -3.852287 & -0.284140 & 3.577687 \\
\hline $\mathrm{H}$ & -4.619736 & -0.028884 & 4.377691 & $\mathrm{H}$ & -3.661559 & 0.781816 & 3.701164 \\
\hline $\mathrm{H}$ & -2.930517 & -0.307635 & 3.882789 & $\mathrm{H}$ & -4.632753 & -0.622355 & 4.264240 \\
\hline $\mathrm{O}$ & -4.500551 & -2.256527 & 2.961948 & $\mathrm{H}$ & -2.940673 & -0.859390 & 3.757387 \\
\hline $\mathrm{N}$ & -5.112668 & -0.528927 & -0.185305 & $\mathrm{O}$ & -4.518023 & -2.659751 & 2.581970 \\
\hline $\mathrm{H}$ & -4.263897 & -0.036438 & -0.434063 & $\mathrm{~N}$ & -5.079958 & -0.543649 & -0.329660 \\
\hline $\mathrm{C}$ & -6.270444 & 0.202651 & -0.193774 & $\mathrm{H}$ & -4.220376 & -0.046744 & -0.528528 \\
\hline $\mathrm{O}$ & -7.328364 & -0.171375 & 0.289384 & $\mathrm{C}$ & -6.211132 & 0.219812 & -0.208000 \\
\hline $\mathrm{O}$ & -6.053871 & 1.369363 & -0.850200 & $\mathrm{O}$ & -7.267091 & -0.179814 & 0.258464 \\
\hline $\mathrm{C}$ & -7.133591 & 2.344086 & -1.040595 & $\mathrm{O}$ & -5.972406 & 1.452469 & -0.719647 \\
\hline $\mathrm{C}$ & -8.256998 & 1.729055 & -1.883414 & $\mathrm{C}$ & -7.015109 & 2.484638 & -0.730237 \\
\hline $\mathrm{H}$ & -8.742689 & 0.911131 & -1.349007 & $\mathrm{C}$ & -8.200283 & 2.029420 & -1.589869 \\
\hline $\mathrm{H}$ & -9.005406 & 2.495349 & -2.116820 & $\mathrm{H}$ & -8.699130 & 1.168629 & -1.141982 \\
\hline $\mathrm{H}$ & -7.855552 & 1.346542 & -2.828479 & $\mathrm{H}$ & -8.922085 & 2.848797 & -1.687101 \\
\hline $\mathrm{C}$ & -7.636289 & 2.845809 & 0.318098 & $\mathrm{H}$ & -7.857037 & 1.757504 & -2.594318 \\
\hline $\mathrm{H}$ & -6.801583 & 3.239999 & 0.908031 & $\mathrm{C}$ & -7.435109 & 2.821750 & 0.705066 \\
\hline $\mathrm{H}$ & -8.359917 & 3.655445 & 0.167829 & $\mathrm{H}$ & -6.559673 & 3.109203 & 1.297524 \\
\hline $\mathrm{H}$ & -8.116007 & 2.041859 & 0.878454 & $\mathrm{H}$ & -8.133699 & 3.666450 & 0.696419 \\
\hline $\mathrm{C}$ & -6.434057 & 3.469466 & -1.808210 & $\mathrm{H}$ & -7.919150 & 1.967628 & 1.181211 \\
\hline $\mathrm{H}$ & -7.141143 & 4.279313 & -2.018098 & $\mathrm{C}$ & -6.299793 & 3.673356 & -1.378539 \\
\hline $\mathrm{H}$ & -5.602349 & 3.876226 & -1.224203 & $\mathrm{H}$ & -6.978368 & 4.530533 & -1.447176 \\
\hline $\mathrm{H}$ & -6.036708 & 3.099398 & -2.758886 & $\mathrm{H}$ & -5.426215 & 3.967474 & -0.788137 \\
\hline $\mathrm{H}$ & -5.972211 & -2.157843 & 0.718284 & $\mathrm{H}$ & -5.960913 & 3.416425 & -2.387409 \\
\hline $\mathrm{O}$ & 2.722948 & -2.270396 & 0.084407 & $\mathrm{H}$ & -5.964232 & -2.264790 & 0.356640 \\
\hline $\mathrm{C}$ & 3.631242 & -3.371506 & -0.036832 & $\mathrm{H}$ & -3.987675 & -3.709599 & 0.180482 \\
\hline $\mathrm{H}$ & 3.501444 & -3.973677 & 0.865480 & $\mathrm{O}$ & 2.779196 & -2.178807 & 0.160555 \\
\hline $\mathrm{H}$ & 3.397470 & -3.966534 & -0.925012 & $\mathrm{C}$ & 3.750247 & -3.231946 & 0.115842 \\
\hline $\mathrm{H}$ & 4.666526 & -3.018209 & -0.092828 & $\mathrm{H}$ & 3.610255 & -3.813705 & 1.029935 \\
\hline $\mathrm{C}$ & -0.031585 & -1.085199 & -0.474238 & $\mathrm{H}$ & 3.590615 & -3.864468 & -0.762770 \\
\hline $\mathrm{C}$ & -0.371477 & -1.707218 & 0.728067 & $\mathrm{H}$ & 4.766692 & -2.824668 & 0.096626 \\
\hline $\mathrm{C}$ & -0.948438 & -1.017453 & -1.522476 & $\mathrm{C}$ & -0.008449 & -1.093346 & -0.617253 \\
\hline
\end{tabular}




\begin{tabular}{|c|c|c|c|c|c|}
\hline $\mathrm{C}$ & $-1.644982-2.251466$ & 0.881759 & C -0.906906 & -0.894657 & -1.664683 \\
\hline $\mathrm{H}$ & $0.364810-1.756350$ & 1.522566 & C -0.369578 & -1.860194 & 0.491881 \\
\hline $\mathrm{C}$ & $-2.218821 \quad-1.569318$ & -1.355123 & C -2.181105 & -1.457436 & -1.589061 \\
\hline $\mathrm{H}$ & $-0.654096-0.542311$ & -2.451638 & H $\quad-0.596448$ & -0.305903 & -2.520908 \\
\hline $\mathrm{C}$ & $-2.592603 \quad-2.185426$ & -0.151649 & C -1.645966 & -2.415691 & 0.553723 \\
\hline $\mathrm{H}$ & $-1.910492-2.732966$ & 1.819737 & H $\quad 0.351396$ & -2.009345 & 1.287605 \\
\hline $\mathrm{H}$ & $-2.929804 \quad-1.525637$ & -2.177455 & C -2.576701 & -2.216473 & -0.477813 \\
\hline $\mathrm{H}$ & $-3.979965 \quad-3.594798$ & 0.709299 & H $\quad-2.877768$ & -1.308257 & -2.411280 \\
\hline $\mathrm{H}$ & $-4.414617 \quad-3.046436$ & -0.915789 & Н -1.928169 & -3.009039 & 1.419949 \\
\hline & TS4-Tyr & & & $\begin{array}{l}\mathrm{H} \quad \mathrm{MeO} \\
\text { TS1-Cys }\end{array}$ & \\
\hline & $\begin{array}{l}\text { Im of electronic and thern } \\
732.910274(i=-282)\end{array}$ & mal Free Energies & $\begin{array}{l}\text { Sum of electro } \\
= \\
-2824.878029\end{array}$ & $\begin{array}{l}\text { nic and therr } \\
(i=-59)\end{array}$ & nal Free Energies \\
\hline $\mathrm{C}$ & 2.461641 & -0.231335 & C 3.761415 & -0.556276 & -0.832530 \\
\hline $\mathrm{P}$ & $2.638071-1.166166$ & -1.162070 & 1.043876 & -1.762192 & -0.385501 \\
\hline $\mathrm{C}$ & $\begin{array}{ll}5.371968 & 2.589974\end{array}$ & -0.856421 & C $\quad 4.510365$ & 0.781238 & -0.969693 \\
\hline $\mathrm{H}$ & 2.042087 & -1.812421 & 4.930751 & 0.892225 & -1.977988 \\
\hline $\mathrm{H}$ & 3.648198 & -1.081808 & 3.801490 & 1.606545 & -0.826394 \\
\hline $\mathrm{C}$ & 2.052717 & 0.036040 & C $\quad 5.645198$ & 0.875950 & 0.072561 \\
\hline $\mathrm{H}$ & 2.659739 & 0.946447 & 6.154758 & 1.841218 & -0.028804 \\
\hline $\mathrm{C}$ & 1.105816 & 0.366209 & 3.207299 & -0.630176 & 0.604665 \\
\hline $\mathrm{C}$ & 0.465093 & 1.151407 & 4.320781 & -0.622457 & 1.653152 \\
\hline $\mathrm{H}$ & 0.988917 & 2.108981 & 3.884307 & -0.713376 & 2.653763 \\
\hline $\mathrm{C}$ & 0.574360 & 0.425530 & 5.181098 & 0.661830 & 1.545997 \\
\hline $\mathrm{H}$ & 0.010069 & -0.514957 & 6.102320 & 0.486887 & 2.127066 \\
\hline $\mathrm{H}$ & $4.639793 \quad-0.581720$ & 1.352715 & 4.960868 & -1.501631 & 1.514420 \\
\hline $\mathrm{S}$ & $2.564951 \quad-2.118271$ & -2.874453 & S $\quad 0.641472$ & -3.710610 & -0.370080 \\
\hline $\mathrm{S}$ & 3.764629 & 1.334969 & S 2.197392 & -0.633980 & -1.843354 \\
\hline $\mathrm{O}$ & $\begin{array}{ll}3.666231 & -0.022218\end{array}$ & -1.019957 & 2.392882 & -1.777376 & 0.708797 \\
\hline $\mathrm{H}$ & 0.952709 & 0.770624 & 2.594287 & 0.269727 & 0.752351 \\
\hline $\mathrm{C}$ & 2.838478 & -1.253332 & 4.633119 & -1.764143 & -1.217394 \\
\hline $\mathrm{H}$ & 2.234743 & -2.167381 & 4.879973 & -1.722833 & -2.284132 \\
\hline $\mathrm{H}$ & 2.698686 & -0.826840 & 5.575490 & -1.798417 & -0.656256 \\
\hline $\mathrm{H}$ & 3.897890 & -1.511780 & H 4.091673 & -2.693720 & -1.026873 \\
\hline
\end{tabular}




\begin{tabular}{|c|c|c|c|c|c|c|c|}
\hline $\mathrm{H}$ & 7.457360 & 2.144935 & -0.491974 & $\mathrm{H}$ & 6.404174 & 0.117101 & -0.153496 \\
\hline $\mathrm{C}$ & 7.409548 & -0.028863 & 1.191694 & $\mathrm{C}$ & 4.566136 & 1.917074 & 2.168520 \\
\hline $\mathrm{C}$ & 8.629380 & -0.358687 & 0.359838 & $\mathrm{C}$ & 5.449854 & 3.147917 & 2.165877 \\
\hline $\mathrm{H}$ & 9.015435 & 0.528572 & -0.158317 & $\mathrm{H}$ & 6.461839 & 2.914431 & 2.526346 \\
\hline $\mathrm{H}$ & 9.438692 & -0.772013 & 0.971708 & $\mathrm{H}$ & 5.566513 & 3.570134 & 1.159433 \\
\hline $\mathrm{H}$ & 8.382887 & -1.090494 & -0.422291 & $\mathrm{H}$ & 5.034416 & 3.933713 & 2.804864 \\
\hline $\mathrm{C}$ & 7.401676 & -0.273837 & 2.507503 & $\mathrm{C}$ & 3.362492 & 1.969098 & 2.750097 \\
\hline $\mathrm{H}$ & 6.544196 & -0.057160 & 3.136323 & $\mathrm{H}$ & 2.679026 & 1.127903 & 2.781042 \\
\hline $\mathrm{H}$ & 8.270741 & -0.698014 & 3.007228 & $\mathrm{H}$ & 3.007301 & 2.886529 & 3.214435 \\
\hline $\mathrm{O}$ & 1.218836 & -0.447714 & -0.707932 & $\mathrm{C}$ & -1.146991 & 0.417611 & -2.295893 \\
\hline $\mathrm{C}$ & -3.983584 & -2.757548 & -0.436461 & $\mathrm{H}$ & -0.215063 & 0.985048 & -2.370479 \\
\hline $\mathrm{C}$ & -4.966026 & -1.823761 & 0.321378 & $\mathrm{C}$ & -1.967249 & 1.013086 & -1.117748 \\
\hline $\mathrm{C}$ & -4.562746 & -1.747333 & 1.801639 & $\mathrm{C}$ & -2.422255 & 2.415366 & -1.502798 \\
\hline $\mathrm{O}$ & -4.243537 & -0.503501 & 2.195851 & $\mathrm{O}$ & -1.493112 & 3.329921 & -1.117090 \\
\hline $\mathrm{C}$ & -3.805531 & -0.380345 & 3.559498 & $\mathrm{C}$ & -1.779124 & 4.676576 & -1.498765 \\
\hline $\mathrm{H}$ & -3.594442 & 0.679297 & 3.703352 & $\mathrm{H}$ & -0.942069 & 5.273138 & -1.130882 \\
\hline $\mathrm{H}$ & -4.588274 & -0.717664 & 4.243994 & $\mathrm{H}$ & -1.862667 & 4.766373 & -2.586533 \\
\hline $\mathrm{H}$ & -2.903866 & -0.975937 & 3.722703 & $\mathrm{H}$ & -2.716736 & 5.015784 & -1.047829 \\
\hline $\mathrm{O}$ & -4.521190 & -2.721971 & 2.524073 & $\mathrm{O}$ & -3.416676 & 2.711447 & -2.127688 \\
\hline $\mathrm{N}$ & -5.079328 & -0.541968 & -0.339960 & $\mathrm{~N}$ & -3.109170 & 0.164384 & -0.840984 \\
\hline $\mathrm{H}$ & -4.218441 & -0.055604 & -0.558896 & $\mathrm{H}$ & -3.002766 & -0.795579 & -1.168156 \\
\hline $\mathrm{C}$ & -6.193677 & 0.234459 & -0.165451 & $\mathrm{C}$ & -3.891698 & 0.398863 & 0.239804 \\
\hline $\mathrm{O}$ & -7.238620 & -0.158572 & 0.330797 & $\mathrm{O}$ & -3.856163 & 1.413781 & 0.926762 \\
\hline $\mathrm{O}$ & -5.955553 & 1.473643 & -0.663041 & $\mathrm{O}$ & -4.735907 & -0.659207 & 0.435858 \\
\hline $\mathrm{C}$ & -6.982105 & 2.520049 & -0.614826 & $\mathrm{C}$ & -5.691409 & -0.659416 & 1.535767 \\
\hline $\mathrm{C}$ & -8.205901 & 2.100050 & -1.437455 & $\mathrm{C}$ & -6.396070 & -2.010112 & 1.367507 \\
\hline $\mathrm{H}$ & -8.702413 & 1.239398 & -0.986742 & $\mathrm{H}$ & -5.673699 & -2.830028 & 1.434986 \\
\hline $\mathrm{H}$ & -8.916473 & 2.933076 & -1.492498 & $\mathrm{H}$ & -7.153509 & -2.144805 & 2.148207 \\
\hline $\mathrm{H}$ & -7.904880 & 1.841187 & -2.458744 & $\mathrm{H}$ & -6.886882 & -2.067489 & 0.390329 \\
\hline $\mathrm{C}$ & -7.342996 & 2.834848 & 0.841602 & $\mathrm{C}$ & -4.958523 & -0.601920 & 2.883003 \\
\hline $\mathrm{H}$ & -6.441108 & 3.094214 & 1.406755 & $\mathrm{H}$ & -4.435746 & 0.348802 & 2.996890 \\
\hline $\mathrm{H}$ & -8.025784 & 3.691757 & 0.876350 & $\mathrm{H}$ & -5.676438 & -0.716987 & 3.704348 \\
\hline $\mathrm{H}$ & -7.824385 & 1.979334 & 1.317933 & $\mathrm{H}$ & -4.229119 & -1.416911 & 2.949821 \\
\hline $\mathrm{C}$ & -6.273748 & 3.711179 & -1.266563 & $\mathrm{C}$ & -6.691824 & 0.493297 & 1.376382 \\
\hline $\mathrm{H}$ & -6.940054 & 4.580354 & -1.289827 & $\mathrm{H}$ & -6.187255 & 1.456305 & 1.466185 \\
\hline $\mathrm{H}$ & -5.372523 & 3.978443 & -0.705679 & $\mathrm{H}$ & -7.174487 & 0.439526 & 0.394107 \\
\hline $\mathrm{H}$ & -5.979584 & 3.470625 & -2.293350 & $\mathrm{H}$ & -7.470002 & 0.420787 & 2.146204 \\
\hline $\mathrm{H}$ & -5.959497 & -2.280838 & 0.312105 & $\mathrm{H}$ & -1.314165 & 1.088915 & -0.244634 \\
\hline $\mathrm{O}$ & 2.775746 & -2.174417 & 0.132202 & $\mathrm{H}$ & -1.711487 & 0.566679 & -3.224577 \\
\hline $\mathrm{C}$ & 3.753991 & -3.217127 & 0.110339 & $\mathrm{O}$ & 0.203488 & -0.661527 & 0.557114 \\
\hline $\mathrm{H}$ & 3.613977 & -3.791291 & 1.030059 & $\mathrm{C}$ & -0.692270 & -1.184823 & 1.536855 \\
\hline $\mathrm{H}$ & 3.610126 & -3.863639 & -0.761483 & $\mathrm{H}$ & -1.463929 & -1.807632 & 1.071085 \\
\hline
\end{tabular}




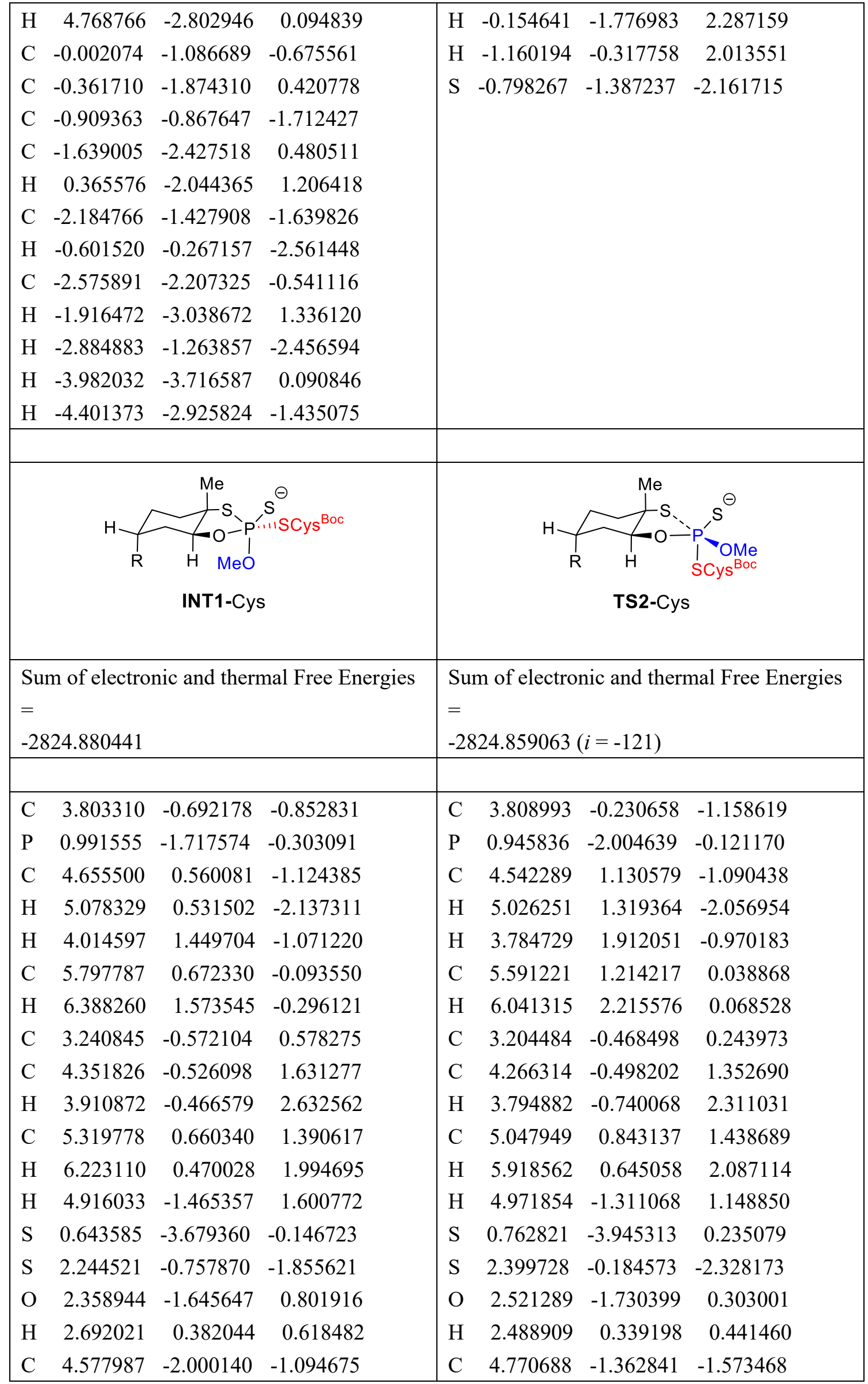




\begin{tabular}{|c|c|c|c|c|c|c|c|}
\hline $\mathrm{H}$ & 4.837215 & -2.088612 & -2.155606 & $\mathrm{H}$ & 5.102474 & -1.189722 & -2.602160 \\
\hline $\mathrm{H}$ & 5.509300 & -2.053867 & -0.516339 & $\mathrm{H}$ & 5.666644 & -1.435577 & -0.938070 \\
\hline $\mathrm{H}$ & 3.957870 & -2.856774 & -0.820321 & $\mathrm{H}$ & 4.252735 & -2.324217 & -1.544002 \\
\hline $\mathrm{H}$ & 6.487609 & -0.169031 & -0.230652 & $\mathrm{H}$ & 6.413500 & 0.522801 & -0.186631 \\
\hline $\mathrm{C}$ & 4.821929 & 2.025581 & 1.868875 & $\mathrm{C}$ & 4.271348 & 1.942779 & 2.162676 \\
\hline $\mathrm{C}$ & 5.807255 & 3.168075 & 1.729063 & $\mathrm{C}$ & 3.888120 & 1.638236 & 3.596003 \\
\hline $\mathrm{H}$ & 6.802735 & 2.885417 & 2.099631 & $\mathrm{H}$ & 3.114496 & 0.862762 & 3.658868 \\
\hline $\mathrm{H}$ & 5.938001 & 3.473436 & 0.683022 & $\mathrm{H}$ & 4.749947 & 1.264493 & 4.166863 \\
\hline $\mathrm{H}$ & 5.473305 & 4.047920 & 2.288329 & $\mathrm{H}$ & 3.503148 & 2.529301 & 4.102349 \\
\hline $\mathrm{C}$ & 3.633734 & 2.246063 & 2.442526 & $\mathrm{C}$ & 3.978001 & 3.137348 & 1.636500 \\
\hline $\mathrm{H}$ & 2.883109 & 1.473953 & 2.566706 & $\mathrm{H}$ & 4.223421 & 3.406136 & 0.615550 \\
\hline $\mathrm{H}$ & 3.362260 & 3.235423 & 2.804337 & $\mathrm{H}$ & 3.455469 & 3.893103 & 2.219152 \\
\hline $\mathrm{C}$ & -1.107637 & 0.395417 & -2.086499 & $\mathrm{C}$ & -0.904206 & 0.016246 & -1.905438 \\
\hline $\mathrm{H}$ & -0.177140 & 0.970075 & -2.091329 & $\mathrm{H}$ & 0.081162 & 0.502055 & -1.920335 \\
\hline $\mathrm{C}$ & -2.028199 & 0.970698 & -0.977146 & $\mathrm{C}$ & -1.826883 & 0.697679 & -0.872685 \\
\hline $\mathrm{C}$ & -2.467453 & 2.367146 & -1.403832 & $\mathrm{C}$ & -2.085375 & 2.121901 & -1.366849 \\
\hline $\mathrm{O}$ & -1.623537 & 3.299839 & -0.890315 & $\mathrm{O}$ & -1.241097 & 2.986393 & -0.761686 \\
\hline $\mathrm{C}$ & -1.894663 & 4.643864 & -1.293070 & $\mathrm{C}$ & -1.323011 & 4.338369 & -1.223205 \\
\hline $\mathrm{H}$ & -1.128944 & 5.256897 & -0.813877 & $\mathrm{H}$ & -0.564735 & 4.886981 & -0.662411 \\
\hline $\mathrm{H}$ & -1.838907 & 4.745221 & -2.381522 & $\mathrm{H}$ & -1.119705 & 4.394430 & -2.296568 \\
\hline $\mathrm{H}$ & -2.891691 & 4.952013 & -0.963995 & $\mathrm{H}$ & -2.317783 & 4.750324 & -1.028904 \\
\hline $\mathrm{O}$ & -3.376485 & 2.642568 & -2.155143 & $\mathrm{O}$ & -2.869939 & 2.442509 & -2.231683 \\
\hline $\mathrm{N}$ & -3.179467 & 0.108172 & -0.795742 & $\mathrm{~N}$ & -3.080085 & -0.028265 & -0.755985 \\
\hline $\mathrm{H}$ & -3.020064 & -0.864161 & -1.053749 & $\mathrm{H}$ & -3.043257 & -1.017832 & -0.973945 \\
\hline $\mathrm{C}$ & -4.081652 & 0.374180 & 0.181219 & $\mathrm{C}$ & -4.048742 & 0.393659 & 0.097465 \\
\hline $\mathrm{O}$ & -4.141647 & 1.423010 & 0.812879 & $\mathrm{O}$ & -4.051981 & 1.476687 & 0.667852 \\
\hline $\mathrm{O}$ & -4.924961 & -0.689912 & 0.332266 & $\mathrm{O}$ & -5.018433 & -0.561813 & 0.196210 \\
\hline $\mathrm{C}$ & -5.992981 & -0.662414 & 1.323277 & $\mathrm{C}$ & -6.203496 & -0.343741 & 1.020262 \\
\hline $\mathrm{C}$ & -6.653040 & -2.033926 & 1.143625 & $\mathrm{C}$ & -6.991175 & -1.643229 & 0.823154 \\
\hline $\mathrm{H}$ & -5.929679 & -2.834704 & 1.327843 & $\mathrm{H}$ & -6.402685 & -2.503870 & 1.157514 \\
\hline $\mathrm{H}$ & -7.489219 & -2.148255 & 1.842995 & $\mathrm{H}$ & -7.924226 & -1.613330 & 1.397204 \\
\hline $\mathrm{H}$ & -7.033440 & -2.145346 & 0.122854 & $\mathrm{H}$ & -7.236512 & -1.786478 & -0.234334 \\
\hline $\mathrm{C}$ & -5.409109 & -0.528791 & 2.736175 & $\mathrm{C}$ & -5.805864 & -0.173131 & 2.492157 \\
\hline $\mathrm{H}$ & -4.912658 & 0.434957 & 2.858314 & $\mathrm{H}$ & -5.222385 & 0.738048 & 2.631419 \\
\hline $\mathrm{H}$ & -6.209553 & -0.616527 & 3.481078 & $\mathrm{H}$ & -6.705386 & -0.121267 & 3.117529 \\
\hline $\mathrm{H}$ & -4.681066 & -1.326737 & 2.919923 & $\mathrm{H}$ & -5.208028 & -1.029681 & 2.823073 \\
\hline $\mathrm{C}$ & -6.989673 & 0.459978 & 1.003574 & $\mathrm{C}$ & -7.003089 & 0.856156 & 0.496077 \\
\hline $\mathrm{H}$ & -6.514619 & 1.436914 & 1.103090 & $\mathrm{H}$ & -6.431782 & 1.779058 & 0.605405 \\
\hline $\mathrm{H}$ & -7.360975 & 0.352556 & -0.021802 & $\mathrm{H}$ & -7.244201 & 0.715311 & -0.563435 \\
\hline $\mathrm{H}$ & -7.846502 & 0.404282 & 1.686405 & $\mathrm{H}$ & -7.943685 & 0.948371 & 1.052622 \\
\hline $\mathrm{H}$ & -1.450416 & 1.052847 & -0.053638 & $\mathrm{H}$ & -1.311464 & 0.749612 & 0.089570 \\
\hline $\mathrm{H}$ & -1.598734 & 0.533556 & -3.057023 & $\mathrm{H}$ & -1.347510 & 0.100124 & -2.903870 \\
\hline
\end{tabular}




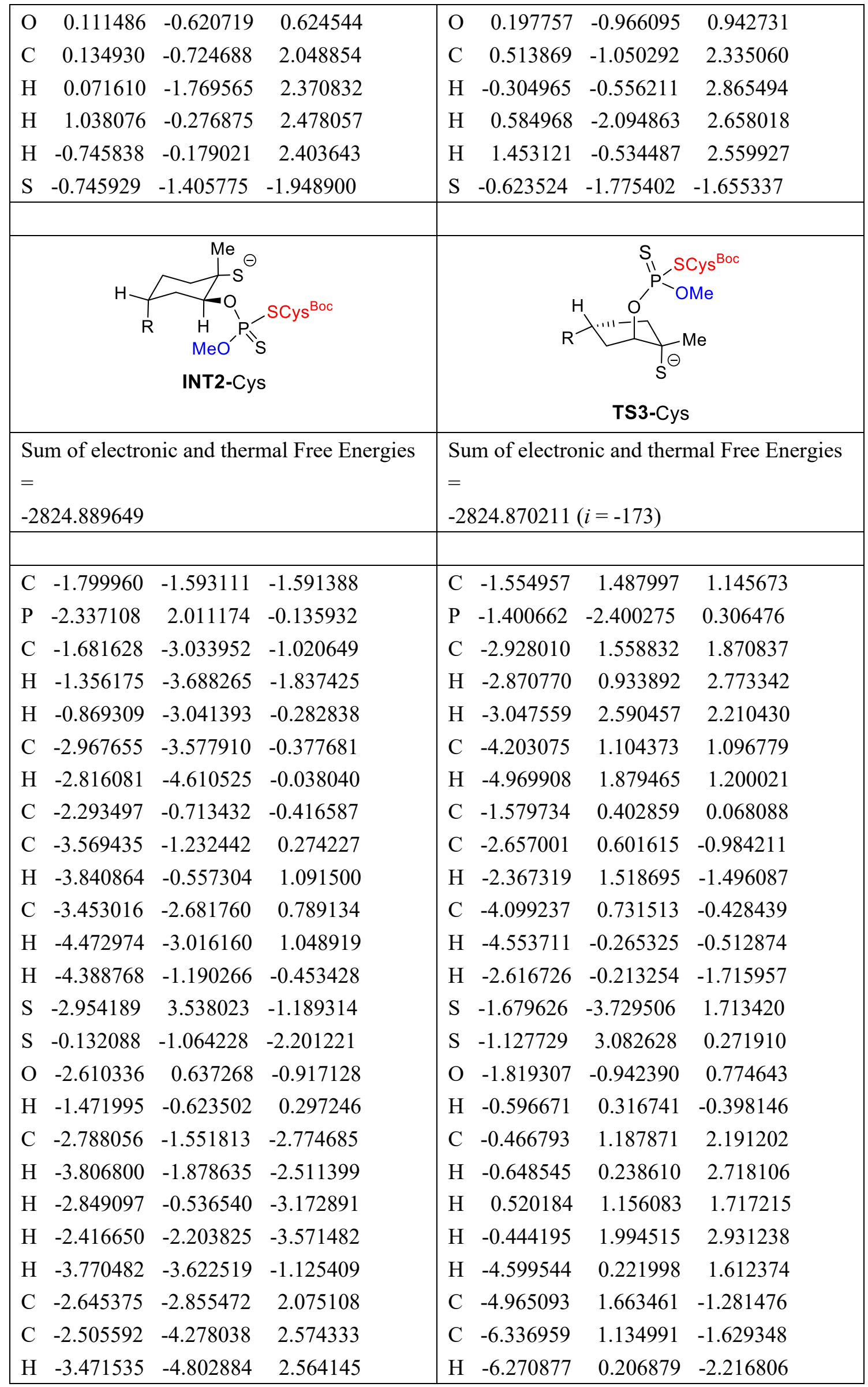




\begin{tabular}{|c|c|c|c|c|c|c|c|}
\hline $\mathrm{H}$ & -1.824333 & -4.863595 & 1.944131 & $\mathrm{H}$ & -6.906656 & 0.883728 & -0.722217 \\
\hline $\mathrm{H}$ & -2.114279 & -4.302135 & 3.596691 & $\mathrm{H}$ & -6.922737 & 1.860843 & -2.204598 \\
\hline $\mathrm{C}$ & -2.129990 & -1.846884 & 2.787619 & $\mathrm{C}$ & -4.572698 & 2.888044 & -1.648890 \\
\hline $\mathrm{H}$ & -2.189485 & -0.808229 & 2.481238 & $\mathrm{H}$ & -3.600663 & 3.287439 & -1.361300 \\
\hline $\mathrm{H}$ & -1.603391 & -2.036413 & 3.720810 & $\mathrm{H}$ & -5.233928 & 3.538290 & -2.220785 \\
\hline $\mathrm{C}$ & 0.567483 & 2.186289 & -0.958700 & $\mathrm{C}$ & 1.561938 & -1.984169 & 0.941345 \\
\hline $\mathrm{H}$ & 0.127541 & 1.480880 & -1.677105 & $\mathrm{H}$ & 1.021756 & -1.284728 & 1.582227 \\
\hline $\mathrm{C}$ & 2.050209 & 1.813093 & -0.779977 & $\mathrm{C}$ & 2.911756 & -1.352433 & 0.543814 \\
\hline $\mathrm{C}$ & 2.744590 & 2.779645 & 0.184333 & $\mathrm{C}$ & 3.773815 & -2.390306 & -0.192170 \\
\hline $\mathrm{O}$ & 2.731791 & 2.352517 & 1.462929 & $\mathrm{O}$ & 4.022431 & -2.059514 & -1.473121 \\
\hline $\mathrm{C}$ & 3.349800 & 3.238163 & 2.400766 & $\mathrm{C}$ & 4.796605 & -3.017663 & -2.208461 \\
\hline $\mathrm{H}$ & 3.243316 & 2.755762 & 3.373632 & $\mathrm{H}$ & 4.896861 & -2.603378 & -3.212307 \\
\hline $\mathrm{H}$ & 4.406846 & 3.375490 & 2.154699 & $\mathrm{H}$ & 5.779099 & -3.152189 & -1.747321 \\
\hline $\mathrm{H}$ & 2.854085 & 4.213268 & 2.399651 & $\mathrm{H}$ & 4.283613 & -3.982821 & -2.238648 \\
\hline $\mathrm{O}$ & 3.186922 & 3.855284 & -0.159736 & $\mathrm{O}$ & 4.169619 & -3.410155 & 0.331808 \\
\hline $\mathrm{N}$ & 2.183131 & 0.418780 & -0.414056 & $\mathrm{~N}$ & 2.746875 & -0.098663 & -0.139352 \\
\hline $\mathrm{H}$ & 1.414012 & -0.215910 & -0.711614 & $\mathrm{H}$ & 2.048185 & -0.011094 & -0.864647 \\
\hline $\mathrm{C}$ & 3.431525 & -0.093195 & -0.270471 & $\mathrm{C}$ & 3.416463 & 1.036534 & 0.241330 \\
\hline $\mathrm{O}$ & 4.464926 & 0.572620 & -0.285896 & $\mathrm{O}$ & 4.228842 & 1.077507 & 1.155192 \\
\hline $\mathrm{O}$ & 3.364543 & -1.437394 & -0.076733 & $\mathrm{O}$ & 3.039008 & 2.047253 & -0.562564 \\
\hline $\mathrm{C}$ & 4.569366 & -2.250978 & -0.013708 & $\mathrm{C}$ & 3.324158 & 3.454702 & -0.232713 \\
\hline $\mathrm{C}$ & 5.367349 & -2.127895 & -1.319000 & $\mathrm{C}$ & 2.765428 & 3.797779 & 1.151211 \\
\hline $\mathrm{H}$ & 5.752466 & -1.114436 & -1.443548 & $\mathrm{H}$ & 3.273810 & 3.229474 & 1.933833 \\
\hline $\mathrm{H}$ & 6.209236 & -2.831205 & -1.310144 & $\mathrm{H}$ & 2.918456 & 4.866949 & 1.343869 \\
\hline $\mathrm{H}$ & 4.726091 & -2.369912 & -2.173512 & $\mathrm{H}$ & 1.687545 & 3.594518 & 1.178544 \\
\hline $\mathrm{C}$ & 5.410193 & -1.869788 & 1.212430 & $\mathrm{C}$ & 4.832565 & 3.702225 & -0.343586 \\
\hline $\mathrm{H}$ & 4.802009 & -1.939720 & 2.121447 & $\mathrm{H}$ & 5.196316 & 3.408450 & -1.335481 \\
\hline $\mathrm{H}$ & 6.258267 & -2.558608 & 1.313513 & $\mathrm{H}$ & 5.042695 & 4.769748 & -0.205774 \\
\hline $\mathrm{H}$ & 5.785161 & -0.849577 & 1.118456 & $\mathrm{H}$ & 5.375840 & 3.133164 & 0.413689 \\
\hline $\mathrm{C}$ & 4.004190 & -3.667764 & 0.136313 & $\mathrm{C}$ & 2.544701 & 4.202261 & -1.317288 \\
\hline $\mathrm{H}$ & 4.817657 & -4.401702 & 0.176359 & $\mathrm{H}$ & 2.667713 & 5.283668 & -1.187237 \\
\hline $\mathrm{H}$ & 3.413434 & -3.748433 & 1.054782 & $\mathrm{H}$ & 2.909692 & 3.928500 & -2.314290 \\
\hline $\mathrm{H}$ & 3.350539 & -3.905844 & -0.708456 & $\mathrm{H}$ & 1.480653 & 3.953593 & -1.241384 \\
\hline $\mathrm{H}$ & 2.525379 & 2.018966 & -1.749918 & $\mathrm{H}$ & 3.452245 & -1.135530 & 1.471390 \\
\hline $\mathrm{H}$ & 0.489393 & 3.215487 & -1.314739 & $\mathrm{H}$ & 1.730649 & -2.921057 & 1.474916 \\
\hline $\mathrm{O}$ & -3.038337 & 1.851932 & 1.345008 & $\mathrm{O}$ & -2.134495 & -2.721561 & -1.120920 \\
\hline $\mathrm{C}$ & -4.386657 & 2.284496 & 1.559907 & $\mathrm{C}$ & -3.449908 & -3.293712 & -1.146100 \\
\hline $\mathrm{H}$ & -4.575947 & 2.157772 & 2.628613 & $\mathrm{H}$ & -3.673030 & -3.483974 & -2.198204 \\
\hline $\mathrm{H}$ & -4.506457 & 3.333825 & 1.275203 & $\mathrm{H}$ & -3.473230 & -4.228632 & -0.578336 \\
\hline $\mathrm{H}$ & -5.091961 & 1.671521 & 0.987883 & $\mathrm{H}$ & -4.186376 & -2.595383 & -0.735578 \\
\hline $\mathrm{S}$ & -0.376428 & 2.037090 & 0.633965 & $\mathrm{~S}$ & 0.541503 & -2.331455 & -0.569128 \\
\hline
\end{tabular}




\begin{tabular}{|c|c|c|c|c|c|c|}
\hline & INT3-Cys & & & & $\begin{array}{c}\mathrm{S} \\
\text { TS4-Cys }\end{array}$ & \\
\hline $\begin{array}{l}\text { Sum of electro } \\
= \\
-2824.889108\end{array}$ & nic and thern & nal Free Energies & $\begin{array}{l}= \\
-2\end{array}$ & $\begin{array}{l}\text { n of electro } \\
24.891402\end{array}$ & $\begin{array}{l}\text { nic and ther } \\
(i=-262)\end{array}$ & nal Free Energies \\
\hline C $\quad-2.927299$ & -2.186534 & -0.146914 & $\mathrm{C}$ & 3.079747 & 2.159186 & -0.593878 \\
\hline $\mathrm{P} \quad-1.229587$ & 1.343176 & -0.522771 & $\mathrm{P}$ & 1.174336 & -1.352409 & -0.228160 \\
\hline C -3.946935 & -2.280727 & -1.306635 & $\mathrm{C}$ & 4.079012 & 1.950984 & -1.750957 \\
\hline H $\quad-3.546915$ & -1.751738 & -2.188473 & $\mathrm{H}$ & 3.618522 & 1.290350 & -2.503449 \\
\hline H $\quad-4.051494$ & -3.337331 & -1.578885 & $\mathrm{H}$ & 4.252587 & 2.922332 & -2.228977 \\
\hline C $\quad-5.324005$ & -1.699630 & -0.962633 & $\mathrm{C}$ & 5.416965 & 1.343968 & -1.310191 \\
\hline Н $\quad-5.760769$ & -2.288291 & -0.148259 & $\mathrm{H}$ & 5.922603 & 2.045143 & -0.636931 \\
\hline C -2.886380 & -0.753420 & 0.383346 & $\mathrm{C}$ & 2.996437 & 0.936918 & 0.274582 \\
\hline C $\quad-4.248307$ & -0.135749 & 0.686103 & $\mathrm{C}$ & 4.288914 & 0.226862 & 0.643708 \\
\hline H $\quad-4.643648$ & -0.710334 & 1.528056 & $\mathrm{H}$ & 4.788274 & 0.868878 & 1.372949 \\
\hline C $\quad-5.209003$ & -0.220717 & -0.511481 & $\mathrm{C}$ & 5.201072 & -0.002679 & -0.573375 \\
\hline Н $\quad-4.751424$ & 0.333202 & -1.347195 & $\mathrm{H}$ & 4.659214 & -0.661442 & -1.269110 \\
\hline H $\quad-4.119133$ & 0.902942 & 1.011346 & $\mathrm{H}$ & 4.051016 & -0.719875 & 1.138758 \\
\hline$S \quad-0.807306$ & 2.372128 & -2.137987 & S & 0.616413 & -2.689373 & -1.562007 \\
\hline$S \quad-3.426464$ & -3.206751 & 1.325927 & $\mathrm{~S}$ & 3.679153 & 3.373053 & 0.684406 \\
\hline O $\quad-2.259478$ & 0.171847 & -0.736428 & $\mathrm{O}$ & 2.211600 & -0.292188 & -0.697711 \\
\hline H $\quad-2.205123$ & -0.675918 & 1.230390 & $\mathrm{H}$ & 2.279521 & 1.026867 & 1.084998 \\
\hline C -1.545471 & -2.634259 & -0.646410 & $\mathrm{C}$ & 1.715476 & 2.589877 & -1.143691 \\
\hline H $\quad-1.205664$ & -2.054474 & -1.517991 & $\mathrm{H}$ & 1.322620 & 1.868064 & -1.873301 \\
\hline H $\quad-0.801928$ & -2.544243 & 0.153238 & $\mathrm{H}$ & 0.991582 & 2.701500 & -0.329664 \\
\hline H $\quad-1.594269$ & -3.692183 & -0.925023 & $\mathrm{H}$ & 1.817642 & 3.567218 & -1.627932 \\
\hline H $\quad-5.986315$ & -1.780669 & -1.836007 & $\mathrm{H}$ & 6.058608 & 1.197216 & -2.189962 \\
\hline C $\quad-6.569330$ & 0.413609 & -0.263859 & $\mathrm{C}$ & 6.513278 & -0.697678 & -0.243095 \\
\hline C $\quad-7.378672$ & 0.722432 & -1.504123 & $\mathrm{C}$ & 7.232509 & -1.319660 & -1.419838 \\
\hline H $\quad-6.833513$ & 1.408975 & -2.167250 & $\mathrm{H}$ & 6.601565 & -2.074884 & -1.909183 \\
\hline Н $\quad-7.574515$ & -0.183800 & -2.091408 & $\mathrm{H}$ & 7.471088 & -0.572057 & -2.187221 \\
\hline H $\quad-8.342937$ & 1.179735 & -1.256345 & $\mathrm{H}$ & 8.168122 & -1.800972 & -1.114781 \\
\hline C -7.054503 & 0.699763 & 0.950377 & $\mathrm{C}$ & 7.030104 & -0.785232 & 0.988532 \\
\hline H $\quad-6.502910$ & 0.492147 & 1.861518 & $\mathrm{H}$ & 6.542613 & -0.356990 & 1.858320 \\
\hline H $\quad-8.040329$ & 1.144841 & 1.073427 & $\mathrm{H}$ & 7.978656 & -1.288443 & 1.167112 \\
\hline C 1.518041 & 1.871369 & 0.684000 & $\mathrm{C}$ & -1.522938 & -1.539934 & 1.209812 \\
\hline $\mathrm{H} \quad 1.479475$ & 2.477709 & -0.225686 & $\mathrm{H}$ & -1.474399 & -2.362416 & 0.489759 \\
\hline
\end{tabular}




\begin{tabular}{|c|c|c|c|c|c|c|}
\hline $\mathrm{C}$ & 2.970408 & 1.436237 & 0.946415 & C -2.980198 & -1.060761 & 1.331545 \\
\hline $\mathrm{C}$ & 3.067484 & 0.730309 & 2.309294 & C -3.103107 & -0.030671 & 2.465852 \\
\hline $\mathrm{O}$ & 3.182547 & -0.603078 & 2.196796 & O $\quad-3.241344$ & 1.228242 & 2.016217 \\
\hline $\mathrm{C}$ & 3.179614 & -1.327780 & 3.438380 & C $\quad-3.271748$ & 2.242555 & 3.033264 \\
\hline $\mathrm{H}$ & 3.263362 & -2.378774 & 3.161912 & H $\quad-3.368246$ & 3.187933 & 2.499043 \\
\hline $\mathrm{H}$ & 4.024901 & -1.020026 & 4.059843 & H $\quad-4.122451$ & 2.085829 & 3.702132 \\
\hline $\mathrm{H}$ & 2.247564 & -1.147480 & 3.979360 & H $\quad-2.346970$ & 2.223920 & 3.615180 \\
\hline $\mathrm{O}$ & 2.998620 & 1.327884 & 3.361301 & O $\quad-3.037834$ & -0.335828 & 3.637111 \\
\hline $\mathrm{N}$ & 3.489913 & 0.683656 & -0.174128 & $\mathrm{~N}-3.484552$ & -0.624799 & 0.049108 \\
\hline $\mathrm{H}$ & 2.848921 & 0.080242 & -0.675444 & H $\quad-2.838081$ & -0.169375 & -0.584187 \\
\hline $\mathrm{C}$ & 4.822714 & 0.397347 & -0.246575 & C $\quad-4.820382$ & -0.427158 & -0.135661 \\
\hline $\mathrm{O}$ & 5.670361 & 0.891248 & 0.483002 & O $\quad-5.680950$ & -0.752183 & 0.670502 \\
\hline $\mathrm{O}$ & 5.042049 & -0.481466 & -1.257133 & O $\quad-5.030301$ & 0.151774 & -1.346343 \\
\hline $\mathrm{C}$ & 6.390906 & -0.966767 & -1.557098 & C -6.384655 & 0.449828 & -1.814594 \\
\hline $\mathrm{C}$ & 7.291608 & 0.199441 & -1.981465 & C -7.193783 & -0.845552 & -1.953334 \\
\hline $\mathrm{H}$ & 7.448006 & 0.892025 & -1.153103 & Н $\quad-7.355453$ & -1.308881 & -0.978830 \\
\hline $\mathrm{H}$ & 8.263371 & -0.185377 & -2.312775 & H $\quad-8.166372$ & -0.627958 & -2.410539 \\
\hline $\mathrm{H}$ & 6.836876 & 0.742877 & -2.817126 & H $\quad-6.664024$ & -1.554651 & -2.599118 \\
\hline $\mathrm{C}$ & 6.958134 & -1.727906 & -0.352634 & C $\quad-7.060574$ & 1.456151 & -0.875195 \\
\hline $\mathrm{H}$ & 6.271452 & -2.527154 & -0.052726 & H $\quad-6.437122$ & 2.350746 & -0.768682 \\
\hline $\mathrm{H}$ & 7.917630 & -2.184924 & -0.622104 & H $\quad-8.027526$ & 1.760984 & -1.292765 \\
\hline $\mathrm{H}$ & 7.110658 & -1.058144 & 0.495178 & H $\quad-7.221583$ & 1.019541 & 0.111583 \\
\hline $\mathrm{C}$ & 6.148668 & -1.917921 & -2.732940 & C -6.131430 & 1.078716 & -3.188140 \\
\hline $\mathrm{H}$ & 7.094950 & -2.362279 & -3.060732 & H -7.081526 & 1.354823 & -3.658768 \\
\hline $\mathrm{H}$ & 5.466686 & -2.723524 & -2.442775 & Н $\quad-5.515252$ & 1.978467 & -3.091822 \\
\hline $\mathrm{H}$ & 5.704591 & -1.380789 & -3.577287 & H $\quad-5.608711$ & 0.374556 & -3.843464 \\
\hline $\mathrm{H}$ & 3.567242 & 2.346701 & 1.058639 & H $\quad-3.577572$ & -1.915277 & 1.664528 \\
\hline $\mathrm{H}$ & 1.160327 & 2.457621 & 1.532285 & Н $\quad-1.175879$ & -1.885248 & 2.185346 \\
\hline $\mathrm{O}$ & -1.737583 & 2.274073 & 0.730161 & 1.694427 & -2.044044 & 1.175108 \\
\hline $\mathrm{C}$ & -2.635584 & 3.371632 & 0.500670 & C $\quad 2.520607$ & -3.215436 & 1.140032 \\
\hline $\mathrm{H}$ & -2.753724 & 3.867691 & 1.466776 & 2.649483 & -3.524785 & 2.180387 \\
\hline $\mathrm{H}$ & -2.215505 & 4.065024 & -0.233996 & 2.037895 & -4.011596 & 0.564907 \\
\hline $\mathrm{H}$ & -3.610117 & 3.014286 & 0.152662 & H 3.501013 & -2.993759 & 0.704115 \\
\hline $\mathrm{S}$ & 0.417769 & 0.400859 & 0.448930 & S $\quad-0.415021$ & -0.186425 & 0.608031 \\
\hline \multicolumn{4}{|c|}{ TS1-Lys } & \multicolumn{3}{|c|}{$\begin{array}{c}\mathrm{Me} \\
\mathrm{H}_{\mathrm{H}}^{\mathrm{O}-\mathrm{P}^{\prime}} \mathrm{PeO}^{\prime \prime} \\
\text { INT1-Lys }\end{array}$} \\
\hline \multicolumn{4}{|c|}{ Sum of electronic and thermal Free Energies } & \multicolumn{3}{|c|}{ Sum of electronic and thermal Free Energies } \\
\hline
\end{tabular}




\begin{tabular}{|c|c|c|c|c|c|c|c|}
\hline \multicolumn{4}{|c|}{$\begin{array}{l}= \\
-3062.272341(i=-387)\end{array}$} & \multicolumn{4}{|c|}{$\begin{array}{l}= \\
-2599.865331\end{array}$} \\
\hline $\mathrm{C}$ & 4.038967 & -1.155541 & 0.687627 & C & 5.038796 & 0.075814 & -1.434002 \\
\hline $\mathrm{P}$ & 2.650684 & 0.186136 & -1.659794 & $\mathrm{P}$ & 3.000660 & -1.789187 & -0.057946 \\
\hline $\mathrm{C}$ & 4.009422 & -2.314898 & 1.698263 & C & 5.260548 & 1.493555 & -1.986879 \\
\hline $\mathrm{H}$ & 3.858215 & -1.938326 & 2.718178 & $\mathrm{H}$ & 5.382573 & 1.473417 & -3.078507 \\
\hline $\mathrm{H}$ & 3.160731 & -2.971986 & 1.470154 & $\mathrm{H}$ & 4.371800 & 2.103389 & -1.777971 \\
\hline $\mathrm{C}$ & 5.326330 & -3.116793 & 1.633178 & C & 6.504733 & 2.141942 & -1.345174 \\
\hline $\mathrm{H}$ & 5.283765 & -3.942915 & 2.350831 & $\mathrm{H}$ & 6.642151 & 3.154760 & -1.743066 \\
\hline $\mathrm{C}$ & 4.249879 & -1.758360 & -0.716500 & C & 4.861074 & 0.186485 & 0.096400 \\
\hline $\mathrm{C}$ & 5.584408 & -2.500431 & -0.824131 & C & 6.109173 & 0.771489 & 0.771250 \\
\hline $\mathrm{H}$ & 5.712032 & -2.883056 & -1.842074 & $\mathrm{H}$ & 5.956573 & 0.817657 & 1.855582 \\
\hline $\mathrm{C}$ & 5.673149 & -3.650558 & 0.210877 & $\mathrm{C}$ & 6.473168 & 2.171905 & 0.213979 \\
\hline $\mathrm{H}$ & 6.729026 & -3.963430 & 0.257750 & $\mathrm{H}$ & 7.508037 & 2.390123 & 0.530011 \\
\hline $\mathrm{H}$ & 6.406489 & -1.795252 & -0.657881 & $\mathrm{H}$ & 6.953360 & 0.090476 & 0.611471 \\
\hline $\mathrm{S}$ & 3.450843 & 1.904934 & -2.356814 & $S$ & 3.545927 & -3.696833 & 0.346609 \\
\hline $\mathrm{S}$ & 2.394484 & -0.335953 & 0.475755 & $\mathrm{~S}$ & 3.430922 & -0.679439 & -1.935824 \\
\hline $\mathrm{O}$ & 4.150069 & -0.721111 & -1.663204 & $\mathrm{O}$ & 4.537963 & -1.073169 & 0.606227 \\
\hline $\mathrm{H}$ & 3.440513 & -2.489239 & -0.867454 & $\mathrm{H}$ & 4.028968 & 0.894911 & 0.255540 \\
\hline $\mathrm{C}$ & 5.072117 & -0.075165 & 1.052075 & $\mathrm{C}$ & 6.160935 & -0.898580 & -1.837873 \\
\hline $\mathrm{H}$ & 4.798055 & 0.397569 & 2.002025 & $\mathrm{H}$ & 6.150881 & -1.051404 & -2.923238 \\
\hline $\mathrm{H}$ & 6.080996 & -0.487383 & 1.166213 & $\mathrm{H}$ & 7.160755 & -0.539252 & -1.559627 \\
\hline $\mathrm{H}$ & 5.106979 & 0.693353 & 0.276280 & $\mathrm{H}$ & 5.999189 & -1.863625 & -1.351810 \\
\hline $\mathrm{H}$ & 6.153440 & -2.479055 & 1.966534 & $\mathrm{H}$ & 7.396881 & 1.581865 & -1.650302 \\
\hline $\mathrm{C}$ & 4.908692 & -4.925632 & -0.153435 & C & 5.655890 & 3.339298 & 0.770750 \\
\hline $\mathrm{C}$ & 5.026411 & -6.066826 & 0.835677 & C & 6.088393 & 4.718478 & 0.315122 \\
\hline $\mathrm{H}$ & 6.069544 & -6.223228 & 1.143127 & $\mathrm{H}$ & 7.177485 & 4.843305 & 0.397378 \\
\hline $\mathrm{H}$ & 4.453840 & -5.878640 & 1.752962 & $\mathrm{H}$ & 5.831839 & 4.903947 & -0.735806 \\
\hline $\mathrm{H}$ & 4.656076 & -7.001757 & 0.404406 & $\mathrm{H}$ & 5.609956 & 5.501020 & 0.913245 \\
\hline $\mathrm{C}$ & 4.226585 & -5.104047 & -1.290350 & $\mathrm{C}$ & 4.659520 & 3.221331 & 1.655547 \\
\hline $\mathrm{H}$ & 4.109316 & -4.329873 & -2.040699 & $\mathrm{H}$ & 4.298180 & 2.264465 & 2.014475 \\
\hline $\mathrm{H}$ & 3.750782 & -6.055991 & -1.513530 & $\mathrm{H}$ & 4.152508 & 4.101072 & 2.047111 \\
\hline $\mathrm{C}$ & -4.156370 & 0.623970 & -1.641111 & C & -2.988022 & -0.881563 & 1.177180 \\
\hline $\mathrm{H}$ & -4.232137 & 1.577133 & -1.098514 & $\mathrm{H}$ & -3.304929 & -1.935659 & 1.164223 \\
\hline $\mathrm{H}$ & -4.161333 & 0.863735 & -2.711580 & $\mathrm{H}$ & -2.516714 & -0.715397 & 2.152534 \\
\hline $\mathrm{C}$ & -5.419303 & -0.216937 & -1.329905 & C & -4.245488 & 0.010892 & 1.102879 \\
\hline $\mathrm{C}$ & -6.666284 & 0.520489 & -1.810430 & C & -5.118550 & -0.206981 & 2.343713 \\
\hline $\mathrm{O}$ & -6.728028 & 0.558293 & -3.152817 & $\mathrm{O}$ & -4.590263 & 0.423620 & 3.415445 \\
\hline $\mathrm{C}$ & -7.847217 & 1.276228 & -3.704272 & C & -5.298925 & 0.239628 & 4.649018 \\
\hline $\mathrm{H}$ & -8.787407 & 0.821945 & -3.381724 & $\mathrm{H}$ & -6.321547 & 0.617413 & 4.563295 \\
\hline $\mathrm{H}$ & -7.826667 & 2.321134 & -3.384148 & $\mathrm{H}$ & -5.333685 & -0.819432 & 4.919829 \\
\hline
\end{tabular}




\begin{tabular}{|c|c|c|c|c|c|c|c|}
\hline $\mathrm{H}$ & -7.735262 & 1.202402 & -4.785953 & $\mathrm{H}$ & -4.741627 & 0.806968 & 5.395406 \\
\hline $\mathrm{O}$ & -7.484540 & 1.039433 & -1.078400 & $\mathrm{O}$ & -6.125153 & -0.880054 & 2.386951 \\
\hline $\mathrm{N}$ & -5.581304 & -0.498505 & 0.085657 & $\mathrm{~N}$ & -4.998811 & -0.257153 & -0.106535 \\
\hline $\mathrm{H}$ & -6.241476 & 0.090132 & 0.579882 & $\mathrm{H}$ & -5.091834 & -1.222381 & -0.394074 \\
\hline $\mathrm{C}$ & -5.377246 & -1.761600 & 0.578278 & $\mathrm{C}$ & -6.010463 & 0.582786 & -0.484924 \\
\hline $\mathrm{O}$ & -4.827102 & -2.659851 & -0.039541 & $\mathrm{O}$ & -6.193566 & 1.694495 & -0.014273 \\
\hline $\mathrm{O}$ & -5.854878 & -1.828319 & 1.844513 & $\mathrm{O}$ & -6.734663 & -0.001929 & -1.474660 \\
\hline $\mathrm{C}$ & -5.725476 & -3.060243 & 2.638292 & $\mathrm{C}$ & -7.863864 & 0.696921 & -2.094033 \\
\hline $\mathrm{C}$ & -6.379757 & -2.667931 & 3.965868 & $\mathrm{C}$ & -8.362353 & -0.322440 & -3.122944 \\
\hline $\mathrm{H}$ & -7.424280 & -2.378308 & 3.811418 & $\mathrm{H}$ & -8.668681 & -1.250336 & -2.628815 \\
\hline $\mathrm{H}$ & -6.353027 & -3.512262 & 4.662739 & $\mathrm{H}$ & -9.221854 & 0.081203 & -3.669227 \\
\hline $\mathrm{H}$ & -5.852088 & -1.824190 & 4.422538 & $\mathrm{H}$ & -7.572855 & -0.560622 & -3.843157 \\
\hline $\mathrm{C}$ & -6.499153 & -4.201114 & 1.968461 & $\mathrm{C}$ & -8.947269 & 0.982822 & -1.047151 \\
\hline $\mathrm{H}$ & -7.541047 & -3.906309 & 1.800735 & $\mathrm{H}$ & -9.236561 & 0.056301 & -0.539093 \\
\hline $\mathrm{H}$ & -6.049117 & -4.470778 & 1.011900 & $\mathrm{H}$ & -8.590210 & 1.694638 & -0.301594 \\
\hline $\mathrm{H}$ & -6.496029 & -5.081302 & 2.621418 & $\mathrm{H}$ & -9.835919 & 1.396535 & -1.538412 \\
\hline $\mathrm{C}$ & -4.245661 & -3.402470 & 2.842017 & $\mathrm{C}$ & -7.378035 & 1.974105 & -2.789504 \\
\hline $\mathrm{H}$ & -3.768672 & -3.661871 & 1.895716 & $\mathrm{H}$ & -7.000015 & 2.693649 & -2.061748 \\
\hline $\mathrm{H}$ & -3.716193 & -2.551459 & 3.284842 & $\mathrm{H}$ & -6.579018 & 1.737823 & -3.500901 \\
\hline $\mathrm{H}$ & -4.155530 & -4.252548 & 3.527795 & $\mathrm{H}$ & -8.205681 & 2.430947 & -3.344845 \\
\hline $\mathrm{C}$ & -2.847648 & -0.083160 & -1.271689 & $\mathrm{C}$ & -1.964601 & -0.627202 & 0.062785 \\
\hline $\mathrm{H}$ & -2.865172 & -0.348448 & -0.207551 & $\mathrm{H}$ & -2.444207 & -0.759471 & -0.916862 \\
\hline $\mathrm{H}$ & -2.777741 & -1.031802 & -1.820012 & $\mathrm{H}$ & -1.645761 & 0.424542 & 0.106101 \\
\hline $\mathrm{C}$ & -1.612687 & 0.778932 & -1.567058 & $\mathrm{C}$ & -0.736530 & -1.540408 & 0.171910 \\
\hline $\mathrm{H}$ & -1.678586 & 1.721533 & -1.004179 & $\mathrm{H}$ & -1.064386 & -2.591849 & 0.137927 \\
\hline $\mathrm{H}$ & -1.606172 & 1.056739 & -2.632186 & $\mathrm{H}$ & -0.235290 & -1.395105 & 1.133873 \\
\hline $\mathrm{C}$ & -0.296647 & 0.065996 & -1.228008 & $\mathrm{C}$ & 0.293248 & -1.303457 & -0.949810 \\
\hline $\mathrm{H}$ & -0.297165 & -0.220892 & -0.170562 & $\mathrm{H}$ & -0.223782 & -1.423461 & -1.920376 \\
\hline $\mathrm{H}$ & -0.217015 & -0.859528 & -1.809307 & $\mathrm{H}$ & 0.633444 & -0.262524 & -0.916353 \\
\hline $\mathrm{N}$ & 0.874248 & 0.941033 & -1.481520 & $\mathrm{~N}$ & 1.460612 & -2.169722 & -0.920692 \\
\hline $\mathrm{H}$ & 0.862722 & 2.201297 & -0.688501 & $\mathrm{H}$ & -3.946562 & 1.062515 & 1.088277 \\
\hline $\mathrm{H}$ & -5.343804 & -1.171743 & -1.860361 & $\mathrm{C}$ & 2.653236 & -0.759562 & 2.439737 \\
\hline $\mathrm{C}$ & 2.705870 & -1.512576 & -3.769703 & $\mathrm{H}$ & 3.330664 & 0.101022 & 2.500358 \\
\hline $\mathrm{H}$ & 3.218361 & -2.391200 & -3.366030 & $\mathrm{H}$ & 1.791421 & -0.576751 & 3.096023 \\
\hline $\mathrm{H}$ & 1.988938 & -1.833041 & -4.532806 & $\mathrm{H}$ & 3.189797 & -1.649559 & 2.785527 \\
\hline $\mathrm{H}$ & 3.445061 & -0.842058 & -4.217669 & $\mathrm{O}$ & 2.128178 & -0.943320 & 1.134770 \\
\hline $\mathrm{O}$ & 1.934978 & -0.843950 & -2.770646 & $\mathrm{H}$ & 1.226479 & -3.135433 & -0.706158 \\
\hline $\mathrm{C}$ & 0.771678 & 3.595765 & 0.996781 & & & & \\
\hline $\mathrm{C}$ & 1.065022 & 4.328574 & -1.286320 & & & & \\
\hline $\mathrm{C}$ & 0.524316 & 2.481843 & 1.987563 & & & & \\
\hline $\mathrm{H}$ & 0.104553 & 4.772131 & -1.586418 & & & & \\
\hline $\mathrm{C}$ & 2.001669 & 5.389931 & -0.720879 & & & & \\
\hline
\end{tabular}




\begin{tabular}{|c|c|c|c|c|}
\hline $\mathrm{C}$ & 1.650550 & 2.291448 & 3.028125 & \\
\hline $\mathrm{H}$ & -0.434076 & 2.657693 & 2.496580 & \\
\hline $\mathrm{C}$ & 0.686121 & 5.231978 & 2.854433 & \\
\hline $\mathrm{H}$ & 2.147327 & 6.206771 & -1.434866 & \\
\hline $\mathrm{C}$ & 1.752593 & 4.745632 & 3.846083 & \\
\hline $\mathrm{H}$ & -0.305016 & 4.871125 & 3.155883 & \\
\hline $\mathrm{C}$ & 1.415149 & 5.942347 & 0.573281 & \\
\hline $\mathrm{N}$ & 0.828090 & 3.295928 & -0.275602 & \\
\hline $\mathrm{N}$ & 0.939462 & 4.859132 & 1.454145 & \\
\hline $\mathrm{H}$ & 0.414569 & 1.561646 & 1.412625 & \\
\hline $\mathrm{H}$ & 1.566698 & 1.268288 & 3.410557 & \\
\hline $\mathrm{H}$ & 0.631425 & 6.324278 & 2.868086 & \\
\hline $\mathrm{H}$ & 0.578018 & 6.623318 & 0.363982 & \\
\hline $\mathrm{H}$ & 2.169674 & 6.512994 & 1.127610 & \\
\hline $\mathrm{H}$ & 2.977331 & 4.926857 & -0.537367 & \\
\hline $\mathrm{H}$ & 1.517526 & 3.828008 & -2.145709 & \\
\hline $\mathrm{H}$ & 0.766316 & 1.313729 & -2.428774 & \\
\hline $\mathrm{C}$ & 1.612266 & 3.263378 & 4.214495 & \\
\hline $\mathrm{H}$ & 0.664062 & 3.126059 & 4.756050 & \\
\hline $\mathrm{H}$ & 2.407606 & 2.994199 & 4.920661 & \\
\hline $\mathrm{H}$ & 2.746199 & 4.945732 & 3.423048 & \\
\hline $\mathrm{H}$ & 1.671225 & 5.350714 & 4.758560 & \\
\hline $\mathrm{H}$ & 2.618184 & 2.339201 & 2.515138 & \\
\hline & 2 & TS2-Lys & $\begin{array}{l}\text { I OMe } \\
\text { NHLys }\end{array}$ & MeO's \\
\hline \multicolumn{4}{|c|}{$\begin{array}{l}\text { Sum of electronic and thermal Free Energies } \\
= \\
-2599.858247(i=-44)\end{array}$} & $\begin{array}{l}\text { Sum of electronic and thermal Free Energies } \\
= \\
-2599.902180\end{array}$ \\
\hline $\mathrm{C}$ & 4.824374 & -0.124911 & -1.357137 & $\begin{array}{llll}\text { C } & -3.836908 & -1.698856 & -0.972493\end{array}$ \\
\hline $\mathrm{P}$ & 3.182608 & -1.997815 & 0.491222 & $\begin{array}{llll}\mathrm{P} & -2.396164 & 1.701716 & -0.202210\end{array}$ \\
\hline $\mathrm{C}$ & 4.883438 & 1.055676 & -2.344541 & $\begin{array}{llll}\mathrm{C} & -4.898343 & -2.694583 & -0.426942\end{array}$ \\
\hline $\mathrm{H}$ & 5.195472 & 0.708523 & -3.338474 & $\begin{array}{llll}\mathrm{H} & -4.677100 & -3.682483 & -0.847591\end{array}$ \\
\hline $\mathrm{H}$ & 3.876726 & 1.478902 & -2.458228 & $\begin{array}{llll}\mathrm{H} & -4.751630 & -2.785720 & 0.656415\end{array}$ \\
\hline $\mathrm{C}$ & 5.858972 & 2.143738 & -1.850537 & $\begin{array}{llll}C & -6.356884 & -2.306387 & -0.715791\end{array}$ \\
\hline $\mathrm{H}$ & 5.880882 & 2.976420 & -2.564152 & $\begin{array}{llll}\mathrm{H} & -7.038371 & -3.080866 & -0.339998\end{array}$ \\
\hline $\mathrm{C}$ & 4.371094 & 0.446638 & -0.000899 & $\begin{array}{llll}\text { C } & -4.209704 & -0.311777 & -0.385877\end{array}$ \\
\hline
\end{tabular}




\begin{tabular}{|c|c|c|c|c|c|c|c|}
\hline $\mathrm{C}$ & 5.361478 & 1.476479 & 0.556489 & $\mathrm{C}$ & -5.675459 & 0.103875 & -0.608523 \\
\hline $\mathrm{H}$ & 5.018917 & 1.827431 & 1.536574 & $\mathrm{H}$ & -5.846048 & 1.078943 & -0.137164 \\
\hline $\mathrm{C}$ & 5.548217 & 2.668232 & -0.415226 & $\mathrm{C}$ & -6.713841 & -0.922733 & -0.113775 \\
\hline $\mathrm{H}$ & 6.450290 & 3.216421 & -0.092716 & $\mathrm{H}$ & -7.689846 & -0.628500 & -0.538166 \\
\hline $\mathrm{H}$ & 6.329892 & 0.991598 & 0.725165 & $\mathrm{H}$ & -5.821334 & 0.252536 & -1.685150 \\
\hline $\mathrm{S}$ & 4.343014 & -3.601392 & 0.860346 & $\mathrm{~S}$ & -1.664673 & 3.146489 & -1.326592 \\
\hline $\mathrm{S}$ & 3.474135 & -1.319919 & -1.714447 & $S$ & -2.167822 & -2.269779 & -0.380517 \\
\hline $\mathrm{O}$ & 4.157944 & -0.582122 & 0.927676 & $\mathrm{O}$ & -3.415698 & 0.754379 & -1.014591 \\
\hline $\mathrm{H}$ & 3.420712 & 0.967982 & -0.198599 & $\mathrm{H}$ & -3.979850 & -0.337108 & 0.681211 \\
\hline $\mathrm{C}$ & 6.158113 & -0.893099 & -1.289778 & $\mathrm{C}$ & -3.849167 & -1.673217 & -2.513176 \\
\hline $\mathrm{H}$ & 6.375932 & -1.331936 & -2.270299 & $\mathrm{H}$ & -4.818595 & -1.370216 & -2.942016 \\
\hline $\mathrm{H}$ & 7.007020 & -0.252796 & -1.012976 & $\mathrm{H}$ & -3.087292 & -0.981875 & -2.879763 \\
\hline $\mathrm{H}$ & 6.089007 & -1.707845 & -0.564332 & $\mathrm{H}$ & -3.607746 & -2.672536 & -2.889690 \\
\hline $\mathrm{H}$ & 6.876493 & 1.734664 & -1.842048 & $\mathrm{H}$ & -6.525811 & -2.256148 & -1.799710 \\
\hline $\mathrm{C}$ & 4.436376 & 3.719115 & -0.386556 & $\mathrm{C}$ & -6.938791 & -0.954238 & 1.396921 \\
\hline $\mathrm{C}$ & 4.652060 & 4.927269 & -1.275165 & $\mathrm{C}$ & -8.010514 & -1.910704 & 1.876448 \\
\hline $\mathrm{H}$ & 5.667747 & 5.331743 & -1.160435 & $\mathrm{H}$ & -7.695617 & -2.957154 & 1.776354 \\
\hline $\mathrm{H}$ & 4.532442 & 4.681401 & -2.338076 & $\mathrm{H}$ & -8.255037 & -1.737692 & 2.929799 \\
\hline $\mathrm{H}$ & 3.939405 & 5.724474 & -1.039400 & $\mathrm{H}$ & -8.933478 & -1.804100 & 1.288514 \\
\hline $\mathrm{C}$ & 3.355491 & 3.664303 & 0.400207 & $\mathrm{C}$ & -6.304500 & -0.171607 & 2.277981 \\
\hline $\mathrm{H}$ & 3.140638 & 2.825339 & 1.052525 & $\mathrm{H}$ & -5.518779 & 0.523336 & 2.001661 \\
\hline $\mathrm{H}$ & 2.627700 & 4.473361 & 0.406652 & $\mathrm{H}$ & -6.545942 & -0.219231 & 3.338239 \\
\hline $\mathrm{C}$ & -2.571430 & -0.215629 & 1.303605 & $\mathrm{C}$ & 4.980851 & 0.959186 & -0.146001 \\
\hline $\mathrm{H}$ & -2.874804 & -1.092058 & 1.896452 & $\mathrm{C}$ & 5.117327 & 2.455393 & 0.118271 \\
\hline $\mathrm{H}$ & -2.014720 & 0.437290 & 1.985266 & $\mathrm{O}$ & 4.868138 & 3.166997 & -0.995116 \\
\hline $\mathrm{C}$ & -3.841351 & 0.540112 & 0.857107 & $\mathrm{C}$ & 4.875072 & 4.595511 & -0.834379 \\
\hline $\mathrm{C}$ & -4.593986 & 1.073299 & 2.081357 & $\mathrm{H}$ & 4.630220 & 4.999165 & -1.816933 \\
\hline $\mathrm{O}$ & -3.974208 & 2.162504 & 2.585574 & $\mathrm{H}$ & 4.126851 & 4.899661 & -0.098268 \\
\hline $\mathrm{C}$ & -4.564705 & 2.713586 & 3.771188 & $\mathrm{H}$ & 5.860465 & 4.940008 & -0.508612 \\
\hline $\mathrm{H}$ & -5.593422 & 3.028734 & 3.575653 & $\mathrm{O}$ & 5.392534 & 2.952221 & 1.191676 \\
\hline $\mathrm{H}$ & -4.566997 & 1.976701 & 4.579337 & $\mathrm{~N}$ & 5.464271 & 0.272430 & 1.041054 \\
\hline $\mathrm{H}$ & -3.944740 & 3.570611 & 4.036955 & $\mathrm{H}$ & 5.573779 & 0.830272 & 1.877873 \\
\hline $\mathrm{O}$ & -5.587267 & 0.577866 & 2.567343 & $\mathrm{C}$ & 5.958573 & -0.995954 & 1.107749 \\
\hline $\mathrm{N}$ & -4.699661 & -0.315444 & 0.061213 & $\mathrm{O}$ & 6.426646 & -1.485918 & 2.124535 \\
\hline $\mathrm{H}$ & -4.819179 & -1.271450 & 0.369246 & $\mathrm{O}$ & 5.854119 & -1.612047 & -0.100919 \\
\hline $\mathrm{C}$ & -5.743439 & 0.223102 & -0.641384 & $\mathrm{C}$ & 6.253633 & -3.014213 & -0.270823 \\
\hline $\mathrm{O}$ & -5.885373 & 1.416764 & -0.855255 & $\mathrm{C}$ & 5.934720 & -3.276003 & -1.745604 \\
\hline $\mathrm{O}$ & -6.552812 & -0.775592 & -1.080820 & $\mathrm{H}$ & 6.503500 & -2.597801 & -2.390691 \\
\hline $\mathrm{C}$ & -7.733062 & -0.482595 & -1.898638 & $\mathrm{H}$ & 6.194903 & -4.306618 & -2.010358 \\
\hline $\mathrm{C}$ & -8.320014 & -1.875450 & -2.147045 & $\mathrm{H}$ & 4.868429 & -3.127019 & -1.942818 \\
\hline $\mathrm{H}$ & -8.580541 & -2.358425 & -1.199485 & $\mathrm{C}$ & 7.755757 & -3.168582 & -0.004892 \\
\hline $\mathrm{H}$ & -9.224940 & -1.800495 & -2.759884 & $\mathrm{H}$ & 7.988785 & -2.952195 & 1.038583 \\
\hline
\end{tabular}




\begin{tabular}{|c|c|c|c|c|c|c|c|}
\hline $\mathrm{H}$ & -7.597417 & -2.510615 & -2.669710 & $\mathrm{H}$ & 8.068398 & -4.193716 & -0.236171 \\
\hline $\mathrm{C}$ & -8.719555 & 0.387450 & -1.110497 & $\mathrm{H}$ & 8.326776 & -2.486153 & -0.644963 \\
\hline $\mathrm{H}$ & -8.962700 & -0.087806 & -0.153794 & $\mathrm{C}$ & 5.407324 & -3.917571 & 0.633070 \\
\hline $\mathrm{H}$ & -8.298025 & 1.374356 & -0.914642 & $\mathrm{H}$ & 5.614450 & -3.720710 & 1.685889 \\
\hline $\mathrm{H}$ & -9.648233 & 0.503270 & -1.681731 & $\mathrm{H}$ & 4.341224 & -3.752018 & 0.444331 \\
\hline $\mathrm{C}$ & -7.311410 & 0.170229 & -3.220338 & $\mathrm{H}$ & 5.631391 & -4.968677 & 0.416828 \\
\hline $\mathrm{H}$ & -6.870827 & 1.152944 & -3.045900 & $\mathrm{H}$ & 5.629002 & 0.712515 & -0.994912 \\
\hline $\mathrm{H}$ & -6.578424 & -0.459114 & -3.737042 & $\mathrm{O}$ & -3.294368 & 2.308014 & 1.049404 \\
\hline $\mathrm{H}$ & -8.185249 & 0.282695 & -3.872889 & $\mathrm{C}$ & -4.113738 & 3.461017 & 0.855734 \\
\hline $\mathrm{C}$ & -1.658486 & -0.652692 & 0.150674 & $\mathrm{H}$ & -3.511695 & 4.315870 & 0.531229 \\
\hline $\mathrm{H}$ & -2.226933 & -1.273719 & -0.555277 & $\mathrm{H}$ & -4.896616 & 3.277032 & 0.109761 \\
\hline $\mathrm{H}$ & -1.346484 & 0.238960 & -0.412994 & $\mathrm{H}$ & -4.580039 & 3.672965 & 1.822606 \\
\hline $\mathrm{C}$ & -0.419196 & -1.413975 & 0.639851 & $\mathrm{~N}$ & -1.385712 & 0.654762 & 0.549406 \\
\hline $\mathrm{H}$ & -0.738355 & -2.307950 & 1.198278 & $\mathrm{H}$ & -1.549004 & -0.361018 & 0.274073 \\
\hline $\mathrm{H}$ & 0.157018 & -0.807594 & 1.345062 & $\mathrm{C}$ & -0.048277 & 0.982617 & 1.022611 \\
\hline $\mathrm{C}$ & 0.498733 & -1.846153 & -0.521347 & $\mathrm{H}$ & -0.000031 & 2.051041 & 1.265857 \\
\hline $\mathrm{H}$ & -0.111271 & -2.412442 & -1.246727 & $\mathrm{H}$ & 0.131372 & 0.436025 & 1.959871 \\
\hline $\mathrm{H}$ & 0.856599 & -0.960410 & -1.057891 & $\mathrm{C}$ & 1.043268 & 0.632404 & 0.000352 \\
\hline $\mathrm{N}$ & 1.662597 & -2.667052 & -0.190241 & $\mathrm{H}$ & 0.830784 & 1.181902 & -0.924893 \\
\hline $\mathrm{H}$ & -3.558420 & 1.398614 & 0.242022 & $\mathrm{H}$ & 0.965275 & -0.435537 & -0.242318 \\
\hline $\mathrm{C}$ & 2.944069 & -1.404946 & 3.164881 & $\mathrm{C}$ & 2.456703 & 0.964487 & 0.494117 \\
\hline $\mathrm{H}$ & 3.277956 & -0.361609 & 3.225095 & $\mathrm{H}$ & 2.512336 & 2.038927 & 0.727457 \\
\hline $\mathrm{H}$ & 2.220769 & -1.597877 & 3.970074 & $\mathrm{H}$ & 2.663941 & 0.434228 & 1.434037 \\
\hline $\mathrm{H}$ & 3.812525 & -2.061940 & 3.302487 & $\mathrm{C}$ & 3.525790 & 0.600672 & -0.542469 \\
\hline $\mathrm{O}$ & 2.285207 & -1.680599 & 1.941530 & $\mathrm{H}$ & 3.307798 & 1.102349 & -1.492816 \\
\hline $\mathrm{H}$ & 1.390875 & -3.409909 & 0.455337 & $\mathrm{H}$ & 3.504336 & -0.476716 & -0.738873 \\
\hline & & TS3-Lys & & & & INT3-Lys & \\
\hline \multicolumn{4}{|c|}{$\begin{array}{l}\text { Sum of electronic and thermal Free Energies } \\
= \\
-2599.876065(i=-171)\end{array}$} & \multicolumn{4}{|c|}{$\begin{array}{l}\text { Sum of electronic and thermal Free Energies } \\
= \\
-2599.896180\end{array}$} \\
\hline $\mathrm{C}$ & 4.050387 & 1.765604 & -0.939065 & $\mathrm{C}$ & 3.941749 & 1.904881 & -0.957371 \\
\hline $\mathrm{P}$ & 2.448077 & -1.538368 & 0.233099 & $\mathrm{P}$ & 2.487637 & -1.491487 & 0.179424 \\
\hline $\mathrm{C}$ & 5.093559 & 1.321431 & -2.003414 & $\mathrm{C}$ & 5.116068 & 1.605324 & -1.920880 \\
\hline $\mathrm{H}$ & 4.566934 & 0.765334 & -2.792794 & $\mathrm{H}$ & 4.909592 & 0.670737 & -2.469945 \\
\hline
\end{tabular}




\begin{tabular}{|c|c|c|c|c|c|c|c|}
\hline $\mathrm{H}$ & 5.474254 & 2.236494 & -2.463524 & $\mathrm{H}$ & 5.164998 & 2.415372 & -2.657894 \\
\hline $\mathrm{C}$ & 6.282749 & 0.420849 & -1.547787 & $\mathrm{C}$ & 6.468791 & 1.475312 & -1.210352 \\
\hline $\mathrm{H}$ & 7.213070 & 0.849825 & -1.935580 & $\mathrm{H}$ & 6.712429 & 2.436002 & -0.743543 \\
\hline $\mathrm{C}$ & 3.999782 & 0.748001 & 0.203346 & $\mathrm{C}$ & 3.941495 & 0.862400 & 0.174122 \\
\hline $\mathrm{C}$ & 5.333086 & 0.568106 & 0.907428 & $\mathrm{C}$ & 5.290828 & 0.705307 & 0.873660 \\
\hline $\mathrm{H}$ & 5.548634 & 1.542031 & 1.345415 & $\mathrm{H}$ & 5.480178 & 1.662800 & 1.366439 \\
\hline $\mathrm{C}$ & 6.492080 & 0.118090 & -0.017564 & $\mathrm{C}$ & 6.423011 & 0.379468 & -0.114848 \\
\hline $\mathrm{H}$ & 6.536925 & -0.976045 & 0.056572 & $\mathrm{H}$ & 6.162089 & -0.566175 & -0.615458 \\
\hline $\mathrm{H}$ & 5.223146 & -0.150037 & 1.729844 & $\mathrm{H}$ & 5.217955 & -0.071558 & 1.644247 \\
\hline $\mathrm{S}$ & 2.417345 & -3.373082 & -0.460784 & $\mathrm{~S}$ & 2.553117 & -3.325781 & -0.514012 \\
\hline $\mathrm{S}$ & 4.457963 & 3.412568 & -0.161898 & $\mathrm{~S}$ & 4.100525 & 3.561708 & -0.129099 \\
\hline $\mathrm{O}$ & 3.606247 & -0.626063 & -0.356285 & $\mathrm{O}$ & 3.608479 & -0.526169 & -0.397965 \\
\hline $\mathrm{H}$ & 3.228999 & 1.034733 & 0.923168 & $\mathrm{H}$ & 3.159126 & 1.101703 & 0.896994 \\
\hline $\mathrm{C}$ & 2.678710 & 1.884611 & -1.626841 & $\mathrm{C}$ & 2.626943 & 1.865035 & -1.752234 \\
\hline $\mathrm{H}$ & 2.339123 & 0.934010 & -2.066286 & $\mathrm{H}$ & 2.443195 & 0.891447 & -2.230951 \\
\hline $\mathrm{H}$ & 1.928617 & 2.254874 & -0.914657 & $\mathrm{H}$ & 1.781646 & 2.120993 & -1.098791 \\
\hline $\mathrm{H}$ & 2.740261 & 2.631344 & -2.425261 & $\mathrm{H}$ & 2.656528 & 2.638056 & -2.527008 \\
\hline $\mathrm{H}$ & 6.167595 & -0.547997 & -2.046500 & $\mathrm{H}$ & 7.252742 & 1.244850 & -1.946033 \\
\hline $\mathrm{C}$ & 7.847763 & 0.641261 & 0.464958 & $\mathrm{C}$ & 7.780926 & 0.170788 & 0.537888 \\
\hline $\mathrm{C}$ & 8.960116 & -0.380194 & 0.505219 & $\mathrm{C}$ & 8.780244 & -0.613662 & -0.282864 \\
\hline $\mathrm{H}$ & 9.110088 & -0.840846 & -0.482559 & $\mathrm{H}$ & 8.950258 & -0.146297 & -1.261598 \\
\hline $\mathrm{H}$ & 9.912744 & 0.061244 & 0.820058 & $\mathrm{H}$ & 9.747554 & -0.698564 & 0.224761 \\
\hline $\mathrm{H}$ & 8.720537 & -1.204722 & 1.193187 & $\mathrm{H}$ & 8.408555 & -1.628210 & -0.484973 \\
\hline $\mathrm{C}$ & 8.063719 & 1.924211 & 0.775814 & $\mathrm{C}$ & 8.110626 & 0.631638 & 1.750365 \\
\hline $\mathrm{H}$ & 7.272123 & 2.669810 & 0.707120 & $\mathrm{H}$ & 7.417123 & 1.194838 & 2.366542 \\
\hline $\mathrm{H}$ & 9.053148 & 2.268052 & 1.076389 & $\mathrm{H}$ & 9.103516 & 0.467582 & 2.165779 \\
\hline $\mathrm{C}$ & -5.318952 & -0.934760 & -0.425382 & $\mathrm{C}$ & -5.314465 & -0.986751 & -0.421802 \\
\hline $\mathrm{C}$ & -5.440445 & -2.454685 & -0.353863 & $\mathrm{C}$ & -5.449669 & -2.505126 & -0.346371 \\
\hline $\mathrm{O}$ & -5.235825 & -3.013639 & -1.559489 & $\mathrm{O}$ & -5.278335 & -3.066767 & -1.556184 \\
\hline $\mathrm{C}$ & -5.260480 & -4.452046 & -1.588998 & $\mathrm{C}$ & -5.318543 & -4.504677 & -1.583808 \\
\hline $\mathrm{H}$ & -5.064113 & -4.724308 & -2.626040 & $\mathrm{H}$ & -5.154645 & -4.779584 & -2.625816 \\
\hline $\mathrm{H}$ & -4.488702 & -4.860111 & -0.931719 & $\mathrm{H}$ & -4.532455 & -4.920311 & -0.948528 \\
\hline $\mathrm{H}$ & -6.237489 & -4.824033 & -1.269360 & $\mathrm{H}$ & -6.289652 & -4.866718 & -1.236051 \\
\hline $\mathrm{O}$ & -5.672344 & -3.087007 & 0.655947 & $\mathrm{O}$ & -5.665010 & -3.135033 & 0.668573 \\
\hline $\mathrm{N}$ & -5.730518 & -0.411591 & 0.866515 & $\mathrm{~N}$ & -5.700317 & -0.458381 & 0.875903 \\
\hline $\mathrm{H}$ & -5.816054 & -1.080768 & 1.620942 & $\mathrm{H}$ & -5.784741 & -1.126286 & 1.631526 \\
\hline $\mathrm{C}$ & -6.265640 & 0.820110 & 1.111826 & $\mathrm{C}$ & -6.207122 & 0.783373 & 1.131021 \\
\hline $\mathrm{O}$ & -6.706448 & 1.158384 & 2.198858 & $\mathrm{O}$ & -6.625693 & 1.127494 & 2.224957 \\
\hline $\mathrm{O}$ & -6.225209 & 1.588607 & -0.009692 & $\mathrm{O}$ & -6.167655 & 1.553156 & 0.010580 \\
\hline $\mathrm{C}$ & -6.709813 & 2.975731 & 0.008783 & $\mathrm{C}$ & -6.606899 & 2.955305 & 0.043259 \\
\hline $\mathrm{C}$ & -6.461971 & 3.435288 & -1.430752 & $\mathrm{C}$ & -6.371175 & 3.412633 & -1.398973 \\
\hline $\mathrm{H}$ & -7.015413 & 2.808496 & -2.138066 & $\mathrm{H}$ & -6.960449 & 2.809657 & -2.098052 \\
\hline
\end{tabular}




\begin{tabular}{|c|c|c|c|c|c|c|c|}
\hline $\mathrm{H}$ & -6.790061 & 4.472646 & -1.556412 & $\mathrm{H}$ & -6.664295 & 4.461698 & -1.513708 \\
\hline $\mathrm{H}$ & -5.397125 & 3.377360 & -1.678154 & $\mathrm{H}$ & -5.314089 & 3.317949 & -1.667391 \\
\hline $\mathrm{C}$ & -8.207180 & 3.005171 & 0.336500 & $\mathrm{C}$ & -8.096115 & 3.032370 & 0.399340 \\
\hline $\mathrm{H}$ & -8.390024 & 2.654222 & 1.353032 & $\mathrm{H}$ & -8.271212 & 2.688449 & 1.419632 \\
\hline $\mathrm{H}$ & -8.585517 & 4.029405 & 0.239399 & $\mathrm{H}$ & -8.442949 & 4.068132 & 0.307582 \\
\hline $\mathrm{H}$ & -8.761784 & 2.370147 & -0.363797 & $\mathrm{H}$ & -8.683599 & 2.414726 & -0.289612 \\
\hline $\mathrm{C}$ & -5.883022 & 3.809675 & 0.993521 & $\mathrm{C}$ & -5.734742 & 3.757342 & 1.015216 \\
\hline $\mathrm{H}$ & -6.038119 & 3.470529 & 2.018653 & $\mathrm{H}$ & -5.875367 & 3.412956 & 2.040723 \\
\hline $\mathrm{H}$ & -4.816890 & 3.735782 & 0.752983 & $\mathrm{H}$ & -4.676819 & 3.657497 & 0.749177 \\
\hline $\mathrm{H}$ & -6.175195 & 4.863504 & 0.919351 & $\mathrm{H}$ & -5.999891 & 4.819301 & 0.957533 \\
\hline $\mathrm{H}$ & -6.013216 & -0.583684 & -1.197486 & $\mathrm{H}$ & -6.017311 & -0.629990 & -1.183604 \\
\hline $\mathrm{O}$ & 2.571792 & -1.483945 & 1.874095 & $\mathrm{O}$ & 2.587184 & -1.430941 & 1.821594 \\
\hline $\mathrm{C}$ & 3.425969 & -2.390003 & 2.578222 & $\mathrm{C}$ & 3.450212 & -2.313440 & 2.544889 \\
\hline $\mathrm{H}$ & 3.157681 & -3.426604 & 2.350768 & $\mathrm{H}$ & 3.220737 & -3.356527 & 2.305368 \\
\hline $\mathrm{H}$ & 4.477770 & -2.224365 & 2.320509 & $\mathrm{H}$ & 4.502989 & -2.114013 & 2.317292 \\
\hline $\mathrm{H}$ & 3.278639 & -2.185637 & 3.642167 & $\mathrm{H}$ & 3.267053 & -2.119213 & 3.605177 \\
\hline $\mathrm{N}$ & 1.051532 & -0.657874 & -0.031205 & $\mathrm{~N}$ & 1.057268 & -0.673903 & -0.104672 \\
\hline $\mathrm{H}$ & 1.195421 & 0.341124 & -0.141462 & $\mathrm{H}$ & 1.164221 & 0.329091 & -0.221049 \\
\hline $\mathrm{C}$ & -0.249909 & -1.058722 & 0.491404 & $\mathrm{C}$ & -0.229365 & -1.115976 & 0.420951 \\
\hline $\mathrm{H}$ & -0.264668 & -2.153979 & 0.521436 & $\mathrm{H}$ & -0.218896 & -2.211850 & 0.429014 \\
\hline $\mathrm{H}$ & -0.401328 & -0.704363 & 1.523785 & $\mathrm{H}$ & -0.381163 & -0.785143 & 1.461084 \\
\hline $\mathrm{C}$ & -1.383337 & -0.557751 & -0.409411 & $\mathrm{C}$ & -1.378732 & -0.619955 & -0.461852 \\
\hline $\mathrm{H}$ & -1.200825 & -0.923058 & -1.427968 & $\mathrm{H}$ & -1.206894 & -0.976018 & -1.485599 \\
\hline $\mathrm{H}$ & -1.349964 & 0.540667 & -0.461705 & $\mathrm{H}$ & -1.354073 & 0.479036 & -0.506500 \\
\hline $\mathrm{C}$ & -2.769448 & -1.004364 & 0.072284 & $\mathrm{C}$ & -2.756463 & -1.076623 & 0.034255 \\
\hline $\mathrm{H}$ & -2.789756 & -2.102793 & 0.129895 & $\mathrm{H}$ & -2.773514 & -2.175453 & 0.084029 \\
\hline $\mathrm{H}$ & -2.947916 & -0.638580 & 1.092141 & $\mathrm{H}$ & -2.922729 & -0.718244 & 1.058754 \\
\hline $\mathrm{C}$ & -3.890072 & -0.510646 & -0.849671 & $\mathrm{C}$ & -3.888691 & -0.577434 & -0.870390 \\
\hline $\mathrm{H}$ & -3.722046 & -0.874299 & -1.870504 & $\mathrm{H}$ & -3.740681 & -0.945366 & -1.892721 \\
\hline $\mathrm{H}$ & -3.884294 & 0.584081 & -0.894559 & $\mathrm{H}$ & -3.873764 & 0.517001 & -0.918800 \\
\hline & & TS4-Lys & . & & & & \\
\hline \multicolumn{8}{|c|}{$\begin{array}{l}\text { Sum of electronic and thermal Free Energies } \\
= \\
-2599.894814(i=-310)\end{array}$} \\
\hline
\end{tabular}




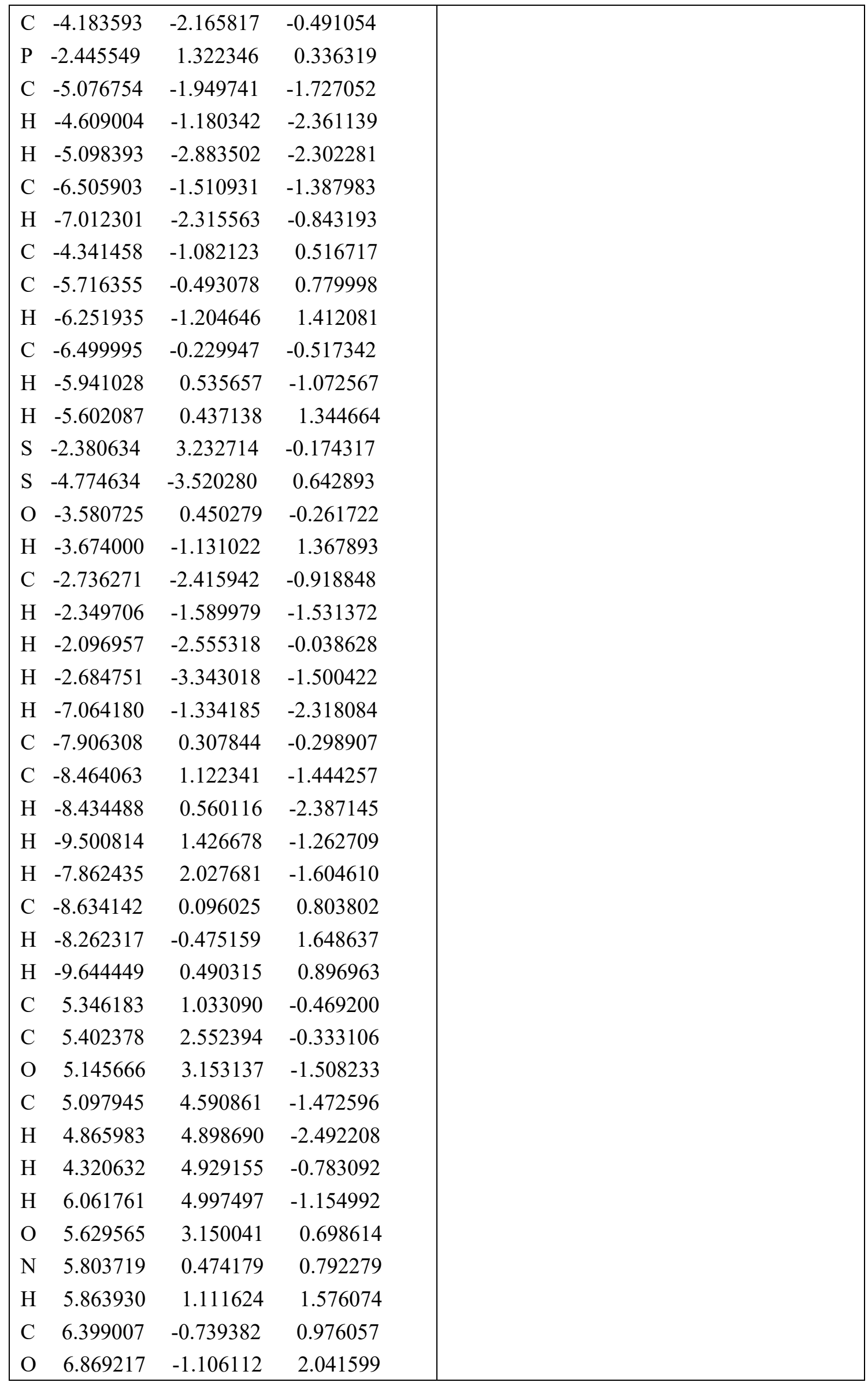




\begin{tabular}{|c|c|c|c|c|}
\hline $\mathrm{O}$ & 6.382204 & -1.458490 & -0.179390 & \\
\hline $\mathrm{C}$ & 6.933626 & -2.818556 & -0.227695 & \\
\hline $\mathrm{C}$ & 6.691049 & -3.225897 & -1.683894 & \\
\hline $\mathrm{H}$ & 7.205195 & -2.542280 & -2.367822 & \\
\hline $\mathrm{H}$ & 7.066961 & -4.239639 & -1.859141 & \\
\hline $\mathrm{H}$ & 5.621724 & -3.208081 & -1.917868 & \\
\hline $\mathrm{C}$ & 8.434706 & -2.789794 & 0.083230 & \\
\hline $\mathrm{H}$ & 8.612574 & -2.475858 & 1.112644 & \\
\hline $\mathrm{H}$ & 8.861110 & -3.788933 & -0.063897 & \\
\hline $\mathrm{H}$ & 8.949200 & -2.097596 & -0.593092 & \\
\hline $\mathrm{C}$ & 6.160552 & -3.735400 & 0.726780 & \\
\hline $\mathrm{H}$ & 6.310767 & -3.433848 & 1.764291 & \\
\hline $\mathrm{H}$ & 5.089275 & -3.703345 & 0.500068 & \\
\hline $\mathrm{H}$ & 6.503206 & -4.769271 & 0.603167 & \\
\hline $\mathrm{H}$ & 6.042449 & 0.746367 & -1.265683 & \\
\hline $\mathrm{O}$ & -2.482678 & 1.141286 & 1.989395 & \\
\hline $\mathrm{C}$ & -3.283410 & 1.991537 & 2.806087 & \\
\hline $\mathrm{H}$ & -3.063081 & 3.045013 & 2.602047 & \\
\hline $\mathrm{H}$ & -4.354041 & 1.814221 & 2.644915 & \\
\hline $\mathrm{H}$ & -3.036621 & 1.751235 & 3.845085 & \\
\hline $\mathrm{N}$ & -1.008592 & 0.508291 & -0.024855 & \\
\hline $\mathrm{H}$ & -1.133032 & -0.500009 & -0.020154 & \\
\hline $\mathrm{C}$ & 0.281147 & 0.955095 & 0.490081 & \\
\hline $\mathrm{H}$ & 0.255024 & 2.049991 & 0.513610 & \\
\hline $\mathrm{H}$ & 0.454844 & 0.613839 & 1.524513 & \\
\hline $\mathrm{C}$ & 1.427915 & 0.492427 & -0.415260 & \\
\hline $\mathrm{H}$ & 1.226799 & 0.851547 & -1.432721 & \\
\hline $\mathrm{H}$ & 1.434789 & -0.606881 & -0.469308 & \\
\hline $\mathrm{C}$ & 2.800704 & 0.987724 & 0.057558 & \\
\hline $\mathrm{H}$ & 2.773841 & 2.084570 & 0.137613 & \\
\hline $\mathrm{H}$ & 3.007981 & 0.609972 & 1.067710 & \\
\hline $\mathrm{C}$ & 3.929802 & 0.564405 & -0.888703 & \\
\hline $\mathrm{H}$ & 3.735140 & 0.949893 & -1.896773 & \\
\hline $\mathrm{H}$ & 3.967507 & -0.528089 & -0.965615 & \\
\hline
\end{tabular}




\section{Troubleshooting: Frequently Asked Questions}

\section{Question 1:}

How can I monitor the coupling reaction?

\section{Answer:}

We monitor the reaction by taking an aliquot out of the reaction and analyze it by LCMS, HPLC or ${ }^{31} \mathrm{P}$ NMR.

\section{Question 2:}

How can I purify my reaction?

\section{Answer:}

The compounds obtained after the coupling are highly polar. We therefore purify them using a preparative HPLC system.

\section{Question 3:}

Can I use a different solvent for the reaction?

\section{Answer:}

Yes. MeCN, DCM, THF and DMSO can also be used for the coupling step.

\section{Question 4:}

Can I use a different base for the reaction?

\section{Answer:}

We don't recommend it as DBU provides higher yields than all the other bases. We have tested $\mathrm{Et}_{3} \mathrm{~N}$, Imidazole, DIPEA, TMG, all resulting in no or lower conversions.

\section{Question 5:}

How do I optimize the coupling reaction?

\section{Answer:}

There are 3 key variables to examine. The amount of $\psi$-module, the amount of base and the total concentration of starting material. 


\section{Question 6:}

How do I assess the selectivity?

\section{Answer:}

This depends on the type of substrate.

Case 1: Your substrate contains only one serine. You can run a ${ }^{31} \mathrm{P}$ NMR (coupled to proton). If you observe a triplet between 50 and $60 \mathrm{ppm}$ then the reaction was successful.

Case 2: Your substrate contains only one threonine. You can run a ${ }^{31} \mathrm{P}$ NMR (coupled to proton). If you observe a doublet between 50 and $60 \mathrm{ppm}$ then the reaction was successful.

Case 3: Your substrate contains more than one serine. You will have to run a MS/MS experiment to determine where the $\psi$-module was attached. 


\section{References}

1. K. W. Knouse, J. N. deGruyter, M. A. Schmidt, B. Zheng, J. C. Vantourout, C. Kingston, S. E. Mercer, I. M. McDonald, R. E. Olson, Y. Zhu, C. Hang, J. Zhu, C. Yuan, Q. Wang, P. Park, M. D. Eastgate and P. S. Baran, Science, 2018, 361, 1234.

2. Kawamata, Y.; Vantourout, J. C.; Hickey, D. P.; Bai, P.; Chen, L.; Hou, Q.; Qiao, W.; Barman, K.; Edwards, M. A.; Garrido-Castro, A. F.; deGruyter, J. N.; Nakamura, H.; Knouse, K.; Qin, C.; Clay, K. J.; Bao, D.; Li, C.; Starr, J. T.; Garcia-Irizarry, C.; Sach, N.; White, H. S.; Neurock, M.; Minteer, S. D.; Baran, P. S. Electrochemically Driven, Ni-Catalyzed Aryl Amination: Scope, Mechanism, and Applications. J. Am. Chem. Soc. 2019, 141, 6392.

3. Kheirabadi, M.; Creech, G. S.; Qiao, J. X.; Nirschl, D. S.; Leahy, D. K.; Boy, K. M.; Carter, P. H.; Eastgate, M. D. Leveraging a "catch-Release" Logic Gate Process for the Synthesis and Nonchromatographic Purification of Thioether- or Amine-Bridged Macrocyclic Peptides. J. Org. Chem. 2018, 83, 4323.

4. 1. Spartan'10; Wavefunction, Inc.: Irvine, CA, 2010.

5. Frisch, M. J.; Trucks, G. W.; Schlegel, H. B.; Scuseria, G. E.; Robb, M. A.; Cheeseman, J. R.; Scalmani, G.; Barone, V.; Mennucci, B.; Petersson, G. A.; Nakatsuji, H.; Caricato, M.; Li, X.; Hratchian, H. P.; Izmaylov, A. F.; Bloino, J.; Zheng, G.; Sonnenberg, J. L.; Hada, M.; Ehara, M.; Toyota, K.; Fukuda, R.; Hasegawa, J.; Ishida, M.; Nakajima, T.; Honda, Y.; Kitao, O.; Nakai, H.; Vreven, T.; Montgomery, J. A., Jr.; Peralta, J. E.; Ogliaro, F.; Bearpark, M.; Heyd, J. J.; Brothers, E.; Kudin, K. N.; Staroverov, V. N.; Kobayashi, R.; Normand, J.; Raghavachari, K.; Rendell, A.; Burant, J. C.; Iyengar, S. S.; Tomasi, J.; Cossi, M.; Rega, N.; Millam, M. J.; Klene, M.; Knox, J. E.; Cross, J. B.; Bakken, V.; Adamo, C.; Jaramillo, J.; Gomperts, R.; Stratmann, R. E.; Yazyev, O.; Austin, A. J.; Cammi, R.; Pomelli, C.; Ochterski, J. W.; Martin, R. L.; Morokuma, K.; Zakrzewski, V. G.; Voth, G. A.; Salvador, P.; Dannenberg, J. J.; Dapprich, S.; 
Daniels, A. D.; Farkas, Ö.; Foresman, J. B.; Ortiz, J. V.; Cioslowski, J.; Fox, D. J. Gaussian 09, revision B.01; Gaussian, Inc.: Wallingford, CT, 2009.

6. (a) Becke, A. D. Density-Functional Thermochemistry. III. The Role of Exact Exchange. J. Chem. Phys. 1993, 98, 5648. (b) Lee, C.; Yang, W.; Parr, R. G. Development of the Colle-Salvetti Correlation-Energy Formula into a Functional of the Electron Density. Phys. Rev. B: Condens. Matter Mater. Phys. 1988, 37, 785-789.

7. (a) Kruse, H.; Goerigk, L.; Grimme, S. Why the Standard B3LYP/6-31G* Model Chemistry Should Not Be Used in DFT Calculations of Molecular Thermochemistry: Understanding and Correcting the Problem. J. Org. Chem. 2012, 77, 10824-10834. (b) Matsuno, R.; Kokubo, Y.; Kumagai, S.; Takamatsu, S.; Hashimoto, K.; Takahara, A. Molecular Design and Characterization of Ionic Monomers with Varying Ion Pair Interaction Energies. Macromolecules 2020, 53, 1629-1637.

8. (a) Fedorova, I. V.; Safonova, L. P. Ab Initio Investigation of the Interionic Interactions in Triethylammonium-Based Protic Ionic Liquids: The Role of Anions in the Formation of Ion Pair and Hydrogen Bonded Structure. Phys. Chem. A 2019, 123, 293-300. (b) Lozynski, M; Pernak, J.; Gdaniec, Z.; Gorska, B.; Béguin, F. Proof of Ion-Pair Structures in Ammonium-Based Protic Ionic Liquids using Combined NMR and DFT/PCM-Based Chemical Shift calculations. Phys. Chem. Chem. Phys. 2017, 19, 25033-25043.

9. (a) González, C.; Schlegel, H. B. Improved Algorithms for Reaction Path Following: Higher-Order Implicit Algorithms. J. Chem. Phys. 1989, 90, 2154-2161. (b) González, C.; Schlegel, H. B. Reaction Path Following in Mass-Weighted Internal Coordinates J. Chem. Phys. 1990, 94, 5523-5527. (c) Fukui, K. The Path of Chemical Reactions-the IRC Approach. Acc. Chem. Res. 1981, 14, 363-368.

10. Legault, C. Y. CYLview, 1.0b; Université de Sherbrooke, 2009 (http://ww- 
w.cylview.org).

11. Cox, Brian G. Acids and Bases: Solvent Effects on Acid-Base Strength. OUP Oxford, 2013.

12. Ravalico, F.; James, S. L.; Vyle, J. S. Synthesis of Nucleoside Analogues in a Ball Mill: Fast, Chemoselective and High Yielding Acylation without Undesirable Solvents. Green Chem. 2011, 13, 1778-1783.

13. Kaljurand, I.; Kütt, A.; Sooväli, L.; Rodima, T.; Mäemets, V.; Leito, I.; Koppel, I. A. Extension of the Self-Consistent Spectrophotometric Basicity Scale in Acetonitrile to a Full Span of $28 \mathrm{p} K_{\mathrm{a}}$ Units: Unification of Different Basicity Scales. J. Org. Chem. 2005, 70, 1019-1028.

14. Kütt, A.; Selberg, S.; Kaljurand, I.; Tshepelevitsh, S.; Heering, A.; Darnell, A.; Kaupmees, K.; Piirsalu, M.; Leito, I. p $K_{\mathrm{a}}$ Values in Organic Chemistry - Making Maximum Use of the Available Data. Tetrahedron Lett. 2018, 59, 3738-3748.

15. Lide, D. CRC Handbook of Chemistry and Physics, 87th ed.; CRC Press: Boca Raton, FL, 2006.

16. Rossini, E.; Bochevarov, A. D.; Knapp, E. W. Empirical Conversion of $\mathrm{p} K_{\mathrm{a}}$ Values between Different Solvents and Interpretation of the Parameters: Application to Water, Acetonitrile, Dimethyl Sulfoxide, and Methanol." ACS Omega 2018, 3, 1653-1662.

17. Hamann, S. D.; Linton, M. Influence of Pressure on the Ionization of Substituted Phenols. J. Chem. Soc., Faraday Trans. 1 1974, 70, 2239-2249.

18. Eckert, F.; Leito, I.; Kaljurand, I.; Kütt, A.; Klamt, A.; Diedenhofen, M.Prediction of Acidity in Acetonitrile Solution with COSMO-RS. J. Comput. Chem. 2009, 30, $799-810$.

19. Tsonopoulos, C.; Coulson, D. M.; Inman, L. B. Ionization Constants of Water Pollutants. J. Chem. Eng. Data 1976, 21, 190-193.

20. Yu, H.-Z.;Yang, Y.-M.; Zhang, L.; Dang, Z.-M.; Hu, G.-H. Quantum-Chemical Predictions of $\mathrm{p} K_{\mathrm{a}}$ 's of Thiols in DMSO J. Phys. Chem. A 2014, 118, 606-622. 
21. (a) Thurkill, R. L.; Grimsley, G. R.; Scholtz, J. M. pK Values of the Ionizable Groups of Proteins. Protein Science 2006, 15, 1214-1218. (b) Shen, B.; Bazinc, C.; English, A. M. Rapid High-Yield $N$-acylation of Aminothiols: $N$-acetylglutathione and $N$-acetylhomocysteine and Their Thiol $\mathrm{p} K_{\mathrm{a}}$ Values. Pept. Sci. 2013; 19, 263-267.

22. For a discussion on retention of configuration in related substrates, see: (a) Stec, W. J.; Karwowski, B.; Boczkowska, M.; Guga, P.; Koziołkiewicz, M.; Sochacki, M.; Wieczorek, M. W.; Błaszczyk, J. Deoxyribonucleoside 3‘-O-(2-Thio-and 2-Oxo-"spiro"-4,4-pentamethylene-1,3,2-oxathiaphospholane)s: Monomers for Stereocontrolled Synthesis of Oligo (Deoxyribonucleoside Phosphorothioate)s and Chimeric PS/PO Oligonucleotides. J. Am. Chem. Soc. 1998, 120, 7156-7167. (b) DeBruin, K. E.; Tang C.-I. W.; Johnson, D. M.; Wilde, R. L. Kinetic Facial Selectivity in Nucleophilic Displacements at Tetracoordinate Phosphorus: Kinetics and Stereochemistry in the Reaction of Sodium Ethoxide with O,S-Dimethyl Phenylphosphonothioate. J. Am. Chem. Soc. 1989, 111, 5871-5879.

23. (a) Westheimer, F. H. Pseudo-Rotation in the Hydrolysis of Phosphate Esters. Acc. Chem. Res. 1968, 1, 70-78. (b) Boyd, D. B. Mechanism of Hydrolysis of Cyclic Phosphate Esters. J. Am. Chem. Soc. 1969, 91, 1200-1205.

24. Park, K.-H.; Kim, M.-H.; Um, I-H. Kinetic Study on Nucleophilic Displacement Reactions of Phenyl Y-Substituted Phenyl Carbonates with 1,8-Diazabicyclo [5.4.0] undec-7-ene: Effects of Amine Nature on Reaction Mechanism. Bull. Korean Chem. Soc. 2016, 37, 77-81.

25. (a) Uchimaru, T.; Stec, W. J.; Taira, K. Mechanism of the Chemoselective and Stereoselective Ring Opening of Oxathiaphospholanes: An Ab Initio Study. $J$. Org. Chem. 1997, 62, 5793-5800. (b) Uchimaru, T.; Stec, W. J.; Tsuzuki, S.; Hirose, T.; Tanabe, K.; Taira, K. Ab Initio Investigation on Nucleophilic Ring opening of 1, 3, 2-Oxathiaphospholane: Nucleophilic Substitution at Phosphorus Coupled with Pseudorotation. Chem. Phys. Lett. 1996, 263, 691-696. 
26. Dixon, D. A.; Komornicki, A. Ab Initio Conformational Analysis of Cyclohexane. J. Phys. Chem. 1990, 94, 5630-5636.

27. The $\mathrm{S}-\mathrm{C}-\mathrm{C}-\mathrm{O}$ dihedral angle was scanned at fixed intervals and the highest energy geometry of the resulting potential energy was fully optimized to afford a twisted half-chair transition structure.

28. Lange's Handbook of Chemistry; Dean, J. A., Ed.; McGraw-Hill Book Co.: New York, 1985.

29. Arantes, G. M.; Chaimovich, H. Thiolysis and Alcoholysis of Phosphate Tri- and Monoesters with Alkyl and Aryl Leaving Groups. An ab Initio Study in the Gas Phase. J. Phys. Chem. A 2005, 109, 5625-5635.

30. DeBruin, K. E.; Petersen, J. R. Steric and Electronic Effects on the Stereochemistry of the Alkaline Hydrolysis of Acyclic Dialkoxyphosphonium Salts. Pseudorotation of Intermediates in Phosphorus Ester Reactions. J. Org. Chem. 1972, 37, 2272-2278.

31. (a) Trippett, S. Apicophilicity and Ring-Strain in Five-Coordinate Phosphoranes. Phosphorus and Sulfur 1976, 1, 89-98. (b) Bone, S.; Trippett, S.; Whittle, P. J. The Apicophilicity of Thio-Substituents in Trigonal Bipyramidal Phosphoranes. J. Chem. Soc., Perkin Trans. 1 1974, 2125-2132.

32. The increased stability of leaving groups in axial orientation is associated to the enhanced bonding character of their low-lying unfilled orbitals, in the case of sulphur 3d orbitals. See: Hoffmann, R.; Howell, J. M.; Muetterties, E. L. J. Am. Chem. Soc. 1972, 94, 3047-3058.

33. Adhikary, K. K.; Lee, H. W. Kinetics and Mechanism of the Benzylaminolysis of $O, O$-Diphenyl $S$-Aryl Phosphorothioates in Dimethyl Sulfoxide. Bull. Korean Chem. Soc. 2011, 32, 1625-1629.

34. Li L.; Lelyveld, V. S.; Prywes, N.; Szostak, J. W. Experimental and Computational Evidence for a Loose Transition State in Phosphoroimidazolide Hydrolysis. J. Am. Chem. Soc. 2016, 138, 3986-3989. 


\section{Spectra}

Compound P(V)-1 ${ }^{1}$ H NMR

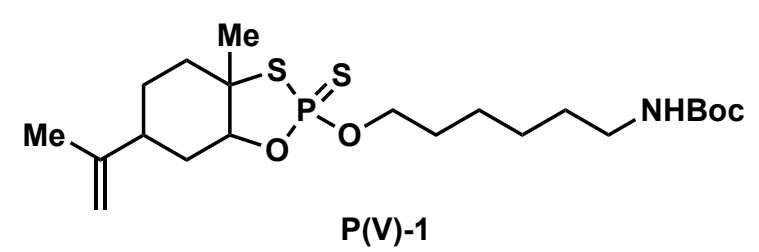

P(V)-1

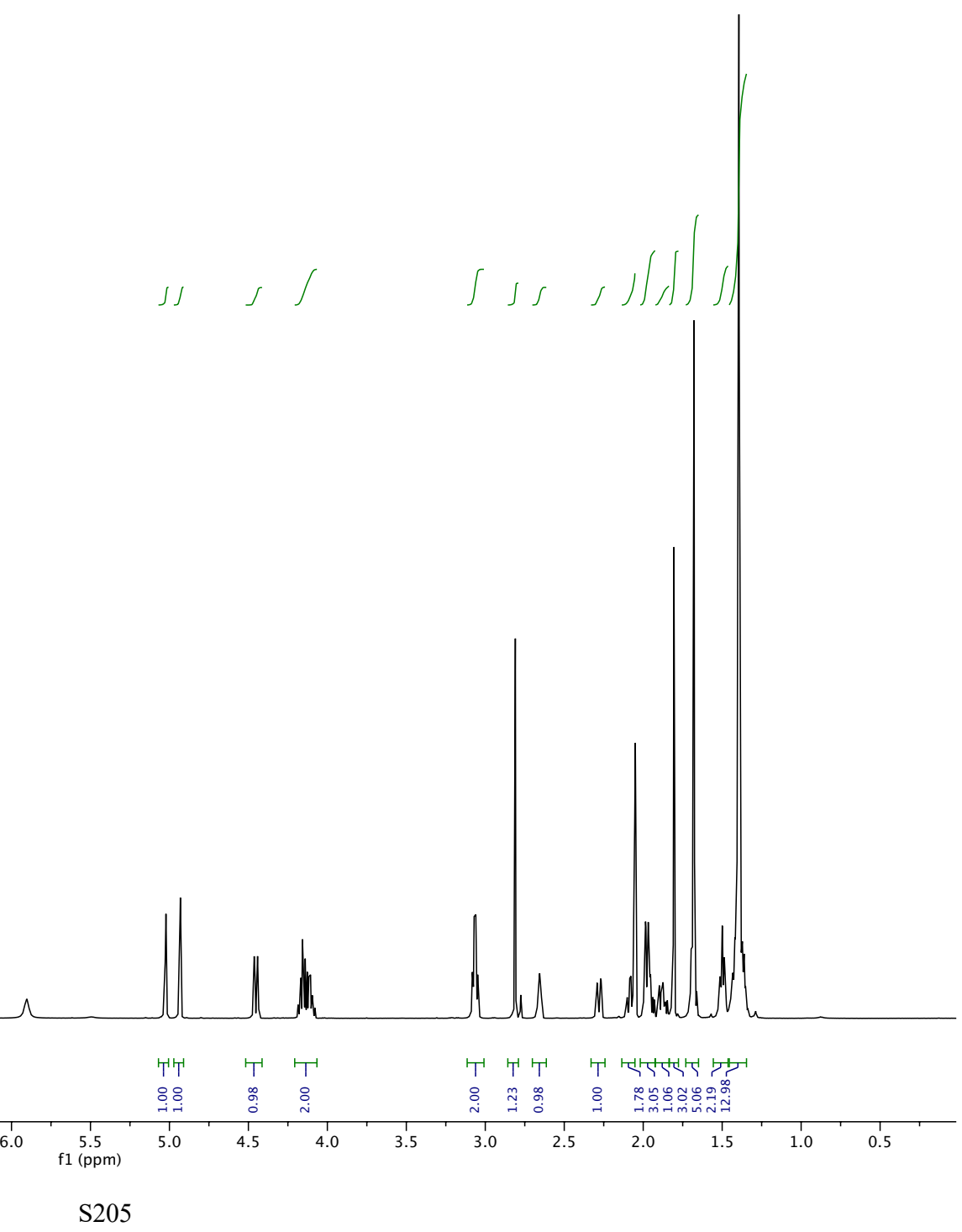




\section{Compound P(V)-1 ${ }^{13} \mathrm{C}$ NMR}

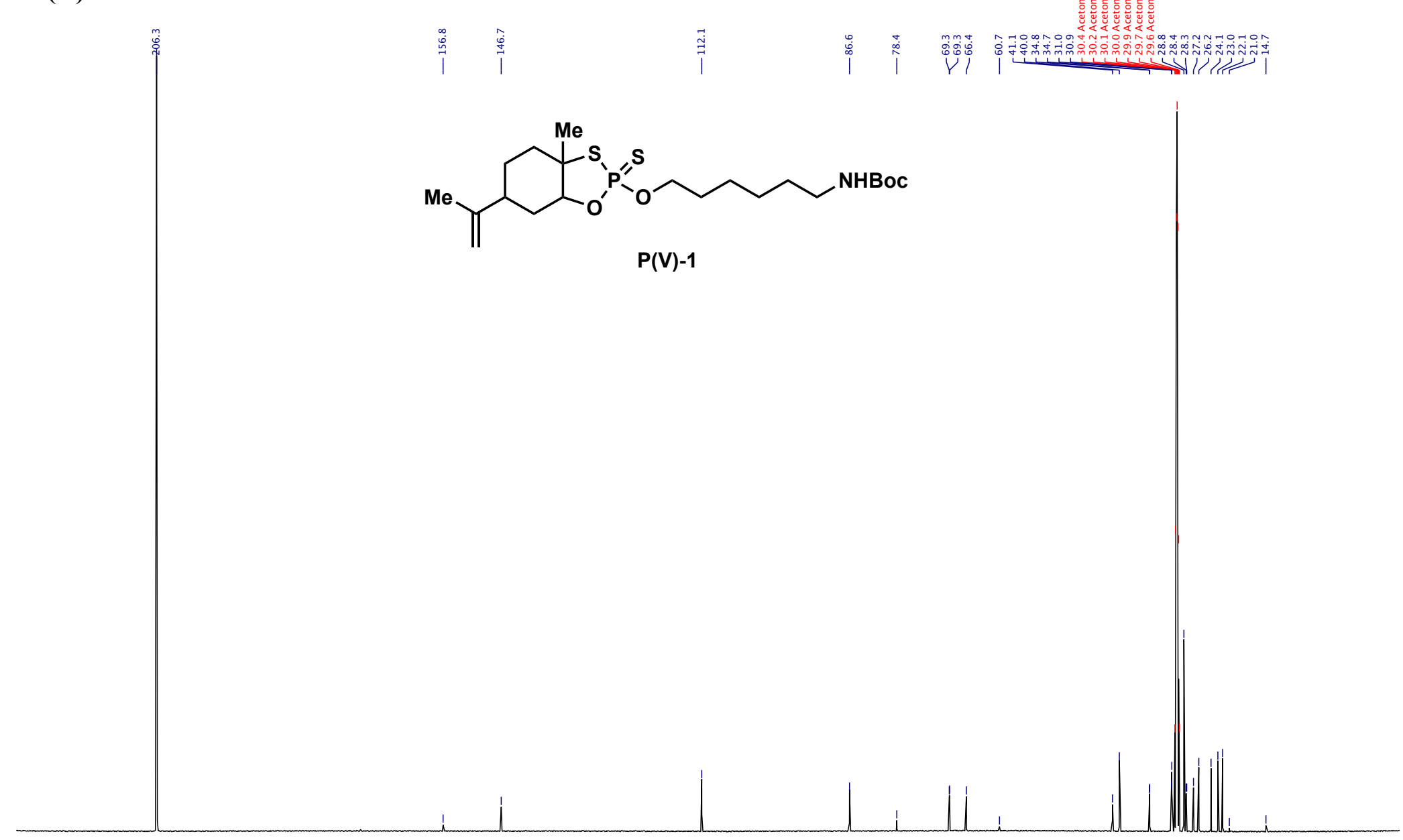

$30 \quad 220$
210

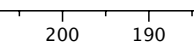




\section{Compound P(V)-1 ${ }^{31}$ P NMR}<smiles>C=C(C)C1CCC2(C)OP(=S)(OCCCCCCNC(=O)OCc3ccccc3)OC2C1</smiles> 


\section{Compound P(V)-2a ${ }^{1}$ H NMR}

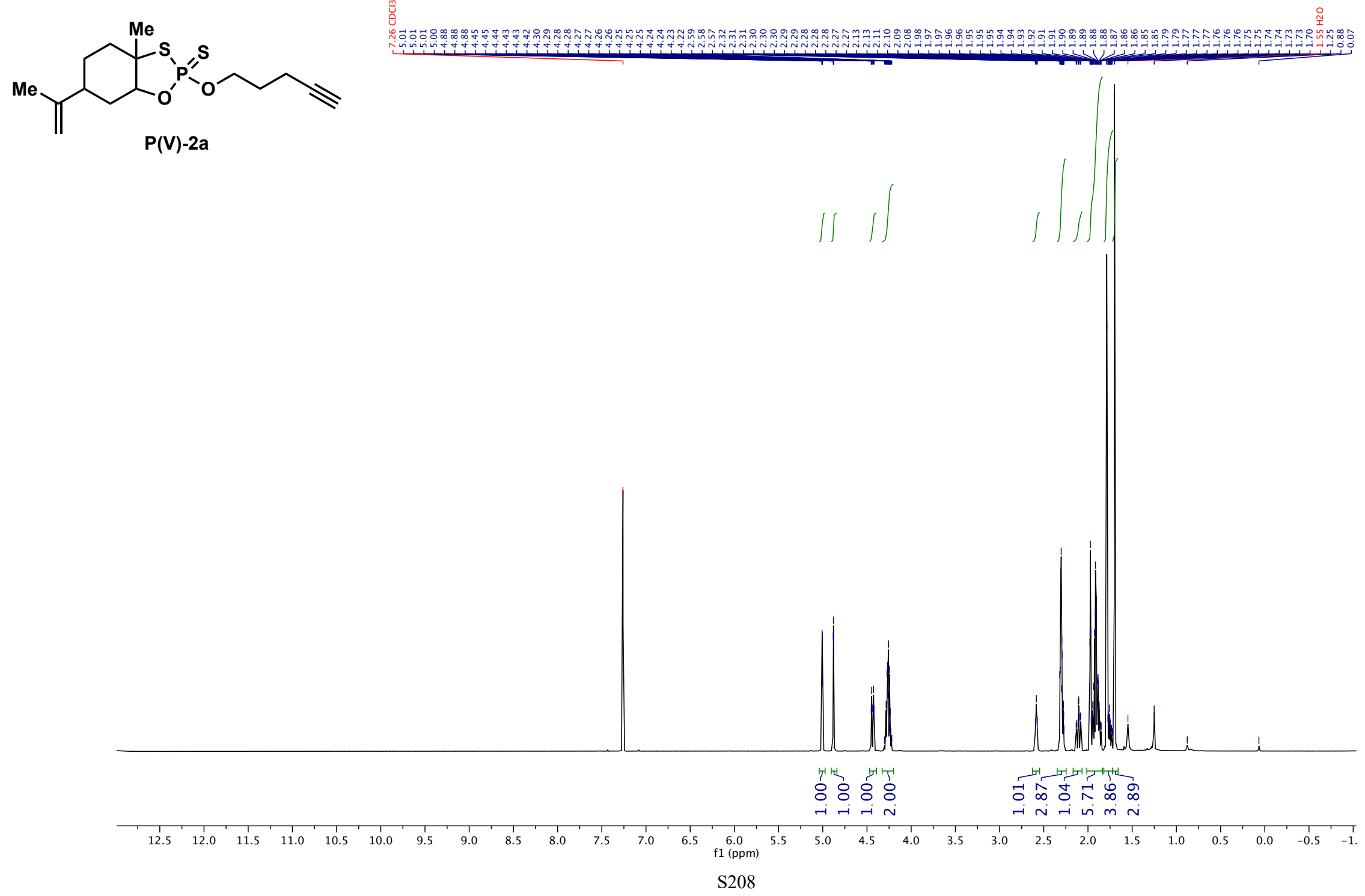




\section{Compound P(V)-2a ${ }^{13} \mathrm{C}$ NMR}
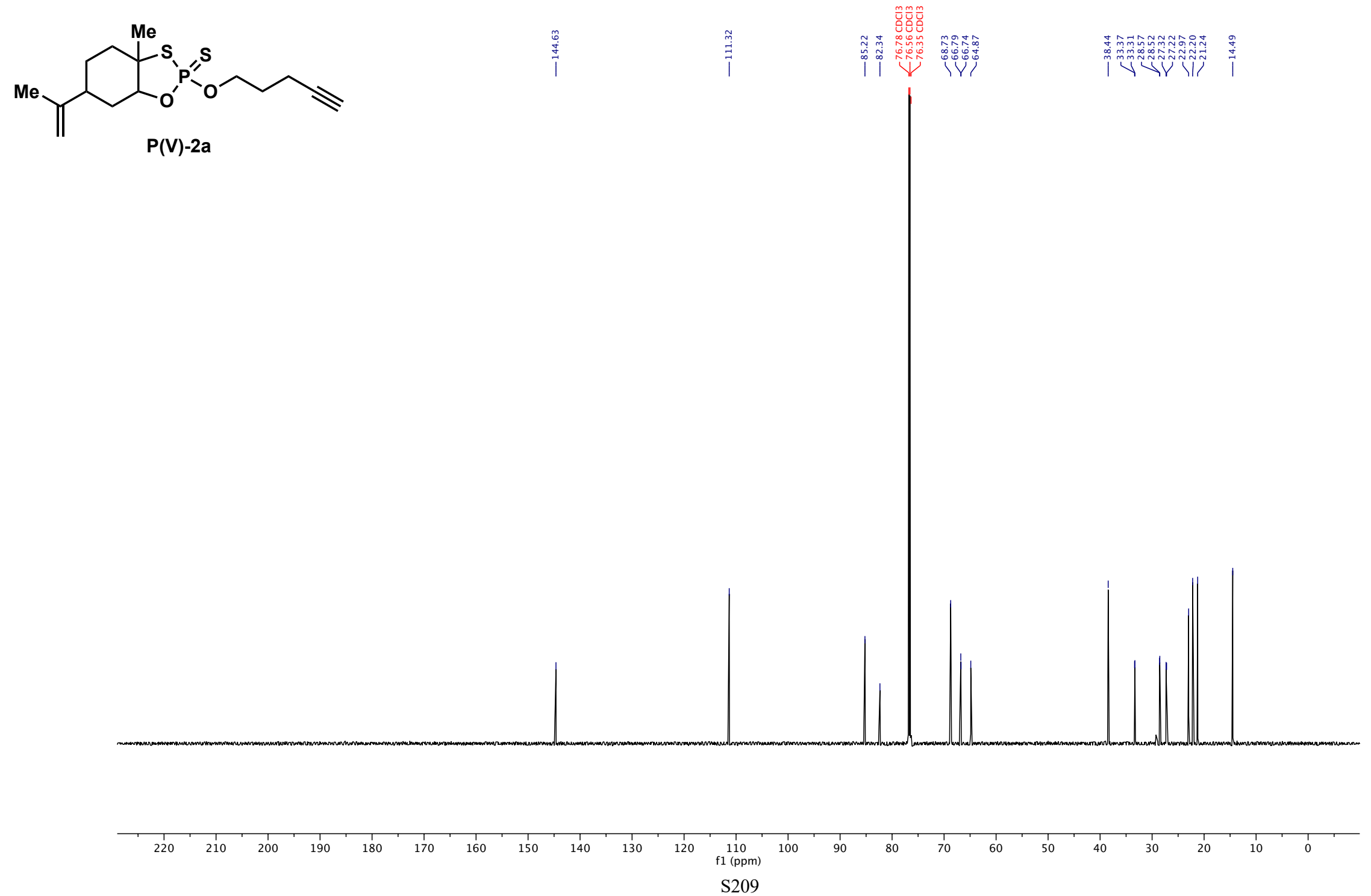
Compound P(V)-2a ${ }^{31}$ P NMR

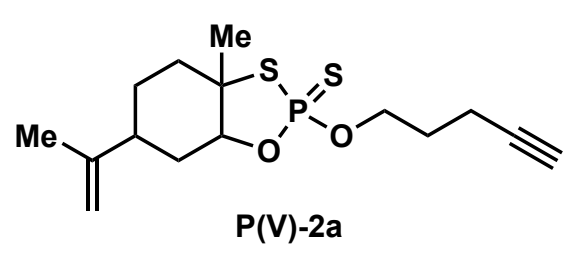

$\mathrm{P}(\mathrm{V})-\mathbf{2 a}$

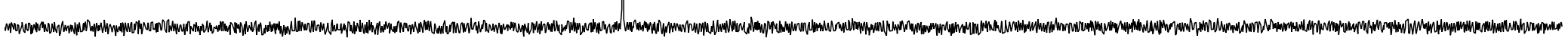

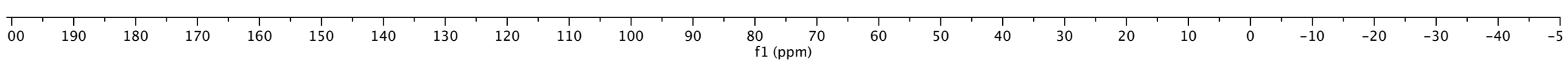

S210 


\section{Compound P(V)-2b ${ }^{1} \mathrm{H}$ NMR}

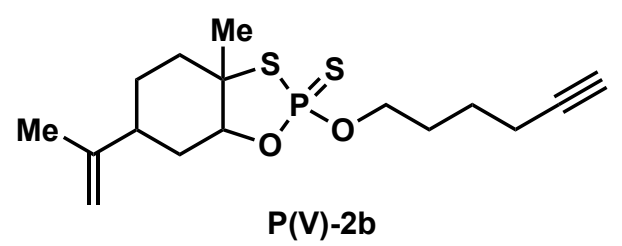

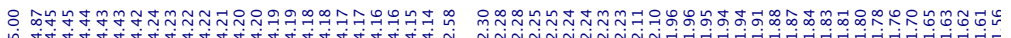
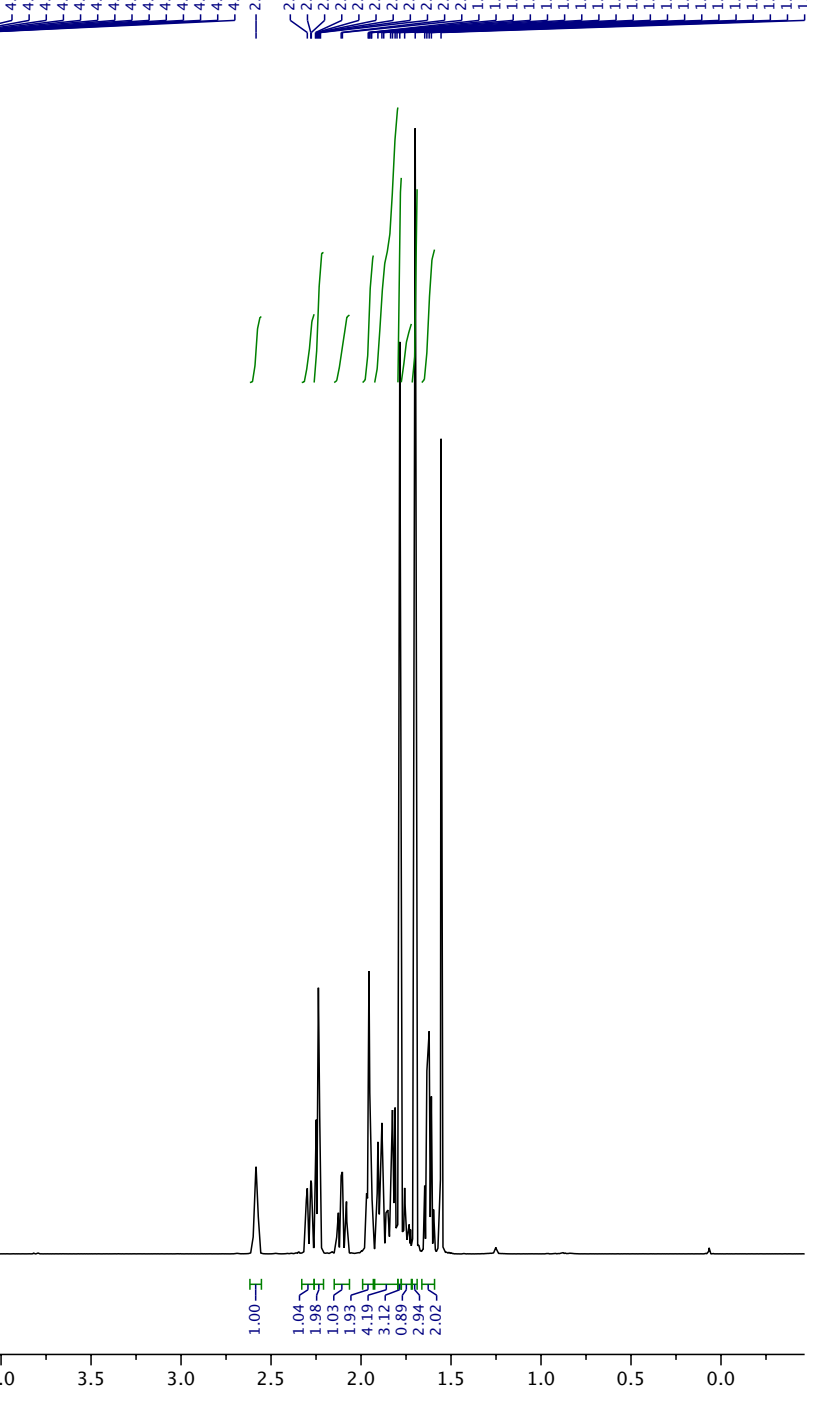
Compound P(V)-2b ${ }^{13} \mathrm{C}$ NMR

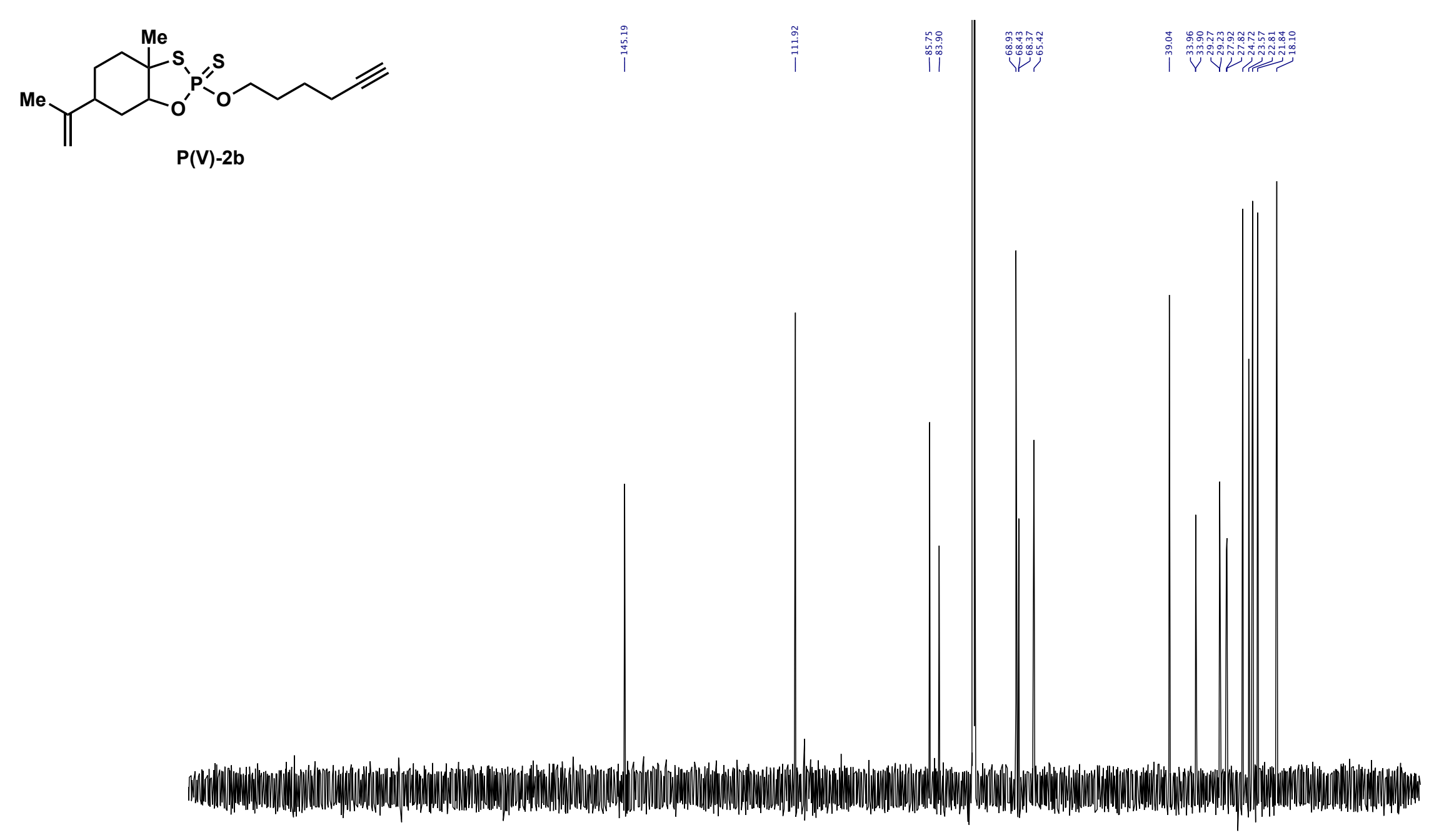

S212 
Compound P(V)-2b ${ }^{31}$ P NMR

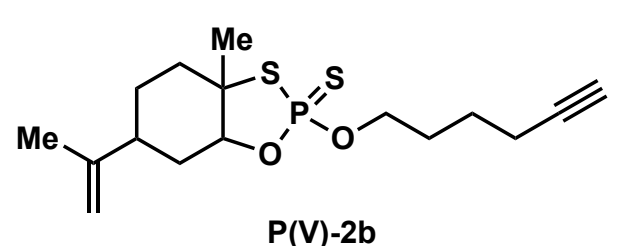

$P(V)-2 b$

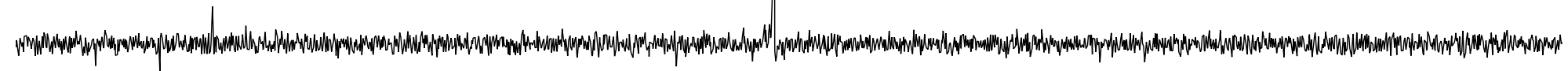

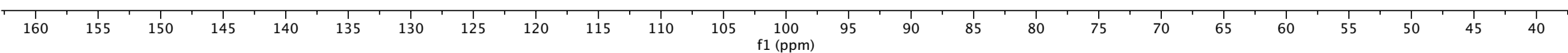




\section{Compound P(V)-3 ${ }^{1}$ H NMR}

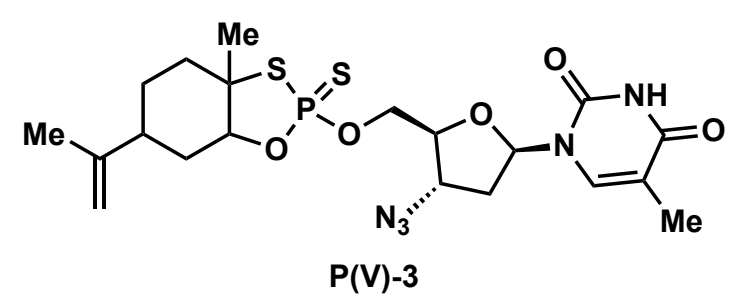

r

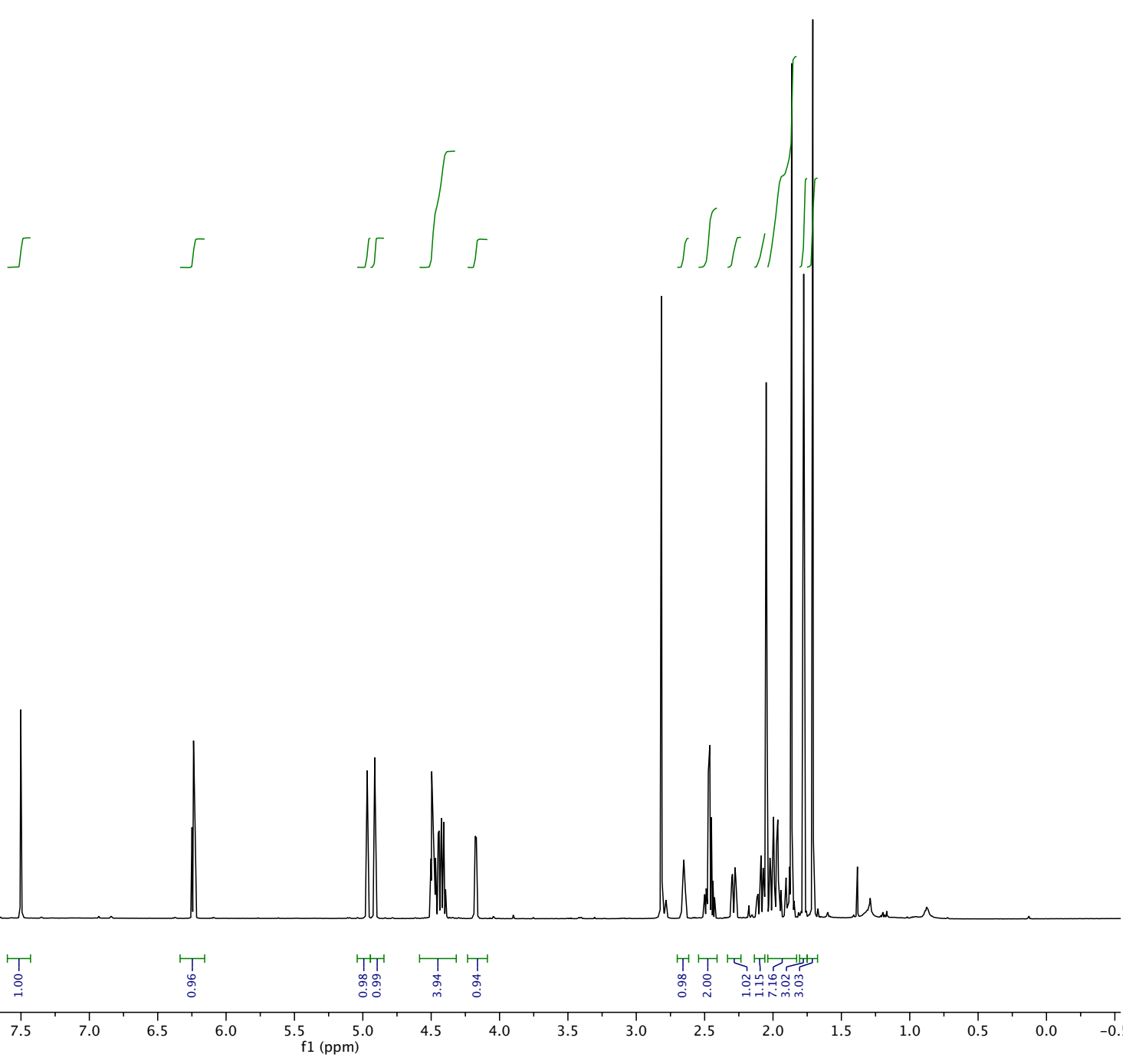


Compound P(V)-3 ${ }^{13} \mathrm{C}$ NMR

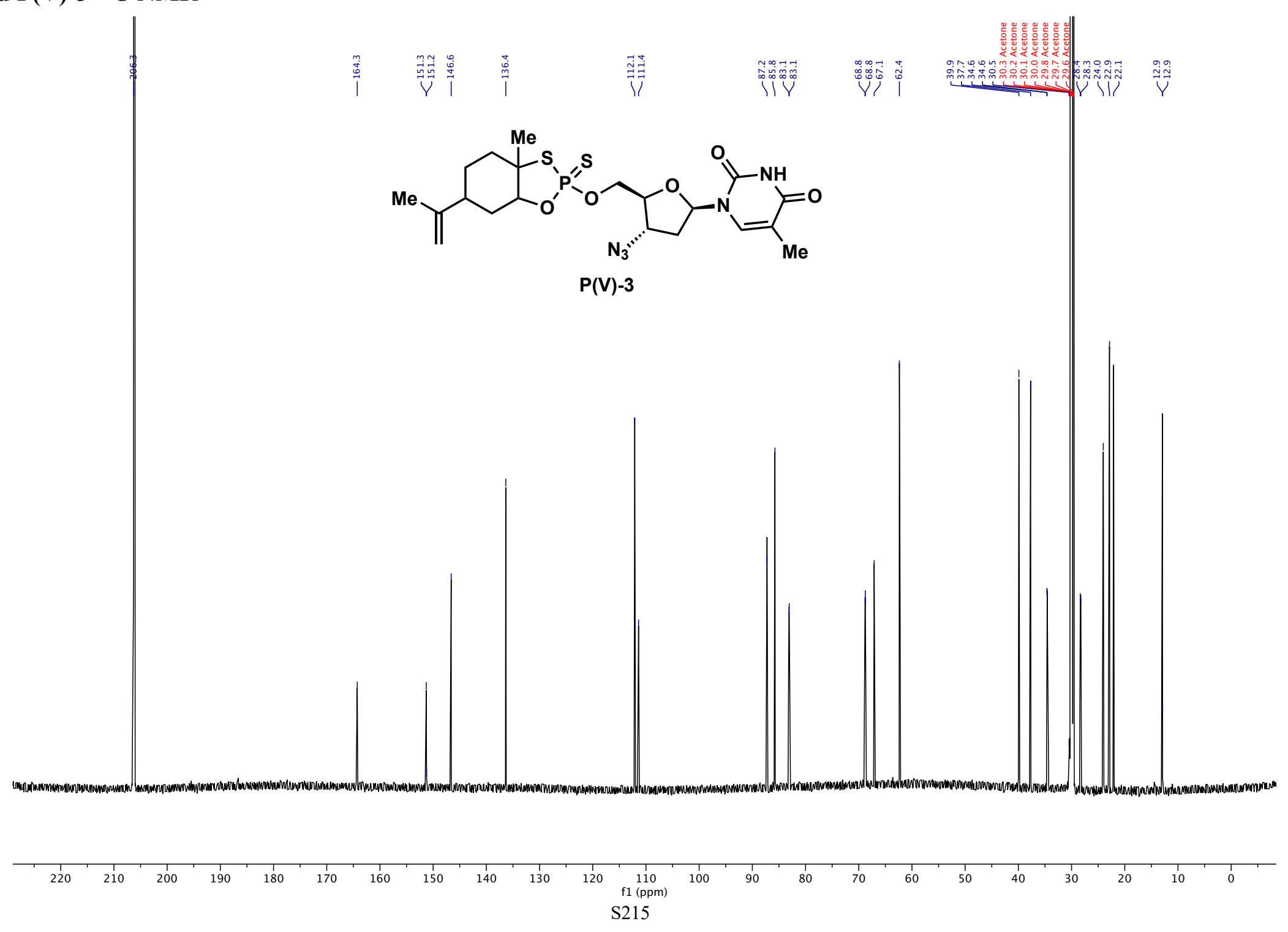




\section{Compound P(V)-3 ${ }^{31}$ P NMR}

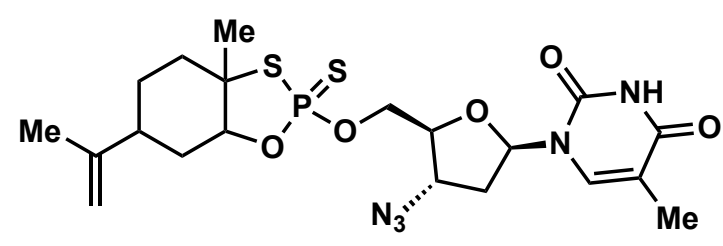

$\mathrm{P}(\mathrm{V})-3$ 


\section{Compound P(V)-4 ${ }^{1}$ H NMR}

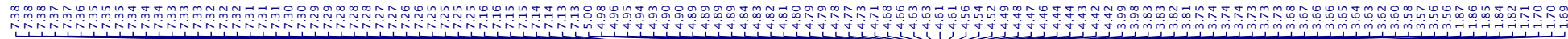
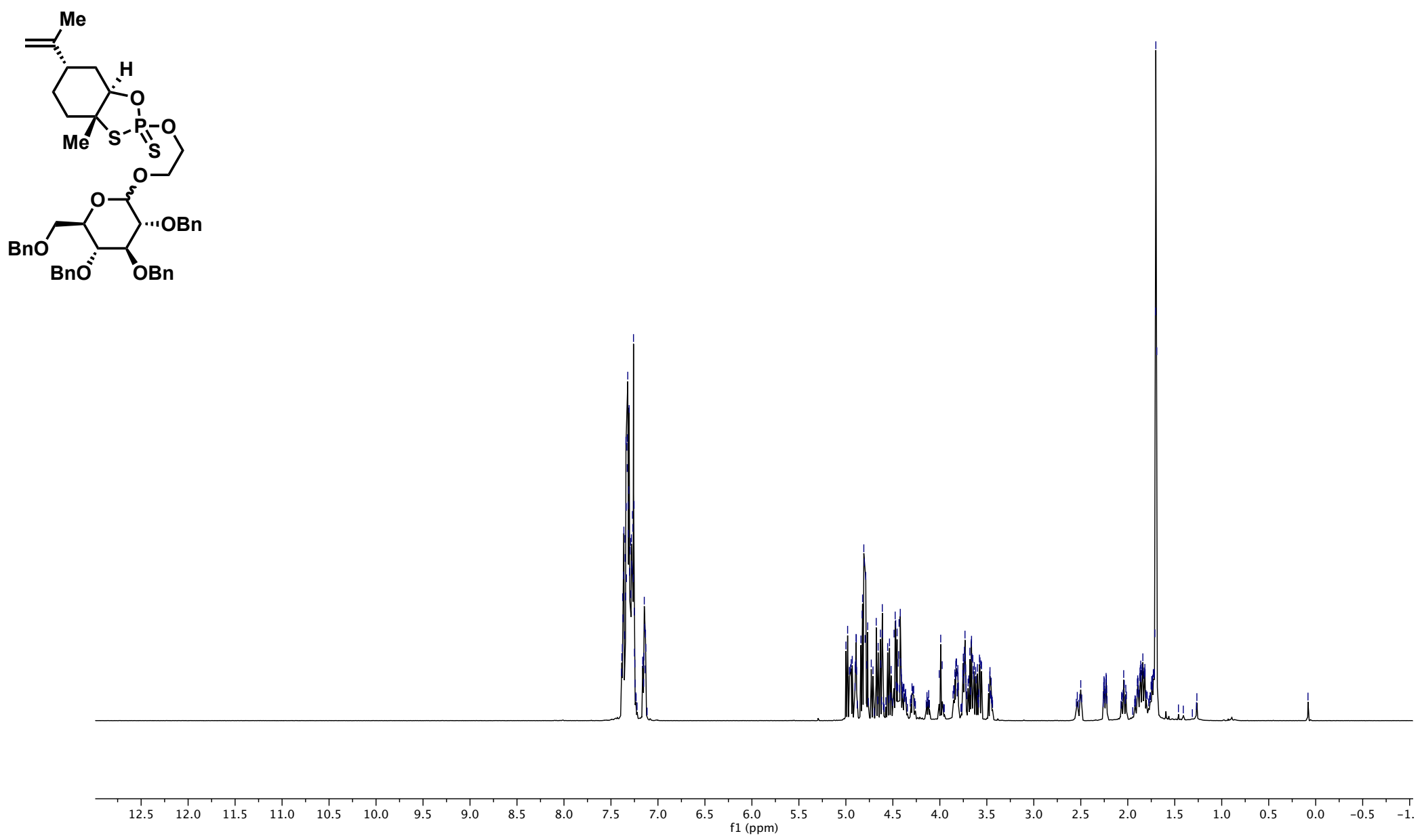


\section{Compound $\mathrm{P}(\mathrm{V})-4{ }^{13} \mathrm{C}$ NMR}
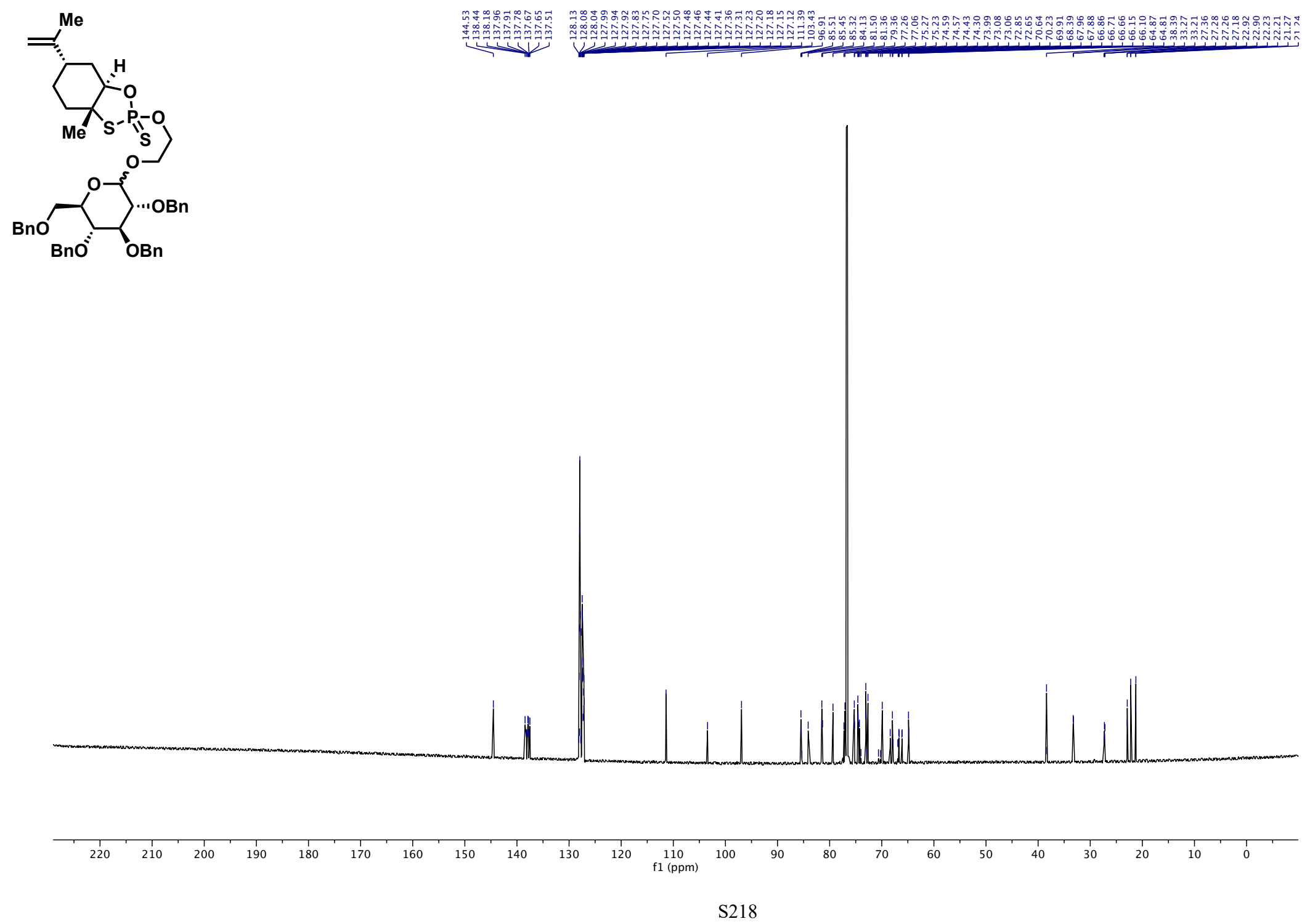
Compound P(V)-4 ${ }^{31}$ P NMR

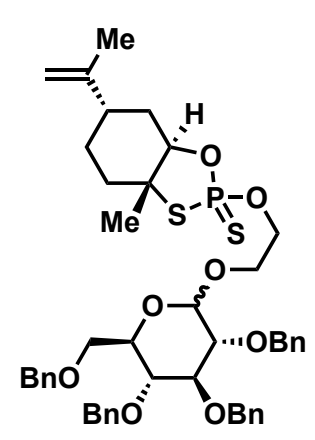

V.

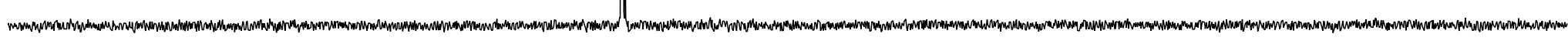

तै:

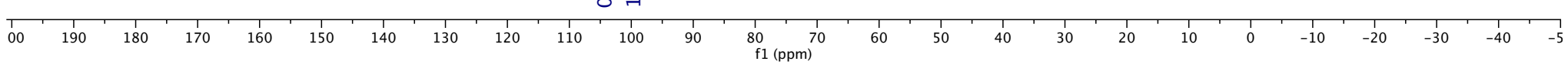

S219 
Compound $2{ }^{31}$ P NMR

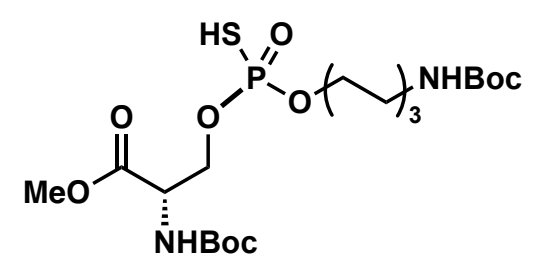

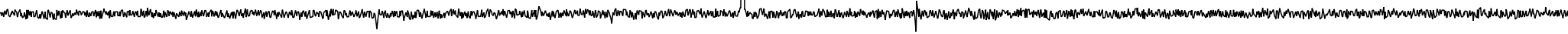

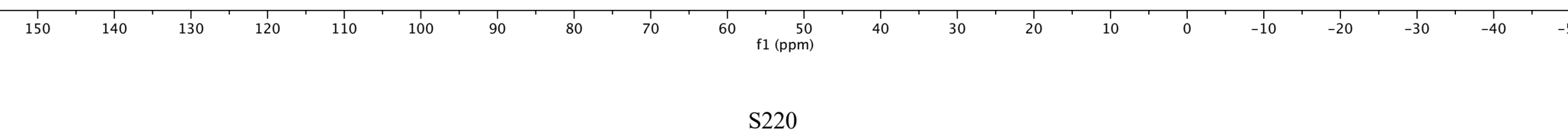




\section{Compound $2{ }^{31} \mathrm{P}$ NMR coupled}

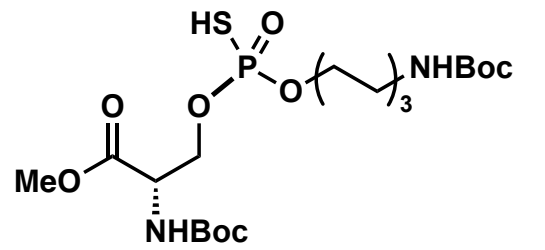




\section{Compound $34{ }^{1}$ H NMR}

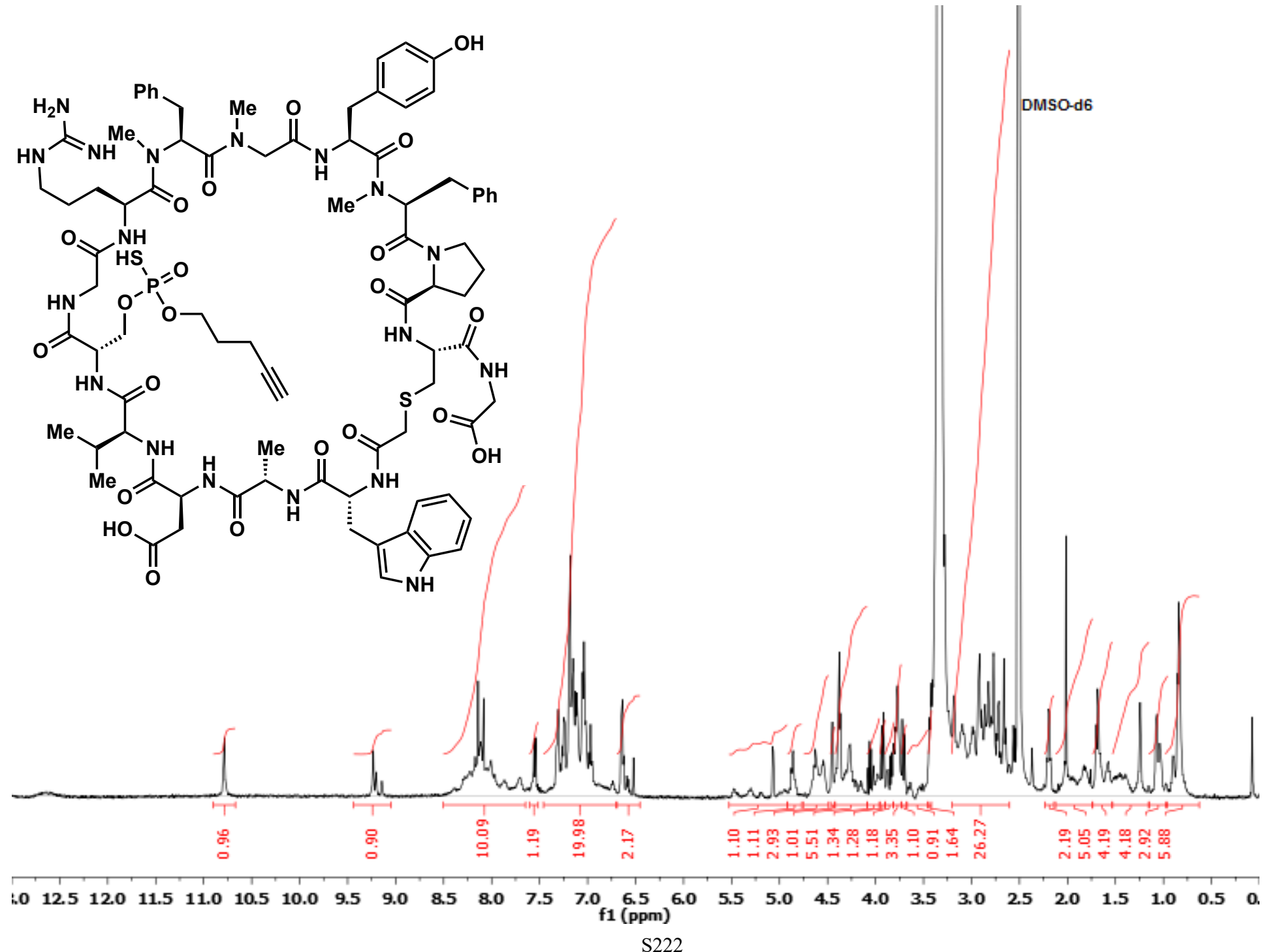


Compound $34{ }^{31}$ P NMR
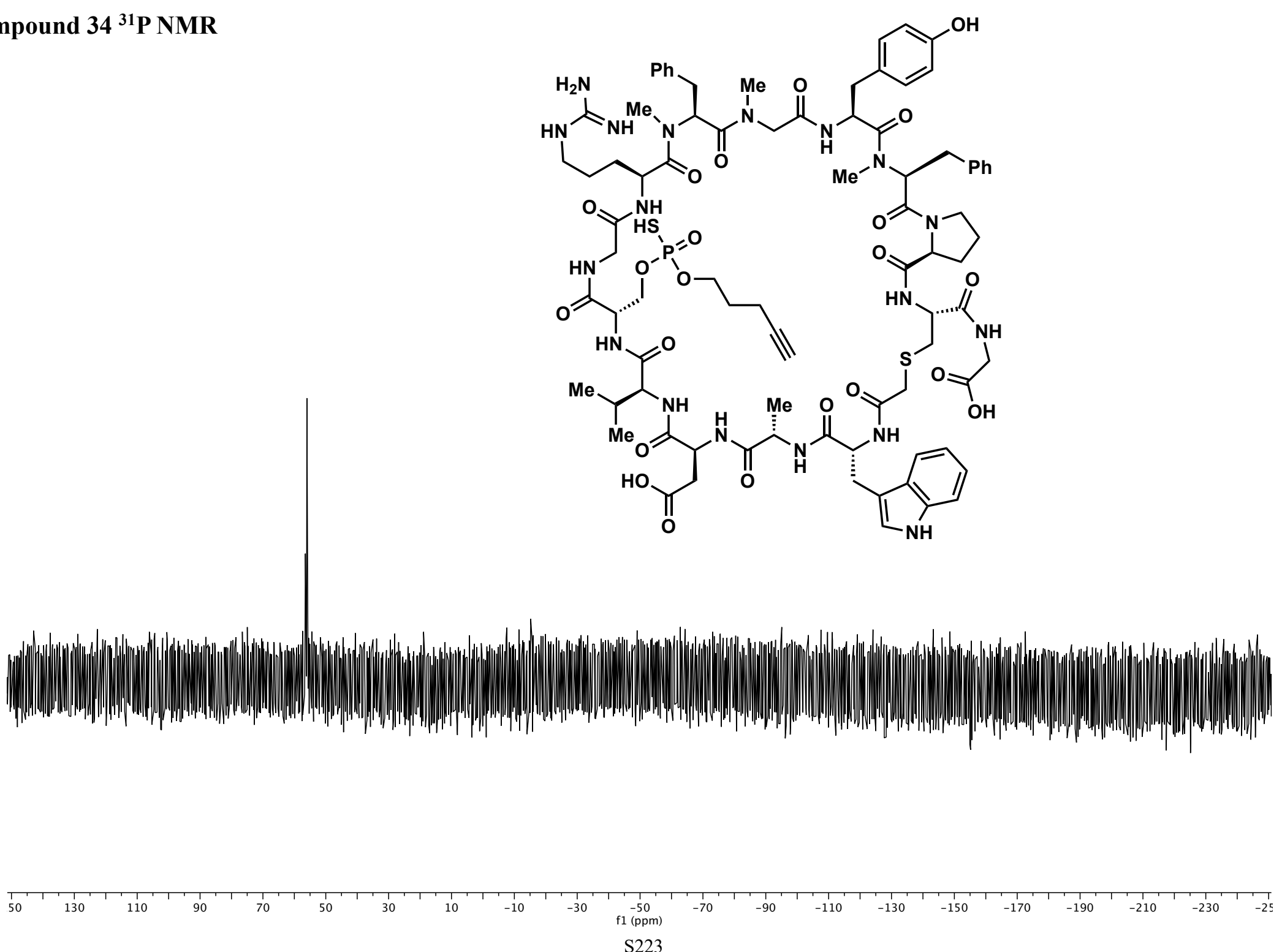
Compound $35{ }^{31}$ P NMR

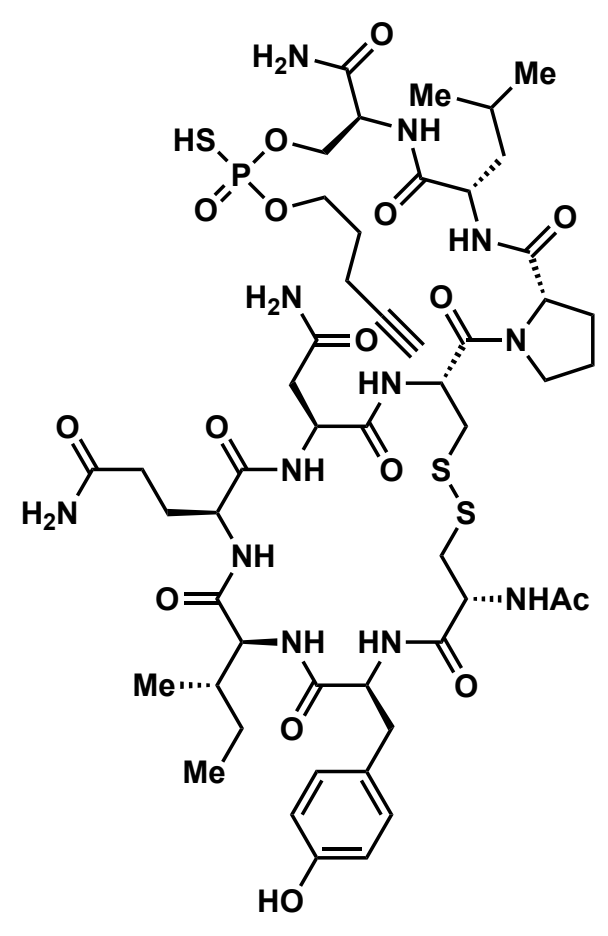

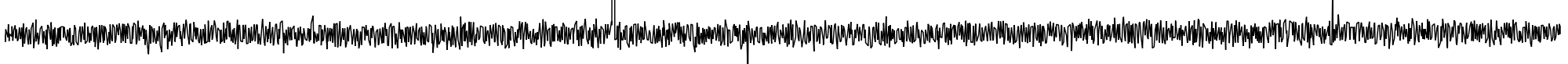

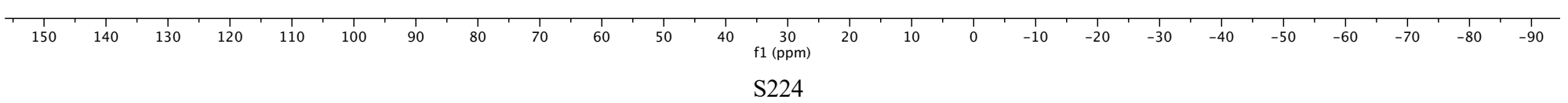




\section{Compound $35{ }^{31} \mathrm{P}$ NMR coupled}

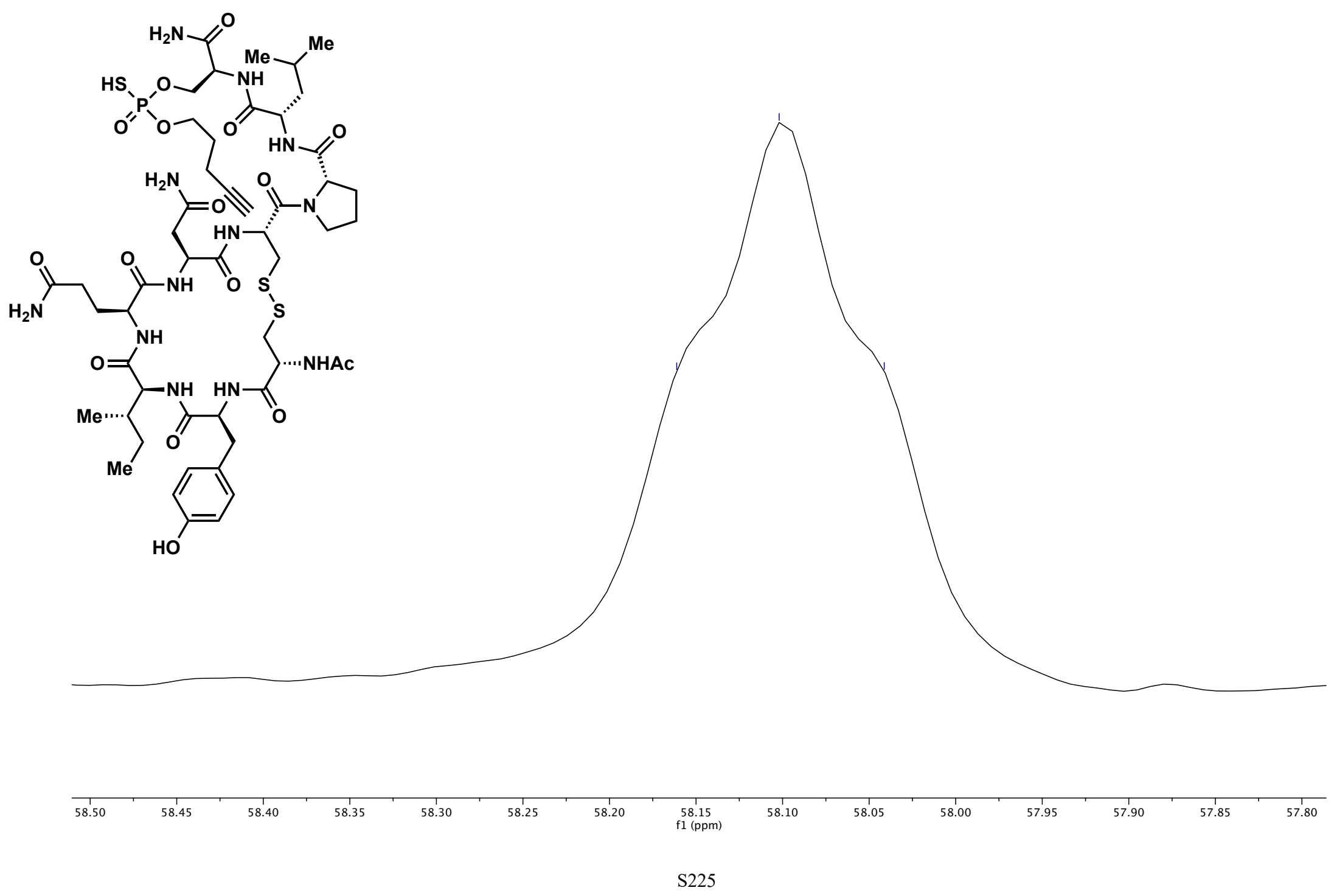




\section{Compound $36{ }^{31}$ P NMR}

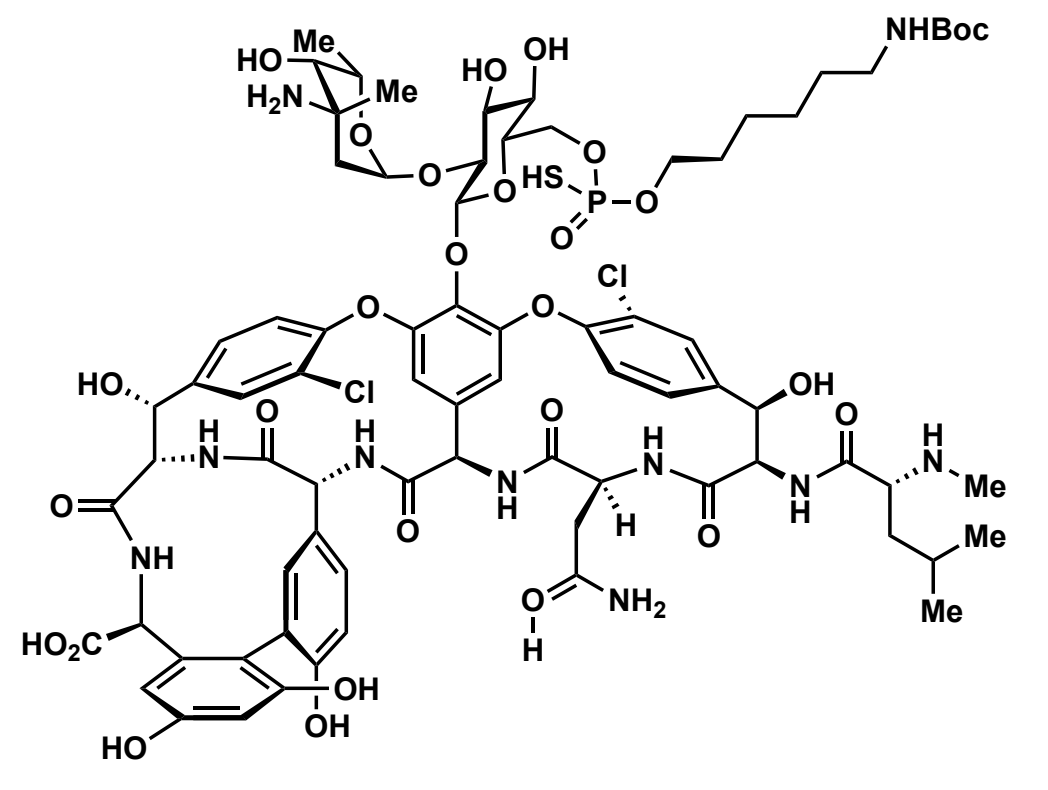

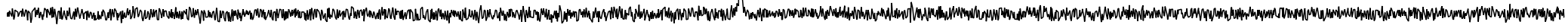

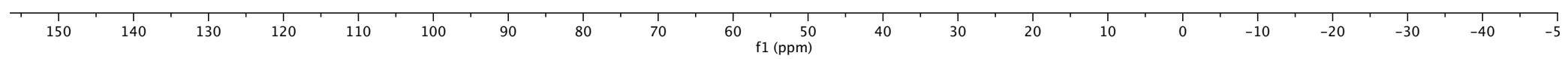




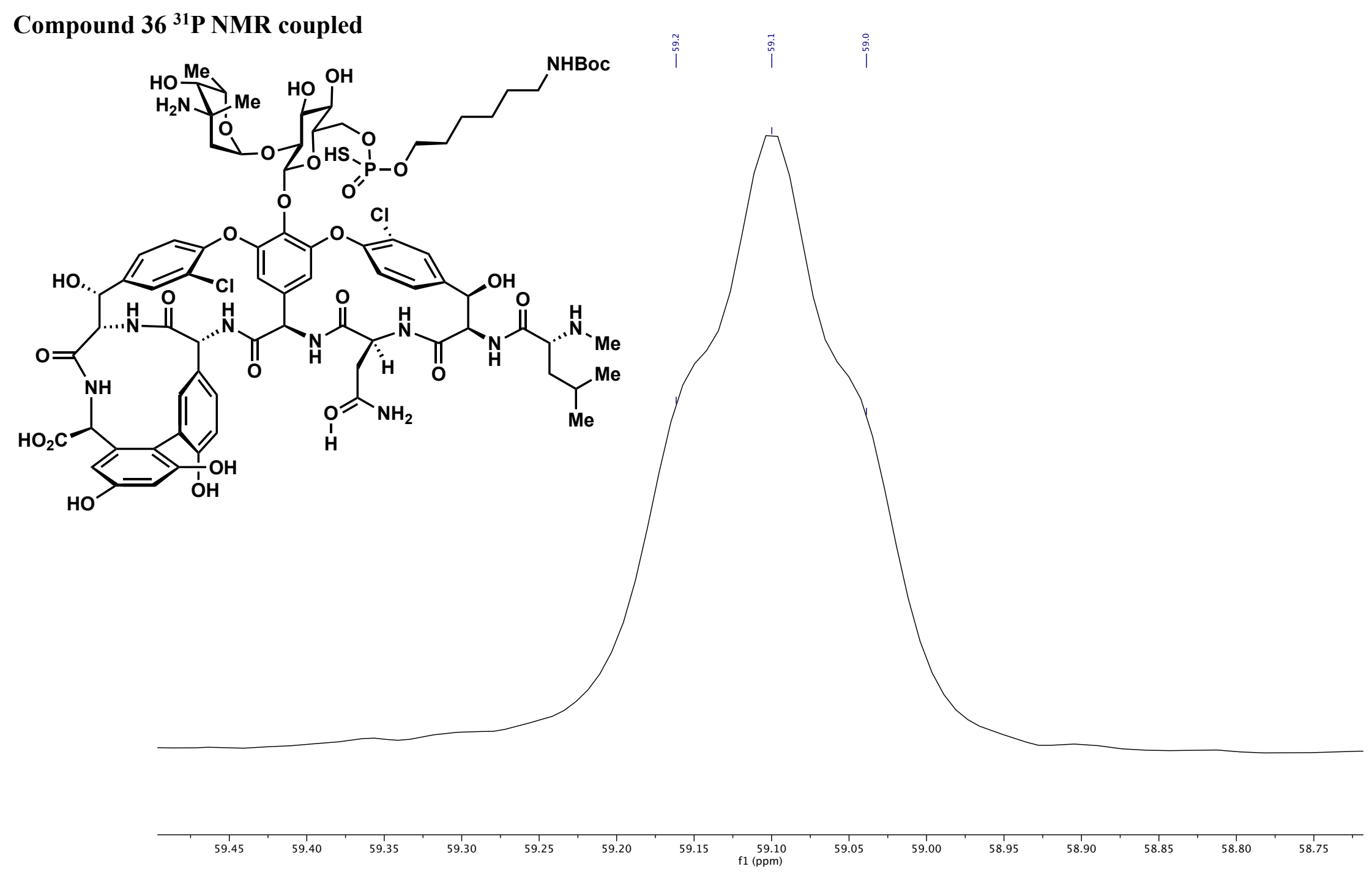




\section{Compound $37{ }^{31}$ P NMR}

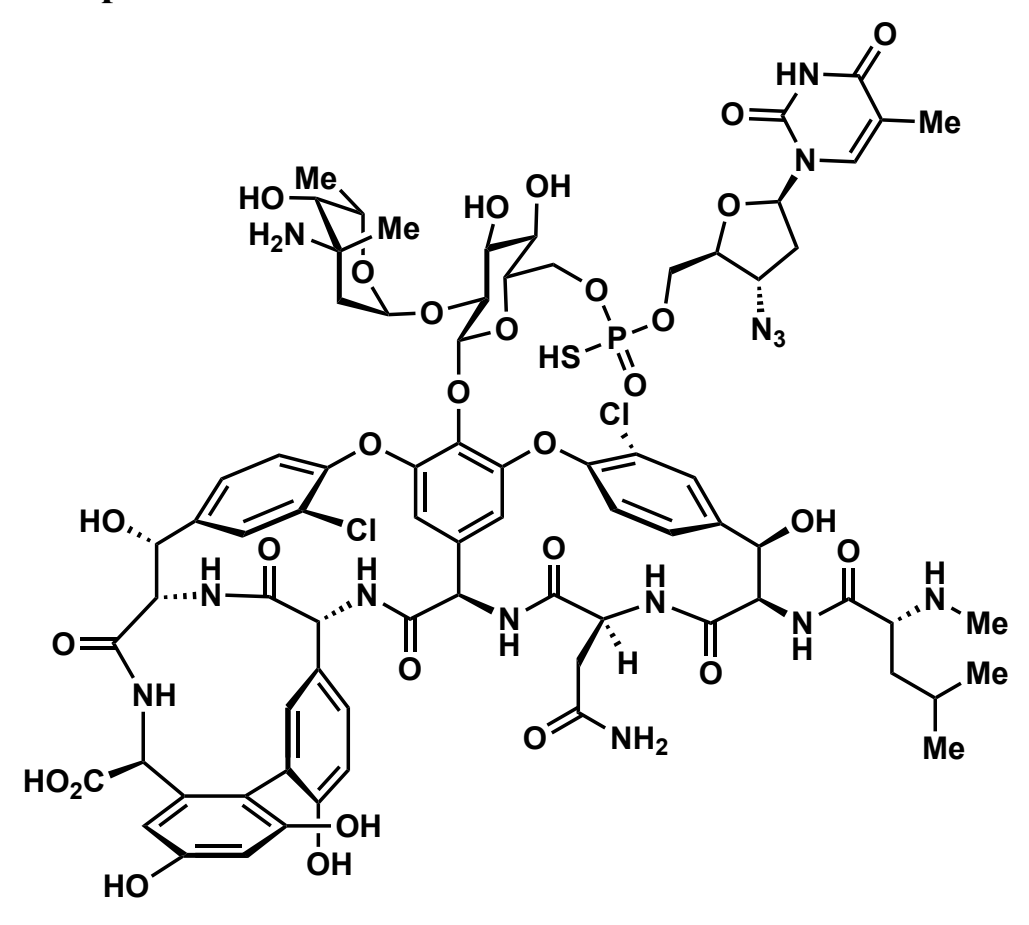

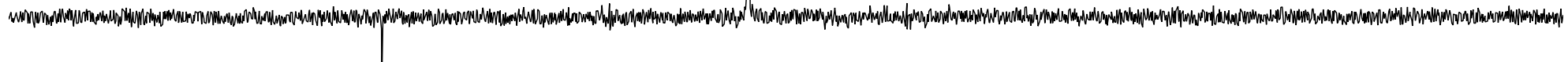

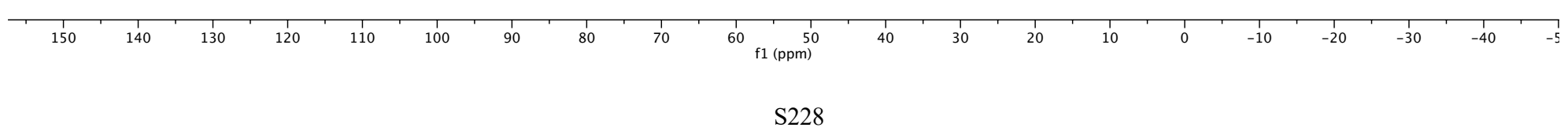




\section{Compound $37{ }^{31} \mathrm{P}$ NMR coupled}

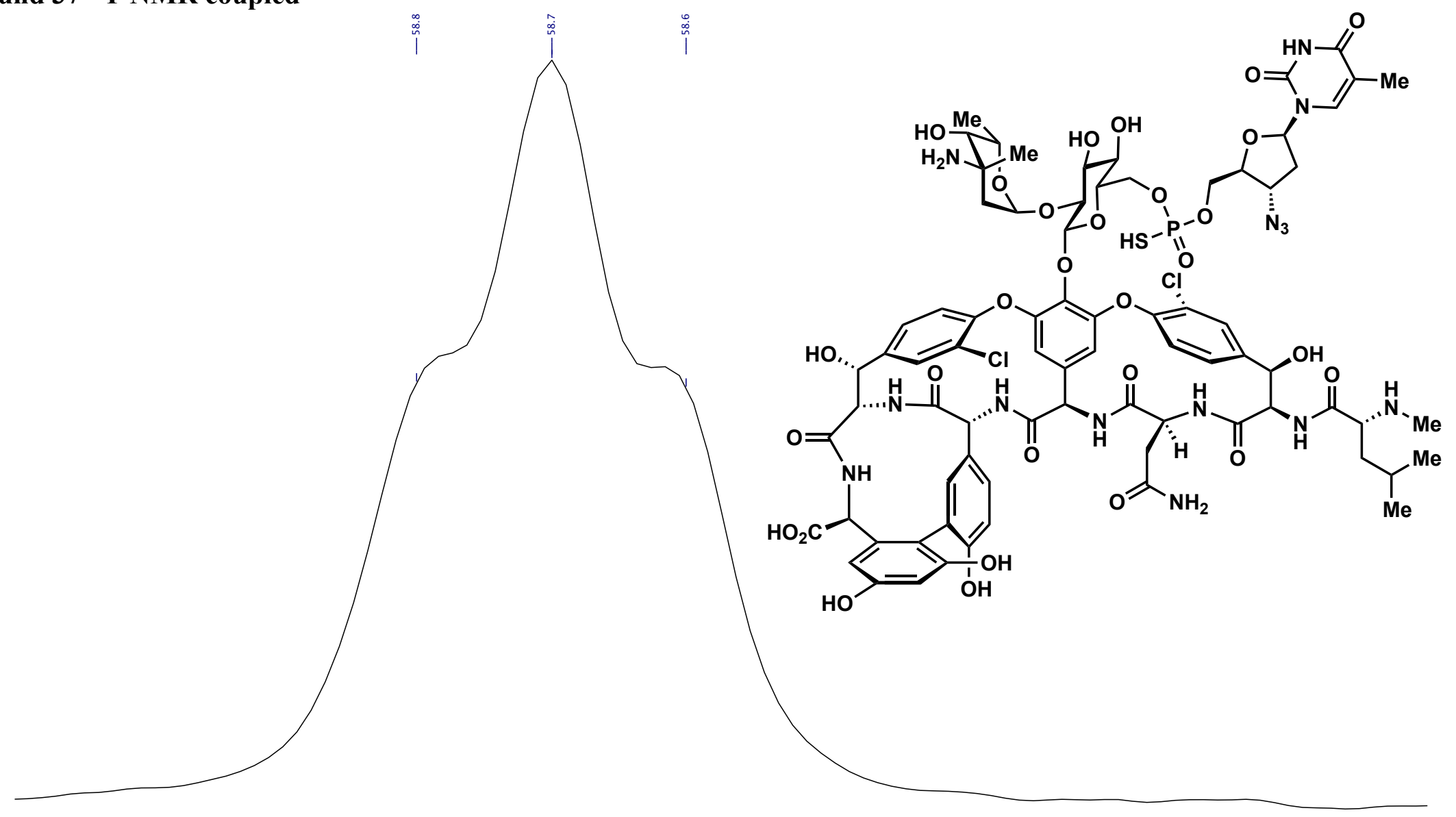

